
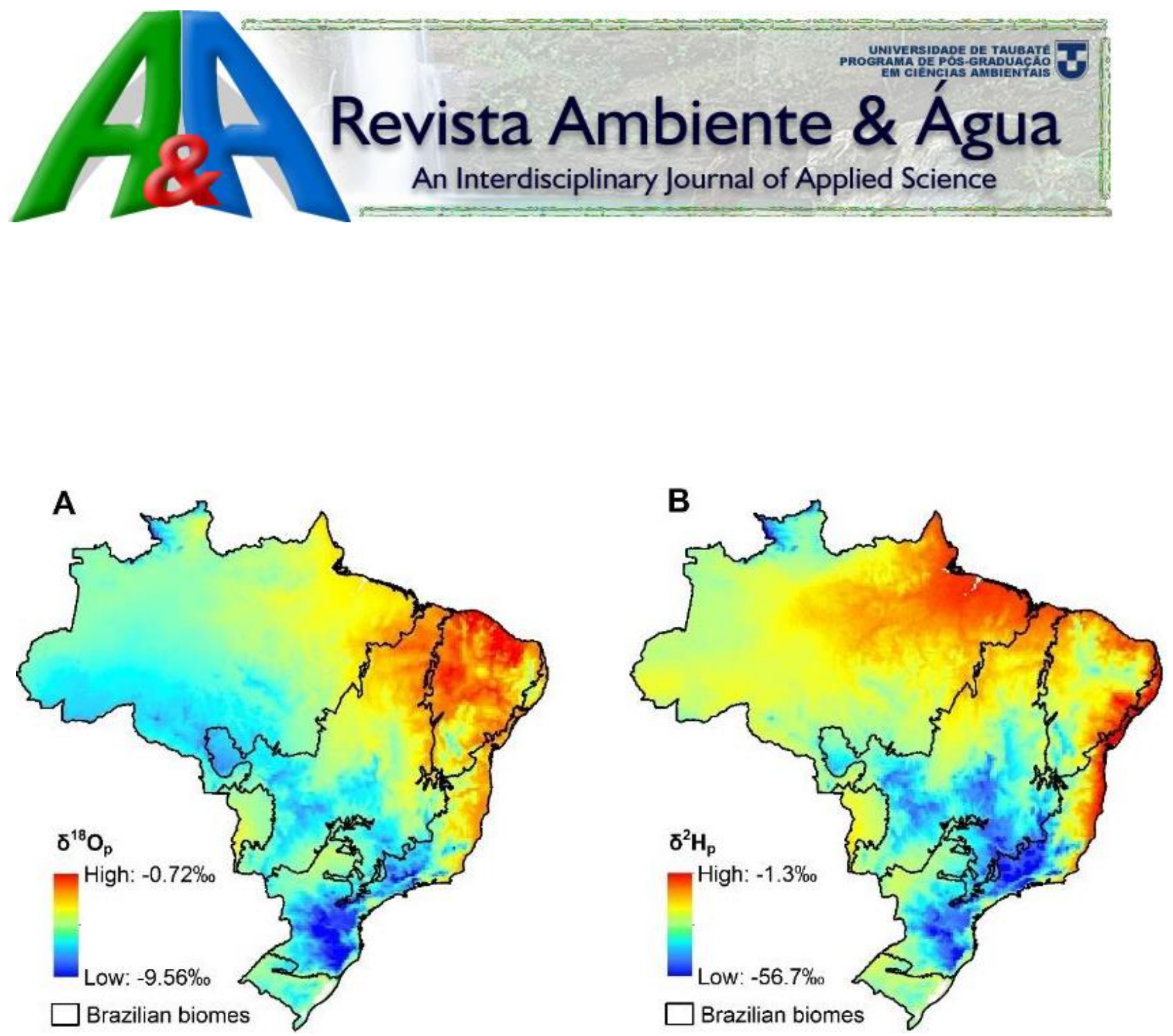

ISSN $=$ 1980-993X $($ Online $)$

http://www.ambi-agua.net

$50^{\text {th }}$ Edition of Revista Ambiente \& Água - An Interdisciplinary Journal of Applied Science,

Taubaté, V. 14, N. 2, p. 1-27 Mar/Apr. 2019. (doi:10.4136/ambi-agua.v14.n2) 


\section{EDITORIAL BOARD}

\section{Editors}

Getulio Teixeira Batista (Emeritus Editor) Universidade de Taubaté - UNITAU, BR

Nelson Wellausen Dias (Editor-in-Chief), Fundação Instituto Brasileiro de Geografia e Estatística - IBGE, BR

Ana Aparecida da Silva Almeida

Marcelo dos Santos Targa

Andrea Giuseppe Capodaglio

Arianna Callegari

Antonio Teixeira de Matos

Apostol Tiberiu

Claudia M. dos S. Cordovil

Dar Roberts

Giordano Urbini

Gustaf Olsson

Hélio Nobile Diniz

Ignacio Morell Evangelista

János Fehér

Julio Cesar Pascale Palhares

Luis Antonio Merino

Maria Cristina Collivignarelli

Massimo Raboni

Petr Hlavínek

Richarde Marques da Silva

Stefan Stanko

Teresa Maria Reyna

Yosio Edemir Shimabukuro

Zhongliang Liu Beijing

Text Editor

Reference Editor

Peer-Reviewing Process

System Analyst

Secretary and Communication

\section{Associate Editors}

Universidade de Taubaté (UNITAU), BR

Universidade de Taubaté (UNITAU), BR

\section{Editorial Commission}

University of Pavia, ITALY

Università degli Studi di Pavia, ITALY

Universidade Federal de Viçosa (UFV), BR

University Politechnica of Bucharest, Romênia

Centro de estudos de Engenharia Rural (CEER), Lisboa, Portugal

University of California, Santa Barbara, United States

University of Insubria, Varese, Italy

Lund University, Lund, Sweden

Inst. Geológico, Sec. do Meio Amb. do Est. de SP (IG/SMA), BR

University Jaume I- Pesticides and Water Research Institute, Spain

Debrecen University, Hungary

Embrapa Pecuária Sudeste, CPPSE, São Carlos, SP, BR

Institute of Regional Medicine, National University of the Northeast, Corrientes, Argentina

University of Pavia, Depart. of Civil Engineering and Architecture, Italy

LIUC - University "Cattaneo", School of Industrial Engineering, Italy

Brno University of Technology República Tcheca

Universidade Federal da Paraíba (UFPB), BR

Slovak Technical University in Bratislava Slovak, Eslováquia

Universidad Nacional de Córdoba, Argentina

Instituto Nacional de Pesquisas Espaciais (INPE), BR

University of Technology, China

Theodore D`Alessio, FL, USA, Maria Cristina Bean, FL, USA

Liliane Castro, Bibliotecária - CRB/8-6748, Taubaté, BR

Marcelo Siqueira Targa, UNITAU, BR

Tiago dos Santos Agostinho, UNITAU, BR

Luciana Gomes de Oliveira, UNITAU, BR

\section{Library catalog entry by Liliane Castro CRB/8-6748}

Revista Ambiente \& Água - An Interdisciplinary Journal of Applied Science / Instituto de Pesquisas Ambientais em Bacias Hidrográficas. Taubaté. v. 14, n.2 (2006) - Taubaté: IPABHi, 2019.

Quadrimestral (2006 - 2013), Trimestral (2014 - 2016), Bimestral (2017), Publicação Contínua a partir de Janeiro de 2018.

Resumo em português e inglês.

ISSN 1980-993X

1. Ciências ambientais. 2. Recursos hídricos. I. Instituto de Pesquisas Ambientais em Bacias Hidrográficas.

CDD - 333.705

CDU - (03)556.18 


\section{TABLE OF CONTENTS}

\section{COVER:}

In a review about the use of isoscapes for natural resource management in the Brazilian context, which has high biological diversity and landscape heterogeneity, the authors present this figure that shows mean annual precipitation $\delta^{18} \mathrm{O}(\mathrm{A})$ and $\delta^{2} \mathrm{H}(\mathrm{B})$ isoscapes. As this figure presents, the average rates show a significantly lower spatial variation in comparison to temporal and spatial fluctuation found by other studies at a state level. Therefore, developing precipitation isoscape models specific for Brazil is imperative, since current global models mask part of the natural variations of isotopic ratios. Source: SENA-SOUZA, J. P. et al. Background and the use of isoscapes in the Brazilian context: essential tool for isotope data interpretation and natural resource management. Rev. Ambient. Água, Taubaté, vol. 14 n. 2, p. 1-27, 2019. doi:10.4136/ambi-agua.2282

\section{ARTICLES}

Acute ecotoxicity on Daphnia magna to evaluate effluent samples of Kraft pulp mill treated by $\mathrm{UV} / \mathrm{H}_{2} \mathrm{O}_{2}$ process

01 doi:10.4136/ambi-agua.2208

Joicy Micheletto; Naiara Mariana Fiori Monteiro Sampaio; Henrique Zavattieri Ruiz;

Lucia Regina Rocha Martins; Marcus Vinicius de Liz; Adriane Martins de Freitas

The importance of climate scenarios in setting the productivity indexes in the Pampa Arenosa subregion of the province of Buenos Aires, Argentina

02

doi:10.4136/ambi-agua.2286

Silvia Patricia Pérez; Julieta Irigoin; Mariano Tomás Cassani; Marcelo Juan Massobrio

Adaptation of domestic effluent for agricultural reuse by biological, physical treatment and disinfection by ultraviolet radiation

03 doi:10.4136/ambi-agua.2292

Andressa de Almeida Soares Oliveira; Reinaldo Gaspar Bastos; Claudinei Fonseca Souza

Evaluation of water resource preservation areas in the Hydrographical Basin of Andreas Stream, RS, Brazil, using environmental monitoring programs

Rodrigo Augusto Klamt; Eduardo Alexis Lobo; Adilson Ben da Costa; Dionei Minuzzi Delevati

A proposal to integrate the legal definition and official delineation of watersheds in Mexico: eight model case studies

05 doi:10.4136/ambi-agua.2198

Sergio Arturo Rentería-Guevara; Antonio Sanhouse-García; Yaneth Bustos-Terrones; Abraham E. Rodriguez-Mata; Jesus Gabriel Rangel-Peraza

Simultaneous removal of nitrogen and organic carbon from swine wastewater using the predenitrification/nitrification process

Marcelo Bortoli; Airton Kunz; Marina Celant De Prá; Marcio Luis Busi Da Silva; Ana Cé;

Hugo Moreira Soares

Background and the use of isoscapes in the Brazilian context: essential tool for isotope data interpretation and natural resource management 
Technical contributions to territorial planning and the use of ecosystemic services in a hydrographic basin with a water deficit in the Atlantic Rainforest of Brazil

Douglas Leite Figueira; Ricardo Valcarcel; Marcelle Nardelli Baptista

Analytical solution for the stationary model of pollutant propagation in an aquatic medium

09

Cíntia Ourique Monticelli; Jorge Rodolfo Zabadal; Daniela Muller Quevedo;

Carlos Augusto Nascimento

Potential for biogas generation from sweet potato genotypes

10 doi:10.4136/ambi-agua.2317

Samantha de Paula Batista; Edson Perez Guerra; Juliano Tadeu Vilela de Resende;

Matheus Vitor Diniz Gueri; Guilherme Campos Carvalho; Jessica Naiara dos Santos Crestani;

Israel Felipe Lustosa da Silva

\section{Shifting habitat mosaic: identification and mapping}

11 doi:10.4136/ambi-agua.2242

João Paulo Simioni; Laurindo Antonio Guasselli; Tatiana Silva da Silva

Rainfall trends for the State of Paraná: present and future climate

12 doi:10.4136/ambi-agua.2258

Luciana Espindula de Quadros; Eloy Lemos de Mello; Benedito Martins Gomes; Fernanda Cristina Araujo

Relationships between land use and water quality obtained for the evaluation of genotoxic effects in plant bioindicators

13 doi:10.4136/ambi-agua.2299

Jéssica Sieklicki; Nilton Cesar Pires Bione; Paulo Costa de Oliveira-Filho; Viviane Fernandes de Souza; Kelly Geronazzo Martins

Impacts of land-use change on southeast Amazonia basin streamflow

14 doi:10.4136/ambi-agua.2303

Vinicius Marques Louzada; Celso Bandeira de Melo Ribeiro

Biomonitors to evaluate the toxic potential of urban solid waste landfill leachate

15 doi:10.4136/ambi-agua.2326

Catiele Vieira; Annette Droste

Ozonation improves physical attributes in domestic sewage effluent

16 doi:10.4136/ambi-agua.2328

Osli Barreto Camilo Júnior; Delvio Sandri; Ernandes Rodrigues de Alencar; Lucas Ferraz Hebling

Frequency of mentum deformity in Chironomus sancticaroli (Diptera: Chironomidae) in a laboratory culture

17 doi:10.4136/ambi-agua.2337

Mariana Silveira Guerra Moura e Silva; Ana Lúcia Silva Marigo; William Viveiros;

Mônica Luisa Kuhlmann 


Ambiente \& Água - An Interdisciplinary Journal of Applied Science
ISSN 1980-993X - doi:10.4136/1980-993X
www.ambi-agua.net
E-mail: ambi.agua@gmail.com

\title{
Acute ecotoxicity on Daphnia magna to evaluate effluent samples of Kraft pulp mill treated by $\mathrm{UV} / \mathrm{H}_{2} \mathrm{O}_{2}$ process
}

\author{
ARTICLES doi:10.4136/ambi-agua.2208
}

Received: 03 Nov. 2017; Accepted: 11 Jan. 2019

\author{
Joicy Micheletto $^{1^{*} \text {; }}$; Naiara Mariana Fiori Monteiro Sampaio(iD; \\ Henrique Zavattieri Ruiz ${ }^{3}$; Lucia Regina Rocha Martins ${ }^{1}$ (D); \\ Marcus Vinicius de Liz ${ }^{1}$; Adriane Martins de Freitas ${ }^{1}$ \\ ${ }^{1}$ Universidade Tecnológica Federal do Paraná (UTFPR), Curitiba, PR, Brasil \\ Departamento de Química e Biologia (DAQBi). E-mail: joicymicheletto@ hotmail.com, \\ luciaregi@utfpr.edu.br, marcusliz@utfpr.edu.br, adrianefreitas@utfpr.edu.br \\ ${ }^{2}$ Universidade Federal do Paraná (UFPR), Curitiba, PR, Brasil \\ Departamento de Química (DQUI). E-mail: naiaramfms@ gmail.com \\ ${ }^{3}$ Universidade Federal do Paraná (UFPR), Curitiba, PR, Brasil \\ Centro Mesorregional de Excelência em Tecnologia do Leite (CMETL). \\ E-mail: henriquezr@hotmail.com \\ *Corresponding author
}

\begin{abstract}
The pulp and paper industry is one of world's largest water consumers, generating high volumes of effluents. The Kraft process produces effluents with high BOD, COD, suspended solids, lignin and a myriad of potentially toxic compounds, which require treatment before discharge into the aquatic environment. Advanced oxidation processes, such as $\mathrm{UV} / \mathrm{H}_{2} \mathrm{O}_{2}$, have been applied as treatment alternatives because they can destroy many compounds before they mineralize. However, when the oxidation process is incomplete, occurs could be produced by products with high toxicity. This study evaluated the acute toxicity on Daphnia magna of two effluent samples of Kraft pulp mill (KE1 and KE2) treated by $\mathrm{UV} / \mathrm{H}_{2} \mathrm{O}_{2}$ process. The effects of the $\mathrm{pH}$ variation and oxidant concentration on the removal of DOC, total UV-vis spectral area and apparent color were considered to adjust the experiments' conditions with diluted effluent $\mathrm{KE} 1$. Both samples were treated at $\mathrm{pH} 4.0$ and $70 \mathrm{mg} \mathrm{L}^{-1}$ of $\mathrm{H}_{2} \mathrm{O}_{2}$ for $40 \mathrm{~min}$, achieving removals of up to $69.4 \%$ in apparent color, $73.7 \%$ of phenolic compounds and $68.9 \%$ of lignin compounds. When the reaction was applied in undiluted effluent samples, the acute toxicity for Daphnia magna decreased for KE1 after 780 min of treatment, whereas KE2 became four times more toxic. The data showed that although the treatment had been efficient considering physics and chemicals parameters, it is necessary follow the oxidative processes with ecotoxicological bioassays to guarantee their safety, since different effluents of the Kraft pulp mill could present different levels of organic compound mineralization.
\end{abstract}

Keywords: advanced oxidation process, ecotoxicology bioassays, industrial effluent. 


\section{Ecotoxicidade aguda em Daphnia magna para avaliação de amostras de efluente de celulose Kraft tratadas por processo $\mathrm{UV} / \mathrm{H}_{2} \mathrm{O}_{2}$}

\section{RESUMO}

A indústria de papel e celulose está entre as que mais consome água no mundo, gerando grandes volumes de efluentes. O processo Kraft produz efluentes com elevada DBO, DQO, sólidos suspensos, teor de lignina e uma mistura complexa de compostos potencialmente tóxicos, os quais necessitam de tratamento para posterior descarte no meio ambiente. Os processos oxidativos avançados, dentre eles o processo $\mathrm{UV} / \mathrm{H}_{2} \mathrm{O}_{2}$, têm sido aplicado como alternativa de tratamento pois é capaz de degradar os mais diversos compostos até sua mineralização. No entanto, quando o processo oxidativo é incompleto, podem ser formados produtos intermediários com elevada toxicidade. Este estudo avaliou a toxicidade aguda em Daphnia magna de duas amostras de efluente Kraft (KE1 e KE2) tratadas por processo $\mathrm{UV} / \mathrm{H}_{2} \mathrm{O}_{2}$. Os efeitos da variação de $\mathrm{pH}$ e da concentração do oxidante sobre a redução de COT, área espectral UV-vis e cor aparente foram utilizados para ajustar as condições experimentais com a amostra KE1 diluida. Ambas as amostras foram tratadas em $\mathrm{pH} 4.0$ e com $70 \mathrm{mg} \mathrm{L}^{-1} \mathrm{de}$ $\mathrm{H}_{2} \mathrm{O}_{2}$ por 40 min, alcançando remoções de até $69,4 \%$ na cor aparente, $73,7 \%$ de compostos fenólicos e 68,9\% de compostos lignínicos. Quando a reação foi aplicada nas amostras não diluídas de efluentes, a toxicidade aguda para Daphnia magna diminuiu para KE1 após 780 min de tratamento, enquanto KE2 tornou-se três vezes mais tóxica. Os dados mostraram que embora o tratamento tenha sido eficiente, considerando os parâmetros físicos e químicos, é necessário acompanhar os processos oxidativos por ensaios ecotoxicológicos para garantir sua segurança, uma vez que cada efluente kraft pode apresentar diferentes níveis de mineralização de seus compostos orgânicos.

Palavras-chave: bioensaio ecotoxicológico, efluente industrial, processos oxidativos avançados.

\section{INTRODUCTION}

The pulp and paper industry consumes a large amount of water (Ashrafi et al., 2015) and is one of the largest polluters due the variety of chemicals that are released into the environment (Savant el al., 2006). One of common pulping technologies is the Kraft process, which is applied for wood delignification with alkaline solutions at high pressures and temperatures (Kamali and Khodaparast, 2015). Kraft effluent has high biochemical oxygen demand (BOD), chemical oxygen demand (COD), suspended solids, lignin and its derivatives and a variety of toxic compounds (Ali and Sreekrishnan, 2001). If these effluents are poorly treated, toxic substances are released into the aquatic environment, affecting many ecosystems (Oller et al., 2011).

In order to mitigate these negative effects, studies have evaluated options of treatments; the application of advanced oxidation processes (AOPs) is a promising alternative (RuedaMárques et al., 2015; Merayo et al., 2013). In wastewater treatment of the pulp and paper industry, the AOPs most used are those wherein a source of radiation is applied (UV, visible or solar light), such as $\mathrm{UV} / \mathrm{H}_{2} \mathrm{O}_{2}$, photo-Fenton and $\mathrm{TiO}_{2}$ photocatalysis (Catalkaya and Kargi, 2008). These processes are based on the generation of hydroxyl radicals in situ that exhibit high oxidizing power, low selectivity and in many cases result in complete degradation of organic matter (Del Moro et al., 2013). In the $\mathrm{UV} / \mathrm{H}_{2} \mathrm{O}_{2}$ process, the hydroxyl radicals are formed by the homolithic break of $\mathrm{H}_{2} \mathrm{O}_{2}$ according to Equation 1:

$\mathrm{H}_{2} \mathrm{O}_{2}+h v \rightarrow 2 \cdot \mathrm{OH}$ 
The hydroxyl radicals $(\bullet \mathrm{OH})$ are capable of mineralizing organic contaminants by three different routes of oxidation: hydrogen abstraction, electron transfer and radical addition (Malato et al., 2009). The efficiency of these processes have been applied to different matrices such as urban wastewater (Silva et al., 2018), petroleum refinery effluent (Moser et al., 2018) and pharmaceutical substances (Alharbi et al., 2017). There are many advantages in the application of AOPs compared with other treatment systems, such as non-phase transfer, high solubility of $\mathrm{H}_{2} \mathrm{O}_{2}$ in water, no sludge formation and relatively low operational cost; but despite these, its application in the treatment of pulp and paper mill effluent is still incipient (Rizzo, 2011).

Some studies show that if the amount of hydroxyl radicals generated in AOPs was insufficient to the complete mineralization the partial oxidation of organic contaminants may result in formation of toxic byproducts (Rizzo, 2011; Rueda-Márquez et al., 2015). In order to avoid this issue, toxicity tests could be used as important tools for the monitoring of the effectiveness of the treatment process (Oller et al., 2011). The main objective of this study was to evaluate the acute ecotoxicity of two effluent samples of a Kraft pulp mill submitted to treatment with the $\mathrm{UV} / \mathrm{H}_{2} \mathrm{O}_{2}$ process, using the Daphnia magna as a test organism.

\section{MATERIALS AND METHODS}

\subsection{Kraft effluent samples}

Two effluent samples (named KE1 and KE2) were collected in different days in a kraft pulp mill of Pinus taeda and Pinus elliottii. These samples were collected before primary treatment (raw effluent) in plastic vessels $(5 \mathrm{~L})$ and stored at $4{ }^{\circ} \mathrm{C}$. After filtration $(7-11 \mu \mathrm{m}$, Quantity) the samples were characterized by standardized methods for $\mathrm{pH}$, Chemical Oxygen Demand (COD), Biochemical Oxygen Demand (BOD 5 ), Dissolved Organic Carbon (DOC), turbidity, apparent color $(440 \mathrm{~nm})$, alkalinity, total phenolics and UV-Vis spectral area (200$800 \mathrm{~nm}$ ) (APHA et al., 2012). Lignin compounds were analyzed by absorbance measured at $280 \mathrm{~nm}$, according to Çeçen (1999). All analyses were performed in triplicate.

\subsection{Experimental design}

The effects of two variables ( $\mathrm{pH}$ and $\mathrm{H}_{2} \mathrm{O}_{2}$ concentration) were evaluated by $2^{2}$ factorial design with triplicate of the central point. The levels for each variable were $\mathrm{pH} 4.0$ and 8.0 and for the $\mathrm{H}_{2} \mathrm{O}_{2}$ concentrations 50 and $70 \mathrm{mg} \mathrm{L}^{-1}$. The performance of experiments was measured by color, UV-Vis spectral area and DOC and the results were expressed as percentage of reduction. The end of the reaction was determined as the time when consumption of hydrogen peroxide was above $95 \%$. Residual $\mathrm{H}_{2} \mathrm{O}_{2}$ was determined by the spectrophotometric method based on reaction with ammonium metavanadate (Nogueira et al., 2005).

The effluent samples $(500 \mathrm{~mL})$ were filtered $(7-11 \mu \mathrm{m}$, Quantity), diluted with demineralized water (fifteen times) and the $\mathrm{pH}$ was adjusted before treatment by the $\mathrm{UV} / \mathrm{H}_{2} \mathrm{O}_{2}$ process. The experiments were conducted in a borosilicate bench photoreactor equipped with a water-cooler and a magnetic stirrer. Artificial radiation was provided by a high-pressure mercury vapor lamp $(125 \mathrm{~W}, \lambda \max =254 \mathrm{~nm}$, Philips $)$ immersed in the solution through a quartz bulb. Before the addition of oxidant and at the end of the treatment, an aliquot of each sample was collected for the measurements indicated in Item 2.1.

The significance of the variables effect was evaluated by the Pareto graph (95\% confidence level, Statistica 7.0). The treatment condition chosen was applied to the other sample.

\subsection{Bioassays with Daphnia magna}

Acute toxicity tests were conducted with effluent samples (KE1 and KE2) before (initial time) and after the $\mathrm{UV} / \mathrm{H}_{2} \mathrm{O}_{2}$ treatment, which was performed with filtered and undiluted 
effluent samples, after adjusting the $\mathrm{pH}$ (4.0). The hydrogen peroxide added was fifteen times more $\left(1050 \mathrm{mg} \mathrm{L}^{-1}\right)$ than in the factorial design because the samples were not diluted. For this reason, the reaction time was 780 min (hydrogen peroxide consumption above $95 \%$ ). Before the tests the samples had the $\mathrm{pH}$ adjusted ( 6.5) and catalase bovine solution (1\%, Sigma) added before and after the treatment for remotion of residual $\mathrm{H}_{2} \mathrm{O}_{2}$. The bioassays with D. magna were performed in triplicate with 20 neonates organisms $(6-24 \mathrm{~h})$ that were exposed to effluent samples at concentrations of 100,50,25, 12.5 and $6.25 \%(\mathrm{v} / \mathrm{v})$ diluted in standard medium, that was used also for the control experiments. All tests were maintained at $20^{\circ} \mathrm{C}$ by $48 \mathrm{~h}$ of exposure and after that the number of immobile organisms was recorded (ABNT, 2016). The results were expressed by $50 \%$ effective concentration $\left(\mathrm{EC}_{50}\right)$ that was calculated through the Probit method and by toxic units (TU), defined as $100 / \mathrm{EC}_{50}$. The sensitivity of the organism batches was evaluated monthly with $\mathrm{KCl}$ solutions (Panreac; purity 99\%) in concentrations between $570-840 \mathrm{mg} \mathrm{L}^{-1}$. In this work, the organisms used for the bioassays presented $\mathrm{EC}_{50, \mathrm{KCl}}=710 \pm 15 \mathrm{mg} \mathrm{L}^{-1}$.

\section{RESULTS AND DISCUSSIONS}

\subsection{Characterization of the effluent samples}

The physical and chemical properties of the effluent samples (KE1 and KE2) reveal that although they originated from the same pulping process there were differences among them (Table 1). In both samples, the COD were quite similar; but there was a wide variation in the $\mathrm{BOD}_{5}$ values. The most adopted method used to quantify biodegradability is the assessment of the $\mathrm{BOD}_{5} / \mathrm{COD}$ ratio (Sarria et al., 2002). According to this, the KE2 sample $\left(\mathrm{BOD}_{5} / \mathrm{COD}=0.905\right)$ was more biodegradable than the KE1 sample $\left(\mathrm{BOD}_{5} / \mathrm{COD}=0.395\right)$ which may be related to the low phenolic content and the turbidity of KE2.

Table 1. Chemical and physical properties of Kraft effluent samples.

\begin{tabular}{|c|c|c|}
\hline Parameter & KE1 & KE2 \\
\hline pH & $10.5 \pm 0.1$ & $9.7 \pm 0.1$ \\
\hline Turbidity (FTU) & $129 \pm 0$ & $73.4 \pm 1.2$ \\
\hline True color $(440 \mathrm{~nm})$ & $0.4144 \pm 0.0005$ & $0.4560 \pm 0.0007$ \\
\hline Apparent color $(440 \mathrm{~nm})$ & $0.7261 \pm 0.0001$ & $0.6070 \pm 0.0002$ \\
\hline $\mathrm{BOD}_{5}\left(\mathrm{mg} \mathrm{L}^{-1} \mathrm{O}_{2}\right)$ & $414 \pm 39$ & $971 \pm 93$ \\
\hline $\operatorname{COD}\left(\mathrm{mg} \mathrm{L}^{-1} \mathrm{O}_{2}\right)$ & $1047 \pm 21$ & $1073 \pm 1$ \\
\hline $\operatorname{DOC}\left(\mathrm{mg} \mathrm{L}^{-1} \mathbf{C}\right)$ & $316 \pm 7$ & $308 \pm 15$ \\
\hline Total phenolics (mg L L Lallic acid) $^{-1}$ & $83.6 \pm 2.8$ & $75.8 \pm 1.7$ \\
\hline Lignin compounds $(280 \mathrm{~nm}) *$ & $0.4944 \pm 0.0001$ & $0.4811 \pm 0.0003$ \\
\hline Spectral area $(200-800 \mathrm{~nm}) *$ & $106.40 \pm 3.56$ & $108.89 \pm 5.45$ \\
\hline Alkalinity (mg L $\left.{ }^{-1} \mathrm{CaCO}_{3}\right)$ & $40.1 \pm 0.9$ & $46.4 \pm 1.1$ \\
\hline
\end{tabular}

$*$ values obtained from diluted sample (factor $=15)$.

\subsection{Experimental design}

The effect of $\mathrm{pH}$ variation and hydrogen peroxide concentration on the performance of the $\mathrm{UV} / \mathrm{H}_{2} \mathrm{O}_{2}$ process was initially evaluated on the KE1 sample (Table 2). The central point (exp. 5) was assayed in triplicate and demonstrated a satisfactory repeatability among experiments (mean SD = 2.67). The results indicated low reduction of the apparent color in all conditions tested, except for the DOC and UV-vis spectral area best results were reached in acidic media and with high peroxide concentration. 
Table 2. Factorial design data for $\mathrm{UV} / \mathrm{H}_{2} \mathrm{O}_{2}$ process for the $\mathrm{KE} 1$ sample (reaction time $=40 \mathrm{~min}$ ).

\begin{tabular}{cccccc}
\hline \multicolumn{2}{c}{ Variable } & \multicolumn{3}{c}{ Reduction (\%) } \\
\hline $\mathbf{E x p}$ & $\mathbf{H}_{\mathbf{2}} \mathbf{O}_{2} /\left(\mathbf{m g ~ \mathbf { ~ } ^ { - 1 }}\right)$ & $\mathbf{p H}$ & Apparent Color & DOC & UV-vis Spectral area \\
\hline $\mathbf{1}$ & 50 & 4 & 23.12 & 62.85 & 56.76 \\
$\mathbf{2}$ & 70 & 4 & 41.33 & 77.45 & 71.04 \\
$\mathbf{3}$ & 50 & 8 & 21.43 & 28.44 & 45.44 \\
$\mathbf{4}$ & 70 & 8 & 22.49 & 45.58 & 45.88 \\
$\mathbf{5}^{*}$ & 60 & 6 & $24.06 \pm 3.72$ & $48.70 \pm 2.17$ & $52.14 \pm 2.12$ \\
\hline
\end{tabular}

*triplicate of central point, mean \pm standard deviation estimative (SD).

The Pareto chart (Figure 1) confirmed that an increase in the dosage of oxidant contributes significantly $(\mathrm{p}=0.95)$ to the decrease of DOC. The $\mathrm{pH}$ variation had a significant effect over the reduction of DOC and UV-vis spectral area; its increase interfered negatively in all studied parameters. This effect was not expected, since $\mathrm{H}_{2} \mathrm{O}_{2}$ have a higher absorptivity at $254 \mathrm{~nm}$ in basic $\mathrm{pH}\left(\mathrm{HO}_{2}{ }^{-}\right)$, generating more hydroxyl radicals.

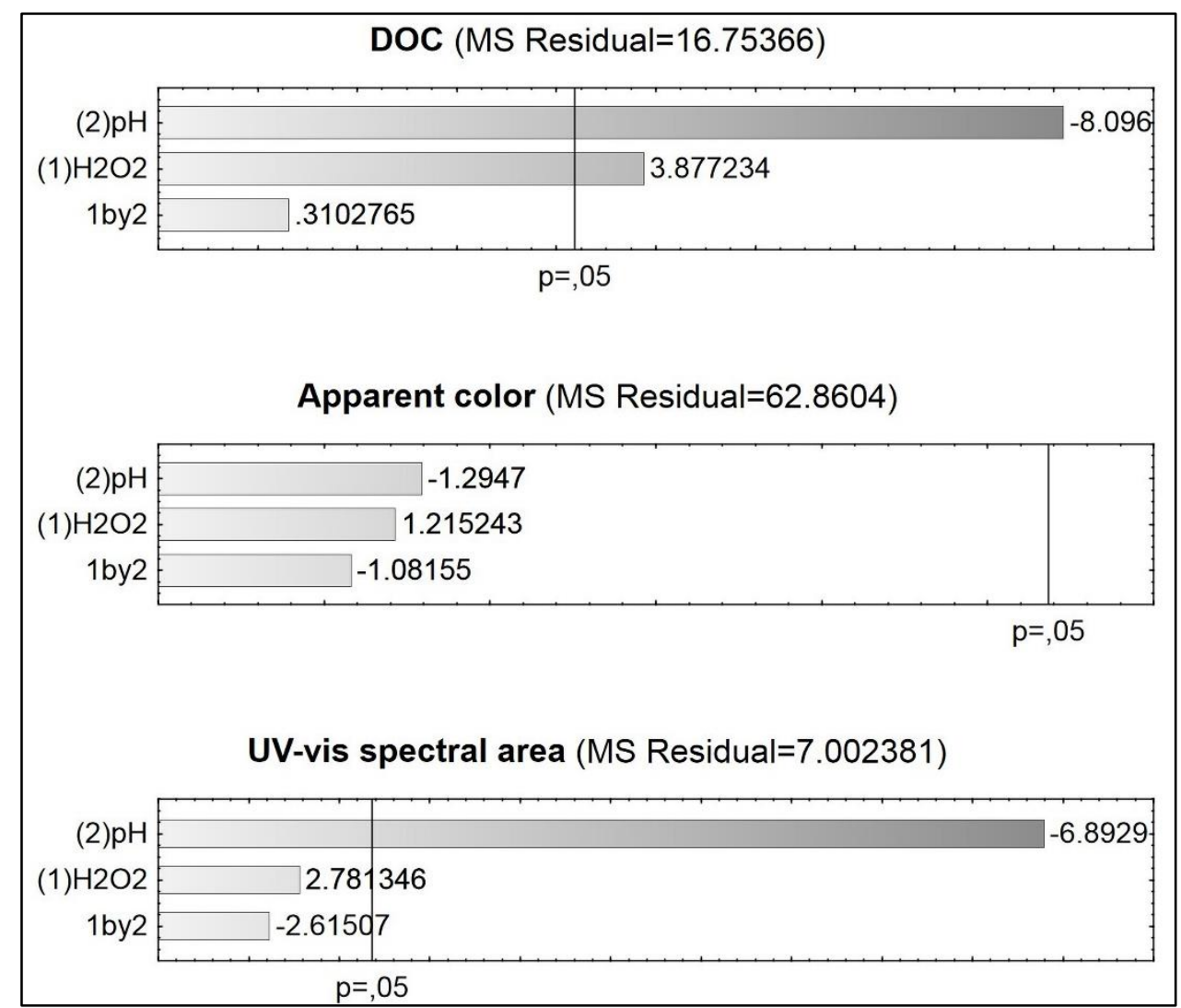

Figure 1. Main effect Pareto charts for apparent color, DOC and spectral area reductions obtained from $2^{2}$ factorial design (Standardized Effect Estimate for absolute values - $95 \%$ confidence interval).

For color removal, the low efficiency of the process can be explained by the presence of some recalcitrant compounds, such as condensed tannins which contribute to the coloration of the sample (Kamali and Khodaparast, 2015). During the oxidative process, these recalcitrant compounds are broken down into smaller chromophore fractions, reaching less-expressive results in the removal of color (Kemeny and Benerjee, 1997). No linear response explain the low correlation $\left(\mathrm{R}^{2}=0.59032\right)$ and adjustment $(0.1864)$ for this parameter in comparison to DOC $\left(R^{2}=0.96415\right.$ and adjustment $\left.=0.9283\right)$ and $U V$-vis spectral area $\left(R^{2}=0.95391\right.$ and 
adjustment $=0.90782$ ). Based on these data, the best treatment condition for KE1 was an oxidant concentration of $70 \mathrm{mg} \mathrm{L}^{-1}$ and $\mathrm{pH} 4.0$, which was then applied to the treatment of the two samples (KE1 and KE2).

\subsection{Effluent treatment by $\mathrm{UV} / \mathrm{H}_{2} \mathrm{O}_{2}$ process}

The adjusted conditions of the $\mathrm{UV} / \mathrm{H}_{2} \mathrm{O}_{2}$ reactions were applied in both effluent samples, and the process performance was evaluated through analytical parameters (Table 3). The variations in the results are probably correlated with the different chemical properties of the samples. Although the treatment was conducted under the same $\mathrm{pH}$ and oxidant concentration conditions, it is not possible to predict how the hydroxyl radicals formed will interact with the organic matter in the effluent. Such interactions are critical for color reduction as a consequence of the breakdown of conjugated double bonds, but the non-selectivity of the hydroxyl radical could affect the samples in different ways (Lee and Von Gunten, 2010). Besides that, the difference in DOC removal between the samples can be explain by the higher biodegradability of KE2 (Table 1). This indicates that this sample had a great amount of labile compounds.

Table 3. Percentual reduction of the parameters after treatment of Kraft effluent samples $\left(\left[\mathrm{H}_{2} \mathrm{O}_{2}\right]=70 \mathrm{mg} \mathrm{L}^{-1}, \mathrm{pH}=4.0\right.$, reaction time $\left.=40 \mathrm{~min}\right)$.

\begin{tabular}{lcc}
\hline \multirow{2}{*}{ Parameter } & \multicolumn{2}{c}{ Removal (\%) } \\
\cline { 2 - 3 } & KE1 & KE2 \\
\hline Turbidity & -41.8 & 0.91 \\
True color $(\mathbf{4 4 0} \mathbf{~ n m})$ & 19.4 & 69.4 \\
Apparent color $(\mathbf{4 4 0} \mathbf{~ n m})$ & 35.0 & 34.2 \\
DOC & 18.8 & 50.7 \\
Total phenolics & 79.3 & 73.7 \\
Lignin compounds $(\mathbf{2 8 0} \mathbf{~ n m})$ & 40.5 & 68.9 \\
UV-vis spectral area $(\mathbf{2 0 0 - 8 0 0} \mathbf{~ n m})$ & 49.4 & 69.9 \\
\hline
\end{tabular}

The best result was expected in the DOC removal in the KE1 sample (18.8\%), since in the literature COD reductions between $45 \%$ and $74 \%$ have been reported with AOPs applied for the treatment of pulp and paper effluents, although the largest reduction was described by combining a coagulation-flocculation process followed by heterogeneous photocatalysis (Catalkaya and Kargi, 2008; Rodrigues et al., 2008).

Satisfactory reductions of lignin compounds and total phenolics can be attributed to aromatic content in the start of the process; above those occur the electrophilic addition of hydroxyl radicals, generating new phenols in the media. Once the oxidative process continues, these formed compounds undergo the breakdown of the aromatic rings, lose their chromophoric groups and afterwards would mineralize (Tiburtius et al., 2009; Kamali and Khodaparast, 2015). Theses results indicate that higher $\mathrm{H}_{2} \mathrm{O}_{2}$ doses should be implemented to mineralize of the organic compounds.

\subsection{Acute ecotoxicity on Daphnia magna}

The bioassay with Daphnia magna is one of the most broadly used in the laboratory routine of industries to evaluate the ecotoxicity of effluent samples. The bioassays data for non-treated samples showed acute toxicity to Daphnia magna. However, for treated samples the results were quite variable for KE1 and KE2 (Table 4), once the toxicity of KE2 increased after $\mathrm{UV} / \mathrm{H}_{2} \mathrm{O}_{2}$ treatment. 
Table 4. Acute toxicity of Kraft effluent samples on D. magna before and after $\mathrm{UV} / \mathrm{H}_{2} \mathrm{O}_{2}$ process $\left(\mathrm{pH}=4.0 ;\left[\mathrm{H}_{2} \mathrm{O}_{2}\right]=1050 \mathrm{mg} \mathrm{L}^{-1}\right.$; reaction time $\left.=780 \mathrm{~min}\right)$.

\begin{tabular}{lcccc}
\hline \multirow{2}{*}{ Sample } & \multicolumn{2}{c}{ KE1 } & \multicolumn{2}{c}{ KE2 } \\
\cline { 2 - 5 } & $\begin{array}{c}\text { Before } \\
\mathbf{U V} / \mathbf{H}_{\mathbf{2}} \mathbf{O}_{\mathbf{2}}\end{array}$ & $\begin{array}{c}\mathbf{A f t e r} \\
\mathbf{U V} / \mathbf{H}_{\mathbf{2}} \mathbf{O}_{\mathbf{2}}\end{array}$ & $\begin{array}{c}\text { Before } \\
\mathbf{U V} / \mathbf{H}_{\mathbf{2}} \mathbf{O}_{\mathbf{2}}\end{array}$ & $\begin{array}{c}\text { After } \\
\mathbf{U V} / \mathbf{H}_{\mathbf{2}} \mathbf{O}_{\mathbf{2}}\end{array}$ \\
\hline $\mathbf{4 8 h}-\mathbf{E C}_{\mathbf{5 0}} \mathbf{a}^{\mathbf{a}}(\boldsymbol{\%} \mathbf{v} / \mathbf{v})$ & 132.90 & Non-toxic $^{\mathrm{b}}$ & 183.51 & 50.05 \\
$\mathbf{T U}$ & 0.752 & Non-toxic $^{\mathrm{b}}$ & 0.545 & 1.998 \\
\hline
\end{tabular}

aconcentration that cause immobilization in $50 \%$ of the test organisms; for results before treatment the values correspond to extrapolation because the effluent did not reach the $\mathrm{EC}_{50}$ index. ${ }^{b}$ no organism presented immobility at the concentrations tested.

The increase of KE2 acute toxicity after treatment could be at least partially explained by the formation of byproducts once complete mineralization has not been achieved. Previous studies suggested that the degradation of high molecular weight compounds can generate highly toxic compounds (Fernandez-Alba et al., 2002; Pereira et al., 2009). The literature suggests that lignins, tannins and resin acids are some of the major compounds in this complex kind of effluent that are responsible for the toxicity in untreated samples (Peitz and Xavier, 2017). Carvalho et al. (2009) described the production of some compounds such as p-hydroxy-phenyl, guaiacyl and syringyl when oxidation process are carried out in degradation of wood. The electrophilic addition of the hydroxyl radical to the aromatic rings of these subunits can lead to the formation of quinone and catechol derivatives (Azevedo et al., 2006). Some of similar molecules such as phenol and hydroquinone have been demonstrated high toxicity to D. magna (48 h-EC50 $=6.6 \mathrm{mg} \mathrm{L}^{-1}$ and $0.15 \mathrm{mg} \mathrm{L}^{-1}$, respectively) (Guerra, 2001). Considering that almost same removal of total phenolics were achieved for both samples, the higher toxicity may have been caused by compounds in a more advanced stage of oxidation. Once the KE2 was a more biodegradable sample, the byproducts formed in the oxidation process grew abundant enough to increase the toxicity after treatment.

\section{CONCLUSIONS}

This study demonstrates that the physical and chemical measures are not sufficient to evaluate the effectiveness of the oxidative treatment of effluent samples of a Kraft pulp mill. Moreover, it was possible to verify that each batch of these complex effluents should be considered a particular case and require additional performance criteria, such as toxicity monitoring. In the same way as in this study, the application of reactional parameters obtained by factorial planning in a preliminary sample on other similar effluent can result in an increase of toxicity due to the partial oxidation of organic compounds.

\section{ACKNOWLEDGEMENTS}

The authors would like to thank CNPq for financial support.

\section{REFERENCES}

ABNT. NBR 12713: Aquatic Ecotoxicology - Acute Toxicity - Method of Daphnia spp assay (Crustacea, Cladocera). Rio de Janeiro, 2016.

ALHARBI, S. K.; KANG, J.; NGHIEM, L. D.; MERWE, J. P.; LEUSCH, F. D. L.; PRICE, W. E. Photolysis and $\mathrm{UV} / \mathrm{H}_{2} \mathrm{O}_{2}$ of diclofenac, sulfamethoxazole, carbamazepine, and trimethoprim: identification of their major degradation products by ESI-LC-MS and assessment of the toxicity of reaction mixtures. Process Safety and Environmental Protection, v. 112, p. 222-234, 2017. https://doi.org/10.1016/j.psep.2017.07.015 
ALI, M.; SREEKRISHNAN, T. R. Aquatic toxicity from pulp and paper mill effluents: a review. Advances in Environmental Research, v. 5, n. 2, p. 175-196, 2001. https://doi.org/10.1016/S1093-0191(00)00055-1

APHA; AWWA; WEF. Standard Methods for the Examination of Water and Wastewater. 22th ed. Washington DC, 2012.

ASHRAFI, O.; YERUSHALMI, L.; HAGHIGHAT, F. Wastewater treatment in the pulp-andpaper industry: a review of treatment processes and the associated greenhouse gas emission. Journal of Environmental Management, v. 158, p. 146-157, 2015. https://doi.org/10.1016/j.jenvman.2015.05.010

AZEVEDO, E. B.; AQUINO NETO, F. R.; DEZOTTI, M. Lumped kinetics and acute toxicity of intermediates in the ozonation of phenols in saline media. Journal of Hazardous Materials, v.128, n.2-3, p. 182-191, 2006. https://doi.org/10.1016/j.jhazmat.2005.07.058

CARVALHO, W.; CANILHA, L.; FERRAZ, A.; MILAGRES, A. M. F. Uma visão sobre estrutura, composição e degradação da madeira. Química Nova, v. 32, n. 8, p. 2191-2195, 2009. https://doi.org/10.1590/S0100-40422009000800033

CATALKAYA, E. C.; KARGI, F. Advanced oxidation treatment of pulp mill effluent for TOC and toxicity removals. Journal of Environmental Management, v. 87, p. 396-404, 2008. https://doi.org/10.1016/j.jenvman.2007.01.016

ÇEÇEN, F. Investigation of substrate degradation and nonbiodegradable portion in several pulp bleaching wastes. Water Science and Technology, v. 40, p. 305-312, 1999.

DEL MORO, G. D.; MANCINI, A.; MASCOLO, G.; IACONI, C. D. Comparison of UV/ $\mathrm{H}_{2} \mathrm{O}_{2}$ based AOP as an end treatment or integrated with biological degradation for treating landfill leachates. Chemical Engineering Journal, v. 218, p. 133-137, 2013. https://doi.org/10.1016/j.cej.2012.12.086

FERNANDÉZ-ALBA, A. R.; HERNANDO, D.; AGÜERA, A.; CÁCERES, J.; MALATO, S. Toxicity assays: a way for evaluating AOPs efficiency. Water Research, v.36, p.42554262, 2002. https://doi.org/10.1016/S0043-1354(02)00165-3

GUERRA, R. Ecotoxicological and chemical evaluation of phenolic compounds in industrial effluents. Chemosphere, v. 44, n. 8, p.1737-1747, 2001. https://doi.org/10.1016/S00456535(00)00562-2

KAMALI, M.; KHODAPARAST, Z. Review on recent developments on pulp and paper mill wastewater treatment. Ecotoxicology and Environmental Safety, v. 114, p. 326-342, 2015. https://doi.org/10.1016/j.ecoenv.2014.05.005

KEMENY, T. E.; BANERJEE, S. Relationships among effluent constituents in bleached kraft pulp mills. Water Research, v. 31, p. 1589-1594, 1997. https://doi.org/10.1016/S00431354(96)00397-1

LEE, Y.; Von GUNTEN, U. Oxidative transformation of micropollutants during municipal wastewater treatment: comparison of kinetic aspects of selective (chlorine, chlorine dioxide, ferrate VI, and ozone) and non-selective oxidants (hydroxyl radical). Water Research, v. 44, p.555-, 2010. https://doi.org/10.1016/j.watres.2009.11.045 
MALATO, S.; FERNÁNDEZ-IBÁÑEZ, P.; MALDONADO, M. I.; BLANCO, J.; GERNJAK, W. Decontamination and disinfection of water by solar photocatalysis: recent overview $\begin{array}{llllllll}\text { and trends. Catalysis Today, v. 147, n. 1, p. } 1-59, & 2009 .\end{array}$ https://doi.org/10.1016/j.cattod.2009.06.018

MERAYO, N.; HERMOSILLA, D.; BLANCO, L.; CORTIJO, L.; BLANCO, A. Assessing the application of advanced oxidation processes, and their combination with biological treatment, to effluents from pulp and paper industry. Journal of Hazardous Materials, v. 262, p. 420-427, 2013. https://doi.org/10.1016/j.jhazmat.2013.09.005

MOSER, P. B.; RICCI, B. C.; REIS, B. G.; NETA, L. S. F.; CERQUEIRA, A.C.; AMARAL, M. C. S. Effect of MBR- $\mathrm{H}_{2} \mathrm{O}_{2} / \mathrm{UV}$ Hybrid pre-treatment on nanofiltration performance for the treatment of petroleum refinery wastewater. Separation and Purification Technology, v. 192, p. 176-184, 2018. https://doi.org/10.1016/j.seppur.2017.09.070

NOGUEIRA, R. F. P.; OLIVEIRA, M.C.; PATERLINI, W. C. Simple and fast spectrophotometric determination of $\mathrm{H}_{2} \mathrm{O}_{2}$ in photo-Fenton reactions using metavanadate. Talanta, v. 66, p. 86-91, 2005. https://doi.org/10.1016/j.talanta.2004.10.001

OLLER, I.; MALATO, S.; SÁNCHEZ-PÉREZ, J. A. Combination of advanced oxidation processes and biological treatments for wastewater decontamination--a review. Science $\begin{array}{llllll}\text { of Total Environment, } & \text { v.409, p.4141- 4166, } 2011 .\end{array}$ https://doi.org/10.1016/j.scitotenv.2010.08.061

PEITZ, C.; XAVIER, C. R. Treatment by moving bed biofilm reactor of Kraft effluent containing phytosterols. Interciência, v. 42, n. 8, p. 536-541, 2017.

PEREIRA, R.; ANTUNES, S. C.; GONÇALVES, A. M. M.; MARQUES, S. M.; GONÇALVEZ, F.; FERREIRA, F.; FREITAS, A. C.; ROCHA-SANTOS, T. A. P.; DINIZ, M. S.; CASTRO, L.; PRES, I.; DUARTE, A. C. The effectiveness of a biological treatment with Rhizopus oryzae and of a photo-Fenton oxidation in the mitigation of toxicity of a bleached kraft pulp mill effluent. Water Research, v.43, p.2471-2480, 2009. https://doi.org/10.1016/j.watres.2009.03.013

RIZZO, L. Bioassays as a tool for evaluating advanced oxidation processes in water and wastewater treatment. Water Research, v.45, p.4311-4340, 2011. https://doi.org/10.1016/j.watres.2011.05.035

RODRIGUES, A. C.; BOROSKI, M.; SHIMADA, N. S.; GARCIA, J. C.; NOZAKIM, J.; HIOKA, N. J. Treatment of paper pulp and paper mill wastewater by coagulationflocculation followed by heterogeneous photocatalysis. Journal of Photochemical and $\begin{array}{llllll}\text { Photobiology A: } & \text { Chemistry, } & \text { v. 194, }\end{array}$ https://doi.org/10.1016/j.jphotochem.2007.07.007

RUEDA-MÁRQUEZ， J. J.; SILLANPÄÄ, M.; POCOSTALES， P.; ACEVEDO, A.; MANZANO, M. A. Post-treatment of biologically treated wastewater containing organic contaminants using a sequence of $\mathrm{H}_{2} \mathrm{O}_{2}$ based advanced oxidation processes: photolysis and catalytic wet oxidation. Water Research, v. 71, p. 85-96, 2015. https://doi.org/10.1016/j.watres.2014.12.054

SARRIA, V.; PARRA, S.; NEVENKA, A.; PÉRINGER, P.; BENITEZ, N.; PULGARIN, C. Recent developments in the coupling of photoassisted and aerobic biological processes for the treatment of bio recalcitrant compounds. Catalysis Today, v. 76, p. 301, 2002. https://doi.org/10.1016/S0920-5861(02)00228-6 
SAVANT, D. V.; ABDUL-RAHMAN, R.; RANADE, D. R. Anaerobic degradation of adsorbable organic halides (AOX) from pulp and paper industry wastewater. Bioresource Technology. v. 97, p. 1092-1104, 2006. https://doi.org/10.1016/j.biortech.2004.12.013

SILVA, D. A.; CAVALCANTE, R. P.; CUNHA, R. F.; MACHULEK, A.; OLIVEIRA S. C. Optimization of nimesulide oxidation via a $\mathrm{UV}-\mathrm{ABC} / \mathrm{H}_{2} \mathrm{O}_{2}$ treatment process: Degradation products, ecotoxicological effects, and their dependence on the water matrix. $\begin{array}{lllll}\text { Chemosphere, } & \text { v. } & 207, & \text { p. } & 457-468,\end{array}$ https://doi.org/10.1016/j.chemosphere.2018.05.115

TIBURTIUS, E. R. L.; PERALTA-ZAMORA, P.; EMMEL, A. Degradação de benzeno, tolueno e xilenos em águas contaminadas por gasolina, utilizando-se processos fotoFenton. Química Nova, v.32, p.2058-2063, 2009. https://doi.org/10.1590/S010040422009000800014 


Ambiente \& Água - An Interdisciplinary Journal of Applied Science
ISSN 1980-993X - doi:10.4136/1980-993X
www.ambi-agua.net
E-mail: ambi.agua@gmail.com

\title{
The importance of climate scenarios in setting the productivity indexes in the Pampa Arenosa sub-region of the province of Buenos Aires, Argentina
}

\author{
ARTICLES doi:10.4136/ambi-agua.2286 \\ Received: 04 Jun. 2018; Accepted: 18 Dec. 2018 \\ Silvia Patricia Pérez ${ }^{1 *}$; Julieta Irigoin ${ }^{2}$; \\ Mariano Tomás Cassani ${ }^{3}$; ; Marcelo Juan Massobrio $^{3}$ (id \\ ${ }^{1}$ Universidad de Buenos Aires (UBA), Buenos Aires, Argentina \\ Facultad de Agronomía (FAUBA). Departamento de Recursos Naturales y Ambiente. \\ E-mail: perezgrima@gmail.com \\ ${ }^{2}$ Instituto Nacional de Tecnología Agropecuaria (INTA), Hurlinghan, Buenos Aires, Argentina \\ Instituto de Suelos (IS). E-mail: irigoin.julieta@inta.gob.ar \\ ${ }^{3}$ Universidad de Buenos Aires (UBA), Buenos Aires, Argentina \\ Facultad de Agronomía (FAUBA). Departamento de Ingeniería Agrícola y Uso de la Tierra. \\ E-mail: mcassani@agro.uba.ar, massobri@agro.uba.ar \\ *Corresponding author
}

\begin{abstract}
Starting in the 1970's, the Pampa Arenosa sub-region experienced an increasing water regime that generated an increased area for dryland farming. With increasing agricultural activity, examining the land is an essential strategic tool for its planning. The objective of this work was to highlight the importance of considering several climate scenarios when setting the productivity index in the sector of longitudinal dunes in the Pampa Arenosa sub-region in the province of Buenos Aires, Argentina. The climate scenarios were set in relation to the shifts in average rain values, according to the Pettitt Test. The land were classified according to their productivity index. It was found that the productivity index of the land increased with the rain, reaching its highest value in the period right after the abrupt shift. Land of moderate productive capacity whose productivity index values are between 65 and 51 comprised the majority of the area of our study.
\end{abstract}

Keywords: agro climatology, land evaluation, Pettitt test, rainfall.

\section{Importância dos cenários climáticos na determinação de índices de produtividade na sub-região Pampa Arenosa da província de Buenos Aires, Argentina}

\section{RESUMO}

A partir da década de 70, a sub-região Pampa Arenosa experimentou um aumento no seu regime de água, o que permitiu o crescimento da área dedicada à agricultura de secas. Em vista da intensificação da atividade agrícola, uma avaliação da terra é uma ferramenta estratégica essencial para o planejamento. O objetivo do trabalho foi destacar a importância de considerar diferentes cenários climáticos, na determinação do Índice de Produtividade, no setor de dunas longitudinais da sub-região Pampa Arenosa na Província de Buenos Aires, Argentina. Os 
cenários climáticos foram estabelecidos de acordo com as mudanças nos valores médios de precipitação, pelo teste Pettitt. As terras foram classificadas pelo índice de produtividade. Verificou-se que o índice de produtividade do solo aumentou com o aumento da precipitação, atingindo sua máxima expressão climática no período após a mudança abrupta. As terras de capacidade produtiva moderada com valores de Índice de Produtividade entre 65-51 ocuparam a maior área da área de estudo.

Palavras-chave: agroclimatologia, avaliação da terra, precipitação, teste de Pettitt.

\section{INTRODUCTION}

The Pampa region, located in the east-central part of the country $\left(30^{\circ} \mathrm{S}-40^{\circ} \mathrm{S}\right.$ y $56^{\circ} \mathrm{O}-$ $65^{\circ} \mathrm{O}$ ), is Argentina's main agricultural area. The Pampa Region has a humid temperate climate (Cf in the Köppen-Geiger classification, as revised by Kottek et al., 2006). East winds predominate, driven by a semi-permanent anticyclone from the coast of Brazil. After being drawn across the Brazilian coastline, maritime subtropical air moves southeast, reaching up to $40^{\circ}$ latitude in summer and about $30^{\circ}$ latitude in winter. In this way, the Pampa Region receives sea winds throughout the year, with a moisture gradient decreasing from east to west (Pérez et al., 2015).

Several studies indicate that the westward advance of the agricultural frontier in the Pampas during the last quarter of the twentieth century (Viglizzo et al., 1995) was partly a consequence of increased rainfall (Castañeda and Barros 1994; Pérez et al., 2011; 2015; Pérez and Sierra 2012). This increase in precipitation acted synergistically with an increasing demand from international markets (Trigo, 2005) and technological innovations (Satorre, 2005).

Some authors believe that the above-mentioned increase in rainfall is permanent. They attribute it to increased energy in the climate system caused by global warming. In their view, this has led to an increased thermal regime throughout the country, affecting the whole of its climate (Carril et al., 1997; Minetti et al., 2003; Barros, 2004). In contrast, others (Suriano and Ferpozzi, 1993; Roberto et al., 1994; Pérez et al., 2003; 2011; Sierra and Pérez, 2006, Pérez et $a l ., 2015)$ suggest that these changes are reversible. In their view, the Pampas have a long-term water cycle with wet and dry phases separated by transition periods during which the agricultural frontier either advances or retreats.

Starting in the 1970's, the Pampa Arenosa sub-region experienced an increasing water regime that generated an increasing area for dryland farming.

With increasing agricultural activity, examining the land becomes an essential strategic tool for its planning.

Several methods are used when creating land evaluation systems in terms of adaptability and/or vulnerability (De la Rosa et al., 2004). In Argentina, the most frequent quantitative indirect classification is the productivity index (PI). This system was developed initially by FAO (Riquier et al., 1970) and adopted by the National Institute of Agricultural Technology (in Spanish, Instituto Nacional de Tecnología Agropecuaria) according to the local agroecological conditions. The productivity index relates the property values or levels that have some influence on land productivity (Irigoin, 2011).

The objective of this work was to highlight the importance of considering several climate scenarios when setting the productivity index in the sector of longitudinal dunes in the Pampa Arenosa sub-region in the province of Buenos Aires, Argentina. 


\section{MATERIAL AND METHODS}

The area of study comprises the second-level administrative subdivisions of Nueve de Julio, Carlos Casares, Pehuajó and Trenque Lauquen, which are located in the province of Buenos Aires, Argentina, in the sector of longitudinal dunes of the Pampa Arenosa sub-region. Annual rainfall data from four towns in the Pampa Arenosa sub-region for the period 19182011 was used (Table 1). Data was provided by the National Weather Service and the National Institute of Agricultural Technology.

The homogeneity of the precipitation series was tested using Alexandersson and Moberg's (1997) Standard Normal Homogeneity Test (SNHT) on AnClim software (Štěpánek, 2006). The test was applied to series of annual values, using the average annual rainfall of each subregion as a reference series.

Table 1. Locations of towns in the Pampa Arenosa sub-region.

\begin{tabular}{lccc}
\hline Town/City & Latitude $(\mathbf{S})$ & Longitude $(\mathbf{W})$ & Altitude $(\mathbf{m s l})$ \\
\hline Nueve de Julio & $35^{\circ} 27^{\prime}$ & $60^{\circ} 53^{\prime}$ & 76 \\
Carlos Casares & $35^{\circ} 55^{\prime}$ & $61^{\circ} 20^{\prime}$ & 88 \\
Pehuajó & $35^{\circ} 48^{\prime}$ & $61^{\circ} 54^{\prime}$ & 85 \\
Trenque Lauquen & $35^{\circ} 58^{\prime}$ & $62^{\circ} 43^{\prime}$ & 80 \\
\hline
\end{tabular}

With the homogeneous precipitation series of each town, shifts in the average values were found using the Pettitt test. The climate scenarios were defined using the temporal series of rainfall for the periods before and after the shifts in the average values, identified as the dry period (DP) and the humid period (HP), respectively.

The productivity index (PI) was obtained by using the changes introduced by the National Institute of Agricultural Technology (INTA) for the Pampa region (Sobral and Nakama 1988; Maccarini, 1990; Sobral et al., 2010). This parametric index comprises the following factors: Macro-climate condition (H); drain (D); effective depth (Pe); surface texture (Ta); sub-surface texture $(\mathrm{Tb})$; salinity $(\mathrm{Sa})$; sodicity $(\mathrm{Na})$; organic matter $(\mathrm{Mo})$; cation-exchange capacity $(\mathrm{T})$, current and potential water and wind erosion (E).

The quantitative expression of the productivity index is calculated by multiplying the factors listed above. This multiplication intends to highlight the influence of each factor on the final value of the index (Equation 1):

$$
\mathbf{P I}=\mathbf{H} * \mathbf{D} * \mathbf{P e} * \mathbf{T a} * \mathbf{T b} * \mathbf{S a} * \mathbf{N a} * \mathbf{M o} * \mathbf{T} * \mathbf{E},
$$

The results of the PI calculation are positive values, the highest of which is equal to 100, where the highest value represents the greater productive capacity of the land.

\subsection{Climate factor of the PI}

The climate factor $\mathrm{H}$ of the PI was calculated following the INTA methodology (Sobral and Nakama 1988; Maccarini, 1990).

The climate factor was calculated using Thornthwaite's global humidity index (Im), the soil moisture regimes (Moscatelli, 1991; Van Wambeke and Scoppa, 1980) and the $16^{\circ} \mathrm{C}$ isotherm (Table 2).

El Im (Thornthwaite, 1948; 1955) was obtained from the difference between the annual water excess (humidity index, Ih) and the deficiencies (aridity index, Ia) as the result of the water balance for maximum water storage capacity in soil of $100 \mathrm{~mm}$ and its relation with the potential evapotranspiration (ETP) estimated by Thornthwaite, where $\mathrm{Im}=(\mathrm{Ih}-\mathrm{Ia}) / \mathrm{ETP}$

\section{IPABH}

Rev. Ambient. Água vol. 14 n. 2, e2286 - Taubaté 2019 
(Castellví Sentí and Castillo, 2001). The value for Im for the area as a whole was obtained from the average of the value for Im for each area.

Table 2. Conversion of climate characteristics into coefficient $\mathrm{H}$ values (Macroclimate condition) (Maccarini 1990).

\begin{tabular}{ccc}
\hline $\begin{array}{c}\text { Global humidity index } \\
(\mathbf{I m})\end{array}$ & $\begin{array}{c}\text { Average annual temperature } \\
\left({ }^{\circ} \mathbf{C}\right)\end{array}$ & $\begin{array}{c}\text { Macro-climate condition } \\
(\mathbf{H})\end{array}$ \\
\hline 10 & $\geq 16$ & 100 \\
10 to 0 & $\geq 16$ & 95 \\
0 to -10 & $\geq 16$ & 90 \\
-10 at ustic/aridic & $\geq 16$ & 75 \\
\hline
\end{tabular}

\subsection{Edaphics factors of the PI}

The edaphic information for the different factors that make up the PI is the following: drain, alkalinity, salinity, texture, cation-exchange capacity, content of organic matter, current and potential water and wind erosion. All this data was obtained from soil charts (INTA, 1990).

The PI value was obtained for each taxonomic unit defined at a series level, from the use of conversion tables (Irigoin, 2011), where each edaphic factor participating in the parametric equation is classified into categories or ranges with their respective coefficients with values between 0 and 1 (Sobral et al., 2010, Sobral and Nakama, 1988).

The PI value of the cartographic unit was calculated by weighing the PI values of each taxonomic unit and in relation to the percentage of area covered by each of them.

The PI values of the cartographic units were divided into six productive categories: very high (>80), high (80-66), moderate (65-51), moderately low (50-36), low (35-20) and very low (<20) (Irigoin, 2011).

\section{RESULTS AND DISCUSSION}

\subsection{Homogeneity Test}

According to the Homogeneity Test (SNHT), two of the annual precipitation series available (Table 3) showed a T value lower than the critical value (Khaliq and Quarda, 2007), and can be considered homogeneous at the level of significance $\alpha=0.05$. The other two series showed $\mathrm{T}$ values higher than the critical value and were thus considered non-homogeneous. For the analysis, the non-homogeneous series were adjusted according to the method proposed by Alexandersson (1986).

Table 3. Test results of the SNHT applied to annual precipitation series for the Pampa Arenosa sub-region.

\begin{tabular}{lcccc}
\hline Town/City & Shift year & T Value & Adjusted shift year & Adjusted T value \\
\hline Nueve de Julio & 1984 & 7.107 & & \\
Carlos Casares & 2010 & 4.157 & & \\
Pehuajo & 1935 & $10.747 *$ & 1954 & 2.191 \\
Trenque Lauquen & 1972 & $14.080 *$ & 2010 & 4.647 \\
\hline
\end{tabular}

(* indicates that the $\mathrm{T}$ value exceeds $95 \%$ ).

\subsection{Pettitt Test}

The shifts in the values of the annual precipitation average according to the Pettitt Test (Pettitt, 1979) (Table 4) were produced in 1962 and 1965, thus defining the dry scenarios, before the shift (1918-1962/65) and wet, after the shift (1962/65-2005). 
Table 4. Results after the Pettitt Test for the annual precipitation of the Pampa Arenosa subregion.

\begin{tabular}{lccc}
\hline Town/City & Shift year & $\begin{array}{c}\text { Average annual rainfall (mm) } \\
\text { Before the shift }\end{array}$ & $\begin{array}{c}\text { Rainfall increase (\%) } \\
\text { After the shift }\end{array}$ \\
\hline Nueve de Julio & 1962 & 893 & 16.8 \\
Carlos Casares & 1965 & 787 & 22.5 \\
Pehuajo & 1965 & 820 & 19.3 \\
Trenque Lauquen & 1962 & 708 & 38.3 \\
\hline
\end{tabular}

The average of Nueve de Julio (Figure 1) showed a positive abrupt change, with the average annual precipitation rising from $893 \mathrm{~mm}$ during the 1918-1962 sub-period, to $1043 \mathrm{~mm}$ during the 1963-2011 sub-period.

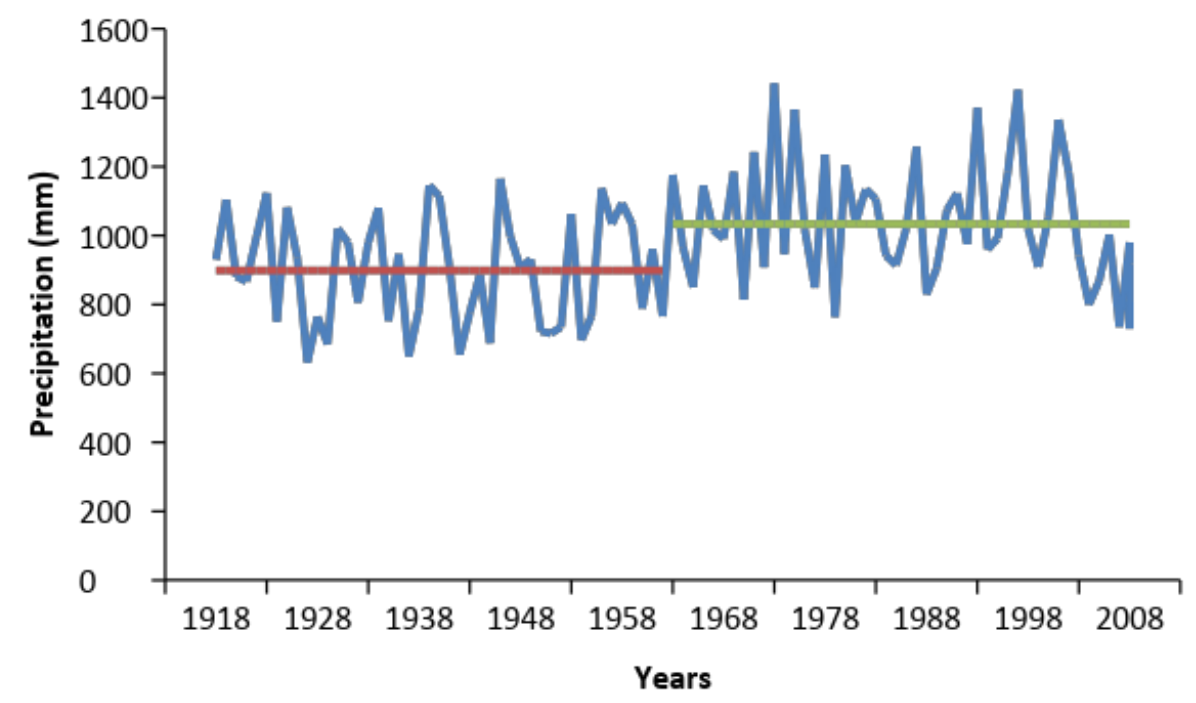

Figure 1. Annual precipitation and means for sub-periods in the Nueve de Julio by Pettitt's method.

The average of Carlos Casares (Figure 2) showed a positive abrupt change, with the average annual precipitation rising from $787 \mathrm{~mm}$ during the 1918-1965 sub-period, to $964 \mathrm{~mm}$ during the 1966-2011 sub-period.

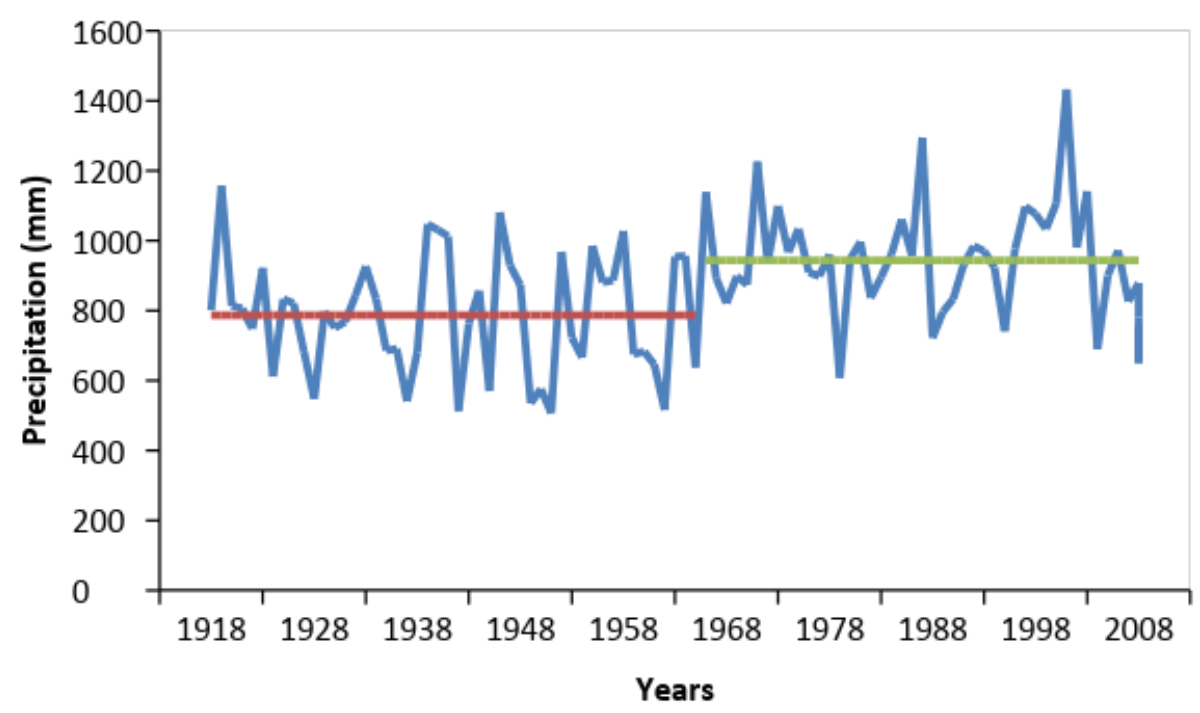

Figure 2. Annual precipitation and means for sub-periods in the Carlos Casares by Pettitt's method.

\section{IPABH}

Rev. Ambient. Água vol. 14 n. 2, e2286 - Taubaté 2019 
The average of Pehuajo (Figure 3) showed a positive abrupt change, with the average annual precipitation rising from $820 \mathrm{~mm}$ during the 1918-1965 sub-period, to $978.2 \mathrm{~mm}$ during the 1966-2011 sub-period.

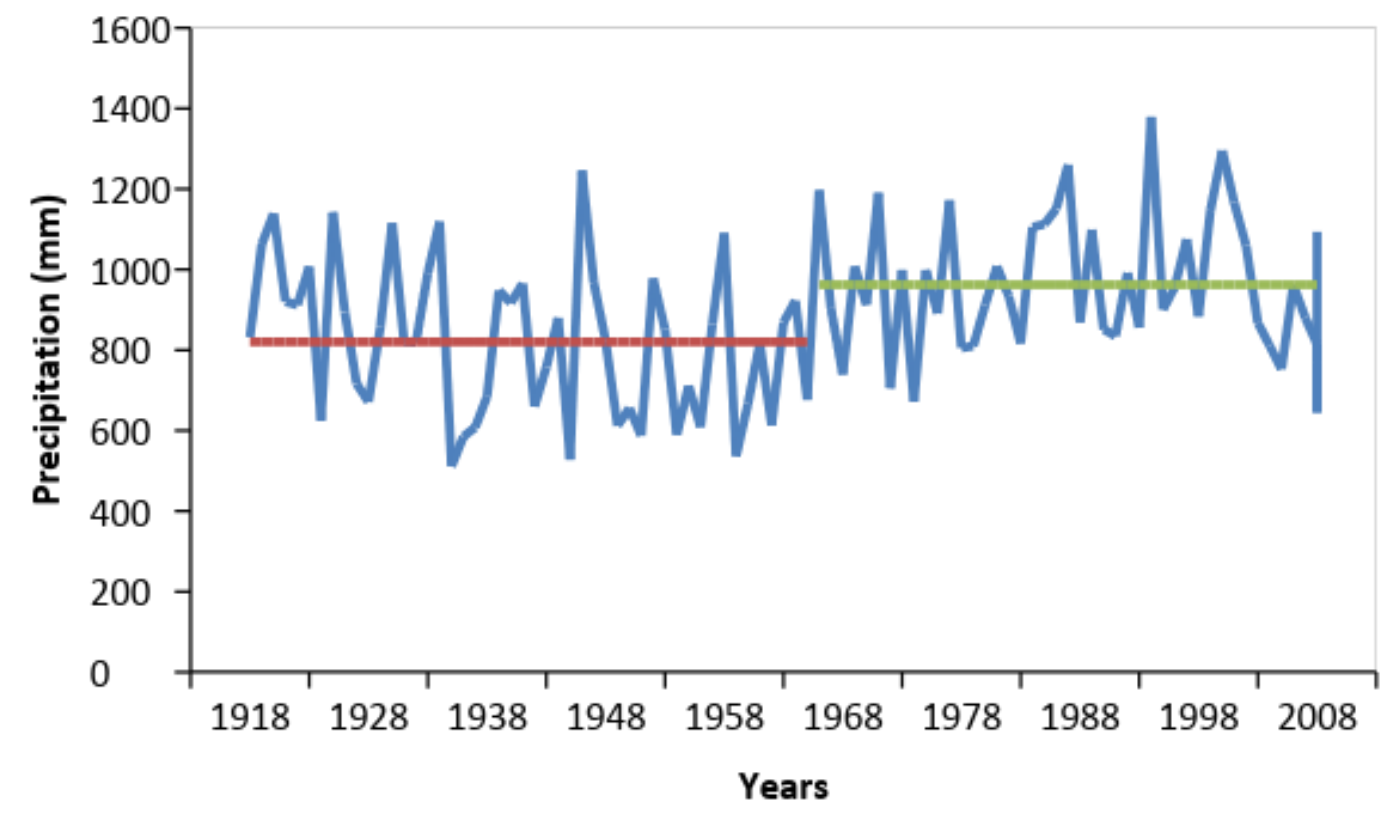

Figure 3. Annual precipitation and means for sub-periods in the Pehuajo by Pettitt's method

The average of Trenque Lauquen (Figure 4) showed a positive abrupt change, with the average annual precipitation rising from $708 \mathrm{~mm}$ during the 1918-1962 sub-period, to $979.2 \mathrm{~mm}$ during the 1963-2011 sub-period.

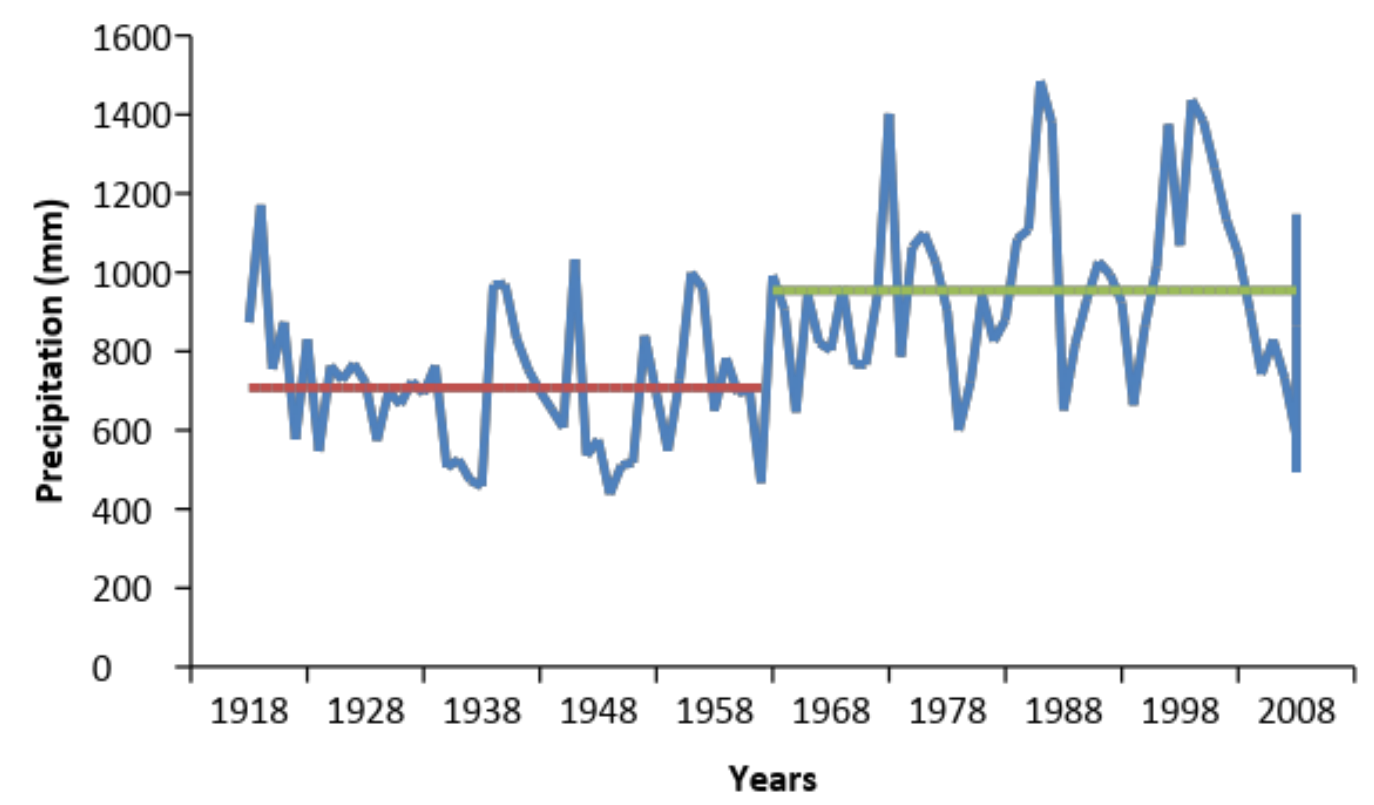

Figure 4. Annual precipitation and means for sub-periods in the Trenque Lauquen by Pettitt's method.

\subsection{Productivity Index}

Table 5 shows the productivity indices in the sector of longitudinal dunes in the Pampa Arenosa sub-region in the province of Buenos Aires, Argentina. In the study area, 
approximately 458,700 hectares have values of productivity index between 65 and 51, indicating that these lands have some type of permanent limitations for the production of common crops. On the other hand, these IP values would indicate that the feasible yield to obtain will correspond between 65 and $50 \%$ of the optimum yield for the region (Sobral and Nakama, 1988). A similar area (460,720 hectares) corresponds to lands of moderately low productive capacity with IP values of 50-36. These two IP categories represent more than half of the study area, approximately $54.7 \%$. At the same time, lands with severe and very severe limitations for agriculture occupy 668,320 hectares with IP values of less than 35 .

Table 5. Classification of the lands according to the Productivity Index (PI) for the study area and for each Town/City, expressed in \% of occupation and $\mathrm{km}^{2}$.

\begin{tabular}{lccccccc}
\hline & & \multicolumn{7}{c}{ Productivity Index (PI) } \\
\hline Town/City & Occupation & $\mathbf{1 0 0 - 8 1}$ & $\mathbf{8 0 - 6 6}$ & $\mathbf{6 5 - 5 1}$ & $\mathbf{5 0 - 3 6}$ & $\mathbf{3 5 - 2 1}$ & $\mathbf{2 0 - 0}$ \\
Nueve de Julio & $\mathbf{k m}^{\mathbf{2}}$ & 88.5 & 623.1 & 1717.8 & 215.2 & 1026.2 & 614.9 \\
& $\mathbf{\%}$ & 2.1 & 14.5 & $\mathbf{4 0 . 1}$ & 5.0 & 23.9 & 14.4 \\
Carlos Casares & $\mathbf{k m}^{\mathbf{2}}$ & 0.0 & 200.0 & 830.4 & 28.3 & 943.5 & 516.5 \\
& $\mathbf{\%}^{2}$ & 0.0 & 7.9 & $\mathbf{3 3 . 0}$ & 1.1 & 37.5 & 20.5 \\
Pehuajó & $\mathbf{k m}^{2}$ & 0.0 & 3.4 & 1312.6 & 1381.7 & 740.6 & 1081.8 \\
& $\mathbf{\%}_{\text {Trenque Lauquen }}$ & 0.0 & 0.1 & $\mathbf{2 9 . 0}$ & $\mathbf{3 0 . 6}$ & 16.4 & 23.9 \\
& $\mathbf{k m}^{2}$ & 0.0 & 0.0 & 726.2 & 2982.0 & 1340.1 & 419.6 \\
Study area & $\mathbf{\%}^{\mathbf{2}}$ & 0.0 & 0.0 & 13.3 & $\mathbf{5 4 . 5}$ & 24.5 & 7.7 \\
& $\mathbf{k m}^{2}$ & 88.5 & 826.5 & 4587.0 & 4607.2 & 4050.4 & 2632.8 \\
& $\mathbf{\%}$ & 0.5 & 4.8 & $\mathbf{2 7 . 3}$ & $\mathbf{2 7 . 4}$ & 24.1 & 15.7 \\
\hline
\end{tabular}

According to the PI values for both climate scenarios and their location, we can observe a shift in the productivity of the land as the consequence of shifts in the climate factor.

The PI weighted average obtained for the period right after the abrupt shift for the Nueve de Julio area was 48.5, for Carlos Casares was 43.7, for Pehuajó was 39.9 and for Trenque Lauquen was 46.1 (Figure 5). On the other hand, the PI values for the period before were 39.4, $36.1,36.9$ and 34.4 , respectively, according to the transect of these areas, from East to West (Figure 6).

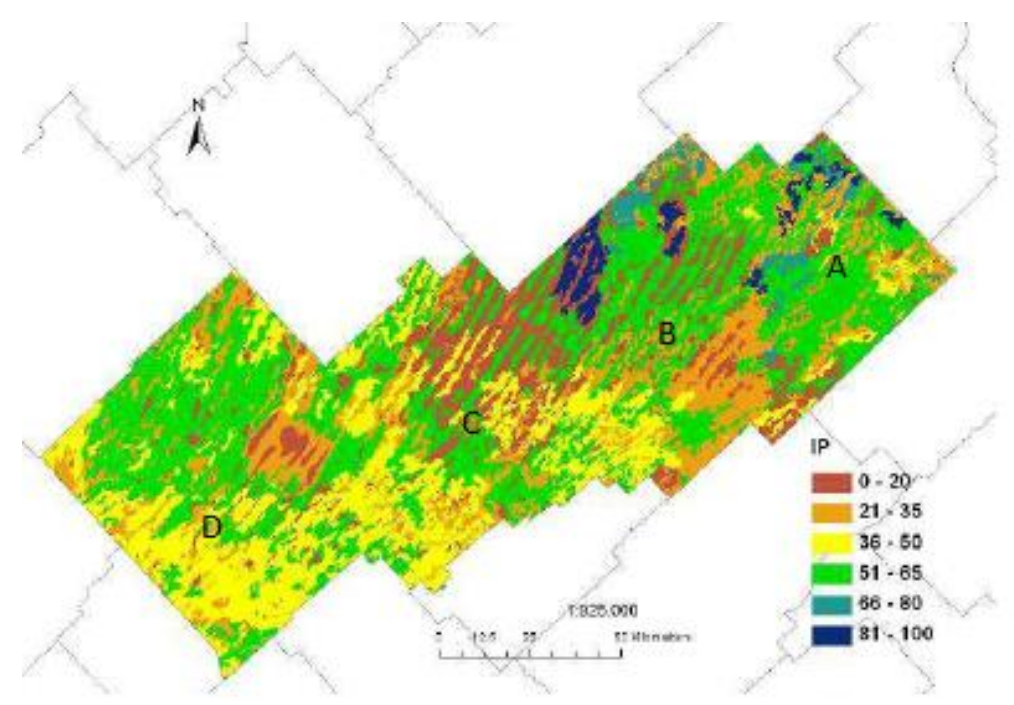

Figure 5. Distribution pattern of the classes of productivity index of the land (PI) for the period after the abrupt shift in the area of Nueve de Julio (A), Carlos Casares (B), Pehuajó (C) and Trenque Lauquen (D). 


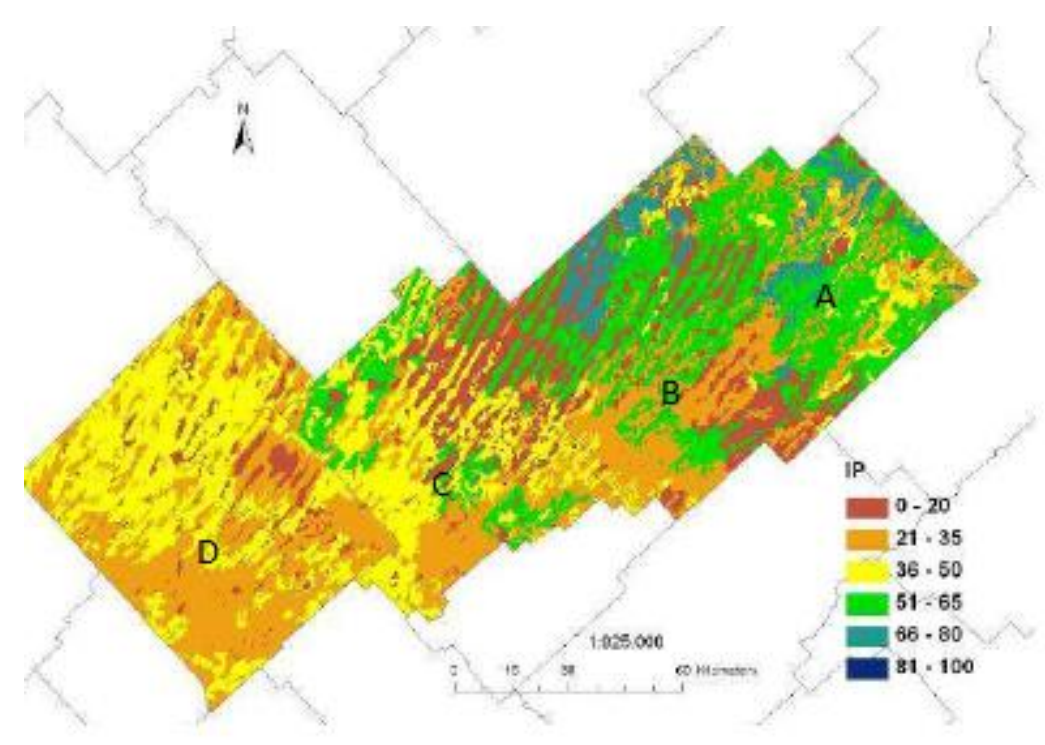

Figure 6. Distribution pattern of the classes of productivity index of the land (PI) for the period before the abrupt shift in the area of Nueve de Julio (A), Carlos Casares (B), Pehuajó (C) and Trenque Lauquen (D).

In this way, the land resulted of moderately low productive capacity (50-36), both for the period after the abrupt shift and for the period before, thus showing that such land has permanent edaphic limitations for the production of conventional crops. The productivity index is interpreted as a proportion of the potential maximum yield of the most common crops in the region, eco-typically adapted, under a determined level of management.

\section{CONCLUSION}

The Pettitt Test (Pettitt, 1979), applied to the annual precipitation series of the Pampa Arenosa sub-region, showed that the sub-region had abrupt positive shifts during the second half of the $20^{\text {th }}$ century. This sub-region was considerably affected by such shifts. Indeed, they changed from a semi-arid steppe climate (Bs in the Köppen Climate Classification System) (Köppen, 1948) during dry phases to a dry-summer subtropical climate $(\mathrm{CW}$ in the Köppen classification) during wet phases, which significantly affects agricultural capacity.

It was found that the PI of the lands increased with the rain, reaching its highest value in the period right after the abrupt shift for all the studied areas. The Trenque Lauquen area was the area most positively affected by increasing precipitation.

\section{REFERENCES}

ALEXANDERSSON, H. A homogeneity test applied to precipitation data. International $\begin{array}{lllllllll}\text { Journal of Climatology, v. } 6, \quad \text { n. } & 6, & \text { p. } & 661-675, & 1986 .\end{array}$ https://doi.org/10.1002/joc.3370060607

ALEXANDERSSON, H.; MOBERG, A. Homogenization of Swedish temperature data. Part I: homogeneity test for linear trends. International Journal of Climatology v. 17, p. 2534, 1997. https://doi.org/10.1002/(SICI)1097-0088(199701)17:1\%3C25::AIDJOC103\%3E3.0.CO;2-J

BARROS, V. El cambio climático global. [S.1.]: Del Zorzal, 2004. 
CARRIL, A. F.; MENÉNDEZ, C. G.; NUÑEZ, M. M. Climate change scenarios over the South American region: an intercomparison of coupled general atmosphere-ocean circulation models. International Journal of Climatology, v. 17, n. 15, p. 1613-1633, 1997. https://doi.org/10.1002/(SICI)1097-0088(199712)17:15\%3C1613::AIDJOC209\%3E3.0.CO;2-8

CASTAÑEDA, M. E.; BARROS, V. Las tendencias de la precipitación en el Cono Sur de América al este de los Andes. Meteorológica, v. 19, n. 1-2, p. 23-32, 1994.

CASTELlVÍ SENTÍS, F.; CASTILlO, F. Agrometeorología. [S.1.]: Mundi-Prensa, 2001, 517 p.

DE LA ROSA, D.; MAYOL, F.; DÍAZ-PEREIRA, E.; FERNÁNDEZ, M.; DE LA ROSA, D. J. R. A land evaluation decision support system (MicroLEIS DSS) for agricultural soil protection with special reference to Mediterranen region. Environmental Modelling \& Sofware, v. 19, p. 929-942, 2004. https://doi.org/10.1016/j.envsoft.2003.10.006

INTA. Atlas de Suelos de la República Argentina. Escala 1: 500.000 y 1: 1.000.000. Tomo I y II. Proyecto PNUD ARG. 85/019. Ed. INTA, Buenos Aires Argentina. 1990, 667 p.

IRIGOIN, J. Sistemas de evaluación de tierras y elaboración de modelos de aptitud de uso agrícola, para distintos escenarios climáticos, en un sector de la subregión Pampa Arenosa (Provincia de Buenos Aires, Argentina). 2011. 160 p. Tesis (Maestría de Agronomía) - Universidad de Buenos Aires, Buenos Aires, 2011. 160 p.

KHALIQ, M. N.; QUARDA, T. B. M. J. On the critical values on the standard normal homogeneity test (SNHT). International Journal of Climatology, v. 27, p. 681-687, 2007. https://doi.org/10.1002/joc.1438

KÖPPEN, W. Climatología. Mexico: Fondo de Cultura Económica, 1948. 478 p.

KOTTEK, M.; GRIESER, J.; BECK, C.; RUDOLF, B.; RUBEL, F. World Map of the KöppenGeiger climate classification updated. Meteorologische Zeitschrift, v. 15, n. 3, p. 259263, 2006. https://doi.org/10.1127/0941-2948/2006/0130

MACCARINI, G. D. Utilización del Método de evaluación de tierras paramétrico de Bramao y Riquier y su adaptación por INTA en un sector de la Región Pampeana Húmeda. 1990. Tesis (Maestría en Ciencias del Suelo) - Escuela de Posgrado, Facultad de Agronomía, Universidad de Buenos Aires, Buenos Aires,1990.

MINETTI, J. L.; VARGAS, W. M.; POBLETE, A. G.; ACUNA, L. G.; CASAGRANDE, G. Non-linear trends and low frequency oscillations in annual precipitation over Argentina and Chile, 1931- 1999. Atmosfera, v. 16, p. 119-135, 2003.

MOSCATELLI, G. Los suelos de la Región Pampeana. In: BARSKY, O. (Ed.). EI desarrollo agropecuario pampeano. Buenos Aires: INDEC-INTA-IICA, 1991. p. 1-76.

PÉREZ, S.; SIERRA, E. M.; CASAGRANDE, G.; VERGARA, G.; BERNAL, F. Comportamiento de las precipitaciones (1918/2000) en el centro oeste de la provincia de Buenos Aires (Argentina). Revista De la Facultad de Agronomía de la Universidad Nacional de La Pampa, v. 14, n. 1-2, p. 39-46, 2003.

PÉREZ, S.; SIERRA, E.; LÓPEZ, E.; NIZZERO, G.; MOMO, F.; MASSOBRIO, M. Abrupt changes in rainfall in the Eastern area of La Pampa Province, Argentina. Theoretical and Applied Climatology, v. 103, p. 159-165, 2011. https://doi.org/10.1007/s00704-0100290-y 
PÉREZ, S.; SIERRA, E. Changes in rainfall patterns in the eastern area of La Pampa province, Argentina. Revista Ambiente \& Agua, v. 7, n. 1, p. 24-35, 2012. http://dx.doi.org/10.4136/ambi-agua.692

PÉREZ, S.; SIERRA, E.; MOMO, F.; MASSOBRIO, M. Changes in Average Annual Precipitation in Argentina's Pampa Region and Their Possible Causes. Climate, v. 3, p. 150-167, 2015. http://d.doi.org/10.3390/cli3010150

PETTITT, A. N. A non-parametric approach to the change point problem. Applied Statistics, v. 28 , n. 2, p. 126-135, 1979. http://dx.doi.org/10.2307/2346729

RIQUIER, J.; BRAMAO, L.; CORNET, S. P. A new system of soil appraisal in terms of actual and potential productivity. Roma: FAO, 1970.

ROBERTO, Z. E.; CASAGRANDE, G.; VIGLIZZO, E. Lluvias en la Pampa Central: tendencia y variaciones del siglo. Cambio Climático y Agricultura Sustentable en la Región Pampeana. Boletine INTA Centro Regional La Pampa-San Luis, n. 2, 1994.

SATORRE, E. H. Cambios tecnológicos en la agricultura argentina actual. Ciencia Hoy, v. 15, n. 87, p. 24-31, 2005.

SIERRA, E. M.; PÉREZ, S. P. Tendencia del régimen de precipitación y el manejo sustentable de los agroecosistemas: estudio de un caso en el noroeste de la provincia de Buenos Aires, Argentina. Revista de Climatología, v. 6, p. 1-12, 2006.

SOBRAL, R. E.; NAKAMA, V. Índices de productividad, método paramétrico para evaluación de tierras. In: CONGRESO ARGENTINO DE LA CIENCIA DEL SUELO, 12., 12 al 16 septiembre 1988, Corrientes. Actas [...] [S.1.]: Comisión mineralogía, génesis, clasificación y cartografía de suelos, 1988. 259 p.

SOBRAL, R. E.; NAKAMA , V.; DE ANTUENO, L. Actualización de los índices de productividad de los suelos de la provincia de Buenos Aires. In: CONGRESO ARGENTINO DE LA CIENCIA DEL SUELO, 22., 31 de mayo al 4 de Junio 2010, Rosario, Argentina. Actas [...] [S.1.]: Comisión mineralogía, génesis, clasificación y cartografía de suelos, 2010.

SURIANO, J. M.; FERPOZZI, L. H. Los cambios climáticos en la Pampa también son historia. Todo es Historia, n. 306, p. 8-25, 1993.

ŠTĔPÁNEK, P. AnClim Software for time series analysis. Masaryk: Masaryk University, 2006.

THORNTHWAITE, C. W. An approach toward a rational classification of climate. The Geografical Review, v. 38, p. 55-94, 1948. http://dx.doi.org/10.2307/210739

THORNTHWAITE, C. W; HARE, F. K. Climate classification in Forestry. Unasylva, v. 9, n. $2,1955$.

TRIGO, E. Consecuencias económicas de la transformación agrícola. Ciencia Hoy, v. 15, n. 87, p. 46-51, 2005.

VAN WAMBEKE, A.; SCOPPA, C. Las taxas climáticas de los suelos argentinos. Castelar: Intacirn, 1980.

VIGLIZZO, E. F.; ROBERTO, Z. E.; FILIPPIN, M. C.; PORDOMINGO, A. J. Climate variability and agroecological change in the Central Pampas of Argentina. Agriculture Ecosystems and Environment, v. 55, p. 7-16, 1995. https://doi.org/10.1016/01678809(95)00608-U 


Ambiente \& Água - An Interdisciplinary Journal of Applied Science
ISSN 1980-993X - doi:10.4136/1980-993X
www.ambi-agua.net
E-mail: ambi.agua@gmail.com

\title{
Adaptation of domestic effluent for agricultural reuse by biological, physical treatment and disinfection by ultraviolet radiation
}

ARTICLES doi:10.4136/ambi-agua.2292

Received: 12 Jun. 2018; Accepted: 18 Dec. 2018

\section{Andressa de Almeida Soares Oliveira ${ }^{1 *(D)}$; Reinaldo Gaspar Bastos ${ }^{2}{ }^{(D}$; Claudinei Fonseca Souza ${ }^{1}$ iD}

\author{
${ }^{1}$ Universidade Federal de São Carlos (UFSCar), Araras, SP, Brasil \\ Departamento de Recursos Naturais e Proteção Ambiental (DRNPA). \\ E-mail: dressasoares89@gmail.com,cfsouza@ufscar.br \\ ${ }^{2}$ Universidade Federal de São Carlos (UFSCar), Araras, SP, Brasil \\ Departamento de Tecnologia Agroindustrial e Socioeconomia Rural (DTAISer). \\ E-mail: reinaldo@cca.ufscar.br \\ *Corresponding author
}

\begin{abstract}
Domestic effluent reuse is an alternative for irrigated agriculture in situations of reduced water availability. However, as there is the presence of pathogens in wastewater, the disinfection process is necessary before use. This research evaluated the sanitary and agricultural viability of treated wastewater at a pilot-scale station composed of a septic tank, Wetlands and an ultraviolet radiation (UV) disinfection system. The Sewage Treatment Station (STS) is installed in the Agricultural Sciences Center, UFSCar, in Araras city, SP, and receives $2000 \mathrm{~L}$ of sewage daily, which was monitored in terms of $\mathrm{pH}$, turbidity, electrical conductivity (EC), dissolved oxygen (DO), sodium (Na), potassium (K), calcium (Ca), total nitrogen (TN), total phosphorus (TP), magnesium (Mg), total organic carbon (TOC), total coliforms (TC), Escherichia coli (E. coli) and Sodium Adsorption Ratio (SAR). The removal efficiency of the parameters was calculated based on the input and output means of each treatment unit. Results indicated removal efficiency for K $(68.2 \%)$, TN $(54.1 \%)$ and TP $(36.1 \%)$. The levels of Na (26.7\%) and $\mathrm{Ca}(22.9 \%)$ demonstrated the contribution of these salts to the wastewater; however, SAR did not present any risks for soil sodification. Microbiologically, the STS presented removal efficiency of 4 and $5 \mathrm{log}$-cycles for TC and E. coli, respectively. Therefore, results of monitoring indicate that the treated wastewater presents sanitary and agricultural viability, and conforms with the current legislation.
\end{abstract}

Keywords: nutrients, sewage, ultraviolet radiation.

\section{Adaptação de efluente doméstico para uso agrícola por tratamento biológico, físico e desinfecção por ultravioleta}

\section{RESUMO}

O reúso de efluente doméstico é uma alternativa para a agricultura irrigada em situações de reduzida disponibilidade de água. No entanto, como é comum a presença de patógenos em águas residuárias, torna-se necessário um processo de desinfecção previamente à sua utilização. Com o desenvolvimento da pesquisa, avaliou-se a viabilidade sanitária e agrícola do efluente 
doméstico tratado em Estação Piloto composta por Tanque Séptico, Wetlands e sistema de desinfecção por radiação ultravioleta (UV). A Estação de Tratamento de Esgoto (ETE) se encontra instalada no Centro de Ciências Agrárias, UFSCar, em Araras-SP, e recebe diariamente $2000 \mathrm{~L}$ de esgoto, o qual foi monitorado em termos de $\mathrm{pH}$, turbidez, condutividade elétrica $(\mathrm{CE})$, oxigênio dissolvido $(\mathrm{OD})$, sódio $(\mathrm{Na})$, potássio $(\mathrm{K})$, cálcio $(\mathrm{Ca})$, nitrogênio total (NT), fósforo total (PT), magnésio (Mg), carbono orgânico total (COT), coliformes totais (CT), Escherichia coli (E. coli) e Razão de Adsorção de Sódio (RAS). A eficiência de remoção dos parâmetros foi calculada com base nas médias de entrada e saída de cada unidade de tratamento. Os resultados apontaram remoção para K $(68,2 \%)$, NT $(54,1 \%)$ e PT $(36,1 \%)$. Os teores de Na $(26,7 \%)$ e Ca $(22,9 \%)$ demonstraram aporte desses sais ao efluente, porém, a RAS não apresentou riscos quanto à sodificação do solo. Com relação aos microbiológicos, a ETE apresentou uma remoção de 4 e 5 ciclos log para CT e E. coli, respectivamente. Sendo assim, os resultados do monitoramento indicam que o efluente tratado da ETE Piloto apresenta viabilidade sanitária e agrícola, estando de acordo com a legislação vigente.

Palavras-chave: esgoto, nutrientes, radiação ultravioleta.

\section{INTRODUCTION}

Population growth, climatic instability and increased demand for food culminated in the scarcity of water of adequate quality to irrigate agriculture (Ahmadi and Merkley, 2017). One of the strategies to ameliorate the water crisis is to invest in the reuse of effluents, which can intensify agricultural production even during off-season periods (Hespanhol, 2008).

Recycling nutrients in agriculture is a sustainable strategy since it minimizes the pollution of aquatic environments and decreases the dependence on mineral fertilizers (Pantano et al., 2016).

However, the practice of reuse with effluents requires treatment steps that are allied with its purpose and application. The most commonly used systems employed for this are septic tanks and Wetlands.

New techniques are being studied in order to improve/increase the efficiency of removal of organic matter, salts and pathogens from Septic Tanks, employing the use of anaerobic reactors filled with zeolites modified with copper (Anil and Neera, 2016) or with the installation of electrodes of stainless steel (Lin et al., 2017).

Increasingly, Wetlands are been implemented for the treatment of effluents from cleaning trucks, septic tanks, chemical toilets and even grease residues. A simple method, but one that requires caution as to its required efficiency, in order not to cause imbalances, such as low disinfection efficiency due to the inhibition of ultraviolet rays (Andrade et al., 2017).

Treatment systems are designed according to removal efficiency, thus enabling the disposal of the effluent. Souza et al. (2015) developed a pilot-scale station consisting of a septic tank, anaerobic filter, microalgae tank and Wetlands, and noted that these associated units removed part of the essential nutrients for agriculture. In addition, there was an impediment to such application: the expressive presence of bacterial from the Coliform class.

In this sense, a disinfection as tertiary treatment becomes essential, considering the high burden of pathogens usually present in domestic effluents, in order to ensure the integrity of human health (Zhou et al., 2015).

One of the options used for sewage disinfection is the application of the ultraviolet system (UV), which is based on electromagnetic radiation and wavelengths less than violet light, without the generation of by-products harmful to health or the release of residuals to the wastewater. 
Fluorescent lamps responsible for the emission of UV radiation have in their interior a tube coated with phosphorus powder containing gas (argon type) and mercury. From an electrical potential difference, the electrons fluxes collide with the mercury atoms providing the UV light, which is absorbed by the phosphorus becoming visible (Salvetti, 2008).

Microorganisms are inactivated by the action of UV radiation, which causes damage to nucleic acids, macromolecules responsible for carrying genetic information (deoxyribonucleic acid - DNA) and protein synthesis (ribonucleic acid - RNA) (USEPA, 2003).

According to Regulatory Brazilian Standard NBR 13.969 (ABNT, 1997), the irrigation technique for some crops with the reuse of treated wastewaters is classified as Class 4 and may be destined to orchards, cereals, fodder, cattle pastures and other crops through surface runoff or point irrigation. Considering the World Health Organization (WHO, 2006) the types of irrigation can be:

- Restricted: cultures cannot be ingested raw, or unprepared, with the maximum of $10^{5}$ allowed of Escherichia coli in $100 \mathrm{~mL}$ in the treated wastewater and;

- Unrestricted: can be consumed without pre-preparation with a total of $10^{3}$ of Escherichia Coli in $100 \mathrm{~mL}$ of treated wastewater.

The perspective of sustainable development proposes the use of treated wastewaters in irrigated agriculture. However, the pathogenic load of sewage is high and may interfere with the advancement of this technique, causing sanitary problems to an extensive population through food and contaminated soil. The incidence of UV radiation in the treated wastewater is mainly aimed at microbiological reduction, especially that of the group of total coliforms and Escherichia coli.

Thus, the objective of the research was to evaluate the sanitary and agricultural viability of a treated domestic effluent, from a Sewage Treatment Station composed of the septic tank units, Wetlands, and UV disinfection.

\section{MATERIAL AND METHODS}

\subsection{Pilot system of treatment of domestic sewage}

Pilot Sewage Treatment Station (STS) is installed and operating at the CCA (Center of Agricultural Sciences - Federal University of São Carlos) in Araras city, State of São Paulo, latitude 22018 '53.23" South, and longitude 470 23'00.91" West; to $701 \mathrm{~m}$ of altitude. With Cwa type-subtropical climate and average annual precipitation of $1300 \mathrm{~mm}$ (Souza et al., 2015). The STS was designed to receive daily volumes of 2000 liters of wastewater from the refectory and bathrooms of the University. Figure 1 shows a schematic of the arrangement of its treatment steps.

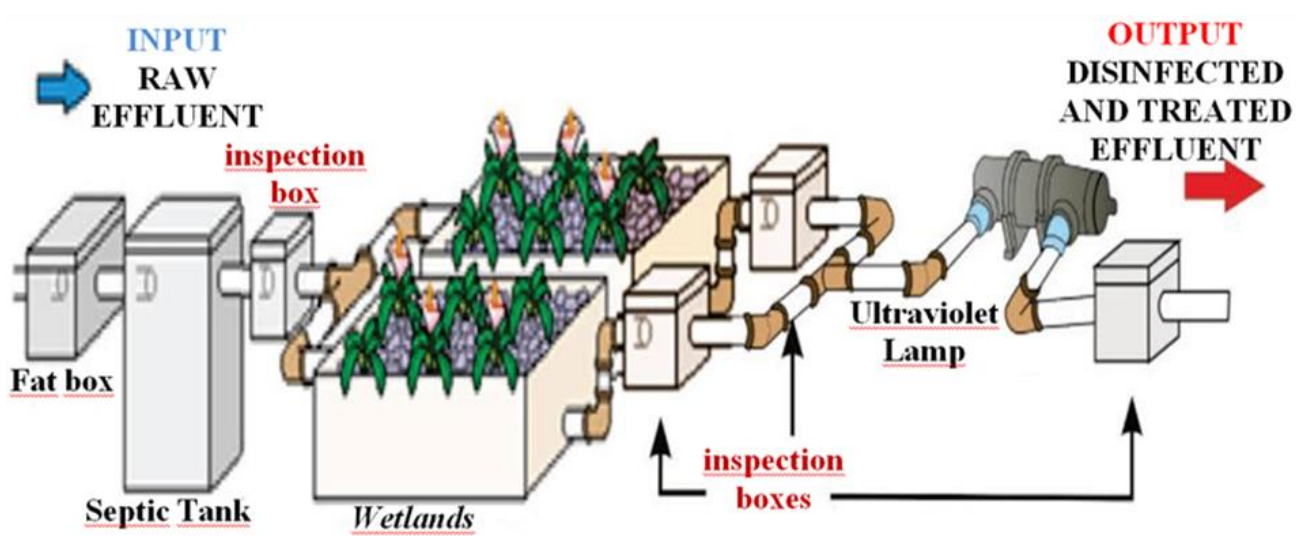

Figure 1. Schematic of the sewage treatment units of the pilot-scale station.

Source: Adapted from Souza et al. (2015). 
In this way, the wastewater treatment system consisted of:

- Fat box: with a capacity of $24 \mathrm{~L}$ and constructed of PVC material, its function is to prevent clogging by coarse materials;

- Septic Tank: constructed according to NBR 7.229/93 (ABNT, 1993) of volume $5.0 \mathrm{~m}^{3}$ (1.723 $\mathrm{m}$ in diameter and $2.57 \mathrm{~m}$ in height), with a hydraulic retention time of 22 hours;

- Wetlands: $2.0 \mathrm{~m}^{3}$ tanks, divided in two $(1.64 \mathrm{~m}$ in diameter $\mathrm{x} 0.44 \mathrm{~m}$ in height for each tank), in which was cultivated macrophyte Papyrus (Cyperus);

- Ultraviolet system: made in stainless steel, brand SODRAMAR (2016) ${ }^{1}$ model SUV 7. Consisting of a lamp, model TUV 4P S/E of 16W, tubular format, length of $32.8 \mathrm{~cm}$ and life of approximately 7000 hours (Philips ${ }^{1}$ ). The light is emitted in the UV-C band, which corresponds to about $260 \mathrm{~nm}$.

The ultraviolet radiation dose of the lamp in question is $0.43 \mathrm{mWscm}^{-2}$, being calculated by the intensity of the flow $\left(\mathrm{mWcm}^{-2}\right)$ and multiplied by the time of exposure of the effluent to the UV (seconds) (Philips, 2006).

All units have appropriate seals so that there is no contamination in the water table.

\subsection{Monitoring of Station}

Sewage samples were collected between October 2016 and September 2017, from 09:30 am to 11:30 am, and were placed in sterilized containers and immediately sent to the Water and Soil Laboratory of the Department of Natural Resources and Environmental Protection (DRNPA/CCA/UFSCar).

Wastewater was monitoring was carried out according to the methodology indicated by the Standard Methods for the Examination of Water and Wastewater (APHA, 2012), in triplicate, corresponding to following parameters: (EC);

- Biweekly analyses: $\mathrm{pH}$, dissolved oxygen (DO), turbidity and electrical conductivity

- Monthly analyses: total phosphorus (TP), total nitrogen (TN), calcium (Ca), magnesium $(\mathrm{Mg})$, potassium $(\mathrm{K})$, sodium $(\mathrm{Na})$, total coliforms (TC), Escherichia coli and Sodium Adsorption Ratio (SAR).

For bacteriological analysis, the enzymatic method Colilert ${ }^{1}$ was used according to IDEXX (2016).

Sodium Adsorption Ratio (SAR) is calculated by sodium ( $\mathrm{Na})$, calcium $(\mathrm{Ca})$ and magnesium (Mg) according to Equation 1 (Lesch and Suarez, 2009):

$$
\mathrm{SAR}=\frac{\mathrm{Na}}{\sqrt{\mathrm{Ca}+\mathrm{Mg}}}
$$

On what:

$\mathrm{SAR}=$ Sodium Adsorption Ratio $\left(\mathrm{mmol}_{\mathrm{c}} \mathrm{L}^{-1}\right)^{1 / 2}$

$\mathrm{Na}=$ concentration of sodium $\left(\mathrm{mmol}_{\mathrm{c}} \mathrm{L}^{-1}\right)$;

$\mathrm{Ca}=$ concentration of calcium $\left(\mathrm{mmol}_{\mathrm{c}} \mathrm{L}^{-1}\right)$;

$\mathrm{Mg}=$ concentration of magnesium $\left(\mathrm{mmol}_{\mathrm{c}} \mathrm{L}^{-1}\right)$.

The efficiency of each parameter was calculated from a balance between the input and output means of each treatment unit (Equation 2) (Von Sperling, 2005): 


$$
\mathrm{E}=\frac{\mathrm{Ce}-\mathrm{Cs}}{\mathrm{Ce}} \times 100
$$

On what:

$$
\begin{aligned}
& \mathrm{E}=\text { removal efficiency }(\%) ; \\
& \mathrm{Ce}=\text { concentration of the parameter in the raw wastewater (input); } \\
& \mathrm{Cs}=\text { concentration of the parameter in the treated wastewater (output). } \\
& { }^{1} \text { Trademark references do not constitute an endorsement by the authors. }
\end{aligned}
$$

\section{RESULTS AND DISCUSSION}

\begin{tabular}{|c|c|c|c|}
\hline Parameters & Input & Output & Overall efficiency (\%) \\
\hline $\mathrm{pH}$ & 6.8 & 6.4 & --- \\
\hline Turbidity (NTU) & 87.3 & 2.7 & 96.9 \\
\hline $\mathrm{EC}\left(\mu \mathrm{S} \mathrm{cm}^{-1}\right)$ & 639.5 & 444 & 30.6 \\
\hline $\mathrm{DO}\left(\mathrm{mg} \mathrm{L}^{-1}\right)$ & 3.3 & 6.5 & $98.5^{*}$ \\
\hline $\mathrm{Na}\left(\mathrm{mg} \mathrm{L}^{-1}\right)$ & 8.2 & 10.3 & $26.7 *$ \\
\hline $\mathrm{K}\left(\mathrm{mg} \mathrm{L}^{-1}\right)$ & 49.4 & 15.7 & 68.2 \\
\hline $\mathrm{Ca}\left(\mathrm{mg} \mathrm{L}^{-1}\right)$ & 13.5 & 16.6 & $22.9^{*}$ \\
\hline $\mathrm{TN}\left(\mathrm{mg} \mathrm{L}^{-1}\right)$ & 23.4 & 10.7 & 54.1 \\
\hline $\mathrm{TP}\left(\mathrm{mg} \mathrm{L}^{-1}\right)$ & 5.6 & 3.6 & 36.1 \\
\hline $\operatorname{Mg}\left(\mathrm{mg} \mathrm{L}^{-1}\right)$ & 10.3 & 8.8 & 14.6 \\
\hline TOC $\left(\mathrm{mg} \mathrm{L}^{-1}\right)$ & 60 & 23.6 & 60.6 \\
\hline TC $\left(\mathrm{MPN} 100 \mathrm{~mL}^{-1}\right)$ & $4.7 \times 10^{7}$ & $8.8 \times 10^{3}$ & 99.98 \\
\hline Escherichia coli (MPN 100 $\mathrm{mL}^{-1}$ ) & $2.6 \times 10^{7}$ & $6.1 \times 10^{2}$ & $>99.99$ \\
\hline
\end{tabular}

Table 1 presents the results of wastewater characterization from 24 samples during the one-year monitoring.

Table 1. Average values of raw wastewater (input) and treated wastewater (output) of monitoring parameters and removal efficiency.

$\mathrm{EC}=$ electrical conductivity $; \mathrm{DO}=$ dissolved oxygen; $\mathrm{Na}=$ sodium $; \mathrm{Ca}=$ calcium; $\mathrm{TN}=$ total nitrogen; $\mathrm{TP}=$ total phosphorus; $\mathrm{K}=$ potassium; $\mathrm{TOC}=$ total organic carbon; $\mathrm{Mg}=$ magnesium; $\mathrm{TC}=$ total coliforms in Most Probable Number (MPN).

* percentage increase of the parameter in the units of the Station.

Reuse in agriculture requires wastewaters to have a $\mathrm{pH}$ that does not negatively influence the development of agricultural crops. Martínez et al. (2015) describe that the $\mathrm{pH}$ for reuse in agriculture should be between 5 and 6.5 , to facilitate the absorption of nutrients by plants.

In this sense, the crude wastewater presented averages of 6.8 at the entrance and 6.4 at the exit. Colares and Sandri (2013) also observed a decrease in $\mathrm{pH}$ in their cultivated bed surveys, concluding that the bacteria produce organic acids due to the anaerobic degradation of the organic matter, leading to discrete acidification of the wastewater.

The station showed a reduction of $96.9 \%$ of turbidity, with input and output averages of 87.3 and 2.7 NTU, respectively. At the exit of the septic tank, the turbidity presented an index of $80.9 \%$ and, after Wetlands, reached 83\%. Colares and Sandri (2013) found lower values in relation to the septic tank of $37.8 \%$; for the flooded systems, the averages found were close to those observed in the Station, with rates from 66.9 to $82.5 \%$, which demonstrates excellent removal of suspended solids from the Pilot Station septic tank and Wetlands.

Electric Conductivity had a reduction efficiency of $30.6 \%$, from $639.5 \mu \mathrm{S} \mathrm{cm}{ }^{-1}$ to $444 \mu \mathrm{S} \mathrm{cm}^{-1}$, and the Na, Ca and K parameters showed variations in their concentrations. Souza 
et al. (2015) found an increase in EC of $36.3 \%$ during the wastewaters treatment and stated that the main reason would be to raise the same parameters mentioned above in units containing brittle.

The content of DO had a mean input of $3.3 \mathrm{mg} \mathrm{L}^{-1}$ and the output wit $6.5 \mathrm{mg} \mathrm{L}^{-1}$, totaling an increase in oxygenation of wastewater of $98.5 \%$. In the Wetlands, there is an occurrence of photosynthesis, leading to an increase of dissolved oxygen at the outlet of the flooded system.

Sodium showed an increase of $26.7 \%$ in the final wastewater, the highest increase was observed at the exit of the septic tank, with rates of $15.8 \%$. The final wastewater of the STS has $0.4 \mathrm{mmol} \mathrm{L}^{-1}$ of sodium and, according to Ayers and Westcot (1999), does not present risk in the case of surface irrigation to the soil and the culture.

The overall efficiency of removal of K of the STS Pilot, since the entry, with $49.4 \mathrm{mg} \mathrm{L}^{-1}$ until the exit with $15.7 \mathrm{mg} \mathrm{L}^{-1}$, was $68.2 \%$. The limit established for irrigation water is up to $2 \mathrm{mg} \mathrm{L}^{-1}$ (Ayers e Westcot, 1999). Therefore, the value of the final wastewater of the STS presents restrictions on $\mathrm{K}$, since they can present problems of loss of water to the plants, reducing transpiration, damaging growth and the absorption of other essential nutrients to the plant, such as calcium, magnesium, boron, zinc, manganese, and ammonium (Fia et al., 2015).

Calcium had an increase of $22.9 \%$ from input to output $\left(0.41 \mathrm{mmol} \mathrm{L}^{-1}\right)$ and its greatest contribution to this elevation was after the wastewater entered the system of Wetlands. According to Ayers and Westcot (1999), the threshold value found in irrigation water would be $10 \mathrm{mmol} \mathrm{L}^{-1}$.

Results of NT demonstrated a contribution of 30.6\% after the septic tank; however, the wastewater entering the Wetlands had a reduction efficiency of $74.6 \%$. In the final wastewater, the concentration of NT detected was $10.7 \mathrm{mg} \mathrm{L}^{-1}$. The total efficiency of removal was $54.1 \%$. According to the recommended literature, the appropriate range for irrigation with wastewater would be $10 \mathrm{mg} \mathrm{L}^{-1}$ of total nitrogen (Ayers and Westcot, 1999).

Total phosphorus showed an average input of $5.6 \mathrm{mg} \mathrm{L}^{-1}$. The Pilot STS presented total removal efficiency of $36.1 \%$ TP. The highest reduction rate recorded in the Pilot Station was in the Wetlands, with $82.7 \%$.

However, after the incidence of UV radiation on the wastewater, TP increased the rate from 2.4 to $3.6 \mathrm{mg} \mathrm{L}^{-1}$, representing 50\%. This elevation in TP contents may be associated with phosphate accumulating organisms present in wastewater under anaerobic and aerobic conditions.

These microorganisms submitted to ultraviolet radiation showed a breakdown of genetic material, where phosphorus would be absorbed intracellularly. After undergoing UV cell lysis, the nutrient becomes available and detectable in the final analysis of the effluent. By classification of Ayers and Westcot (1999), the maximum found in irrigation water for TP would be $0-2 \mathrm{mg} \mathrm{L}^{-1}$.

A concentration of $\mathrm{Mg}$ had a total removal efficiency of $14.6 \%$, the final wastewater was observed with $8.8 \mathrm{mg} \mathrm{L}^{-1}$. The recommendation for application of water in irrigation is not to exceed the margin of $100 \mathrm{mg} \mathrm{L}^{-1}$ (Ayers and Westcot, 1999).

The overall efficiency of removal of TOC from input to output was $60.6 \%$. Only at the exit of the septic tank was the removal $59.8 \%$, due to the biodegradation of the organic matter. After this process, the wastewater practically remained with the same average until the exit of the pilot STS.

Total coliforms reached a full efficiency of removal, that is to say, $99.98 \%$, from $4.7 \times 10^{7}$ to $8.8 \times 10^{3} \mathrm{MPN}$ per $100 \mathrm{~mL}$ in the crude wastewater. Moreover, removal was greater than $99.99 \%$ for $E$. coli from $2.6 \times 10^{7}$ to $6.1 \times 10^{2} \mathrm{MPN}$ per $100 \mathrm{~mL}$ in the crude wastewater, which demonstrates the high disinfection potential of ultraviolet radiation, reducing more than 4 log- 
cycles from an initial load of TC and 5 log-cycles from an initial load of $E$. coli, suggesting microbiological safety.

The NBR 13.969/97 allows the application of water for reuse to include maximum values of 5.000 NMP $100 \mathrm{~mL}$ of E. coli. However, the World Health Organization (WHO, 2006) recommends that the values for $E$. coli do not exceed $10^{3}$ in $100 \mathrm{~mL}$ for unrestricted irrigation, that is, crops that can be ingested raw.

As with the efficiency of the UV treatment unit, removals were 96.6 and $91 \%$ for TC and E. coli, respectively, reducing $1 \log$-cycle with a radiation dose of $0.43 \mathrm{~mW} . \mathrm{s.cm}^{-2}$.

For this result, the difference between the wastewater values of the Wetlands outlet and the UV outlet was analyzed (Table 2).

Table 2. Monitoring of total coliforms (TC) and E. coli in the input and output of the treatment unit by UV radiation.

\begin{tabular}{lcc}
\hline & \multicolumn{1}{c}{ Wetlands output } & UV output \\
\cline { 2 - 3 } TC & $8.2 \times 10^{4} \mathrm{MPN} 100 \mathrm{~mL}^{-1}$ & $8.8 \times 10^{3} \mathrm{MPN} 100 \mathrm{~mL}^{-1}$ \\
E. coli & $6.8 \times 10^{3} \mathrm{MPN} 100 \mathrm{~mL}^{-1}$ & $6.1 \times 10^{2} \mathrm{MPN} 100 \mathrm{~mL}^{-1}$ \\
\hline
\end{tabular}

Bilotta and Daniel (2012) tested the effect of effective UV doses (123.0 and $247.0 \mathrm{mWscm}^{-2}$ ) on effluent from secondary treatment with exposure times of 60/120 seconds and noted the inactivation of 1.6 to $5.2 \mathrm{log}$-cycles of $E$. coli.

Souza et al. (2012) in one of their UV assays observed that $317.1 \mathrm{mWscm}^{-2}$ were required to inactivate 3.7 and $2.0 \mathrm{log}$-cycles of E. coli and CT, respectively. However, a dose of $42.28 \mathrm{~mW} \mathrm{scm}^{-2}$ was able to disinfect approximately $5 \mathrm{log}$ of the same microorganisms.

Therefore, it is understood that the effluent quality interferes directly with the dose applied by UV radiation.

Sodium Adsorption Ratio (SAR) of the final wastewater presented an average of $0.5\left(\mathrm{mmol}_{\mathrm{c}} \mathrm{L}^{-1}\right)^{1 / 2}$, where the minimum observed was $0.2\left(\mathrm{mmol}_{\mathrm{c}} \mathrm{L}^{-1}\right)^{1 / 2}$ and the maximum $2.2\left(\mathrm{mmol}_{\mathrm{c}} \mathrm{L}^{-1}\right)^{1 / 2}$. This discrepancy in SAR may be associated with a disproportionate increase in $\mathrm{Na}, \mathrm{Ca}$ and $\mathrm{Mg}$. In order to avoid impacts by the application of the wastewater, the classification according to Ayers and Westcot (1999) for SAR should be between $0-15\left(\mathrm{mmol}_{\mathrm{c}} \mathrm{L}^{-1}\right)^{1 / 2}$.

The septic tank, Wetlands and UV showed distinct behaviors, in which the parameters suffered inflow or removal efficiency (Table 3).

Table 3. Removal efficiency of parameters for treatment units.

\begin{tabular}{cccc}
\hline & \multicolumn{3}{c}{ Removal efficiency $\%$} \\
\cline { 2 - 4 } & Septic Tank & Wetlands & UV \\
\hline Turbidity & 80.9 & 83 & 4.3 \\
EC & NR & 38.5 & NR \\
DO & NR & NR & NR \\
Na & NR & NR & NR \\
K & 11.8 & 71.4 & NR \\
Ca & NR & NR & 9.9 \\
TN & NR & 74.6 & NR \\
TP & NR & 82.7 & NR \\
Mg & 14.3 & NR & 3.7 \\
TOC & 59.8 & NR & 2.19 \\
TC & 96.3 & 95.2 & 89.3 \\
E. coli & 99.3 & 96.1 & 91 \\
\hline
\end{tabular}

NR: not removed. 
The septic tank, considered a unit of primary treatment, was responsible for the largest removals of TOC, $\mathrm{Mg}$, TC and E. coli.

The first two parameters are associated with the degradation and stabilization of organic matter by the anaerobic bacteria present in this treatment phase, and the release of methane gas. For the bacteriological indicators, the average of efficient removal may range from 60 to $90 \%$ (Von Sperling, 2005).

In the Wetlands, due to filtration and the polishing of wastewater, there was greater removal turbidity and a decreased EC, due to the consumption of salts by the macrophytes (Santos et al., 2016).

The nutrients NT (74.6\%), PT (82.7\%) and K (71.4\%), the main ones for the development of agricultural crops, demonstrated the removal efficiency of the percentages found in the literature (Fia et al., 2017).

According to the presented results, the viability of the agricultural use of the treated wastewater of the Pilot STS is verified, mainly due to the contribution of nutrients. Therefore, this proposal is in line with sustainable agricultural production, since it represents an economy in terms of nutrients/water resources, combining agriculture with the environment.

\section{CONCLUSIONS}

In experimental conditions, it is possible to state that the final wastewater from the pilot scale Sewage Treatment Station has sanitary and agricultural viability for irrigation application.

\section{ACKNOWLEDGMENTS}

The authors gratefully acknowledge Coordination for the Improvement of Higher Education Personnel (CAPES) for the scholarship granted to A. A.S. Oliveira. Financial support was provided by FAPESP (2010/20081-7 and 2013/14893-7) and National Council for Scientific and Technological Development (CNPq) (303583/2012-6).

\section{REFERENCES}

AHMADI, L.; MERKLEY, G. P. Wastewater reuse potential for irrigated agriculture. Irrigation Science, v. 35, n. 4, p. 275-285, 2017. https://doi.org/10.1007/s00271-0170539-7

ANDRADE, C. F.; VON SPERLING, M.; MANJATE, E. S. Treatment of septic tank sludge in a vertical flow constructed wetland system. Engenharia Agrícola, v.37, n.4, p.811819, 2017. http://dx.doi.org/10.1590/1809-4430-eng.agric.v37n4p811-819/2017

ANIL, R.; NEERA, A. L. Modified Septic Tank Treatment System. Procedia Technology, v. 24, p. 240-247, 2016. https://doi.org/10.1016/j.protcy.2016.05.032

ABNT. NBR-13.969: Tanques sépticos - Unidades de tratamento complementar e disposição final dos efluentes líquidos - Projeto, construção e operação. Rio de Janeiro, 1997.

ABNT. NBR-7.229: projeto, construção e operação de sistemas de tanques sépticos: procedimento. Rio de Janeiro, 1993.

APHA. Standard Methods for the Examination of Water and Wastewater. 22. ed. Washington, 2012.

AYERS, R. S.; WESTCOT, D. W. A qualidade da água na agricultura. 2. ed. Campina Grande: UFPB, 1999. 153p. (Estudos FAO: Irrigação e Drenagem, 29). 
BILOTTA, P.; DANIEL, L. A. Utilização de lâmpadas germicidas na desinfecção de esgoto sanitário. Revista Ambiente \& Água, v. 7, n. 1, p. 120-129, 2012. http://dx.doi.org/10.4136/ambi-agua.845

COLARES, C. J. G.; SANDRI, D. Efficiency of sewage treatment with septic tanks followed by constructed Wetlands with different support materials. Revista Ambiente \& Água, v. 8, n. 1, p. 172-185, 2013. http://dx.doi.org/10.4136/ambi-agua.1047

FIA, F. R. L.; MATOS, A. T.; FIA, R.; BORGES, A. C.; ABREU, E. C. Influência da carga de nutrientes e da espécie cultivada na remoção de $\mathrm{K}, \mathrm{Na}, \mathrm{Cu}$ e $\mathrm{Zn}$ da água residuária da suinocultura tratada em sistemas alagados construídos. Revista Ambiente \& Água, v. 10, n. 3, p. 542-553, 2015. http://dx.doi.org/10.4136/ambi-agua.1216

FIA, F. R. L.; MATOS, A. T.; FIA, R.; BORGES, A. C.; CECON, P. R. Efeito da vegetação em sistemas alagados construídos para tratar águas residuárias da suinocultura. Engenharia Sanitária e Ambiental, v. 22, n. 2, p. 303-311, 2017.

HESPANHOL, I. Um novo paradigma para a gestão de recursos hídricos. Estudos Avançados, v. 22, n. 63, p.1 31-158, 2008.

IDEXX. Colilert ${ }^{\circledR}$. Available in: https://www.idexx.com/water/products/colilert.html. Access: 15 Dec. 2016.

LESCH, S. M.; SUAREZ, D. L. Technical Note: A short note on calculating the adjusted SAR index. Transactions of the ASABE, v. 52, n. 2, p. 493-496, 2009.

LIN, H.; LIU, W.; ZHANG, X.; WILLIAMS, N.; HU, B. Microbial electrochemical septic tanks (MESTs): An alternative configuration with improved performance and minimal modifications on conventional septic systems. BiochemicalEngineeringJournal, v. 120, p. 146-156, 2017. https://doi.org/10.1016/j.bej.2017.01.003

MARTÍNEZ, F. Z.; BRAVO, D. R.; ALVARÉZ, A. C.; LOMELI, M. G. Desinfección de aguas residuales entres sistemas de humedales construidos híbridos. Revista Interciência, v. 40, n. 6, p. 409-415, 2015.

PANTANO, G.; GROSSEli, G. M.; MOZETO, A. A.; FADINI, P. S. Sustainability in phosphorus use: a question of water and food security. Química Nova, v. 39, n. 6, p. 732 740, 2016. http://dx.doi.org/10.5935/0100-4042.20160086

PHILIPS. Ultraviolet purification application information. 2006. 31p. Available in: https://goo.gl/1vLPCa. Access: 19 Nov. 2018.

SAlVETTI, A. R. A história da Luz. São Paulo: Livraria da Física, 2008. Available in: https://goo.gl/omZSPs. Access: 29 May 2017.

SANTOS, B. S.; COSTA, P. F.; EYNG, E.; CÂMARA, C. D. Avaliação da eficiência de um sistema de tratamento por wetland construído aplicado ao efluente de um frigorífico de suínos. Semina, v. 37, n. 2, p. 13-22, 2016. http://dx.doi.org/10.5433/16790375.2016v37n2p13

SODRAMAR. Desinfecção UVC para piscinas. Available in: https://goo.gl/cEqC1K. Access: 19 Aug. 2016.

SOUZA, J. B.; VIDAL, C. M. S.; CAVALLINI, G. S.; QUARTAROLI, L.; MARCON, L. R. C. Avaliação do emprego da radiação ultravioleta na desinfecção de esgoto sanitário. Semina,v. 33, n. 2, p. 117-126, 2012. 
SOUZA, C. F.; BASTOS, R. G.; GOMES, M. P. M.; PULSCHEN, A. A. Eficiência de estação de tratamento de esgoto doméstico visando reúso agrícola. Revista Ambiente \& Água, v. 10, p. 587-597, 2015. http://dx.doi.org/10.4136/ambi-agua.1549

UNITED STATES. Environmental Protection Agency - USEPA. Ultraviolet disinfection guidance manual. Washington, 2003. 478 p. Available in: pha.poli.usp.br/LeArq.aspx?id_arq=1120. Access: 22 Aug. 2016.

VON SPERLING, M. Introdução a qualidade das águas e ao tratamento de esgotos: princípios do tratamento biológico de águas residuárias. 3. ed. Minas Gerais: UFMG, 2005. $452 \mathrm{p}$.

WHO. Excreta and greywater use in agriculture: Safe use of wastewater, excreta and greywater. 2. ed. Geneva, 2006. 196 p.

ZHOU, X.; GUO, H.; LI, Z.; ZHAO, J.; YUN, Y. Experimental study on the disinfection efficiencies of a continuous-flow ultrasound/ultraviolet baffled reactor. Ultrasonics Sonochemistry, v. 27, p. 81-86, 2015. https://doi.org/10.1016/j.ultsonch.2015.05.002 


Ambiente \& Água - An Interdisciplinary Journal of Applied Science
ISSN 1980-993X - doi:10.4136/1980-993X
www.ambi-agua.net
E-mail: ambi.agua@gmail.com

\title{
Evaluation of water resource preservation areas in the Hydrographical Basin of Andreas Stream, RS, Brazil, using environmental monitoring programs
}

\author{
ARTICLES doi:10.4136/ambi-agua.2307 \\ Received: 26 Jul. 2018; Accepted: 11 Jan. 2019 \\ Rodrigo Augusto Klamt ${ }^{1 *}$; Eduardo Alexis Lobo $^{2}$ (D); \\ Adilson Ben da Costa ${ }^{2}$; Dionei Minuzzi Delevati ${ }^{3}$ \\ ${ }^{1}$ Universidade de Santa Cruz do Sul (UNISC), Santa Cruz do Sul, RS, Brasil \\ Programa de Pós-Graduação em Tecnologia Ambiental (PPGTA). E-mail: rodrigoklamt@ hotmail.com \\ ${ }^{2}$ Universidade de Santa Cruz do Sul (UNISC), Santa Cruz do Sul, RS, Brasil \\ Departamento de Biologia e Farmácia. Programa de Pós-Graduação em Tecnologia Ambiental (PPGTA). \\ E-mail: lobo@unisc.br, adilson@unisc.br \\ ${ }^{3}$ Universidade de Santa Cruz do Sul (UNISC), Santa Cruz do Sul, RS, Brasil \\ Departamento de Engenharia e Ciência Agrárias. \\ Programa de Pós-Graduação em Tecnologia Ambiental (PPGTA). E-mail: dionei@unisc.br \\ *Corresponding author
}

\begin{abstract}
This research evaluated the effectiveness of the implementation of water resource preservation areas in the Hydrographical Basin of Andreas Stream, county of Vera Cruz, RS, Brazil, established through Payment for Environmental Services (PES), using an environmental monitoring program to assess physical, chemical and microbiological variables. The PES is linked to the "Water Guardian" project, which aims to ensure the preservation of water resources by paying farmers for providing the environmental services to protect the springs and riparian areas that lie within their properties. Twenty sampling stations were selected for collecting water samples monthly during the period July 2012 to June 2014 (460 samples) to evaluate the following variables: water temperature, $\mathrm{pH}$, turbidity, dissolved oxygen, biochemical oxygen demand, nitrate, ammonia nitrogen, phosphate, total dissolved solids and thermotolerant coliforms. The evaluation was made based on decree 357/2005 of the National Environmental Council (CONAMA) and by applying the Water Quality Index (WQI). The results indicated a significant improvement in the water quality when comparisons were made between the periods before and after the installation of the preservation areas. The sampling points classified as "good" (CONAMA and WQI), which indicates water of good quality that is appropriate for multiple uses, increased from $52.0 \%$ to $72.0 \%$. In this sense, promoting the preservation of headwaters and riparian zones becomes of fundamental importance and highlights the role of PES as an operational tool for water resource preservation.
\end{abstract}

Keywords: hydrographical Basin of Andreas Stream, payment for environmental services (PES), water quality. 


\section{Avaliação de áreas de preservação de recursos hídricos na Bacia Hidrográfica do Arroio Andreas, RS, utilizando programas de monitoramento ambiental}

\section{RESUMO}

A presente pesquisa objetivou avaliar a efetividade da implantação de áreas de preservação de recursos hídricos na Bacia Hidrográfica do Arroio Andreas, município de Vera Cruz, RS, estabelecida através do Pagamento por Serviços Ambientais (PSA), utilizando um programa de monitoramento ambiental para avaliar variáveis físicas, químicas e microbiológicas. O PES está vinculado ao projeto "Guardião da Água", que visa garantir a preservação dos recursos hídricos, pagando aos agricultores a prestação de serviços ambientais para proteger as nascentes e áreas ribeirinhas que se encontram dentro de suas propriedades. Vinte estações de amostragem foram selecionadas para coleta mensal de amostras de água no período de julho de 2012 a junho de 2014 (460 amostras) para avaliar as seguintes variáveis: temperatura da água, $\mathrm{pH}$, turbidez, oxigênio dissolvido, demanda bioquímica de oxigênio, nitrato, nitrogênio amoniacal, fosfato total sólidos dissolvidos e coliformes termotolerantes. A avaliação foi feita com base no decreto 357/2005 do Conselho Nacional do Meio Ambiente (CONAMA) e na aplicação do Índice de Qualidade da Água (IQA). Os resultados indicaram uma melhora significativa na qualidade da água quando comparações foram feitas entre os períodos antes e depois da instalação das áreas de preservação. Os pontos de amostragem classificados como "bons" (CONAMA e WQI), que indicam água de boa qualidade e adequada para usos múltiplos, aumentaram de 52,0\% para $72,0 \%$. Nesse sentido, promover a preservação de cabeceiras e zonas ribeirinhas passa a ser de fundamental importância e destaca o papel do PSA como ferramenta operacional para a preservação dos recursos hídricos.

Palavras-chave: Bacia Hidrográfica do Arroio Andreas, pagamento por serviços ambientais (PSA), qualidade da água.

\section{INTRODUCTION}

In Brazil, water is considered an abundant natural resource compared to the current demand, although there are dry areas where water is used only for human needs. Although Brazil holds $8 \%$ of all freshwater in the world, the situation in the country is delicate. Most of the available volume (80\%) is in the Amazon region, and the remaining $20 \%$ is unevenly divided among the other regions in which $95 \%$ of the population lives (UNEP; IETEC, 2001). In the South, there are water shortages despite the large rivers and flow. These shortages are due to the cumulative effects of environmental processes and a broad spectrum of multiple water use in agriculture, industry, fisheries, navigation and recreation (Tundisi, 2000). Additionally, the quality of the small amount of available freshwater is degraded, mainly due to the rapid population growth observed in recent decades. This growth has generated a growing number of polluting processes that significantly alter the ecological balance of ecosystems, highlighting cultural eutrophication as one of the biggest problems for surface water and one of the most visible examples of the changes caused by humans to the biosphere (Smith and Schindler, 2009).

According to Esteves (2011), eutrophication is the concentration of nutrients, particularly nitrogen and phosphorus species or derivatives, in aquatic ecosystems; one result of eutrophication is increased productivity of biomass and decreasing of dissolved oxygen content, and thus the death of living biomass and biodegradation intensification. Eutrophication is a global problem that produces a marked deterioration of rivers, reservoirs, lakes and coastal 
waters and causes direct and indirect effects on biodiversity. Additionally, eutrophication jeopardizes the multiple uses of surface and groundwater resources, causing substantial losses to the local and regional economy. Eutrophication is a threat to public health and the general functioning of aquatic systems and is an important economic factor that can prevent or delay sustainable development (Tundisi, 2000; 2003; 2006 and 2007).

Among the complementary alternatives to local-sustainable development, payment for the provision of environmental services (PES) has been highlighted as a recent and innovative policy for environmental conservation. PES is defined as the voluntary transfer of funds from beneficiaries of such environmental services to those who perform them for the proper management of the ecosystem where these environmental services are being provided (Wunder et al., 2008). Because PES is a relatively new concept and practice, governments have only recently begun to recognize the role that farmers and users in rural areas can have on the improvement of environmental management. Tools for payment or compensation suggest that through incentives there will be a change in the behavior of economic agents in relation to the environment. According to the United Nations (ONU, 2011), the following environmental services are included in PES: the conservation and natural treatment of water resources, the preservation and conservation of biodiversity, soil erosion protection, carbon sequestration in the growth stage of the plant, regulating the local climate, besides the landscape formation and composition.

Based on these antecedents, the University of Santa Cruz do Sul (UNISC), in partnership with the Universal Leaf Tobacco Company and Fundación Altadis (non-profit organization, part of the Imperial Tobacco Group) signed a contract in 2011 for the execution of the project "Payment for Environmental Services" (PES) in the "Hydrographical Basin of Andreas Stream, county of Vera Cruz, RS, Brazil." The project, "Water Guardian," was to be developed over a period of five years (2011-2015) with the goal to protect the headwaters and the riparian areas of this basin and ensure the preservation of water resources by paying smallholder farmers for providing the environmental service to protect the headwaters located in their properties.

In this context, this study evaluated the effectiveness of the implementation of these conservation areas in the basin of Andreas Stream, RS, from July 2012 to June 2014, using environmental monitoring programs to assess physical, chemical, and microbiological variables.

\section{MATERIALS AND METHODS}

\subsection{Field of study}

The Hydrographical Basin of Andreas Stream, RS, is of fundamental importance as the source of water for the city of Vera Cruz. The soil relief map shows variations and terrain altitudes ranging between 500 and $100 \mathrm{~m}$. Land use is characterized by agriculture, including the cultivation of rice. It has an area of $80.2 \mathrm{~km}^{2}$ with a $21 \mathrm{~km}$ extension, with a population of 11,183 inhabitants in the urban area and 2,964 inhabitants in the rural area (IBGE, 2010). Along this basin, 20 sampling points have been selected (Figure 1) to carry out environmental monitoring studies in the rural properties that have joined the "Water Guardian" project.

\subsection{Collection/analysis of samples}

Monthly scientific expeditions were carried out from July 2012 to June 2014 in the 20 sampling points distributed along the Andreas Basin stream to measure physical, chemical and microbiological variables; a monthly sample was collected at each point during the period. The study period was divided into two stages: from July 2012 to June 2013, during which the conservation areas around the sampling points were being installed; and from July 2013 to June 2014, during which the areas of preservation around the sampling points were installed. 


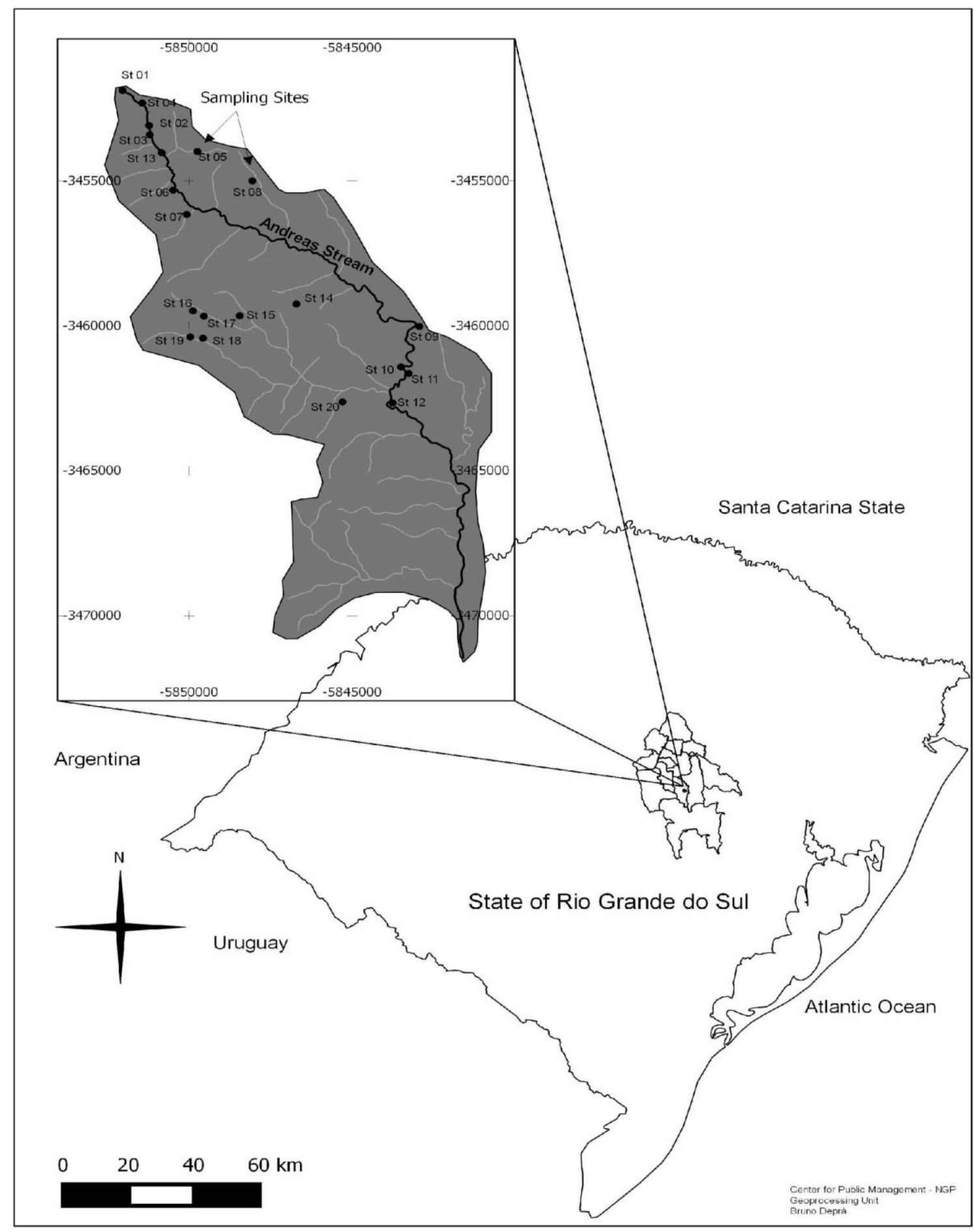

Figure 1. Map of the study area showing the location of Hydrographical Basin of Andreas Stream in the state of Rio Grande do Sul, highlighting the selected sampling points.

The following variables were considered as environmental evaluation parameters: temperature, $\mathrm{pH}$, turbidity, dissolved oxygen, biochemical oxygen demand after five days, nitrate, nitrite, total ammonia nitrogen, phosphate, total dissolved solids and thermotolerant coliforms. The samples were collected on the water surface using 300-1000 ml glass bottles packed in a Styrofoam box containing ice and the samples were analyzed the day after collection. The techniques used in sample collection and analytical determination of the physical, chemical and microbiological variables are described in APHA (2005). 


\subsection{Water Quality Assessment}

Based on the environmental analysis, the assessment of water quality was determined by Resolution Number 357 of the National Environmental Council (CONAMA), 2005 (CONAMA, 2005), which classifies fresh water into five different classes depending on the uses for which it is intended. The assessment of water quality was also made using the Water Quality Index (WQI) originally developed by the National Sanitation Foundation (NFS, 2007) of the United States and adapted for Brazilian waters by COMITESINOS (1993). To use the WQI in southern Brazilian river systems, Moretto et al. (2012) conducted a calibration of the weights of the variables used in the WQI formulation, checking for a significant correlation between the new calibrated weights and resolution 357/2005 of CONAMA (2005). The WQI calculations were made using the IQAData program developed by Posselt and Costa (2010). This software allows for both the application of the original NSF model or the development of new quality models, such as the calibrated WQI proposed by Moretto et al. (2012).

To operationally compare the water-use classes of CONAMA related to the quality requirements set by the IQA, a relative scale of agreement was used (Table 1). The scale reflects the main objective of the "Water Guardian" project, which is to achieve good water quality in the preserved areas, providing water that is suitable for multiple uses (human consumption after simplified treatment, protection of aquatic communities and primary contact recreation), a condition that characterizes the water-use Classes 1 and 2 of CONAMA (2005).

Table 1. Relative scale of agreement between the water use classes of CONAMA and the quality levels of the IQA.

\begin{tabular}{cc}
\hline Classes of use of CONAMA 357/2005 & Quality levels \\
\hline Special & Excellent \\
Class 1 & Good \\
Class 2 & Good \\
Class 3 & Regular \\
Class 4 & Poor/very poor \\
\hline
\end{tabular}

\section{RESULTS AND DISCUSSION}

The results of water quality evaluation in the 20 sampling points distributed along the Andreas stream from July 2012 to June 2013, (Table 2), (before installation of the protected areas), using Resolution 357/2005 of CONAMA (2005), are shown in Figure 2. Among the 220 sampling points, $32.0 \%$ were evaluated as "Class 1," $29.0 \%$ as "Class 2," $22.0 \%$ as "Class 3," and $17.0 \%$ as "Class $4 . "$

Table 2. Results of physico-chemical and biological analyses 2012-2013.

\begin{tabular}{lcc}
\hline Quality indicator & Average & Standard deviation \\
\hline Dissolved oxygen, $\mathrm{mg} \mathrm{O}_{2} / \mathrm{L}$ & 6,887 & 0,437 \\
$\mathrm{pH}$ & 6,876 & 0,903 \\
Temperature water, ${ }^{\circ} \mathrm{C}$ & 18,496 & 2,163 \\
Turbidity, FTU & 23,592 & 13,938 \\
Nitrate, $\mathrm{mg} / \mathrm{L} \mathrm{NO}{ }_{3-}$ & 1,351 & 0,723 \\
Thermotolerant coliforms, $\mathrm{NMP} / 100 \mathrm{~mL}$ & 2273,926 & 7740,408 \\
BOD-biochemical oxygen demand, $\mathrm{mg} \mathrm{O}_{2} / \mathrm{L}$ & 4,181 & 0,846 \\
Phosphate, mg/L $\left(\mathrm{PO}_{4}\right)_{3-}$ & 0,119 & 0,108 \\
Total ammonia nitrogen, $\mathrm{mg} / \mathrm{L} \mathrm{NH} \mathrm{N}_{3}$ & 163,452 & 0,565 \\
Nitrite, mg/L $\mathrm{NO}_{2-}$ & 174,425 & 0,017 \\
Total dissolved solids, $\mathrm{mg} / \mathrm{L}$ & 114,512 & 28,007 \\
\hline
\end{tabular}




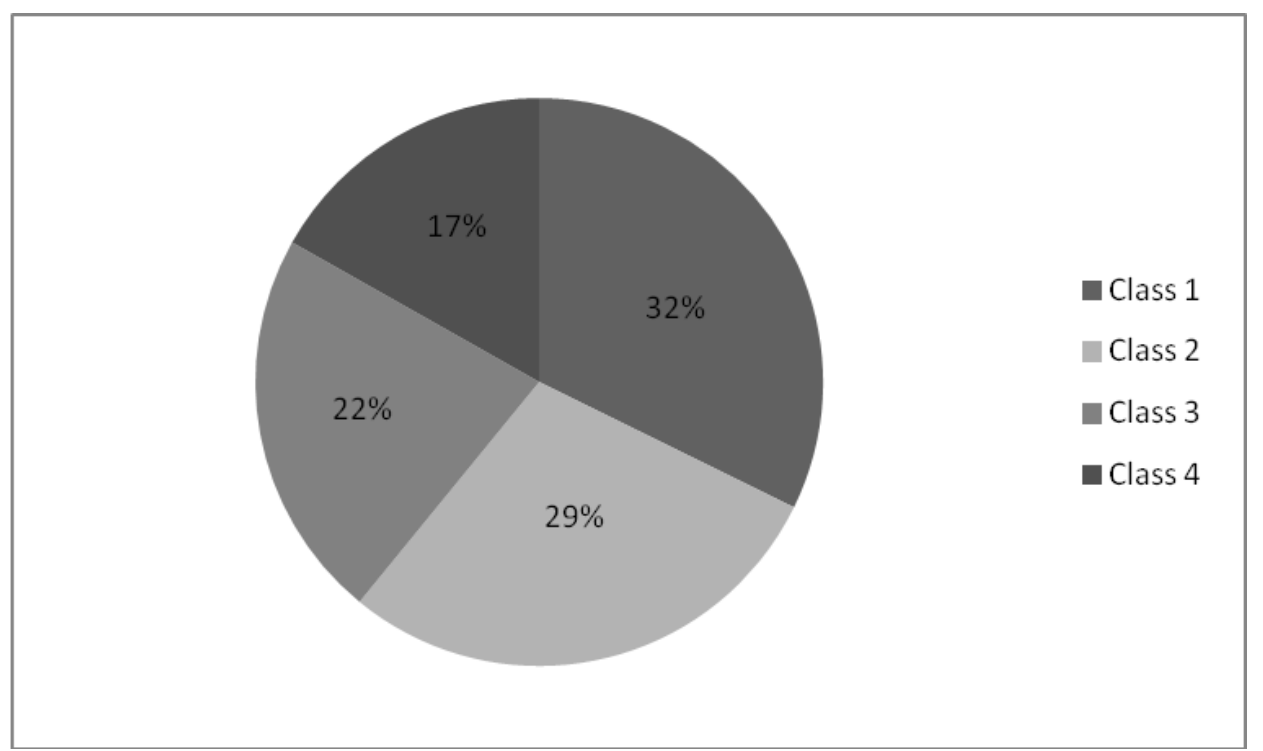

Figure 2. Classification of the 220 sampling points according to the decree 357/2005 of CONAMA (points P1 to P20), from July 2012 to June 2013.

The sampling points classified as Class 1 of CONAMA $(32.0 \%)$ are characterized as having good water quality that is appropriate for human consumption after simple treatment, the protection of aquatic communities and primary contact recreation (bathing), as its main features (CONAMA, 2005). The sampling points classified as Class 2 of CONAMA (29.0\%) also correspond to good quality water; the main difference compared to Class 1 is that Class 2 water can be used for human consumption only after conventional treatment (CONAMA, 2005).

The sampling points classified as Class 3 of CONAMA $(22.0 \%)$ have much more restrictive uses for their water than Class 2; for example, human consumption after conventional or advanced treatment, secondary contact for recreation and for cattle. Finally, the sample points classified as belonging to Class 4 of CONAMA (17.0\%) correspond to a class of lower quality water intended only for navigation and landscape harmony (CONAMA, 2005).

The results of evaluation using the Water Quality Index (WQI) adapted to the conditions in southern Brazilian by Moretto et al. (2012) in the 20 sampling points distributed along the basin of Andreas stream, RS, from July 2012 to June 2013 (before installation of the conservation areas), are shown in Figure 3. Among the 220 sampling points, $52.0 \%$ were classified as "good," $46.0 \%$ as "Regular" and $2.0 \%$ as "Poor."

Overall, during the period prior to the installation of the conservation areas, the results of the application of WQI indicated that $52.0 \%$ of the 220 samples collected were classified as "good," which corresponds to the $61 \%$ of Class 1 and 2 samples of CONAMA, indicating that these sampling points are characterized by good water quality that is appropriate for multiple uses. For the critical sampling points that showed water quality lower than the desired standards, the results of the application of WQI indicated that $48.0 \%$ of the 220 samples collected were classified as "Fair" or "Poor," values that correspond to the $39.0 \%$ of samples classified as Classes 3 and 4 of CONAMA, indicating that these sampling points have far more restrictive uses. 


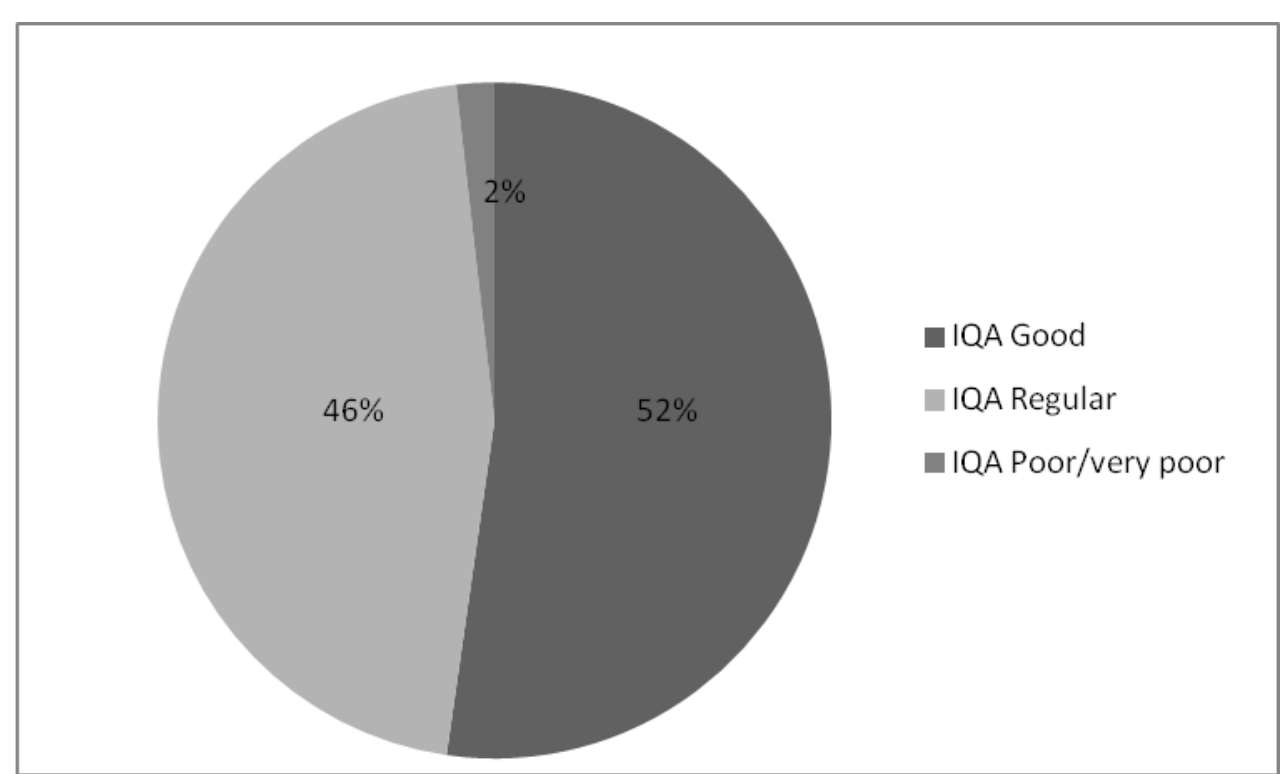

Figure 3. Rating of sampling points according to the WQI (points P1 to P20), from July 2012 to June 2013.

From July 2013, the installation of conservation areas in the 20 sampling points distributed along the Andreas stream was completed, and then a new sampling campaign started, according to results of the (Table 3). The results of the water quality evaluation, using the Resolution 357/2005 of CONAMA (2005), from July 2013 to June 2014 are shown in Figure 4. Among the 240 sampling points, $49.0 \%$ were classified as "Class 1," $24.0 \%$ as "Class 2," $15.0 \%$ as "Class 3," and 12.0\% as "Class 4". The results of the WQI are shown in Figure 5. Among the 240 sampling points, $72.0 \%$ were classified as "Good" and $28.0 \%$ as "Regular."

Table 3. Results of physico-chemical and biological analyses 2013-2014.

\begin{tabular}{lcc}
\hline Quality indicator & Average & Standard deviation \\
\hline Dissolved oxygen, $\mathrm{mg} \mathrm{O}_{2} / \mathrm{L}$ & 8,695 & 0,952 \\
$\mathrm{pH}$ & 6,919 & 0,036 \\
Temperature water, ${ }^{\circ} \mathrm{C}$ & 19,561 & 0,531 \\
Turbidity, FTU & 13,638 & 2,628 \\
Nitrate, $\mathrm{mg} / \mathrm{L} \mathrm{NO}{ }_{3-}$ & 1,023 & 0,235 \\
Thermotolerant coliforms, NMP/100 mL & 744,891 & 851,480 \\
BOD-biochemical oxygen demand, $\mathrm{mg} \mathrm{O}_{2} / \mathrm{L}$ & 2,334 & 1,455 \\
Phosphate, mg/L $\left(\mathrm{PO}_{4}\right)_{3-}$ & 0,069 & 0,126 \\
Total ammonia nitrogen, mg / $\mathrm{L} \mathrm{NH}_{3}$ & 0,510 & 0,258 \\
Nitrite, mg/L NO & 0,033 & 0,005 \\
Total dissolved solids, mg/L & 100,489 & 11,286 \\
\hline
\end{tabular}




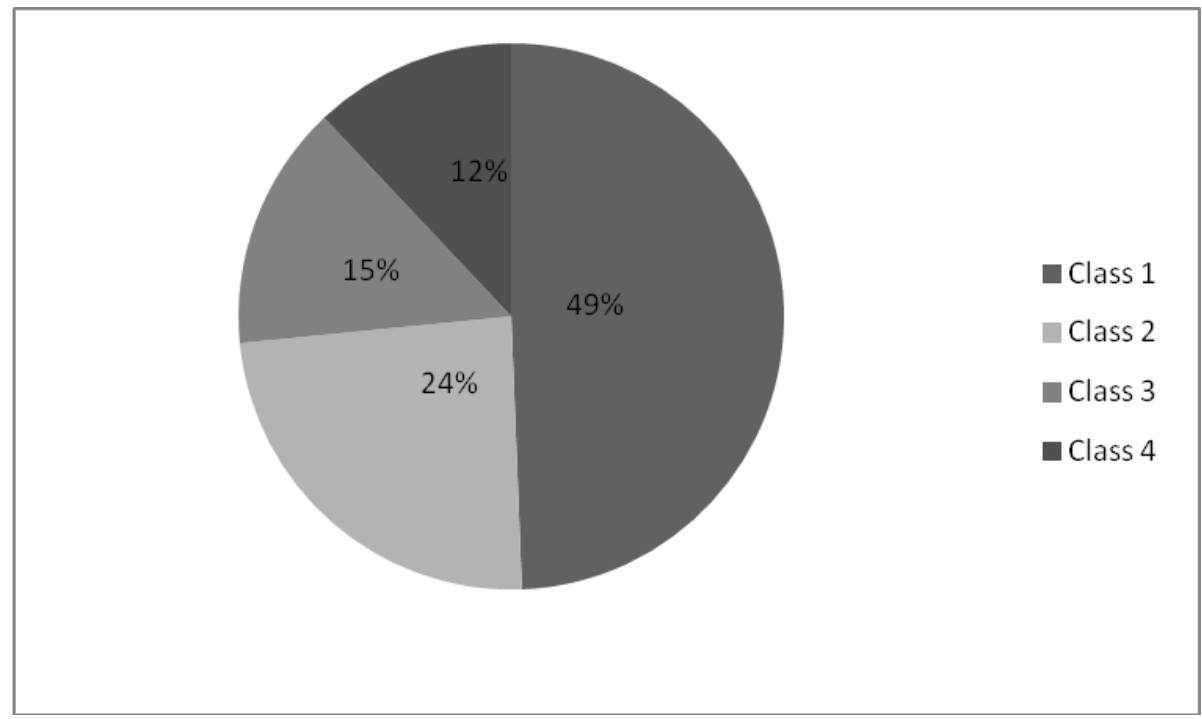

Figure 4. Classification of the 240 sampling points according to the decree 357/2005 of CONAMA (points P1 to P20), from July 2013 to June 2014.

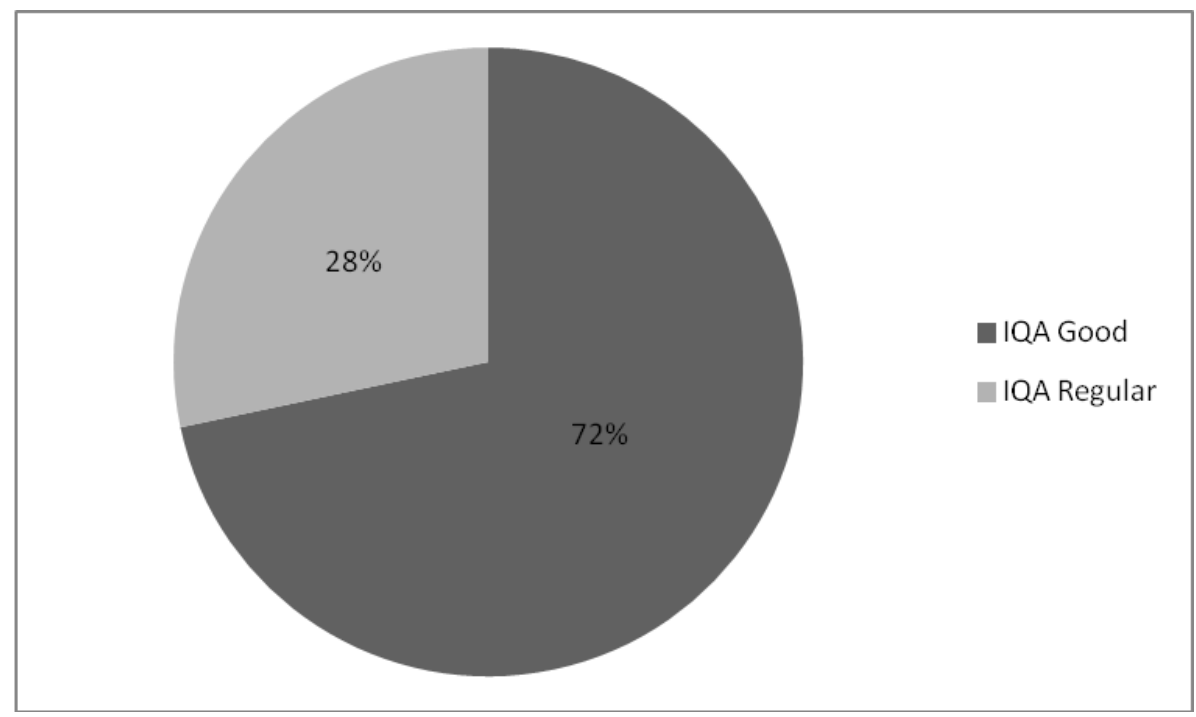

Figure 5. Rating of sampling points according to the WQI (points P1 to P20), from July 2013 to June 2014.

The results of the application of WQI after the installation of the conservation areas indicated that $72.0 \%$ of the 240 samples collected were classified as "good," which corresponds to the $73.0 \%$ of samples belonging to Classes 1 and 2 of CONAMA. The results indicated that $28.0 \%$ of the critical sampling points were classified "Regular," which corresponds to the $27.0 \%$ of samples belonging to classes 3 and 4 of CONAMA.

Comparing the results of the WQI with those of Resolution CONAMA 357/2005, small differences, $9.0 \%$ and $2.6 \%$, respectively, were found in the percentages separating sampling points appropriate for the noble uses of water (level "good" or Classes 1 and 2) from the critical sampling points (levels "Regular or Bad" or Classes 3 and 4) in the period before the installation of the conservation areas, whereas $1 \%$ differences were found in both cases in the period after the installation of the conservation areas. These differences could be explained by the differences in evaluation methods; when applying the CONAMA resolution in any point of collection, the value of the variable with the worst performance will be responsible for the final framing of this sampling point, while the WQI is calculated by the weighted multiplier of the 
corresponding water quality for each parameter evaluated, from the weights of importance of the nine variables used to set the index. The WQI is, therefore, a holistic index that characterizes the overall condition of a sampling point from the interaction of the nine variables that comprise the index. The WQI used was modified by Moretto et al. (2012) for their application in the Brazilian southern river systems. Thus, this WQI constitutes an effective technological tool to be used in environmental monitoring programs in Brazilian southern river systems, and it also provides significant information about the general environmental condition of a sampling point, complementing the results from the implementation of Resolution 357/2005 of CONAMA.

Overall, the results indicated that there was a significant improvement of water quality from the physical, chemical and microbiological points of view, comparing the periods before and after the installation of the preservation areas. We can actually see the results comparing Table 2 with Table 3, which demonstrates that the parameters obtained a significant improvement. There was a $38.5 \%$ increase of sampling points classified as having "good" water quality (CONAMA Classes 1 and 2), represented by increases from 52.0\% to 72.0\%, indicating that these sampling points are characterized as having good water quality suitable for multiple uses. Concomitantly, it was found that there was a $39.1 \%$ reduction of sampling points classified as "Regular" (CONAMA Class 3), represented by decreases from $46.0 \%$ to $28 \%$. Additionally, in the period after installation of the conservation areas, there was no sampling point ranked as "Poor" (CONAMA Class 4) compared to the previous period, when $2 \%$ of the sampling points were determined to be in this condition.

Although the reductions of the number of sampling points classified as "Regular" was evident, these points are critical, because the uses for the water in these points is more restrictive than for the water in sampling points classified as Class 1 and 2. These results could be explained by considering that these areas, even though protected, are still subject to the impact of a series of local human activities, such as the supply of nutrients and organic load from domestic sewage, cattle raising and the excess of fertilizers and agricultural inputs used in crops.

These environmental impacts can be evaluated from the variables responsible for the classification of the $28.0 \%$ of the samples as "Regular" (CONAMA Class 3), namely, the biochemical oxygen demand, dissolved oxygen, phosphorus, turbidity, nitrate and coliform. Thus, according to these variables, it is concluded that organic contamination and eutrophication of the water are the main environmental problems that characterized these water bodies. These results corroborate the environmental monitoring work in the regional water systems performed by UNISC, which has demonstrated that these water systems already have advanced stages of eutrophication (Bes et al., 2012; Böhm et al., 2013; Düpont et al., 2007; Hermany et al., 2006; Lobo et al., 2004a, 2004b, 2004c, 2004d, 2010, 2014; Oliveira et al., 2001; Salomoni et al., 2006; 2011; Schuch et al., 2012; 2014; Wetzel et al., 2002). According to Tundisi (2006), this condition characterizes in a general way all the waterways throughout the southern region of Brazil, according to the results obtained by the project "Brazil Waters."

\section{CONCLUSION}

The results clearly show that the preservation of water resources in headwaters and riparian zones plays an important role in water quality because the forests develop naturally and act as a protection zone in addition to being a source of food and protection for wildlife (Felfili et al., 2000). It is essential to recognize the importance of the environmental services provided by riparian forests and their influence on soil conditions, biodiversity, hydrological cycle and climate (Franco, 2010). Thus, promoting the recovery of degraded areas, especially those that are part of the permanent protection areas along rivers and springs, is of fundamental importance and highlights the role of the Payment for Environmental Services (PES) as an operational tool in the preservation of water resources (Tundisi et al., 2007).

\section{IPABH}

Rev. Ambient. Água vol. 14 n. 2, e2307 - Taubaté 2019 
Currently in Brazil, there is a number of projects aimed at water resource preservation that utilize PES, such as the project "Production of Water" in the basin of Pipiripau stream, DF. This project verified a $74 \%$ reduction of the costs of water treatment and a reduction of approximately $70 \%$ in water pollution by mercury and pesticides (Melo, 2013). There are other ongoing projects, such as the River Basin Benavente, ES, which is expected to expand to the entire state (ANA, 2014). In the basin of the Cantareira system, there are also PES experiences in Ribeirões do Moinho in Nazaré Paulista, SP, and Cancã in Joanópolis, SP (Melo, 2013). Finally, the Secretary of State for the Environment in Rio de Janeiro launched a River Parks Program aimed at the preservation of water resources by planting millions of trees on the banks of the Guandu and Macacu Rivers (INEA, 2014).

\section{ACKNOWLEDGEMENTS}

The authors thank CAPES/FAPERGS (Higher Education Personnel Training Coordination/Rio Grande do Sul Research Foundation) for the scholarship grant to the first author to pursue graduate studies. We like to thank CNPq for financial support through the Edict MCT/CNPq/Universal $n^{\circ}$ 14/2011. Also thanks are due to Universal Leaf Tobacco Company and Fundación Altadis, for financial support to the project "Water Guardian" in the period 2011/2015.

\section{REFERENCES}

ANA (Brasil). Produtor de água. 2014. Available in: http://produtordeagua.ana.gov.br/. Access in: 22 Dec. 2014.

APHA Standard methods for the examination of water and wastewater. 21. ed. Washington, 2005.

BES, D.; LUC, E.; TORGAN, L. C.; LOBO, E. A. Composition of the epilithic diatom flora from a subtropical river, Southern Brazil. Iheringia Série Botânica, v. 67, n. 1, p. 93$125,2012$.

BÖHM, J. S.; SCHUCH, M.; DÜPONT, A.; LOBO, E. A. Response of Epilithic Diatom Communities to Downstream Nutrient Increases in Castelhano Stream, Venâncio Aires City, RS, Brazil. Journal of Environmental Protection, v. 4, p. 20-26, 2013. http://dx.doi.org/10.4236/jep.2013.411A1003

COMITESINOS. Programa integrado de monitoramento da qualidade da água do rio dos Sinos e seus afluentes. Aplicação de um índice de qualidade da água no rio dos Sinos: período de novembro/1989 a outubro/1991. Porto Alegre, 1993. 38 p.

CONAMA. Resolução $n^{\circ}$. 357, de 17 de março de 2005. Diário Oficial [da] União, Brasília, n. 53, p. 58-63, 18 Mar. 2005.

DÜPONT, A.; LOBO, E. A.; BEM da COSTA, A.; SCHUCH, M. Avaliação da Qualidade da Água do Arroio do Couto, Santa Cruz do Sul, RS, Brasil. Caderno de Pesquisa Série Biologia, v. 19, n. 1, p. 56-74, 2007.

ESTEVES, F. A. Fundamentos de Limnologia. 3. ed. Rio de Janeiro: Interciência LTDA, 2011.

FELFILI, J. M. et al. Recuperação de matas de galeria. Brasília, 2000. p. 45. (Embrapa Cerrado Série Técnica, 21). 
FRANCO, J. G. O. Direito ambiental, matas ciliares: conteúdo jurídico e biodiversidade. Curitiba: Juruá, 2010.

HERMANY, G.; SCHWARZBOLD, A.; LOBO, E. A.; OLIVEIRA, M. A. Ecology of the epilithic diatom community in a low-order stream system of the Guaíba hydrographical region: subsidies to the environmental monitoring of southern Brazilian aquatic systems. Acta Limnologica Brasiliensia, v. 1, n. 18, p. 9-27, 2006.

IBGE. Censo 2010. Available in: http://cidades.ibge.gov.br/xtras/temas.php?lang=\&codmun= 432270\&idtema=16\&search=rio-grande-do-sul|vera-cruz|sintese-das-informacoes .

Access: 10 Dec. 2014.

INEA (RJ). Elaboração do Plano Estadual de Recursos Hídricos do Estado do Rio de Janeiro: R9 - metas e estratégias de implementação dos cenários propostos (versão final). Rio de Janeiro: Fundação COPPETEC: Laboratório de Hidrologia e Estudos de Meio Ambiente, 2014. 258 p. Available in: http://www.inea.rj.gov.br/cs/groups/public/documents/document/zwew/mdyy/ edisp/in ea0062140.pdf.Access: 14 Feb. 2017.

LOBO, E. A.; CAlleGARO, V. L. M.; HeRMANY, G.; BES, D.; WeTZEL, C. E., OLIVEIRA, M. A. Use of epilithic diatoms as bioindicator from lotic systems in southern Brazil, with special emphasis on eutrophication. Acta Limnologica Brasiliensia, v. 16, n. 1, p. 25-40, 2004a.

LOBO, E. A.; CALLEGARO, V. L. M.; HERMANY, G.; GOMEZ, N.; ECTOR, L. Review of the use of microalgae in South America for monitoring rivers, with special reference to diatoms. Vie et Milieu, v. 53, n. 2/3, p. 35-45, 2004 b.

LOBO, E. A.; BES, D.; TUDESQUE, L.; ECTOR, L. Water quality assessment of the Pardinho River, RS, Brazil, using epilithic diatom assemblages and faecal coliforms as biological indicators. Vie et Milieu, v. 53, n. 2/3, p. 46-53, $2004 \mathrm{c}$.

LOBO, E. A; CALLEGARO, V. L.; WETZEL, C. E.; HERMANY, G.; BES, D. Water quality study of Condor and Capivara streams, Porto Alegre municipal district, RS, Brazil, using epilithic diatoms biocenoses as bioindicators. Oceanological and Hydrobiological Studies, v. 33, n. 2, p. 77-93, 2004d.

LOBO, E. A.; WETZEL, C. E.; ECTOR, L.; KATOH, K.; BLANCO, S.; MAYAMA, S. Response of epilithic diatom community to environmental gradients in subtropical temperate Brazilian rivers. Limnetica, v. 29, n. 2, p. 323-340, 2010.

LOBO, E. A.; SCHUCH, M.; HEINRICH, C. G.; COSTA, A, B.; DÜPONT, A.; WETZEL, C. E.; ECTOR, L. Development of the Trophic Water Quality Index (TWQI) for subtropical temperate Brazilian lotic systems. Environmental and Monitoring Assessment, 2014. https://doi.org/10.1007/s10661-015-4586-3

MELO, J. P. F. O Projeto Produtor de Água no Pipiripau (DF) e o pagamento por serviços ambientais. 2013. Dissertação (Mestrado Profissional em Saúde Pública) - FIOCRUZ, Brasília, 2013.

MORETTO, D. L.; PANTA, E.; COSTA, A. B.; LOBO, E. A. Calibration of Water Quality Index (WQI) based on Resolution $n^{\circ} 357 / 2005$ of the Environment National Council (CONAMA) Brazil. Acta Limnologica Brasiliensia, v. 24, n. 1, p. 29-42, 2012.

NSF. Water Quality Index (WQI). 2007. Available in: http://www.nsf.org/consumer/earth_day/wqi.asp. Access in: 11 June 2007. 
OLIVEIRA, M. A.; TORGAN, L.; LOBO, E. A.; SCHWARZBOLD, A. Association of epiphytic diatom species on artificial substrate in lotic environments in the Arroio Sampaio basin, RS, Brazil: relationships with abiotic variables. Revista Brasileira de Biologia, v. 4, n. 61, p. 523-540, 2001.

ONU. Relatório-Síntese da Avaliação Ecossistêmica do Milênio. 2011. Available in: http://www.millenniumassessment.org/documentsdocument.446.aspx.pdf. Access in: 22 Dec. 2014.

POSSELT, E. L.; COESTA, A. B. Software IQAData 2010. Programa (Mestrado em Sistemas e Processos Industriais) - Universidade de Santa Cruz do Sul, Santa Cruz do Sul, 2010.

SALOMONI, S. E.; ROCHA, O.; CALLEGARO, V. L. M.; LOBO, E. A. Epilithic diatoms as indicators of water quality in the Gravataí river, Rio Grande do Sul, Brazil. Hydrobiologia, v. 559, p. 233-246, 2006. https://doi.org/10.1007/s10750-005-9012-3

SALOMONI, S. E.; ROCHA, O., HERMANY, G.; LOBO, E. A. Application of water quality biological indices using diatoms as bioindicators in Gravataí River, RS, Brazil. Brazilian Journal of Biology, v. 71, n. 4, p. 949-959, 2011. http://dx.doi.org/10.1590/S151969842011000500015

SCHUCH, M.; ABREU JÚNIOR, E.; LOBO, E. A. Water quality of urban streams, Santa Cruz do Sul, Rio Grande do Sul, based on physical, chemical and biological analyses. Bioikos, v. 26, n. 1, p. 3-12, 2012.

SCHUCH, M.; OLIVEIRA, M. A.; LOBO, E. A. Spatial Response of Epilithic Diatom Communities to Downstream Nutrient Increases. Water Environment Research, v. 87, n. 6, p. 547-558, 2014. https://doi.org/10.2175/106143014X14062131178196

SMITH, V. H.; SCHINDLER, D. W. Eutrophication science: where do we go from here?

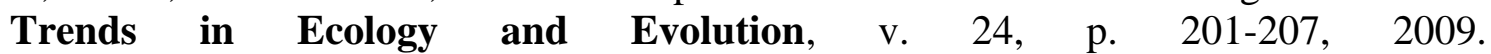
https://doi.org/10.1016/j.tree.2008.11.009

TUNDISI, J. G. Limnologia e gerenciamento de recursos hídricos: avanços conceituais e metodológicos. Ciência e Ambiente, v. 21, p. 9-20, 2000.

TUNDISI, J. G. Água no século XXI: enfrentando a escassez. São Carlos: RiMa, 2003.

TUNDISI, J. G. O Futuro dos Recursos Hídricos no Brasil. Projeto Brasil das Águas. 2006. http://www.brasildasaguas.com.br. Access in: 15 Dec. 2006.

TUNDISI, J. G. et al. Uso atual e potencial do solo no município de São Carlos, SP - base do planejamento urbano e rural. São Carlos: Instituto Internacional de Ecologia, 2007. (FAPESP - Políticas Públicas - Processo 98/10924-3).

WETZEL, C. E.; LOBO, E. A.; OLIVEIRA, M. A.; BES, D.; HERMANY, G. Diatomáceas epilíticas relacionadas a fatores ambientais em diferentes trechos dos rios Pardo e Pardinho, Bacia Hidrográfica do Rio Pardo, RS, Brasil: Resultados preliminares. Caderno de Pesquisa Série Biologia, v. 14, n. 2, p. 17-38, 2002.

WUNDER, S.; BORNER, J.; TITO, M. R.; PEREIRA, L. Pagamentos por Serviços Ambientais: Perspectivas para a Amazônia Legal. Brasília: MMA, 2008. 136p.

UNEP; IETEC. Planejamento e gerenciamento de lagos e reservatórios: uma abordagem integrada ao problema da eutrofização. Belo Horizonte, 2001. 385p. 


Ambiente \& Água - An Interdisciplinary Journal of Applied Science
ISSN 1980-993X - doi:10.4136/1980-993X
www.ambi-agua.net
E-mail: ambi.agua@gmail.com

\title{
A proposal to integrate the legal definition and official delineation of watersheds in Mexico: eight model case studies
}

ARTICLES doi:10.4136/ambi-agua.2198

Received: 18 Oct. 2017; Accepted: 18 Jan. 2019

\section{Sergio Arturo Rentería-Guevara ${ }^{1,2}{ }^{D}$; Antonio Sanhouse-García1(D; Yaneth Bustos-Terrones $^{3}{ }^{(D}$; Abraham E. Rodriguez-Mata ${ }^{3}{ }^{(D}$; Jesus Gabriel Rangel-Peraza ${ }^{*}$ (D);}

\author{
${ }^{1}$ Instituto Tecnológico de Culiacán, Culiacán, Sinaloa, Mexico \\ E-mail: sergiorenteria@uas.edu.mx, asanhouse@itculiacan.edu.mx, jesus.rangel@itculiacan.edu.mx \\ ${ }^{2}$ Universidad Autónoma de Sinaloa, Culiacán, Sinaloa, Mexico \\ E-mail: sergiorenteria@uas.edu.mx \\ ${ }^{3}$ Consejo Nacional en Ciencia y Tecnología (Conacyt), Mexico City, Mexico \\ Cátedras Conacyt. E-mail: yabustoste@conacyt.mx, arodriguez@itculiacan.edu.mx \\ *Corresponding author
}

\begin{abstract}
A hydrological basin is established as a geographic frame to officially determine surface water availability and is basic to confer or deny water rights. In Mexico, the legal definition of a hydrological basin is confusing and inconsistent with the official basin delineation published by the authority. This situation is demonstrated through the analysis of eight study cases located in Hydrological Region 10 Sinaloa. A proposal to define the legal term of hydrological basin, ensuring its consistency with official delineation of hydrological basins is presented. Geographic analysis was performed using QGIS software, by using official sources of Mexico and worldwide data bases. By law, in Mexico a water parting is defined as a borderline of maximum elevation. Nevertheless, the legal definition fails to explain hydrologic basin official boundaries where the basin limit is the location of a hydrometric station. Besides, the presence of this equipment does not mean that a waterbody exists in a hydrological basin, or that the delimited basin is an autonomous differentiated unit, as it is required by the legal definition. Other inconsistencies are presented dealing with the presence of inland water bodies as watershed limits and with groups of independent watersheds incongruously considered as a single basin. An amendment is proposed to harmonize this situation, with a minimum of changes in policy documents. The method proposed can be useful to analyze similar situations in other countries where discrepancies between the legal and official definitions of watershed delineation are also observed, or in countries where no official watershed definition has been established.
\end{abstract}

Keywords: hydrological basin delineation, surface water availability, water parting. 


\section{Uma proposta para harmonizar a definição legal e delimitação oficial das bacias hidrográficas no México: oito casos estudados como exemplo}

\section{RESUMO}

Uma bacia hidrológica é estabelecida como um quadro geográfico para determinar a disponibilidade oficial de água superficial. Portanto, a delimitação da bacia hidrológica é básica para conferir ou negar os direitos da água. Apesar disso, em certas regiões, como o México, a definição legal da bacia hidrológica é confusa e não é consistente com a delimitação oficial da bacia publicada pelas autoridades. Isso é demonstrado neste trabalho por meio de oito estudos de caso. É apresentado um esquema para definir o termo legal da bacia hidrológica, garantindo sua consistência com a delimitação oficial das bacias hidrológicas. A análise geográfica foi realizada utilizando o software QGIS, utilizando fontes oficiais do México e bases de dados internacionais. Por lei, no México, uma separação de água é definida como uma fronteira de elevação máxima. Porém, a definição legal não explica os limites oficiais da bacia hidrológica, onde o limite da bacia é a localização de uma estação hidrométrica. Além disso, a presença deste equipamento não significa que existe um corpo de água em uma bacia hidrológica, ou que a bacia delimitada é uma unidade autónoma diferenciada, como é exigido pela definição legal. São apresentadas outras inconsistências que tratam da presença de canos de água do interior como limites de bacia hidrográfica e com grupos de bacias hidrográficas independentes consideradas incongruentes com uma bacia única. Uma alteração é proposta para harmonizar esta situação com mudanças mínimas nos documentos oficiais. O esquema proposto neste trabalho pode ser útil para analisar situações semelhantes em outros países onde também são observadas discrepâncias entre a definição legal da bacia hidrográfica e a delimitação oficial das bacias hidrográficas ou em países onde nenhuma bacia hidrográfica oficial esteja estabelecida.

Palavras-chave: delimitação da bacia hidrológica, disponibilidade de água superficial, linha divisória de águas.

\section{INTRODUCTION}

A hydrological basin is an area delineated by nature itself, fundamentally by the borders of surface runoff zones that converge towards a single watercourse (Reis et al., 2015). It is considered the suitable territorial unit to manage water resources, even to manage the whole environment. Watershed management is an essential component of adequate environmental administration (Imperial, 2005). The watershed concept is also considered a risk management unit for hydrometeorological events due to the fact that climate change has made it necessary to develop adaptation programs to maintain and increase surface and ground water availability, with a focus on integrated hydrographic watershed management (Tomer and Schilling, 2009).

Thus, this natural territorial division tends to acquire an administrative connotation: "The current National Water Bank (NWB) watersheds is basically an administrative application" (Chile, 2013). Such connotation can even become official as in Chile and Mexico, respectively: "[...]this watershed delineation is the administrative official delineation of General Water Administration (GWA)" (Chile, 2013); "Therefore, it is necessary to specify and publish the watershed limits to provide water users with a higher certitude about the exact localization of the geographic sites where water use occurs and to improve water management [...]" (CONAGUA, 2016a).

This watershed delineation is an input for governmental instruments for river basin

Rev. Ambient. Água vol. 14 n. 2, e2198 - Taubaté 2019 
development planning and management (RBDPM), by which water is distributed among users in a watershed-based territory division. However, "sometimes political influence is observed in RBDPM boundaries, where the political territorial limits match rather than natural drainage basin delineation" (Barrow, 1998). In Mexico, the National Water Commission (CONAGUA) recognizes 37 Hydrological Regions whose basin-based frontiers are adjusted to municipal political limits to form the borders among hydrological administrative regions (CONAGUA, 2010). The distribution of municipalities among Mexican watersheds was carried out depending on their socioeconomic, demographic and territorial dynamics (Espejel et al., 2005; Sotelo et al., 2010). In this sense, territorial divisions in natural hydrological basins and administrative hydrological basins do not match: "The first evident problem, and the most important of all, is the differences between NWB watersheds and real watersheds" (Chile, 2013).

When natural and administrative boundaries do not match, problems arise in calculating water balances in hydrological basins. Further problems generated by mismatch between natural and official limits affect underground water recharge calculation, hydrogeological modeling, surveillance plan design for water quality norms and aquifer sectorization (Chile, 2013). Therefore, the official delineation of a hydrological basin, as an administrative and a legal instrument, must be consistent with the legal definition of this territorial entity.

Countries like Argentina (2003), Bolivia (1992), Chile (2018), Colombia (2004), Ecuador (2014), México (CONAGUA, 2017a) and Peru (1969), among others, have their respective legal definitions of a hydrological basin named according to local terminology: "As a consequence of this lack of conceptual consensus, due to the Spanish terminology, there have been interagency problems about hydrological basin management actions and law formulation deficiencies" (CEPAL, 1994).

The aim of this paper is to contrast the definition of a hydrological river basin established in the Mexican Water Law with officially delineated basins to determine discrepancies and to present a proposal to overcome them. This is achieved by analyzing eight official river basins in Sinaloa, Mexico. Based on the differences found, a new definition of hydrological basin is proposed with the purpose of harmonizing this situation.

\section{MATERIALS AND METHODS}

\subsection{Study area}

The Mexican territory is divided in 37 hydrological regions. Eight basins were taken as study cases for this paper. All of these basins are in Hydrological Region 10 of Sinaloa (Figure 1).
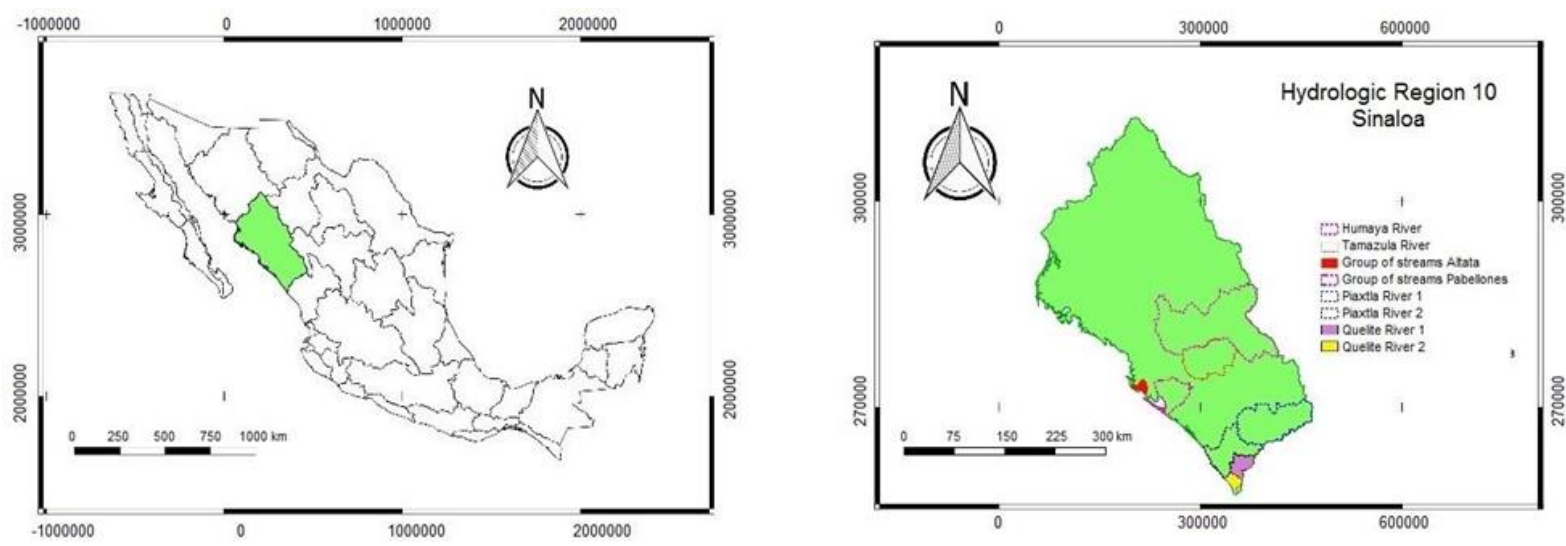

Figure 1. Hydrological regions in Mexico, Hydrological Region 10 Sinaloa and basins under study. Sources: Prepared by authors with shape files from CONABIO (2009) and basin vertices published in CONAGUA (2016a).

\section{IPABH}




\subsubsection{Humaya and Tamazula basins}

These basins are part of the Culiacan River Basin that is located between parallels $26^{\circ} 03^{\prime} 12.98^{\prime \prime} \mathrm{N}$ and $24^{\circ} 27^{\prime} 09.78^{\prime \prime} \mathrm{N}$ and between meridians 107 ${ }^{\circ} 45^{\prime} 38.81^{\prime \prime} \mathrm{W}$ and $105^{\circ} 48^{\prime} 34.16^{\prime \prime} \mathrm{W}$. Culiacan River watershed occupies the second-most important terrain portion of Hydrological Region 10. The Culiacan River is $305 \mathrm{~km}$ long; it is a sixth-order stream and has an angular drainage pattern. This basin is exorheic, draining to the California Gulf and has a maximum altitude of 3,207 meters above sea level. Culiacan River Basin occupies territories of the Mexican states of Chihuahua, Durango and Sinaloa. The Culiacan River is the main stream which is formed by the junction of Humaya and Tamazula rivers in the city of Culiacan (Sanhouse-Garcia et al., 2017).

The Humaya River is the largest affluent of the Culiacan River. This river has its origin in Durango state, located at 3,100 m.a.s.l. The Humaya River Basin has a surface area of $11,104.0 \mathrm{~km}^{2}$, where its runoff is estimated in 1,907.0 $\mathrm{Mm}^{3}$ per year (CONAGUA, 2016b). The Adolfo Lopez Mateos dam is situated on the Humaya River upstream from its confluence with the Tamazula River located in Culiacan City. The Tamazula River Basin has a catchment area of 3,307.0 $\mathrm{km}^{2}$ and a natural runoff annual volume of $755.4 \mathrm{Mm}^{3}$ (CONAGUA, 2016b). The Sanalona Dam is located on this river before its confluence with the Humaya River.

\subsubsection{Group of streams Altata and Pabellones basins}

Group of Streams Altata Basin is in an area situated between parallels $24^{\circ} 45^{\prime} 45.54^{\prime \prime} \mathrm{N}$ and $24^{\circ} 32^{\prime} 27.20^{\prime \prime} \mathrm{N}$ and between meridians $107^{\circ} 59^{\prime} 37.21^{\prime \prime} \mathrm{W}$ and $107^{\circ} 46^{\prime} 10.81^{\prime \prime} \mathrm{W}$. Its topography is mainly flat, with a maximum altitude of 9 m.a.s.l. This watershed has a surface area of $299.1 \mathrm{~km}^{2}$ and a natural surface runoff of $17.6 \mathrm{Mm}^{3}$ per year (CONAGUA, 2016b). The Group of Streams Altata area has no main stream. Its territory is drained by diverse small watercourses to the sea through Altata cove

Group of Streams Pabellones is an area placed between parallels $24^{\circ} 47^{\prime} 28.51^{\prime \prime} \mathrm{N}$ and $24^{\circ} 16^{\prime} 17.63^{\prime \prime} \mathrm{N}$ and between meridians $24^{\circ} 16^{\prime} 17.63^{\prime \prime} \mathrm{W}$ and $107^{\circ} 05^{\prime} 09.77^{\prime \prime} \mathrm{W}$. Its surface area is of $1818 \mathrm{~km}^{2}$ and its natural surface runoff is $92.1 \mathrm{Mm}^{3}$ per year (CONAGUA, 2016b). The Group of Stream Pabellones area has a mean altitude of 330 m.a.s.l. Because this watershed has no main stream, it is drained by multiple small streams that flow to Pabellones cove that is connected to the Pacific Ocean.

\subsubsection{Piaxtla River watershed}

The Piaxtla River Watershed is located between parallels $23^{\circ} 40^{\prime} \mathrm{N}$ and $26^{\circ} 30^{\prime} \mathrm{N}$ and between meridians $105^{\circ} 20^{\prime} \mathrm{W}$ and $106^{\circ} 50^{\prime} \mathrm{W}$. The catchment area is about 7,447.1 $\mathrm{km}^{2}$ and the natural annual surface water runoff is $1,397 \mathrm{Mm}^{3}$ (CONAGUA, 2016b). This wathershed is exorheic with a very elongated ellipse shape having a maximum altitude of 3,206 m above sea level (de la Lanza Espino et al., 2015). Its hydrographic scheme is simple. Its main collector follows an approximate southwest direction towards the sea receiving streams on both sides. The Piaxtla River springs in Sierra Madre Occidental ridge above 2,800 meters above the sea.

The Piaxtla River has a longitude of $220 \mathrm{~km}$ and an angular drainage pattern. Based on CONAGUA criterion, the Piaxtla River Watershed is divided in two basins: the Rio Piaxtla 1 and the Rio Piaxtla 2 that are described below. Rio Piaxtla 1 basin drains an area of $4,842.7 \mathrm{~km}^{2}$ and is bordered to the north by the San Lorenzo River watershed, to the south by the watersheds of the rivers Presidio and Quelite, to the east by Hydrological Region 36 Nazas-Aguanaval, and to the west by the Elota River Watershed. Rio Piaxtla 1 basin extreme altitude sites are the source of the Piaxtla River and the Piaxtla hydrometric station. Rio Piaxtla 2 basin drains an area of $2,604.4 \mathrm{~km}^{2}$ and it is limited at north by the Elota River watershed, to the south by the Quelite River watershed, to the east by the Presidio River watershed, and to the west by the Pacific Ocean. 


\subsubsection{Quelite River Watershed}

The Quelite River Watershed is situated between $23^{\circ} 48^{\prime} 43.85^{\prime \prime} \mathrm{N}$ and $23^{\circ} 18^{\prime} 16.30^{\prime \prime} \mathrm{N}$ and between $106^{\circ} 36^{\prime} 57.09^{\prime \prime} \mathrm{W}$ and $106^{\circ} 10^{\prime} 04.35^{\prime \prime} \mathrm{W}$. This watershed has a surface area of $1,194.5 \mathrm{~km}^{2}$ and its main water course has a longitude of $67 \mathrm{~km}$. It has a natural surface runoff of $154.0 \mathrm{Mm}^{3}$ (CONAGUA, 2016b).

The Quelite River watershed has the shape of an irregular four-sided polygon having a very simple hydrographic structure with a single central collector flowing to the southwest. It receives unnamed small streams on both sides. The Quelite River originates in the Sierra del Espinazo del Diablo ridge around 1,050 m.a.s.l. running through Los Naranjos village and six kilometers downstream through El Quelite village, from which this river takes its name (Ramos and Gracia, 2012).

The Quelite River watershed is divided into two basins, Rio Quelite 1 and Rio Quelite 2, as described below. Rio Quelite 1 basin includes an area from the Quelite River origins to the El Quelite hydrometric station. It drains an area of $829.9 \mathrm{~km}^{2}$ and it is limited to the north and to the west by the Piaxtla River watershed, to the south by the Rio Quelite 2 Basin, and to the west by the Presidio River Watershed. Rio Quelite 2 Basin extends from the El Quelite hydrometric station to the sea. It drains an area of $364.6 \mathrm{~km}^{2}$ and limits to the north by Quelite 1 Basin, to the east by the Presidio River Watershed, to the south by a marsh zone and by the Presidio River Watershed, and to the west by the Piaxtla 2 Basin and the Pacific Ocean.

\subsection{Software and databases}

The dataset used in this study was obtained from Mexican government and worldwide databases. Mexican official information includes hydrography, official watershed delineation, and localization of discharge gauging stations. In turn, worldwide databases provided terrain elevations and satellite images.

Maps were generated using QGIS 2.18.3 Las Palmas software. GIS software selection was based on the criterion that this software is an open-source tool. Also, this software is useful and simple and shows a friendly interface that allows for the processing of many file formats (both input and output) and the exchange of information through the publication of cartography. QGIS was executed from the Windows platform. Georeferencing of the basic cartography set was carried out using the WGS84 reference system (World Geodetic System, 1984) and UTM projection (Universal Transverse Mercator), zone 13.

Maps were generated using vector files containing information such as the delineation of basins, sub-basins, watercourses and waterbodies. This information is available from National Institute of Geography and Statistics (INEGI, 2017a). Layers corresponding to Hydrological Region 10 Sinaloa (scale 1:50 000) were downloaded. They are vector files in shape format (*.shp).

Mapping of the official delineation of river basins in Mexico was performed based on vertex coordinates. Official delineation in Mexico is published in the Official Journal of the Federation (CONAGUA, 2016c) in PDF text format. These coordinates were converted from Adobe Acrobat to Excel files. They were then saved in comma delimited text format and added to the GIS canvas using option "Add comma delimitated text layer". Terrain elevation layers were generated from elevation data using GIS tool "Level curves".

Watercourses and water bodies were incorporated into maps by loading vector layers from Hydrographic Network 1:50 000. The Hydrographic Network used in this paper is a drainage model of river basins (INEGI, 2010). This information is stored in a database in geographic coordinates Datum ITRF92 epoch 1988.0 with eight decimal digits of decimal degrees. In some maps, terrain satellite images were used as background to enhance visual perception of terrain. Hydrometric station coordinates were consulted in the Surface Water National Data Bank (CONAGUA, 2017b). In addition, ASTER GDEM v2 Worldwide 
Elevation Data with one arcsec resolution (NASA, 2011) and satellite images from Google Earth Pro were used to identify elevations of official river basin boundaries and to display orography as a natural terrain background, respectively. Both data sources were selected as cartographic sources.

It should be noted that neither river basin boundaries nor other hydromorphological features were generated by using digital elevation model processing. This is because the purpose of this paper is to compare official information issued from different governmental sources: official river delineation from the water authority (CONAGUA), hydrography from INEGI and the legal definition of "river basin" from the Federal Official Diary.

\subsection{Analysis of the legal definition of watershed and watershed official delineation}

The definition of watershed established in Mexican Water Law was examined and compared with officially delineated basins. The characteristics that distinguish the official watershed definition were separated and examined in eight basins, which constitute the study cases. They were selected from a representative hydrological region with diverse hydrographic features, like basins with and without water reservoirs, borders established by the presence of hydrometric stations and territories drained by no main streams.

The GIS capabilities were used to prepare maps having official basin delineation and hydrography coming from different data sources. This allowed for the examination of specific characteristics of selected official basins and for the comparison of these with their corresponding concept established in the legal definition of watershed.

Finally, a new watershed definition is proposed, which tries to keep the essence of the original one proposed by the Mexican Federal Government. No changes in official watershed delineation are mandatory for this definition proposal. The eight study cases were also used to probe the suitability of the new definition.

\section{RESULTS AND DISCUSSION}

\subsection{Legal definition of watershed in Mexico}

In Mexico, a legal definition of hydrological basin is established in the National Water Law (NWL) (CONAGUA, 2017a):

Hydrological basin: is a territory unit, differentiated from other units, usually delimited by a water parting or water divide, which is a polygonal line formed by the highest elevation points in that unit, where water courses in different ways and this resource is stored or flows to an outlet point that can be the sea or other inland waterbody, through a hydrographic network of streams that converges in a main one, or it is the territory in which the waters form an autonomous unit or differentiated from others, even without draining water towards the sea. In this space, delimited by a topographic diversity, water, soil, flora, fauna, and other natural resources coexist. The hydrological basin in conjunction with the aquifers constitutes the management unit of water resources. The hydrological basin is in turn composed of sub-basins and they are integrated by micro-basins.

This definition shows inconsistencies with respect to the official delineation of hydrological basins in Mexico, which are published in the Official Journal of the Federation. The territory division in official hydrological basins is used as a geographic framework to determine water availability "Natural runoff is among the elements considered to update mean annual national water availability in the 731 hydrological basins[...]” (CONAGUA, 2016d). In turn, official water availability is the base to confer or deny water use rights (CONAGUA, 2017a). 
According to official information, 26 new small basins or watersheds were aggregated. Hence, there are 757 official hydrological basins in Mexico (CONAGUA, 2016a; 2016b; 2016c; 2016d; 2016e; 2016f). However, these delimited basins do not meet the characteristics given in the legal definition, as it is discussed in this article through the respective study cases.

\subsection{Water parting: a line of the highest elevation points}

In the hydrological basin definition, the NWL establishes that "Hydrological basin: is a territory unit, differentiated from other units, usually delimited by a water parting or water divide, which is a polygonal line formed by the highest elevation points in that unit [...]",

Based on this definition, the word "usually" gives the idea that there are unusual situations. Commonly a hydrological basin is defined as a polygonal line formed by the highest elevation points. However, there are some official hydrological basins in Mexico which are delimited, and they do not meet with this requirement. Official delineation of Piaxtla River 1 and Piaxtla River 2 Basins are shown in Figure 2 (CONAGUA, 2016a).

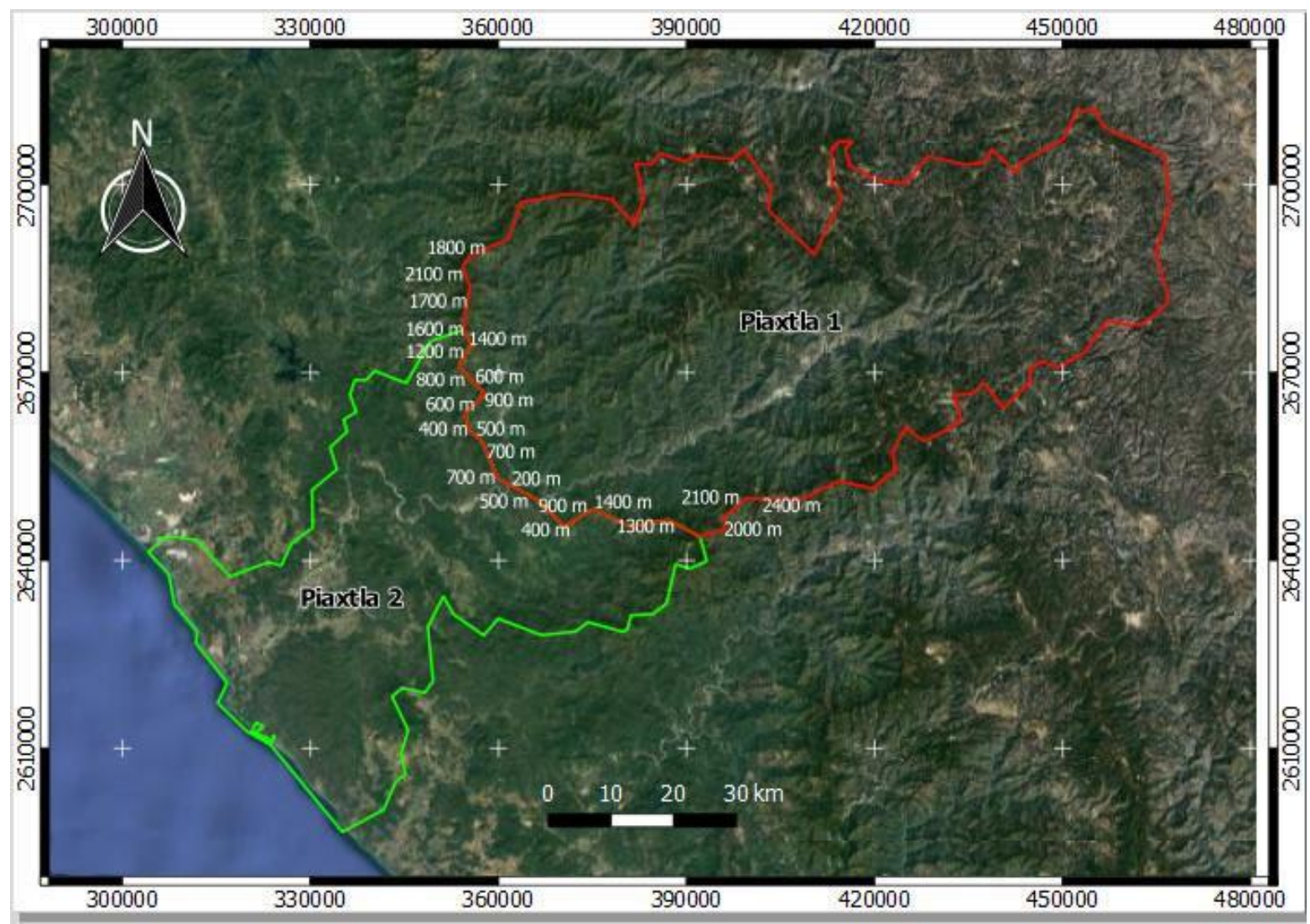

Figure 2. Contour lines in the frontier of Piaxtla River 1 and Piaxtla River 2 Basins.

Source: Prepared by the authors using Google Earth and CONAGUA (2016a).

Boundary details of both basins demonstrate that delineation boundary dramatically decreased from an elevation of 2100 m.a.s.l. to 400 m.a.s.l. This situation indicates that an important part of the basins' border, i.e., the common frontier, does not meet the hydrological basin definition of the NWL. An arbitrary unnatural delineation was carried out for dividing both basins. A similar situation is presented for Quelite River 1 and Quelite River 2 Basins, as shown in Figure 3. Based on the level curves of the study area, elevations of 20 m.a.s.l were registered as part of the delineation boundaries of these basins. 


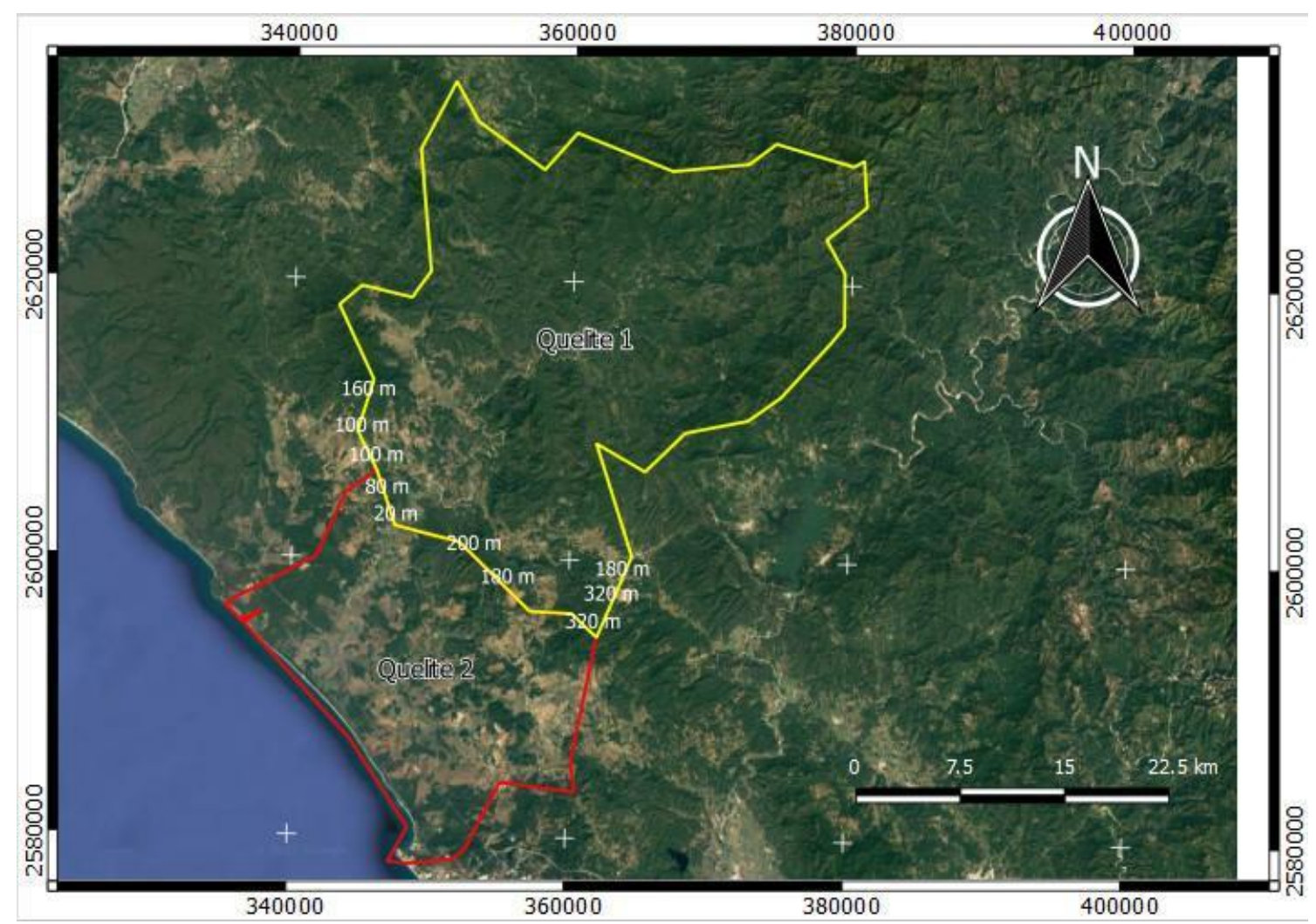

Figure 3. Contour lines in the frontier of Quelite River 1 and Quelite River 2 Basins.

Source: Prepared by the authors using Google Earth and CONAGUA (2016a).

\subsection{Location of hydrometric stations as a criterion for basin delineation}

A common practice for hydrographic basin delineation in Mexico is to define its boundaries through the presence of hydrometric stations located on the main stream. In the previous section (Figures 2 and 3), two study cases were present: Piaxtla River Basin and Quelite River Basin. Based on the description of Piaxtla River 1 Basin boundaries, this hydrological basin "[...]starts from the beginning of the Piaxtla River until where the Piaxtla hydrometric station is located." (CONAGUA, 2013a). This hydrometric station is located in the coordinates $106^{\circ} 25^{\prime} 30.0^{\prime \prime}$ and 23 56'00.0" (CONAGUA, 2017b). In accordance with official information, the division between these basins was determined by the locations of the hydrometric stations registered in the National Data Bank of Surface Waters (NDBSW). This situation could explain the fact that none of the basins is formed by the highest elevation points. A similar situation occurs for the Quelite River Basin. This hydrological basin: "[...]starts from the beginning of the Quelite River until where the hydrometric station El Quelite is located" (CONAGUA, 2013b). The hydrometric station mentioned above is located in the coordinates $106^{\circ} 29^{\prime} 00^{\prime \prime} \mathrm{N}$ and $23^{\circ} 30^{\prime} 45^{\prime \prime} \mathrm{S}$ (CONAGUA, 2017b).

On the other hand, Figures 2 and 3 show that the sea or other interior water bodies are not located at the outlet of the upstream basins (Piaxtla and Quelite). In this sense, these study cases do not fulfill with the definition of hydrological basin of the NWL, which specifies that the territory of a hydrological basin is: "[...]where water courses in different ways and this resource is stored or flows to an outlet point that can be the sea or other inland waterbody". The basins demonstrated that the legal definition of hydrological basin in Mexico is not linked to the official delineation of hydrological basin. Consequently, it is not consistent with the characteristics that legal definition establishes. Furthermore, according to legal definition, a hydrological basin is "[...] the territory in which the waters form an autonomous unit or differentiated from others, even without draining water towards the sea." Piaxtla River 1 and Piaxtla River 2 Basins do not form autonomous units, nor are differentiated from one another. 
The only thing that distinguishes them is the existence of a hydrometric station located on a site, which is considered appropriate for measurement purposes. A similar situation is presented in the Quelite River 1 and Quelite River 2 Basins. Thus, the legal definition of hydrological basin should be flexible and should include cases such as those described here.

\subsection{Water bodies as boundaries of a hydrological basin}

The National Water Law establishes that surface water in a hydrological basin: "[...]is stored or flows to an outlet point that can be the sea or other inland waterbody, through a hydrographic network of streams that converges in a main one". In this statement, there is a parallelism between the sea and other waterbody as destinations of the water that drains out the basin. This means that neither the sea, nor the "other waterbody" are part of the basin. According to this wording, this receptor waterbody should be located outside the basin, downstream from it.

In Mexico, waterbodies' boundaries are used to define hydrological basins. The presence of water bodies inside a hydrological basin demonstrates that the official delineation of hydrological basin does not meet with the characteristics established by the legal definition. Such a discrepancy is observed specially in hydrological basins with reservoirs. The Humaya River and Tamazula River Basins could be considered as examples. The official description of Humaya River Basin indicates that: "The available volume of Humaya River basin goes from the beginning of the Humaya River up to the Adolfo Lopez Mateos reservoir", while the official description of Tamazula River basin is: "The volume available of Tamazula River basin goes from the beginning of Tamazula River until where the Sanalona reservoir is located." (CONAGUA, 2010).

CONAGUA (2016a) provides the vertices of the polygon lines that define these hydrological basins boundaries. This polygon includes Adolfo López Mateos reservoir inside Humaya River Basin and Sanalona reservoir inside Tamazula River Basin, as shown in Figure 4.

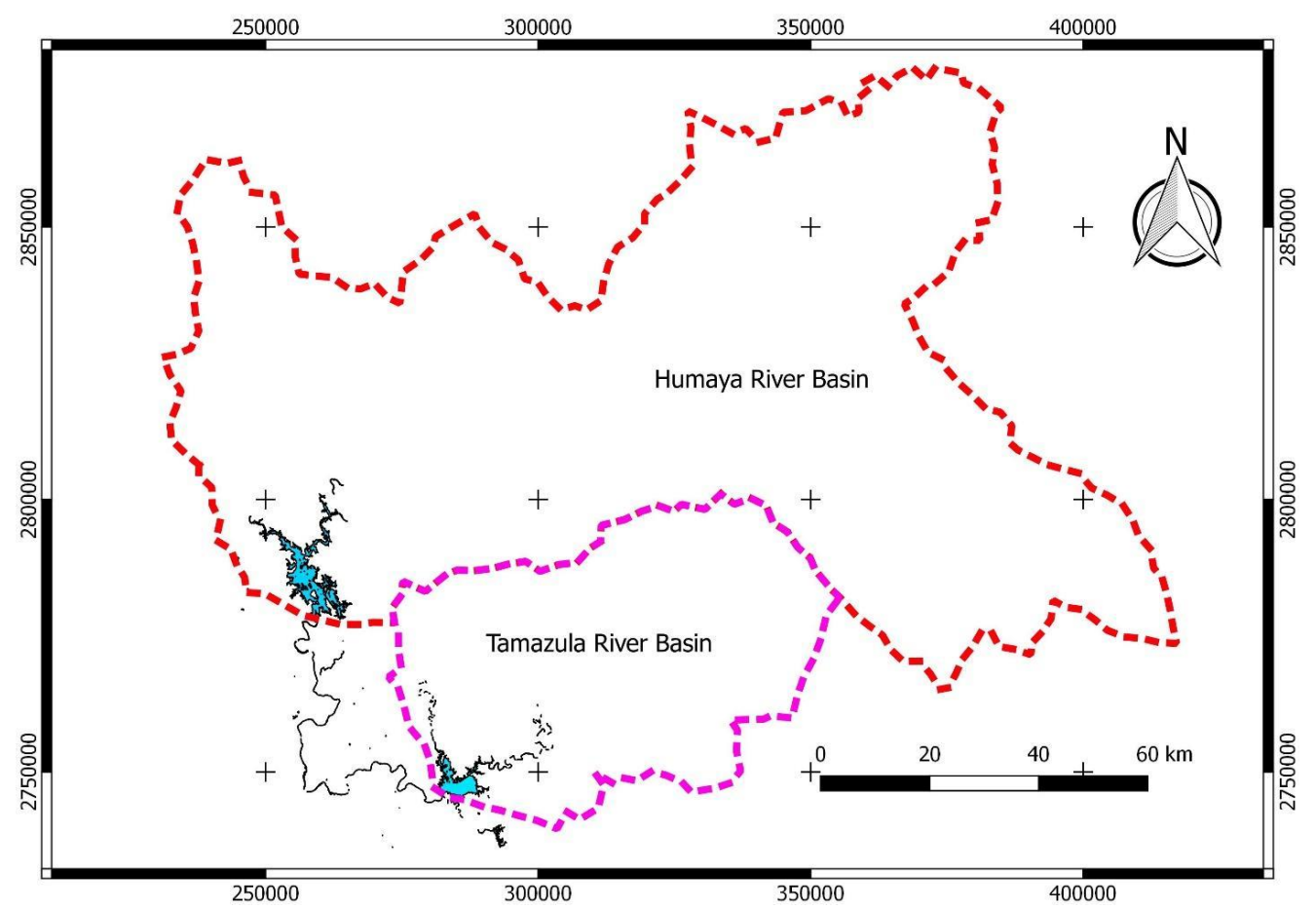

Figure 4. Humaya River and Tamazula River Basins and their reservoirs. Source: Prepared by the authors using INEGI (2017a) and CONAGUA (2016a). 
In both cases, the water does not drain towards a waterbody located outside the basin, because the waterbody (reservoir) is inside of it. In addition, some streams belonging to the hydrographic network of the basin do not converge towards a main course but converge towards the reservoir. An inspection of the surrounding areas reveals that there are multiple inputs to each reservoir (Figures 5 and 6). Since each waterbody located inside the basin has multiple inlets, they could be also considered as hydrological basin outlets, including the corresponding to the main stream.

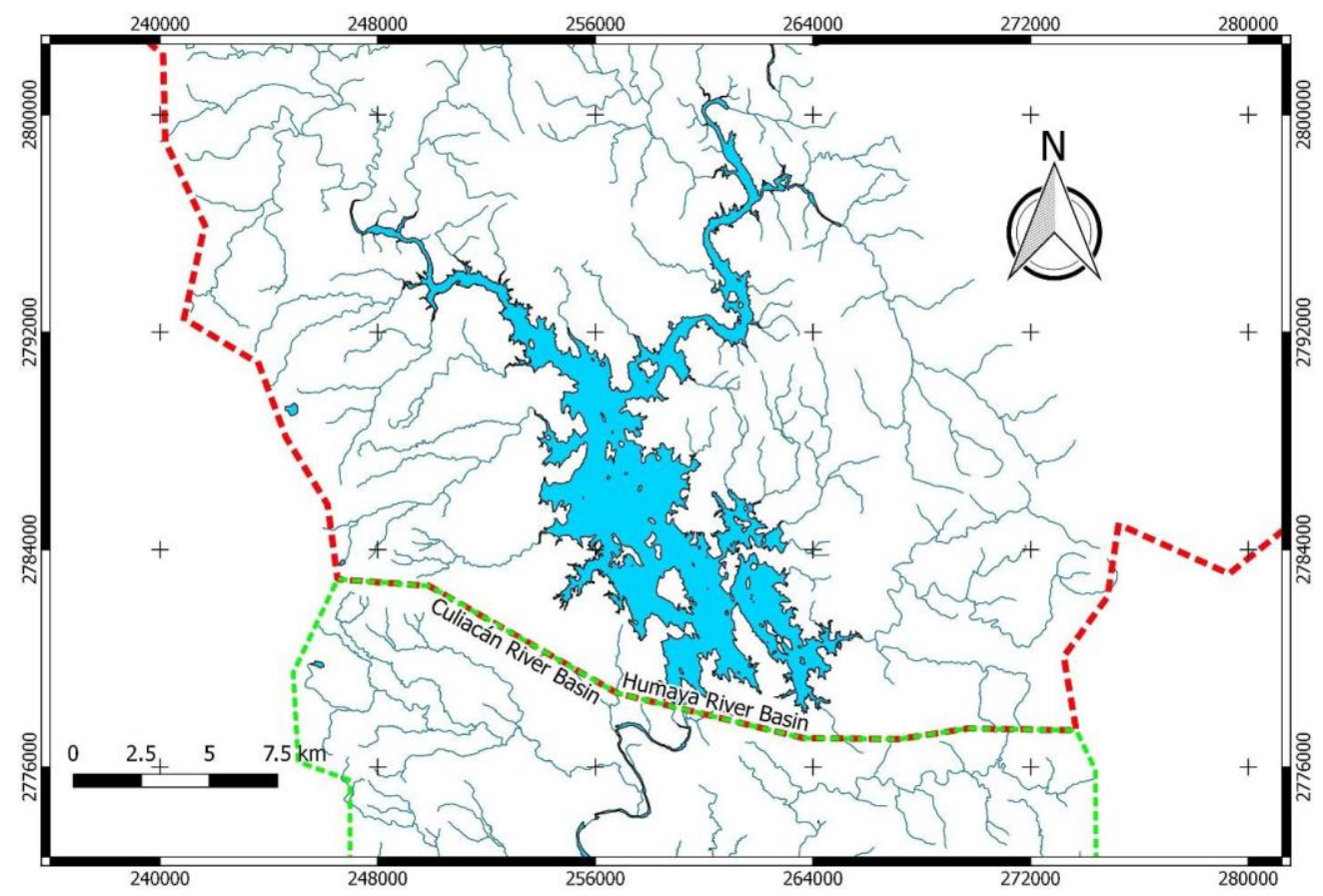

Figure 5. Streams draining to the reservoir of Adolfo López Mateos Dam. Source: Prepared by the authors using INEGI (2017a) y CONAGUA (2016a).

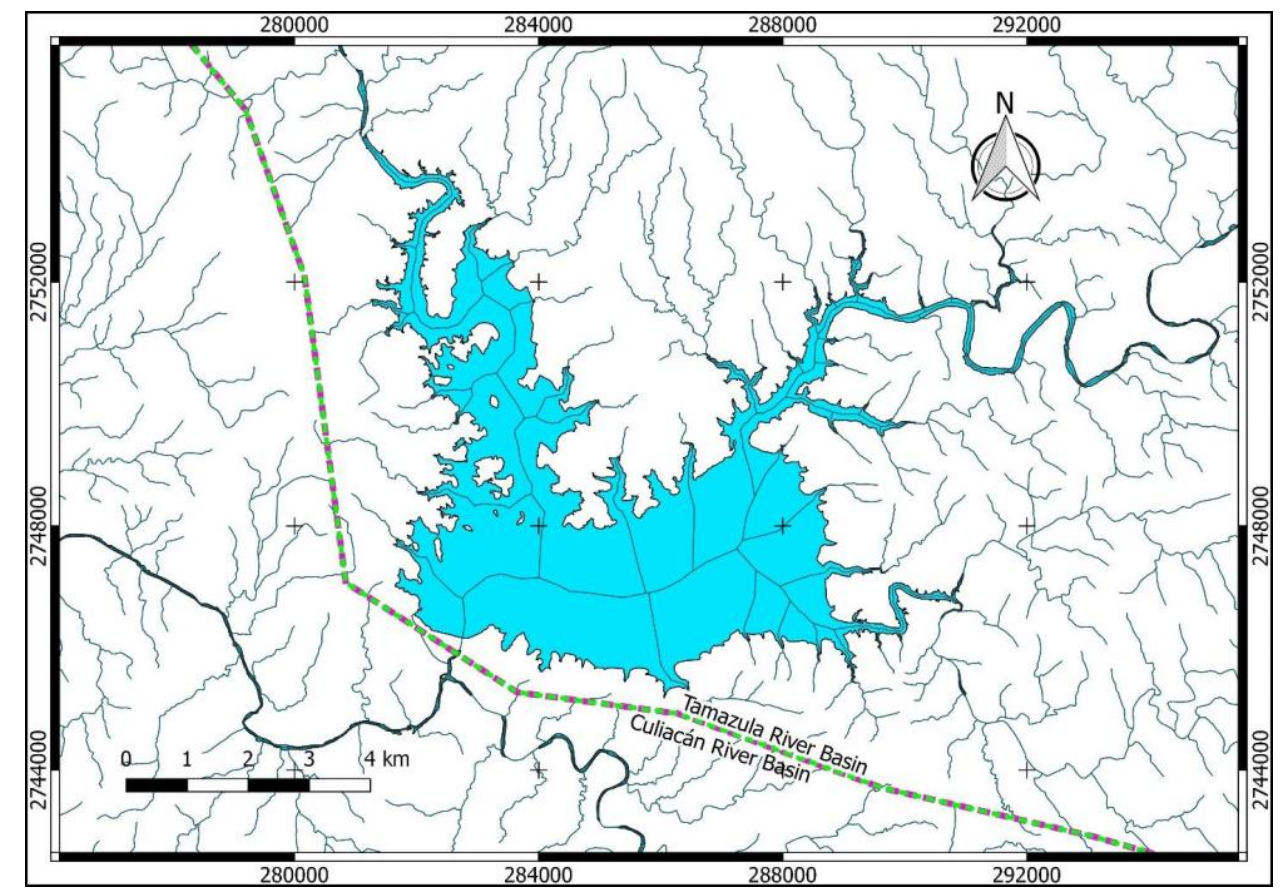

Figure 6. Streams draining to the reservoir of Sanalona Dam.

Source: Prepared by the authors using (INEGI, 2017b) y (CONAGUA, 2016a). 
Therefore, if the whole drained area is characterized, maintaining the principle that a basin should have a single outlet point, the first alternative would be to indicate that in the case of a waterbody presence in a hydrological basin: 1) the drained area is constituted by the main stream basin and a set of minor basins; 2) the convergence entity is the waterbody located inside of the basin; and, 3) the boundary of this basin is the output point of the reservoir or where its outflows merge. A second alternative would be to modify the definition of hydrological basin in such a way that this definition could be consistent with the existing official delineations.

\subsection{Groups of minor coastal basins}

In the Federation Official Diary (CONAGUA, 2016a), it is also noted that:

"[...]within the 37 hydrological regions of the country, there are areas where no perennial streams exist, which are not within the 731 basins identified previously. Hence the identification of 26 new hydrological basins is required to cover the whole national territory."

In the area under study there are two of these types of areas. This type of terrain is characterized by multiple small watercourses draining to the sea, each of them having multiple drainage points, as shown in Figure 7. These officially-delimited basins do not fulfill with the established in the legal definition, where an only drainage point is required (CONAGUA, 2017a).

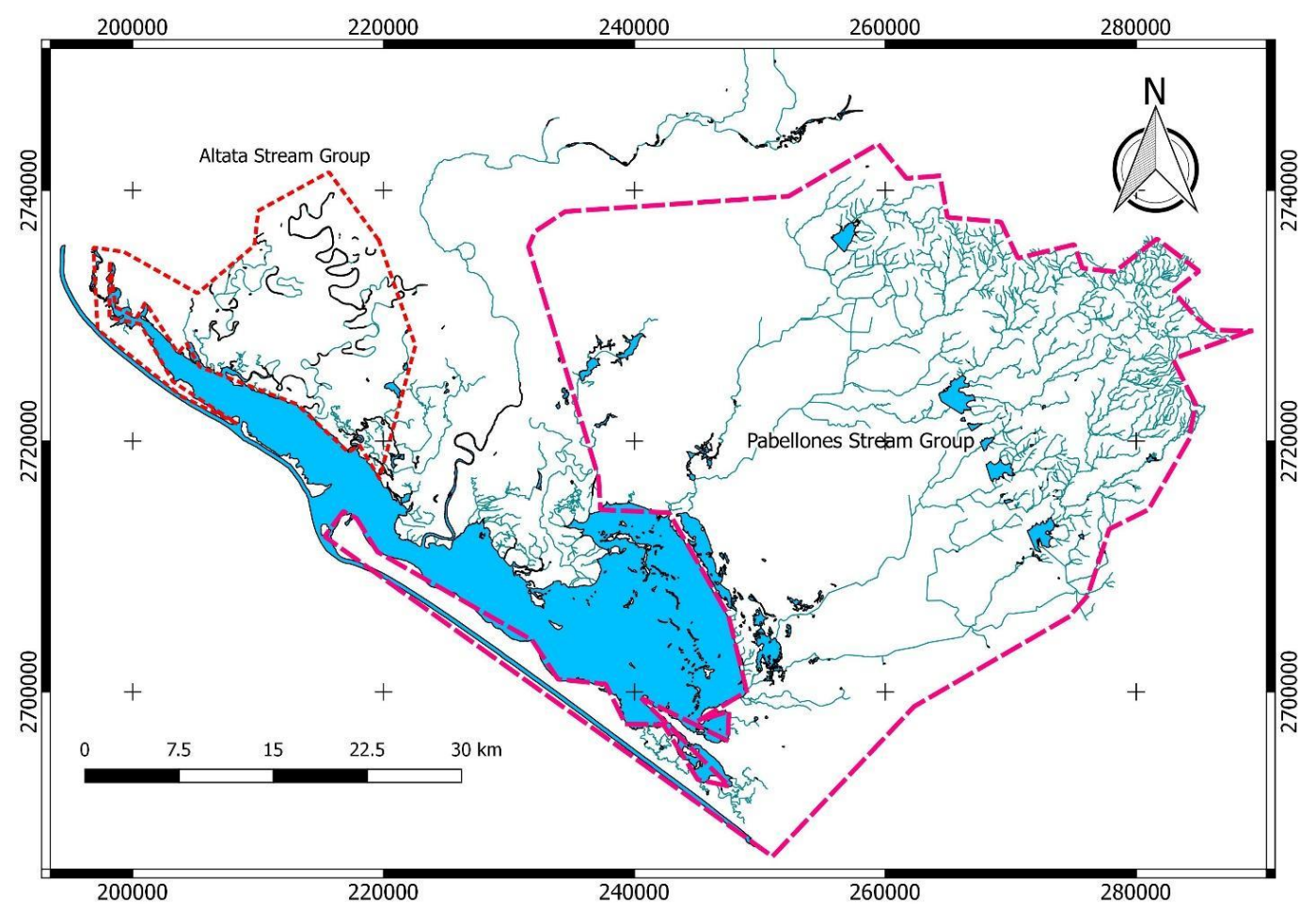

Figure 7. Group of streams Altata and Pabellones.

Source: Prepared by the authors using CONAGUA (2016b).

In order to look for consistency between the legal definition of hydrological basin and these types of drainage entities, which are already defined and officially referred as "new hydrological basins", it is necessary to consider the configuration variability of these territories. Cotler (2007) suggests that:

"Some hydrological basin boundaries might vary due to the time of the year, an anthropogenic modification of the drainage network and even because of the presence of some special meteorological phenomenon like hurricanes, which could generate the displacement of basin boundaries downstream". 
According to this, the establishment of individual boundaries for each of these basins is not a viable option, given the permanent nature of the official precepts. Gathering them in a single drainage official entity, as a "group of minor basins", could make consistent the natural configuration variability of these basins with official denomination. In addition, this boundary would be at the same time a limit of adjacent basins with more stability in their configuration. "Group of minor basins" is a concept that can be extended to a set of small hydrological basins, which drain into a waterbody located inside a basin.

\subsection{Complexity of the legal definition}

According to the Oxford Dictionary, a definition is: "[...]an exact statement or description of the nature, scope, or meaning of something" (Oxford, 2018). The Dictionary of the Royal Spanish Academy adds "clarity" to the characteristics that a definition must have (Real Academia Española, 2017). The definition of "hydrological basin" in Mexico is provided by the National Water Law. Neither references nor technical fundamentals are specified. However, the wording of this definition is inconsistent with the concept of definition itself. The definition of hydrological basin established in the NWL has a generic character, as being "[...] a territory unit". This could be a physiographic region, a municipality or other natural or artificial zoning.

In the CONAGUA definition of hydrological basin, it is also established that the basin is usually delimited by a water parting. The word usually refers to the existence of different cases. However, it does not indicate how these cases would be delimited. This wording fails to fulfill the exactitude and clarity that a definition should have. On the other hand, the wording of the hydrological basin definition is comprised of several watershed definitions, as shown in Table 1.

Table 1. Definitions contained in the definition of watershed of Mexican National Water Law.

\begin{tabular}{|c|c|}
\hline al Water Law & Other sources \\
\hline $\begin{array}{l}\text { "[...]is a territory unit, differentiated from } \\
\text { other units, usually delimited by a water } \\
\text { parting or water divide }[. . .] "\end{array}$ & $\begin{array}{l}\text { Watershed: Surface bordered by a water parting so that } \\
\text { its runoff flows towards a main water course, or } \\
\text { waterbody. It is a subdivision of a hydrological region } \\
\text { (Omernik and Bailey, 1997). } \\
\text { basin syn. drainage basin, catchment, river basin, } \\
\text { watershed (USU): Area having a common outlet for its } \\
\text { surface runoff (OMM, 2012). }\end{array}$ \\
\hline $\begin{array}{l}\text { "[...]a polygonal line formed by the highest } \\
\text { elevation points in that unit }[\ldots] "\end{array}$ & $\begin{array}{l}\text { Watershed divide (USU) syn. drainage divide, water } \\
\text { parting: Summit or boundary line separating adjacent } \\
\text { drainage basins (OMM, 2012). }\end{array}$ \\
\hline $\begin{array}{l}\text { "[...] where water courses in different ways } \\
\text { and this resource is stored or flows to an } \\
\text { outlet point that can be the sea or other inland } \\
\text { waterbody, through a hydrographic network } \\
\text { of streams that converges in a main one }[. . .] "\end{array}$ & $\begin{array}{l}\text { Exorheic basin: A basin draining to the sea (García- } \\
\text { Tortosa et al., 2008). } \\
\text { Endorheic basin: A basin having no outlet to the sea but } \\
\text { receiving temporary or permanent streams. That is the } \\
\text { reason why a permanent or temporal aquifer exists } \\
\text { (CONANP, 2016). }\end{array}$ \\
\hline $\begin{array}{l}\text { "[...]or it is the territory in which the waters } \\
\text { form an autonomous unit or differentiated } \\
\text { from others, even without draining water } \\
\text { towards the sea." }\end{array}$ & $\begin{array}{l}\text { Endorheic basin: A basin having no outlet to the sea but } \\
\text { receiving temporary or permanent streams. That is the } \\
\text { reason why a permanent or temporary aquifer exists } \\
\text { (CONANP, 2016). }\end{array}$ \\
\hline
\end{tabular}

Source: Prepared by the authors. 
In addition, this definition includes differential characters (CONAGUA, 2017a):

- "In this space, delimited by a topographic diversity, water, soil, flora, fauna, and other natural resources coexist.

- The hydrological basin in conjunction with the aquifers constitutes the management unit of water resources.

- The hydrological basin is in turn composed of sub-basins and they are integrated by micro-basins".

The elevated number of definitions and differential characters in the same paragraph which constitutes a single definition complicates its interpretation. In this sense, hydrological basin definition is not presented with clarity. These differential characters are excluded from the hydrological watershed definition in a new Mexican water law project proposed since 2015.

On the other hand, the Mexican Modern Government Program for 2013-2018 states that the initiatives must be communicated in plain language (line of action 1.5.2 Diffusion of the progress and results of the programs derived from the National Development Program (NDP) must be in plain language) (Mexico, 2013). Plain language is: "[...] simple expression, clear and direct information that readers (public servants and citizens) need to know" (Valdovinos Chávez et al., 2004). This initiative comes from an international effort of several countries, including some Spanish-speaking countries like Spain, Mexico and Chile.

As can be seen, the hydrological basin definition is not expressed in plain language; however, it is "[...]information that readers (public servants and citizens) need to know". This is by virtue of the fact that the definition of basin contained in the NWL is an essential element in determining the average annual availability of surface water (SEMARNAT, 2015). The availability of surface water is one of the central themes of the Water National Program 2014 - 2018 (CONAGUA, 2014), a document that is derived from the NDP.

\subsection{Proposal of a hydrological basin definition}

A proposal for a new hydrological basin definition is presented to harmonize this definition with the hydrological basin delineation published in the Federation Official Diary (FOD). This modification proposal represents minor consequences in terms of: 1) technical work to review the boundaries of the 757 hydrological basins already defined; 2) editing the vertices that do not meet the legal definition; 3 ) administrative work to review and modify the publications of the FOD that establish the official delineation (CONAGUA, 2016a; 2016b; 2016c; 2016d; 2016e; 2016f); and 4) dealing with technical, administrative and even legal implications on calculation of average annual availability of surface water and consequently with the already given or denied water rights (CONAGUA, 2017).

The proposal has the following characteristics:

- Defines the concept of hydrological basin in a simple way, in a single paragraph and in accordance with the examples of basins analyzed in this manuscript and based on a definition supported by a recognized publication in the hydrology field.

- Considers the concept of "new hydrological basins" and the rest of the concepts that the current definition includes.

- When an area is drained by various minor currents, their basins are congregated in groups and are considered a special unit for the management of water resources (Group of minor basins or sub-basins).

\section{IPABH}


Derived from the above, a proposal for hydrological basin definition is presented in a plain language, followed by six definitions, corresponding to the characteristics that the Mexican authority establishes for resource management purposes:

\section{Hydrological Basin}

Area that has a single outlet point for its surface runoff (adapted from OMM, 2012).

In addition, the following definitions are proposed to complement this definition; they include the aspects considered in the original definition, as well as the concept that defines published "additional basins".

\section{Sub-basin}

Next-level subdivision of a hydrological basin.

\section{Micro-basin}

Next-level subdivision of a sub-basin.

\section{Group of minor basins}

A land area where surface flow originates entirely within the hydrologic unit and drains to multiple points along a large waterbody such as the ocean, or large reservoir or lake (adapted from SSWD, 2003).

\section{Water Parting}

Boundary line that separates adjacent hydrological basins (OMM, 2012).

\section{Exorheic basin}

Drainage basin whose surface water runs into the ocean or into another waterbody having a connection to the ocean (CONANP, 2016).

\section{Endorheic basin}

Basin whose surface waters do not drain towards the sea but receives temporary or permanent flows. For that reason, a permanent or temporary aquifer is present (CONANP, 2016).

\subsection{Discussion}

The aim of this paper is not to propose criteria to delineate new hydrologic units. Discussion deals with the suitability of the proposed definition for a watershed and its applicability to the current official watershed delineations in Mexico. Countries mentioned in this paper also must deal with current official delineations that are used for administrative and legal purposes. Thus, congruence between legal definitions of watershed and official delineations is an issue that this manuscript addresses.

Strong interagency efforts are needed to establish watershed delineations. "The delineation shall be as simple as it is practical, and will keep hydrologic units from benefiting a particular agency, program, administrative area or special project." (SSWD, 2003). Cotler (2007) suggests that this delineation should be determined solely upon science-based hydrological principles to assure a homogeneous national seamless digital data layer.

In this sense, several basin delineations have been carried out by government entities in Mexico. CONABIO (2012) reported 3115 sub-basins in 2001. This entity has also reported different numbers of natural basins for the Mexican territory: 160, 142 and 1,474 (CONABIO, 2008; 2012 respectively). National Institute of Statistics and Geography (INEGI) considered 150 basins and 1,001 sub-basins (INEGI, 2001). National Water Commission (CONAGUA) has also stated a number of basins of 314 (CONAGUA, 1996). In 2007, based upon the "[...]join effort of INEGI, National Institute of Ecology and CONAGUA to establish concerted and common criteria to delimitate the basins of Mexico and toponymy definition", 
the Mexican territory was divided into 1,471 basins (Cotler, 2007). This delineation was performed with a rigorous and documented process based on natural criteria such as topography and hydrography. Despite these efforts, CONAGUA published different numbers of basins for Mexico: 718, 728, 722 (CONAGUA, 2009; 2008; 2010, respectively). In 2012, the number of basin was defined in 731 (CONAGUA, 2012). This number of basins and their respective vertex coordinates were formalized in the Federation Official Diary (CONAGUA, 2016d). Later, 26 new additional hydrological basins were set up. Therefore, a total of 757 basins is the currently official number of watersheds in Mexico.

Despite having access to a delineation of 1,471 basins obtained by a rigorous process based on natural criteria (Cotler, 2007), the water authority decided to make a different basin delineation and give it an official status. This is evidence that the working criteria were also different. The 757-basin delineation was configured progressively, probably by technical and administrative departments of CONAGUA. This delineation aims "[...] to give higher certainty to water users with respect to the exact localization of the site where the exploitation, usage or harnessing of water takes place as well as to improve the administration and management of water resources" (CONAGUA, 2016a). In other words, this watershed delineation has a clear administrative purpose with intrinsic legal and technical implications that prevents its drastic modification (Cuevas et al., 2010). This kind of inertia is recognized even in systematic science-based efforts to delineate watersheds: "the diversity of hydrological conditions nationwide, complexity of surface hydrology and the number of factors involved in the delineation process preclude an all-inclusive guideline. Variations will generally be limited to previously delineated units with a long history of use" (SSWD, 2003).

In Mexico, a modification of official basin delineation can motivate important issues to deal with in water administration. Water-right title is a legal document which specifies the basin where water usage occurs (CONAGUA, 2017a). Thus, if a change of basin delineation or denomination is carried out, then a proper legally-valid procedure must be followed. Similar situations can occur with other legal documents, such as discharge of wastewater permits, water quality certificates, among others (CONAGUA, 2017c). Even legal processes against water authorities' resolutions about surface water availability should be considered before such changes.

The difficulty of modifying the official delineation of hydrological basins was also considered unfeasible in Chile:

[...]it was concluded that new water delineation could be useful in some cases... but being a new delineation, it is very likely to have a different number of watersheds and database with respect to the current NWB System, which means that this new watershed division will be separated from NWB codification. This disconnection would represent that the new delineation will not be used (Chile, 2013).

The proposal for legal definition of hydrological basin in Mexico made in this paper is based on the definition of the World Meteorological Organization (OMM, 2012). The purpose of defining terms separately is to consider the concepts included in the original definition and the results obtained in this study. The proposed definition is expressed in a simple language, which is clear and direct. On the one hand, the hydrological basin definition proposed in this manuscript fulfills with the initiative to express concepts of public interest in plain language. On the other hand, this definition does not establish the maximum elevation points as a criterion to define the hydrological basin boundaries, which offsets the deficiencies identified in the official definition.

Based on the inconsistencies found in this study, the proposed definition establishes that the surface water of a basin should not flow towards the sea or a waterbody, nor should the basin be autonomous from others. Therefore, this definition proposal could adapt to the official delineation of hydrological basins defined by the criterion of hydrometric station

\section{IPABH}

Rev. Ambient. Água vol. 14 n. 2, e2198 - Taubaté 2019 
presence. The proposed definition could be also adapted to official delineations where the hydrological basin boundaries are determined by the presence of a waterbody. The area referred to in the proposed definition covers a surface area without including water stored in a waterbody, and the single outlet is constituted by the structures built with the purpose of extracting the water stored in the inland waterbody. The introduction of "group of minor basis" concept refers to an aggregate of basins with reduced dimensions which serves as a management unit of water resources. These are the 26 cases that were recognized by federal authority and called "new hydrological basins". This concept could also be applied to groups of small hydrological basins defined by the presence of a waterbody.

It is also noted that official hydrological basins were defined based on superficial terrain criteria. This situation can be deduced by the fact that its configuration is used to calculate and disclose the average annual surface water availability. The average annual groundwater availability is computed separately from surface water availability (SEMANAT, 2015). Groundwater availability is based on the aquifers' delineation and then it is calculated with an independent method (SEMANAT, 2015). Hence, official definition of hydrological basin in Mexico (CONAGUA, 2017a) is, in fact, the definition of hydrographical basin. According to Moura and Henry-Silva (2015), hydrographic basins are part of larger systems, involving aspects of geology, vegetation, climate and land use and occupation, consisting of a mosaic of functional subsystems interconnected by biotic and abiotic processes. In contrast, the concept of hydrological basin: "Unlike the hydrographic basins, hydrological basins, besides including the first ones, they also include underground hydrogeological systems. Therefore, hydrological basins could vary in their purely hydrographic limits"(INECOL, 2005).

In accordance with Campos Aranda (1992), the difference between the territorial delineation of a hydrographic basin (the topographic basin) and a hydrological basin (the groundwater table basin) is reduced to special cases, such as karst terrain or regions with coarser sediment on rock beds. Except in the cases mentioned above, both boundaries should match. Therefore, if discrepancy cases are sought, a detailed analysis is required to determine and compare the aquifer-recharge areas in conjunction with the surface topography. At most, when the water balance in the basins and aquifers is carried out, these differences would be clear and a distinction between the boundaries of the hydrological and hydrographic basins would be required.

Hydrological basin definition is used in the totality of the publications in the FOD dealing with surface water availability, as well as all derived documents of a normative character. Therefore, the use of hydrological basin definition is generalized in this area. Changing this term to hydrographic basin would imply substantial modifications to official, legal, and regulatory documents. A duly substantiated and instrumented superior law would be required to make this change. Hence, if both types of basins are equivalent from the point of view of topographic layout maps, the official delineation can be considered as hydrological basins.

\section{CONCLUSIONS}

Official delineation of hydrological basin is fundamental to determine official water surface availability, which is in turn essential to confer or deny water rights. This delineation must be consistent with the legal definition of hydrological basin, a term that is persistently defined in water laws of Latin America. This manuscript presents a discussion about inconsistencies between the legal definition and the official delineation of eight study cases constituted by hydrological basins in Sinaloa, Mexico.

Based on the analysis of the current hydrological basin definition included in the National Water Law, it is concluded that the legal definition should be amended to establish 
consistency with the basins delineated in the Official Federation Diary. This is because significantly less technical and administrative effort is required to modify one definition than to modify the official watershed delineation, as it is also recognized by Chilean experts.

In this article, an amendment is proposed to harmonize this situation, with a minimum of changes in policy documents. This definition preserves the essence of the current legal definition, which highlights the hydrological basin as a management unit of water resources in Mexico. However, it is recognized that it is necessary to confront progressively the proposed definition with study cases of basins located in other parts of Mexico for its further improvement. Besides, for future analyses, it is convenient to use digital elevation models of higher resolution to perform more precise basin delineation.

This paper also proposes a scheme to establish a legal definition of watershed and issues directly associated with it, which can be useful to analyze similar situations in other countries where there is a watershed legal definition and official watershed delineation. In Latin American countries where there is no official watershed delineation to confer or deny water rights, this definition should be used from the beginning to assure consistency between legal definitions and such delineation. This could prevent technical, administrative and even legal problems to manage water resources derived from a lack of consistency between the basin's legal definition and the official watershed delineation.

\section{ACKNOWLEDGMENTS}

The authors would like to thank the Associate Editor and all the reviewers for their constructive suggestions. They also gratefully acknowledge the support of Ulysses Zaldívar Higuera, José Emerio Parra Flores, Rafael Sanz Ramos. This work was supported by Cátedras CONACYT 2014 project ("Diseño e instrumentación de una red de monitoreo y de alerta para la gestión del agua en Sinaloa” Ref. 2572).

\section{REFERENCES}

ARGENTINA. Ley 25688 Régimen de Gestión Ambiental de Aguas. Boletin Oficial Republica Argentina, Buenos Aires, 03 Jan. 2003.

BARROW, C. J. River basin development planning and management: A critical review. World Development, v. 26, n. 1, p. 171-186, 1998. https://doi.org/10.1016/S0305750X(97)10017-1

BOLIVIA. Ley no. 1333. Ley Del Medio Ambiente. Gaceta Oficial [de] Bolivia, La Paz, 15 June 1992.

CAMPOS ARANDA, D. F. Procesos del Ciclo Hidrológico. 1. ed. San Luis Potosí: Universidad Autónoma de San Luis Potosí, 1992.

CEPAL. Políticas públicas para el desarrollo sustentable: la gestión integrada de cuencas. 1. ed. Nueva York, 1994.

CHILE. Análisis Crítico de la Definición de Cuencas del Banco Nacional de Aguas. 1. ed. Santiago, 2013.

CHILE. Ministerio De Justicia. Lei 21064. Introduce modificaciones al marco normativo que rige las aguas en materia de fiscalización y sanciones. Diário Oficial, Santiago, 17 Jan. 2018. Available in: http://bcn.cl/23mc1. Access: 05 Feb. 2019.

COLOMBIA. Decreto 00155 de 2004. Diario Oficial, Bogotá, 2004. 8 p.

\section{IPABH}

Rev. Ambient. Água vol. 14 n. 2, e2198 - Taubaté 2019 
CONABIO. Subcuencas hidrológicas. 2008. Available in: https://goo.gl/xuaY6Z Access: 18 June 2017.

CONABIO. Cuencas Hidrográficas de México, 2007. 2009. Available in: https://goo.gl/jVycEi. Access: 18 June 2017.

CONABIO. Portal de Geoinformación. c2012. Available in: http://www.conabio.gob.mx/informacion/gis/ Access: 22 June 2017.

CONAGUA. 2a Sección ACUERDO por el que se dan a conocer los límites de las 757 cuencas hidrológicas que comprende las 37 regiones hidrológicas en que se encuentra dividido los Estados Unidos Mexicanos (continúa en la Tercera Sección). Diario Oficial [de la] Federación, Mexico DF, 2016a.

CONAGUA. 3a Sección ACUERDO por el que se dan a conocer los límites de las 757 cuencas hidrológicas que comprenden las 37 regiones hidrológicas en que se encuentra dividido los Estados Unidos Mexicanos (continúa en la Cuarta Sección). Diario Oficial [de la] Federación, Mexico DF, 2016e.

CONAGUA. 4a Sección ACUERDO por el que se dan a conocer los límites de las 757 cuencas hidrológicas que comprenden las 37 regiones hidrológicas en que se encuentra dividido los Estados Unidos Mexicanos (continúa en la Quinta Sección). Diario Oficial [de la] Federación, Mexico DF, $2016 f$.

CONAGUA. 7a Sección ACUERDO por el que se dan a conocer los límites de las 757 cuencas hidrológicas que comprenden las 37 regiones hidrológicas en que se encuentra dividido los Estados Unidos Mexicanos (continúa de la Sexta Sección). Diario Oficial [de la] Federación, Mexico DF, 2016c.

CONAGUA. ACUERDO por el que se actualiza la disponibilidad media anual de las aguas superficiales en las cuencas hidrológicas Río Piaxtla 1 y Río Piaxtla 2, mismas que forman parte de la Subregión Hidrológica Río Piaxtla de la Región Hidrológica número 10 Sinaloa. Diario Oficial [de la] Federación, Mexico DF, 2013a.

CONAGUA. ACUERDO por el que se actualiza la disponibilidad media anual de las aguas superficiales en las cuencas hidrológicas Río Quelite 1 y Río Quelite 2, mismas que forman parte de la Subregión Hidrológica Río Quelite de la Región Hidrológica número 10 Sinaloa. Diario Oficial [de la] Federación, Mexico DF, 2013 b.

CONAGUA. ACUERDO por el que se actualiza la disponibilidad media anual de las aguas nacionales superficiales de las 757 cuencas hidrológicas que comprenden las 37 regiones hidrológicas en que se encuentra dividido los Estados Unidos Mexicanos. Diario Oficial [de la] Federación, Mexico DF, 2016b.

CONAGUA. ACUERDO por el que se actualiza la disponibilidad media anual de las aguas superficiales nacionales de las 731 cuencas hidrológicas que comprenden las 37 regiones hidrológicas en que se encuentra dividido los Estados Unidos Mexicanos. Diario Oficial [de la] Federación, Mexico DF, 2016d.

CONAGUA. Atlas del agua en México 2009. 2009 ed. Mexico DF, 2009.

CONAGUA. Banco Nacional de Datos de Aguas Superficiales (Bandas). Available in: http://www.conagua.gob.mx/CONAGUA07/Contenido/Documentos/PortadaBANDAS. htm Access: 28 May $2017 \mathrm{~b}$.

CONAGUA. Estadísticas del Agua en México Edición 2010. 2010. ed. Mexico DF, 2010.

Rev. Ambient. Água vol. 14 n. 2, e2198 - Taubaté 2019 
CONAGUA. Estadísticas del Agua en México Edición 2012. 2012. ed. Mexico DF, 2012.

CONAGUA. Ley De Aguas Nacionales. 2017. ed. Mexico: SEMARNAT, 2017a.

CONAGUA. Programa Hidráulico 1995-2000. 1995 ed. Diario Oficial [de la] Federación, Mexico DF, 1996.

CONAGUA. Programa Nacional Hídrico 2007-2012. 2007 ed. Diario Oficial [de la] Federación, Mexico DF, 2008.

CONAGUA. Programa Nacional Hídrico 2014-2018. 2014. ed. Diario Oficial [de la] Federación, Mexico DF, 2014.

CONAGUA. Trámites de Administración del Agua. Available in: https://www.gob.mx/conagua/acciones-y-programas/tramites-de-administracion-delagua Access: 28 May 2017c.

CONANP. Programas de Manejo. Available in: http://www.conanp.gob.mx/que_hacemos/programa_manejo.php Access: 10 June 2017.

COTLER, H. Delimitación de las Cuencas Hidrográficas de México a escala 1:250 000. 1. ed. Mexico DF: CONAGUA, 2007.

CUEVAS, M. L.; GARRIDO, A.; SOTELO, E. I. Regionalización de las cuencas hidrográficas de méxico. In: GARRIDO PÉREZ, A. (Ed.). Las cuencas hidrográficas de México. Diagnóstico y Priorización. 1. ed. México DF: SEMARNAT, 2010. p. 1013 .

DE LA LANZA ESPINO, G.; SALINAS RODRÍGUEZ, S. A.; CARBAJAL PÉREZ, J. L. Environmental flow calculation for the maintenance of the water reserve of the Piaxtla River, Sinaloa, Mexico. Investigaciones Geograficas, v. 87, p. 25-38, 2015. http://dx.doi.org/10.14350/rig.35269

ECUADOR. Ley orgánica de recursos hídricos, usos y aprovechamiento del agua. Registro Oficial, Quito, 06 Aug. 2014.

ESPEJEL, I.; HERNÁNDEZ, A.; RIEMAN, H.; HERNÁNDEZ, L. Propuesta para un nuevo municipio con base en las cuencas hidrográficas. Estudio de caso: San Quintín, B.C. Gestión y Política Pública, v. 14, n. 1, p. 129-168, 2005.

GARCÍA-TORTOSA, F. J.; SANZ DE GALDEANO, C.; ALFARO, P.; JIMÉNEZ ESPINOSA, R.; JIMÉNEZ-MILLÁN, J.; LORITE HERRERA, M. Nueva evidencia sobre la edad del tránsito endorreico-exorreico de la cuenca de Guadix-Baza New. Geogaceta, v. 44, p. 211-214, 2008. http://hdl.handle.net/10261/29431

IMPERIAL, Mark T. Using collaboration as a governance strategy. Lessons from six watershed management programs. Administration \& Society, v. 37, n. 3, p. 281-320, 2005. https://doi.org/10.1177\%2F0095399705276111

INECOL. Instructivo para la revisión y delimitación de las cuencas hidrográficas de México a escala 1: 250 000. 1. ed. México DF: Instituto Nacional de Ecología, 2005.

INEGI. Diccionario de Datos Hidrológicos de Aguas Superficiales Escalas 1:250 000 y 1: 100000 (Vectorial). Aguascalientes, 2001.

INEGI. Documento Técnico Descriptivo de La Red Hidrográfica Escala 1:50 000. 2. ed. Aguascalientes, 2010. 
INEGI. Red Hidrográfica escala 1:50 000 edición 2.0. Available in: http://www.inegi.org.mx/geo/contenidos/topografia/regiones_hidrograficas.aspx. Access: 21 Sep. 2017a.

INEGI. Cartas Topográficas. Available in: https://goo.gl/UYrvRR Access: 21 May 2017b.

MEXICO. Secretaría de Gobernación. Programa para un Gobierno Cercano y Moderno 20132018. Diario Oficial [de la] Federación, Mexico DF, 20 May 2013. Available in: https://goo.gl/yCrpvS Access: 06 Feb. 2019.

MOURA, R. S. T. de; HENRY-SILVA, G. G. Limnological characteristics of a hydrographic basin of the Brazilian semiarid region. Acta Limnologica Brasiliensia, v. 27, n. 1, p. 51-59, 2015. http://dx.doi.org/10.1590/s2179-975x3114

NASA. ASTER Global Digital Elevation Model (GDEM). 2011. Available in: http://www.jspacesystems.or.jp/ersdac/GDEM/E/4.html Access: 8 Oct. 2017.

OMERNIK, J. M.; BAILEY, R. G. Distinguishing between watersheds and ecoregions. Journal Of The American Water Resources Association, v. 33, n. 5, p. 935-949, 1997. https://doi.org/10.1111/j.1752-1688.1997.tb04115.x

OMM. International glossary of hydrology. Geneva, 2012.

OXFORD. English Dictionary, Thesaurus, grammar help. Available in: https://en.oxforddictionaries.com/ Access: 15 Nov. 2018.

PERU. Decreto Ley $n^{\circ}$ 17752. Ley general de aguas establece su uso justificado y racional, incluye las producidas, nevados, glaciares, precipitaciones, etc. Diário Oficial el Peruano, Lima, 24 Jul. 1969. Available in: https://goo.gl/pfJgrj Access: 06 Feb. 2019.

RAMOS, J.; GRACIA, J. Spatial-temporal fluvial morphology analysis in the Quelite river: It's impact on communication systems. Journal of Hydrology, v. 412-413, p. 269-278, 2012. https://doi.org/10.1016/j.jhydrol.2011.05.007

REAL ACADEMIA ESPAÑOLA. Diccionario de la Lengua Española. Available in: http://dle.rae.es/?id=0NO8Xkn Access: 9 May 2017.

REIS, D. R.; PLANGG, R.; TUNDISI, J. G.; QUEVEDO, D. M. Physical characterization of a watershed through GIS: a study in the Schmidt stream, Brazil. Brazilian Journal of Biology, v. 75, n. 4, suppl 2, p. 16-29, 2015. http://dx.doi.org/10.1590/15196984.01313suppl

SANHOUSE-GARCIA, A. J.; BUSTOS-TERRONES, Y.; RANGEL-PERAZA， J. G.; QUEVEDO-CASTRO, A.; PACHECO, C. Multi-temporal analysis for land use and land cover changes in an agricultural region using open source tools. Remote Sensing Applications: Society and Environment, v. 8, p. 278-290, 2017. http://dx.doi.org/10.1016/j.rsase.2016.11.002

SEMARNAT. Norma Oficial Mexicana NOM-011-CONAGUA-2015, Conservación del recurso agua-Que establece las especificaciones y el método para determinar la disponibilidad media anual de las aguas nacionales. Diario Oficial [de la] Federación, Mexico DF, 2015.

SOTELO, E.; GARRIDO, A.; RUIZ, K.; CUEVAS, M. L. Asignación de municipios a las cuencas hidrográficas de México. In: COTLER, H. (Ed.). Las cuencas hidrográficas de México: Diagnóstico y Priorización. 1. ed. México DF: SEMARNAT, 2010. p. 1821.

Rev. Ambient. Água vol. 14 n. 2, e2198 - Taubaté 2019 
SSWD. Federal standards for delineation of hydrologic unit boundaries working draft. Washington: Advisory Committee on Water Information, 2003.

TOMER, M. D.; SCHILLING, K. E. A simple approach to distinguish land-use and climatechange effects on watershed hydrology. Journal of Hydrology, v. 376, n. 1-2, p. 24 33, 2009. https://doi.org/10.1016/j.jhydrol.2009.07.029

VALDOVINOS CHÁVEZ, C. M.; QUINTANA MANZANILLA, R. J.; MARES CHALELA, A. A.; MALDONADO VENEGAS, F.; MALDONADO RIOS, O.; PONTIGO SÁNCHEZ, F. de J.; RAMÍREZ VILLANUEVA, D. Lenguaje ciudadano. Un manual para quien escribe en la Administración Pública Federal. 2. ed. México DF: Secretaría de la Función Pública, 2004. 


Ambiente \& Água - An Interdisciplinary Journal of Applied Science
ISSN 1980-993X - doi:10.4136/1980-993X
www.ambi-agua.net
E-mail: ambi.agua@gmail.com

\title{
Simultaneous removal of nitrogen and organic carbon from swine wastewater using the pre-denitrification/nitrification process
}

\author{
ARTICLES doi:10.4136/ambi-agua.2241
}

Received: 12 Feb. 2018; Accepted: 29 Jan. 2019

\author{
Marcelo Bortoli $^{*}$; ; Airton Kunz ${ }^{2,3}$; Marina Celant De Prá4 ${ }^{(D)}$; \\ Marcio Luis Busi Da Silva ${ }^{2}$; Ana Cé5 ${ }^{5}$; Hugo Moreira Soares 6 \\ ${ }^{1}$ Universidade Tecnológica Federal do Paraná (UTFPR), Francisco Beltrão, PR, Brasil \\ Programa de Pós-graduação em Engenharia Ambiental (PPGEA). \\ Departamento Acadêmico de Engenharia Ambiental (DAEAM). E-mail: marcelobortoli@utfpr.edu.br \\ ${ }^{2}$ Embrapa Suínos e Aves, Concórdia, SC, Brasil \\ E-mail: airton.kunz@embrapa.br, marcio.busi@embrapa.br \\ ${ }^{3}$ Universidade Estadual do Oeste do Paraná (UNIOESTE), Cascavel, PR, Brasil \\ Programa de Pós-graduação em Engenharia Agrícola (PGEAGRI). E-mail: airton.kunz@embrapa.br \\ ${ }^{4}$ Universidade Tecnológica Federal do Paraná (UTFPR), Dois Vizinhos, PR, Brasil \\ Coordenação do Curso de Engenharia de Bioprocessos e Biotecnologia. E-mail: marinapra@utfpr.edu.br \\ ${ }^{5}$ Universidade Tecnológica Federal do Paraná (UTFPR), Francisco Beltrão, PR, Brasil \\ Programa de Pós-graduação em Engenharia Ambiental (PPGEA). E-mail: aninhace_@ hotmail.com \\ ${ }^{6}$ Universidade Federal de Santa Catarina (UFSC), Florianópolis, SC, Brasil \\ Departamento de Engenharia Química e de Alimentos. E-mail: soares@enq.ufsc.br \\ *Corresponding author
}

\begin{abstract}
Wastewater from confined animal feeding operations (CAFOs) can interfere significantly with the natural nitrogen and phosphorus balance in the environment if not treated adequately prior to disposal. In this work, a modified Lutzak-Ettinger (MLE) consisting of sequential predenitrification/ nitrification was used to determine the effects of nutrient loading rates and hydraulic retention times (HRT) on total nitrogen (TN) and organic carbon (TOC) removal from swine wastewater. MLE reactor was continuously fed swine wastewater for over 205 days using different recycle ratios (Rr) and HRT. Higher TN and TOC removal efficiencies $(90.7 \%$ and $96.1 \%$, respectively) were obtained when recycling effluent from the nitrification tank (4.5:1) combined with effluent from the final clarifier (1:1). Removal efficiencies of $96 \%$ for TOC and $90 \%$ for TN were obtained for the maximum loading rates of $0.56 \mathrm{gTN} \mathrm{L}^{-1} \mathrm{~d}^{-1}$ and $2.15 \mathrm{~g}^{\mathrm{TOC}} \mathrm{L}^{-1} \mathrm{~d}^{-1}$, respectively. TN and TOC removal rates were achieved with HRT in as little as 3.5 days. Overall, MLE was a robust bioprocess withstanding variations in wastewater physical-chemical composition and/or changes in operational conditions without significant impairment of $\mathrm{N}$ and TOC removal efficiencies.
\end{abstract}

Keywords: ammonia, high organic rate, nitrate. 


\section{Remoção simultânea de nitrogênio e carbono orgânico em efluentes da suinocultura utilizando processo pré-desnitrificação/ nitrificação}

\section{RESUMO}

Os efluentes dos sistemas de produção de animais confinados (SPACs), se não tratados adequadamente antes do descarte, podem interferir significativamente no balanço natural do nitrogênio no meio ambiente. Nesse trabalho, um sistema Lutzak-Ettinger modificado (MLE), consistindo de dois reatores sequenciais, um pré-desnitrificante (RD) e um nitrificante (RN), foi utilizado para determinar os efeitos da carga de alimentação e o tempo de retenção hidráulico (TRH), na remoção simultânea de nitrogênio total (NT) e carbono orgânico total (COT) de efluentes da suinocultura. O sistema MLE foi alimentado com efluente da suinocultura por 205 dias, usando diferentes razões de recirculação (Rr) e TRH. Foram obtidas eficiências de remoção de NT e COT $(90,7 \%$ e $96,1 \%$, respectivamente) com a recirculação do meio do RN (4.5:1) combinado com o lodo do decantador final (1:1). Essas eficiências foram obtidas com TRH de 3,5 dias e cargas de alimentação de $0,56 \mathrm{gNT} \mathrm{L}^{-1} \mathrm{~d}^{-1}$ e $2,15 \mathrm{~g} \mathrm{TOC} \mathrm{L}^{-1} \mathrm{~d}^{-1}$. Concluiu-se que o processo MLE se demonstrou robusto, resistindo a grandes variações na composição físico-química do efluente de alimentação e nas condições de operação, sem sofrer impacto importante nas eficiências de remoção de NT e COT.

Palavras-chave: alta carga orgânica, amônia, nitrato.

\section{INTRODUCTION}

Concentrated animal feeding operations (CAFOs) are increasingly being used for the enhancement of swine production. Consequently, much higher wastewater volumes are expected which, if not treated properly, could contaminate soils and water resources (Kunz et al., 2012). For instance, the presence of high organic content and nutrients (e.g., nitrogen and phosphorus) in these effluents can exacerbate biological oxygen demand (BOD) and favor eutrophication (Techio et al., 2011).

Different system configurations are considered including intermittent aeration, the use of selective membranes, sequencing batch reactors (Lee and Han, 2012), and/or the modified Ludzack-Ettinger (MLE). The MLE, also known as anoxic pre-denitrification process (Rajagopal et al., 2011; Hafez et al., 2010), was initially proposed by Ludzack and Ettinger for treatment of municipal sewage (Ludzack and Ettinger, 1962).

In the MLE, the oxidized nitrogen species $\left(\mathrm{NOx}=\mathrm{NO}_{2}{ }^{-}+\mathrm{NO}_{3}{ }^{-}\right)$are recycled into an anoxic reactor to serve as electron acceptors for heterotrophic denitrification. MLE has been used to remove TOC and nitrogen from a wide variety of effluents, including landfill leachate (Hafez et al., 2010) and wastewaters from animal farming (Castrillón et al., 2009; Vanotti et al., 2009).

In the MLE system, the NOx recycle ratio $(\mathrm{Rr})$ to the anoxic reactor can limit nitrogen removal efficiency (Tchobanoglous et al. 2014). A high $\mathrm{Rr}$ can increase the oxidation-reduction potential (ORP) in the anaerobic reactor, inhibiting denitrification. Conversely, a low $\mathrm{Rr}$ can lead to insufficient concentrations of NOx as electron acceptors, thus hindering complete denitrification. Thus, whereas the use of the MLE to remove N and TOC from swine wastewater effluents has already been demonstrated (Hafez et al., 2010; Vanotti et al., 2009), uncertainties still remain on how different Rr affects MLE system performance, especially treating CAFOs effluents.

Therefore, this study investigated the effects of different recycling ratios and nitrogen and the increase of organic loading rates (by decreasing HRT) on N and TOC removal efficiencies, using an MLE system to treat swine wastewater effluent. 


\section{MATERIALS AND METHODS}

\subsection{Experimental setup}

A schematic representation of the lab scale MLE experimental setup is shown in Figure 1. Two 5 L completely stirred bioreactors connected in series were continuously fed swine wastewater. The first bioreactor was designed to promote anaerobic denitrification. The second was aerated to stimulate nitrification. Aerobic conditions were maintained with the use of a pneumatic air pump (PowerAIR 2000) and two cylindrical air diffusers (bubble stones) placed at the bottom of the bioreactor. The nitrified mixed liquor (NML) from the nitrification bioreactor as well as the settled solid (SS) from the clarifier were both recycled into denitrification bioreactor. Peristaltic pumps (Masterflex ${ }^{\circledR}$ L/S ${ }^{\circledR}$ Standard Digital Pump) were utilized to control different $\mathrm{Rr}$ flow rates (Q) in the MLE system (Table 1).

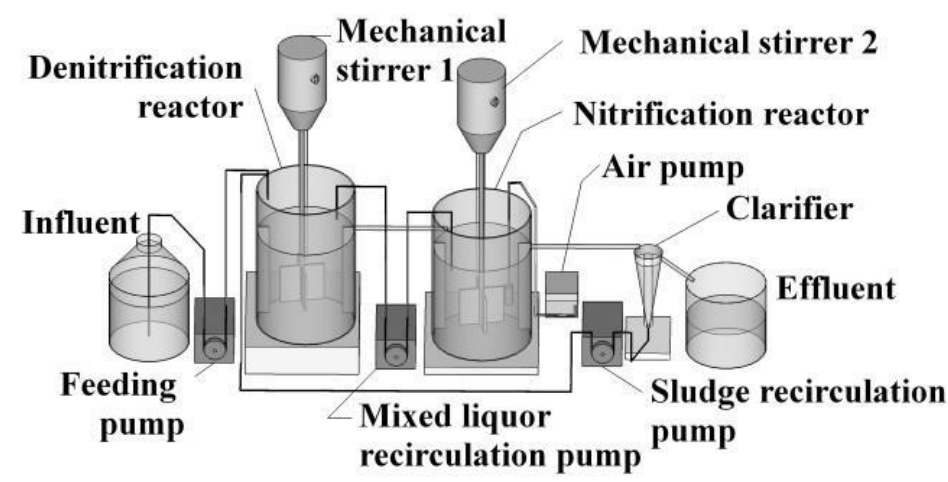

Figure 1. Schematic representation of the modified LudzakEtinger (MLE) experimental setup utilized in this work.

Table 1. MLE experimental configurations.

\begin{tabular}{lccccc}
\hline Period & $\begin{array}{c}\text { Time } \\
(\mathrm{d})\end{array}$ & $\begin{array}{c}\mathrm{Q} \text { (flow) } \\
\left(\mathrm{mL} \mathrm{min}^{-1}\right)\end{array}$ & $\mathrm{Rr}$ & $\begin{array}{c}\text { Nitrogen Loading Rate (NLR) } \\
\left(\mathrm{gN} \mathrm{L}^{-1} \mathrm{~d}^{-1}\right)\end{array}$ & $\begin{array}{c}\text { Hydraulic retention time } \\
(\mathrm{HRT})(\mathrm{d})\end{array}$ \\
\hline I & $1-126$ & 1.0 & $4-5.5-6.5$ & 0.15 & 6.9 \\
II & $127-140$ & 1.5 & 5.5 & 0.20 & 4.6 \\
III & $141-152$ & 1.8 & 5.5 & 0.24 & 3.9 \\
IV & $153-164$ & 2.0 & 5.5 & 0.30 & 3.5 \\
V & $165-185$ & 2.0 & 5.5 & 0.41 & 2.6 \\
VI & $186-196$ & 2.7 & 5.5 & 0.60 & 3.5 \\
VII & $197-205$ & 2.0 & 5.5 & 0.41 & \\
\hline
\end{tabular}

The initial HRT was calculated using Equation 1 in order to obtain the initial nitrogenloading rate (NLR) of $0.15 \mathrm{gN} \mathrm{L}^{-1} \mathrm{~d}^{-1}$ achieved by Vanotti et al. (2009) and based on the initial concentration of $\mathrm{N}-\mathrm{NH}_{3}$ from the first bath.

$$
H R T=\frac{\left[N H_{3}-N\right]}{N L R}
$$

Where:

$$
\begin{aligned}
& {\left[\mathrm{NH}_{3}-\mathrm{N}\right]=\mathrm{NH}_{3}-\mathrm{N} \text { concentratio }\left(\mathrm{g} \mathrm{L}^{-1}\right)} \\
& \mathrm{NLR}=\text { Nitrogen loading rate }\left(\mathrm{g} \mathrm{L}^{-1} \mathrm{~d}^{-1}\right)
\end{aligned}
$$

The initial calculated HRT is close to the HRTs used by other studies, mainly as a function of NLR, such as Vanotti et al. (2009) and Loughrin et al. (2009), who studied MLE systems

\section{IPABH}


for the swine wastewater treatment and used HRT between 10 and $17 \mathrm{~d}$ and 4.1 and $6 \mathrm{~d}$, respectively.

\subsection{MLE Inoculation}

Sludge from a pilot scale activated sludge bioreactor treating swine wastewater effluents at Embrapa Swine and Poultry [total suspended solids (TSS) of $7.1 \mathrm{~g} \mathrm{~L}^{-1}$ ] was used as inoculum (Viancelli et al., 2013). For the startup, the nitrification and denitrification reactors were inoculated with $0.25 \mathrm{~L}$ of inoculum and the reactor was filled with $4.75 \mathrm{~L}$ of diluted swine manure effluent (1:10 swine manure/tap water; v/v) to minimize likely inhibition by substrate restriction.

\subsection{Operational conditions}

Liquid swine wastewater effluent collected from a solid-liquid separation tank at wastewater treatment plant was utilized as feeding solution. $250 \mathrm{~L}$ of the same wastewater batch was kept under refrigeration $\left(-5^{\circ}\right)$ and utilized throughout the experimental time frame as feeding solution. Therefore, confounding effects due to variations in influent wastewater physical-chemical characteristics were avoided. The first batch $\left(\mathrm{NH}_{3}-\mathrm{N}=1.05 \mathrm{~g} \mathrm{~L}^{-1}\right)$ was used for 157 days. The second batch $\left(\mathrm{NH}_{3}-\mathrm{N}=1.36 \mathrm{~g} \mathrm{~L}^{-1}\right)$ was used from day 158 to day 205 . Different flow rates (Q), Rr, NLR, and HRT were evaluated (Table 1). It was not necessary to discard sludge from the MLE system, and consequently, the Solid Retention Time (SRT) does not need to be controlled, which reduces disposition and treatment costs.

\subsection{Analytical methods and calculation of recycle ratio and removal efficiencies}

TOC was measured in a TOC analyzer (Multi Elemental Analitic ${ }^{\circ}$ Multi C/N 2100 Analytik Jena). The $\mathrm{NH}_{3}-\mathrm{N}$ concentration was determined electrochemically by the ionselective electrode following the methodology described by APHA et al. (2012). Free ammonia (FA) and free nitrous acid (FNA) concentrations were estimated using the standard Equations proposed by Anthonisen et al. (1976).

Dissolved oxygen and $\mathrm{pH}$ were determined using an oximeter (YSI Model 55) and a $\mathrm{pH}$ meter (HANNA - HI8424), respectively. $\mathrm{NO}_{3}^{-}-\mathrm{N}$ and $\mathrm{NO}_{2}^{-}-\mathrm{N}$ were quantified by the colorimetric method using a Multi-Channel Flow Injection (FIAlab - 2500).

The recycle ratio was defined by the ratio of the recirculation flow sum (mixer liquor + sludge) by the system feed rate (Equation 2). The sludge recycle pump flow was fixed at $1 \mathrm{~mL} \mathrm{~L}^{-1}$ during the experiment.

Nitrogen removal efficiencies (NRE) were obtained after the establishment of steadyconditions in the MLE reactor according to Equation 3.

$R r=\frac{Q_{R M L}+Q_{R S}}{Q_{\text {in }}}$

Where:

$Q_{R M L}$ is nitrified mixed liquor recycle flow;

$Q_{R S}$ is clarified sludge recycle flow;

$Q_{\text {in }}$ is feeding flow.

$\operatorname{NRE}(\%)=R r \cdot(1+R r)^{-1}$ 


\section{RESULTS AND DISCUSSION}

\subsection{MLE reactors start up}

$\mathrm{NH}_{3}-\mathrm{N}$ concentrations in the batches were continuously monitored over time to account for significant losses. $\mathrm{NH}_{3}-\mathrm{N}$ concentrations in the first and second batches were $10.6 \%$ (after 165 days of storage) and $0.8 \%$ (after 40 days of storage), respectively (data not shown). The observed decrease in $\mathrm{NH}_{3}-\mathrm{N}$ influent concentrations observed in period I (Figure 2) was primarily due to dilution effects as results of the increasing recirculation ratios. Measured $\mathrm{NH}_{3}-\mathrm{N}$ concentrations at the MLE effluent were higher at the beginning of the experiments, probably due to the lack of significant nitrifying-specific biomass (Figure 2). After 32 days of continuous operation, nitrification acclimation time was reached as observed by the reduction in ammonia and the concomitant increase in effluent $\mathrm{NO}_{3}{ }^{-} \mathrm{N}$ concentrations.

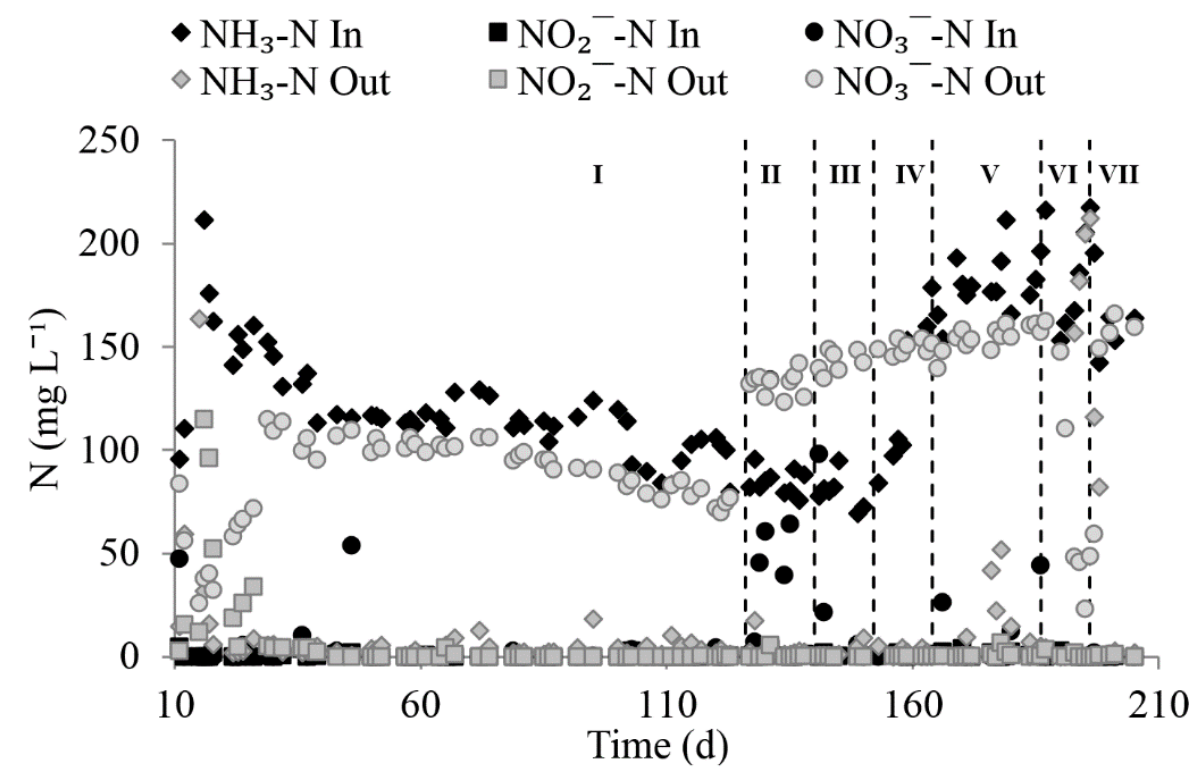

Figure 2. Nitrogen concentration profile over time in the nitrifying reactor under different reactor operational conditions (Table 1).

The average temperature $\left(23 \pm 1.6^{\circ} \mathrm{C}\right), \mathrm{pH}(7.8 \pm 0.3)$ and dissolved oxygen concentration (> $3 \mathrm{mg} \mathrm{L}^{-1}$ ) obtained during this experimental time frame were within the physiological requirements for nitrifying microorganisms (Ordaz et al., 2008). Interestingly, the observed acclimation period was much shorter than the 100 to 175 days (Jubany et al., 2008) reported for other nitrification systems treating swine wastewater. The rapid acclimation time obtained in this study was most likely due to the use of a diluted raw effluent $(1: 10 \mathrm{v} / \mathrm{v})$, which minimizes the inhibitory effects of high influent $\mathrm{NH}_{3}$ concentrations on microorganisms (De Prá et al., 2012). Therefore, the use of a diluted wastewater influent during the initial MLE start up process could minimize time required to establish steady-state conditions at field-scale operations.

To stimulate denitrification processes, the reactor was continuously fed at an influent

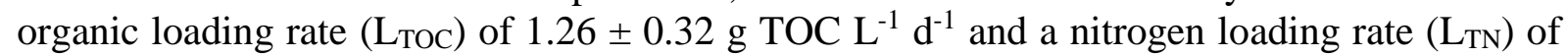
$0.15 \mathrm{~g} \mathrm{TN} \mathrm{L}^{-1} \mathrm{~d}^{-1}$. Temperature and $\mathrm{pH}$ were kept at $28 \pm 1.2^{\circ} \mathrm{C}$ and $8.4 \pm 0.2$, respectively. After 11 days of continuous operation, effluent NOx-N concentrations decreased from $52.1 \mathrm{mg} \mathrm{L}^{-1}$ to $0.21 \mathrm{mg} \mathrm{L}^{-1}$, indicating the establishment of denitrifying processes.

\subsection{MLE - Nitrification reactor performance}

After 45 days, $\mathrm{NH}_{3}-\mathrm{N}$ and TN removal efficiencies of $97.7 \%$ and $84.4 \%$, respectively, were obtained for an influent $\mathrm{L}_{\mathrm{NH}_{3}-\mathrm{N}}$ of $0.21 \pm 0.1 \mathrm{~g} \mathrm{~L}^{-1} \mathrm{~d}^{-1}$ (Period I, Figure 2). During this

\section{IPABH}


experimental time frame, dissolved oxygen (DO) $\left(3.2 \pm 0.4 \mathrm{mg} \mathrm{L}^{-1}\right)$ was unlikely limiting to nitrification because DO concentration $>2 \mathrm{mg} \mathrm{L}^{-1}$ is sufficient to maintain the growth and activity of ammonia oxidizing bacteria (AOB) and nitrite oxidizing bacteria (NOB) populations (Ordaz et al., 2008).

Changes in $\mathrm{Rr}$ from 5.5 to 6.5 decreased $\mathrm{NH}_{3}-\mathrm{N}$ removal efficiency from 96.1 to $87.5 \%$ (Figure 2). Following 86 days of experiment (Period I), however, $\mathrm{NH}_{3}$ removal efficiency reestablished from the initial 87.5 to $96.1 \%$ as result of microorganism adaptation to the newer imposed operational conditions. A further decrease in HRT (periods II, III, and IV) did not affect nitrification efficiencies, which remained within 96.4 to $98.4 \%$.

Increasing $\mathrm{NH}_{3}-\mathrm{N}$ influent loading rate by $50 \%$ (Period $\mathrm{V}$, LNH3-N of $0.39 \pm 0.1 \mathrm{~g} \mathrm{~L}^{-1} \mathrm{~d}^{-1}$ ) did not show significant changes in ammonia removal efficiencies $(93.5 \pm 4.3 \%)$, demonstrating the robustness of the MLE process to withstand variations in operational feeding rates. A decrease in HRT from $3.5 \mathrm{~d}$ to $2.7 \mathrm{~d}$ (period VI), however, led to a decrease in $\mathrm{NH}_{3}$ removal efficiency from $93.5 \pm 4.3 \%$ to $57.8 \pm 51.1 \%$. In order to re-establishment $\mathrm{NH}_{3}$ removal efficiencies, HRT was adjusted to the previous $3.5 \mathrm{~d}$.

Free ammonia (FA) concentrations in the reactor were below the inhibitory threshold reported for NOB $\left(0.1\right.$ and $\left.10.0 \mathrm{mg} \mathrm{L}^{-1}\right)$ and $\mathrm{AOB}\left(>150 \mathrm{mg} \mathrm{L}^{-1}\right)$ (Rongsayamanont et al., 2010) (Figure 3). Additionally, the absence of detectable free nitrous acid (FNA) suggested that nitrification was unlikely inhibited by the formation of FNA. Efficient $\mathrm{NH}_{3}$ oxidation ( $>99 \%$ ) was observed throughout the remaining experimental time frame (Figure 3).

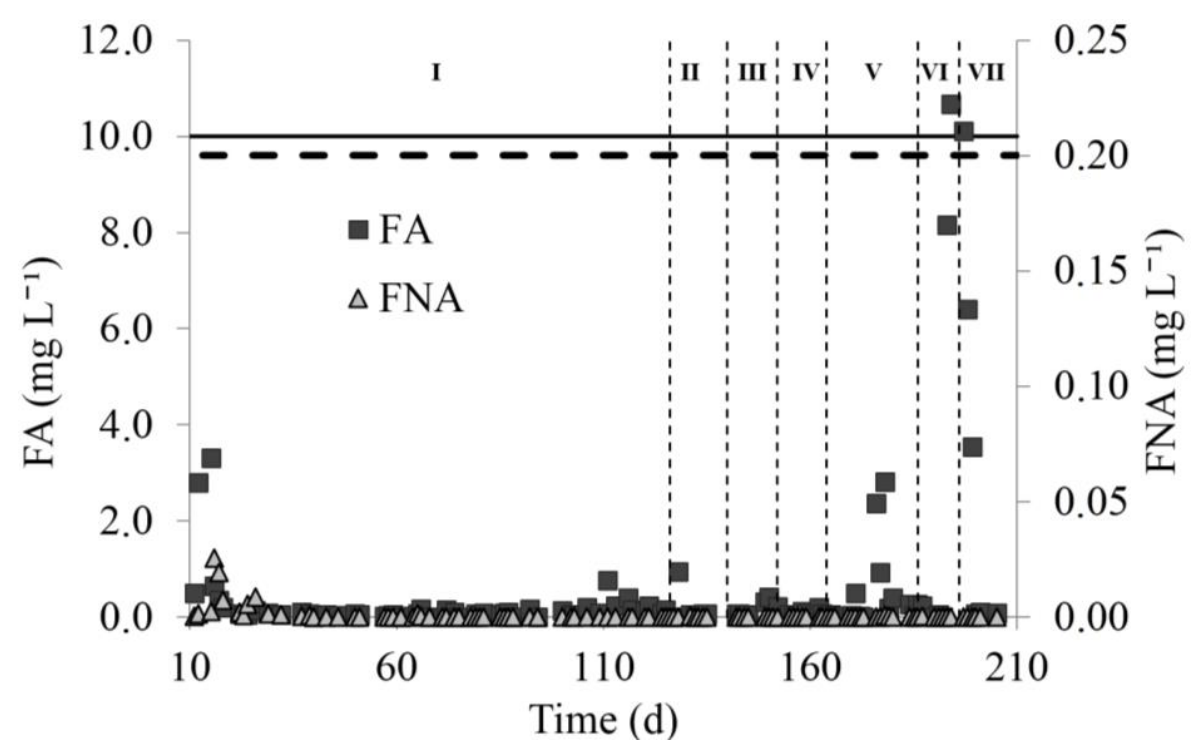

Figure 3. FA and FNA concentrations profile over time in the nitrifying reactor. Solid and dashed lines represent inhibitory thresholds for AOB and NOB, respectively (Rongsayamanont et al., 2010).

Nitrification efficiency ( $>95 \%$ ) was in agreement with previously reported data obtained for reactors treating cattle manure (Castrillón et al., 2009) or digested sow manure (Rajagopal et al., 2011). Total nitrogen removal as low as $19.1 \pm 13.2 \%$ was achieved in the nitrification reactor. This low removal value was somewhat unexpected, considering the favorable nitrification conditions in the reactor (i.e., $>2 \mathrm{mgO}_{2} \mathrm{~L}^{-1}$ and low FA concentrations). Therefore, circumstantial evidence supports the notion that other biological nitrogen removal processes were occurring concomitantly with nitrification. Whereas the investigation of such biological mechanisms was beyond the scope of this study, it is worth mentioning that biomass agglutination in MLE systems could aid the formation of anoxic micro niches, thus favoring autotrophic denitrification and/or anammox (Park et al., 2009). 


\subsection{MLE - Denitrification reactor performance}

Changes in $\mathrm{Rr}$ can play an important role in denitrification efficiency. Denitrification and TOC removal efficiencies of 88.9 and $83.5 \%$, respectively, were achieved when $\mathrm{Rr}$ was set at 4.0:1 (Period I) (Figure 4). During this experimental time frame, the reactor was fed with a $\mathrm{L}_{\mathrm{TOC}}$ of $0.41 \pm 0.1 \mathrm{~g} \mathrm{~L}^{-1} \mathrm{~d}^{-1}$ and $\mathrm{L}_{\mathrm{NOx}}$ of $0.26 \pm 0.1 \mathrm{gN} \mathrm{L}^{-1} \mathrm{~d}^{-1}$. Denitrification and TOC removal efficiencies were increased with higher influent organic and nitrogen loading rates (Figure 4). Negligible denitrification and TOC removal efficiencies were observed when raising Rr from 5.5 to $6.5: 1$. Therefore, we opted to maintain the $\mathrm{Rr}$ at 5.5:1 throughout the experiment.

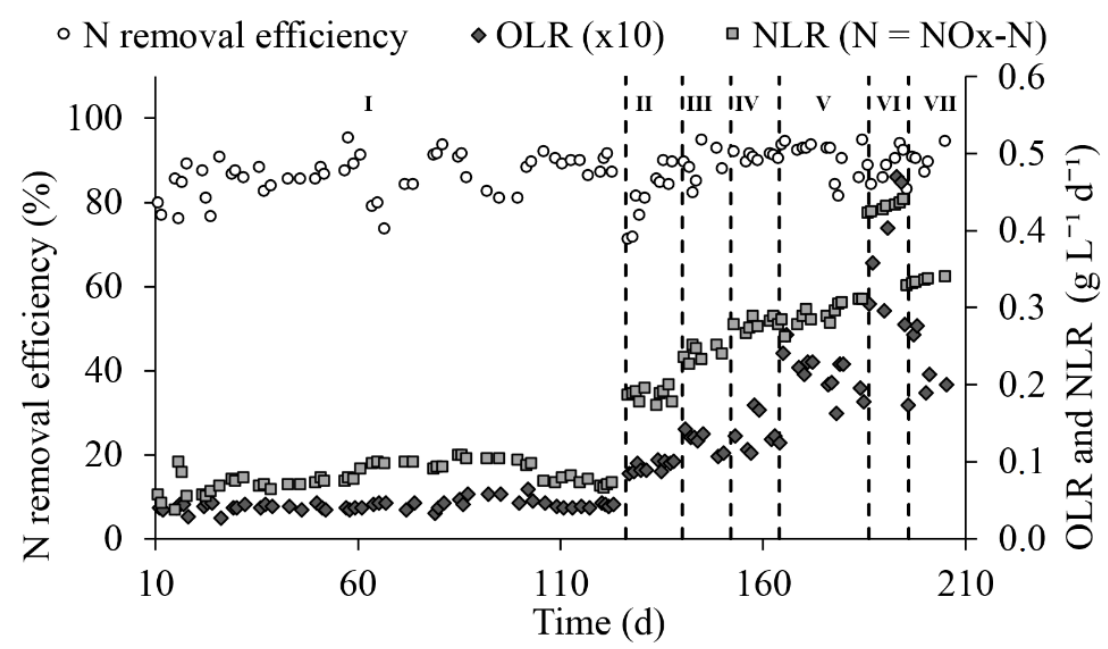

Figure 4. Correlation between Organic loading rate (OLR) and Nitrogen loading rate (NLR) on nitrogen removal efficiency by denitrification bioprocesses.

A reduction in HRT from 6.9 to 3.5 (from day 127 to 164) did not affect denitrification and TOC removal, which remained at $95.4 \%$ and $99.4 \%$, respectively. These results served to demonstrate the effectiveness of MLE to operate at relatively low HRT.

In experimental period $\mathrm{V}$, a new batch of wastewater effluent sample was used as substrate to feed the MLE system. Denitrification efficiency was kept at $99.1 \%$ with a TOC removal efficiency of $96 \%$. Interesting to note, changes in wastewater physical-chemical characteristics, such as the higher TOC, did not affect reactor efficiency. From the operational point of view, this is relevant considering the inherent variability in swine wastewater effluent composition commonly observed at field scale. After reaching steady-state conditions, the HRT was intentionally adjusted from 3.5 to $2.6 \mathrm{~d}$, resulting in an influent $\mathrm{L}_{\mathrm{TOC}}$ of $3.68 \pm 0.79 \mathrm{~g} \mathrm{~L}^{-1} \mathrm{~d}^{-1}$ and $\mathrm{L}_{\mathrm{N}-\mathrm{NOx}}$ of $0.43 \pm 0.02 \mathrm{~g} \mathrm{~L}^{-1} \mathrm{~d}^{-1}\left(0.01 \mathrm{NO}_{2}^{-} / \mathrm{NO}_{3}^{-}\right.$ratio). Even at this low HRT, the average denitrification and TOC removal efficiencies were notably high $(93.7 \%$ and $94.4 \%$, respectively).

\subsection{MLE efficiency}

Overall, the MLE system was not sensitive to major changes in nitrogen loading conditions maintaining satisfactory TOC and TN removal efficiencies of $96.1 \%$ and $90.7 \%$, respectively (for a $\mathrm{L}_{\mathrm{TOC}}$ of $2.15 \pm 0.41 \mathrm{~g} \mathrm{~L}^{-1} \mathrm{~d}^{-1}$ and $\mathrm{L}_{\mathrm{TN}}$ of $0.56 \pm 0.03 \mathrm{~g} \mathrm{~L}^{-1} \mathrm{~d}^{-1}$; Figure 5). These results were comparatively higher than the removal efficiencies reported for similar nitrificationdenitrification systems treating swine wastewater effluent. For instance, Park et al. (2009), utilizing an anoxic-aerobic-anoxic sequence reactors, obtained TN removal of $90 \%$ for a LTN of $0.18 \mathrm{~g} \mathrm{~L}^{-1} \mathrm{~d}^{-1}$. Removal efficiency below $80 \%$ was reported by Vanotti et al. (2009) for a nitrification-denitrification system using a $\mathrm{L}_{\mathrm{TN}}$ of $0.31 \mathrm{~g} \mathrm{~L}^{-1} \mathrm{~d}^{-1}$. Castrillón et al. (2009) reported $68 \%$ removal efficiency for influent $\mathrm{L}_{\mathrm{TOC}}$ of $4.5 \mathrm{gCOD} \mathrm{L}^{-1} \mathrm{~d}^{-1}$ and $\mathrm{L}_{\mathrm{TN}}$ of $0.40 \mathrm{gTN} \mathrm{L}^{-1} \mathrm{~d}^{-1}$.

\section{IPABH}

Rev. Ambient. Água vol. 14 n. 2, e2241 - Taubaté 2019 


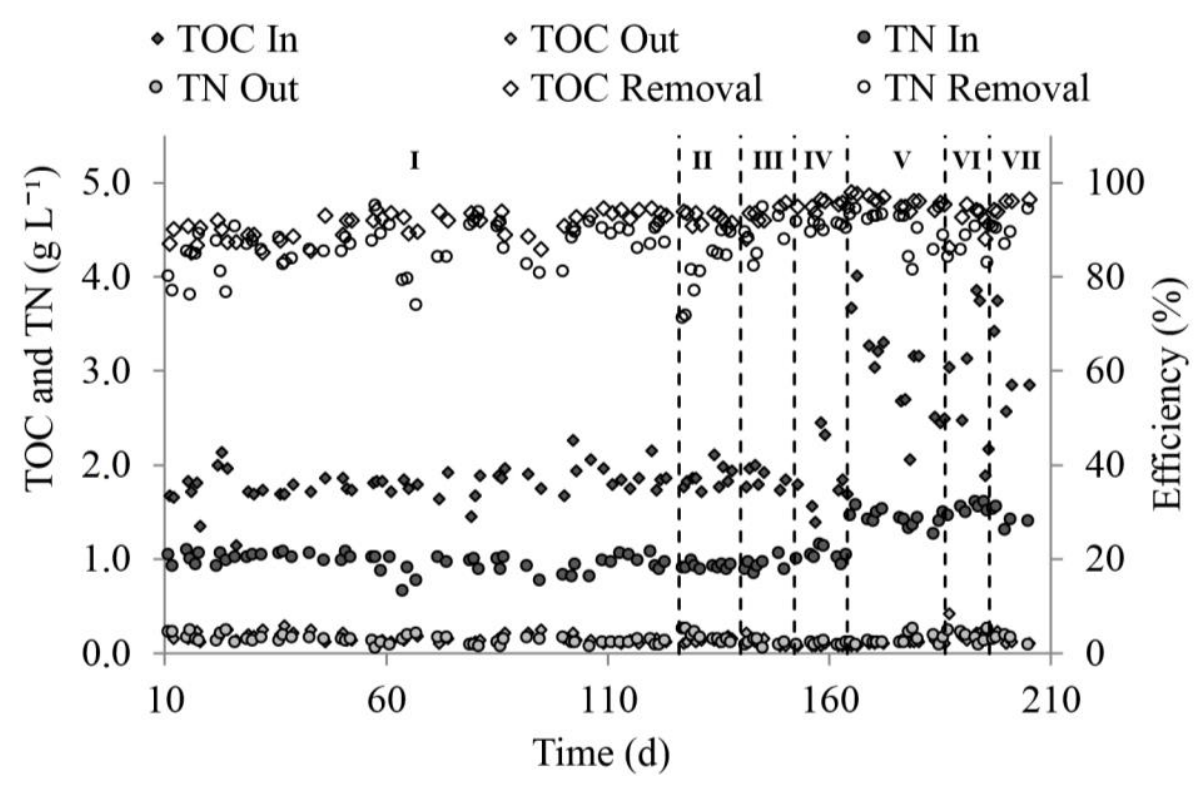

Figure 5. TOC and TN removal efficiencies in a MLE system under different carbon and nitrogen influent concentrations.

The final effluent obtained at the exit of the MLE system was relatively transparent, oxidized, and odorless, with $1.9 \mathrm{mg} \mathrm{L}^{-1}$ of $\mathrm{NH}_{3}-\mathrm{N}, 161.2 \mathrm{mg} \mathrm{L}^{-1}$ of $\mathrm{NO}_{3}-\mathrm{N}+\mathrm{NO}_{2}-\mathrm{N}$, and $144.7 \mathrm{mg} \mathrm{L}^{-1}$ of TOC. These are physical-chemical parameters that meet water quality standards that permit the reuse of water to wash swine facilities (Kunz et al., 2012).

\section{CONCLUSIONS}

The lab scale MLE reactor was continuously fed swine wastewater effluent for over 210 days under different $\mathrm{N}$ and TOC loading rates and HRT operational conditions. Dilution of swine wastewater effluent at the reactor's startup minimized acclimation time required to reach steady state conditions. Denitrification and nitrification conditions were established after 12 and 32 days, respectively. $\mathrm{NH}_{3}$ oxidation above $95 \%$ was achieved. Denitrification efficiencies $>90 \%$ were observed under different $\mathrm{N}$ and TOC influent loading rates and HRT. The highest total nitrogen removal of $89 \%$ was accomplished by recycling effluent from the nitrification reactor (4.5:1) together with the effluent from the clarifier (1:1). HRT as low as 3.5 days $\left(\mathrm{L}_{\mathrm{TN}}\right.$ of $0.56 \mathrm{~g} \mathrm{~L}^{-1} \mathrm{~d}^{-1}$ and $\mathrm{L}_{\mathrm{TOC}}$ of $\left.2.15 \mathrm{~g} \mathrm{~L}^{-1} \mathrm{~d}^{-1}\right)$ led to nitrogen and TOC removal efficiencies > $90 \%$.

This study demonstrated that nitrogen-rich swine wastewater effluent can be efficiently treated by the MLE process. Changes in raw wastewater physical-chemical composition and/or operational conditions should not significantly affect $\mathrm{N}$ and TOC removal efficiencies. This denotes the robustness of the approach and its potential application to field-scale operations.

\section{ACKNOWLEDGMENTS}

The authors thank the CNPq for its financial support.

\section{REFERENCES}

ANTHONISEN, A. C.; LOEHR, R. C.; PRAKASAM, T. B. S.; SRINATH, E. G. Inhibition of nitrification by ammonia and nitrous acid. Journal Water Pollution Control Federation, v. 48, p. 835-852, 1976. https://www.jstor.org/stable/25038971 
APHA; AWWA; WEF. Standard methods for the examination of water and wastewater. 21th ed. Washington, DC, 2012.

CASTRILLÓN, L.; FERNÁNDEZ-NAVA, Y.; MARAÑÓN, E.; GARCÍA, L.; BERRUETA, J. Anoxic-aerobic treatment of the liquid fraction of cattle manure. Waste Management, v. 29, p. 761-766, 2009. https://doi.org/10.1016/j.wasman.2008.06.027

DE PRÁ, M. C. et al. Simultaneous removal of TOC and TSS in swine wastewater using the partial nitritation process. Journal of Chemical Technology \& Biotechnology, v. 87, n. 12, p. 1641-1647, 2012. http://dx.doi.org/10.1002/jctb.3803

HAFEZ, H.; ELBESHBISHYA, E.; CHOWDHURYA， N.; NAKHLAA， B.G.; FITZGERALDC, J.; VAN ROSSUMC, A.; GAULDC, G. Pushing the hydraulic retention time envelope in Modified Ludzack Ettinger systems. Chemical Engineering Journal, v. 163, p. 202-211, 2010. https://doi.org/10.1016/j.cej.2010.07.033

JUBANY, I.; CARRERA, J.; LAFUENTE, J.; BAEZA, J. A. Start-up of a nitrification system with automatic control to treat highly concentrated ammonium wastewater: Experimental results and modeling. Chemical Engineering Journal, v. 144, p.407-419, 2008. https://doi.org/10.1016/j.cej.2008.02.010

KUNZ, A.; STEINMETZ, R. L. R.; DAMASCENO, S.; COLDEBELA, A. Nitrogen removal from swine wastewater by combining treated effluent with raw manure. Scientia Agricola, v. 69, p. 352-356, 2012. http://dx.doi.org/10.1590/S0103-90162012000600002

LEE, Y. S.; HAN, G. B. Pig slurry treatment by a hybrid multi-stage unit system consisting of an ATAD and an EGSB followed by a SBR reactor. Biosystems Engineering, v. 111, p. 243-250, 2012. https://doi.org/10.1016/j.biosystemseng.2011.11.014

LOUGHRIN, J. H.; VANOTTI, M. B.; SZOGI, A. A.; LOVANH, N. Evaluation of SecondGeneration Multistage Wastewater Treatment System for the Removal of Malodors from Liquid Swine Waste. Journal of Environmental Quality, v. 4, p. 23-38, 2009. http://dx.doi.org/10.2134/jeq2008.0430

LUDZACK, F. J.; ETTINGER, M. B. Controlling operation to minimize activated sludge effluent nitrogen. Journal (Water Pollution Control Federation), v. 34, p. 920-931, 1962. https://www.jstor.org/stable/25034693

ORDAZ, A.; OLIVEIRA, C. S.; AGUILAR, R.; CARRIÓN, M.; FERREIRA, E. C.; ALVES, M.; THALASSO, F. Kinetic and Stoichiometric Parameters Estimation in a Nitrifying Bubble Column Through "In-Situ', Pulse Respirometry. Biotechnology and Bioengineering, v. 100, p.94-102, 2008. https://doi.org/10.1002/bit.21723

PARK, J. J. et al. Use of spent sulfidic caustic for autotrophic denitrification in the biological nitrogen removal processes: Lab-scale and pilot-scale experiments, Journal of Industrial and Engineering Chemistry, v. 15, p. 316-322, 2009. https://doi.org/10.1016/j.jiec.2008.11.008

RAJAGOPAL, R.; ROUSSEAU, P.; BERNETC, N.; BÉLINE, F. Combined anaerobic and activated sludge anoxic/oxic treatment for piggery wastewater. Bioresource Technology, v. 102, p. 2185-2192, 2011. https://doi.org/10.1016/j.biortech.2010.09.112

RONGSAYAMANONT, C.; LIMPIYAKORN, T.; LAW, B.; KHAN, E. Relationship between respirometric activity and community of entrapped nitrifying bacteria: Implications for partial nitrification. Enzyme and Microbial Technology, v. 46, p. 229-236, 2010. https://doi.org/10.1016/j.enzmictec.2009.10.014 
TECHIO, V. H.; STOLBERG, J.; KUNZ, A.; ZANIN, E.; PERDOMO, C. C. Genotoxicity of swine effluents. Water Science \& Technology, v. 63, p. 970-976, 2011. http://dx.doi.org/10.2166/wst.2011.278

TCHOBANOGLOUS, G.; ABU-ORF, M.; BURTON, F. L. et al. Wastewater Engineering: Treatment and Resource Recovery. Volume 2. New York: McGraw-Hill Education, 2014.

VANOTTI, M. B.; SZOGI, A. A.; MILLNER, P. D.; LOUGHRIN J. H. Development of a second-generation environmentally superior technology for treatment of swine manure in the USA. Bioresource Technology, v. 100, p. 5406-5416, 2009. https://doi.org/10.1016/j.biortech.2009.02.019

VIANCELLI, A.; KUNZ, A.; STEINMETZ, R. L. R.; KICH, J. D.; SOUZA, C. K.; CANAL, C. W.; COLDEBELLA, A.; ESTEVES, P. A.; BARARDI, C. R. M. Performance of two swine manure treatment systems on chemical composition and on the reduction of pathogens. Chemosphere, v. 90, p. 1317-1572, 2013. https://doi.org/10.1016/j.chemosphere.2012.08.055 


Ambiente \& Água - An Interdisciplinary Journal of Applied Science
ISSN 1980-993X - doi:10.4136/1980-993X
www.ambi-agua.net
E-mail: ambi.agua@gmail.com

\title{
Background and the use of isoscapes in the Brazilian context: essential tool for isotope data interpretation and natural resource management
}

\author{
ARTICLES doi:10.4136/ambi-agua.2282
}

Received: 23 May 2018; Accepted: 01 Feb. 2019

\author{
João Paulo Sena-Souza ${ }^{1 *(\mathbb{D})}$; Fábio José Viana $\operatorname{Costa}^{2}{ }^{(D}$; Gabriela Bielefeld Nardoto ${ }^{1}$ \\ ${ }^{1}$ Universidade de Brasília (UnB), Brasília, DF, Brasil \\ Instituto de Ciências Biológicas (IB). Departamento de Ecologia. E-mail: jpsenasouza@gmail.com, \\ gbnardoto@unb.br \\ ${ }^{2}$ Instituto Nacional de Criminalística (INC), Brasília, DF, Brasil \\ Departamento de Polícia Federal. E-mail:mr.f.bio@gmail.com \\ *Corresponding author
}

\begin{abstract}
Spatial patterns of stable isotope ratios can be represented in spatial models called isoscapes, and have been widely used to track biogeochemical processes in natural and anthropic systems. Isoscapes have the potential to improve isotope dissemination and interpretation of spatial patterns, increase scientific results appropriation by non-specialists and improve natural resource management. However, the isoscape approach has not commonly been used in studies performed in the Brazilian context. Isoscapes with oxygen, hydrogen, nitrogen and carbon stable isotopes contribute in areas such as animal migration, forensics, hydrology, and studies on population, community and ecosystem level, among others. Here, we show the well-known global use and applications of isoscapes in different studies worldwide as a background to point out the potential for more Brazilian researchers to employ this approach in their studies, taking advantage of existing methods and filling spatial and methodological gaps. The incorporation of isoscapes may broaden the understanding of mechanisms and processes of major biogeochemical cycles in Brazil, assist in solving crimes, track illicit drug origins, help to detect wild animal trafficking, and increase Brazilian knowledge about the hydrological cycle and animal migration patterns in the Neotropics.
\end{abstract}

Keywords: isotopic landscape, spatial patterns, stable isotope.

\section{Isoscapes e seu uso no contexto brasileiro: ferramenta essencial para a interpretação dos dados isotópicos e a gestão dos recursos naturais}

\section{RESUMO}

Padrões de distribuição espacial de isótopos estáveis podem ser apresentados em mapas chamados de isoscapes e têm sido amplamente utilizados para rastrear processos biogeoquímicos em sistemas naturais e antrópicos. Isoscapes têm o potencial de melhorar a disseminação e interpretação dos padrões espaciais de isótopos estáveis, aumentar a apropriação de resultados científicos por não-especialistas e melhorar a gestão de recursos naturais. No entanto, a abordagem de isoscape não tem sido comumente usada em estudos realizados no Brasil. Isoscapes de isótopos estáveis de oxigênio, hidrogênio, nitrogênio e carbono contribuem em áreas como migração animal, ciência forense, estudos hidrológicos e 
ecológicos a nível de população, comunidade e ecossistema, entre outros. Aqui nós mostramos uma revisão sobre o uso e as aplicações de isoscapes em diferentes estudos em todo o mundo. Também apontamos uma forma de mais pesquisadores brasileiros empregarem essa abordagem em seus estudos, aproveitando os métodos existentes e preenchendo lacunas espaciais e metodológicas. A incorporação de isoscapes pode ampliar o entendimento dos mecanismos e processos dos ciclos biogeoquímicos no Brasil, auxiliar na resolução de crimes, tráfico de drogas ilícitas e de animais silvestres e aumentar o conhecimento brasileiro sobre o ciclo hidrológico e os padrões de migração animal nos neotrópicos.

Palavras-chave: isótopos estáveis, padrões espaciais, paisagem isotópica.

\section{INTRODUCTION}

Stable isotope ratio distribution is related to geographic space. This is a fundamental feature that has led to the emergence of many studies in this growing field of knowledge with a series of new applications in recent years. This spatial variation is related to how spatially explicit variables influence isotopic fractionation and discrimination. For example, altitude and latitude highly influence $\delta^{2} \mathrm{H}$ and $\delta^{18} \mathrm{O}$, differences in regional nitrogen cycles influence $\delta^{15} \mathrm{~N}$, and differences in the plant photosynthetic pathways $\left(\mathrm{C}_{3}\right.$ or $\left.\mathrm{C}_{4}\right)$ influence $\delta^{13} \mathrm{C}$.

Spatial patterns of stable isotope ratios have been represented in spatial models, called isoscapes (isoscapes $=$ isotopic + landscapes), which allow visualization and help both data interpretation and decision making when managing natural resources (Bowen, 2010a). Isoscapes enable the statistical filling of spatial gaps where isotope ratio information has not been represented (Bowen, 2010a). Isoscapes can be based on any of both abiotic elements, such as water (Terzer et al., 2013) and soil (Weintraub et al., 2016), as well as biotic elements, such as plant (Powell et al., 2012), animal (Vander Zanden et al., 2018) and human tissues (Valenzuela et al., 2011). For this reason, isoscapes have been used in a wide range of scientific areas, such as ecology, climate change, biogeochemistry, hydrology, forensic sciences, anthropology, and commercial regulation, among others (Bowen et al., 2009).

The effort to map stable isotope ratios in the landscape precedes the term "isoscape", which was idealized in 2006 (West et al., 2006). Before that, mathematical models were developed to map global $\delta^{15} \mathrm{~N}$ patterns in soil (Amundson et al., 2003), global $\delta^{13} \mathrm{C}$ patterns in biosphere focusing on carbon isotope discrimination during photosynthesis (Lloyd and Farquhar, 1994), and of $\delta^{18} \mathrm{O}$ in atmospheric $\mathrm{CO}_{2}$ (Farquhar et al., 1993). The $\delta^{18} \mathrm{O}$ and $\delta^{2} \mathrm{H}$ global maps were also developed, mainly based on a database with precipitation isotopic ratios provided by the Global Network for Isotopes in Precipitation (GNIP) (Bowen and Revenaugh, 2003). With improvements in mapping technologies, interpolation techniques, and transfer functions, the isoscape approach has become a fertile scientific application field (West et al., 2010).

Reviews of isoscapes (Bowen et al., 2009; Bowen, 2010a) and a book focused on isoscape concepts and techniques (West et al., 2010) have already been published. However, the present compilation is the first that presents an extensive update on isoscape application followed by indications of perspectives and future applicability in Brazil, a region recognized worldwide for its high biological diversity and landscape heterogeneity. As a country of continental size, Brazilian scientific works that use stable isotopes can adapt global isoscapes from literature to solve national scientific problems. In addition, creating new isoscapes in different spatial and temporal scales to Brazil may fill existent scientific gaps on stable isotope distribution, improving the knowledge on spatial patterns of carbon and nitrogen biogeochemical cycles, hydrological cycles, trophic niches and animal movements, and food authentication and forensics. 
In this context, we explore here the key concepts and methods used in the design of isoscapes presenting a brief explanation about stable isotope spatial distribution mechanisms, the major problems related to scale definition, and the already used methodologies to generate isoscapes. With that in mind, associated to a summary of the main applications of isoscapes in the areas of water cycle, ecosystem ecology, animal movement and forensic studies, we present how the use of isoscapes could be an essential tool for isotope data interpretation and natural resource managing in Brazil.

\section{METHODOLOGY}

We searched for publications in the Web of Science (http://thomsonreuters.com/web-ofscience) databases using the word "isoscape" or "isoscapes" as a topic (present in the abstract, keyword, or title). In order to expand the search, we explored the reference lists of the retrieved articles. We classified the articles according to the topics defined in this work: water cycle studies, ecosystem approach studies, animal movement, and forensic applications. Although there are isoscapes of several elements, we restricted the search to $\delta^{2} \mathrm{H}, \delta^{18} \mathrm{O}, \delta^{13} \mathrm{C}$ and $\delta^{15} \mathrm{~N}$ isoscapes. To present papers in which isoscapes could be used in order to show the potential use of this approach in the Brazilian context, we searched for articles using the word "stable isotopes". This search was performed on the Web of Science and Scielo databases.

To illustrate some existent isoscapes that can be used in the Brazilian context, we used isoscapes available in literature. World precipitation $\delta^{2} \mathrm{H}$ and $\delta^{18} \mathrm{O}$ isoscapes are accessible to download on http://www.waterisotopes.org in raster format, with $10 \mathrm{~km} \mathrm{x} 10 \mathrm{~km}$ spatial resolution. We used climatic data from http://www.worldclim.org to elaborate soil $\delta^{15} \mathrm{~N}$ isoscape to Brazil based in Amundson et al. (2003) equation for $0-10 \mathrm{~cm}$ depth $\left(\delta^{15} \mathrm{~N}_{\text {soil((0-10) }}\right.$ $=0.134 *$ MAT $-0.0005 *$ MAP +3.1985$)$. For $\delta^{13} \mathrm{C}$ isoscape, we used the model elaborated by Powell et al. (2012) to South America under their previous authorization.

\section{KEY CONCEPTS AND METHODS USED IN THE DESIGN OF ISOSCAPES}

\subsection{Describing stable isotopes and their natural variations}

Isotopes are atopic species of the same element. Therefore, they contain the same number of protons in the atomic nucleus, but different numbers of neutrons. The stable isotopes are those that do not emit any kind of radiation. Carbon stable isotopes, for example, are ${ }^{12} \mathrm{C}$ and ${ }^{13} \mathrm{C}$. The first one contains 6 protons and 6 neutrons in the nucleus, the second has the same number of protons, but 7 neutrons. The elements of major biogeochemical cycles that have more than one isotope (hydrogen, oxygen, carbon and nitrogen) are so called the light stable isotopes.

The natural abundance of heavier isotope atoms is significantly smaller compared to the lighter atoms. Therefore, the isotope ratio $(\mathrm{R})$ of the sample is compared to the $\mathrm{R}$ of a preset international standard to define the value of delta: $\delta=\left(R_{\text {sample }} / R_{\text {standard }}-1\right) * 1000$, where $R_{\text {sample }}$ is the ratio between heavier and lighter atoms of the sample, and $R_{\text {standard }}$ is the ratio between heavier and lighter atoms of a standard. The $R$ value is dimensionless and via criteria of provenance is less than zero. Thus, its value is multiplied by a thousand, creating a notation called $\delta$ per mil (\%o).

Biogeochemical and physical processes lead to differences in reaction between light-heavy isotopes generating different proportion of them on materials or environment. The main process that leads the carbon isotope discrimination $\left(\Delta^{13} \mathrm{C}\right)$ is photosynthesis. There are two main metabolic pathways of $\mathrm{CO}_{2}$ absorption by plants: $\mathrm{C}_{3}$ (Calvin Cycle) and $\mathrm{C}_{4}$ (Hatch-Slack Cycle). $\mathrm{C}_{3}$ plants discriminate more ${ }^{13} \mathrm{C}$ from $\mathrm{CO}_{2}$, thus have lower $\delta^{13} \mathrm{C}$, varying between -35 
$\%$ and $-20 \%$. In contrast, $\mathrm{C}_{4}$ plants have higher $\delta^{13} \mathrm{C}$ values, with variation pattern between $15 \%$ and $-11 \%$ (Powell et al., 2012). In general, $C_{3}$ plants are tree and shrub species, while $\mathrm{C}_{4}$ plants are represented by tropical grasses (e.g. corn and sugarcane). The $\delta^{13} \mathrm{C}$ isoscapes are generally elaborated through methods that differentiate plants with $\mathrm{C}_{3}$ or $\mathrm{C}_{4}$ metabolisms (Powell et al., 2012).

However, differences in carbon isotope ratio can be found in the same photosynthetic group $\left(\mathrm{C}_{3}\right.$ or $\left.\mathrm{C}_{4}\right)$ or even in multiple individuals in the same species. Those differences occur due to environmental control or genotype-specific physiological influences in carbon isotopic discrimination among plants (Cernusak et al., 2013). In $\mathrm{C}_{3}$ plants, leaf $\delta^{13} \mathrm{C}$ might decrease with increasing the ratio of intercellular to ambient $\mathrm{CO}_{2}$ concentrations $(\mathrm{ci} / \mathrm{ca})$, which is a function of $\mathrm{CO}_{2}$ supply from the atmosphere to the intercellular air spaces through stomata (Orchard $e t$ al., 2010). In addition to allowing the diffusion of $\mathrm{CO}_{2}$ in the leaf, the stoma prevents water loss. Therefore, soil water availability and atmospheric pressure also influence $\Delta^{13} \mathrm{C}$. Plant $\delta^{13} \mathrm{C}$ has a negative correlation with the transpiration efficiency and has been used to access wateruse efficiency, which can change following environmental gradients. Generally, $\Delta^{13} \mathrm{C}$ decreases with the decrease of MAP (Cernusak et al., 2013).

There is a general pattern of increasing $\delta^{13} \mathrm{C}$ value with the increase of elevation among $\mathrm{C}_{3}$ plants. In higher altitudes, the ci/ca ratio decreases with the decrease of atmospheric pressure. The lower temperature in high altitudes can increase the $\Delta^{13} \mathrm{C}$ as well. The availability of nutrients in the soil is another factor that influences the isotopic discrimination of carbon by the $\mathrm{C}_{3}$ plant due to the direct influence on photosynthetic capacity. Discrimination of the carbon isotope decreases with increasing $\mathrm{N}$ concentration in the leaf (Cernusak et al., 2013). Light availability is the main environmental condition that causes $\Delta{ }^{13} \mathrm{C}$ variation among $\mathrm{C}_{4}$ plants. Generally, $\Delta^{13} \mathrm{C}$ increases with irradiance in $\mathrm{C}_{4}$ plants. Water use efficiency also influences $\mathrm{C}_{4}$ plants $\Delta^{13} \mathrm{C}$; however, with an opposite trend compared with $\mathrm{C}_{3}$ plants. Also, there may be a trend for increased isotope carbon discrimination with increased drought stress in $\mathrm{C}_{4}$ plants (Murphy and Bowman, 2009).

Global atmospheric circulation of water is the most important process that influences global distribution of $\delta^{18} \mathrm{O}$ and $\delta^{2} \mathrm{H}$. Oxygen and hydrogen isotope ratios of water change primarily from the isotopic discrimination by sea water evaporation and precipitation. The standard mean ocean water (SMOW) is the international standard for $\delta^{18} \mathrm{O}$ and $\delta^{2} \mathrm{H}$, which is $0 \%$, by convention. Furthermore, $\delta^{18} \mathrm{O}$ and $\delta^{2} \mathrm{H}$ ratios become negative due to differential evaporation between heavier and lighter molecules, where lighter molecules evaporate more easily. In the process of rain formation and precipitation, clouds turn more negative as they advance toward the continent. In this way, $\delta^{18} \mathrm{O}$ and $\delta^{2} \mathrm{H}$ ratios present latitudinal, longitudinal and/or altitude variation, undergoing continental effects.

At smaller scales, water isotopes differ according to the scale and processes that drive the hydrological cycle. In a watershed, regardless of its extent, the water isotopic variation goes beyond the influence of precipitation. The $\mathrm{O}$ and $\mathrm{H}$ isotope ratios of surface water depend mainly on the water source (Bowen and Good, 2015; Liu et al. 2010; Birkel et al., 2018) and downstream transport-related processes during the terrestrial water fluxes in a watershed (Jasechko et al., 2013). Differences in soil texture or hillslope angle can drive differential variation in the evaporation leading to variation in water isotope values at local scales (Mueller et al., 2014). Differences in environmental conditions (temperature and air humidity) influence leaf water evaporation leading to possible variation of tissue $\mathrm{O}$ and $\mathrm{H}$ isotope ratios and it can vary according to the plant species (West et al., 2008).

The spatial variation of $\delta^{15} \mathrm{~N}$ depends on a complex set of processes. Each process of oxidation and reduction of nitrogen causes isotope fractionation. Nitrogen makes up about $78 \%$ of the atmosphere in the form of $\mathrm{N}_{2}$, a little-reactive gas. This gas is the international standard for $\delta^{15} \mathrm{~N}$ which is $0 \%$, by convention. Processes such as dry and/or wet deposition of $\mathrm{N}$, and 
decomposition of organic matter transform $\mathrm{N}$ into more reactive forms. When nitrogen is transformed from $\mathrm{N}_{2}$ to $\mathrm{NH}_{3}$ and $\mathrm{NH}_{4}{ }^{+}$, assimilated by the organisms and transformed into organic molecules, $\delta^{15} \mathrm{~N}$ values of the substrate increase. Therefore, soil $\delta^{15} \mathrm{~N}$ is generally high, especially in tropical ecosystems (Martinelli et al., 1999).

Climatic influences on soil $\delta^{15} \mathrm{~N}$ values occur mainly due to the higher gaseous $\mathrm{N}$ losses in hot/dry places than in wet/cold places (Craine et al., 2015a). High values of $\delta^{15} \mathrm{~N}$ in the soil can indicate high relative losses of $\mathrm{N}$ for the atmosphere while $\mathrm{N}$ losses due to leaching and erosion do not cause significant fractionation. Soil $\delta^{15} \mathrm{~N}$ varies as a function of clay content and soil organic carbon concentration at global scale (Craine et al., 2015a) while at local and regional scales, soil $\delta^{15} \mathrm{~N}$ values are a function of organic matter decomposition (Craine et al., 2015b). Generally, the higher the level of organic matter decomposition, the greater the soil $\delta^{15} \mathrm{~N}$ (Craine et al., 2015b). Moreover, topographic position influences soil particle size by erosion and deposition processes and can be an important predictive variable of the nitrogen cycle, which consequently influences soil $\delta^{15} \mathrm{~N}$ spatial variation (Berhe et al., 2018).

\subsection{Scaling isoscapes}

Scale is a fundamental aspect of studying all phenomena and processes that vary in space and/or time (Goodchild, 2011). In general, a scale reflects the limit of a given phenomenon representation. Several studies use categoric terminology from geographical scale approach in the application or elaboration of isoscapes or in works on processes that lead to a spatial variation of isotopic fractionation and discrimination, which can be used as predictive variables for isoscape elaboration (eg.: landscape-scale - Bai et al., 2009; continental-scale - Powell et al., 2012; ecosystem-scale Wang et al., 2013; community-scale - Rascher et al., 2012).

Large-scale isoscapes often need to be simplified and generalized due to the necessary match with secondary data sources available at these scales (Bowen, 2010a). In this sense, global or continental-scale isoscapes may not be suitable for landscape-scale applications without going through a downscaling process considering more variables. Likewise, isoscapes elaborated on very detailed scales may not address issues at larger scales (Bowen, 2010a).

The isotope ratio of a given substrate varies with time, location, and spatially. Therefore, depending on the chosen scale, the predictive variables of a given isotopic ratio may change. The spatial variation of water stable isotopes of precipitation $\left(\delta^{18} \mathrm{O}\right.$ and $\left.\delta^{2} \mathrm{H}\right)$, for example, is clearly influenced mainly by climatic patterns, with the main variables predicting the annual mean precipitation and temperature (Terzer et al., 2013). However, in smaller scales, the influence of other variables such as topography may be more evident (Baisden et al., 2016).

\subsection{Mapping isoscapes}

One of the main principles of isoscapes is to determine isotopic composition in places where there is no sampling, extrapolating a limited number of sampled sites. Therefore, we mainly use methods and algorithms from the geostatistics. The choice of the appropriate method for the mapping depends on the purpose of the work, the number of spatially explicit dependent variables and predictors available, and the scale. At the local and regional scale, it is feasible to collect in the field to feed isoscapes models. Usually, these studies have used ordinary kriging after semivariogram fit to construct the isoscapes (Oliver and Webster, 2014).

Isoscapes with larger scales are usually built by the compilation of data from literature. Another way is setting up global networks of isotopic monitoring. As an example, $\delta^{18} \mathrm{O}$ and $\delta^{2} \mathrm{H}$ isoscapes in water were used to compile the GNIP database that has been applied in hydrological and ecological approaches in many spatial scales (IAEA/WMO, 2015).

Spatial autocorrelation is considered as a fundamental condition for the application of geostatistical methods. That is, values from nearby places tend to be more similar than values from places more distant in space. In this sense, the independent or predictive variable must influence the values of the target variable, which are the stable isotope values. Geostatistical 
models usually bring an error that must be measured and considered in the studies. The model settings seek to reduce the error, increasing accuracy.

When the spatial process influencing the variable is well-known, the search for a methodological standardization is more feasible. That is the case of the influence of atmospheric water circulation on precipitation $\delta^{18} \mathrm{O}$ and $\delta^{2} \mathrm{H}$, for example, which allows the application of special regression in most mappings (Bowen, 2010b).

Most of the well-known global isoscapes are for $\delta^{18} \mathrm{O}$ and $\delta^{2} \mathrm{H}$, and they are basically based on equations of spatial regressions, with variations and adaptations between studies. Since there are global isoscapes of environmental elements such as precipitation of water, they can be adjusted for global isoscapes of biological tissues, as was done for leaf water (West et al., 2010) and bird feathers (Bowen et al., 2005; Hobson et al., 2012a). It is important to highlight here the work of Terzer et al. (2013) that proposed a new approach to raise accuracy of $\delta^{18} \mathrm{O}_{\mathrm{p}}$ and $\delta^{2} \mathrm{H}_{\mathrm{p}}$ isoscape global models, called Regionalized Cluster-based Water Isotope Precipitation (RCWIP). The method differs from previous ones because the authors made a more accurate model from a set of regionalized multivariate regression equations. The predictive variables were gridded climatic and geographic variables (elevation, latitude / longitude). Terzer et al. (2013) compared the results with the model of Bowen and Wilkinson (2002), showing that uncertainty generally decreased. These results are available for download on the internet in raster format with 10' x 10' spatial resolution on http://www.iaea.org/water.

The only existing global nitrogen isoscape was proposed by Amundson et al. (2003), based on a regression using global patterns of precipitation and temperature as predictive variables. They used values of foliar $\delta^{15} \mathrm{~N}$, soil $\delta^{15} \mathrm{~N}$, and enrichment factor available in the literature at that time, showing that, on a global scale, soil and plant $\delta^{15} \mathrm{~N}$ have a negative relation with MAP and positive correlation with MAT. It served as a first proxy of $\delta^{15} \mathrm{~N}$ global distribution. However, it presented considerable limitations due to the complexity of factors that affect $\delta^{15} \mathrm{~N}$ fractionation, many gaps in spatial distribution data, which results in augmented error in the final model (Pardo and Nadelhoffer, 2010).

For carbon isoscapes, Still and Powell (2010) developed a methodology to estimate the percentage of $\mathrm{C}_{3}$ and $\mathrm{C}_{4}$ plants by area unit, allowing $\delta^{13} \mathrm{C}$ plant spatial distribution pattern estimation in a large mapping scale. Powell et al. (2012) used similar methodology to map $\delta^{13} \mathrm{C}$ in South America in 2000, using empirical measurements of plants and soils. They estimated $\delta^{13} \mathrm{C}$ values for plants and soil organic matter from vegetation type mapping (grasses, shrubs and trees) by classifying each pixel of an image as potentially favorable for $\mathrm{C}_{3}$ plant or $\mathrm{C}_{4}$ plant. The authors used temperature and precipitation dataset incorporated to previous classifications of agricultural cover and type of crop. First, they considered vegetation pattern and visual interpretation of satellite image and incorporated information of managed agro-ecosystems. Second, they partitioned the area considered herbaceous in the previous step in natural grasses percentage and crop percentage based on global data of agricultural area distribution, separating in $\mathrm{C}_{3}$ and $\mathrm{C}_{4}$ plant culture from a global database of types of agriculture. This approach may be applied at a regional scale by incorporating new datasets that represent regional relationships between ${ }^{13} \mathrm{C}$ discrimination and abiotic factors.

\section{MAIN APPLICATIONS OF THE ISOSCAPES}

\subsection{Water isoscapes}

Global and regional $\delta^{18} \mathrm{O}$ and $\delta^{2} \mathrm{H}$ isoscapes provide information that integrate a number of water cycle mechanisms and have strong spatial correlation (Bowen and Good, 2015). This approach serves as base to models that assign samples to their regions of origin, such as animal migration and forensic models. Due to the importance and utility of maps for water $\delta^{18} \mathrm{O}$ and $\delta^{2} \mathrm{H}$, many works adapted methodologies by downscaling precipitation, surface water and 
groundwater isoscapes for different locations. Water isoscapes have been used to measure contributions of surface water and groundwater to rivers, water loss to atmosphere through evaporation or transpiration, and rain-type contribution to total precipitation (Aggarwal et al., 2016). Precipitation $\delta^{18} \mathrm{O}$ isoscapes also contribute to the understanding of climatic variations and anomalies (Kern et al., 2014) and the determination of seasonal variation in water sources (Brooks et al., 2012). In the latter, during the dry season, the major contribution was found to be from snow accumulated at higher altitudes (60-80\%), helping to understand the vulnerability of the Willamette River hydrographical system in the climate change scenario (Brooks et al., 2012).

\subsection{Isoscapes on ecosystem ecology approach}

Isoscapes have been used in the ecosystem approach mainly to provide a basis for studies of carbon and nitrogen biogeochemical cycles from local to global scales.

At the global scale, atmospheric and plant $\delta^{13} \mathrm{C}$ isoscapes provide fundamental information to the comprehension of $\mathrm{CO}_{2}$ exchanges between the biosphere and atmosphere by calculating net assimilation of carbon by plants based on carbon discrimination models (Lloyd and Farquhar, 1994; Suits et al., 2005); global plant $\delta^{13} \mathrm{C}$ isoscape models have great potential to improve estimates of the carbon sinks and sources spatial distribution, knowledge about plant physiology, and their interaction with climatic and edaphic factors (Powell et al., 2012); global isoscapes of soil $\delta^{15} \mathrm{~N}$ integrate important information about $\mathrm{N}$ global input and output tendencies of ecosystems (Amundson et al., 2003; Houlton et al., 2015).

At smaller scales, isoscapes have been used for both aquatic and terrestrial environments with an ecosystem approach to understand regional and local patterns of carbon and nitrogen cycles as well as human activities and local environmental changes are affecting the dynamics of these elements. In aquatic ecosystems, $\delta^{13} \mathrm{C}$ and $\delta^{15} \mathrm{~N}$ isoscapes have been coupled with various elemental ratios to analyze nutrient dynamics ( $\mathrm{N}$ and $\mathrm{P}$ ) (Fourqurean et al., 2015). In terrestrial ecosystems, soil $\delta^{15} \mathrm{~N}$ spatial variation may be shaped considering elevation, which has a direct relationship to climatic patterns (e.g.: MAT and MAP) (Arnold et al., 2009; Weintraub et al., 2016), but may also help to compose future predictive models about nutrient cycling and $\mathrm{CO}_{2}$ emission in a climate change scenario (Houlton et al., 2015). $\delta^{13} \mathrm{C}$ and $\delta^{15} \mathrm{~N}$ isoscapes have also been applied to measure spatial correlation of soil $\delta^{13} \mathrm{C}$ in natural environments and pastures (Powers, 2006), to evaluate invasive plant effects in local ecosystem processes (Bai et al., 2009; 2012a; 2013; Rascher et al., 2012; Hellmann et al., 2016a; 2016b; 2017; Nielsen et al., 2016) and to assess the effects of land use change to nutrient cycle in rural areas (Nitzsche et al., 2016) as well as in urban areas (Boeckx et al., 2006). Local $\delta^{13} \mathrm{C}$ and $\delta^{15} \mathrm{~N}$ isoscapes have been also used to track soil organic matter dynamics. For instance, variations in tropical forest soil $\delta^{15} \mathrm{~N}$ may also be explained by topographic variations, mainly by slope (Hilton et al., 2013; Weintraub et al., 2015) and elevation (Arnold et al., 2009; Weintraub et al., 2016).

\subsection{Isoscapes on animal movement and biological conservation studies}

There are two major approaches to use isoscapes in animal migration studies: nominal assignment and continuous surface assignment (Wunder, 2012). Nominal assignment approach divides the continuous surface with isotopic ratios (predictive variables) in smaller named blocks, easier to manipulate (categoric variables). The most-used methods in the nominal assignment approach are decision trees or discriminatory functions that create attributions and clusters (Hobson et al., 2012b; Vander Zanden et al., 2015). Continuous surface assignment approach is based on continuous surface models with isotopic ratios attributed to each pixel on a model. In these cases, the continuous surface approach requires a small set of sample data adjusted to inorganic variable models (such as precipitation, for instance) (Wunder, 2012). 
Assignments have usually been made by applying Bayesian analysis in order to estimate the likelihood that each isoscape pixel represents the origin of a given sample. The same approach is used in forensic studies (see section below). Some prior information may lead to greater likelihood that an unknown sample may have originated from an area. In the absence of isotope data, given the greater natural abundance of individuals from a same species in a region versus in another region, it is reasonable to think that the target individual would have a greater chance to have come from the former region. This way of thinking may be traduced to mathematical terms using Bayesian rules: $P(B \mid A)=P(A \mid B) * P(B) / P(A)$, where, $P(B \mid A)$ is the posterior probability of an event $B$ given event $A, P(A \mid B)$ is the probability of the observed data given the model parameters (for example, the normal probability function cited below), $P(B)$ is the prior probability for $B$ and $P(A)$ is a marginal probability that serves as a normalizing constant.

There are several algorithms and computational platforms that support the Bayesian analysis specific for sample assignment to isoscapes. One of the most-used platforms is the IsoMAP, cyber-GIS system that supports basic isoscape modeling and sample assignment based on Bayesian analysis (http://isomap.org; Bowen et al., 2014). Recently, many packages have emerged on the R statistical computing environment (R Core Team, 2018) that permit geostatistical analyses, isoscape modelling, and sample assignment. Some of them combined different GIS packages in one specific for isoscape assignment, such as IsoriX package, for example (Courtiol et al., 2019).

Assignment models use tissue isoscape as a probability surface, where an unknown origin sample value may be assigned to a region as a function of a normal distribution, given its isotopic value and the expected standard deviation (Wunder, 2012; Reed et al., 2018; Hobson et al., 2018). For that reason, the construction of tissue isoscapes is a priority for studies on animal migration. Studies with this objective should consider the characteristics of each species and generate isoscape models with appropriate spatial resolution. Also, the majority of existing models are static, not taking into account temporal variation that may be incorporated to animal tissue. Isoscapes based on global databases, for example, should be associated with fieldvalidated samplings and other, more refined, local climatic models (Hobson et al., 2010). The mechanisms of tissue renewal and how they affect isotopic fractionation in the animal must be considered in the analysis (Wunder and Norris 2008). Studies about migratory species using isoscapes in countries with few available data should elaborate ground-validated models for the species in question (Gutiérrez-Expósito et al., 2015). The tissue-calibrated isoscape can be made by using the residual from a regression analysis between the environment isoscape and the target tissue isotopic value (Hobson et al., 2018). The tissues to calibrate the isoscapes must have known origins.

Scientists must be aware of the challenges of using organic tissue for stable isotope analysis, mainly for $\delta^{2} \mathrm{H}$ values (Hobson et al., 2012a; Soto et al., 2017). Samples for this type of analysis are very sensitive to contamination by any water from the natural ambient humidity. The analysis of the same sample at different sites may also affect the final result, which can be solved by more intensive drying of the sample (Soto et al., 2017). Even more complex is the exchangeable nature of some hydrogen molecules, which may affect the final bulk tissue $\delta^{2} \mathrm{H}$ value. That is due to the characteristics of some chemical structures of the materials, such as amino $\left(\mathrm{NH}_{2}\right)$, carboxyl $(\mathrm{COOH})$, hydroxyl $(\mathrm{OH})$, or thiol $(\mathrm{SH})$, which can exchange hydrogen atoms with ambient water (Meier-Augenstein et al., 2013). Therefore, exchangeable hydrogen must be considered in the analysis to maintain the accuracy of assignment models with precipitation isoscapes (Meier-Augenstein et al., 2013; Soto et al., 2017).

Building an organic tissue $\delta^{2} \mathrm{H}$ dataset must follow controlled methods to determine nonexchangeable ${ }^{2} \mathrm{H}$ abundance in animal tissue, so the analysis can be validated and applied in spatial models (Meier-Augenstein et al., 2013). Some methods have recently been accessed in 
an attempt to standardize $\delta^{2} \mathrm{H}$ analyzes on tissues in different laboratories and should be considered in future analyses (Soto et al., 2017). These challenges must be considered on any analysis that uses organic tissue $\delta^{2} \mathrm{H}$ to track animal movement, as well as any forensic application involving tracking humans, food provenance, and illegal trade of wildlife, timber and drugs.

Most papers on the use of isoscapes in animal migration studies are focused on birds, due to the large number of migratory species (eg Vander Zanden et al., 2015; Reed et al., 2018). However, the isoscape approach has been used in studies of the movement of any species or group of animals that exhibit some geographic variation during the life cycle. In terms of wild fauna conservation studies, regional isoscapes have been used with great potential to assist decision makers (Hénaux et al., 2011). For example, Hénaux et al. (2011) observed the dispersion routes of pumas (Puma concolor) using $\delta^{2} \mathrm{H}$ and $\delta^{13} \mathrm{C}$ isoscapes to approach prey with sedentary behavior, an important work in identifying critical conservation areas for big carnivores, and Rodríguez-Pérez et al. (2018) identified critical habitats of vaquitas (Phocoena sinus) using sediment and zooplankton $\delta^{13} \mathrm{C}$ and $\delta^{15} \mathrm{~N}$ isoscapes in marine ecosystems.

\subsection{Isoscapes on forensic applications}

The success of prior uses of animal-tissue isoscapes has led the increased use of isoscape approach in human forensic studies. Stable isotopes serve as geographical indications of illegal material seized, such as drugs or trafficked wild animals and have the potential to link these materials to geographic positions (Bowen et al., 2007; Ehleringer et al., 2008; Warner et al., 2018; Chesson et al., 2018).

The success of using isoscapes to help solve forensic questions depends on a series of factors. First, is important to know how mechanisms and chemical materials used on fixation and storage affect the material, component or organism isotope ratio. Second, is necessary to know the predictive power of the model, which may be recognized from a regression, to describe relations between a specimen isotopic ratio with environmental variables (Ehleringer et al., 2010).

Ehleringer et al. (2008) mapped $\delta^{2} \mathrm{H}$ and $\delta^{18} \mathrm{O}$ human hair for the United States, while Valenzuela et al. (2011) elaborated human hair isoscapes for the United States, using $\delta^{15} \mathrm{~N}$, $\delta^{13} \mathrm{C}$, and $\delta^{34} \mathrm{~S}$. Both papers discussed the possible applications of this model to identify the region of unidentified human origin, movement reconstruction, and studies on human diet. Isoscape from tap water is also a solid base to forensic studies (Bowen et al., 2007) and has been useful in identifying human geographical origin (Warner et al., 2018). Hydrogen and oxygen isoscapes have been also employed for the identification of the geographic region of food production, such as wine, olive oil, coffee, meat (Ehleringer et al., 2000; Carter et al., 2015; Chiocchiani et al., 2016), beer, bottled water, soda, and milk (Chesson et al., 2010a; 2010b).

Although the use of isoscapes are efficient in numerous forensic studies, generally the models are not capable of predicting the exact specimen origin place due to climatic conditions that shape stable isotopes spatial patterns in similar ways in different regions (Ehleringer et al., 2010). If there is some previous knowledge of the specimens' probable origin areas or assistance from other complementary tools, it is possible to increase the predictive capacity of coupled models. As an example, Mallette et al. (2016) used $\mathrm{O}$ and $\mathrm{H}$ isoscapes coupled to alkaloid studies to detect the possible origin of seized cocaine in the United States among 19 crop areas in South America; but also, they could compare cocaine isotopic ratios to a geographically validated database and that allowed the authors to discover new cocaine cultivation areas formerly unknown. 


\section{POTENTIAL USE OF ISOSCAPES IN BRAZIL}

In Brazil, the number of studies using light stable isotope ratios to track local and regional carbon and nitrogen dynamics in the soil-plant-atmosphere system from different Brazilian regions has grown considerably in the last decades: in the North region - Amazonia (Ometto et al., 2002; 2005; 2006; Pérez et al., 2006; Nardoto et al., 2008; 2014); northeastern region Caatinga (Teixeira et al., 2006; Freitas et al., 2010), Central region - Cerrado (Bustamante et al., 2004; Coletta et al., 2009; Viani et al., 2011), southeastern region - Atlantic forest (Lins et al., 2016; Vitoria et al., 2018).

The combination of $\delta^{15} \mathrm{~N}$ and $\delta^{13} \mathrm{C}$ has been the basis for studies about diet of different animals such as aquatic macrofaunal (Hardt et al., 2013; Castro et al., 2016), fishes and dolphins (Di Beneditto et al., 2013), arthropods (Salgado et al., 2014) and small mammals (Galetti et al., 2016), and human diet in different regions of Brazil (Nardoto et al., 2006, 2011; Gragnani et al., 2014; Rodrigues et al., 2016).

The $\delta^{2} \mathrm{H}$ and $\delta^{18} \mathrm{O}$ have been applied to hydrological cycle studies in Brazil. These isotopes have been applied in the understanding of local and regional hydrological cycles (Martinelli et al., 2004; Soler i Gil and Bonotto, 2014). Mixture models of $\delta^{2} \mathrm{H}$ and $\delta^{18} \mathrm{O}$ indicated the role of plant transpiration and soil evaporation on local hydrological cycle in Amazonia (Moreira et al., 1997), Cerrado (Jackson et al., 1999), and Atlantic forest ecosystems (Cassana et al., 2015). An isotope map has been made to verify chemical and isotopic characteristics at the west portion of the Guarani Aquifer System (among the states of Mato Grosso do Sul, Mato Grosso and Goiás) for a paleoclimate study (Gastmans et al., 2010) while Martinelli et al. (2004) showed the potential of using $\delta^{2} \mathrm{H}$ and $\delta^{18} \mathrm{O}$ isotopes from precipitation and river water in the Piracicaba's River Basin's hydrological monitoring station, in São Paulo State.

The applications of stable isotopes to detect food authentication and adulteration have also been used in Brazil to evaluate the quality and origin of Brazilian wines (Martinelli et al., 2003) and beers (Mardegan et al., 2013), soy sauce (Morais et al., 2018), but also to determine differences in diet of barn versus free-range chickens for studying animal nutrition with food authentication implications (Coletta et al., 2012).

Stable-isotope forensic studies have sporadically been used in Brazil. $\delta^{15} \mathrm{~N}$ and $\delta^{13} \mathrm{C}$ helped to identify the origin of Brazilian marijuana seized (Shibuya et al., 2007), to trace origin and effect of illegal discharge of residues in streams and sediment (Barbieri et al., 2014; Roth et al., 2016), but also for an isotopic assessment to help understand the effects of the 2012 Brazilian Forest Act on tropical riparian zones (Salemi et al., 2016).

Very few studies using $\delta^{13} \mathrm{C}$ spatial patterns have been employed to measure land-use effects in aquatic (Sanaiotti et al., 2002; Augusto et al., 2015) and terrestrial ecosystems (Assad et al., 2013; Salemi et al., 2016; Figueira et al., 2016), which, therefore, might closely fit what has been applied in Brazil in terms of the isoscape approach in any published study led by Brazilian research groups.

\subsection{Perspectives of using isoscapes in Brazil}

Published global and continental isoscape models can be downloaded for the Brazilian context. These isoscapes may serve as a first approximation to perform larger scales mapping in Brazilian biomes. $\delta^{13} \mathrm{C}$ isoscape elaborated by Powell et al. (2012) for South America shows carbon stable isotope spatial distribution patterns along Brazilian biomes (Figure $1 \mathrm{~A}$ ). The equations from Amundson et al. (2003) for soil and vegetation $\delta^{15} \mathrm{~N}$ may be applied to Brazil from records of spatial climatic variables (Figura $1 \mathrm{~B}$ ).

Global precipitation $\delta^{2} \mathrm{H}$ and $\delta^{18} \mathrm{O}$ isoscapes can also be downloaded and easily applied in Brazilian scale (Figure 2). However, elaboration of local and regional isoscapes in the Brazilian context is essential in order to reduce associated model errors. Developing precipitation 
isoscape models specific for Brazil is imperative, since current global models mask part of the natural variations of isotopic ratios. For instance, average rates presented in Figure 2, show a significantly lower spatial variation in comparison to temporal and spatial fluctuation found by Soler i Gil and Bonotto (2014) only in the area of São Paulo State.
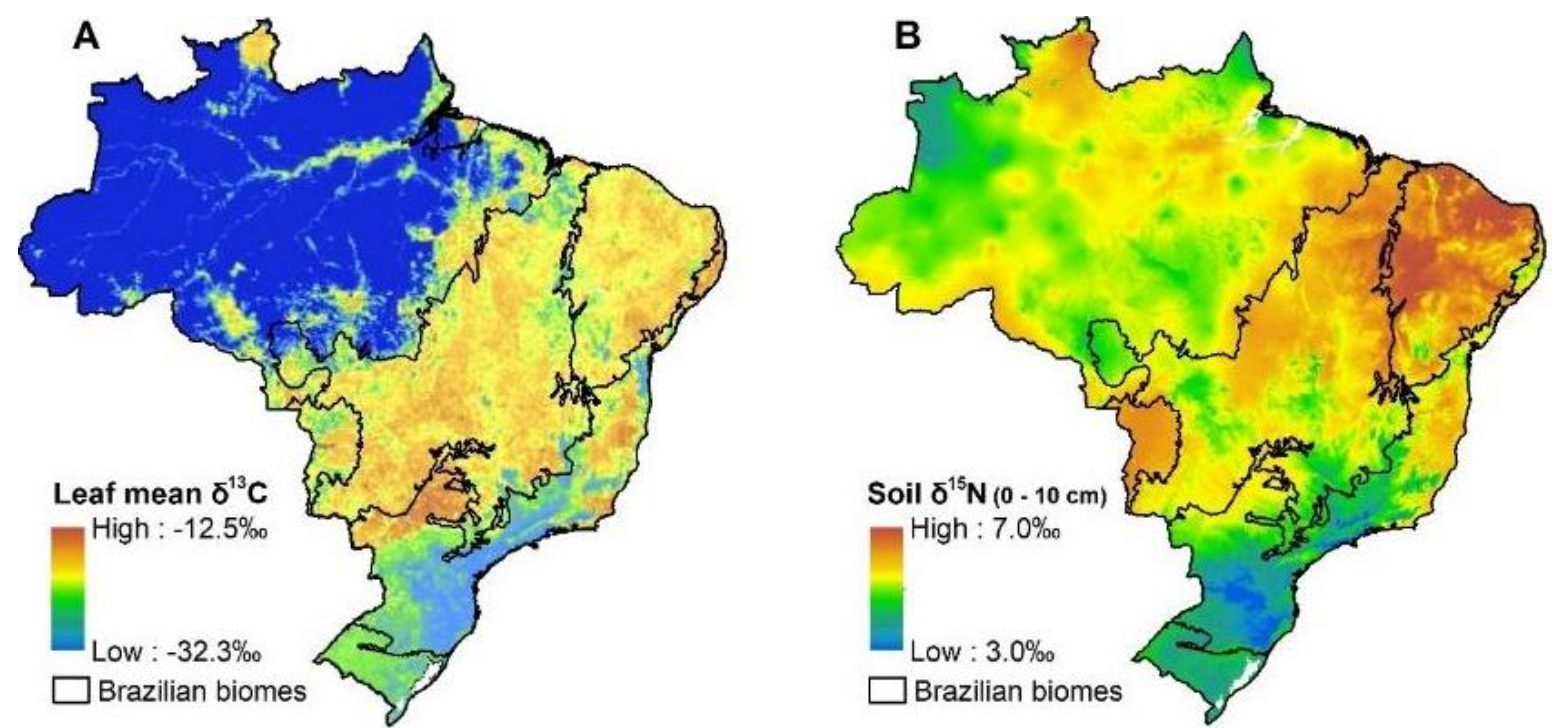

Figure 1. Plant $\delta^{13} \mathrm{C}$ isoscape from Powell et al. (2012) with author's consent (A); and soil $\delta^{15} \mathrm{~N}$ isoscape based in Amundson et al. (2003) equation for $0-10 \mathrm{~cm}$ depth $\left(\delta^{15} \mathrm{~N}_{\mathrm{soil}(0-10)}=0.134 *\right.$ MAT $-0.0005 * \mathrm{MAP}+3.1985)$ applied using climatic data from http://www.worldclim.org to elaborated (B).
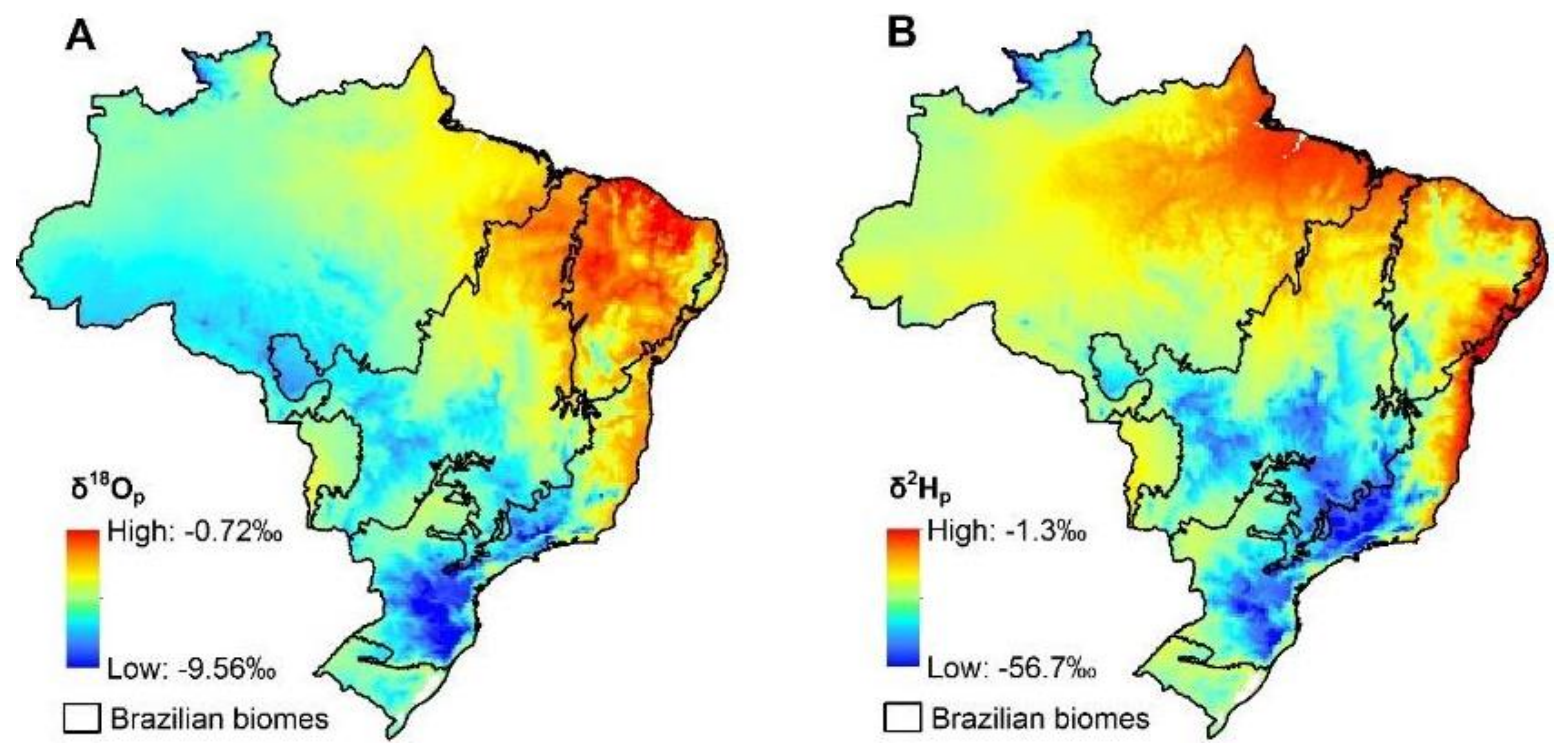

Figure 2. Mean annual precipitation $\delta^{18} \mathrm{O}(\mathrm{A})$ and $\delta^{2} \mathrm{H}(\mathrm{B})$ isoscapes. Data were downloaded from http://www.waterisotopes.org.

Taking into account the number of studies that have been using the stable isotope approach in Brazil together with the facility to use the equations and methods already tested and applied worldwide, the potential to develop carbon, nitrogen, oxygen and hydrogen and isoscapes with improved scale will definitely support both basic and applied studies in different areas of knowledge as pointed out in Section 4 above.

In terms of developing $\delta^{2} \mathrm{H}$ and $\delta^{18} \mathrm{O}$, local to regional isoscapes to study hydrological cycles in different regions of Brazil could be easily applied to groundwater management in Brazil and should be complemented by spatial modelling for isoscape creation that would 
facilitate data interpretation. There are 26 geographic locations with precipitation stable isotope historic data from GNIP stations in Brazil, which are available for download in shapefile format (http://wateriso.utah.edu/). Currently, 10 GNIP monitoring stations are operating in Brazil (Peeva, 2018). This amount of GNIP stations cannot represent the climatic and hydrographic diversity for the Brazilian territory. Some alternatives are suggested in the literature, such as the Ehleringer et al. (2008) work collecting tap water and human hair, or using specific resident species (Hobson et al., 2009) to construct indirectly water based isoscapes in a continental level. These approaches can be used to fill-in gaps on water based isoscapes for the continental territory of Brazil.

Future $\delta^{13} \mathrm{C}$ isoscapes for Brazil should be made using samples with large spatial representation, such as the one performed by Assad et al. (2013) to study changes in carbon stock caused by land-use changes. It may help to decrease model errors. For the Cerrado region, for example, Powell et al. (2012) indicated considerable uncertainty due to huge land cover heterogeneity in Cerrado biome. Brazilian researchers can integrate soil and vegetation samples from collections of previous field work and publications to increase the number of sampling sites for biogeochemical studies, both for carbon and nitrogen stable isotopes.

Local and regional biogeochemical changes result in problems related to $\mathrm{N}_{\mathrm{r}}$ in Latin America (Austin et al., 2013), especially in Brazil. $\delta^{15} \mathrm{~N}$ isoscapes for vegetation and, mainly, for soil are important tools to study $\mathrm{N}$ input and output mechanisms from ecosystems (Bai et al., 2012b, Houlton et al., 2015). Nitzsche et al. (2016) discussed the importance of $\delta^{15} \mathrm{~N}$ mapping in complex agricultural areas to disclose results to farmers and decision makers. It may be applied in Brazil, considering the large extension of agricultural areas. Another possibility would be to map $\delta^{15} \mathrm{~N}$ in agricultural areas considering landforms, potential ways in which the land can influence soil characteristics and agricultural productivity (Siqueira et al., 2010). In this case, a regional and local soil $\delta^{15} \mathrm{~N}$ isoscape could point to the topographic position where $\mathrm{N}$ losses to the atmosphere or leaching area are happening, aiding agricultural management.

Some plants used in agriculture and livestock were introduced in natural ecosystems in Brazil. There are at least 54 potentially invasive plants in Brazil and their effects on local biogeochemical cycles are little known (Zenni and Ziller 2011; Dias et al., 2013). Similar approaches as above described (Bai et al., 2013) should be used to help in the understanding of invasion vectors and the biogeochemical cycle changing (Rascher et al., 2012, Bai et al., 2012a, Hellmann et al., 2016a, 2017).

Considering the extensive biodiversity and animal migration in Brazil, existing global isoscape models may be used for first approximations of animal wintering and reproduction localities. Geographic assignment models of migratory birds to geographic origins have already been made for South America (García-Pérez and Hobson, 2014; Hobson and Kardynal, 2016). Despite the use of water isoscapes applicability to infer origin or wintering places of animals at regional and continental scales, the highest potential of this approach lies at medium to high latitude regions due to the strong spatial gradient of isotopic ratios in precipitation. However, this limitation does not narrow the application of isoscapes in issues of this nature in regions of low latitude, such as South America and Africa. In these cases, a multi-isotope approach coupling $\delta^{2} \mathrm{H}$ isoscapes with $\delta^{13} \mathrm{C}$ and $\delta^{15} \mathrm{~N}$ isoscapes may raise the inference efficiency (GarcíaPérez and Hobson, 2014; Hobson and Kardynal, 2016). Another way to raise the isoscape efficiency is to perform an integrated use with other tracing methods, such as satellite tracking or combined with genetic markers (Rundel et al., 2013).

Isoscape approach used in animal migration studies could be adapted to determine the origin of seized animals and trafficking routes. There is still a huge number of live animals and animal products being seized every year in illegal activities (Alves et al., 2012; Regueira and Bernard, 2012). Illegal animal trade usually results in the withdrawal of aminals from those 
natural origins and transporting them to other regions where illegal markets, intermediate sellers or final consumers are present (Alves et al., 2012; Destro et al., 2012). Transportation caused by illegal wildlife traffic may be compared to natural bird migration, as both imply animal displacement at a continental scale (Destro et al., 2012).

In the forensic context, many applications should be accomplished in numerous investigation cases, since it is usually necessary to link crime traces to their geographical origin (Cerling et al., 2016). In addition to wildlife illegal trade, other common crimes, such as illicit drug trafficking, wood trafficking, food frauds cases, and individual human crime investigations would benefit from isoscape approaches in the Brazilian context. All materials or components seized that go through isotopic analysis should have their isotopic ratios compared to spatial databases which may indicate the origin or traveled path (see Cerling et al., 2016). For example, the US Drug Enforcement Agency (DEA) has a drug signature program, with the aim to construct specific drugs isoscapes (Chesson et al., 2018). This initiative should be replicated here, for marijuana and cocaine drugs. Shibuya et al. (2007) studied different marijuana-producing regions in Brazil and could assign seized samples. This knowledge can be updated and used for drug enforcement.

Illegal logging in Brazil, specially in the Amazon region, is still a big issue, with selected species being collected using fraud in mechanisms of control (Brancalion et al., 2018). Considering the Brazilian potential for wood commercialization, certification of commercialized wood would benefit from the isoscape approach, considering the well-known relation between local water and wood isotopic ratios (Gori et al., 2018).

Provenance of food production for human consumption is also a forensic issue. Regional certified products have specific organoleptic and culinary qualities, such as wine, cheese, and coffee, which sometimes are subject to mislabeling or other fraud (Camim et al., 2017). Camim et al. (2017) reviewed methods and necessary legal aspects to state geographic origins of food products. Besides basic element isoscape knowledge, they state the importance of complementing isotopic information with standard values of authentic products in available databases.

\section{SYNTHESIS AND FUTURE}

The isoscape approach has been applied in different scales and its use as a basis for many scientific subjects has increased in the last decade. Its main advantage is deriving isotopic ratios with a statistical consistency in real sample points gap. Since spatial and temporal isotopic continuous maps integrate chemical processes occurring in ecosystems, the use of grid-based isoscape models has facilitated and simplified the isotope interpretation in different contexts, from terrestrial to aquatic ecosystems, either in natural or anthropic conditions.

Both global and regional $\delta^{2} \mathrm{H}$ and $\delta^{18} \mathrm{O}$ isoscapes indicate elements of water cycle, such as inputs and outputs in water pools, and have helped in water management. However, these isoscapes are also used as tracers to identify origin of animals, products and chemical elements and may amplify their utility when coupled with $\delta^{15} \mathrm{~N}$ and/or $\delta^{13} \mathrm{C}$ isoscapes.

Existent global and continental isoscapes can already be framed into the Brazilian boundaries and applied in many studies, although they are general models with relatively low spatial resolution, not being able to represent regional or local variations of stable isotope values. However, by improving technologies and possibilities of isoscape applications, studies tend to seek more-refined isoscapes, with better spatial and temporal resolution. There is a tendency pointed out by Bowen (2010a), a transition from descriptive models to comprehensive models, where isoscapes help explain ecosystem mechanisms and processes, and it must be incorporated into future studies in Brazil. The Brazilian challenge will be to develop regional and local isoscapes, upscaling existing isoscapes and/or elaborating new ones from new systematic sampling. 
There is a global trend for the development of an integrated and centralized isotopic database. An example is an initiative from scientists, museum curators, data analysts, and educators to build the IsoBank, which they say would be a dynamic and sustainable repository that would accelerate the resolution of urgent issues in all disciplines involving stable isotopes (Pauli et al., 2017).

Another example is the GNIP for precipitation data, which has currently 10 stations in operation in Brazil. The integration of laboratories and the establishment of a national network could increase the number of monitoring stations. However, to build a national network to collect water samples regularly and to have them analyzed to $\delta^{2} \mathrm{H}$ and $\delta^{18} \mathrm{O}$ is far from being an easy task considering the immense Brazilian territory and especially the logistics and infrastructure involved. It should take into account the need to measure the years on a regular basis (rainfall event or least monthly). Most important is to be aware of the global networks and to be integrated with them.

Brazil has a basic structure of laboratories that carry out isotopic analyses in the northeastern, central-western and southeastern regions; however, the challenge is to increase the amount of specific funding involving stable isotope research. The establishment of museum networks and integrated access to animal and plant collections has great potential to increase the spatial distribution of samples with isotopic values in Brazil. The same is true for an integrated network for accessing soil samples from collections in Brazilian laboratories. Both networks would improve the access to data and the construction of isoscapes to answer current issues in biogeochemistry, ecology, conservation and forensics.

\section{ACKNOWLEDGMENTS}

This study was financed in part by the Coordenação de Aperfeiçoamento de Pessoal de Nível Superior - Brasil (CAPES) - Finance Code 001. We would like to thank the Graduate Program of Environmental Sciences of University of Brasília for the financial support to English review. We would like to thank to the Graduate Program of Environmental Sciences of University of Brasília for the financial support to English review.

\section{REFERENCES}

AGGARWAL, P. K.; ROMATSCHKE, U.; ARAGUAS-ARAGUAS, L.; BELACHEW, D.; LONGSTAFFE, F. J.; BERG, P.; SCHUMACHER, C.; FUNK, A. Proportions of convective and stratiform precipitation revealed in water isotope ratios. Nature Geoscience, v. 9, p. 624-629. 2016. http://dx.doi.org/10.1038/ngeo2739

ALVES, R. R. N.; PEREIRA FILHO, G. A.; VIEIRA, K. S.; SOUTO, W. M. S.; MENDONÇA, L. E. T.; MONTENEGRO, P. F. G. P.; ALMEIDA, W. O.; VIEIRA, W. L. S. A zoological catalogue of hunted reptiles in the semiarid region of Brazil. Journal of Ethnobiology and Ethnomedicine, v. 8, n. 27, 2012. http://dx.doi.org/10.1186/17464269-8-27

AMUNDSON, R.; AUSTIN, A. T.; SCHUUR, E. A. G.; YOO, K.; MATZEK, V.; KENDALL, C.; UEBERSAX, A.; BRENNER, D.; BAISDEN, W. T. Global patterns of the isotopic composition of soil and plant nitrogen. Global Biogeochemical Cycles, v. 17, n. 1, p. 1031-1041. 2003. http://dx.doi.org/10.1029/2002GB001903

ARNOLD, J.; CORRE, M. D.; VELDKAMP, E. Soil N cycling in old-growth forests across an Andosol toposequence in Ecuador. Forest Ecology and Management, v. 257, n. 10, p. 2079-2087, 2009. 
ASSAD, E. D.; PINTO, H. S.; MARTINS, S. C.; GROPPO, J. D.; SALGADO, P. R.; EVANGELISTA, B.; VASCONCELlOS, E.; SANO, E. E.; PAVÃO, E.; LUNA, R.; CAMARGO, P. B.; MARTINELLI, L. A. Changes in soil carbon stocks in Brazil due to land use: Paired site comparisons and a regional pasture soil survey. Biogeosciences, v. 10, p. 6141-6160, 2013. http://dx.doi.org/10.5194/bg-10-6141-2013

AUGUSTO, F. G.; TASSONI FILHO, M.; FERRERA, A.; PEREIRA, A. L.; CAMARGO, P. B.; MARTINELLI, L. A. Land use change in the Atlantic Forest affects carbon and nitrogen sources of streams as revealed by the isotopic composition of terrestrial invertebrates. Biota Neotropica, v. 15, n. 2, 2015. http://dx.doi.org/10.1590/167606032015018814

AUSTIN, A. T.; BUSTAMANTE, M. M. C.; NARDOTO, G. B.; MITRE, S. K.; PÉREZ, T.; OMETTO, J. P. H. B.; ASCARRUNZ, N. L.; FORTI, M. C.; LONGO, K.; GAVITO, M. E.; MARTINELLI, L. A. Latin America's nitrogen challenge. Science, v. 340, p. 149, 2013. http://dx.doi.org/10.1126/science.1231679

BAI, E.; BOUTTON, T. W.; BEN WU, X.; LIU, F.; ARCHER, S. R. Landscape-Scale vegetation dynamics inferred from spatial patterns of soil $\delta^{13} \mathrm{C}$ in a subtropical savanna parkland. Journal of Geophysical Research: Biogeosciences, v. 114, n. 1, p. 1-10, 2009. http://dx.doi.org/10.1029/2008JG000839

BAI, E.; BOUTTON, T. W.; LIU, F.; BEN WU, X.; HALLMARK, C. T.; ARCHER, S. R. Spatial variation of soil $\delta^{13} \mathrm{C}$ and its relation to carbon input and soil texture in a subtropical lowland woodland. Soil Biology and Biochemistry, v. 44, n. 1, p. 102-112. 2012a. http://dx.doi.org/10.1016/j.soilbio.2011.09.013

BAI, E.; BOUTTON, T.; LIU, F.; WU, X.; ARCHER, S. ${ }^{15} \mathrm{~N}$ isoscapes in a subtropical savanna parkland: spatial-temporal perspectives. Ecosphere, v. 4, n. 1, p. 1-17, 2013. http://dx.doi.org/10.1890/ES12-00187.1

BAI, E.; HOULTON, B. Z.; WANG, Y. P. Isotopic identification of nitrogen hotspots across natural terrestrial ecosystems. Biogeosciences, v. 9, n. 8, p. 3287-3304, 2012b. http://dx.doi.org/10.5194/bg-9-3287-2012

BAISDEN, W. T.; KELLER, E. D.; VAN HALE, R.; FREW, R. D.; WASSENAAR, L. I. Precipitation isoscapes for New Zealand: enhanced temporal detail using precipitationweighted daily climatology. Isotopes in Environmental and Health Studies, v. 52, n. 4, p. 343-352, 2016. http://dx.doi.org/10.1080/10256016.2016.1153472

BARBIERI, C. B.; SARKIS, J. E. S.; MARTINELli, L. A.; BORDON, I. C. A. C.; MITTEREGGER, H.; HORTELLANI, M. A. Forensic evaluation of metals $(\mathrm{Cr}, \mathrm{Cu}, \mathrm{Pb}$, $\mathrm{Zn})$, isotopes $\left(\delta^{13} \mathrm{C}\right.$ and $\left.\delta^{15} \mathrm{~N}\right)$, and $\mathrm{C}: \mathrm{N}$ ratios in freshwater sediment. Environmental $\begin{array}{lllllll}\text { Forensics, } & \text { v. } & 15, & \text { n. } & 2, & \text { p. } & 134-146,\end{array}$ http://dx.doi.org/10.1080/15275922.2014.890144

BERHE, A. A.; BERNES, R. T.; SIX, J.; MARÍN-SPIOTTA, E. Role of soil erosion in biogeochemical cycling of essential elements: Carbon, Nitrogen, and Phosphorous. Annual Review of Earth and Planetary Sciences, v. 46, p. 521-548, 2018. https://doi.org/10.1146/annurev-earth-082517-010018 
BIRKEL, C.; HELLIWELL, R.; THORNTON, B.; GIBBS, S.; COOPER, P.; SOULSBY, C.; TETZLAFF, L.; SPEZIA, L.; ESQUIVEL-HERNÁNDEZ, G.; SÁNCHEZ-MURILLO, R.; MIDWOOD, A. J. Characterization of surface water isotope spatial patterns of Scotland. Journal of Geochemical Exploration, v. 194, p. 71-80, 2010. http://dx.doi.org/10.1016/j.gexplo.2018.07.011

BOECKX, P.; VAN MEIRVENNE, M.; RAULO, F.; VAN CLEEMPUT, O. Spatial patterns of $\delta^{13} \mathrm{C}$ and $\delta^{15} \mathrm{~N}$ in the urban topsoil of Gent, Belgium. Organic Geochemistry, v. 37, n. 10, p. 1383-1393. 2006. http://dx.doi.org/10.1016/j.orggeochem.2006.04.015

BOWEN, G. J. Isoscapes: Spatial pattern in isotopic biogeochemistry. Annual Review of Earth and Planetary Sciences, v. 38, n. 1, p. 161-187, 2010a. http://dx.doi.org/10.1146/annurev-earth-040809-152429

BOWEN, G. J. Statistical end geostatistical mapping of precipitation water isotope ratios. In: Isoscapes: Understanding movement, pattern, and process on earth through isotope mapping. Netherlands: Springer, p. 139-150, 2010b. http://dx.doi.org/10.1007/978-90481-3354-3_7

BOWEN, G. J.; EHLERINGER, J. R.; CHESSON, L. A.; STANGE, E.; CERLING, T. E. Stable isotope ratios of tap water in the contiguous United States. Water Resources Research, v. 43, p. 1-12, 2007. http://dx.doi.org/10.1029/2006WR005186

BOWEN, G. J.; GOOD, S. P. Incorporating water isoscapes in hydrological and water resource investigations. WIREs Water, v. 2, n. 2, p. 107-119. 2015. http://dx.doi.org/10.1002/wat2.1069

BOWEN, G. J.; LIU, Z.; VANDER ZANDEN, H. B.; ZHAO, L.; TAKAHASHI, G. Geographic assignment with stable isotopes in IsoMAP. Methods in Ecology and Evolution, v. 5, p. 201-206, 2014. https://doi.org/10.1111/2041-210X.12147

BOWEN, G. J.; REVENAUGH, J. Interpolating the isotopic composition of modern meteoric precipitation. Water Resources Research, v. 39, n. 10, p. 1-13, 2003. http://dx.doi.org/10.1029/2003WR002086

BOWEN, G. J.; WASSENAAR, L. I.; HOBSON, K. A. Global application of stable hydrogen and oxygen isotopes to wildlife forensics. Oecologia, v. 143, n. 3, p. 337-348, 2005. http://dx.doi.org/10.1007/s00442-004-1813-y

BOWEN, G. J.; WEST, J. B.; HOOGEWERFF, J. Isoscapes: Isotope mapping and its applications. Journal of Geochemical Exploration, v. 102, n. 3, p. v-vii. 2009. http://dx.doi.org/10.1016/j.gexplo.2009.05.001

BOWEN, G. J.; WILKINSON, B. Spatial distribution of $\delta^{18} \mathrm{O}$ in meteoric precipitation. Geology, v. 30, n. 4, p. 315-318, 2002. https://doi.org/10.1130/00917613(2002)030\%3C0315:SDOOIM\%3E2.0.CO;2

BRANCALION, P. H. S.; ALMEIDA, D. R. A.; VIDAL, E.; MOLIN, P. G.; SONTAG, V. E.; SOUZA, S. E. X. F.; SCHULZE, M. D. Fake legal logging in the Brazilian Amazon. Science Advances, v. 4, p. 1-7, 2018. http://dx.doi.org/10.1126/sciadv.aat1192

BROOKS, J. R.; WIGINGTON, P. J.; PHILliPS, D. L.; COMELEO, R.; COULOMBE, R. Willamette River Basin surface water isoscape $\left(\delta^{18} \mathrm{O}\right.$ and $\left.\delta^{2} \mathrm{H}\right)$ : temporal changes of source water within the river. Ecosphere, v. 3, n. 5, p. 1-21, 2012. http://dx.doi.org/10.1890/ES11-00338.1 
BUSTAMANTE, M. M. C.; MARTINELLI, L. A.; SILVA, D. A.; CAMARGO, P. B.; KLINK, C. A.; DOMINGUES, T. F.; SANTOS, R. V. ${ }^{15} \mathrm{~N}$ natural abundance in woody plants and soils of central Brazilian savannas (Cerrado). Ecological Applications, v. 14, n. 4, p. 200213, 2004. http://dx.doi.org/10.1890/01-6013

CAMIN, F.; BONER, M.; BONTEMPO, L.; FAUHL-HASSEK, C.; KELLY, S. D.; RIEDL, J.; ROSSMANN, A. Stable isotope techniques for verifying the declared geographical origin of food in legal cases. Trends in Food Science and Technology, v. 61, p. 176187, 2017. http://dx.doi.org/10.1016/j.tifs.2016.12.007

CARTER, J. F.; YATES, H. S. A.; TINGGI, U. The isotopic and elemental composition of roasted coffee as a guide to authenticity and origin. Journal of Agricultural and Food Chemistry, v. 63, p. 5771-5779, 2015. http://dx.doi.org/10.1021/acs.jafc.5b01526

CASSANA, F. F.; ELLER, C. B.; OLIVEIRA, R. S.; DILLENBURG, L. R. Effects of soil water availability on foliar water uptake of Araucaria angustifolia. Plant and Soil, v. 399, n. 1, p. 2015. http://dx.doi.org/10.1007/s11104-015-2685-0

CASTRO, D. M. P.; CARVALHO, D. R.; POMPEU, P. D. S.; MOREIRA, M. Z.; NARDOTO, G. B.; CALLISTO, M. Land use influences niche size and the assimilation of resources by benthic macroinvertebrates in tropical headwater streams. PLoS One, v. 11, n. 3, p. 119, 2016. http://dx.doi.org/10.1371/journal.pone.0150527

CERLING, T. E.; BARNETTE, J. E.; BOWEN, G. J.; CHESSON, L. A.; EHLERINGER, J. R.; REMIEN, C. H.; SHEA, P.; TIPPLE, B. J.; WEST, J. B. Forensic stable isotope biogeochemistry. Annual Review of Earth and Planetary Sciences, v. 44, p. 175-206, 2016. http://dx.doi.org/10.1146/annurev-earth-060115-012303

CERNUSAK, L. A.; UBIERNA, N.; WINTER, K.; HOLTUM, J. A. M.; MARSHALL, J. D.; FARQUHAR, GD Environmental and physiological determinants of carbon isotope discrimination in terrestrial plants. New Phytologist, v. 200, p. 950-965, 2013. http://dx.doi.org/10.1111/nph.12423

CHESSON, L. A.; BARNETTE, J. E.; BOWEN, G. J.; BROOKS, J. R.; CASALE, J. F.; CERLING, T. E.; COOK, C. S.; DOUTHITT, C. B.; HOWA, J. D.; HURLEY, J. M.; KREUZER, H. W.; LOTT, M. J.; MARTINELLI, L. A.; O'GRADY, S. P.; PODLESAK, D. W.; TIPPLE, B. J.; VALENZUELA, L. O.; WEST, J. B. Applying the principles of isotope analysis in plant and animal ecology to forensic science in the Americas. Oecologia, v. 187, p. 1007-1094, 2018. http://dx.doi.org/10.1007/s00442-018-4188-1

CHESSON, L. A.; VAlENZUELA, L. O.; O'GRADY, S. P.; CERLING, T. E.; EHLERINGER, J. R. Hydrogen and oxygen stable isotope ratios of milk in the United States. Journal of Agricultural and Food Chemistry, v. 58, n. 4, p. 2358-2363, 2010a. http://dx.doi.org/10.1021/jf904151c

CHESSON, L. A.; VALENZUELA, L. O.; O'GRADY, S. P.; CERLING, T. E.; EHLERINGER, J. R. Links between purchase location and stable isotope ratios of bottled water, soda, and beer in the united states. Journal of Agricultural and Food Chemistry, v. 58, n. 12, p. 7311-7316, 2010b. http://dx.doi.org/10.1021/jf1003539

CHIOCCHINI, F.; PORTARENA, S.; CIOLFI, M.; BRUGNOLI, E.; LAUTERI, M. Isoscapes of carbon and oxygen stable isotope compositions in tracing authenticity and geographical origin of Italian extra-virgin olive oils. Food Chemistry, v. 202, p. 291301, 2016. http://dx.doi.org/10.1016/j.foodchem.2016.01.146 
COLETTA, L. D.; NARDOTO, G. B.; LATANSIO-AIDAR, S. R.; ROCHA, H. R. Isotopic view of vegetation and carbon and nitrogen cycles in a Cerrado ecosystem, southeastern Brazil. Scientia Agricola, v. 66, n. 4, p. 467-475, 2009. http://dx.doi.org/10.1590/S010390162009000400006

COLETTA, L. D.; PEREIRA, A. L.; COELHO, A. A. D.; SAVINO, V. J. M.; MENTEN, J. F. M.; CORRER, E.; FRANÇA, L. C.; MARTINELLI, L. A. Barn vs. Free-range chickens: Differences in their diets determined by stable isotopes. Food Chemistry, v. 131, n. 1, p. 155-160, 2012. http://dx.doi.org/10.1016/j.foodchem.2011.08.051

COURTIOL, ALEXANDRE, FRANÇOIS ROUSSET, MARIE-SOPHIE ROHWÄDER, DAVID X. SOTO, LINN LEHNERT, CHRISTIAN C. VOIGT, KEITH A. HOBSON, LEONARD I. WASSENAAR, AND STEPHANIE KRAMER-SCHADT. Isoscape computation and inference of spatial origins with mixed models using the $\mathrm{R}$ package IsoriX. In: Tracking Animal Migration with Stable Isotopes, second. London: Elsevier, 2019.

CRAINE, J. M.; BROOKSHIRE, E. N. J.; CRAMER, M. D.; HASSELQUIST, N. J.; KOBA, K.; MARIN-SPIOTTA, E.; WANG, L. Ecological interpretations of nitrogen isotope ratios of terrestrial plants and soils. Plant and Soil, v. 396, n. 1, p. 1-26, 2015b. http://dx.doi.org/10.1007/s11104-015-2542-1

CRAINE, J. M.; ELMORE, A. J.; WANG, L.; AUGUSTO, L.; BAISDEN, W. T.; BROOKSHIRE, E. N. J.; CRAMER, M. D.; HASSELQUIST, N. J.; HOBBIE, E. A.; KAHMEN, A.; KOBA, K.; KRANABETTER, J. M.; MACK, M. C.; MARIN-SPIOTTA, E.; MAYOR, J. R.; MCLAUCHLAN, K. K.; MICHELSEN, A.; NARDOTO, G. B.; OLIVEIRA, R. S.; PERAKIS, S. S.; PERI, P. L.; QUESADA, C. A.; RICHTER, A.; SCHIPPER, L. A.; STEVENSON, B. A.; TURNER, B. L.; VIANI, R. A. G.; WANEK, W.; ZELLER, B. Convergence of soil nitrogen isotopes across global climate gradients. Scientific Reports, v. 5, 2015a. http://dx.doi.org/10.1038/srep08280

DESTRO, G. F. G.; PIMENTEL, T. L.; SABAINI, R. M.; BORGES, R. C.; BARRETO, R. Efforts to combat wild animals trafficking in Brazil. In: Biodiversity enrichment in a diverse world. Intech, p. 421-436, 2012. http://dx.doi.org/10.5772/48351

DI BENEDITTO, A. P. M.; REZENDE, C. E.; CAMARGO, P. B.; KEHRIG, H. A. Trophic niche comparison between two predators in northern Rio de Janeiro State, Brazil: a stable isotopes approach. Biota Neotropica, v. 13, n. 3, p. 29-33, 2013. http://dx.doi.org/10.1590/S1676-06032013000300002

DIAS, J.; FONTE, M. A. M. A.; BAPTISTA, R.; MANTOANI, M. C.; HOLDEFER, D. R.; TOREZAN, J. M. D. Invasive alien plants in Brazil: A nonrestrictive revision of academic works. Natureza \& Conservação, v. 11, n. $1, \quad$ p. $31-35,2013$. http://dx.doi.org/10.4322/natcon.2013.004

EHLERINGER, J. R.; BOWEN, G. J.; CHESSON, L. A.; WEST, A. G.; PODLESAK, D. W.; CERLING, T. E. Hydrogen and oxygen isotope ratios in human hair are related to geography. Proceedings of the National Academy of Sciences of the United States of America, v. 105, n. 8, p. 2788-2793, 2008. http://dx.doi.org/10.1073/pnas.0712228105

EHLERINGER, J. R.; CASALE, J. F.; LOTT, M. J.; FORD, V. L. Tracing the geographical origin of cocaine: Cocaine carries a chemical fingerprint from the region where the coca was grown. Nature, v. 408, p. 311-312, 2000. http://dx.doi.org/10.1038/35042680 
EHLERINGER, J. R.; THOMPSON, A. H.; PODLESAK, D.; BOWEN, G. J.; CHESSONLESLEY, L. A.; CERLING, T. E.; PARK, T.; DOSTIE, P.; SCHWARCZ, H. A framework for the incorporation of isotopes and isoscapes in geospatial forensic investigations. In: Isoscapes: Understanding movement, pattern, and process on earth through isotope mapping. Netherlands: Springer, p. 357-388, 2010. http://dx.doi.org/10.1007/978-90-481-3354-3_17

FARQUHAR, G. D.; LLOYD, J.; TAYLOR, J. A.; LAWRENCE, F. B.; SYVERTEN, J. P.; HUBICK, K. T.; WONG, C. S.; EHLERINGER, J. R. Vegetation effects on the isotope composition of oxygen in atmospheric $\mathrm{CO}_{2}$. Nature, v. 363, p. 439-443, 1993. http://dx.doi.org/10.1038/363439a0

FIGUEIRA, A. M. S.; DAVIDSON, E. A.; NAGY, R. C.; RISKIN, S. H.; MARTINELLI, L. A. Isotopically constrained soil carbon and nitrogen budgets in a soybean field chronosequence in the Brazilian Amazon region. Journal of Geophysical Research: Biogeosciences, v. 121, p. 2520-2529, 2016. http://dx.doi.org/10.1002/2016JG003470

FOURQUREAN. J. W.; MANUEL, S. A.; COATES, K. A.; KENWORTHY, W. J.; BOYER, J. N. Water quality, isoscapes and stoichioscapes of seagrasses indicate general $\mathrm{P}$ limitation and unique $\mathrm{N}$ cycling in shallow water benthos of Bermuda. Biogeosciences, v. 12 , n. 20, p. 6235-6249, 2015. http://dx.doi.org/10.5194/bg-12-6235-2015

FREITAS, A. D. S.; SAMPAIO, E. V. S. B.; MENEZES, R. S. C.; TIESSEN, H. ${ }^{15} \mathrm{~N}$ natural abundance of non-fixing woody species in the Brazilian dry forest (caatinga). Isotopes in Environmental and Health Studies, v. 46, n. 2, p. 210-218, 2010. http://dx.doi.org/10.1080/10256016.2010.488805

GALETTI, M.; RODARTE, R. R.; NEVES, C. L.; MOREIRA, M.; COSTA-PEREIRA, R. Trophic niche differentiation in rodents and marsupials revealed by stable isotopes. PLoS One, v. 11, n. 4, 2016. http://dx.doi.org/10.1371/journal.pone.0152494

GARCÍA-PÉREZ, B.; HOBSON, K. A. A multi-isotope $\left(\delta^{2} \mathrm{H}, \delta^{13} \mathrm{C}, \delta^{15} \mathrm{~N}\right)$ approach to establishing migratory connectivity of Barn Swallow (Hirundo rustica). Ecosphere, v. 5, n. 2, p. 1-12, 2014. http://dx.doi.org/10.3161/000164514X682896

GASTMANS, D.; CHANG, H. K.; HUTCHEON, I. Stable isotopes $\left({ }^{2} \mathrm{H},{ }^{18} \mathrm{O}\right.$ and $\left.{ }^{13} \mathrm{C}\right)$ in groundwaters from the northwestern portion of the Guarani Aquifer System (Brazil). Hydrogeology Journal, v. 18, n. 6, p. 1497-1513, 2010. http://dx.doi.org/10.1007/s10040-010-0612-2

GOODCHILD, M. F. Scale in GIS: An overview. Geomorphology, v. 130, p. 5-9, 2011.

GORI, Y.; STRADIOTTI, A.; CAMIN, F. Timber isoscapes. A case study in a mountain area in the Italian Alps. Plos One, v. 13, n. 2, p. 1-22, 2018.

GRAGNANI, J. G.; GARAVELlO, M. E. P. E.; SILVA, R. J.; NARDOTO, G. B.; MARTINELLI, L. A. Can stable isotope analysis reveal dietary differences among groups with distinct income levels in the city of Piracicaba (southeast region, Brazil)? Journal of Human Nutrition and Dietetics, v. 27, n. 3, p. 270-279, 2014. http://dx.doi.org/10.1111/jhn.12148

GUTIÉRREZ-EXPÓSITO, C.; RAMÍREZ, F.; AFÁN, I.; FORERO, M. G.; HOBSON, K. A. Toward a deuterium feather isoscape for sub-Saharan Africa: Progress, challenges and the path ahead. PLoS One, v. 10, n. 9, p. 1-12, 2015. http://dx.doi.org/10.1371/journal.pone.0135938 
HARDT, F. A. S.; CREMER, M. J.; TONELLO JUNIOR, A. J.; BELLANTE, A.; BUFFA, G.; BUSCAINO, G.; MAZZOLA, S.; BARRETO, A. S.; MARTINELLI, L. A.; ZUPPI, G. M. Use of carbon and nitrogen stable isotopes to study the feeding ecology of small coastal cetacean populations in southern Brazil. Biota Neotropica, v. 13, n. 4, p. 90-98, 2013. http://dx.doi.org/10.1590/S1676-06032013000400009

HELLMANN, C.; GROBE-STOLTENBERG, A.; THIELE, J.; OLDELAND, J.; WERNER, C. Heterogeneous environments shape invader impacts: integrating environmental, structural and functional effects by isoscapes and remote sensing. Scientific Reports, v. 7, p. 1-11, 2017.

HELLMANN, C.; RASCHER, K. G.; OLDELAND, J.; WERNER, C. Isoscapes resolve species-specific spatial patterns in plant-plant interactions in an invaded Mediterranean dune ecosystem. Tree Physiology, v. 36, n. 12, p. 1460-1470, $2016 \mathrm{~b}$. http://dx.doi.org/10.1093/treephys/tpw075

HELLMANN, C.; WERNER, C.; OLDELAND, J. A spatially explicit dual-isotope approach to map regions of plant-plant interaction after exotic plant invasion. PLoS One, v. 11, n. 7, p. 1-16, 2016a. http://dx.doi.org/10.1111/j.1461-0248.2012.01761.x

HÉNAUX, V.; POWELL, L. A.; HOBSON, K. A.; NIELSEN, C. K.; LARUE, M. A. Tracking large carnivore dispersal using isotopic clues in claws: an application to cougars across the Great Plains. Methods in Ecology and Evolution, v. 2, n. 5, p. 489-499, 2011. http://dx.doi.org/10.1111/j.2041-210X.2011.00107.x

HILTON, R. G.; GALY, A.; WEST, A. J.; HOVIUS, N.; ROBERTS, G. G. Geomorphic control on the $\delta^{15} \mathrm{~N}$ of mountain forests. Biogeosciences, v. 10, n. 3, p. 1693-1705, 2013. http://dx.doi.org/10.5194/bg-10-1693-2013

HOBSON, K. A.; BARNET-JOHNSON, R.; CERLING, T. 2010. Using isoscapes to track animal migration. In: Isoscapes: Understanding movement, pattern, and process on earth through isotope mapping. Netherlands: Springer, p. 273-298, 2010. http://dx.doi.org/10.1007/978-90-481-3354-3_13

HOBSON, K. A.; DOWARD, K.; KARDYNAL, K. J.; MCNEIL, J. N. Inferring origins of migrating insects using isoscapes: a case study using the true armyworm, Mythimna unipuncta, in North America. Ecological Entomology, v. 43, n. 3, p. 332-341, 2018. http://dx.doi.org/10.1111/een.12505

HOBSON, K. A.; KARDYNAL, K. J. An isotope $\left(\delta^{34} \mathrm{~S}\right)$ filter and geolocator results constrain a dual feather isoscape $\left(\delta^{2} \mathrm{H}, \delta^{13} \mathrm{C}\right)$ to identify the wintering grounds of North American Barn Swallows. The Auk: Ornithological Advances, v. 133, n. 1, p. 86-98, 2016. http://dx.doi.org/10.1642/AUK-15-149.1

HOBSON, K. A.; VAN WILGENBURG, S. L.; LARSON, K.; WASSENAAR, L. I. A feather hydrogen isoscape for Mexico. Journal of Geochemical Exploration, v. 102, n. 3, p. 167-174, 2009. http://dx.doi.org/10.1016/j.gexplo.2009.02.002

HOBSON, K. A.; VAN WILGENBURG, S. L.; WASSENAAR, L. I.; POWELL, R. L.; STILL, C. J.; CRAINE, J. M. A multi-isotope $\left(\delta^{13} \mathrm{C}, \delta^{15} \mathrm{~N}, \delta^{2} \mathrm{H}\right)$ feather isoscape to assign Afrotropical migrant birds to origins. Ecosphere, v. 3, n. 5, p. 1-20, 2012b. http://dx.doi.org/10.1890/ES12-00018.1 
HOBSON, K.A.; VAN WILGENBUG, S. L.; WASSENAR, L.I.; LARSON, K. Linking hydrogen $(\mathrm{d} 2 \mathrm{H})$ isoscapes in feathers and precipitation: sources of variance and consequences for assignment to isoscapes. PLoS One, v. 7, n. 4, e35137, 2012a. http://dx.doi.org/10.1371/journal.pone.0035137

HOULTON, B. Z.; MARKLEIN, A. R.; BAI, E. Representation of nitrogen in climate change forecasts. Nature Climate Change, vol. v. 5, p. 398-401, 2015. http://dx.doi.org/10.1038/nclimate2538

IAEA/WMO. Global Network of Isotopes in Precipitation. The GNIP Database. Vienna: International Atomic Energy Agency, 2015.

JACKSON, P. C.; MEINZER, F. C.; BUSTAMANTE, M.; GOLDSTEIN, G.; FRANCO, A.; RUNDEL, P. W.; CALDAS, L.; IGLER, E.; CAUSIN, F. Partitioning of soil water among tree species in a Brazilian Cerrado ecosystem. Tree Physiology, v. 19, n. 11, p. 717-724, 1999. http://dx.doi.org/10.1093/treephys/19.11.717

JASECHKO, S.; SHARP, Z. D.; GIBSON, J. J.; BIRKS, S. J.; YI, Y.; FAWCETT, P. J. Terrestrial water fluxes dominated by transpiration. Nature, v. 496, p. 347-350, 2013.

KERN, Z.; KOHÁN, B.; LEUENBERGER, M. Precipitation isoscape of high reliefs: Interpolation scheme designed and tested for monthly resolved precipitation oxygen isotope records of an Alpine domain. Atmospheric Chemistry and Physics, v. 14, n. 4, p. 1897-1907, 2014. http://dx.doi.org/10.5194/acp-14-1897-2014

LINS, S. R. M.; COLETTA, L. D.; RAVAGNANI, E. C.; GRAGNANI, J. G.; MAZZI, E. A.; MARTINELLI, L. A. Stable carbon composition of vegetation and soils across an altitudinal range in the coastal Atlantic Forest of Brazil. Trees, v. 30, n. 4, p. 1315-1329, 2016. http://dx.doi.org/10.1007/s00468-016-1368-7

LIU, Z.; BOWEN, G. J.; WELKER, J. M. Atmospheric circulation in reflected in precipitation isotope gradients over the conterminous United States. Journal of Geophysical Research, v. 115, D22120, 2010. http://dx.doi.org/10.1029/2010JD014175

LLOYD, J.; FARQUHAR, G. D. ${ }^{13} \mathrm{C}$ discrimination during $\mathrm{CO}_{2}$ assimilation by the terrestrial biosphere. Oecologia, v. 99, p. 201-215, 1994. http://dx.doi.org/10.1007/BF00627732

MALlETTE, J. R.; CASAlE, J. F.; JORDAN, J.; MORELlO, D. R.; BEYER, P. M. Geographically sourcing cocaine's origin - Delineation of the nineteen major cocoa growing regions in South America. Scientific Reports, v. 6, p. 1-10, 2016. http://dx.doi.org/10.1038/srep23520

MARDEGAN, S. F.; ANDRADE, T. M. B.; SOUSA NETO, E. R.; VASCONCELLOS, E. B. C.; MARTINS, L. F. B.; MENDONÇA, T. G.; MARTINELLI, L. A. Stable carbon isotope composition of Brazilian beers - A comparison between large- and small-scale breweries. Journal of Food Composition and Analysis, v. 29, n. 1, p. 52-57, 2013. http://dx.doi.org/10.1016/j.jfca.2012.10.004

MARTINELLI, L. A.; GAT, J. R.; CAMARGO, P. B.; LARA, L. L.; OMETTO, J. P. H. B. The Piracicaba River basin: isotope hydrology of a tropical river basin under anthropogenic stress. Isotopes in Environmental and Health Studies, v. 40, n. 1, p. 45 56, 2004. http://dx.doi.org/10.1080/10256010310001652016 
MARTINELLI, L. A.; MOREIRA, M. Z.; OMETTO, J. P. H. B.; ALCARDE, A. R.; RIZZON, L. A.; STANGE, E.; EHLERINGER, J. R. Stable carbon isotopic composition of the wine and $\mathrm{CO}_{2}$ bubbles of sparkling wines: detecting $\mathrm{C}_{4}$ sugar additions. Journal of Agricultural and Food Chemistry, v. 51, n. 9, p. 2625-2631, 2003. http://dx.doi.org/10.1021/jf026088c

MARTINELLI, L. A.; PICCOLO, M. C.; TOWSAND, A. R.; VITOUSEK, P. M.; CUEVAS, E.; MCDOWELL, W.; ROBERTSON, G. P.; SANTOS, O. C.; TRESEDER, K. Nitrogen stable isotopic composition of leaves and soil: Tropical versus temperate forests. Biogeochemistry, v. 46, n. 1, p. 45-65, 1999. http://dx.doi.org/10.1023/A:1006100128782

MEIER-AUGENSTEIN, W.; HOBSON, K.A.; WASSENAR, L.I. Critique: measuring hydrogen stable isotope abundance of proteins to infer origins of wildlife, food and people. Bioanalysis, v. 5, n. 7, p. 751-767, 2013. http://dx.doi.org/10.4155/bio.13.36

MORAiS, M. C.; PELlegrinetTI, T. A.; STURION, L. C.; SATTOlO, T. M. S.; MARTINELLI, L. A. Stable carbon isotopic composition indicates large presence of maize in Brazilian soy sauces (shoyu). Journal of Food Composition and Analysis, v. 70, p. 18-21, 2018. https://doi.org/10.1016/j.jfca.2018.04.001

MOREIRA, M. Z.; STERNBERG, L. S. L.; MARTINELLI, L. A.; VICTORIA, R. L.; BARBOSA, E. M.; BONATES, L. C. M.; NEPSTAD, D. C. Contribution of transpiration to forest ambient vapour based on isotopic measurements. Global Change Biology, v. 3, n. 5, p. 439-450, 1997. http://dx.doi.org/10.1046/j.1365-2486.1997.00082.x

MUELlER, M. H.; ALAOUI, A.; KUELLS, C.; LEISTERT, H.; MEUSBURGER, K.; STUMPP, C.; WEILER, M.; ALEWELL, C. Tracking water pathways in steep hillslopes by $\delta^{18} \mathrm{O}$ depth profiles of soil water. Journal of Hydrology, v. 519, p. 340-352, 2014. http://dx.doi.org/ 10.1016/j.jhydrol.2014.07.031

MURPHY, B.P.; BOWMAN, D. The carbon and nitrogen isotope composition of Australian grasses in relation to climate. Functional Ecology, v. 23, p. 1040-1049, 2009. http://dx.doi.org/10.1111/j.1365-2435.2009.01576.x

NARDOTO, G. B.; MURRIETA, R. S. S.; PRATES, L. E. G.; ADAMS, C.; GARAVELLO, M. E. P. E.; SCHOR, T.; MORAES, A.; RINALDI, F. D.; GRAGNANI, J. G.; MOURA, E. A. F.; DUARTE-NETO, P. J.; MARTINELLI, L. A. Frozen chicken for wild fish: Nutritional transition in the Brazilian Amazon region determined by carbon and nitrogen stable isotope ratios in fingernails. American Journal of Human Biology, v. 23, p. 642650, 2011. http://dx.doi.org/10.1002/ajhb.21192

NARDOTO, G. B.; OMETTO, J. P. H. B.; EHLERINGER, J. R.; HIGUCHI, N.; BUSTAMANTE, M. M. C.; MARTINELLI, L. A. Understanding the influences of spatial patterns on $\mathrm{N}$ availability within the Brazilian Amazon Forest. Ecosystems, v. 11, n. 8, p. 1234-1246, 2008. http://dx.doi.org/10.1007/s10021-008-9189-1

NARDOTO, G. B.; QUESADA, C. A.; PATIÑO, S.; SAIZ, G.; BAKER, T. R.; SCHWARZ, M.; SCHRODT, F.; FELDPAUSCH, T. R.; DOMINGUES, T. F.; MARIMON, B. S.; MARIMON, JUNIOR, B. H.; VIEIRA, I. C. G.; SILVEIRA, M.; BIRD, M. I.; PHILLIPS, O. L.; LLOYD, J.; MARTINELLI, L. A. Basin-wide variations in Amazon forest nitrogen-cycling characteristics as inferred from plant and soil ${ }^{15} \mathrm{~N}:{ }^{14} \mathrm{~N}$ measurements.

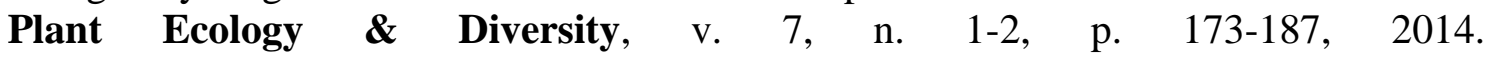
http://dx.doi.org/10.1080/17550874.2013.807524 
NARDOTO, G. B.; SILVA, S.; KENDALL, C.; EHLERINGER, J. R.; CHESSON, L. A.; FERRAZ, E. S. B.; MOREIRA, M. Z.; OMETTO, J. P. H. B.; MARTINELLI, L. A. Geographical patterns of human diet derived from stable-isotope analysis of fingernails. American Journal of Physical Anthropology, v. 131, n. 1, p. 137-146, 2006. http://dx.doi.org/10.1002/ajpa.20409

NIELSEN, J. A.; FREW, R. D.; WHIGHAM, P. A.; CALLAWAY, R. M.; DICKINSON, K. J. M. Thyme travels: ${ }^{15} \mathrm{~N}$ isoscapes of Thymus vulgaris $L$. invasion in lightly grazed pastoral communities. Austral Ecology, v. 41, n. 1, p. 28-39, 2016. http://dx.doi.org/10.1111/aec.12284

NITZSCHE, K. N.; VERCH, G.; PREMKE, K.; GESSLER, A.; KAYLER, Z. E. Visualizing land-use and management complexity within biogeochemical cycles of an agricultural landscape. Ecosphere, v. 7, n. 5, p. 1-16, 2016. http://dx.doi.org/10.1002/ecs2.1282

OLIVER, M. A.; WEBSTER, R. A tutorial guide to geostatistics: Computing and modelling variograms and kriging. Catena, v. 113, p. 56-69, 2014. http://dx.doi.org/10.1016/j.catena.2013.09.006

OMETTO, J. P. H. B.; EHLERINGER, J. R.; DOMINGUES, T. F.; BERRY, J. A.; ISHIDA, F. Y.; MAZZI, E.; HIGUCHI, N.; FLANAGAN, L. B.; NARDOTO, G. B.; MARTINELLI, L. A. The stable carbon and nitrogen isotopic composition of vegetation in tropical forests of the Amazon Basin, Brazil. Biogeochemistry, v. 79, p. 251-274, 2006. http://dx.doi.org/10.1007/s10533-006-9008-8

OMETTO, J. P. H. B.; FLANAGAN, L. B.; MARTINELli, L. A.; EHLERINGER, J. R. Oxygen isotope ratios of waters and respired $\mathrm{CO}_{2}$ in Amazonian forest and pasture ecosystem. Ecological Applications, v. 15, n. 1, p. 58-70, 2005. http://dx.doi.org/10.1890/03-5047

OMETTO, J. P. H. B.; FlANAGAN, L. B.; MARTINELli, L. A.; MOREIRA, M. Z.; HIGUCHI, N.; EHLERINGER, J. R. Carbon isotope discrimination in forest and pasture ecosystems of the Amazon Basin, Brazil. Global Biogeochemical Cycles, v. 16, n. 4, p. 1-10, 2002. http://dx.doi.org/10.1029/2001GB001462

ORCHARD, K. A.; CERnUSAK, L. A.; HUTLEY, L. B. Photosynthesis and water-use efficiency of seedlings from northern Australian monsoon forest, savanna, and swamp habitats grown in a common garden. Functional Plant Biology, v. 37, p. 1050-1060, 2010. http://dx.doi.org/10.1071/FP09306

PAULI, J. N.; NEWSOME, S. D.; COOK. J. A.; HARROD, C.; SHAWN, S. A.; BAKER, C. J. O.; BEN-DAVID, M.; BLOOM, D.; BOWEN, G. J.; CERLING, T. E.; CICERO, C.; COOK, C. DOHM, M.; DAHRAMPAL, P. S.; GRAVES, G.; GROPP, R.; HOBSON, K. A.; JORDAN, C.; MACFADDEN, B.; BIRCH, S. P.; POELEN, J.; RATNASIGHAM, S.; ROSSEL, L.; STRICKER, C. A.; UHEN, M. D.; YARNES, C. T.; HAYDEN, B. Why we need a centralized repository for isotopic data. PNAS, v. 114, n. 12, p. 2997-3001, 2017. http://dx.doi.org/10.1073/pnas.1701742114

PARDO, L. H.; NADELHOFFER, K. J. Using nitrogen isotope ratios to assess terrestrial ecosystems at regional and global scales. In: Isoscapes: Understanding movement, pattern, and process on earth through isotope mapping. Netherlands: Springer, p. 212250, 2010. 
PEEVA, A. IAEA Helps Brazil Strengthen Isotope Monitoring of Precipitation. Available in: https://www.iaea.org/newscenter/news/iaea-helps-brazil-strengthen-isotopemonitoring-of-precipitation. Access: Dec. 2018.

PÉREZ, T.; GARCIA-MONTIEL, D.; TRUMBORE, S.; TYLER, S.; CAMARGO, P. B.; MOREIRA, M.; PICCOLO, M.; CERRI, C. Nitrous oxide nitrification and denitrification ${ }^{15} \mathrm{~N}$ enrichment factors from amazon forest soils. Ecological Applications, v. 16, n. 6, p. 2153-2167, 2006. http://dx.doi.org/10.1890/1051-0761(2006)016[2153:NONADN]2.0.CO

POWELL, R. L.; YOO, E. H.; STILL, C. J. Vegetation and soil carbon-13 isoscapes for South America: integrating remote sensing and ecosystem isotope measurements. Ecosphere, v. 3, n. 11, p. 1-25, 2012. http://dx.doi.org/10.1890/ES12-00162.1

POWERS, J. S. Spatial variation of soil organic carbon concentrations and stable isotopic composition in 1-ha plots of forest and pasture in Costa Rica: Implications for the natural abundance technique. Biology and Fertility of Soils, v. 42, n. 6, p. 580-584, 2006. http://dx.doi.org/10.1007/s00374-005-0054-5

RASCHER, K. G.; HELlMANN, C.; MÁGUAS, C.; WERNER, C. Community scale ${ }^{15} \mathrm{~N}$ isoscapes: Tracing the spatial impact of an exotic $\mathrm{N}_{2}$-fixing invader. Ecology Letters, v. 15, n. 5, p. 484-491, 2012. http://dx.doi.org/10.1111/j.1461-0248.2012.01761.x

REED, E. T.; KARDYNAL, K. J.; HORROCKS, J. A.; HOBSON, K. A. Shorebird hunting in Barbados: Using stable isotopes to link the harvest at a migratory stopover site with sources of production. The Condor, v. 120, p. 357-370, 2018. http://dx.doi.org/10.1650/CONDOR-17-127.1

REGUEIRA, R. F. S.; BERNARD, E. Wildlife sinks: Quantifying the impact of illegal bird trade in street markets in Brazil. Biological Conservation, v. 149, n. 1, p. 16-22, 2012. http://dx.doi.org/10.1016/j.biocon.2012.02.009

RODRIGUES, L. P. F.; CARVALHO, R. C.; MACIEL, A.; OTANASIO, P. N.; GARAVELHO, M. E. P. E.; NARDOTO, G. B. Food insecurity in urban and rural areas in Central Brazil: Transition from locally produced foods to processed items. Ecology of Food and Nutrition, v. 55, n. 4, p. 365-377, 2016. http://dx.doi.org/10.1080/03670244.2016.1188090

RODRÍGUEZ-PÉREZ, M. Y.; AURIOLES-GAMBOA，D.; SÁNCHEZ-VELASCO， L.; LAVÍN, M. F.; NEWSOME, S. D. Identifying critical habitat of the endangered vaquita (Phocoena sinus) with regional $\delta^{13} \mathrm{C}$ and $\delta^{15} \mathrm{~N}$ isoscapes of the upper gulf of California, Mexico. Marine Mammal Science, v. 34, n. 3, 2018.

ROTH, F.; LESSA, G. C.; WILD, C.; KIKUCHI, R. K. P.; NAUMANN, M. S. Impact of a high-discharge submarine sewage outfall on water quality in the coastal zone of Salvador (Bahia, Brazil). Marine Pollution Bulletin, v. 106, p. 43-48, 2016. http://dx.doi.org/10.1016/j.marpolbul.2016.03.048

RUNDEL, C. W.; WUNDER, M. B.; ALVARADO, A. H.; RUEGG, K. C.; HARRIGAN, R.; SCHUH, A.; KELLY, J. F.; SIEGEL, R. B.; DESANTE, D. F.; SMITH, T. B.; NOVEMBRE, J. Novel statistical methods for integrating genetic and stable isotope data to infer individual-level migratory connectivity. Molecular Ecology, v. 22, n. 16, p. 4163-4176, 2013. http://dx.doi.org/10.1111/mec.12393 
SALEMI, L. F.; LINS, S. R. M.; RAVAGNANI, E. D. C.; FROSINI, S.; FERRAZ, D. B.; MARTINELLI, L. A. Past and present land use influences on tropical riparian zones: an isotopic assessment with implications for riparian forest width determination. Biota Neotropica, v. 16, n. 2, 2016. http://dx.doi.org/10.1590/1676-0611-BN-2015-0133

SALGADO, S. S.; MOTTA, P. C.; AGUIAR, L. M. S.; NARDOTO, G. B. Tracking dietary habits of cave arthropods associated with deposits of hematophagous bat guano: A study from a neotropical savanna. Austral Ecology, v. 39, n. 5, p. 560-566, 2014. http://dx.doi.org/10.1111/aec.12116

SANAIOTTI, T. M.; MARTINELLI, L. A.; VICTORIA, R. L.; TRUMBORE, S. E.; CAMARGO, P. B. Past vegetation changes in Amazon savannas determined using carbon isotopes of soil organic matter. Biotropica, v. 34, n. 1, p. 2-16, 2002. http://dx.doi.org/10.1111/j.1744-7429.2002.tb00237.x

SHIBUYA, E. K.; SARKIS, J. E. S.; NIGRINO-NETO, O.; OMETTO, J. P. H. B. Multivariate classification based on chemical and stable isotopic profiles in sourcing the origin of marijuana samples seized in Brazil. Journal of the Brazilian Chemical Society, v. 18, n. 1, p. 205-214, 2007. http://dx.doi.org/10.1590/S0103-50532007000100024

SHIBUYA, E. K.; SARKIS, J. E. S.; NIGRINO-NETO, O.; OMETTO, J. P. H. B. Multivariate classification based on chemical and stable isotopic profiles in sourcing the origin of marijuana samples seized in Brazil. Journal of the Brazilian Chemical Society, v. 18, n. 1, p. 205-214, 2007. http://dx.doi.org/10.1590/S0103-50532007000100024

SIQUEIRA, D. S.; MARQUES, J.; PEREIRA, G. T. The use of landforms to predict the variability of soil and orange attributes. Geoderma, v. 155, n. 1-2, p. 55-66, 2010. http://dx.doi.org/10.1016/j.geoderma.2009.11.024

SOLER I GIL, A.; BONOTTO, D. M. Hydrochemical and stable isotopes (H, O, S) signatures in deep groundwaters of Paraná basin, Brazil. Environmental Earth Sciences, v. 73, n. 1, p. 95-113, 2014. http://dx.doi.org/10.1007/s12665-014-3397-0

SOTO, D.X.; KOEHLER, G.; WASSENAR, L.I.; HOBSON, K.A. Re-evaluation of the hydrogen stable isotopic composition of keratin calibration standards for wildlife and forensic science applications. Rapid Communication in Mass Spectrometry, v. 31, n. 14, p. 1193-1203, 2017. http://dx.doi.org/10.1002/rcm.7893

STILL, C. J.; POWELL, R. L. Continental-scale distributions of vegetation stable carbon isotope ratios. In: Isoscapes: Understanding movement, pattern, and process on earth through isotope mapping. Netherlands: Springer, p. 179-194, 2010. http://dx.doi.org/10.1007/978-90-481-3354-3_9

SUITS N. S.; DENNING A. S.; BERRY J. A.; STILL C. J.; KADUK J.; MILLER J. B.; BAKER I. T. Simulation of carbon isotope discrimination of the terrestrial biosphere. Global Biogeochemical Cycles, v. 19, n. 1, p. 1-15, 2005. http://dx.doi.org/10.1029/2003GB002141

TEIXEIRA, F. C. P.; REINERT, F.; RUMJANEK, N. G.; BODDEY, R. M. Quantification of the contribution of biological nitrogen fixation to Cratylia mollis using the ${ }^{15} \mathrm{~N}$ natural abundance technique in the semi-arid Caatinga region of Brazil. Soil Biology and $\begin{array}{lllllll}\text { Biochemistry, } & \text { v. } \quad 38, \quad \text { n. } \quad 7, \quad \text { p. } & 1989-1993,\end{array}$ http://dx.doi.org/10.1016/j.soilbio.2005.11.013 
TERZER, S.; WASSENAAR, L. I.; ARAGUÁS-ARAGUÁS, L. J.; AGGARWAL, P. K. Global isoscapes for $\delta^{18} \mathrm{O}$ and $\delta^{2} \mathrm{H}$ in precipitation: Improved prediction using regionalized climatic regression models. Hydrology and Earth System Sciences, v. 17, n. 11, p. 4713-4728, 2013. http://dx.doi.org/10.5194/hess-17-4713-2013

VALENZUELA, L. O.; CHESSON, L. A.; O’GRADY, S. P.; CERLING, T. E.; EHLERINGER, J. R. Spatial distributions of carbon, nitrogen and sulfur isotope ratios in human hair across the central United States. Rapid Communications in Mass Spectrometry, v. 25, n. 7, p. 861-868, 2011. http://dx.doi.org/10.1002/rcm.4934

VANDER ZANDEN, H. B.; NELSON, D.; WUNDER, M. B.; CONKLING, T. J.; KATZNER, T. Application of isoscapes to determine geographic origin of terrestrial wildlife for conservation and management. Biological Conservation, v. 228, p. 268-280. 2018. https://doi.org/10.1016/j.biocon.2018.10.019

VANDER ZANDEN, H. B.; WUNDER, M. B.; HOBSON, K. A.; VAN WILGENBURG, S. L.; WASSENAAR, L. I.; WELKER, J. M.; BOWEN, G. J. Space-time tradeoffs in the development of precipitation-based isoscape models for determining migratory origin. Journal of Avian Biology, v. 46, n. 6, p. 658-667, 2015. http://dx.doi.org/10.1111/jav.00656

VIANI, R. A. G.; RODRIGUES, R. R.; DAWSON, T. E.; OLIVEIRA, R. S. Functional differences between woodland savannas and seasonally dry forests from south-eastern Brazil: Evidence from ${ }^{15} \mathrm{~N}$ natural abundance studies. Austral Ecology, v. 36, n. 8, p. 974-982, 2011. http://dx.doi.org/10.1111/j.1442-9993.2010.02233.x

VITÓRIA, A. P.; ÁVILA-LOVERA, E.; VIEIRA, T. O.; COUTO-SANTOS, A. P. L.; PEREIRA, T. J.; FUNCH, L. S.; FREITAS, L.; MIRANDA, L. D. P.; RODRIGUES, P. J. F. P.; REZENDE, C. E.; SANTIAGO, L. S. Isotopic composition of leaf carbon $\left(\delta^{13} \mathrm{C}\right)$ and nitrogen $\left(\delta^{15} \mathrm{~N}\right)$ of deciduous and evergreen understory trees in two tropical Brazilian Atlantic forests. Journal of Tropical Ecology, v. 34, n. 2, p. 145-156, 2018. http://dx.doi.org/10.1017/S0266467418000093

WANG, L.; OKIN, G. S.; D’ODORICO, P.; CAYLOR, K. K.; MACKO, S. A. Ecosystemscale spatial heterogeneity of stable isotopes of soil nitrogen in African savannas. Landscape Ecology, v. 28, p. 685-698, 2013

WARNER, M. M.; PLEMONS, A. M.; HEEMANN, N. P.; REGAN, L. A. Refining stable oxygen and hydrogen isoscapes for the identification of human remains in Mississippi. Journal of Forensic Sciences, v. 63, n. 2, p. 395-402, 2018.

WEINTRAUB, S. R.; COLE, R. J.; SCHMITT, C. G.; ALL, J. D. Climatic controls on the isotopic composition and availability of soil nitrogen across mountainous tropical forest. Ecosphere, v. 7, n. 8, p. 1-13, 2016. http://dx.doi.org/10.1002/ecs2.1412/supinfo

WEINTRAUB, S. R.; TAYLOR, P. G.; PORDER, S.; CLEVELAND, C. C.; ASNER, G. P.; TOWNSEND, A. R. Topographic controls on soil nitrogen availability in a lowland tropical forest. Ecology, v. 96, n. 6, p. 1561-1574, 2015. http://dx.doi.org/10.1890/140834.1

WEST, J. B.; BOWEN, G. J.; CERLING, T. E.; EHLERINGER, J. R. Stable isotope as one of nature's ecological recorders. Trends in Ecology \& Evolution, v. 21, n. 7, p. 408-414, 2006. http://dx.doi.org/ 10.1016/j.tree.2006.04.002 
WEST, J. B.; BOWEN, G. J.; DAWSON, T. E.; TU, K. P. Isoscapes: Understanding movement, pattern, and process on earth through isotope mapping. Netherlands: Springer, 2010 .

WEST, J. B.; SOBEK, A.; EHLERINGER, J. R. A simplified GIS approach to modeling global leaf water isoscapes. PLoS One, v. 3, n. 6, p. 1-8, 2008. http://dx.doi.org/10.1371/journal.pone.0002447

WUNDER, M. B. Determining geographic patterns of migration and dispersal using stable isotopes in keratins. Journal of Mammalogy, v. 93, n. 2, p. 360-367, 2012. http://dx.doi.org/10.1644/11-MAMM-S-182.1

WUNDER, M. B.; NORRIS, D. R. Improved estimates of certainty in stable-isotope-based methods for tracking migratory animals. Ecological Applications, v. 18, n. 2, p. 549-559, 2008 .

ZENNI, R. D.; ZILLER, S. R. An overview of invasive plants in Brazil. Revista Brasileira de Botânica, v. 34, n. 3, p. 431-446, 2011. http://dx.doi.org/10.1590/S010084042011000300016 


Ambiente \& Água - An Interdisciplinary Journal of Applied Science
ISSN 1980-993X - doi:10.4136/1980-993X
www.ambi-agua.net
E-mail: ambi.agua@gmail.com

\title{
Technical contributions to territorial planning and the use of ecosystemic services in a hydrographic basin with a water deficit in the Atlantic Rainforest of Brazil
}

\author{
ARTICLES doi:10.4136/ambi-agua.2296
}

Received: 27 Jun. 2018; Accepted: 11 Jan. 2019

\author{
Douglas Leite Figueira ${ }^{(\mathbb{D})}$; Ricardo Valcarcel ${ }^{D}$; Marcelle Nardelli Baptista* \\ Universidade Federal Rural do Rio de Janeiro (UFRRJ), Seropédica, RJ, Brasil \\ Instituto Florestas (IF). Departamento de Ciências Ambientais (DCA). \\ E-mail: douglas_nf@hotmail.com,ricardo.valcarcel@gmail.com,marcellenardelli@gmail.com \\ *Corresponding author
}

\begin{abstract}
The catchment basin of the Dois Rios River (R2R) $\left(3159 \mathrm{~km}^{2}\right)$ unites the climatic and environmental effects typical of areas located on the leeward side of mountain chains. It has a deficient water balance, with sparse and very specific wet areas. This study identifies delimitation areas, and characterizes and groups those basins and floodplains which show the greatest capacity for producing ecosystemic services related to maintaining the continuity of water resources in the $\mathrm{R} 2 \mathrm{R}$ basin. Locations with higher pluviometric indices (1500 to $2800 \mathrm{~mm} /$ year) were selected and grouped into micro basins with the highest potential for capturing rainfall due to their being on the leeward side of the mountains in the region (with their slopes oriented to permit them to capture humidity and concave plane curvature). The 42 basins formed 4 groups, from which the 17 micro basins with the highest probability of providing ecosystemic services were chosen, belonging to Groups III and IV. Within these groups, the 498 floodplains with the highest potential for offering ecosystemic services (Group D) present the greatest capacity for water retention and sustainable effects (high average circularity index, higher altitudes and low occupation rates). The correct use of $0.0006 \%$ of the basin can guarantee the direct flow of the drainage for the entire basin. This strategy only requires renaturation measures, discipline with regard to the land uses and strict observance of the processes which generate ecosystemic services in the floodplains of these basins, resulting in relevant socio-environmental benefits for all socioeconomic segments within the R2R basin.
\end{abstract}

Keywords: floodplain, planning, water regulation.

\section{Subsídio para ordenamento territorial e aproveitamento de serviços ecossistêmicos em bacia hidrográfica com déficit hídrico na Mata Atlântica}

\section{RESUMO}

A bacia do rio Dois Rios (R2R) $\left(3.159 \mathrm{~km}^{2}\right)$ recolhe os efeitos climáticos e ambientais típicos de zonas situadas a sotavento de cadeias montanhosas. Tem balanço hídrico deficitário, havendo poucos e específicos locais úmidos. Este estudo identifica, espacializa, caracteriza e agrupa as planícies de inundação com maior habilidade em produzir serviços ecossistêmicos 
relacionados à perenidade de recursos hídricos na bacia R2R. Foram segregados locais com maiores índices pluviométrico (1500 a $2800 \mathrm{~mm} / \mathrm{ano}$ ), agrupados em microbacias com maior potencial de captação em função de estarem a sota-vento na região (slopes oriented to permit them to capture humidity and concave plane curvature). As 42 bacias formaram 4 grupos, onde levantou-se 17 microbacias com alto potencial de fornecer serviços ecossistêmicos pertencentes aos Grupos III e IV. Nestes grupos, 498 planícies de inundação com maior potencial de oferta de serviços ecossistêmicos (grupo D) apresentam habilidades para retenção hídrica e efeitos de perenização (high average circularity index, higher altitudes and low occupation rates). O uso correto de $0,0006 \%$ pode garantir o escoamento direto das drenagens de toda a bacia. Está estratégica implicaria em medidas de renaturalização, disciplinamento dos usos e estrita observação dos processos que geram serviços ecossistêmicos nas planícies das bacias, trazendo relevantes benefícios socioeconômicos para todos os segmentos da bacia do R2R.

Palavras-chave: planejamento, planície de inundação, regulação hídrica.

\section{INTRODUCTION}

Floodplains are the first areas to be saturated after intense precipitation and the overflow of river channels in hydrographic basins (Baptista et al., 2014). They accumulate water and gradually release it into channels, filling up with a backflow (Baptista et al., 2017). The ecosystemic services related to water production permit the survival of these ecosystems, in which humans are an integral and inseparable part and are directly benefited. Among the relevant hydrological ecosystemic services are water regularization, lamination of flooding and amplification of the minimum flows during dry periods (Baptista et al., 2017). The conservation of wet areas in the floodplains is considered to be more efficient from the hydrological point of view, and more economical than the construction of large reservoirs (Baptista and Valcarcel, 2018) when the principles of sustainable development prevail.

Steeply sloping regions which are blocked from the direct influence of humid winds by mountain chains present specific environmental constraints and require objective planning strategies in order to achieve sustainability, especially those areas with a potential for water storage, such as floodplains. Headwaters present characteristics such as precipitation, sizes and forms of floodplains which are distinct from the rest of the catchment basin, affecting the hydric performance of lower areas. In this upper section of the basin, drainage patterns are particularly rectilinear, with fewer contributions from upstream and lower retention capacity, with fast flows and less lateral connection between the channel and the floodplains.

Floodplains are distinguished by their capacity to store water in "flood buffering basins", which reduce the discharge from the headwaters, thus affecting the potential for flooding during rainfall and the contribution from the basic flow afterwards (Reinhardt et al., 2011). The drainage coefficient can be variable in small basins which contribute to the direct runoff (both surface and sub-surface) in catchment basins with low storage capacity (Oswald et al., 2011), as well as the basic flow in catchment basins with high storage capacity.

Decentralized measures for administering the hydrographic basins of rivers may be efficient strategies for managing floods, water retention and recharging of the aquifers (Reinhardt et al., 2011). Being open systems, they join the combined effects of characteristics such as the surface area, the circularity index, the plane of the curve of the slope and the orientation of the slopes in relation to the humid winds (windward slopes) which interfere in the micro basins (Cardoso et al., 2006) and extrapolate the products to the larger catchment basins, influencing the dynamics of water capture and transmission from the slopes to the floodplains, where that water will be stored. 
The Dois Rios River Basin $\left(3159 \mathrm{~km}^{2}\right)$ is located on the right bank $\left(14,165 \mathrm{~km}^{2}\right)$ of the Paraíba do Sul River (total catchment area 55,400 $\mathrm{km}^{2}$ ), has a gradient of $2348 \mathrm{~m}$ and receives the climatic and environmental effects typical of sheltered areas, situated on the leeward slopes of the Serra do Mar Mountains. Its water balance is predominantly deficient, with few and specific wet areas, determined by the aerial basins, vertical precipitation and horizontal interception (dew, mist and other hidden precipitation). The region has a strong agricultural presence with high production, which leads to high water consumption. This study identifies, delimitation areas, characterizes and groups the floodplains with the highest capacity for producing ecosystemic services related to maintaining constant water resources in the R2R catchment basin for the purpose of the sustainable management of those resources.

\section{MATERIALS AND METHODS}

\subsection{Study Area}

The slopes and channels of the Paraiba do Sul River catchment basin $\left(55,400 \mathrm{~km}^{2}\right)$ have their orientation and shape conditioned by the geological limits of the Serra da Mantiqueira Mountains on the left side and the Serra do Mar Mountains on the right side of the main channel. Its headwaters in the region of Guararema, in the Brazilian state of São Paulo, present a reduction in declivity, which decreases from $4.9 \mathrm{~m} / \mathrm{km}$ to $0.19 \mathrm{~m} / \mathrm{km}$. This configuration of the relief conditions the drainage pattern and the formation of floodplains.

The left bank features a high plateau on top of the mountains and gentler slopes which, associated with the topographic divisions far from the channels, form the relief with reduced steepness, similar to the regions known as "oceans of hills". The extensive rivers are nestled in the valleys that separate these hills from the high plateaus of the southern portion of Minas Gerais state, where they receive the climatic influence of the sea, in spite of the distance and the interference of the Serra do Mar Mountains.

The right bank has a few low plateaus and presents a sharper relief, with steep cliffs and small valleys. Even though it is closer to the sea, it receives less influence from the moist winds because it is sheltered, which justifies the predominance of a generalized water deficit, most accentuated in the middle and lower stretches of the Paraiba do Sul catchment basin. In this region, the lack of water and the low capacity for supporting ecosystems confer less resilience, with an increase in erosive processes. In these areas, $50 \%$ of the territory presents high to very high vulnerability to erosion (AGEVAP, 2006).

The R2R catchment basin $\left(3159 \mathrm{~km}^{2}\right)$ is located on the right bank of the Paraiba do Sul River (Figure 1). It is formed by the Negro River and the Grande River, and has a predominantly ENE orientation. The entrance of moist air masses is descending due to the orientation and orography. The circulation of humid air masses immediately downstream of the interfluvial areas alters the saturation of atmospheric humidity and creates zones with different levels of humidity, conditioning the ecological diversity and offer of environmental attributes (Barboza et al., 2015).

The high-altitude tropical climate $(\mathrm{Cf})$ and subtropical climate $(\mathrm{Cw})$, according to Köppen's classification, have an average annual rainfall of $1500 \mathrm{~mm}$ and average annual temperature of $17.8^{\circ} \mathrm{C}$ (average in winter of $9^{\circ} \mathrm{C}$; average in summer of $28^{\circ} \mathrm{C}$ ). The vegetation in this catchment basin was originally composed of Dense Ombrophilous Mountain Forest and Semi Deciduous Broadleaved Forest of the Atlantic Rainforest biome (IBGE, 2012).

The Serra do Mar mountain chain affects the water balance of the catchment basin, with the discharge from the moist winds occurring on the slopes of Cachoeiras de Macacu, on the windward side of these mountains. The majority of the hidden precipitation in the zones located on the leeward side occurs at points near gorges, where the passage of humid air masses is concentrated (Cortines et al., 2011) and where the vegetation is able to reinforce the maximum 
horizontal interception. These points and the neighboring steep slopes, more exposed to these humid winds, are the most important locations for recharging the soil with water (Barboza et al., 2015). In these mountainous cliffs, the average annual rainfall is $2700 \mathrm{~mm}$, due to the orography which contrasts with the high plateau beyond the Serra do Mar Mountains, where the average humidity is less than $1100 \mathrm{~mm}$ per year (CPRM, 2001). The altitude of the catchment basin reaches 2366 meters at the peaks and drops to 12 meters at the mouth. The direction in which the drainage networks are oriented is influenced by the geology of the reactivated faults of the Mesozoic separation and the consequent subdivision of the Gondwana supercontinent (AGEVAP, 2006).

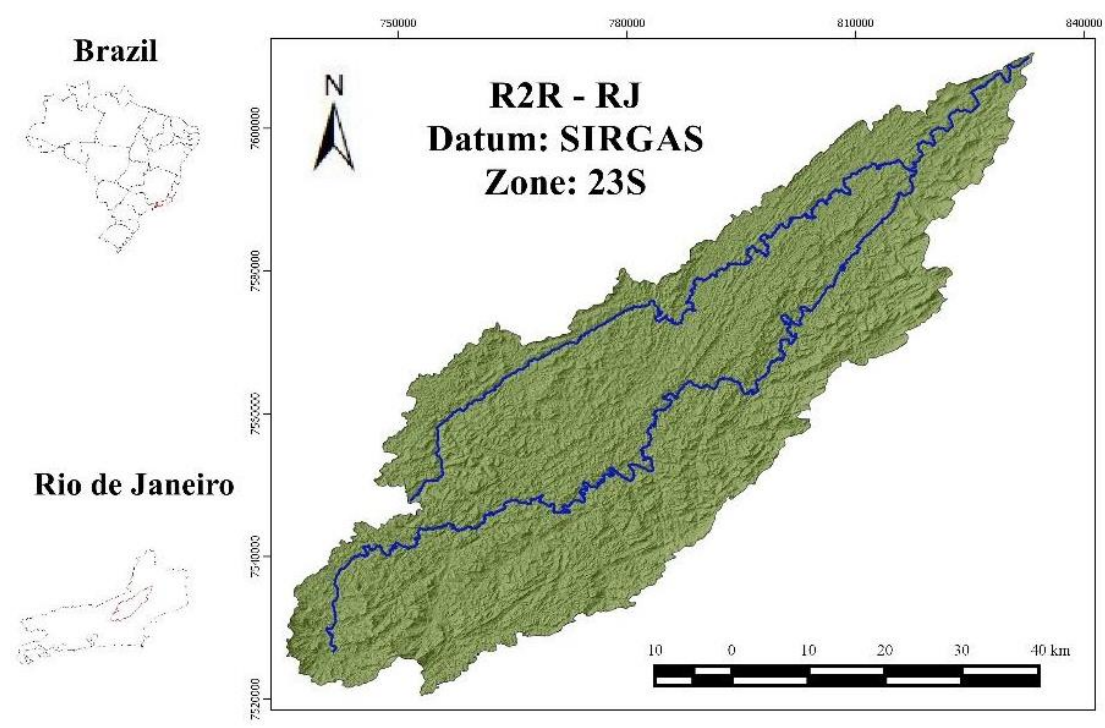

Figure 1. Dois Rios River Basin (R2R) - Rio de Janeiro State, Brazil.

\subsection{Hydrologically Consistent Digital Elevation Model}

The Hydrologically Consistent Digital Elevation Model (HCDEM) was generated from the continuous vectorial cartographic base of the state of Rio de Janeiro, on a scale of 1:25,000 (IBGE, 2012), using the procedures performed by ArcGIS 10.2 software (Figure 2).

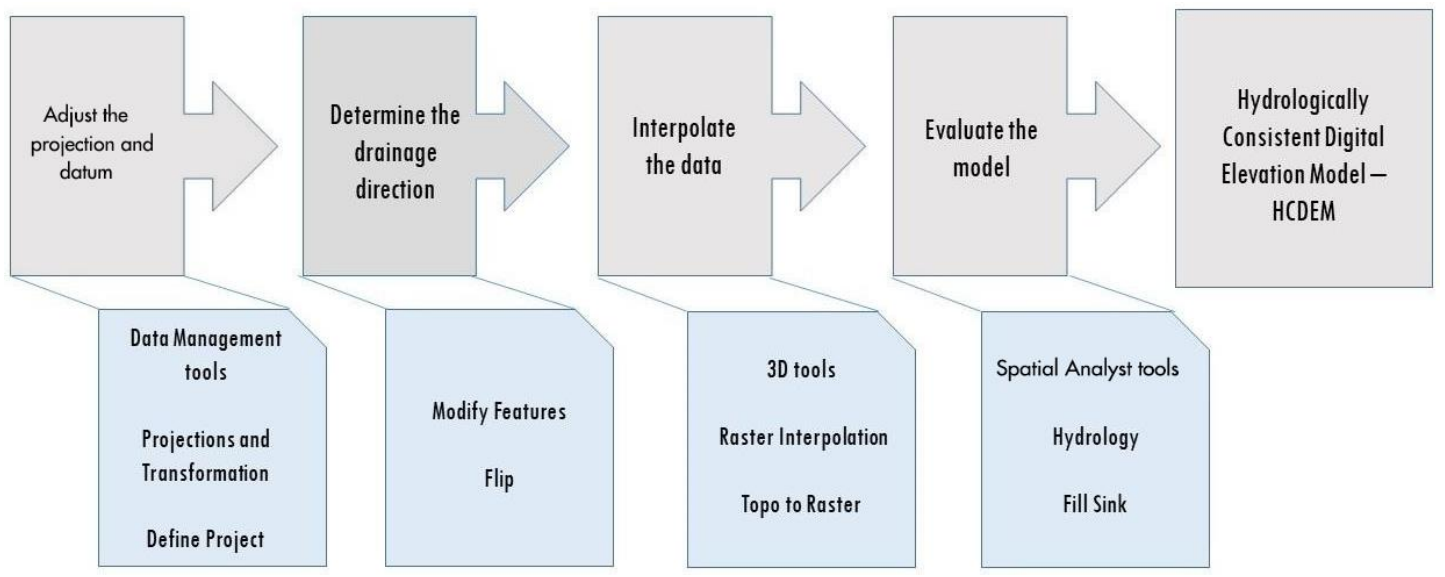

Figure 2. Procedures employed for determining the Hydrologically Consistent Digital Elevation Model (HCDEM).

\subsection{Geospatial Attributes and Ecosystemic Services}

Ecosystemic services related to water resources are factors of the physical environment itself combined with the biotic environment, which, when functioning in an integrated fashion, 
can improve the water supply in hydrographic basins. In order to delimit, characterize, group and select the floodplains with similar propensities for producing ecosystemic services which maximize the perennialization of water in the R2R catchment basin, the following indicators were established: $i$ ) Regions with the highest pluviometric indexes; ii) Identification of their micro basins (capture zones) based on morphometric attributes (area, circularity index, orientation and plane of the curve); and iii) Selection of floodplains with the greatest capacity for retaining water based on the parameters of area, circularity index, altitude and land use and occupation.

The minimum precipitation which was considered was $1500 \mathrm{~mm} / \mathrm{year}$. This was spatialized with help from the Clip tool in the QGIS 2.18 software, with an isohyetal map as database (CPRM, 2001). This part of the catchment basin was sectorized according to its micro basins of up to $3^{\text {rd }}$ order, utilizing the Basin tool of the ArcGIS 10.2 software, available in Spatial Analyst Tools $\rightarrow$ Hydrology, as well as the circularity index (CI) (Equation 1) (Cardoso et al., 2006).

$$
C I=\frac{(12.57 \times A)}{P^{2}}
$$

In which:

$$
\begin{aligned}
& \mathrm{CI}=\text { Circularity Index (adimensional); } \\
& \mathrm{A}=\text { Drainage Area }\left(\mathrm{m}^{2}\right) \\
& \mathrm{P}=\text { Perimeter }(\mathrm{m})
\end{aligned}
$$

In the ArcGIS 10.2 software, the slope areas were calculated according to their orientation (Aspect, in Spatial Analyst Tools $\rightarrow$ Surface), then the results were vectorized (from Raster to Polygon, in Conversion Tools). After this procedure, the area of each stretch of the slope was calculated according to its orientation (Calculate Geometry $\rightarrow$ Area). The plane of the curve was obtained using the Curvature command in Spatial Analyst Tools $\rightarrow$ Surface, followed by vectorization of the results (from Raster to Polygon, in Conversion Tools). Using the results of this vectorization, the area of each stretch of the slope was calculated according to its orientation (Calculate Geometry $\rightarrow$ Area). Based on these parameters, the micro basins were grouped according to the hydrographic attributes they offer and their similarities. The Cluster analysis of the SPSS 15.0 software was used to define the group with the best hydrological attributes.

The hydrological model for identifying areas saturated with water - "Topographic Wetness Index" (TWI) - was extracted from the SAGA GIS 2.0.8 HCDEM software (Olaya and Conrad, 2009), using the tool Terrain Analysis > Hydrology > Topographic Indices. The division of these areas was established by the cut-off line in the TWI by the adimensional value 5.85 . These data were later validated during in situ field visits in $10 \%$ of the areas studied. They were then verified using Landsat images with a resolution of 15 meters.

The hydrological attributes of water retention analyzed in the floodplains were: $i$ ) Area; $i$ ) Circularity Index; iii) Altitude; and iv) Land Use and Coverage. To obtain the area and circularity index of these floodplains, the commands described previously were used. Altitude was obtained by using Elevation - Obtain Elevation, in the QGIS 2.18 software, clicking on the highest point, where the floodplain ends.

Soil use and coverage for the floodplains were obtained by using the cutout of the vector provided by the IBGE, on the scale of 1:25,000, which, superimposed on the areas of the floodplains, identify land use, plant coverage and the existence of stone outcroppings in the areas surrounding the floodplains. Subsequently, these floodplains were grouped by similarity of hydrological attributes, using the Cluster analysis of the SPSS 15.0 software and selecting the group of floodplains with the best hydrological attributes for water retention.

\section{IPABH}

Rev. Ambient. Água vol. 14 n. 2, e2296 - Taubaté 2019 


\section{RESULTS AND DISCUSSION}

The R2R basin $\left(3159 \mathrm{~km}^{2}\right)$ is influenced by the leeward side of the Serra do Mar mountains, and contains 220.000 inhabitants, 09 municipalities, 42 micro basins and 7467 floodplains. The distribution of rainfall varies between 1000 and $2800 \mathrm{~mm} /$ year, with the management of the part with rainfall higher than $1500 \mathrm{~mm}$ /year being of strategic priority, where the use of the catchment basins is an important form of managing their ecosystemic services, both for capturing horizontal precipitation which is a hidden component of the total humidity on the slopes during the rainy seasons, and for storing and maintaining the flow during the dry seasons through the action of the floodplains in the smaller areas which belong to the higher parts of the basin. Thus, the strategic areas which generate water benefits for the entire catchment basin can be defined.

\subsection{Areas with High Rainfall}

The orographic and environmental condition of the catchment basin shows that the greatest volumes of rainfall (between 1500 and $2800 \mathrm{~mm} /$ year) occur in only $13.1 \%$ of its area (Figure 3 ), and that these locations must be treated with the highest priority. Below these locations, an increase in temperature and a decrease in the volume of precipitation occur, increasing loss due to evapotranspiration.

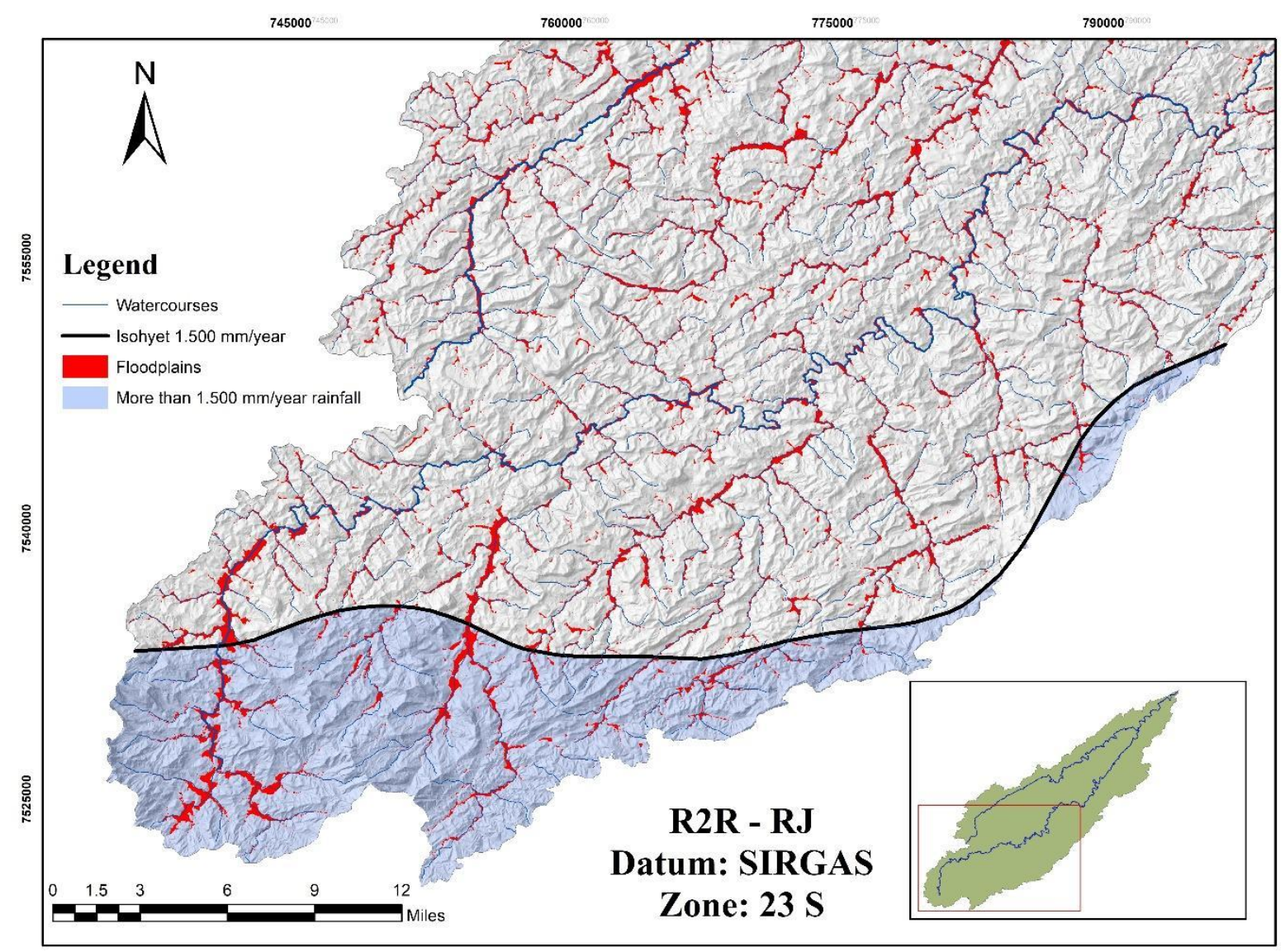

Figure 3. Floodplains located in the area with annual rainfall greater than $1.500 \mathrm{~mm}$.

\subsection{Grouping micro basins}

Excessive rainfall can also be a source of degradation, if the landscape is not environmentally adjusted, as can be seen by the frequent landslides and floods and prolonged droughts in the low areas (CPRM, 2001; Corrêa and Costa, 2016). The combination of the water 
entering the catchment basins and the storage of that water in the floodplains is fundamental 1 for sustainable water supply projects, for both agriculture and the population.

During this study, 42 micro basins of up to the third order were encountered which presented a potential for producing relevant ecosystemic services related with water resources. Area is a morphometric characteristic which can be related to the maximum discharge (Horton, 1945), depending on the types and characteristics of the soils. The average size of the micro basins (320-1835 ha) determines the prioritization of the smaller basins, both because these show greater hydrological sensitivity to the uses to which they are subject, and because they contain fewer users, thus facilitating regional agreements with the objective of adopting conservationist practices. The smaller basins offer greater options for the management of their slopes and other areas (Tonello et al., 2006). Another fact which attests to the greater interactivity between characteristics of their physical environment and the management of these basins is the influence of a greater number of factors, such as the effects of water storage in floodplains in large catchment basins, with less pronounced flood peaks (Borsato and Martone, 2004).

The circularity index of these 42 micro basins was an average of 0.48 , ranging from 0.43 to 0.53 , similar to the results encountered by Oliveira et al. (2010). CI values greater than 0.51 indicate a tendency for the basin to be circular (Schumm, 1956), thus favoring flooding processes; lower values indicate elongated forms, suggesting shorter water paths from the slopes, reducing the concentration time and draining the water more rapidly. Cardoso et al. (2006) state that the greater the circularity of a catchment basin, the greater the tendency for intense rain to occur simultaneously throughout its entire extension, which concentrates a large volume of water in the principle tributary. Tonello et al. (2006) add that the elongated form of the catchment basin - defined by the index number farthest from unity - causes a lower concentration of runoff and less risk of flooding. Therefore, the micro basins with the highest CI were selected.

The predominance of convex slopes (an average of 50.2\%) was detected in relation to concave plane curvature $(39.8 \%)$, which demonstrates the character of these slopes for dispersing water (Dragut and Blaschke, 2006). The micro basins selected present a higher average of slopes with a concave plane curvature $(40.4 \%)$ than the others $(39.2 \%)$. The concave plane curvature is related to a concentration of water, increasing the potential for mass movements (flow of debris and landslides) (Silveira et al., 2013), and thus being a factor associated with erosive processes (Sartori et al., 2005). The concentration of water indicates a delay in the runoff of that water.

The predominance of slopes oriented to leeward (an average of 44.3\%) was apparent, with only 7 micro basins showing a predominance of windward orientation. Micro basins with a higher percentage of windward slopes $(34.4 \%)$ in comparison to the others $(29.6 \%)$ were selected, because due to the steep terrain, there is a difference in the precipitation received between windward slopes and leeward slopes, considering the masses of moist air to which they are exposed (Dragut and Blaschke, 2016).

After the identification and selection of the micro basins with the best environmental attributes for water production (larger areas, higher CIs, concave plane curvature and slopes oriented to windward), it was possible to identify, group and select the floodplains situated within these micro basins which present geospatial environmental attributes which favor the supply of hydrological ecosystemic services. Grouping them according to similar capacities offers classifications to the hydrological processes in 4 groups (Table 1).

Groups III (12 micro basins) and IV (5 micro basins) include areas with slopes oriented to permit them to capture humidity $(35.33 \%$ e $33.42 \%$ of their areas, respectively) and a concave plane curvature ( $40.5 \%$ and $40.2 \%$, respectively), as well as possessing larger surface areas, conditioning factors which increase the rainfall they receive and induce a higher concentration 
of humidity per area, physical attributes capable of conferring a higher probability of offering ecosystemic services.

Table 1. Groups of micro basins, units per group and average values of morphometric variables.

\begin{tabular}{lccccc}
\hline Micro- Basin Group & $\mathbf{n}$ & Average Area (hectares) & $\begin{array}{c}\text { Southern Orientation } \\
\left(\mathbf{S O / S E / S )} \mathbf{~}^{(\%)}\right.\end{array}$ & $\begin{array}{c}\text { Concave Plane } \\
\text { Curvatura (\%) }\end{array}$ & CI $^{2}$ \\
\hline Group I & 16 & 635.1 & 28.9 & 40.0 & 0.50 \\
Group II & 09 & 320.0 & 30.4 & 38.4 & 0.43 \\
Group III & 12 & 1061.6 & 35.3 & 40.5 & 0.47 \\
Group IV & 05 & 1835.3 & 33.4 & 40.2 & 0.53 \\
\hline Total & 42 & 963.0 & 32.0 & 39.8 & 0.48 \\
\hline
\end{tabular}

$\mathrm{n}$ - Number of Units (micro basins).

1 - Oriented to Southwest, Southeast or South.

2 - Circularity Index.

Groups III (12 micro basins) and IV (5 micro basins) include areas with slopes oriented to permit them to capture humidity (35.33\% e $33.42 \%$ of their areas, respectively) and a concave plane curvature ( $40.5 \%$ and $40.2 \%$, respectively), as well as possessing larger surface areas, conditioning factors which increase the rainfall they receive and induce a higher concentration of humidity per area, physical attributes capable of conferring a higher probability of offering ecosystemic services.

\subsection{Grouping of Floodplains}

In the R2R Hydrographic Basin, 7467 floodplains cover $241.91 \mathrm{~km}^{2}$, which represents $6.58 \%$ of the basin's total area. This value is similar to that observed in other literature (Hamilton, 2002). In the basin of the main river (Paraíba do Sul), the floodplains are larger and fewer in number, totaling 1.16\% of the surface area (Baptista et al., 2014). This information shows their high potential for producing ecosystemic services related to water regularization. Of these floodplains, 1071 are located in the region with precipitation greater than $1500 \mathrm{~mm} /$ year and within the 42 micro basins with the highest priority in terms of territorial management, based on the differentiated supply of environmental attributes which can offer distinct environmental services, corresponding to $20.37 \mathrm{~km}^{2}$ or $8.42 \%$ of the area of all the floodplains in the basin (Figure 3).

Of the floodplains located in the region with rainfall of more than $1500 \mathrm{~mm} / \mathrm{year}, 729$ $(68.06 \%)$ are located in the 17 micro basins whose morphometric attributes confer the highest probability of producing water through their ecosystemic services (Groups III and IV). These micro basins are steep, with a high number of floodplains and heterogeneous geospatial attributes, which, to a certain degree, justify the integration and interdependence of their effects for guaranteeing the continuity of water production.

The average area of 1.5 hectares is not significant, because of the high variability (ranging from 0.008 to 119.6 ha). This high variability was also observed in relation to the circularity index ( 0.07 to 0.98 ). The larger floodplains present low circularity indices, affecting the rate at which water is liberated and contributing to its regularization. It can be observed that floodplains along the channel of the Paraíba do Sul River follow this trend, with CIs ranging from 0.001 to 0.52 (Baptista et al., 2014), with no significant difference being noted between this characteristic of the main river and that of the tributaries of the Paraíba do Sul, confirming the replicability of the study.

Of these 729 floodplains, $42.1 \%$ present forest coverage. Agriculture and pastures compose another $42.8 \%$ of that coverage. Even though nearly half of the floodplains are 
anthropized by farming activities, these areas are still subject to alterations of their land use which can be reversed through renaturation activities. Only $14.9 \%$ of the areas are occupied by residences or infrastructure (consolidated uses). This value is near to that encountered in the floodplains of the Paraíba do Sul River (18.94\%), showing that, in general, the floodplains present a low level of urbanization, with part of their hydrological functions still being preserved. This fact, associated with adequate planning for the orderly advance of urbanization in the floodplains, may enhance services for the renaturation of their hydrological functions (Baptista et al., 2014). Urbanization impairs the hydrological functions and ecosystemic services provided by floodplains (Baptista et al., 2017), as it leaves the soil compacted and impermeable, and also impedes the connection with the river channel. The low proportion of occupied areas demonstrates that it is still possible to adequate the land uses demanded by society with the offer of ecosystemic services, permitting the implantation of renaturation measures to improve the performance of areas with high water production (Baptista e Valcarcel, 2018).

As mentioned earlier, by using the Cluster function, 4 groups of floodplains with similar environmental attributes were formed (Table 2). The fourth group stands out from the rest because of its capacity for retaining water, with a total of 498 floodplains with high potential for water reservation, if the necessary conservational measures are utilized.

Table 2. Groups of floodplains, units per group and averages of the variables analyzed.

\begin{tabular}{lccccc}
\hline & N & AA $(\mathbf{h a})$ & ACI & UAP $(\boldsymbol{\%})$ & AAl $(\mathbf{m})$ \\
\hline Group A & 213 & 0.9 & 0.63 & 92.2 & 1014.9 \\
Group B & 3 & 91.2 & 0.12 & 86.5 & 981.6 \\
Group C & 15 & 30.9 & 0.21 & 49.0 & 984.1 \\
Group D & 498 & 0.4 & 0.60 & 1.9 & 1112.1 \\
\hline Total & 729 & 30.8 & 0.40 & 57.4 & 1023.2 \\
\hline
\end{tabular}

$\mathrm{N}$ - Number of Units (Floodplains); AA - Average Area in hectares; ACI Average Circularity Index; UAP - Percentage of the area occupied by Urbanization, Agriculture and Pasture; AAl - Average Altitude in meters.

Considering the high percentage of the surface area occupied by Urbanization, Agriculture and Pasture, Groups A and B do not possess the ability to administer water resources, because the anthropic uses of the floodplains have diminished their capacity for water storage and their ability to offer ecosystemic services (Baptista et al., 2017). In these areas, the elevated levels of anthropization have prioritized strategic solutions, although actions for water renaturation should be reinforced, with a view toward increasing the delay time for filling those floodplains which show a high potential for flooding and water regularization within Group A (a high ACI).

While half of the floodplains in Group $\mathrm{C}$ are not anthropized, this group has a low ACI. According to Schumm (1956), CI values greater than 0.51 indicate that the basin tends to be circular, favoring flooding processes (higher flood peaks); values lower than 0.51 suggest that the basin tends to be elongated, contributing to the drainage process and the escape of water resources from the hydrographic basin. Considering the analogous reasoning between hydrological units and floodplains, this means that the floodplains of Group $\mathrm{C}$ have a tendency to disperse water, similar to the findings of Oliveira et al. (2010).

Group D has a high ACI, which indicates a lower capacity for superficial runoff, and consequently an increase in water retention. The higher altitude guarantees that precipitation normally exceeds evapotranspiration, providing enough water to maintain a constant supply to the aquifers which are responsible for the springs that feed the watercourses (Cardoso et al., 2006). Low occupation rates increase the infiltration and water storage capacity (Vanzela et al.,

\section{IPABH}

Rev. Ambient. Água vol. 14 n. 2, e2296 - Taubaté 2019 
2010) and contribute to low-cost management. These factors permit this group of floodplains, which correspond to $0.01 \%$ of the total area of all the floodplains and $0.0006 \%$ of the total area of the catchment basin, to be selected as the best areas in the catchment basin in terms of potential for offering ecosystemic services for water retention.

\subsection{The Supply of Ecosystemic Services}

The $13.1 \%$ of the basin with rainfall between 1500 and $2800 \mathrm{~mm} /$ year has a greater horizontal interception, which may add up to $44 \%$ to the pluviometric precipitation (Barboza et al., 2015) in its $6.93 \%$ of the territory total of the basin in Groups III and IV, which has an environmental advantage related to a greater propensity for receiving both pluviometric rainfall and occult precipitation. This volume of water entering the subsystems of the slopes and the floodplains, if managed according to conservationist techniques and/or reinforced through measures for the renaturation of water functions, can produce benefits for water regulation in the areas located downriver which present a water deficit. This effect also reduces flooding and its consequences in both urban and rural spaces (Baptista and Valcarcel, 2018). The ecosystemic services for water regularization observed in the 7467 floodplains $\left(241.91 \mathrm{~km}^{2}\right)$, which represents $6.58 \%$ of the basin's total area, affect the recharge and discharge. These are the main ecosystemic services related with water regularization (Schindler et al., 2016).

A variety of renaturating actions have been utilized around the world, including the hydromorphological restoration in the Danube River (Riquier et al., 2015) and the revitalization of wetlands in the Anacostia (Baldwin, 2004), Isar (Binder, 2010) and Rheine rivers (Lamers, 2006). These measures require the integration of technical, socio-economic and legal approaches (González et al., 2017). The mapping of floodplains with high potential for the renaturation of water functions is fundamental for increasing the supply of water in terms of both quantity and quality for the population located downriver. This mapping and the identification of the peculiar characteristics of each location are essential to the success of such measures.

Physical and biological measures are important for potentializing ecosystemic services. An example of a physical measure is the opening of recharge areas at sites far from the river channel (Hein et al., 2016), providing great benefits at a low cost because they increase the water storage capacity of the floodplains. Biological measures such as selective cutting of trees (instead of the clear cutting of forests), maintenance of woody vegetation and prioritization in planting species with appropriate root systems are efficient in maintaining the hydrological functions of floodplains, integrated with social demands (González et al., 2017). As a renaturalization proposal for the middle stretch of the Ebro River, the creation of a "river territory" was suggested, aimed at creating conditions for the river to resume its conditions of navigability (Ollero, 2010). Other measures based on a combination of physical, physical-biological and biological works could also be implemented (Schindler et al., 2014).

Even by selecting strategic floodplains, these do not function in a homogeneous way throughout their entire extension. Their main processes must be studied in order to separate them into sectors with distinct hydrological capabilities, based on their specific geomorphological characteristics, aimed at achieving functional synergy and increasing their water capture and storage functions, thus permitting the development of techniques which can be directed towards the better administration of water resources.

\section{CONCLUSIONS}

In order to contribute to territorial planning and the optimal utilization of the ecosystemic services of floodplains, groups of micro basins (I, II, III and IV) were first formed based on favorable environmental attributes (slopes oriented to permit them to capture humidity and concave plane curvature to retain that humidity) so that the best locations for receiving 
pluviometric precipitation (rainfall between 1500 and $2800 \mathrm{~mm} / \mathrm{ano}$ ) and occult precipitation could be defined, according to the aerial corridors which transport humidity and the locations with frontal exposure to the geographical entrances of those corridors into the region, determined by the lowest passes in the high Serra do Mar mountain range. In the groups with adequate attributes and the highest rate of capture of rainfall (Groups III and IV), the floodplains were identified and grouped according to the highest propensity for storing water and contributing to water regularization, forming 4 groups (A, B, C and D). Group D presented the greatest potential for water retention, with the highest average characteristics of surface area, circularity index and altitude, and the lowest occupation rates, for the implantation of measures for renaturizing the hydrological functions, with the objective of increasing the offer of ecosystemic services downriver and promoting water regularization in the catchment basin.

The precipitation concentrated in the headwaters of hydrographic basins $(13.1 \%$ of the total area, in the case of the $\mathrm{R} 2 \mathrm{R}$ region) is an important element to be considered in planning land use focused on the management of the ecosystemic services capable of interfering in the production and administration of water. Of the 7467 floodplains in the R2R catchment basin, only 498 (corresponding to $0.0006 \%$ of the total surface area) present optimum conditions for promoting water regulation through the management of their distinctive supply of ecosystemic services, which can benefit the entire catchment basin. These criteria for safeguarding their hydrological functions may affect the collection of water in the micro basins and the water regulation in the floodplains. These results will be materialized in the form of water regulation and continuity of flow, notably in the dry periods, improving the quality and quantity of water in the catchment basin. These focal actions offer greater responses with less investment. Any planning activities which pursue the sustainability of the water system should take these areas into consideration, because they are strategic for guaranteeing perennial flow in the springs and providing water for all the different activities being developed within the catchment basin.

Considering the repressed demands for an adequate water supply, the potential ecosystemic services offered by floodplains and the scarcity of information about these environments, the development of studies which permit deeper knowledge of the sectors within those floodplains, which offer different ecosystemic services and different functional relationships with the physical surroundings, is of extreme importance.

\section{ACKNOWLEDGEMENTS}

We wish to thank the Municipal Government of Nova Friburgo for having permitted time off from other functions to perform these studies. Also, the UFRRJ/PPGCAF (the PostGraduate Program for Environmental and Forestry Sciences of the Federal Rural University of the State of Rio de Janeiro) for permitting this opportunity for learning, and the CAPES (the Coordination for Perfection of University-Level Personnel, of the Brazilian Ministry of Education) for providing the necessary support.

\section{REFERENCES}

AGEVAP. Plano de recursos hídricos da bacia do rio Paraíba do Sul: Diagnóstico dos recursos hídricos - relatório Final. Laboratório de Hidrologia e Estudos de Meio Ambiente, 2006. (Relatório Contratual R-7). Available in: www.ceivap.org.br/downloads/PSR-010-R0.pdf. Access: June 042018.

BALDWIN, A. H. Restoring complex vegetation in urban settings: The case of tidal freshwater $\begin{array}{llllll}\text { marshes. Urban } & 2004 .\end{array}$ https://doi.org/10.1023/B:UECO.0000036265.86125.34 
BAPTISTA, M. N.; VALCARCEL, R. Renaturalizing Floodplains. Journal of Water Resource and Protection, v. 10, n. 05, p. 533- 537, 2018. https://dx.doi.org/10.4236/jwarp.2018.105029

BAPTISTA, M. N.; VALCARCEL, R.; MATEUS, F. A.; MEDEIROS, W. S.; ANDRADE, F. C. Impact of Urbanization on the Hydrodynamics of a Water Table in a Floodplain with High Potential for Renaturation. Water Resources Management, v. 31, n. 13, p. 40914102, 2017. http://dx.doi.org/10.1007/s11269-017-1731-5

BAPTISTA, M. N.; VALCARCEL, R.; MAYA, V.; CANTO, F. Floodplains for the Renaturalization of Hydrologic Functions: A Case Study of the Paraíba do Sul River Basin, Brazil. Water Resources Management, v. 28, n. 13, p. 4781-4793, 2014. https://dx.doi.org/10.1007/s11269-014-0775-z

BARBOZA, R. S.; VALCARCEL, R.; SANTOS, E. O.; PEREIRA, C. R. Air basins of Rio de Janeiro - Brazil. Journal of Water Resource and Protection, v. 7, p. 781-791, 2015. http://dx.doi.org/10.4236/jwarp.2015.710064

BINDER, W. The Restoration of the Isar South of Munich. Wasserwirtschaft, v. 100, p. 1519, 2010.

BORSATO, F. H.; MARTONI, A. M. Estudo da fisiografia das bacias hidrográficas urbanas no município de Maringá, estado do Paraná. Acta Scientiarum, v. 26, n. 2, p. 273-285, 2004. http://dx.doi.org/10.4025/actascihumansoc.v26i2.1391

CARDOSO, A. C.; DIAS, H. C. T.; SOARES, C. P. B.; MARTINS, S. V. Caracterização morfométrica da bacia hidrográfica do rio Debossan, Nova Friburgo-RJ. Revista Árvore, v. 30, n. 2, p. 241-248, 2006. http://dx.doi.org/10.1590/S0100-67622006000200011

CORRÊA, C. A.; COSTA, A. J. T. Usos na Bacia Hidrográfica do Paraíba do Sul: considerações acerca da escassez de água, inundações e Área de Preservação Permanente no trecho fluminense. Revista de Geografia, v. 33, n. 3, 2016.

CORTINES, E.; PEREIRA, A. L.; DOS SANTOS, P. R. O.; SANTOS, G. L.; VALCARCEL, R. Vegetação arbórea em vertentes com orientação norte e sul na Floresta Montana, Nova Friburgo-RJ. Floresta e Ambiente, v. 18, n. 4, p. 428-437, 2011. http://dx.doi.org/10.4322/floram.2011.062

CPRM. Mapa de isoietas do estado do Rio de Janeiro. Brasília, 2001. 1 map. Scale 1:500000. 1 CD-ROM.

DRAGUT, L.; BLASCHKE, T. Automated Classification of Landform Elements Using ObjectBased Image Analysis. Geomorphology, v. 81, p. 330-344, 2006. https://dx.doi.org/10.1016/j.geomorph.2006.04.013

GONZÁLEZ, E.; FELIPE-LUCIA, M.; BOURGEOIS, B.; BOZ, B.; NILSSON, C.; PALMER, G.; SHER, A. Integrative conservation of riparian zones. Biological Conservation, v. 211, p. 20-29, 2017. https://dx.doi.org/10.1016/j.biocon.2016.10.035

HAMILTON, S. Comparison of inundation patterns among major South American floodplains. Journal of Geophysical Research, v. 107, p. 1-14, 2002. https://dx.doi.org/10.1029/2000JD000306

HEIN, T.; SCHWARZ, U.; HABERSACK, H.; NICHERSU, I.; PREINER, S.; WILLBY, N.; WEIGELHOFER, G. Current status and restoration options for floodplains along the Danube River. Science of the Total Environment, v. 543, p. 778-790, 2016. https://dx.doi.org/10.1016/j.scitotenv.2015.09.073 
HORTON, R. E. Erosional development of streams their drainage basins: hidrophysical approach to quantitative morphology. Geological Society of America Bulletin, v. 56, p. 275-370, 1945. https://dx.doi.org/10.1016/j.landusepol.2014.10.015

IBGE. Manual Técnico de Vegetação Brasileira. 2. ed. Rio de Janeiro, 2012. 276p.

LAMERS, L.; LOERB, R.; ANTHEUNISSE, A.; MILETTO, M.; LUCASSEN, E. Biogeochemical constraints on the ecological rehabilitation of wetland vegetation in river floodplains. Hydrobiologia, v. 565, p. 165-186, 2006. http://dx.doi.org/10.1007/s10750005-1912-8

OLAYA, V.; CONRAD, O. Geomorphometry in SAGA. Developments in Soil Science, v. 33, p. 293-308, 2009. https://dx.doi.org/10.1016/S0166-2481(08)00012-3

OLIVEIRA, P. T. S. DE; SOBRINHO, T. A.; STEFFEN, J. L.; RODRIGUES, D. B. B. Caracterização morfométrica de bacias hidrográficas através de dados SRTM. Revista Brasileira de Engenharia Agrícola e Ambiental, v. 14, n. 8, p. 819-825, 2010.

OLLERO, A. Channel changes and floodplain management in the meandering middle Ebro River, Spain. Geomorphology, v. 117, n. 3-4, p. 247-260, 2010. https://dx.doi.org/10.1016/j.geomorph.2009.01.015

OSWALD, C. J.; RICHARDSON, M. C.; BRANFIREUN, B. A. Water storage dynamics and runoff response of a boreal Shield headwater catchment. Hydrological Processes, v. 25, n. 19, p. 3042-3060, 2011. https://dx.doi.org/10.1002/hyp.8036

REINHARDT, C.; BÖLSCHER, J.; SCHULTE, A.; WENZEL, R. Decentralised water retention along the river channels in a mesoscale catchment in south-eastern Germany. Physics and Chemistry of the Earth, Parts A/B/C, v. 36, n. 7, p. 309-318, 2011. https://dx.doi.org/10.1016/j.pce.2011.01.012

RIQUIER, J.; PIÉGAY, H.; MICHALKOVÁ, M. Hydromorphological conditions in eighteen restored floodplain channels of a large river: linking patterns to processes. Freshwater Biology, v. 60, p. 1085-1103, 2015. http://dx.doi.org/10.1111/fwb.12411

SARTORI, A.; LOMBARDI NETO, F.; GENOVEZ, A. M. Classificação hidrológica de solos brasileiros para a estimativa da chuva excedente com o método do Serviço de Conservação do Solo dos Estados Unidos Parte 1: Classificação. Revista Brasileira de Recursos Hídricos, v. 10, n. 4, p. 05-18, 2005.

SCHINDLER, S.; O’NEILL, F. H.; BIRO, M.; DAMM, C.; GASSO, V.; KANKA, R.; SLUIS, T. V.; KRUG, A.; LAUWAARS, S. G.; SEBESVARI, Z.; PUSCH, M.; BARANOVSKY, B.; EHLERT, T.; NEUKIRCHEN, B.;MARTIN, J. R.; EULLER, K.; MAUERHOFER, V.; WRBKA, T. Multifunctional floodplain management and biodiversity effects: a knowledge synthesis for six European countries. Biodiversity Conservation, v. 25, p. 1349-1382, 2016. http://dx.doi.org/10.1007/s10531-016-1129-3

SCHINDLER, S.; SEBESVARI, Z.; DAMM, C.; EULLER, K.; MAUERHOFER, V.; SCHNEIDERGRUBER, A.; BIRÓ, M.; ESSL, F.; KANKA, R.; LAUWAARS, S.; SCHULZ-ZUNKEL, C.; VAN DER SLUIS, T.; KROPIK, M.; GASSO, V.; KRUG, A.; PUSCH, M.; ZULKA, K.; LAZOWSKI, W.; HAINZ-RENETZEDER, C.; HENLE, K.; WRBKA, T. Multifunctionality of floodplain landscapes: Relating management options to ecosystem services. Landscape Ecology, v. 29, n. 2, p. 229-244, 2014. http://dx.doi.org/10.1007/s10980-014-9989-y 
SCHUMM, S. A. Evolution of drainage systems and slopes in badlands at Perth Amboy, New Jersey. Geological Society of America Bulletin, v. 67, n. 5, p. 597-646, 1956. https://dx.doi.org/10.1130/0016-7606(1956)67[597:EODSAS]2.0.CO;2

SILVEIRA, C. T.; FIORI, A. P.; FERREIRA, A. M.; DE GÓIS, J. R.; DE MIO, G.; SILVEIRA, R. M. P; MASSULINI, N. E. B.; LEONARDI, T. M. H. Emprego de atributos topográficos no mapeamento da susceptibilidade a processos geoambientais na bacia do rio Jacareí, Paraná. Sociedade \& Natureza, v. 25, n. 3, 2013.

TONELlO, K. C.; DIAS, H. C. T., SOUZA, A. L.; RIBEIRO, C. A. A. S.; LEITE, F. P. Morfometria da bacia hidrográfica da Cachoeira das Pombas, Guanhães-MG. Revista Árvore, v. 30, n. 5, p. 849-857, 2006.

VANZELA, L.; HERNANDEZ, F. B.; FRANCO, R. A. Influência do uso e ocupação do solo nos recursos hídricos do Córrego Três Barras, Marinópolis. Revista Brasileira de Engenharia Agrícola e Ambiental, v. 14, n. 1, 2010. 


Ambiente \& Água - An Interdisciplinary Journal of Applied Science
ISSN 1980-993X - doi:10.4136/1980-993X
www.ambi-agua.net
E-mail: ambi.agua@gmail.com

\title{
Analytical solution for the stationary model of pollutant propagation in an aquatic medium
}

\author{
ARTICLES doi:10.4136/ambi-agua.2298
}

Received: 13 Jul. 2018; Accepted: 11 Jan. 2019

\author{
Cíntia Ourique Monticelli ${ }^{*}$; ; Jorge Rodolfo Zabadal ${ }^{2}$; \\ Daniela Muller Quevedo ${ }^{1}$; ; Carlos Augusto Nascimento ${ }^{1}$ id \\ ${ }^{1}$ Universidade FEEVALE (FEEVALE), Novo Hamburgo, RS, Brasil \\ Instituto de Ciências Exatas e Tecnológicas (ICET). E-mail: cintiam@feevale.br, \\ danielamq@feevale.br, nascimento@feevale.br \\ ${ }^{2}$ Universidade Federal do Rio Grande do Sul (UFRGS), Tramandaí, RS, Brasil \\ Departamento Interdisciplinar. E-mail: jorge.zabadal@ufrgs.br \\ *Corresponding author
}

\begin{abstract}
This work presents a new analytical approach for solving pollutant dispersion problems along irregular-shaped water bodies. In this approach, the advection-diffusion equation is expressed in terms of orthogonal curvilinear coordinates, defined by the velocity potential and the corresponding stream function for inviscid flows. The boundary condition rewritten in terms of these new coordinates is reduced to a classical third kind one, i.e., the derivative of the concentration distribution with respect to the stream function is proportional to the numerical value of the local pollutant concentration. The solution obtained from the proposed formulation was employed to simulate pollutant dispersion (thermotolerant coliforms) along the Pampa Creek, a tributary of the Sinos River at the outskirts of Novo Hamburgo city, South Region of Brazil. The results obtained reproduce the qualitative behavior of the expected concentration distribution.
\end{abstract}

Keywords: advection-diffusion equation, analytical solutions, mass transport, orthogonal curvilinear coordinates system, pollutant dispersion.

\section{Solução analítica do modelo estacionário de propagação de poluentes em meio aquático}

\section{RESUMO}

Este trabalho apresenta uma nova abordagem analítica para a solução de problemas de dispersão de poluentes ao longo de corpos hídricos com contornos irregulares. Nesta abordagem, a equação advectivo-difusiva é expressa em termos de coordenadas curvilíneas ortogonais que são definidas pelo potencial de velocidade e pela função de corrente correspondente para fluídos invíscivos. A condição de contorno reescrita em termos destas novas coordenadas é reduzida a uma de terceira espécie clássica, isto é, a derivada da distribuição de concentração em relação à função de corrente é proporcional ao valor numérico da concentração de poluente local. A solução obtida a partir da formulação proposta foi empregada para simular dispersão de poluentes (coliformes termotolerantes) ao longo do Arroio Pampa, afluente do rio dos Sinos, na periferia de Novo Hamburgo, cidade do sul do Brazil. Os 
resultados obtidos reproduzem o comportamento qualitativo da distribuição de concentração esperada.

Palavras-chave: dispersão de poluentes, equação advectivo-difusiva, sistema de coordenadas curvilíneas ortogonais, soluções analíticas, transporte mássico.

\section{INTRODUCTION}

The conservation of surface water quality is of great importance for society, since this water is collected in order to supply public distribution systems. However, due to their power of dilution and self-purification, several rivers also serve as the final destination of sanitary sewage. Hence, the technical tools to aid in the planning, monitoring and management of water resources, among which mathematical modeling stands out as a fundamental instrument, are very important. Mathematical models allow the generation of properly organized data, spatially and temporally integrating dispersed data, as well as promoting a better understanding of the dynamics of the processes and a prediction of future conditions of the system regarding relevant parameters.

Rivers are the main source of water for human consumption. Thus, controlling the water quality of the rivers is very important because water is directly related to human health (Qishlaqi et al., 2017). In environmental impact studies of sewage transport network projects, part of the data to be produced is the determination of a safe distance from the vicinal area or points of raw water collection for water treatment plants, where effluents can be discharged through an emissary so that the dispersion plume does not reach these areas. Surely, one can also estimate the contamination level that would be produced if the pollutant inevitably reached the regions of interest.

To obtain reliable results regarding the distance of the sewage outfall in relation to the source and to the point of water collection, and thus minimize the total costs of an enterprise, it is necessary to carry out several computational simulations. These simulations would be able to predict the approximate spatial distribution of pollutant concentrations considering a large quantity of scenarios by using mathematical models for mass transport. However, the time required by computational programs capable of implementing such models can become a critical point for certain applications that require a high level of detail, since the large number of mathematical calculations in a commonly used numerical model (Rosman, 2001), (Gomes et al., 2018) causes delays in the generation of the results.

The governing equation of pollutant transmission in rivers is the advection diffusion equation (ADE). This is a partial equation that is very important in environmental engineering, and several hydraulic phenomena such pollution transmission, suspended sediment transport modeling, etc. are involved (Parsaie and Haghiabi, 2017). The ADE includes two differential parts, advection and diffusion; the advection part characterizes the velocity's contribution in the pollutant transmission, and the diffusion or dispersion part characterizes the molecular transmission from highest concentration region to lowest concentration region. In addition to the differential terms present in ADE, there are the physical parameters which will be described throughout this work.

Three possible solutions could be proposed to solve the differential equation that describe the problem in question: the numerical, analytical and hybrid methods. Numerical methods, usually employed by the scientific community, often provide sufficiently realistic results for particle transport problems (Jobim, 2012). In the application of numerical solutions to computational fluid dynamics, either by applying the finite difference, finite element or finite volume methods and artificial neural network - ANN (Parsaie and Haghiabi, 2017), it is common to have to discretize the domain into a mesh with thousands or even millions of points. 
This may produce algebraic systems of a very high order (Fernandez, 2007); thus, in most cases, the numerical solutions demand a high computational effort. Consequently, they require a high processing time, which may make it impossible in some cases to generate a sufficient number of scenarios in a timely manner.

In order to avoid these problems, the use of analytical solutions is more advantageous. As they are expressed in closed form, it is possible to write small source codes that are executed in a shorter processing time, which is due to the decrease in the number of operations to be performed and, consequently, in the memory required for all the necessary routines. The advection-diffusion equation, which describes the transport of particles, has several proposed analytical solutions, such as the integral transform method (Mikhailov and Ozisik, 1984), the generalized integral transform method (Cotta, 1993), the change of variables combined with the integral transform method (Guerrero et al., 2009), using the Green's function (Sanskrityayn and Kumar, 2016), among others. However, changes in the geometry of the domain are not considered, whereas this would be required in the problem of transporting particles in a water body.

This study presents a new analytical approach to solve the problem of pollutant dispersion in the aquatic environment, in which the advection-diffusion equation is expressed in terms of new orthogonal curvilinear coordinates, defined by the velocity potential and by the stream function. Such reformulation aims to standardize the boundary conditions to be prescribed, in addition to considerably increasing the size of the elements of the corresponding mesh. The use of this technique produces a closed solution for the propagation model of conservative or nonconservative pollutants and its implementation generates very compact symbolic codes and high computational performance.

In addition, the that way the physical parameters, present in the ADE, are obtained has fundamental importance. The determination of the longitudinal dispersion coefficients that properly describes the stream behavior is one of the main objectives of research works, like those of Paisaie et al. (2018) Haghiabi (2016; 2017), that use different techniques to obtain them. In the solution proposed by this study, the dispersion coefficients used are the ones obtained by Garcia in 2009 and the velocity coefficients obtained by Lersh et al. in 2013.

In order to prove the feasibility and validity of the proposed method, we present the results of a one-dimensional model for the simulation of dispersion of organic pollutants (thermotolerant coliforms) in a $7 \mathrm{~km}$-stretch of the Pampa Creek until its mouth in the Sinos River - located in an urban area of the city of Novo Hamburgo, Rio Grande do Sul, Brazil.

\section{MATERIAL AND METHODS}

\subsection{Equations Model}

In this study, in order to obtain an approximation for estimating the concentration of thermotolerant coliforms downstream from a point source, the flow was considered to be: homogeneous, isotropic, uniform, incompressible and irrotational. That is, respectively: absence of regions with "superconcentrations" or even actions of fields that interact with the substance of interest, absence of the characteristic that causes the molecule to migrate from one point to another that differ in each direction of pollutant propagation, and the pressure and turbulence temperature conditions are approximately the same at all points. The velocity field has divergent zero, i.e., there are no diffusive terms nor generation or decay. And finally, considering the irrotational flow to be the viscosity effects forming the hydrodynamic boundary layer on the banks of the river, they can be neglected and the fluid considered with viscosity equal to zero, which does not constitute vorticity.

Yet, many rivers and lakes can be reduced to a two-dimensional problem by behaving like water slides, since the depth is much smaller than the distance between the boundaries, so the 
dispersion would have enough time to homogenize the vertical concentration profile at the moment the plume has spread horizontally on a geographic scale. Consequently, the dispersion in the z-direction will be neglected.

With the changes and simplifications applied to the general equation of the particle balance (Cranck, 1975; Kambe, 2007) based on an Eulerian view of the process, and assuming that the kinetics of reactions could be represented by a first-order decay, the two-dimensional advection-diffusion equation for non-conservative pollutants is given as Equation 1:

$\frac{\partial C}{\partial t}+u \frac{\partial C}{\partial x}+v \frac{\partial C}{\partial y}=D\left(\frac{\partial^{2} C}{\partial x^{2}}+\frac{\partial^{2} C}{\partial y^{2}}\right)-k C$

In Equation 1, $C$ is the pollutant concentration, $x$ and $y$ are the directions of motion, $u$ and $v$ are the velocities of the water body in the directions $x$ and $y$ respectively, $D$ is the surface oscillation diffusion coefficient (Garcia et al., 2009) and $k$ is the coefficient of velocity.

When one intends to estimate the level of pollution caused by the discharge of sewage systems in different regions of a watercourse, whether for classification and framing according to current regulations or for the projection of bathing conditions, it is desirable to generate results that express the system in its steady state. Since the time scale in which the dispersion occurs is much higher than the characteristic period of the thermal and hydrodynamic fluctuations of the flow, the time evolution pattern of the diffusion, kinetic and velocity field coefficients present stationarity, that is, low amplitude stochastic oscillations around a fixed mean value. In this study, the coefficients of diffusion and velocity shall be considered constant, representing temporal arithmetic means independent of time.

Since the only transient effect on the concentration distribution to be considered is due to the effects of degradation kinetics, which is a phenomenon independent of mass transport, Equation 1 can be decoupled through the split process (Zabadal and Ribeiro, 2012):

In the kinetic Equation 2:

$\frac{\partial C}{\partial t}=-k C$

And in the transport Equation 3:

$u \frac{\partial C}{\partial x}+v \frac{\partial C}{\partial y}=D\left(\frac{\partial^{2} C}{\partial x^{2}}+\frac{\partial^{2} C}{\partial y^{2}}\right)$

\subsection{Analytical Solution}

With the target equation decoupled in a system of two equations, Equation 2 and Equation 3 , they can be solved in parallel.

\subsubsection{Solution of the kinetic equation for first-order decay}

The asymptotic behavior of the kinetic model for most pollutants is exponential, thus solving Equation 2 by separation of variables we obtain Equation 4:

$C(x, y, t)=f(x, y) e^{-k t}$

The function $f(x, y)$ is precisely the exact solution for the transport equation, Equation 3. Thus, substituting Equation 5 into Equation 3 restored the transport equation:

$\left(u \frac{\partial f}{\partial x}+v \frac{\partial f}{\partial y}\right)=D\left(\frac{\partial^{2} f}{\partial x^{2}}+\frac{\partial^{2} f}{\partial y^{2}}\right)$ 


\subsection{Solution of transport equation for point sources}

It is possible to produce the solution of the transport equation by writing it in terms of a new curvilinear coordinate system $(\phi, \psi)$ and, only then, solve it. To perform this task, initially, it is necessary to redefine the first and second order partial derivatives of the function $f(x, y)$ in terms of the velocity potential $\phi(x, y)$ and the stream function $\psi(x, y)$. By using the chain rule (Equations 6 and 7):

$$
\begin{aligned}
& \frac{\partial f}{\partial x}=\frac{\partial f}{\partial \phi} \frac{\partial \phi}{\partial x}+\frac{\partial f}{\partial \psi} \frac{\partial \psi}{\partial x} \\
& \frac{\partial f}{\partial y}=\frac{\partial f}{\partial \phi} \frac{\partial \phi}{\partial y}+\frac{\partial f}{\partial \psi} \frac{\partial \psi}{\partial y}
\end{aligned}
$$

And the identities and conditions of Cauchy-Riemann Equation 8:

$$
u=\frac{\partial \phi}{\partial x}=\frac{\partial \psi}{\partial y}, v=\frac{\partial \phi}{\partial y}=-\frac{\partial \psi}{\partial x}
$$

Writing the write the second-order derivative, regrouping the terms and making the necessary simplifications, the Laplacian of $f(x, y)$ is yielded in terms of the new coordinates $\phi$ and $\psi$ Equation 9:

$$
\begin{aligned}
& \nabla^{2} f(x, y)=\left(u^{2}+v^{2}\right)\left(\frac{\partial^{2} f}{\partial \phi^{2}}+\frac{\partial^{2} f}{\partial \psi^{2}}\right)+\frac{\partial f}{\partial \phi}\left(\left(u \frac{\partial u}{\partial \phi}-v \frac{\partial u}{\partial \psi}\right)+\left(v \frac{\partial v}{\partial \phi}+u \frac{\partial v}{\partial \psi}\right)\right)+\frac{\partial f}{\partial \psi}\left(\left(v \frac{\partial u}{\partial \phi}+u \frac{\partial u}{\partial \psi}\right)-\right. \\
& \left.\left(u \frac{\partial v}{\partial \phi}-v \frac{\partial v}{\partial \psi}\right)\right)
\end{aligned}
$$

The partial derivatives of the velocity field components $u$ and $v$ can be defined with the help of the chain rule, thus Equations 10 and 11:

$$
\begin{aligned}
& \frac{\partial u}{\partial x}=u \frac{\partial u}{\partial \phi}-v \frac{\partial u}{\partial \psi} \text { and } \frac{\partial u}{\partial y}=v \frac{\partial u}{\partial \phi}+u \frac{\partial u}{\partial \psi} \\
& \frac{\partial v}{\partial x}=u \frac{\partial v}{\partial \phi}-v \frac{\partial v}{\partial \psi} \text { and } \frac{\partial v}{\partial y}=v \frac{\partial v}{\partial \phi}+u \frac{\partial v}{\partial \psi}
\end{aligned}
$$

Once the relations Equation 10 and Equation 11 had replaced into Equation 9, the divergent and rotational of the velocity field will be cancelled, since incompressible and irrotational flows are being considered. This allows us to rewrite the diffusion terms of the target Equation 12 as:

$$
\nabla^{2} f(x, y)=\left(u^{2}+v^{2}\right)\left(\frac{\partial^{2} f}{\partial \phi^{2}}+\frac{\partial^{2} f}{\partial \psi^{2}}\right)
$$

In order to complete the procedure, it is also necessary to rewrite the advection terms of Equation 5 as a function of the new coordinates Equation 13:

$u \frac{\partial f}{\partial x}+v \frac{\partial f}{\partial y}=u\left(u \frac{\partial f}{\partial \phi}-v \frac{\partial f}{\partial \psi}\right)+v\left(v \frac{\partial f}{\partial \phi}+u \frac{\partial f}{\partial \psi}\right)=\left(u^{2}+v^{2}\right) \frac{\partial f}{\partial \phi}+(u v-v u) \frac{\partial f}{\partial \psi}$

Finally, the advection-diffusion equation for the steady state can be explained as a function of the new coordinate system. Equating the two sides in Equation 12 and Equation 13 and dividing by $\left(u^{2}+v^{2}\right)$, Equation 5 is thus rewritten as a function of curvilinear coordinates Equation 14:

\section{IPABH}


$\frac{\partial f}{\partial \phi}=D\left(\frac{\partial^{2} f}{\partial \phi^{2}}+\frac{\partial^{2} f}{\partial \psi^{2}}\right)$

The Equation 14, that describes the bi-dimensional model, can be solved by using Bäcklund (Polyanin and Zaitzev, 2004) and Fourier transformations (Spiegel, 1976). However, in this study, due to the restricted number of experimental data, we will consider the onedimensional problem.

\subsection{One-dimensional Model}

In the case of narrow or slow-flow rivers, as soon as the concentration distribution reaches the steady state the cross profile will be homogenized. Therefore, the diffusion term in this direction, $\left(\frac{\partial^{2} f}{\partial \psi^{2}}\right)$, can be neglected and the model will become one-dimensional, described through the ordinary differential Equation 15:

$\frac{d f}{d \phi}=D \frac{d^{2} f}{d \phi^{2}}$

Solving Equation 16 by the method of separation of variables and a second integration, the result is:

$f(\phi)=b_{0}+c_{o} e^{\frac{\phi}{D}}$

In this solution $b_{0}$ represents a constant buffer, namely, the minimum value of concentration that the substance of interest will reach, which can be considered null for nonconservative pollutants, since for these the concentration $C$ will fall to zero when $\phi \rightarrow-\infty$ in the absence of new sources. The constant $c_{0}$ represents the initial concentration of the contaminant at the point of discharge.

Reacting the solution obtained by Equation 17 to the solution of the kinetic equation given by Equation 4, we obtain:

$C=c_{0} e^{\left(\frac{\phi}{D}-k t\right)}$

Expression Equation 17 results in the concentration of the pollutant downstream from the point source given that the initial concentration of the pollutant and its velocity profile in the stretch are known.

\section{RESULTS AND DISCUSSION}

\subsection{Experimental data}

In order to validate the proposed solution, experimental data were used (Nascimento and Naime, 2009). The data were collected at the source, main body and mouth of the Pampa Creek, an affluent of the Sinos River, shown in Figure 1. The Sinos River supplies approximately 97\% of the urban population of the city of Novo Hamburgo in Rio Grande do Sul, Brazil (COMUSA, 2015). This city has an estimated population of 249,113 inhabitants (IBGE, 2017). Pampa Creek receives a domestic load from a region with approximately $40 \%$ of the total population of the city (Novo Hamburgo, 2017). Their effluents are discharged in the stream without any treatment, subsequently flowing into the Sinos River for about $1.5 \mathrm{~km}$ to the water collection point for treatment and subsequent public distribution for the city.

Point P1, located at the source of the Pampa Creek, has been taken as the starting point of the particles. Point P2, located midstream the course of Pampa is $3919 \mathrm{~m}$ away from P1, as well as P3, the mouth of the creek, which is located at $7669 \mathrm{~m}$ away from P1. Point P4, on the Sinos 
River, located next to the raw water pumping station of the water treatment plant is $1668 \mathrm{~m}$ downstream of P3.

Although the model described here has the ability to change the geometry under study, once the coordinate system has been modified, we intend to validate the results based on the one-dimensional approach given by Equation 17. For validation of the two-dimensional solution, Equation 14, it is necessary to obtain a more robust amount of data, such as pollutant concentration and velocity in more than one line along the water body.
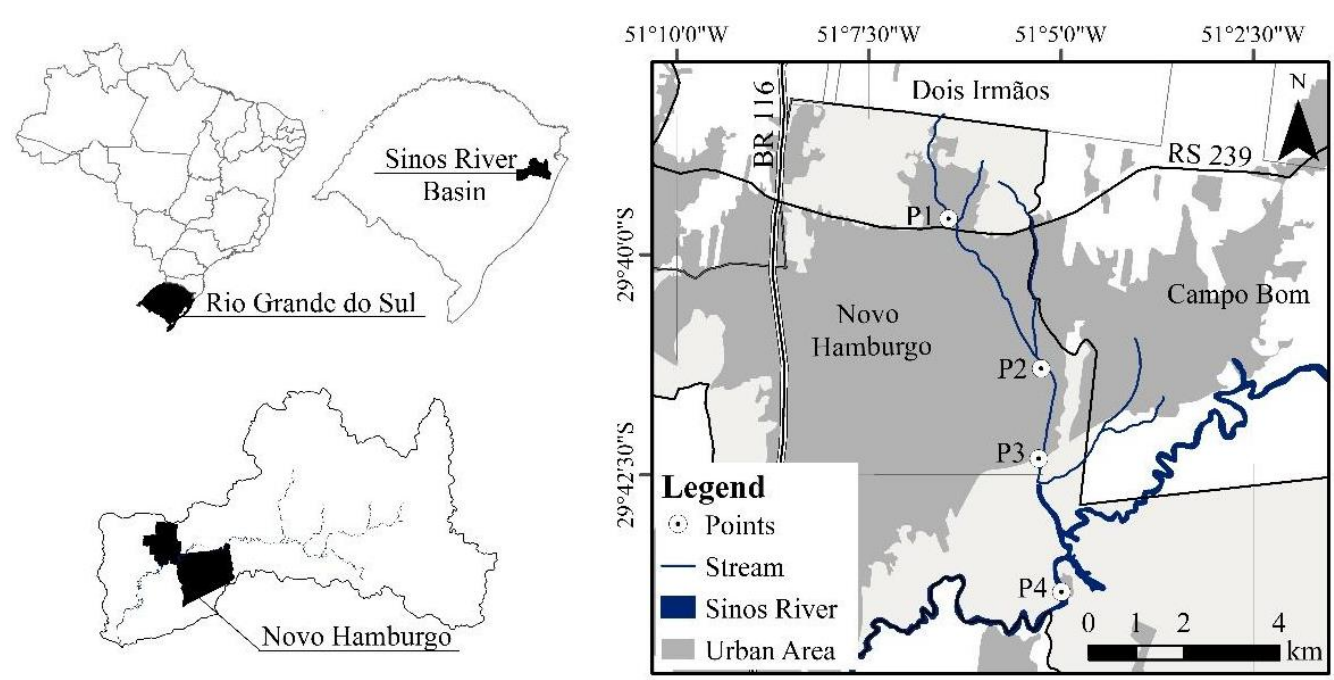

Figure 1. Pampa creek's location and data collection points.

The next figures show that the expression found as a problem solution (Equation 17) is experimental data adherent. The mean values for the thermotolerant coliforms measured from May 2006 to August 2006, and from January 2007 to March 2007, are presented, respectively, in Figures 2 and 3. We choose these periods because they had a similar precipitation profile. The samples were collected at the source of the Pampa Creek (P1), midstream along the course (P2), at the mouth of the brook (P3) and at the raw water collection point for water treatment in the Sinos River (P4), on eight different dates, at the four points of interest. The mean values show that the profile of coliform concentration from the data collected experimentally presents exponential decay, as suggested by the solution.

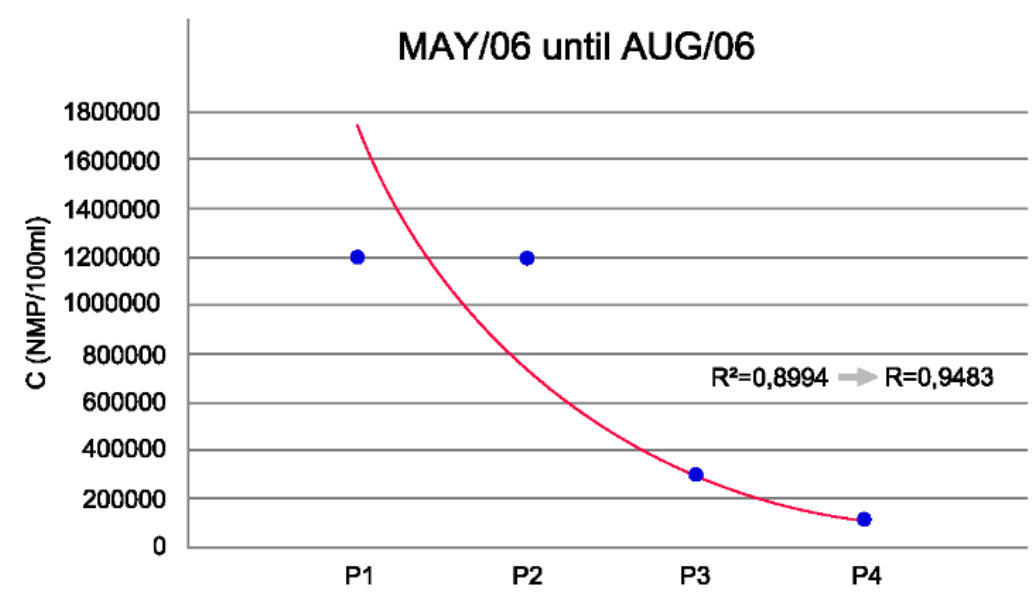

Figure 2. Average coliform concentration profile, from May to August 2006 at the 4 sampling points.

\section{IPABH}




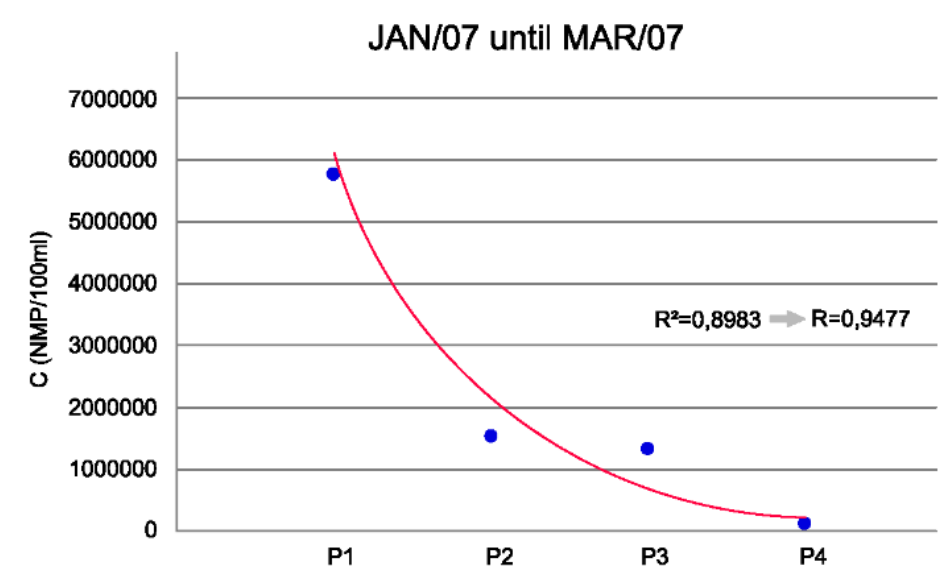

Figure 3. Average coliform concentration profile, from January to March 2007 at the 4 sampling points.

\subsection{Velocity Potentials}

The hydraulic variables are directly related to the watercourse flow. Thus, during rainy periods, and more frequently throughout autumn and winter, in this region of the country the flow velocity increases, as well as the level of the watercourse. Consequently, the depth and width of the water resource, along with the drainage area, increase.

The velocities at the four points selected for this study were obtained with the Flo-Mate ${ }^{\mathrm{TM}}$ portable speed meter Model 2000. Monthly measurements were performed at each of the points and are described in Tables 1,2 and 3. The mean velocity was used in each point and period of interest.

At the raw water collection point by the Municipal Company of Sanitation of Novo Hamburgo (COMUSA), P4, the mean velocity of the watercourse was used for the spring/summer period, which was measured at $0.37 \mathrm{~m} / \mathrm{s}$, and for the fall $/$ winter period, $0.69 \mathrm{~m} / \mathrm{s}$.

The $\phi(x)$ coordinate values were calculated at each point and date considering the mean value of flow velocity, $\underline{u}$, by the definition of the velocity potential (Equation 18):

$\phi(x)_{i}=\alpha \int_{0}^{-X_{i}} \bar{u} d x$

In Equation 18, $\alpha=10^{-4}$ represents a dimensionless correction value at the order of magnitude of the velocity to contemplate the effect that the stirring of the liquid mass exerts on the velocity measurement float, since it moves in all directions in very short intervals of time. This effect causes considerable amplifications on the diffusion coefficient as it promotes an essentially isotropic mixture when the shells formed on the surface of the water rise and fall alternately. Thus, it is not necessary to calculate the effective distance traveled over time accumulating the projections of the velocity vector on the main direction of the flow. The diffusion coefficient for the stagnant water (Brownian motion), for which the order of magnitude is 0.000001 (Bird et al., 2002), is then divided by the diffusion coefficient estimated by means of an oscillatory model derived from Navier-Stokes equations (model Korteweg-de Vries), the value of which is approximately 0.01 (Garcia et al., 2009). Thus, this quotient is on the order of $10^{-4}$. Note that this quotient equals the product between the instantaneous velocity and half of the mean free course.

Table 1. Measured velocity and velocity potentials at P1.

\begin{tabular}{lcccccccc}
\hline Period & May/06 & Jul/06 & Aug/06 & Oct/06 & Nov/06 & Jan/07 & Mar/07 & May/07 \\
\hline$\underline{u}(\mathrm{~m} / \mathrm{s})$ & 0.081 & 0.10 & 0.175 & 0.149 & 0.134 & 0.062 & 0.154 & 0.12 \\
$\phi(x)\left(\mathrm{m}^{2} / \mathrm{s}\right)$ & 0 & 0 & 0 & 0 & 0 & 0 & 0 & 0 \\
\hline
\end{tabular}


Table 2. Measured velocity and velocity potentials at $\mathrm{P} 2$.

\begin{tabular}{ccccccccc}
\hline Period & May/06 & Jul/06 & Aug/06 & Oct/06 & Nov/06 & Jan/07 & Mar/07 & May/07 \\
\hline$\underline{u}(\mathrm{~m} / \mathrm{s})$ & 0.23 & 0.102 & 0.376 & 0.326 & 0.392 & 0.367 & 0.394 & 0.39 \\
$\phi(x)\left(\mathrm{m}^{2} / \mathrm{s}\right)$ & -0.0966 & -0.03997 & -0.1435 & -0.1279 & -0.15391 & -0.14393 & -0.15441 & -0.15284 \\
\hline
\end{tabular}

Table 3. Measured velocity and velocity potentials at P3.

\begin{tabular}{ccccccccc}
\hline Period & May/06 & Jul/06 & Aug/06 & Oct/06 & Nov/06 & Jan/07 & Mar/07 & May/07 \\
\hline$\underline{u}(\mathrm{~m} / \mathrm{s})$ & 0.03 & 0.456 & 0.28 & 0.4518 & 0.063 & 0.221 & 0.242 & 0.18 \\
$\phi(x)\left(\mathrm{m}^{2} / \mathrm{s}\right)$ & -0.02301 & -0.34971 & -0.21473 & -0.3465 & -0.04875 & -0.16948 & -0.18559 & -0.13804 \\
\hline
\end{tabular}

\subsection{Coefficient of diffusion}

In the absence of any other characteristic that might make the probability of a molecule to migrate from one point to another be different for each direction of propagation of the pollutant, it is safe to assume that the diffusion coefficient is a constant value. Thus, the coefficient of diffusion by surface oscillation in microscale, $D$, was given by the quotient between the mean free courses and double the period between successive molecular collisions, in which $D=0.25 \mathrm{~m}^{2} / \mathrm{s}$ (Garcia et al., 2009).

\subsection{Coefficient of velocity}

The coefficient of velocity, $k$, presented in the model referring to the kinetics of bacterial and chemical pollutants decay, is indirectly dependent on the position and on the time variable. This dependency is due to the velocity constant being influenced by factors that can vary both in space and time, such as temperature, turbulence and wind incidence, which cause oscillations on the surface of the water body, in addition to the pollutant concentration itself.

For the determination of , the data for the calculation of another coefficient, T90, was used. This coefficient was obtained through laboratory assays and measures the time required to reduce the level of bacteria present in water by $90 \%$, i.e., to reduce the concentration to $10 \%$ of the original value at the point of emission. In the experiment (Lersch et al., 2013), this reduction occurred in $48 \mathrm{~h}$, which, based on the solution of the first order differential equation that describes the degradation kinetics, allowed us to estimate that the rate constant in $k=-0.0479$.

\subsection{Time}

The time has been calculated based on the distance that the particle traveled in each section and the mean velocity obtained experimentally. For each section, on each different date, the mean travel time was calculated. Given the ease of calculation by the reader and the great amount of information, no further explanations on this specific topic will be given, since there are eight different dates and four different points of the course evaluated.

\subsection{Simulations}

By using all the described data, it was possible to simulate the dispersion of thermotolerant coliforms based on the hypothesis that they are discharged at a specific location in the Pampa Stream and dispersed along its course.

The results of the simulations are presented on the different dates in which the samples were collected. Point P1 was taken as a source of pollutant discharge near the source of the stream and the amount of coliforms remaining at point P2 (midstream) was then simulated. Figure 4 presents the results obtained in the simulations and the measured values distributed in a scatter plot. In this graph, the complete agreement of the results with the experimental data is not shown, since this area is a highly urbanized zone, so point P1 is certainly not the only source of load in this stretch. 


\section{P1-P2}

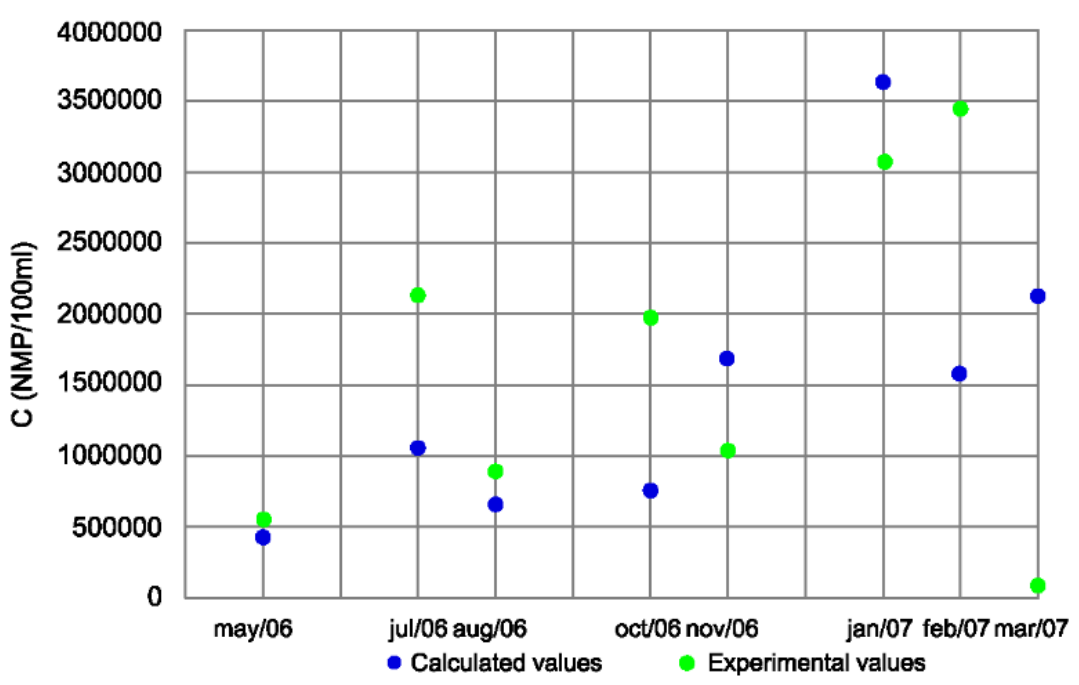

Figure 4. Experimental and simulated data. Discharge influence of $\mathrm{P} 1$ in $\mathrm{P} 2$.

Considering P2 as a point source of discharge, the amount of thermotolerant coliforms remaining at point $\mathrm{P} 3$, that is, at the mouth of the stream, was simulated. This result was presented in Figure 5, which shows a better agreement of the data obtained through the simulation and the values measured experimentally, due to the order of magnitude of the parameter involved.

\section{P2-P3}

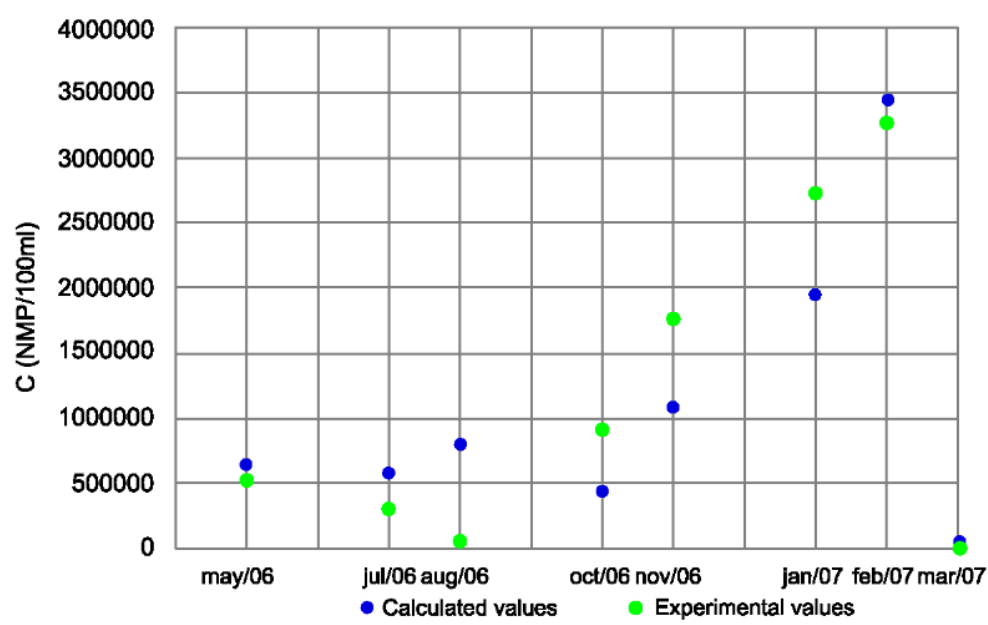

Figure 5. Experimental and simulated data. Discharge influence of $\mathrm{P} 2$ in $\mathrm{P} 3$.

The stretch from the mouth of the Pampa Creek (P3) to the point of water collection for treatment in the Sinos River (P4) is not urbanized, so there is no discharge point in between these places. Thus, all coliforms arriving at $\mathrm{P} 3$ were considered as input data and the remaining value at $\mathrm{P} 4$ was simulated, as shown in Figure 6. However, although the results obtained in the simulations were expected to agree almost totally with experimental data, the expected results were not verified on three of the dates. This is due to the input of water from the Sinos River near the mouth of the Pampa Creek, which impacts the poor quality of the experimental data obtained and, consequently, on the simulations. Given all hypothesis constraints imposed to the model performed, the reality hasn't reflected, at all. 


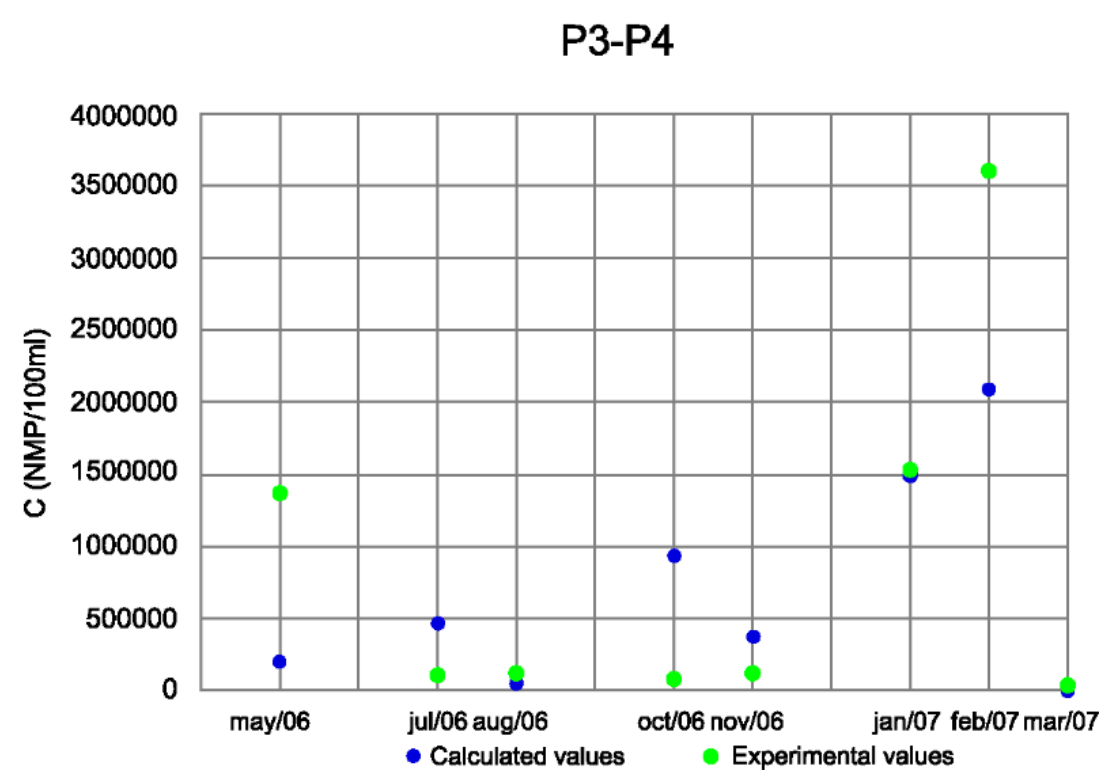

Figure 6. Experimental and simulated data. Discharge Influence ofP3 in $\mathrm{P} 4$.

The points P1, P2 and P3 are in the same watercourse, the Pampa Stream, whereas P4 is located in the course of the Sinos River, where the water flow and velocity change considerably. Thus, the difference between the calculated values and the respective experimental data is basically due to two causes of error: flow inversion and considerable fluctuations in the velocity field. Both factors are observed, frequently in periods of high flow rates, as was the case when experimental data were obtained. Since the hydrodynamic model employed considers the flow to be potential, implicitly the hypothesis of steady state is assumed. Therefore, any perturbation that produces transients in the velocity field had been neglected in the proposed model. Moreover, even the most refined hydrodynamic formulations based on the Navier-Stokes and Helmholtz equations (Bird et al., 2002; Mott, 2006) produce equally disparate results, since it is not possible to reproduce such fluctuations with fidelity, but only to estimate their amplitudes and frequencies in a relatively coarse manner. Haghiabi et al. (2018) examining models of artificial neural networks (ANN) and support vector machine (SVM), showed that all of them had some over-estimation properties. In short, the simplified hydrodynamic model is, in practice, as realistic as the finer formulations in fluid mechanics, even though they contemplate turbulence models.

In order to enable the analysis of the agreement of the results with the experimental data, both data were contrasted in dot cloud graphs, shown in Figure 7 and Figure 8. The bisecting line $y=x$, was plotted, in which the correlation coefficient was above $80 \%$, thus evidencing that the data are correlated.

\section{CONCLUSIONS}

The results obtained in this work are qualitatively consistent with the behavior of the phenomenon and relatively concordant from the quantitative point of view, proving the feasibility of the proposed solution. Even if some divergence is present, at least two main reasons could be listed. First, there may be regions where the cross stratification of the concentration profile is not negligible, whereas sampling may have been done in different flow lines, and such precision is not attainable experimentally. Second, the adoption of a constant mean velocity in each modeled portion could have caused a insignificant error in the calculation.

\section{IPABH}




\section{Relation P2 in P3}

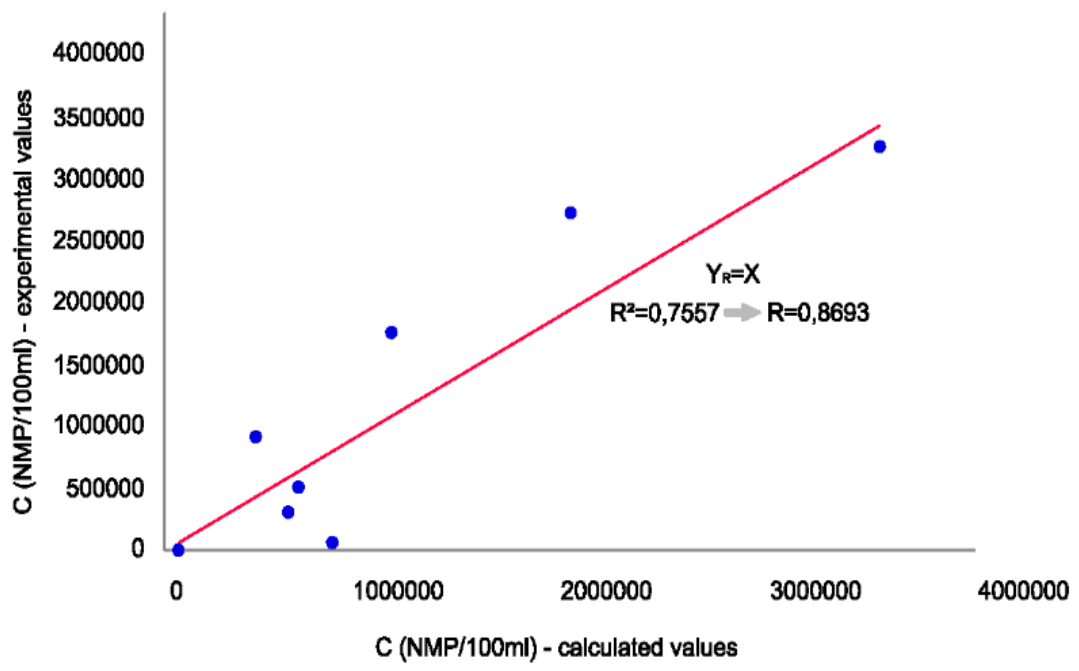

Figure 7. Distribution of the results around the bisector. Influence of $\mathrm{P} 2$ in $\mathrm{P} 3$.

\section{Relation P3 in P4}

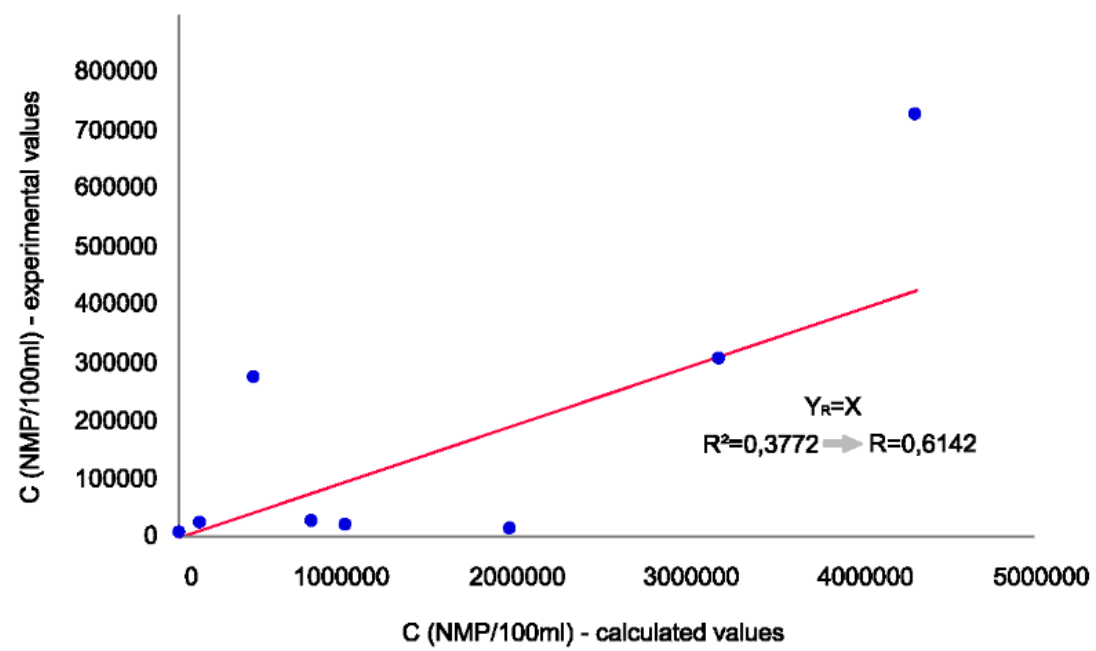

Figure 8. Distribution of the results around the bisector. Influence of $\mathrm{P} 3$ in $\mathrm{P} 4$.

However, despite the limitations of this preliminary analysis, the overall trend displayed by the complete set of numerical results agrees well with the experimental data given the proportion of order of magnitude involved. Considering that a deterministic model was proposed, while the studied phenomenon is strongly influenced by stochastic factors, a certain difference is not only expected but also perfectly understood due to the different characteristics of the data.

Once results had been obtained for the one-dimensional model, it seems reasonable to assume that the use of a two-dimensional model will refine the estimates. This assumption has been based on the possibility of reducing, for example, the potential error generated by not considering the different flow lines of each section. Thus, the authors intend to implement simulations of the two-dimensional model based on the solution of Equation 14 proposed in this study as soon as new experimental data of concentration and velocity are obtained in different flow lines along the water body. 


\section{REFERENCES}

BIRD, R. B.; STEWART, W. E.; LIGHTFOOT, E. N. Transport Phenomena. $2^{\text {nd }}$ ed. New York: John Wiley \& Sons, 2002.

COMPANHIA MUNICIPAL DE SANEAMENTO DE NOVO HAMBURGO/RS - COMUSA. Economias abastecidas pela Comusa aumentam 7\% nos últimos cinco anos. 2015. Available in: https://goo.gl/nD4tLN. Access: 21 Apr. 2017.

COTTA, R. M. Integral Transforms in Computational Heat and Fluid Flow. Boca Raton: CRC Press, 1993.

CRANK, J. The Mathematics of Diffusion. $2^{\text {nd }}$ ed. Bristol: Oxford University Press, 1975.

FERNANDEZ, L. C. Simulação da propagação de poluentes utilizando transformação de Backlund: modelo bidimensional. 2007. Dissertação (Mestrado em Engenharia Mecânica) - Universidade Federal do Rio Grande do Sul, Porto Alegre, 2007.

GARCIA, R. L.; ZABADAL, J.; RIBEIRO, V.; POFFAL, C. Definição do coeficiente de difusão para propagação de poluentes em águas rasas empregando um modelo baseado em soluções exatas para a equação de Korteweg-de Vries. Vetor, v. 19, n. 1, p. 15-27, 2009.

GOMES, S. H. R., SIQUEIRA, T. M.; GUEDES, H.; ANDREAZZA, R.; HUFFNER, A. N.; CORREAA, L. Modelagem sazonal da qualidade da água do Rio dos Sinos/RS utilizando o modelo QUAL-UFMG. Engenharia Sanitária e Ambiental, v. 23, p. 275-285, 2018.

GUERRERO, J. S.; PIMENTEL, L.; SKAGGS, T.; GENUCHTEN, M. Analytical solution of the advection-diffusion transport equation using a change-of-variable and integral transform technique. International Journal of Heat and Mass Transfer, v. 52, p. 3297 3304, 2009.

HAGHIABI, A. H. Prediction of longitudinal dispersion coefficient using multivariate adaptive regression splines. Journal of Earth System Science, v. 125, n. 5, p. 985-995, 2016.

HAGHIABI, A. H. Modeling River Mixing Mechanism Using Data Driven Model. Water $\begin{array}{lllllll}\text { Resources Management, } & \text { v. 31, n. 3, p. 811-824, }\end{array}$ http://dx.doi.org/10.1007/s11269-016-1475-7

HAGHIABI, A. H.; NASROLAHI, A. H.; PARSAIE, A. Water quality prediction using machine learning methods. Water Quality Research Journal, v. 53, n. 1, 2018. http://dx.doi.org/10.2166/wqrj.2018.025

IBGE. Infográficos: evolução populacional e pirâmide etária. 2017. Available in: https://goo.gl/zEUMpm. Access: 21 Apr. 2017.

KAMBE, T. Elementary Fluid Mechanics. Singapore: World Scientific Publishing, 2007.

JOBIM, G. S. Dispersão de poluentes: simulação numérica do Lago Guaíba. 2012. TCC (Graduação em Engenharia Civil) - Departamento de Engenharia Civil, UFRGS, Porto Alegre, 2012.

LERS.CH, E. C.; HOFFMANN, C. X.; ROSMAN, P. C. Relatório complementar de avaliação do impacto ambiental do projeto socioambiental ETE Serraria. Aplicação de Modelos Matemáticos Transientes. Porto Alegre: DMAE, 2013.

\section{IPABH}

Rev. Ambient. Água vol. 14 n. 2, e2298 - Taubaté 2019 
MIKHAILOV, M. D.; OZISIK, M. N. Unified Analysis and Solutions of Heat and Mass Diffusion. New York: John Wiley \& Sons, 1984.

MOTT, R. Applied Fluid Mechanics. $6^{\text {th }}$ ed. New Jersey: Prentice Hall, 2006.

NASCIMENTO, C.; NAIME, R. Monitoramento físico-químico das águas do Arroio Pampa em Novo Hamburgo/RS. Estudos Tecnológicos, v. 5, n. 2, p. 245-269, 2009.

NOVO HAMBURGO. Prefeitura Municipal. Estudos de concepção e projetos básicos de requalificação urbana e ambiental da sub-bacia do arroio Pampa - Novo Hamburgo - RS. 2017. Available in: https://goo.gl/VTLLUi. Access: 21 Nov. 2017.

PARSAIE, A.; HAGHIABI, A. H. Computational Modeling of Pollution Transmission in Rivers. Applied Water Science, v. 7, n. 3, p. 1213-1222, 2017. http://dx.doi.org/10.1007/s13201-015-0319-6

PARSAIE, A.; EMAMGHOLIZADEH, S.; AZAMATHULlA, H. M.; HAGHIABI, A. H. ANFIS-based PCA to predict the longitudinal dispersion coefficient in rivers. International Journal of Hydrology Science and Technology, v. 8, n. 4, p. 410-424, 2018. http://dx.doi.org/10.1504/IJHST.2018.095537

POLYANIN, A.; ZAITZEV, V. Handbook of Nonlinear Partial Differential Equations. Boca Raton: Chapman \& Hall/CRC, 2004.

QISHLAQI, A.; KORDIAN, S.; PARSAIE, A. Hydrochemical evaluation of river water quality - a case study. Applied Water Science, n. 7, p. 2337-2342, 2017. http://dx.doi.org/10.1007/s13201-016-0409-0

ROSMAN, P. C. C.; MASCARENHAS, F. C.; MIGUEZ, M.; CAMPOS, R.; EIGER, S. Um sistema computacional de hidrodinâmica ambiental. In: ABRH. Métodos Numéricos em Recursos Hídricos. vol. 5. Rio de Janeiro, 2009.

SANSKRITYAYN, A.; KUMAR, N. Analytical solution of advection-diffusion equation in heterogeneous infinite medium using Green's function method. Journal of Earth System Science, v. 125, p. 1713, 2016. https://doi.org/10.1007/s12040-016-0756-0

SPIEGEL, M. R. Fourier Analysis. New York: McGraw-Hill Publications, 1976.

ZABADAL, J. R.; RIBEIRO, V. Equações diferenciais para engenheiros: uma abordagem prática. Porto Alegre: UniRitter, 2012. 


\begin{tabular}{|c} 
Ambiente \& Água - An Interdisciplinary Journal of Applied Science \\
ISSN 1980-993X - doi:10.4136/1980-993X \\
www.ambi-agua.net \\
E-mail: ambi.agua@gmail.com
\end{tabular}

\title{
Potential for biogas generation from sweet potato genotypes
}

\author{
ARTICLES doi:10.4136/ambi-agua.2317
}

Received: 22 Aug. 2018; Accepted: 18 Dec. 2018

\author{
Samantha de Paula Batista ${ }^{1 *}$; Edson Perez Guerra ${ }^{2}$; \\ Juliano Tadeu Vilela de Resende ${ }^{2}$; ; Matheus Vitor Diniz Gueri ${ }^{3}{ }^{(D}$; \\ Guilherme Campos Carvalho ${ }^{\oplus}$; Jessica Naiara dos Santos Crestani2 ${ }^{\circledR}$; \\ Israel Felipe Lustosa da Silva ${ }^{2}$ iD

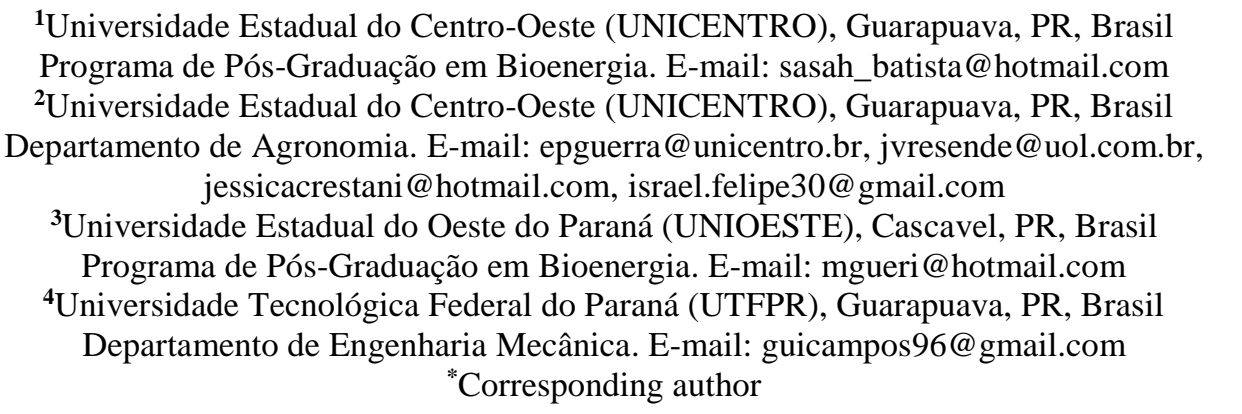

\section{ABSTRACT}

Biogas is a technology that enables the generation of energy through the process of anaerobic biodigestion, and sweet potato is an option as an energy production source. This research evaluated biogas production in anaerobic biodigesters and characterized the physicochemical composition of two commercial sweet potato cultivars, BRS Cuia and BRS Rubissol, and two genotypes, Bela Vista and Laranjeiras. Variance analysis, the Tukey test and the physical-chemical characterization were completed, and the results were correlated using principal component analysis (PCA). In the analyses of tuberous root composition, significant differences between the genotypes were observed because of the influence of the absorption of moisture, decomposition, and variations in the yield and quality of roots. For the biochemical methane potential (BMP) test, the estimate of biogas production was 2,906.5 liters ha-1 for the cultivar BRS Cuia, 2,712.4 liters ha ${ }^{-1}$ for Laranjeiras, 2,906.5 liters ha ${ }^{-1}$ for BRS Rubissol, and 398,2 liters ha ${ }^{-1}$ for Bela Vista. The PCA analysis of sweet potato genotypes, physical-chemical and agronomic parameters showed all genotypes have a direct correlation with the amount of reducing sugars and humidity, with $97.77 \%$ of the data variability explained. The Laranjeiras genotype has the most significant potential to produce biogas, followed by the BRS Cuia cultivar. The results emphasize that the sweet potato crop is a good source of biomass for energy generation.

Keywords: biodigester, bioenergy, Ipomoea batatas L.

\section{Potencial de geração de biogás de genótipos de batata-doce}

\section{RESUMO}

O biogás é uma tecnologia que possibilita a geração de energia através do processo de biodigestão anaeróbia, sendo uma opção a produção a partir de batata-doce como fonte 
energética. A presente pesquisa teve por objetivo avaliar a produção de biogás em biodigestores anaeróbios de bancada, caracterizar os parâmetros físico-química das cultivares de batata-doce BRS Cuia e BRS Rubissol e dos genótipos Bela Vista e Laranjeiras. Foi feita análise de variância, teste Tukey e correlação com a caracterização físico-química dos genótipos por análise de componentes principais (ACP). A partir das análises da composição das raízes tuberosas, foram observadas diferenças significativas entre os genótipos, devido a influência na absorção da umidade, decomposição, ocorrendo variações na produtividade e qualidade das raízes. Para os ensaios do potencial bioquímico de metano (BMP - biochemical methane potential) a estimativa de produção de biogás foi de $2.906,5 \mathrm{~L} \mathrm{ha}^{-1}$ para a cultivar BRS Cuia e de 2.712,4 L ha ${ }^{-1}$ para Laranjeiras, de 2906,5 L ha ${ }^{-1}$ para BRS Rubissol e de 398,2 $\mathrm{L} \mathrm{ha}^{-1}$ para Bela Vista. A partir da ACP com a produção de biogás dos genótipos de batata-doce, dos parâmetros físico-químicos e agronômicos, foi possível identificar que todos os genótipos têm correlação direta com a quantidade de açúcares redutores e umidade, com explicação de 97,77\% da variabilidade dos dados, e que o genótipo Laranjeiras foi o que apresentou maior potencial significativo em produzir biogás, seguido da BRS Cuia. Diante dos resultados obtidos enfatizase a cultura da batata-doce como fonte de biomassa para a geração de energia.

Palavras-chave: biodigestor, bioenergia, Ipomoea batatas L.

\section{INTRODUCTION}

The sweet potato (Ipomoea batatas L.) is a herbaceous plant native to Central and South America. It is adapted to the tropical and subtropical climate, presenting favorable characteristics such as low production cost, resistance to pests, wide adaptation in degraded soils, prolonged harvest, being considered a rustic crop (Miranda et al., 1995; Silva et al., 2008; Stathers et al., 2013).

Biomass is a renewable source of energy that can generate heat, electricity and biofuels (McKendry, 2002). With the expansion of clean and renewable energy, the production of biofuel from the biomass of several crops has been used, since they contain high content of organic matter from the carbohydrates (sugars and starches) stored (Brasil, 2015). Among the biomass used are: sugarcane, corn, oats, manioc, castor bean, pine, sugar beet, sunflower, potato (Silveira, 2008).

The sweet potato genotypes differ in many aspects, such as root structure, root shape, reserve root bark color, pulp color, flavor, texture, resistance to pests and yields (Borém, 2005). These characteristics are important in deciding which variety to use for trade and for other processing (Stathers et al., 2013).

In the harvest period of the sweet potato, losses of tuberous root can occur in the field, in the process of washing, grading, packaging and transport, or even in market wholesale, retail and with the consumer. When the tuberous root is considerably depreciated and does not meet the aesthetic standards of market quality, such as showing small or very large deformities, part of the harvest is destined to animal feed or become waste and is sent to landfills or even left in the field (Chitarra; Chitarra, 2005). One way to take advantage of these sweet potato tailings would be to use their biomass energetically through the anaerobic process to obtain biogas (Brasil, 2015).

Sweet potatoes have high potential as an energy source in the production of ethanol and biogas. In an experiment conducted at a small industrial plant in Palmas, Tocantins, Brazil, Silva et al. (2018) obtained a high yield of sweet potato bioethanol of $161.4 \mathrm{~L} \mathrm{t}^{-1}$ corresponding to $10,598 \mathrm{~L} \mathrm{ha}^{-1}$, based on the productivity of $65.5 \mathrm{t} \mathrm{ha}^{-1}$ of the evaluated cultivar. They considered the result $46 \%$ superior to the ethanol yield of sugarcane, $34 \%$ superior to that of 
sugar beet and $149 \%$ superior to that of corn ethanol. For biogas production, however, research work is needed to determine the potential for energy production from the sweet potato.

The process of anaerobic bio-digestion is the biological conversion of organic matter in the absence of oxygen. There are four phases: hydrolysis, acidogenesis, acetogenesis and methanogenesis transforming into biogas, consisting mainly of methane and carbon dioxide. This process occurs in biodigesters, structures designed and constructed from a closed chamber where the organic material is deposited and undergoes decomposition, generating the biogas (Yu; Schanbacher, 2010; Zhang et al., 2018).

In Brazil the most-used models of biodigesters are the Indian, tubular and Chinese, considered the oldest of those for agricultural use. With the use of biodigesters in expansion, several models have been proposed and the technology is being adapted to the needs of the field and for sanitary treatment (Deganutti et al., 2002).

In this context, biogas is a technology that enables solutions to problems such as the production of alternative energy, the safe management of human, animal, municipal and industrial waste and the control of environmental contamination (Xumeng et al., 2014).

\section{MATERIALS AND METHODS}

The BRS Cuia and BRS Rubissol sweet potato cultivars developed by Embrapa Clima Temperado (Pelotas, RS) and the Bela Vista and Laranjeiras genotypes were selected for the experiment and come from the germplasm bank of the Horticulture Research Center.

Samples of the four sweet potato genotypes were placed in a drying oven at $60^{\circ} \mathrm{C}$ for approximately eight hours. Flour was obtained by grinding and sieving, and stored in polyethylene bags packed in a vacuum to avoid contamination. The characterization parameters were moisture, acidity, $\mathrm{pH}$, starch, and reducing sugars for sweet potato genotypes (Cecchi, 2003; IAL, 2008).

The presence of inoculum benefits the biodigestion process of the raw material, improving the methane content in the biogas composition (Xavier et al., 2010; Hassan et al., 2017). Cattle manure inoculum was collected and transported in borosilicate vials and kept under refrigeration conditions at $10^{\circ} \mathrm{C}$. This material presented $72.68 \%$ humidity and $\mathrm{pH}$ of 5.93 , characterized according to AOAC (2007).

According to Azevedo (2010), it is necessary to dilute the inoculum in a solution of mineral salts in a 1:1 ratio. The mineral salt solution was prepared using $1.0 \mathrm{~L}$ of distilled water with $2.0 \mathrm{~g}$ of potassium dibasic phosphate $\left(\mathrm{K}_{2} \mathrm{HPO}_{4}\right) 20 \mathrm{~g}$ of potassium phosphate monobasic $\left(\mathrm{KH}_{2} \mathrm{PO}_{4}\right)$ and $3.5 \mathrm{~g}$ of urea $\left(\mathrm{NH}_{2} 2 \mathrm{CO}\right)$. After the addition of the salts, the solution was homogenized with the cattle manure inoculum and samples of the sweet potato genotypes were added. Subsequently, they were transferred to the biodigesters until the volume of $150 \mathrm{~mL}$ was completed for $250 \mathrm{~mL}$ glass vials.

\subsection{Laboratory tests to obtain biogas}

The anaerobic biodigesters was monitored by means of the biochemical methane potential (BMP) tests, which measure the biodegradability of organic matter through total methane production (Gueri, 2018). Nine lab bench biodigesters were used (Figure 1). 


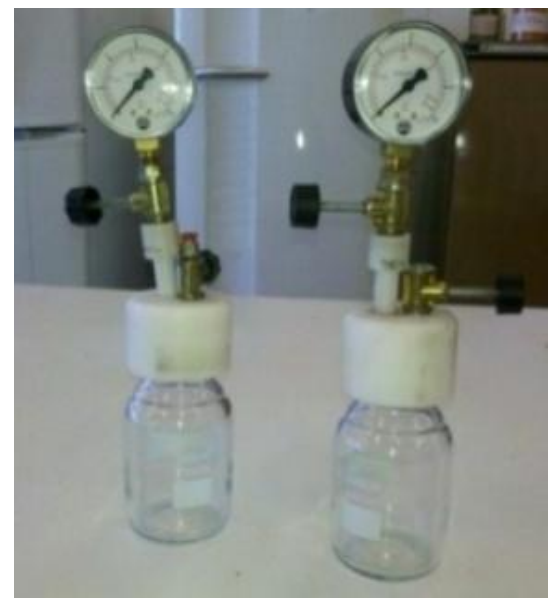

Figure 1. Bench scale anaerobic biodigesters (Personal Archive, 2016).

\subsection{Preparation of biodigesters}

The bench anaerobic biodigesters were assembled using BMP assays. Each biodigester was composed of $250 \mathrm{~mL}$ borosilicate vials, with a nylon screw cap, containing a gas outlet valve and a valve with manometer for the internal pressure monitoring (Figure 1).

Two treatments were used for the tests:

Treatment 1: Raw material + Inoculum, composed of $50 \mathrm{~g}$ of sweet potato flour inoculated with $20 \mathrm{~g}$ of bovine manure diluted in $20 \mathrm{~g}$ of salt solution;

Treatment 2: only inoculum in biodigester as control (white) composed of $20 \mathrm{~g}$ of bovine manure.

After inoculation, the moisture content obtained from the substrate with the genotypes was 83.3\% for Bela Vista, 79.18\% for Laranjeiras, $76.08 \%$ for BRS Cuia and 83.28\% BRS Rubissol. The screw caps were fixed in the vials and a stream of nitrogen gas was circulated into the headspace of each biodigester for about four minutes to ensure anaerobiosis of the medium.

\subsection{Test Monitoring BMP}

The biogas volume generated was measured by the U-liquid column type manometric method, by reading of the liquid column coupled in the biodigesters.

The experiment was installed into a BOD Illumination Incubator Automatic, with lights turned off, to have constant temperature of $36^{\circ} \mathrm{C}$, monitored daily; the local atmospheric pressure (National Institute of Meteorology - INMET) was monitored every six hours.

The internal pressure of the flasks was converted into volume of the generated biogas by Equations 1 and 2, for the different sweet potato genotypes evaluated and transformed to the normal conditions of temperature and pressure (CNTP) (Harries et al., 2001). This procedure was performed by Alves (2008), Gueri (2018), recommended by Angelidaki et al. (2009) and reported by Alzate et al. (2012).

Volume of biogas generated between $T+(T+1)=\frac{[\mathrm{PF}(\mathrm{mbar}) \cdot \mathrm{VUF}(\mathrm{L}) \cdot 22,42] \cdot 1000]}{[83,14 \cdot T F(K)]}$

Where: $\mathrm{T}=$ time $($ days $) ; \mathrm{PF}(\mathrm{mbar})=$ bottle pressure in millibar; VUF $(\mathrm{L})=$ useful volume of the bottle in liters; $\mathrm{TF}(\mathrm{K})=$ bottle temperature in Kelvin.

Volume of accumulated biogas $(m L)=[$ Generated betweenT $+(T+1)]+V G A(m L)$ 
Where: $\mathrm{T}=$ time (days); VGA $(\mathrm{mL})=$ volume of accumulated biogas from the previous day in milliliters.

\subsection{Statistical analysis}

The physico-chemical analyzes and the BMP tests of the biogas production process were submitted to Analysis of Variance (ANOVA), to the Tukey test $(p<0.05$ ) of the means significant differences, and the correlation with the physicochemical characterization of the genotypes by the principal components analysis (PCA). The statistical program Minitab17 was used.

\section{RESULTS AND DISCUSSION}

\subsection{Physico-chemical characterization}

The flour of sweet potato genotypes was characterized for physicochemical composition (Tables 1 and 2).

Table 1. Summary of physical-chemical variance analyzes of flour of sweet potato genotypes.

\begin{tabular}{lccccccc}
\hline \multicolumn{7}{c}{ Means Square } \\
\hline Variation of source & GL & Moisture & Acidity & Starch & R.S. & pH & Ashes \\
\hline Block & 2 & 0.03331 & 0.00212 & 0.02083 & 0.12 & 0.00033 & 0.19341 \\
Genotypes & 3 & $36.8768^{* *}$ & $0.0498^{* *}$ & $66.6244^{* *}$ & $2.996389^{* *}$ & $0.0123^{* *}$ & $0.7120^{*}$ \\
Residue & 6 & 0.04181 & 0.00203 & 0.1492 & 0.101667 & 0.00075 & 0.1149 \\
Total & 11 & - & - & - & - & - & - \\
CV $(\%)$ & & 2.63 & 4.69 & 1.89 & 5.99 & 0.45 & 10.90 \\
\hline
\end{tabular}

*, ** significant at the level of $5 \%$ and $1 \%$ of probability, $(\mathrm{p}<0.05)$ and $(\mathrm{p}<0.01)$, respectively; R.S. (Reducing Sugars); CV (coefficient of variation).

Table 2. Means of physical-chemical parameters in sweet potato genotypes.

\begin{tabular}{lcccc}
\hline Parameters $^{1}$ & Bela Vista & BRS Cuia & BRS Rubissol & Laranjeiras \\
\hline Moisture (\%) & $10.62 \mathrm{a}$ & $3.40 \mathrm{c}$ & $10.60 \mathrm{a}$ & $6.50 \mathrm{~b}$ \\
Acidity (\%) & $1.09 \mathrm{a}$ & $1.04 \mathrm{a}$ & $0.84 \mathrm{~b}$ & $0.85 \mathrm{~b}$ \\
pH & $5.99 \mathrm{~b}$ & $6.12 \mathrm{a}$ & $6.10 \mathrm{a}$ & $6.00 \mathrm{~b}$ \\
Starch (\%) & $53.04 \mathrm{~b}$ & $67.60 \mathrm{a}$ & $37.69 \mathrm{c}$ & $30.30 \mathrm{c}$ \\
Reducing sugars (\%) & $3.70 \mathrm{c}$ & $4.30 \mathrm{~b}$ & $2.92 \mathrm{~d}$ & $4.49 \mathrm{a}$ \\
Total sugar & $56.73 \mathrm{~b}$ & $71.90 \mathrm{a}$ & $40.61 \mathrm{c}$ & $34.79 \mathrm{c}$ \\
Ashes (\%) & $2.78 \mathrm{~b}$ & $3.17 \mathrm{ab}$ & $2.70 \mathrm{~b}$ & $3.77 \mathrm{a}$ \\
\hline
\end{tabular}

Means followed by the same letter in row do not differ statistically from each other by the Tukey test $(\mathrm{p}<0.05) ;{ }^{1} \mathrm{n}=$ three replicates.

According to the Technical Regulation for Setting Identity and Quality Standards for Tubers, the sweet potatoes samples were within the maximum range of $2.0 \%$ of titratable total acidity desirable (Table 2). So, when acidity is decreased, the fermentation intensity decreased and the processing time increased (Brasil, 1978).

The flour purity index is measured by the ash percentage. A high ash content will indicate more minerals present. The values obtained (Table 2) were similar to those found by Lima et al. (2001), with an averaged of $2.0 \%$.

According to Alves (2008), the ideal $\mathrm{pH}$ for anaerobic digestion should be in the 6.3 to 7.8 range, which demonstrates greater efficiency of the methanogenic phase. Considering the $\mathrm{pH}$ values obtained (Table 2), it was lower than ideal, and the process could be more efficient. 
The moisture obtained for the sweet potato flour (Table 2) was similar to that found by Borba et al. (2005), 8.7\%, considering an average value of the cultivars.

Sugar levels are variable due to cultivar, growing season, climate and storage time, and because the starch over time is converted to simple sugars. The values obtained in sweet potato flour (Table 2) were similar to those of Silva et al. (2008), who established values of 4.8 to $7.8 \%$ without specifying the cultivar.

The starch is the main component of dry matter of the sweet potato tuberous roots $(66.8$ $78.5 \%$ ) followed by soluble sugars $(8.2-15.3 \%)$ which represent 6.17 to $7.69 \%$ of the total dry matter (Kohyama; Nishinari, 1992). The values obtained in sweet potato flour (Table 2) were similar to those of Borba et al. (2005), who established values of $51.8 \%$ starch without specifying the cultivar.

\subsection{Assay of the biochemical potential of methane (BMP)}

After calculations (Equations 1 and 2), a biogas production profile graph was generated for each genotype over time. It is observed that they were very different from the inoculum used as control (Figure 2). The daily production of biogas varied for days of incubation and for sweet potato genotypes, making it necessary to check the production at each hour of the day, for five consecutive days.
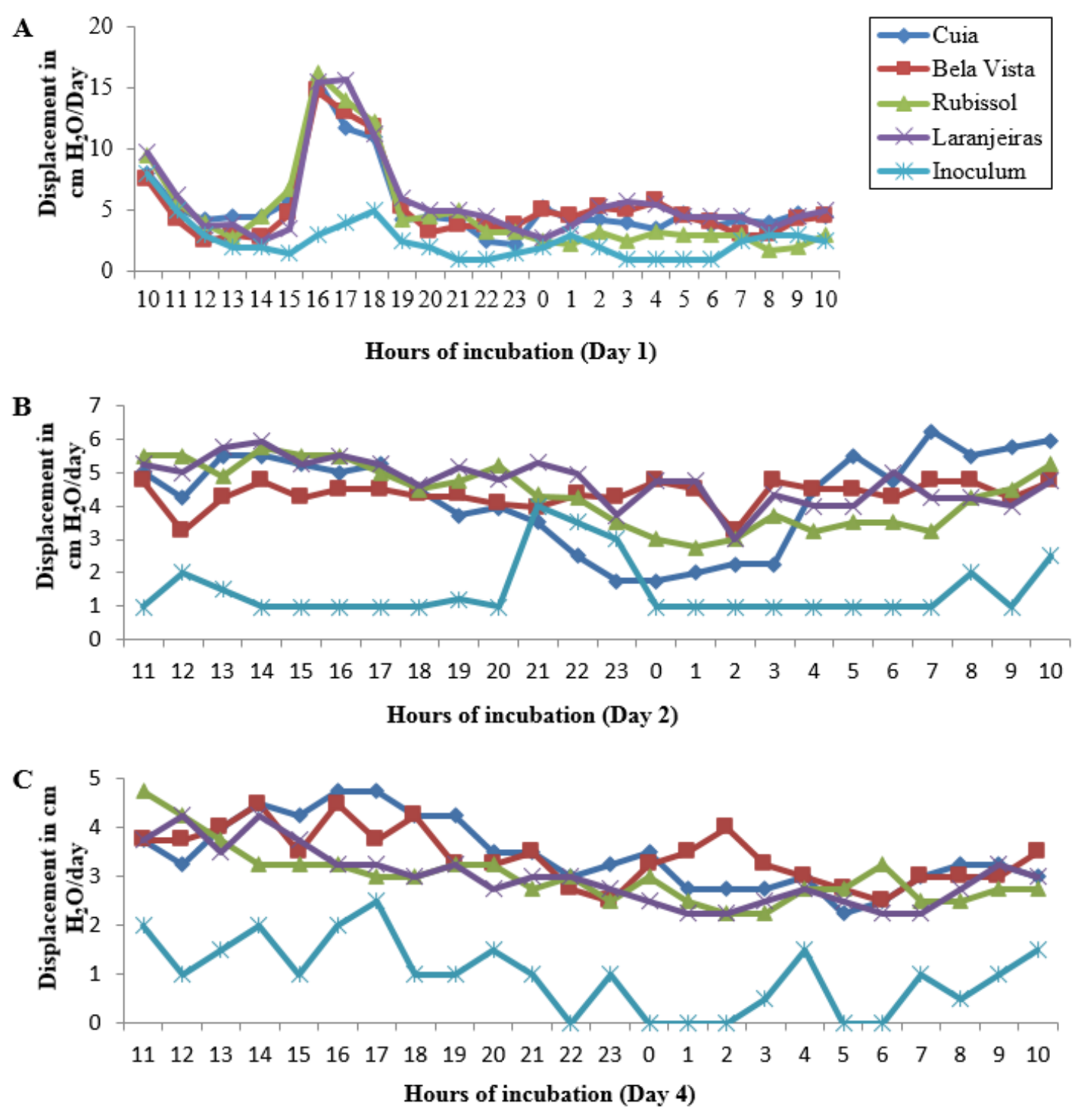

Rev. Ambient. Água vol. 14 n. 2, e2317 - Taubaté 2019 

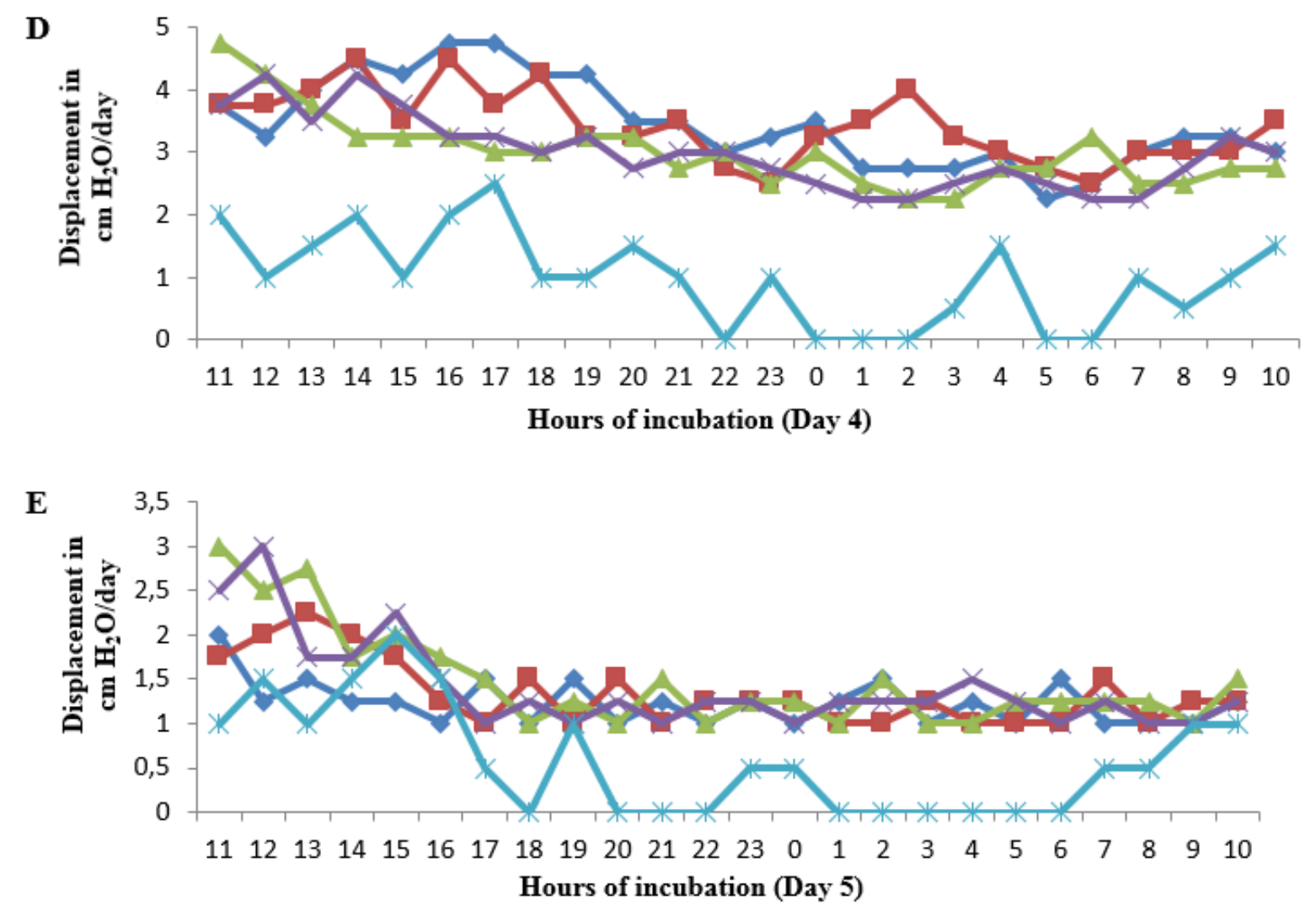

Figure 2. Profile of biogas production of sweet potato genotypes every hour from first day to fifth day (2A to $2 \mathrm{E})$.

From the inoculums incubation, there were different production peaks in the process of anaerobic biodigestion, as observed between the 16h-18h (Figure 2A), due to physicochemical factors such as $\mathrm{pH}$, sugars and atmospheric pressure. The temperature was kept constant at $\pm 36^{\circ} \mathrm{C}$.

However, it was necessary to monitor the biogas production test every hour as observed in Figures $2 \mathrm{~A}$ to $2 \mathrm{E}$, as the sweet potato undergoes the biodigestion process rapidly, consuming its simple sugars, since no hydrolysis was performed to test the carbohydrate reserve of the starch. This justifies the different displacement reading peaks that occurred each day. Schirmer et al. (2014) obtained similar results, with peak generation of biogas reached in the first five days of the experiment.

\subsection{Biogas generation}

The generated and accumulated average volume of biogas produced during the incubation period is shown in Table 3. The atmospheric pressure was measured every six hours during the test period. The values of the internal pressure of the bottles, by displacing the bubble in the hose column, were converted into the volume of biogas generated by means of Equations 1 and 2 and transformed to the normal conditions of temperature and pressure (CNTP).

The maximum daily rate of biogas production was reached on the first monitoring day (Figure 3A); this chart shows the daily accumulated biogas volume of the four sweet potato genotypes and for the inoculum (control).

\section{IPABH}


Table 3. Biogas production of sweet potato genotypes with water column displacement measurement every hour for five days, with calculation of CNTP.

\begin{tabular}{|c|c|c|c|c|c|c|}
\hline \multirow[b]{2}{*}{ Day } & \multicolumn{6}{|c|}{ Biogas production } \\
\hline & $\begin{array}{c}\mathrm{SDC} \\
\left(\mathbf{c m ~ \mathrm { H } _ { 2 } \mathrm { O } )}\right)\end{array}$ & $\begin{array}{c}\text { CNTP } \\
\text { Ger. }(\mathrm{mL})\end{array}$ & $\begin{array}{c}\text { CNTP } \\
\text { Ac. }(\mathbf{m L})\end{array}$ & $\begin{array}{c}\mathrm{SDC} \\
\left(\mathbf{c m ~ \mathrm { H } _ { 2 } \mathrm { O } )}\right)\end{array}$ & $\begin{array}{c}\text { CNTP } \\
\text { Ger. (mL) }\end{array}$ & $\begin{array}{c}\text { CNTP } \\
\text { Ac. }(\mathrm{mL})\end{array}$ \\
\hline & \multicolumn{3}{|c|}{ BRS Cuia } & \multicolumn{3}{|c|}{ BRS Rubissol } \\
\hline 1 & 135.85 & 9.80 & 9.80 & 125.60 & 9.06 & 9.06 \\
\hline 2 & 102.15 & 7.65 & 17.83 & 104.15 & 7.80 & 17.21 \\
\hline 3 & 83.00 & 6.02 & 23.29 & 72.50 & 5.26 & 21.93 \\
\hline 4 & 29.50 & 2.13 & 25.29 & 35.50 & 2.56 & 24.37 \\
\hline \multirow[t]{2}{*}{5} & 8.50 & 0.64 & 27.05 & 10.25 & 0.77 & 26.22 \\
\hline & \multicolumn{3}{|c|}{ Bela Vista } & \multicolumn{3}{|c|}{ Laranjeiras } \\
\hline 1 & 132.65 & 9.57 & 9.57 & 145.60 & 10.50 & 10.50 \\
\hline 2 & 98.70 & 7.39 & 17.33 & 113.60 & 8.51 & 19.41 \\
\hline 3 & 82.00 & 5.95 & 22.73 & 72.00 & 5.22 & 24.03 \\
\hline 4 & 32.00 & 2.31 & 24.92 & 33.75 & 2.44 & 26.34 \\
\hline 5 & 7.25 & 0.55 & 26.57 & 9.75 & 0.73 & 28.23 \\
\hline \multicolumn{4}{|c|}{ Inoculum } & & & \\
\hline 1 & 63.50 & 4.58 & 4.58 & & & \\
\hline 2 & 35.70 & 2.67 & 7.43 & & & \\
\hline 3 & 23.50 & 1.71 & 8.90 & & & \\
\hline 4 & 14.00 & 1.01 & 9.87 & & & \\
\hline 5 & 5.30 & 0.40 & 10.70 & & & \\
\hline
\end{tabular}

SDC - Sum of the displacement of the water column; CNTP Ger. - normal conditions of temperature and pressure generated; CNTP Ac.- accumulated.

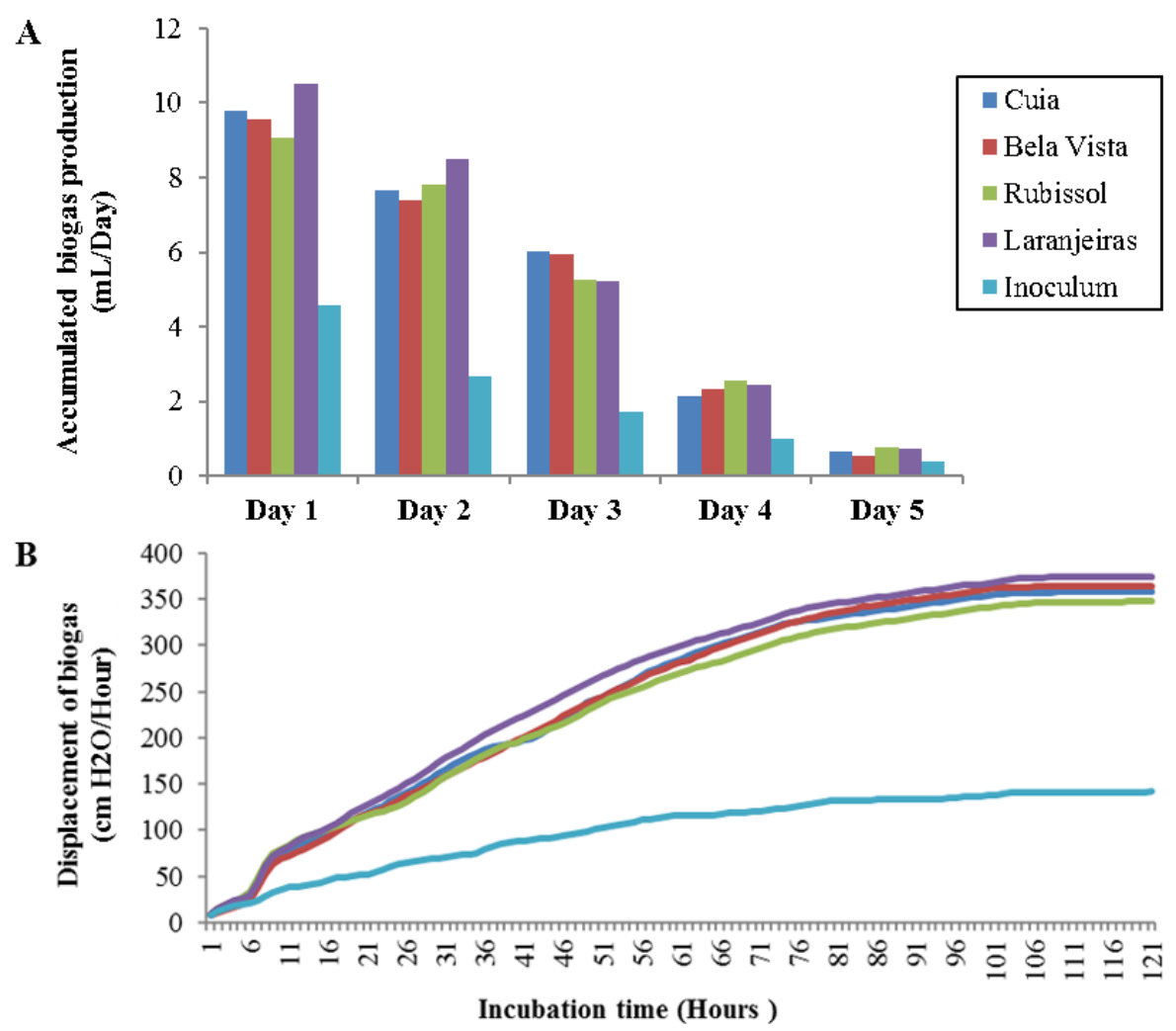

Figure 3. Profile of the medium (A) and accumulated (B) biogas production of sweet potato genotypes. 
The biogas generation peak of the sweet potato genotypes can also be explained by the absence of oxygen, as the circulation of the gaseous nitrogen stream in the headspace of the biodigesters provides anaerobiosis of the medium. The high generation observed and accumulated in the five days is due to the easily biodegradable substances of its composition, the simple sugars (Figure 3B).

According to Alves (2008), in the BMP assays it is justified that this rapid generation may be due to the small amount of substrate used, since $50 \mathrm{~g}$ of sample was used in the present experiment. It is observed that there was a correlation of the internal pressure of the flask with the atmospheric pressure, thus having different peaks of displacement in the biogas production generated. Figure 4 shows, in the first and fifth days, as an example, the values of atmospheric pressure and the normal conditions of temperature and pressure (CNTP) every six hours of evaluation for the different evaluated sweet potato genotypes.
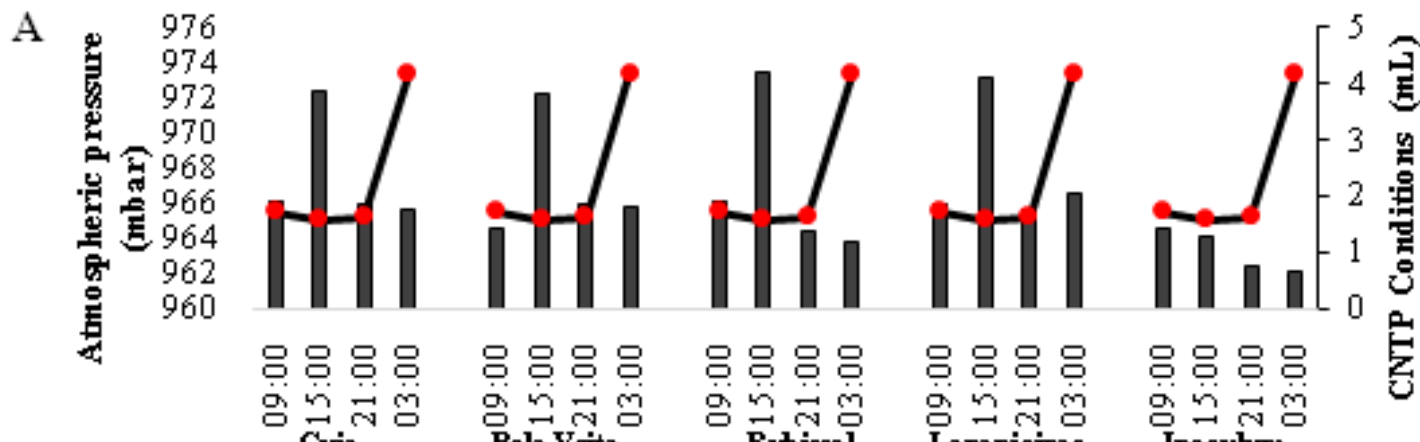

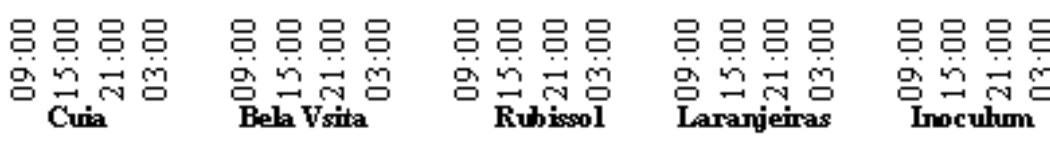
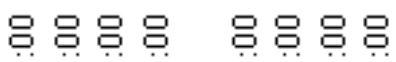

B

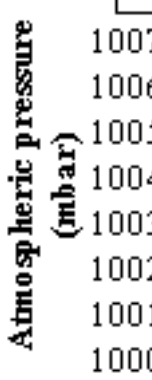

$\square$ CNTP conditions (mL)

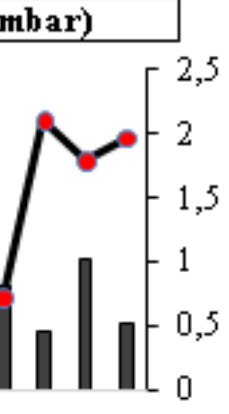

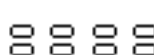

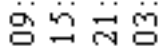

응응

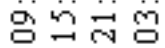

Beh Vsita
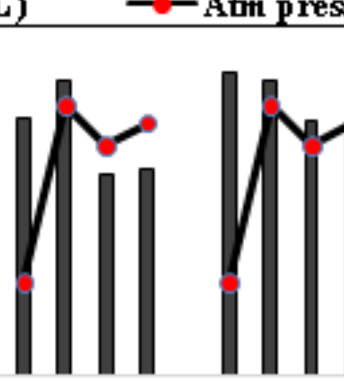

宣

$$
\text { Cuia }
$$

음응

음음

음음

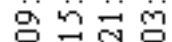

Rubissol

g음

Inocuhm

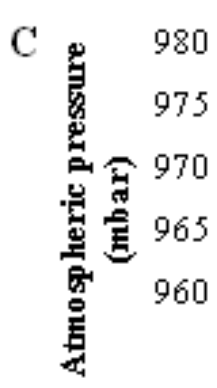

CNTP conditions (mL) - -Atm pressure (mbar)
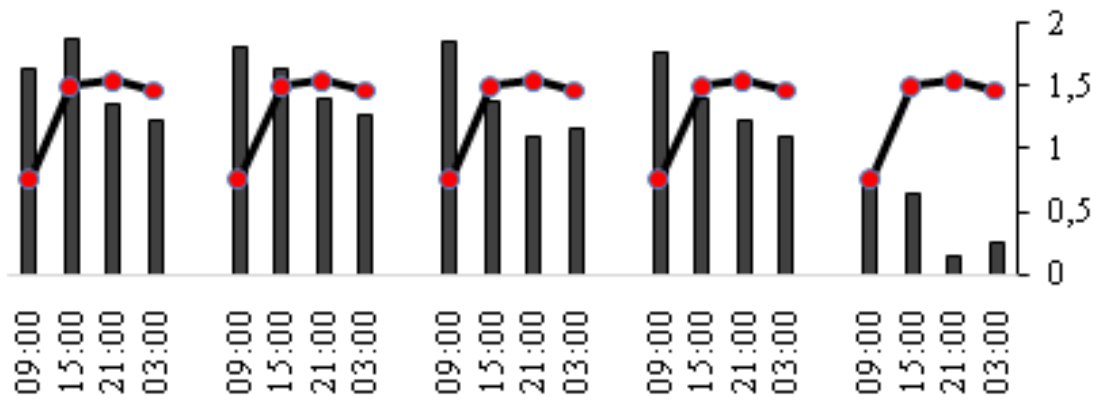

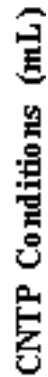

Cuia

号魚胃号

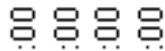

号号号号

음음

g금ำ

g금ำ

g금

gำ

Inoculum

$\square$ CNTP conditions (mL) - - Atm pressure (mbar) 

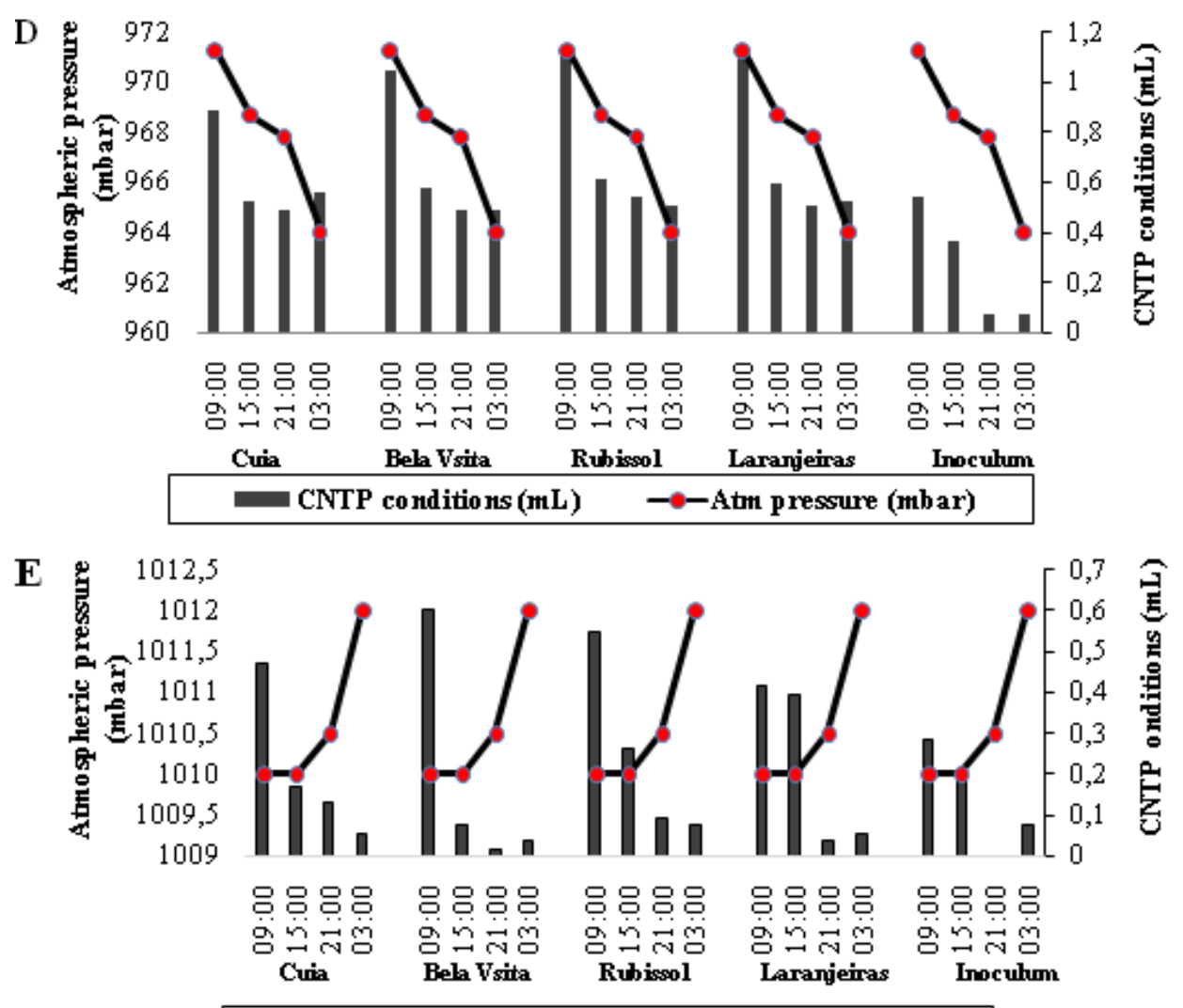

$\square$ CNTP conditio ns (mL) - - -Atm pressure (mbar)

Figure 4. Correlation of atmospheric pressure with the volume of biogas generated from sweet potato genotypes under CNTP conditions from the first day (A) to the fifth day (E).

The internal pressure of the bottles was monitored daily and converted into daily biogas generation. On the first day (Figure 4A), when the peak atm pressure was maximum, the gas production decreased. When the pressure drops, the gas increases. All cultivars and inoculum obtained the same behavior, thus observing the correlation with the volume of biogas generated.

In the second and third days (Figure 4B, 4C), this correlation was not completely observed, because the $\mathrm{pH}$ was reduced in the anaerobic biodigestion process, using simple sugars from the beginning of the process. However, the $\mathrm{pH}$ can not be monitored due to strict anaerobiosis of the flask.

On the fourth day (Figure 4D) the correlation was inversed due to the behavior of the biodigestion caused by the biochemical factors of the genotypes composition. Biodigestion and $\mathrm{pH}$ may have influenced. Then, on the fifth day (Figure 4E), biogas production decreased, but the highest peak volume occurred in the morning, although less than in previous days. Consequently, because the process was in the final stage, as the reaction rate was high, the experiment was shorter in time. If the starch reserve were available, the experimental time would be longer.

The atmospheric pressure played an important role in the interaction of the flask internal pressure with the volume of biogas generated. It was similar for the genotypes, except for the inoculum that practically obtained the production generated on the fifth day due to the difference in the proportion of the biodegradability.

Hansen et al. (2017) indicate that the determination of methane generation potential is a biological method dependent on several factors, since the inoculum used are not standardized and the matter has heterogeneous composition, which denotes the need for procedures that allow repeatability and reproducibility of the experiments. 
To verify the influenced the biogas production, principal components statistical analysis (PCA) was applied, in order to determine the spatial distribution of the physicochemical analyses and of the genotypes, decomposing the original data matrix in two other matrices: the Loading with the physical-chemical analyses and the Scores with the genotypes (Table 4). For the analysis, a preliminary selection was made for the variables that showed the highest correlation with biogas generation: $\mathrm{pH}$, humidity, biogas generated and reducing sugars.

Table 4. Correlation of the variables (Loading) and genotypes (Scores) with the principal components (PCA) of the physicochemical analysis of sweet potato genotypes.

\begin{tabular}{llll}
\hline & \multicolumn{3}{l}{ Principal Components } \\
\hline Physicochemical analysis & PCA1 & PCA2 & PCA3 \\
\hline Moisture & -0.52695 & 0.84984 & 0.0096883 \\
pH & -0.56791 & -0.80817 & 0.15598 \\
Reducing sugars & 0.93057 & -0.34601 & -0.11962 \\
Biogas & 0.91307 & 0.34043 & 0.22452 \\
\hline Genotypes & PCA1 & PCA2 & PCA3 \\
\hline Bela Vista & -0.042424 & 1.2052 & -0.3466 \\
BRS Cuia & 0.13833 & -1.7876 & -0.1517 \\
BRS Rubissol & -1.9019 & 0.2032 & 0.24101 \\
Laranjeiras & 1.806 & 0.37922 & 0.25729 \\
\hline
\end{tabular}

Figure 5 shows the distribution of the variables with PCA1 presenting $57.50 \%$ explanation of the variations and, in order of importance, the reducing sugars, $\mathrm{pH}$ and humidity. In PCA2 of $40.27 \%$, the variables with higher loadings were moisture, $\mathrm{pH}$ and reducing sugars. The sum of components 1 and 2 is equivalent to $97.77 \%$; that is, how much of the variability of the data can be explained by the PCA model.
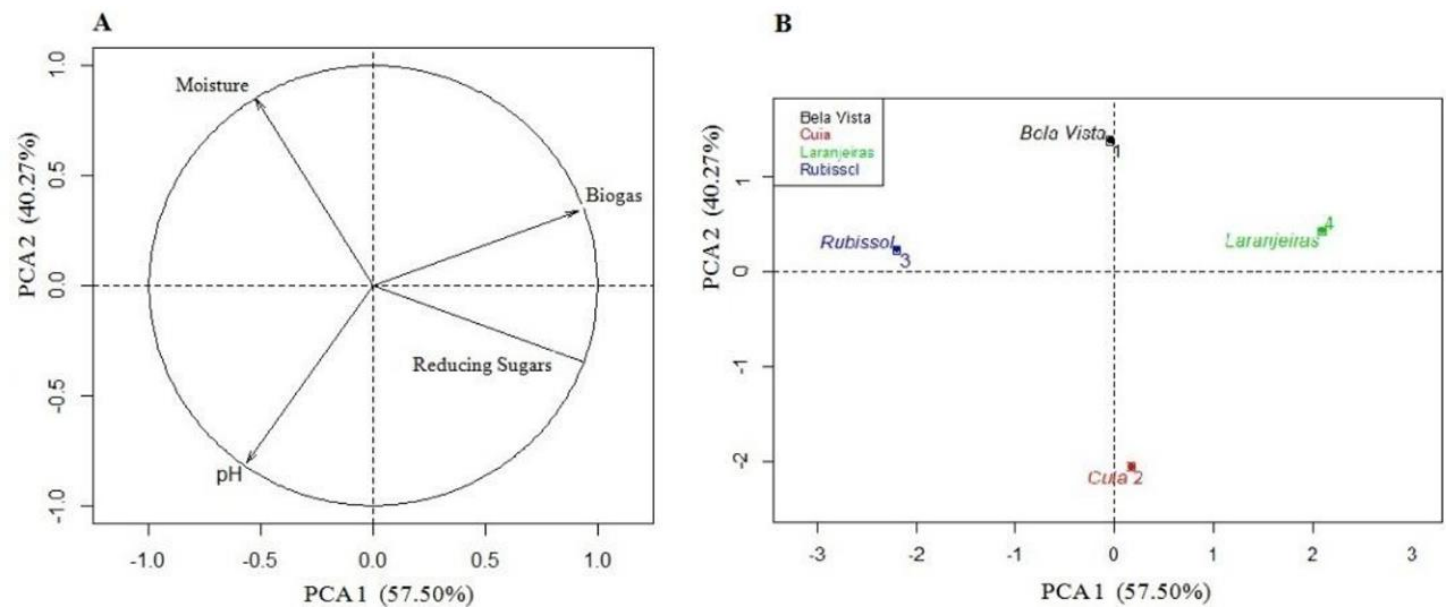

Figure 5. Loadings (A) and Scores (B) of the principal components (PCA) of the physicalchemical variables of sweet potato.

The $\mathrm{pH}$ is related to the first two principal components, and has influence on the biogas production, but did not present a significant correlation, shown by the obtuse angle formed in relation to the biogas (Figure 5A). In the case of reducing sugars and moisture, there was a correlation with the biogas production, evidenced by the acute angle.

The positive signals denote a direct correlation with the component and the negative signals mean an inverse correlation. Each line corresponds to a principal component that

\section{IPABH}

Rev. Ambient. Água vol. 14 n. 2, e2317 - Taubaté 2019 
explains a percentage of data variation, and the selected variables relate to these principal components (Crovador, 2014).

In relation to biogas production with the variables, the Laranjeiras genotype presented most significant potential to produce biogas, followed by BRS Cuia correlated with the three variables, in an intermediate region of the graph, (Figure 5B). The Bela Vista genotype and BRS Rubissol are more correlated with moisture than sugar, and have not been efficient in producing biogas. All genotypes have direct correlation with the amount of reducing sugars and moisture.

With the set of scores and loadings, it was possible to estimate the domain of each variable in each sample. The variables that caused the most biogas generation were the reducing sugars of each genotype, followed by humidity and $\mathrm{pH}$.

The BMP assays has shown the lack of compatibility of the experiments results, highlighted by Angelidaki et al. (2009). According to Elbeshbishy et al. (2012), there is no standard protocol to perform the experiment, or standardize parameters such as: equipment used, inoculum, bottle volume, $\mathrm{pH}$, headspace, among other factors. Another point that makes comparisons difficult is how the results are expressed, often in different units and incubation times.

The volume of biogas produced from the four genotypes was verified in the present test. The sweet potato genotype that stood out for the agronomic, physical-chemical characteristics and the greatest biogas generation potential were BRS Cuia and Laranjeiras. The information collected, such as the agronomic characterization of the new genotypes, viability and performance in the field, were important for possible release as a new cultivar. It was also possible to demonstrate the quality of the genotypes for energy or food destination through their physicochemical characterization.

The knowledge of biogas generation potential is a key factor in the study of the technical and economic viability of the energy obtained by biodigestion. This enables exploration of an alternative energy source, aimed at producing bioenergy with low environmental impact.

\section{CONCLUSION}

Among the evaluated sweet potato genotypes, the cultivars BRS Cuia and genotype Laranjeiras demonstrated bioenergy potential for biogas production, with 2,906.5 liters ha ${ }^{-1}$ and 2,712.4 liters $\mathrm{ha}^{-1}$, respectively.

The cultivation of the genotypes in field experiments, morphological characterization and the physico-chemical composition characteristics, mainly the amount of sugars available and the phenotypic aspects of the size and shape of their tuberous roots, demonstrate the quality of the genotypes.

The proposed procedure for the production of biogas in anaerobic biodigesters, carried out with the Biochemical Potential of Methane (BMP) test, was easy to perform and an efficient analytical method to analyze the biodegradability of organic materials.

\section{REFERENCES}

ALVES, I. R. F. S. Análise experimental do potencial de geração de biogás em resíduos sólidos urbanos. 2008. 118 f. Dissertação (Mestrado) - Programa de Pós-Graduação em Engenharia Civil, CTG - Centro de Tecnologia e Geociências, Universidade Federal de Pernambuco, Recife, 2008.

ALZATE, M. E. et al. Biochemical methane potential of microalgae: influence of substrate to inoculum ratio, biomass concentration and pretreatment. Bioresource Technology, v. 123, p. 488-494, 2012. https://doi.org/10.1016/j.biortech.2012.06.113 
ANGELIDAKI, I. et al. Defining the biomethane potential (BMP) of solid organic wastes and energy crops: a proposed protocol for batch assays. Water Science \& Technology, v. 59, n. 05, p. 927-934, 2009. https://doi.org/10.2166/wst.2009.040

ASSOCIATION OF OFFICIAL ANALYTICAL CHEMISTS - AOAC. Official methods of analysis. 18. ed. Washington: AOAC, 2007. 3000 p.

AZEVEDO, F. G. Estudo das condições ambientais para produção de Biogás a partir de glicerol co-produto do Biodiesel. 2010. 88p. Dissertação (Mestrado em Engenharia Química) - Universidade Federal de Pernambuco, Recife, 2010.

BORBA, A. M.; SARMENTO, S. B. S.; LEONEL, M. Efeito dos parâmetros de extrusão sobre as propriedades funcionais de extrusados da farinha de batata-doce. Ciência e Tecnologia de Alimentos, v. 25, n. 4, p. 835-843, 2005.

BORÉM, A.; MIRANDA, G.V. Melhoramento de plantas. Viçosa: UFV, 2005. 525 p.

BRASIL. Ministério da Saúde. Agência Nacional de Vigilância Sanitária. Resolução - CNNPA no 12 1978. Diário Oficial [da] União, 24 jul., 1978.

BRASIL. Secretaria Nacional de Saneamento Ambiental. Probiogás. Tecnologias de digestão anaeróbia com relevância para o Brasil: substratos, digestores e uso de biogás.et al. Brasília, DF: Ministério das Cidades, 2015. 83 p.

CECCHI, H. M. Fundamentos teóricos e práticos em análises de alimentos. 2. ed. Campinas: Editora da Unicamp, 2003. 207 p.

CHITARRA, M. I. F.; CHITARRA, A. B. Pós-colheita de frutos e hortaliças. 2. ed. Lavras: ESAL, 2005. 783 p.

CROVADOR, M. I. C. Potencial de geração de biogás a partir da fração orgânica de resíduos sólidos urbanos. 2014. 103 p. Dissertação (Mestrado) - Universidade Estadual do Oeste do Paraná Programa de Pós-Graduação em Bioenergia, Guarapuava, PR.

DEGANUTTI, R. et al. Biodigestores rurais: modelo indiano, chinês e Batelada. Procedings of the 4th Encontro de Energia no Meio Rural, n. 4, 2002.

ELBESHBISHY, E.; NAKHLA, G.; HAFEZ, H. Biochemical methane potential (BMP) of food waste and primary sludge: influence of inoculum pre-incubation and inoculum source. $\begin{array}{llllll}\text { Bioresource } & \text { Technology, } & \text { v. } & 110, & \text { p. } & 18-25,\end{array}$ https://doi.org/10.1016/j.biortech.2012.01.025

GUERI, M. V. D. et al. Digestão anaeróbia de resíduos alimentares utilizando ensaios bmp. $\begin{array}{lllllllll}\text { BIOFIX Scientific Journal, } & \text { v. } 3, \quad \text { n. } & 1, & \text { p. } & 08-16,\end{array}$ http://dx.doi.org/10.5380/biofix.v3i1.55831

HARRIES, C. R. et al. Development of a biochemical methane potential (BMP) test and application to testing of municipal solid waste samples. In: INTERNATIONAL WASTE MANAGEMENT AND LANDFILL SYMPOSIUM, 8., Cagliari, Italy. Proceedings Sardinia[...] Cagliari: CISA, 2001. v.1, p. 579-588.

HASSAN, M. et al. Batch and semi-continuous anaerobic co-digestion of goose manure with alkali solubilized wheat straw: a case of carbon to nitrogen ratio and organic loading rate regression optimization. Bioresour Technol, p. 230:24-32, 2017. https://doi.org/10.1016/j.biortech.2017.01.025 
INSTITUTO ADOLFO LUTZ - IAL. Normas Analíticas do Instituto Adolfo Lutz. Vol. 1: Métodos físicos e químicos para análise de alimentos. 3 ed. São Paulo: IMESP, 2008. p.1020.

KOHYAMA, K.; NISHINARI, K. Cellulose derivatives effects on gelatinization and retrogradation of sweet potato starch. Journal of Food Science, v. 57, n. 1, p. 128131, 1992. https://doi.org/10.1111/j.1365-2621.1992.tb05439.x

LIMA, U. A.; BASSO, L. C.; AMORIM, H. V. Produção de etanol. In: SCHMIDELL, W.; LIMA, U. A.; AQUARONE, E.; BORZANI, W. (Coords.). Biotecnologia Industrial: Processos Fermentativos e Enzimáticos, v. 3, capítulo 1. São Paulo: Edgard Blücher, 2001. p. 1-43.

MCKENDRY, P. Energy production from biomass: overview of biomass. Bioressource Technology, v. 83, p. 37- 46, 2002. https://doi.org/10.1016/S0960-8524(01)00118-3

MIRANDA, J. E. C. et al. A cultura da batata-doce. Brasília: EMBRAPA, 1995. 94 p.

SILVA, J. B. C. et al. Cultura da batata-doce. Brasília: EMBRAPA, 2008. Disponível em: http://www.cnph.embrapa.br/sistprod/batatadoce. Acesso em: 15 jan. 2016.

SILVA, J. O. V.; ALMEIDA, M. F.; ALVIM-FERRAZ, M. da C.; DIAS, J. M. Integrated production of biodiesel and bioethanol from sweet potato. Renewable Energy, v. 124, p. 114-120, 2018. https://doi.org/10.1016/j.renene.2017.07.052

SILVEIRA, M. A. Batata-doce: Uma nova alternativa para a produção de etanol. Brasília: IEL, 2008. p. 109-122.

SCHIRMER, W. N.; JUCÁ, J. F. T.; SCHULER, A. R. P.; HOLANDA, S.; JESUS, L. L. Methane production in anaerobic digestion of organic waste from Recife (Brazil) Landfill: 102 evaluation in refuse of different ages. Brazilian Journal of Chemical Engineering, v. 31, n. 02, p. 373-384, 2014. http://dx.doi.org/10.1590/01046632.20140312s00002468

STATHERS, T. et al. Tudo o Que Sempre Quis Saber Sobre a Batata-doce: Manual de capacitação CdF - Alcançando Agentes de Mudança. Nairobi: Centro Internacional da Batata, 2013. 436 p.

XAVIER, C. A. N. et al. Parâmetros de dimensionamento para biodigestores batelada operados com dejetos de vacas leiteiras com e sem uso de inóculo. Engenharia Agrícola, v. 30, n. 2, p. 212-223, 2010. https://doi.org/10.1590/S0100-69162010000200003

XUMENG, G. et al. Biogas energy production from tropical biomass wastes by anaerobic digestion. Bioresource Technology, n. 169, p. 38-44, 2014. https://doi.org/10.1016/j.biortech.2014.06.067

YU, Z.; SCHANBACHER, F. L. Production of Methane Biogas as Fuel Through Anaerobic Digestion. New York: Springer, 2010. p.105-127.

ZHANG, et al. Anaerobic digestion performance of sweet potato vine and animal manure under wet, semi-dry, and dry conditions. AMB Express, v. 8, p. 45, 2018. https://doi.org/10.1186/s13568-018-0572-9 


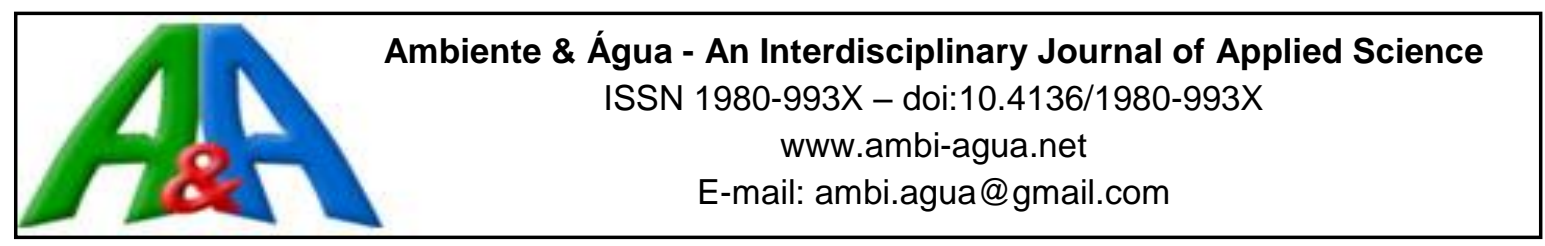

\title{
Shifting habitat mosaic: identification and mapping
}

\author{
ARTICLES doi:10.4136/ambi-agua.2242
}

Received: 13 Mar. 2018; Accepted: 18 Dec. 2018

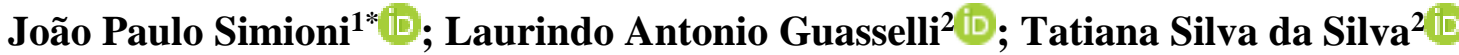 \\ ${ }^{1}$ Universidade Federal do Rio Grande do Sul (UFRGS), Porto Alegre, RS, Brasil \\ Centro Estadual de Pesquisas em Sensoriamento Remoto e Meteorologia (CEPSRM). \\ E-mail: joao.delapasse@ufrgs.br \\ ${ }^{2}$ Universidade Federal do Rio Grande do Sul (UFRGS), Porto Alegre, RS, Brasil \\ Instituto de Geociências (IGeo/UFRGS). \\ Centro Estadual de Pesquisas em Sensoriamento Remoto e Meteorologia (CEPSRM). \\ E-mail: laurindo.guasselli@ufrgs.br, tatiana.silva@ufrgs.br \\ *Corresponding author
}

\begin{abstract}
The Shifting Habitat Mosaic refers to temporal changes in the spatial pattern of habitats, through the flood and dry pulses. This work mapped the dynamics of a Shifting Mosaic associated with the flood and dry pulses in the Environmental Protection Area of the Banhado Grande (EPABG). The research was divided into four stages: i) acquisition of satellite images; ii) obtaining rainfall river basin data from the Gravataí River; iii) identification of the flood and dry pulses; and iv) mapping of the Shifting Mosaic in the wetlands of the EPABG. In large swaths of flooding, a shifting connectivity is established between the AUs of EPABG, providing several interactions among these wetlands, such as nutrient exchange, sediments and living organisms. It was found that in periods where the accumulation of precipitation in the last 30 days is greater than $200 \mathrm{~mm}$, we have the presence of predominantly aquatic mosaic with the presence of predominantly aquatic animals and vegetation; In periods where the cumulative precipitation in the 30 days is less than $200 \mathrm{~mm}$, a terrestrial mosaic predominates, with increase of ciliary vegetation.
\end{abstract}

Keywords: floodplain, flood pulses, shifting mosaic, wetlands.

\section{Mosaico de habitat móvel: identificação e mapeamento}

\section{RESUMO}

O Mosaico de Habitat Móvel (SHM) refere-se às mudanças temporais no padrão espacial dos habitats, através dos pulsos de inundação e seca. Este trabalho teve por objetivo mapear a dinâmica de um Mosaico Móvel associado aos pulsos de inundação e seca, na Área de Proteção Ambiental do Banhado Grande (APABG). A realização desta pesquisa dividiu-se em quatro etapas: i) aquisição das imagens de satélite; ii) obtenção dos dados de precipitação pluviométrica e de cota do rio Gravataí; iii) identificação dos pulsos de inundação e seca; e iv) mapeamento do Mosaico Móvel nas Áreas Úmidas da APABG. Em grandes pulsos de inundação se estabelece, no mosaico móvel, uma conectividade entre as AUs da APABG, proporcionando diversas interações entre essas AUs, tais como, troca de nutrientes, sedimentos e organismos vivos. Identificou-se que em períodos onde o acumulado de precipitação nos 
últimos 30 dias é maior que $200 \mathrm{~mm}$, tem-se a presença de um mosaico predominantemente aquático com a presença de peixes e macrófitas; já em períodos onde o acumulado de precipitação nos 30 dias é menor que $200 \mathrm{~mm}$, predomina-se um mosaico terrestre, com aumento da vegetação ciliar.

Palavras-chave: áreas úmidas, mosaico móvel, planície de inundação, pulsos de inundação.

\section{INTRODUCTION}

Considered environments of high productivity and ecological value, flood plains are areas flooded by the lateral overflow of rivers or lakes, by the rainwater or groundwater (Schindler et al., 2014). Due to phytosociological features and substrates, they constitute a variety of ecosystems (Haines-Young et al., 2012).

The flood plains can be called the Aquatic/Terrestrial Transition Zone - ATTZ. This alternation between aquatic and terrestrial increases the decomposition of organic matter and the nutrient cycling, in addition to reducing the periods of stagnation in comparison with the conditions in permanently flooded habitats (Tracy-Smith et al., 2012).

Neiff (2003) points out that the transition concepts, ecotone and wetlands have been used without considering their conceptual differences. For floodplains to be ecotones (intermediate areas of tension between two communities) the physicochemical environment should have a flotation system (climate, hydro-sedimentological) that is difficult to predict. Also, populations of narrow niches should predominate (estenotípicos) as ecotone components.

However, the floodplain areas are constant in time and their operation is predictable (Schindler et al., 2014) due to the regularity of flood pulses (Junk, 2015). Therefore, environments commonly with flood pulses have no ecotone features, being characterized as macro-ecosystems that have no transitional features between terrestrial and aquatic ecosystems (Neiff, 2003).

Nevertheless, there may exist locally and continuous ecotones in some flood plains, depending on the degree of environmental interactions and the hydrological regime associated with flood pulses (Piazza, et al., 2014). As a result this highly complex structure of floodplains, there is the formation of functional landscape mosaics as from the drastic seasonal changes to which the system is periodically subject (Milne and Bennett, 2007).

Stanford et al. (2005) deal with these mosaics as "Shifting Habitat Mosaic" (SHM) that change seasonally, determining an important spatiotemporal variability, characterized by the presence of habitats that interrelate in different degrees (Lim et al., 2016).

The SHM refer to temporal changes in landscape fragments, which are presented sometimes dry, sometimes flooded, with exposed vegetation or soil. These changes seasonally create a mosaic of landscapes by natural processes such as floods, mass movements, fluvial deposits, defrosting, etc., but also by human activities such as burnings, deforestation and dams (Engle et al., 2008).

In floodplains, the SHM approach recognizes that the interactions between physical and biotic processes produce constant changes of its spatial pattern through flood pulses (Wang and Finley, 2011).

The concept of flood pulse (Junk, 2005) considers the lateral exchanges between the river and its floodplain, as well as the change and exchanges between the terrestrial (dry) and aquatic (flood) phases on the same plain. Therefore, the system can incorporate and efficiently take advantage of the organic matter, which explains the richness and diversity of rivers with floodplains (Sanches et al., 2012).

Studies involving SHM are characterized by a multidisciplinary approach: Wimberly (2006) deals with the dynamics of species in degraded landscapes, to understand if the 
connectivity (Tischendorf and Fahrig, 2000; Luque et al. 2012) between landscapes is influenced by SHM; Engle et al. (2008) analyze the sensitivity of the invertebrate community; Armstrong and Schindler (2013) analyzed the relationship between the water temperature and the spatial distribution of the silver-Salmon (Oncorhynchus kisutch), address the restoration of successional dynamics of a SHM in a floodplain.

Thus, this study maps the dynamics of a SHM associated with flood pulse and drought in the connectivity area between the Wetlands of Environmental Protection Area of Banhado Grande (EPABG).

\section{MATERIAL AND METHODS}

\subsection{Study area}

The Environmental Protection Area of Banhado Grande was established by State Decree N. 38,971/1998, and its basic objectives are to protect biological diversity, to discipline the occupation process and to ensure the sustainable use of natural resources (Brenner, 2016).

Located in the Metropolitan Region of Porto Alegre (MRPA), the EPABG has an area of 136,935 ha, covering the municipalities of Santo Antonio da Patrulha, Gravataí, Viamão and Glorinha (Figure 1) (Brenner, 2016; Simioni et al., 2017).

The EPABG comprises three areas of marsh, the Banhado Grande, the Banhado Chico Lomã and the Banhado dos Pachecos, which form a large composition of wetlands in the basin of the Gravataí River, defined as Banhado Grande System (BGS) (Scherer, 2014). The BGS is delimited by an altimetry quota of $20 \mathrm{~m}$, and according to Accordi and Hartz (2006) it consists of a continuous area of swamps or marshes, flooded lands and rice fields.

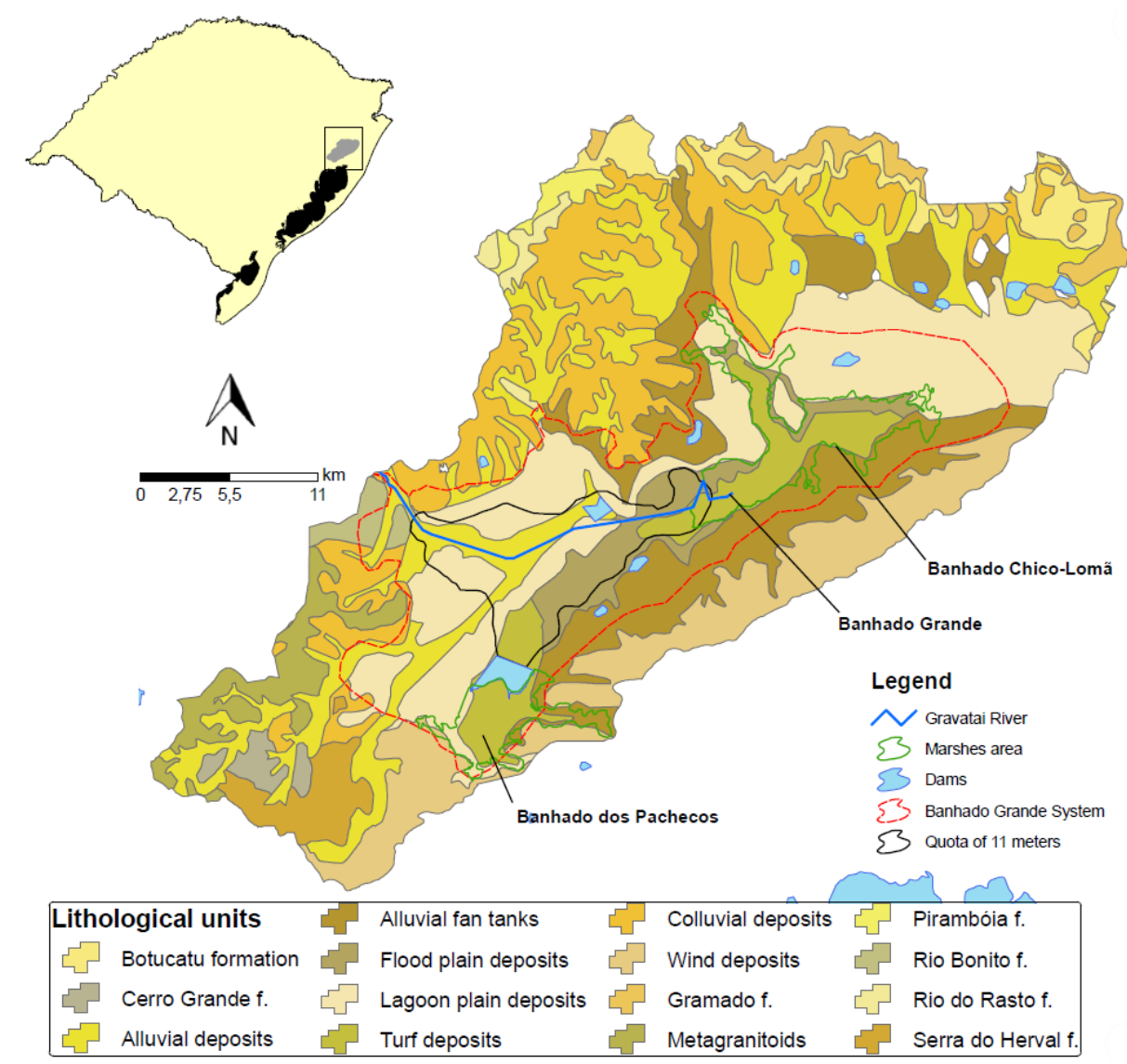

Figure 1. Lithology of the Environmental Protection Area of Banhado Grande, RS. 
According to the geological map (Figure 1), the BGS area consists of four geological compartments: lagoon plains deposits, peat deposits, alluvial deposits and floodplain deposits. The areas of marshes associated with turf deposits are found in areas where the marshes of Banhado Grande, Chico-Lomã and Pachecos are located (Scherer, 2014). In large flood pulses, a polygon associated with $11 \mathrm{~m}$ quota floods connects (Simioni et al., 2017) the areas of Banhado Grande and Pachecos and the floodplain of the Gravataí River.

EPABG is part of the Subtropical Climate III (Rossato, 2011), with its average annual temperature ranging between 17 and $20^{\circ} \mathrm{C}$ and pluviometric regime between 1,700-1,800 mm per year (Alvares et al., 2013). The monthly average rainfall between 1981-2010 in the INMET Meteorological Station in Porto Alegre is $112.6 \mathrm{~mm}$. The months with the lowest average rainfall (dry) are April, May and December, with $86 \mathrm{~mm}, 95 \mathrm{~mm}$ and $100 \mathrm{~mm}$, respectively (Inmet, 2016). On the other hand, the months with the highest average rainfall (floods) are June, August and September, with $135 \mathrm{~mm}, 140 \mathrm{~mm}$ and $139 \mathrm{~mm}$, respectively.

\subsection{Methodological procedures}

The work was divided into four stages: i) the acquisition of satellite images; ii) obtaining the rainfall and the Gravataí River quota data compatible with the dates of the images; iii) identification of the flood pulse and drought in the polygon area concerning the quota of 11 meters; and iv) mapping of the SHM in the wetlands of APABG.

Unlike Stanford et al. (2005) which defined the term SHM, this work will only address the spatialization of a SHM, associated with a flood pulse (Junk, 2005) and drought, in the polygon area associated with elevation of $11 \mathrm{~m}$.

\subsection{Acquisition of Satellite Images}

The satellite images were obtained from the USGS website (United States Geological Survey). We chose to work with images in periods of large flood pulses and drought. Six Landsat images were selected from 1983 to 2014, Table 1.

Table 1. Landsat TM images utilized.

\begin{tabular}{lccc}
\hline Image Date & Satellite & Cumulative rainfall in 30 days (mm) & Quota (m) \\
\hline $11 / 24 / 1983$ & Landsat 4 & 186.5 & 2.3 \\
$09 / 21 / 1992$ & Landsat 4 & 111.1 & 2.8 \\
$10 / 21 / 2000$ & Landsat 7 & 250.8 & 4.5 \\
$04 / 29 / 2009$ & Landsat 5 & 31.0 & 0.9 \\
$08 / 31 / 2013$ & Landsat 8 & 247.5 & 5.5 \\
$10 / 21 / 2014$ & Landsat 8 & 204.3 & 4.6 \\
\hline
\end{tabular}

\subsection{Rainfall and River level quota}

The rainfall data were obtained from the website of the Brazilian Institute of MeteorologyINMET, daily rainfall data for the 30 days prior to obtaining the satellite images.

On the Weather Forecasting and Climate Studies Center - CPTEC/INPE website, event data were obtained from El Niño and La Niña, to relate to the flood pulses and drought in the wetlands of EPABG.

For the data analysis of variations in the level of the river quota, the measurement gauge of Passo das Canoas was used as the basis, administered by the Mineral Resources Research Company (CPRM), installed in Gravataí, available in the system of the Hidroweb of the National Water Agency (ANA). 


\subsection{Identification of pulses flood and drought}

To identify and map the flood pulses and drought (Junk et al., 2012) in EPABG, the Normalized Difference Water Index - NDWI was used (Gao, 1996), using satellite images from Landsat 4, 5 TM and 7 ETM+, Equation 1:

$N D W I=\frac{(B 2-B 4)}{(B 2+B 4)}$

Where: B2 - green wavelength; and B4 - near infrared.

And to calculate the NDWI using Landsat 8 OLI images, Equation 2:

$N D W I=\frac{(B 3-B 5)}{(B 5+B 5)}$

Where: B3 - green wavelength; and B5 - near infrared.

The NDWI images (Gao, 1996) have identified the flood pulses and drought. The six images used were added through the Raster Calculator tool. The NDWI images were overlapped on the polygon referring to the limits of EPABG quantified floodplains located in the EPA. The calculation was performed using the ArcGIS Calculate Geometry tool.

\subsection{Characterization of the Shifting Habitat Mosaic}

The methodology of Kleindl et al. (2015) was adapted to characterize the SHM in the wetlands of the EPABG. The focus of this work is the river-floodplain system and wetlands dynamics in the corridor between two major wetland areas, Banhado Grande and Pachecos, considering an 11-meter quota. Differently from Kleindll et al. (2015), this study analyzed these areas using only data derived from remote sensing, measured precipitation data, and quota level data of Gravataí River, to understand and characterize the dynamics of an SHM in the EPABG.

The study of Kleindll et al. (2015) consisted in analyzing the expansion of a floodplain due the forest fires, using the concept of SHM. The authors worked with remote sensing images, rainfall data, outflow data (empirical and shaped), and data on the extension and frequency of forest fires of the past, to examine the relations between hydrology, fire, land use, as well as geomorphological and dynamic position of the SHM. In this way, the authors had concluded that the current composition of the SHM in the area of the floodplain of the River Flathead resulted from diverse interactions between flooding events, erosive processes, and forest fires, influenced by the geomorphic composition of the floodplain.

\section{RESULTS}

The average annual growth (1973-2014) of the river-level maximum quota, as registered by the measurement gauge of Passo das Canoas, in the Gravataí River (Figure 2), shows a range between $1.25 \mathrm{~m}$ to $2.70 \mathrm{~m}$ over the 41 years of analysis.

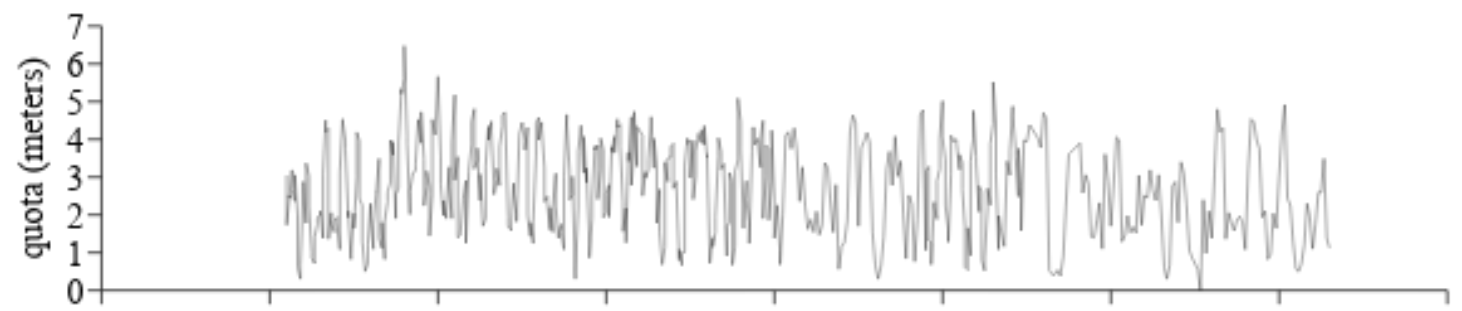

Figure 2. Monthly variation (1980-2014) of the maximum quota as measured by the measurement gauge of Passo das Canoas, Gravataí River. 
According to Brazil (Inmet, 2016), the years of occurrence of the El Niño classified as "strong" were 1983, 1986-1988, 1991-1992, 1997-1998, 2002 and 2009-2010. In these years, water levels were higher when compared to other years analysed. In all the years of occurrence of El Niño considered strong by the CPTEC/INPE, the average fluctuation of water levels was higher than $2.00 \mathrm{~m}$.

On the other hand, the La Niña events, considered strong by the CPTEC/INPE, occurred in the years of 1988-1990 and 2006-2008. These years were those which had the lowest maximum monthly values of water level elevation in the Gravataí River (1.25 to $1.50 \mathrm{~m})$ (Inmet, 2016).

Figure 3 shows the rainfall and the Gravataí River quota for the 30 days preceding the date of satellite images. The years 1983 (Figure 3a) and 2009 (Figure 3d) were characterized by the strong influence of the La Niña (Inmet, 2016). Rainfall totals in the official INMET Meteorological Station in Porto Alegre were $186.5 \mathrm{~mm}$ and $31.0 \mathrm{~mm}$, respectively, and the quotas were $2.3 \mathrm{~m}$ and $0.9 \mathrm{~m}$. In Figs. 3b, 3c, 3e and 3f, the events of the El Niño are highlighted. In Figure 3b, it rained $101.1 \mathrm{~mm}$, and the Gravataí River quota reached its maximum value for the period $(4.25 \mathrm{~m})$.
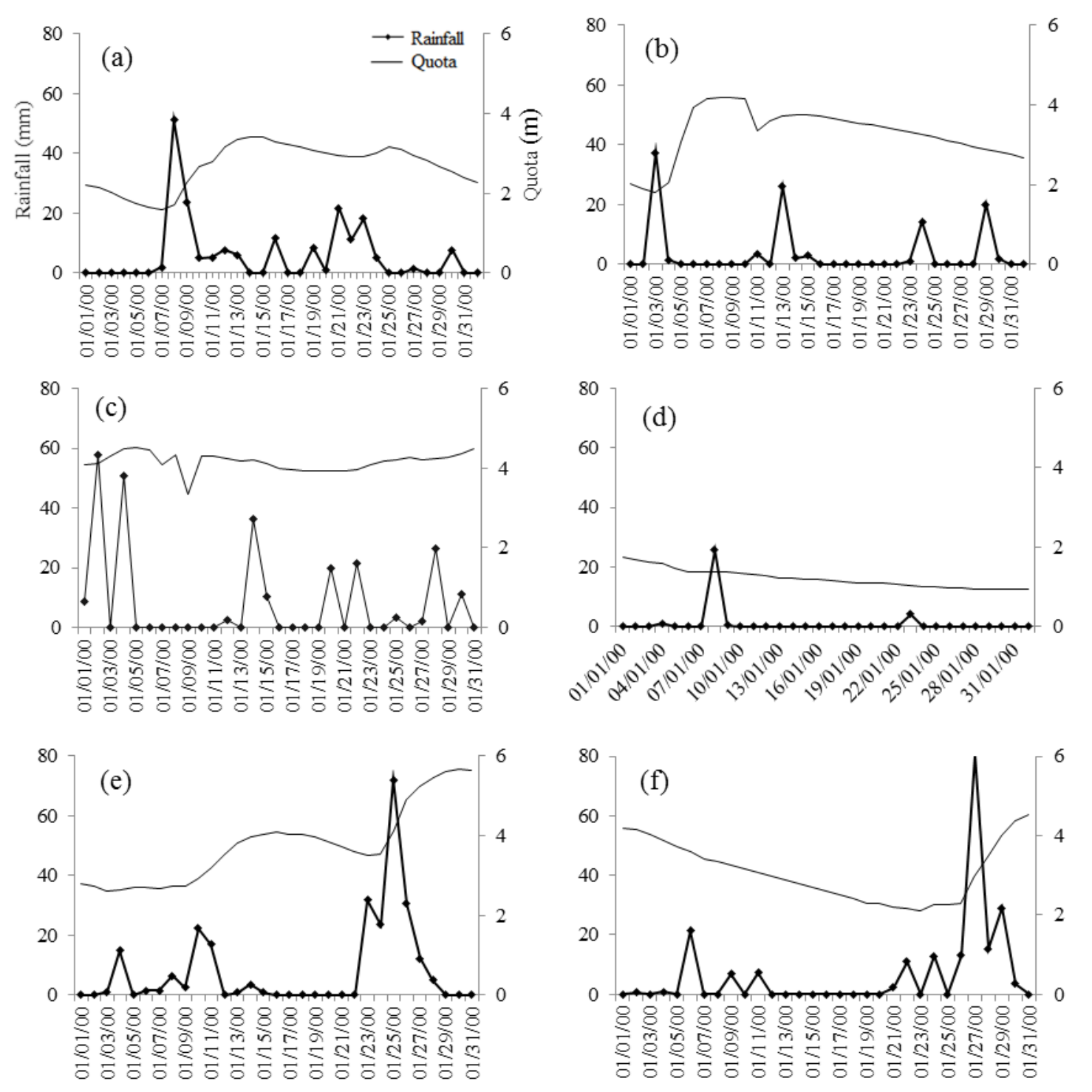

Figure 3. Relationship between the accumulated rain and the Gravataí River quota. 
Figure $3 \mathrm{c}$ shows the highest rainfall, detected of $250.8 \mathrm{~mm}$, distributed in 14 days. However, since the maximum rainfall peak occurred 20 days before obtaining the image, this period did not present the highest Gravataí River quota, which marked $4.5 \mathrm{~m}$.

According to Colombo and Pessoa (2013), the year of 2009 was characterized by a severe drought in Rio Grande do Sul, causing several impacts, especially on the economy of the state. The year of 2009, Figure 3d, was the one with the lowest rainfall, when it rained a total of $31.0 \mathrm{~mm}$. As a result, this period also had the lowest quota in the level of the Gravataí River $(0.9 \mathrm{~m})$.

In Figure 3e, the rainfall value recorded between August 25th and 26th, 2013 is highlighted, $72 \mathrm{~mm}$. This amount resulted in the highest Gravataí River quota among the analyzed dates $(5.5 \mathrm{~m})$.

Similar to the date of 2013, Figure $3 \mathrm{f}$ also presents only one maximum rainfall peak, verified on 17 October 2014, when it rained $80 \mathrm{~mm}$ in 24 hours. This peak increased the Gravataí River quota in more than $2 \mathrm{~m}$. The quota value was $2.5 \mathrm{~m}$, and at the time of image acquisition the registered quota was $4.6 \mathrm{~m}$.

Figure 4 refers to the flooded area for each Landsat image. The accumulated precipitation was $186.5 \mathrm{~mm}$, and flooded area in the polygon referring to the quota of 11 meters was 367.4 ha, corresponding to $3.8 \%$ polygonal area (Figure 4a). This area is located mostly in the floodplain of the Gravataí River, in the area popularly known as Anastacia Lagoon. On that date, the two dams did not exist, located within and south of the polygon related to the 11-meter quota. The Gravataí River quota level on the date of the image was $2.3 \mathrm{~m}$.

In Figure 4b, the two dams already existed. The accumulated rainfall was $111.1 \mathrm{~mm}$ and the flooded area was 322.5 ha. The quota of the Gravataí River on the date of the image was $2.8 \mathrm{~m}$. Figure $4 \mathrm{c}$ presents, along with Figure 4e, larger amounts of accumulated precipitation, $250.8 \mathrm{~mm}$ and $247.5 \mathrm{~mm}$, respectively. Consequently, these figures show the biggest flooded areas among the analyzed images, $7577.5 \mathrm{ha}$, and in Figure $4 \mathrm{c}$ and 7853.9 ha in Figure 4e. The quota of the Gravataí River on the dates of the images was $4.5 \mathrm{~m}$ and $5.5 \mathrm{~m}$, respectively.

Figure $4 \mathrm{~d}$ shows a period of drought, the flooded area was 67.5 ha. The quota of the Gravataí River in Figure 4d was 0.9 m. In Figure 4f, the flooded area is 3,796 ha and the accumulated rainfall $204.4 \mathrm{~mm}$. The quota of the Gravataí River on this date was 4.6 meters.

It is understood, therefore, that when the accumulated precipitations are greater than 200 $\mathrm{mm}$, during 30 days, SHM are formed in the EPABG wetlands. Figure 5 shows a SHM in the EPABG wetlands. The rectified stretch of the Gravataí River is highlighted, near the area known as Anastacia Lagoon. In this area, the river flood pulses create a mosaic that seasonally alternates between aquatic and land, being responsible for the habitat heterogeneity (Junk et al., 1989). In Figure 5a, the drought period, there is a predominance of a terrestrial environment. The flooded area is restricted to the main channel (rectified) and the intricacies that, although abandoned, still remain active in Anastasia Lagoon. This lagoon is erroneously named as such, since this environment is just an old meander of the Gravataí River, which was closed by rice farmers to stop the water so that it could be used for crop irrigation.

Figure 5b shows a flood period in the Gravataí River. It is noticeable that the meanders are completely flooded, forming a predominantly aquatic SHM that remains until the recession of the waters, which lasts from 15 to 30 days. 


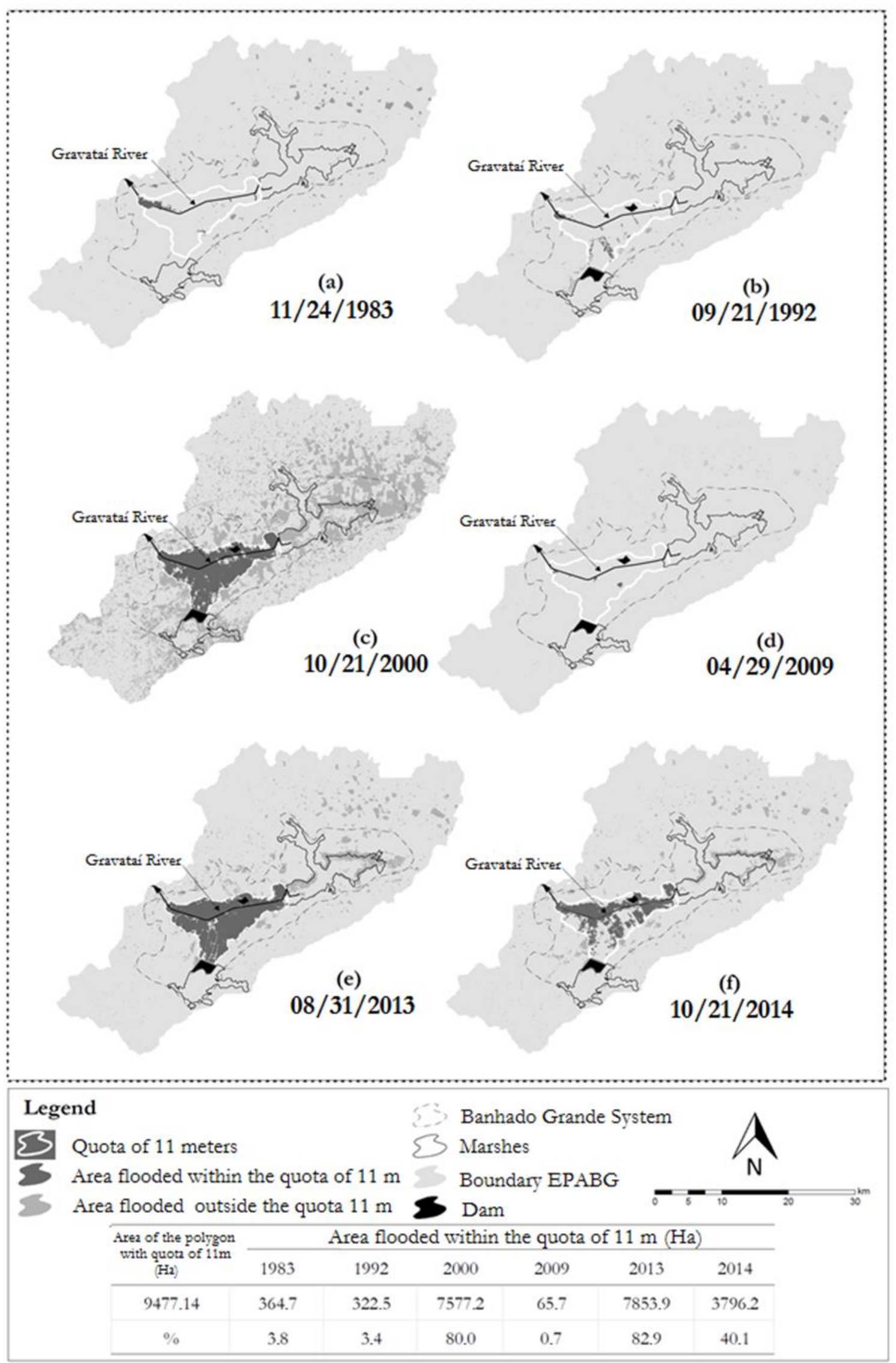

Figure 4. Flood area for the studied images. 


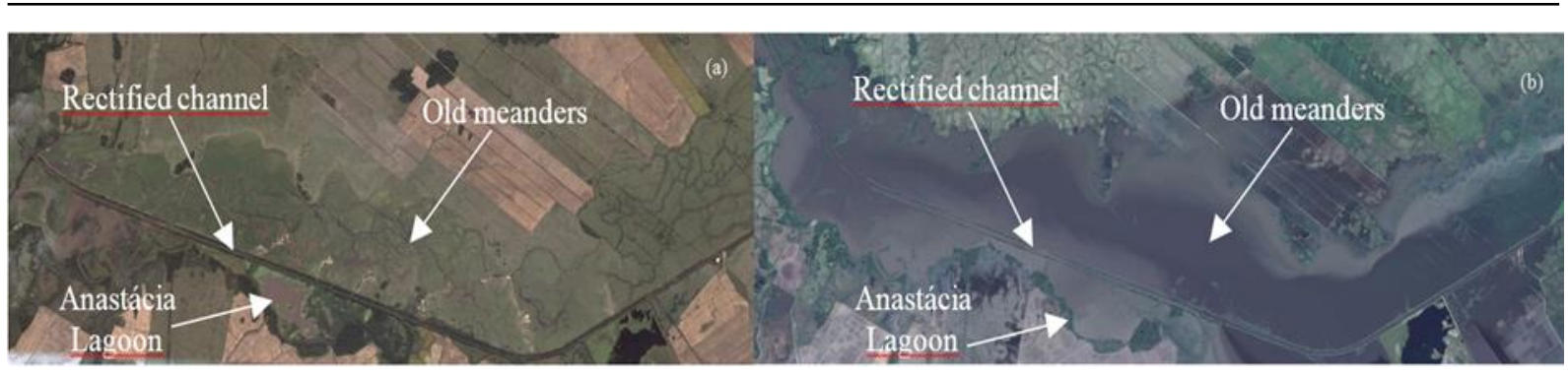

Figure 5. Shifting Mosaic in a rectified section of the Gravataí River: (a) dry phase, 04/30/2009; and (b) flooded phase, 08/11/2011.

Source: Google Earth Pro (2016).

\section{DISCUSSION}

The quota of the Gravataí River is considered normal between 2.70 to $3.00 \mathrm{~m}$, on the measurement gauge of Passo das Canoas (Relf, 2015). From the quota of $4.5 \mathrm{~m}$, the Gravataí River begins to overflow, and riverine families need to be relocated (Relf, 2015). Still, in the 1970s, part of the Gravataí River was rerouted with the intention of draining the wetlands, seeking to expand the areas intended for rice cultivation (Brenner, 2016).

However, despite the correction, the area near the Anastacia Lagoon remains with its old meanders, being horizontally connected to the river, in large flood pulses. In this area, Brenner (2016) has proposed measures to return the meanders to a more-natural state, using bioengineering techniques. This process would reduce the speed of the water runoff, since the channel would go from rectilinear to meandering, reducing erosion problems and drainage of wetlands.

Regarding the discharge, according to the Institute of Hydraulic Research (IPH, 2002), the minimum discharge of 7 days to 10 years of TR (Q 7.10) in the post of Passo das Canoas (located at the boundary between the low and medium Gravatai) is $6.02 \mathrm{~m}^{3} / \mathrm{s}$, which corresponds to $25 \%$ of the long-period average. For the same post, the discharge full of TR of 10 years and 100 years are respectively $206 \mathrm{~m}^{3} / \mathrm{s}$ and $311 \mathrm{~m}^{3} / \mathrm{s}$.

Simioni et al. (2017) point out that the DNOS report in 1985, analysing of the number of flow rates from 1940 to 1981, states that the course correction of the channel did not cause changes in the water regime, nor an increase in flow of the Gravataí River.

However, according to the authors, through the analysis of the flow in the period after 1981 , the increase of flow in the post-correction period is evident. The maximum flow rates (Rio Grande do Sul, 2011) increased due to the ease of flow provided by the correction. The river course, when meandering, favored the decrease in the flow speed and, with the correction, the rectilinear course favored the increased flow speed (Brenner, 2016). In Figure 5, the images allow easy identification of the SHM providing a concise overview of rivers, even for nonscientists (Stanford et al., 2005).

Thus, when analyzing the maps of variation of the SHM, it is possible to realize that the fluvial action of floods and temporal migration of the channel, especially in Anastacia Lagoon, create different SHM through the riverside landscape (Stanford et al. 2005).

Thus, ecotones (present in the floodplain) (Neiff, 2003), connectivity (between Banhados Grande, Pachecos and the floodplain of the Gravataí River) (Vanderhoof et al., 2016; Simioni et al., 2017) and succession play important roles in the structuring of spatiotemporal heterogeneity that leads to high biodiversity that characterizes the Gravataí River (Rio Grande do Sul, 2011; Cardoso, 2016).

In periods of great flood pulses, this connectivity established between the wetlands of EPABG, especially in the corridor that connects the Banhado Grande, Pachecos and floodplain of the Gravataí River, provides several interactions between wetlands, such as the exchange of nutrients, sediments and organisms (Vanderhoof et al. 2016). 
Given this ecological dynamism, Wang and Finley (2011) pointed out how critical this is to managers of Conservation Units (CU's), because they often choose to preserve the shape of the landscape in its present condition, or lead to landscape back to some historical appearance based on studies of changes in the landscape. The interference in natural patterns alters or disturbs the ecological flows. So, if the goal is to maintain the natural ecosystem processes, it should be accepted that the configuration of the landscape is changing over time (Wang and Finley, 2011).

Temporal shifts in the mosaic associated with temporal changes in the main channel and in the floodplains create fragments with different environmental conditions (Lima et al., 2013), the SHM. These conditions are directly related to the dynamics of the EPABG wetlands, which are presented sometimes dry, sometimes flooded, forming the SHM, with the growth of the vegetation and the presence of land animals in dry periods, and the presence of fish and aquatic plants in flood periods (Cardoso, 2016).

Furthermore, Tittensor (2013) states that the result of SHM in flood plains are considered productivity hotspots because they provide the proliferation of algae during the flood and enrichment of nutrients in the soil after drought.

Additionally, according to Junk et al. (2012), the wetlands along small rivers, small depressions, such as wetlands of the EPABG, have an unpredictability in the occurrence of flood pulses (Neiff, 2003), and its amplitude is variable. Given this, the characterization of the SHM in the wetlands of EPABG is essential, as it allows us to understand the dynamics and compartments subject to the formation of this mosaic.

\section{CONCLUSION}

The satellite images allowed concise mapping of the SHM in EPABG. It was found that in periods where the cumulative rainfall in the past 30 days is greater than $200 \mathrm{~mm}$, there is the presence of a predominantly aquatic mosaic on the polygon referring to the $11 \mathrm{~m}$ quota, with the presence of amphibians, reptiles, fish and birds that depend on them for feeding.

On the other hand, in periods where the cumulative rainfall is less than $200 \mathrm{~mm}$, a terrestrial mosaic predominates, with the increase of riparian vegetation and animals, especially amphibians and mammals. Regarding the methodology, it's adaptation allowed the analysis and spatial distribution of the SHM throughout the polygon area concerning the $11 \mathrm{~m}$ quota, not restricting it only to the temporal displacement of the meanders.

\section{REFERENCES}

ACCORDI, I. A.; HARTZ, S. M. Distribuição espacial e sazonal da avifauna em uma área úmida costeira do sul do Brasil. Revista Brasileira de Ornitologia, v. 2, p. 117-135, 2006.

ALVARES, C. A.; STAPE, J. L.; SENTELHAS, P. C.; GONÇALVES, J. L. M.; SPAROVEK, G. Köppen's climate classification map for Brazil. Meteorologische Zeitschrift, v. 22, n. 6, p. 711-728, 2013. https://doi.org/10.1127/0941-2948/2013/0507

ARMSTRONG, J.; SCHINDLER, D. Going with the Flow: Spatial Distributions of Juvenile Coho Salmon Track an Annually Shifting Mosaic of Water Temperature. Ecosystems, v. 16, n. 8, p. 1429-1441, 2013. https://doi.org/10.1007/s10021-013-9693-9

BRENNER, V. Proposta metodológica para renaturalização de trecho retificado do rio Gravataí-RS. 2016. Dissertação (Mestrado em Geografia) - Instituto de Geociências, UFRGS, Porto Alegre, 2016. 
CARDOSO, S. Flora e Fauna do rio Gravataí e ecossistemas associados. Gravataí: Projeto rio limpo, 2016.

COLOMBO, J. A.; PESSOA, M. L. O impacto dos eventos de estiagem na economia dos municípios do RS. Carta de Conjuntura, v. 12, n. 22, 2013.

ENGLE, D. M.; FUHLENDORF, S. D.; ROPER, A.; LESLIE Jr., D. M. Invertebrate Community Response to a Shifting Mosaic of Habitat. Rangeland Ecology \& Management, v. 61, p. 55-62, 2008. https://doi.org/10.2111/06-149R2.1

GAO, B. NDWI-A Normalized Difference Water Index for Remote Sensing of Vegetation Liquid Water From Space. Remote Sensing of Environment, v. 58, p. 257-266, 1996. https://doi.org/10.1016/S0034-4257(96)00067-3

HAINES-YOUNG, R.; POTSCHIN, M.; KIENAST, F. Indicators of ecosystem services potential at European scales: mapping marginal changes and trade-offs. Ecological Indicators, v. 21, p. 39-53, 2012. https://doi.org/10.1016/j.ecolind.2011.09.004

INSTITUTO DE PESQUISAS HIDRÁULICAS - IPH. Universidade Federal do Rio Grande do Sul. Identificação das alternativas possíveis e prováveis para regularização da vazão do rio Gravataí-RS. Porto Alegre: IPH/CPRM, 2002.

INSTITUTO NACIONAL DE METEOROLOGIA - INMET (Brasil). Dados meteorológicos históricos. $2016 . \quad$ Available in: http://www.inmet.gov.br/portal/index.php?r=estacoes/estacoesConvencionais. Access: Feb. 2019.

JUNK, W. J. Flood pulsing and the linkages between terrestrial, aquatic, and wetland systems. SIL Proceedings, 1922-2010, v. 29, p. 11-38, 2005. https://doi.org/10.1080/03680770.2005.11901972

JUNK, W. J.; BAYLEY, P. B.; SPARKS, R. E. The flood pulse concept in river-floodplain systems. Canadian Journal of Fisheries and Aquatic Sciences, v. 106, p. 110-127, 1989.

JUNK, W. J. et al. Definição e classificação das áreas úmidas (AUs) brasileiras: base científica para uma nova política de proteção e manejo sustentável. Cuiabá: INAU/CPP, 2012.

KLEINDL, W. J.; RAINS, M. C.; MARSHALL, L. A.; HAUER, F. R. Fire and flood expand the floodplain shifting habitat mosaic concept. Freshwater Science, v. 34, n. 4, p. 13661382, 2015. https://doi.org/10.1086/684016

LIM, I. E.; WILSON, S. K.; HOLMES, T. H.; NOBLE, M. M.; FULTON, C. J. Specialization within a shifting habitat mosaic underpins the seasonal abundance of a tropical fish. Ecosphere, v. 7, n. 2, p. 1-13, 2016. https://doi.org/10.1002/ecs2.1212

LIMA, G.; SILVA, M.; CURI, N.; SILVA, M.; OLIVEIRA, A.; AVANZI, J. C.; UMMUS, M. E. Avaliação da cobertura vegetal pelo índice de vegetação por diferença normalizada (IVDN). Revista Ambiente \& Água, v. 8, n. 2, p. 204-214, 2013. http://dx.doi.org/10.4136/ambi-agua.959

LUQUE, S.; SAURA, S.; FORTI, M. J. Landscape connectivity analysis for conservation: insights from combining new methods with ecological and genetic data. Landscape Ecology, v. 27, n. 2, p. 53-157, 2012. https://doi.org/10.1007/s10980-011-9700-5 
MILNE, R.; BENNETT, L. Biodiversity and ecological value of conservation lands in agricultural landscapes of southern Ontario, Canada. Landscape Ecology, v. 22, n. 5, p. 657-670, 2007. https://doi.org/10.1007/s10980-006-9063-5

NEIFF, J. J. Planícies de inundação são Ecótonos? In: HENRY, R. Ecótonos nas interfácies dos sistemas aquáticos. São Carlos: UFSCar, 2003.

PIAZZA, B. P.; ALLEN, Y. C.; MARTIN, R.; BERGAN, J. F.; KING, K.; JACOB, R. Floodplain conservation in the Mississippi River Valley: combining spatial analysis, landowner outreach, and market assessment to enhance land protection for the Atchafalaya River Basin, Louisiana, U.S.A. Restoration Ecology, v. 23, p. 65-74, 2014. https://doi.org/10.1111/rec.12120

RELF, K. Rio Gravataí chega a 5,55 metros e pode aumentar em Cachoeirinha. Correio do Povo, 17 July 2015. Available in: http://www.correiodopovo.com.br/Noticias/561994/Rio-Gravatai-chega-a-5,55-metrosem-Cachoeirinha-. Access: 2017.

RIO GRANDE DO SUL. Plano de Bacia Hidrográfica do Rio Gravataí. Porto Alegre: Comitê Gravatahy, 2011.

ROSSATO, M. S. Os Climas do Rio Grande do Sul: variabilidade, Tendências e Tipologia. 2011. Tese (Doutorado em Geografia) - Universidade Federal do Rio Grande do Sul, Porto Alegre, 2011.

SANCHES, R. A.; ROSSETE, A. N.; REZENDE, A. C. P.; ALVES, H. Q.; VILLAS-BÔAS, A. Subsídios para a proteção de Áreas Úmidas da bacia do rio Xingu (Mato Grosso, Brasil). Revista Árvore, v. 1, p. 489-498, 2012. https://doi.org/10.1590/S010067622012000300011

SCHERER, R. S. Urbanização na planície inundável do rio Gravataí, RS. 2014. Dissertação (Mestrado em Geografia) - Universidade Federal do Rio Grande do Sul, Porto Alegre, 2014.

SCHINDLER, S.; SEBESVARI, Z.; DAMM, C. et al. Multifunctionality of floodplain landscapes: relating management options to ecosystem services. Landscape Ecology, v. 29, p. 229-244, 2014. https://doi.org/10.1007/s10980-014-9989-y

SIMIONI, J. P. D.; GUASSELLI, L. A.; ETCHELAR, C. B. Connectivity among Wetlands of EPA of Banhado Grande, RS. RBRH, v. 22, e15, 2017. http://dx.doi.org/10.1590/23180331.011716096

STANFORD, J. A.; LORANG, M. S.; HAUER, F. R. The shifting habitat mosaic of river ecosystems. SIL Proceedings, 1922-2010, v. 29, p. 123-136, 2005. https://doi.org/10.1080/03680770.2005.11901979

TISCHENDORF, L.; FAHRIG, L. How should we measure landscape connectivity? $\begin{array}{llllllll}\text { Landscape } & \text { Ecology, } & \text { v. } 15, \quad \text { n. } & \text { 7, } & \text { p. 633-641, }\end{array}$ https://doi.org/10.1023/A:1008177324187

TITTENSOR, D. P. Biodiversity: Temperate hotspots. Nature, v. 501, p. 64-78, 2013. https://doi.org/10.1038/501494a

TRACY-SMITH, E.; GALAT, D. L.; JACOBSON, R. B. Effects of flow dynamics on the Aquatic-Terrestrial Transition Zone (ATTZ) of lower Missouri river sandbars with implications for selected biota. River Research and Applications, v. 28, p. 793-813, 2012. https://doi.org/10.1002/rra.1492 
VANDERHOOF, M.; ALEXANDER, L. C.; TODD, M. J. Temporal and spatial patterns of wetland extent influence variability of surface water connectivity in the Prairie Pothole Region, United States. Landscape Ecology, v. 31, p. 805-824, 2016. https://doi.org/10.1007/s10980-015-0290-5

WANG, P. C.; FINLEY, J. C. A landscape of shifting-mosaic steady state in Lassen Volcanic National Park, California. Ecological Research, v. 26, p. 191-199, 2011. https://doi.org/10.1007/s11284-010-0776-1

WIMBERLY, M. C. Species dynamics in disturbed landscapes: when does a shifting habitat mosaic enhance connectivity? Landscape Ecology, v. 21, p. 35-46, 2006. https://doi.org/10.1007/s10980-005-7757-8 


Ambiente \& Água - An Interdisciplinary Journal of Applied Science
ISSN 1980-993X - doi:10.4136/1980-993X
www.ambi-agua.net
E-mail: ambi.agua@gmail.com

\title{
Rainfall trends for the State of Paraná: present and future climate
}

\author{
ARTICLES doi:10.4136/ambi-agua.2258 \\ Received: 21 Mar. 2018; Accepted: 18 Dec. 2018 \\ Luciana Espindula de Quadros ${ }^{*}$ (D) Eloy Lemos de Mello ${ }^{2}$;
Benedito Martins Gomes ${ }^{2}$; Fernanda Cristina Araujo \\ ${ }^{1}$ Instituto Federal do Paraná (IFPR), Foz do Iguaçu, PR, Brasil \\ E-mail: luciana.quadros@ifpr.edu.br \\ ${ }^{2}$ Universidade Estadual do Oeste do Paraná (UNIOESTE), Cascavel, PR, Brasil \\ E-mail: eloymello@gmail.com, benedito.gomes@unioeste.br, fer.crisaraujo@yahoo.com.br \\ *Corresponding author
}

\begin{abstract}
This paper analyzes the variability and the precipitation trend of the State of Paraná, in Brazil. For that, monthly precipitation data belonging to 24 precipitation stations in a 30-year period (1980-2010) were analyzed and they were compared with projections of precipitation for the years 2016-2050. These data were simulated by Eta/Miroc5 for RCP 4.5 (Representative Concentration Pathways) from the Center for Weather Forecasting and Climate Studies CPTEC/INPE and the historical data of precipitation were taken from National Water Agency (ANA). The Mann-Kendall non-parametric test and the Sen's slope estimator were applied to detect trends and magnitudes, respectively. The MannWhitney test was used to compare the median of the historical series (1980-2010) with the simulated series (2016-2050) and the comparison of the means between the two series was performed by Test $t$. The results draw attention to the great variability and significant changes in the monthly average rainfall that may occur, if the climate change scenarios that were considered become a reality in the near future.
\end{abstract}

Keywords: climate changes, climate models, precipitation variability.

\section{Tendência da precipitação no Estado do Paraná: clima presente e futuro}

\section{RESUMO}

O objetivo deste artigo é analisar a variabilidade e a tendência de precipitação do Estado do Paraná, Brasil. Para isso, foram analisados os dados de precipitação mensal pertencentes a 24 estações de precipitação pluviométrica em um período de 30 anos (1980-2010) e foi comparado com as projeções futuras sobre a precipitação para os anos de 2016-2050. Estes dados foram simulados por Eta/Miroc5 para RCP 4.5 (Caminhos Representativos de Concentrações) proveniente do Centro de Previsão de Tempo e Estudos Climáticos CPTEC/INPE e os dados históricos de precipitação utilizados foram da Agência Nacional de Águas (ANA). O teste não-paramétrico de Mann-Kendall e o estimador de Sen foram aplicados para detectar tendências e sua magnitude, respectivamente. O teste de Mann-Whitney foi usado para comparar a mediana da série histórica (1980-2010) com a mediana da série simulada (2016-2050) e a comparação das médias entre as duas séries foram realizadas pelo Test $t$. Os resultados chamam atenção para a grande variabilidade e mudanças significativas na 
precipitação média mensal que poderá ocorrer, se os cenários de mudanças climáticas que foram consideradas se tornarem uma realidade no futuro próximo.

Palavras-chave: modelos climáticos, mudanças climáticas, variabilidade de precipitação.

\section{INTRODUCTION}

Among the many effects that climate variability could be responsible for, a major concern is the imminence of a possible increase in the occurrence of extreme events around the globe, which could directly affect the human population and other living organisms. Several studies and investigations have been conducted in order to identify which elements are causing such impacts and what are their intensities and frequencies of occurrence (Zandonadi and Acquaotta, 2016).

According to the Brazil Panel on Climate Change (PBMC, 2013), some regions of Brazil may experience changes in temperature and rainfall with global warming. Intensifications of severe events should occur, causing severe impacts in cities and areas vulnerable to climate change. The possible impacts of these changes will occur at different scales, according to the specific characteristics of each region of Brazil. It is necessary to know and map the vulnerabilities of Brazilian regions to identify, propose and implement adaptation measures.

Among all the variables, the precipitation is one of the most important meteorological variables which can impact the occurrence of drought or flood. Analysis of precipitation data yields relevant information which can be used to improve water management strategies, protect the environment, agricultural production planning or impact economic development of a certain region (Gocic and Trajkovic, 2013).

In recent years, scientists worldwide have compared and analyzed precipitation trends, but precipitation isn't the only focus; other meteorological parameters have also been studied for adaptation and mitigation strategies for potential future changes. The Global Climate Models (GCMs) and dynamical downscaling using Regional Climate Models (RCMs) are the main tools of the analyses aimed at assessing what climate we are likely to have in the near- and notso-near future (Marengo et al., 2012). According to Adam and Collischonn (2013), the GCMs take into account the behavior of climate compartments (atmosphere, oceans, vegetation, soils, etc.) and their interactions in a quantitative model (numerical), allowing the simulation of probable climate evolution projections for various scenarios of emissions of greenhouse gases. These simulations have resulted in four pathways being adopted by the IPCC, denominated "Representative Concentration Pathways" (RCPs). The four RCPs included one mitigation scenario leading to a very high baseline emission scenarios (RCP 8.5), two medium stabilization scenarios (RCP 4.5/RCP 6.0) and one very low forcing level (RCP 2.6) (Vuuren et al., 2011).

The use of RCMs also contributed to information enhancement, because on a regional scale the information is more accurate and the computational advancement allowed the inclusion of more components and processes in the simulations and spatial resolution of the models, thus increasing their complexity (Marengo et al., 2009). In South America, the Eta Model has been used to provide time forecasts, because this model is able to produce satisfactory results in regions that contain sharp orography, such as the Andeas Mountains (Chou et al., 2011).

Singh and Goyal (2016) analyzed the spatial and temporal variability of precipitation lapse rate and of precipitation extreme indices of the Teesta River catchment, which corresponds to north Sikkim eastern Himalayas. For this, they used series durations observed (1980-2005) and simulated precipitation data sets (2006-2100) simulated by CMIP5 ESM-2 M Model (Coupled Model Intercomparison Project Phase 5 Earth System Model 2), employing three different radiative forcing scenarios Representative Concentration Pathways (RCP). 
In Korea, Kim et al. (2016) researched heat waves associated with climate change using a series of observational data from 1994 to 2012 to deduce the causal factors that affect the number of deaths from heat disorders, because the greater concern is that the steady increase in death rate is expected to be intercepted by more severe events in the future compared to the present period. To simulate future changes in heat wave incidences in Korea for the period from 2013 to 2060, they used data simulated using the Hadley Centre Global Environmental for two RCP scenarios: RCP 4.5 and RCP 8.5.

In the southeast Brazil, a study was done on possible changes in air temperature and the effect of this on coffee beverage quality. Based on climate projections using the Eta/HadCM3 for the period of 2011 to 2100 , the simulation of future changes was possible. The effects of this process on coffee beverage quality were simulated and the results indicated that, in the case of an occurrence of A1B emission scenario, the coffee beverage quality could be affected in this region due to the fact that the flavor may become stronger and unpleasant caused by rising air temperatures (Giarolla et al., 2012).

Therefore, this study sought to use simulations to understand changing trends in different contexts. This paper analyzes the variability and the precipitation trend of the observed precipitation data (1980-2010) and simulated data by Eta/Miroc5 (2016-2050) for RCP 4.5 of the State of Paraná, in Brazil.

\section{MATERIAL AND METHODS}

Monthly precipitation series from 1980 to 2010 from the National Water Agency (ANA) database from 24 precipitation stations in the State of Paraná were used. Figures 1 and 2 represent the spatial distribution of the stations. Data gaps were filled using values from the nearest neighboring observatories. To apply this method, two criteria were established: 1) the correlation (Pearson's r) between the monthly precipitation series from both observatories was required to be higher than 0.7 (Barbosa et al., 2005; Pruski et al., 2004); and 2) the nearest stations were considered, with a maximum distance of $100 \mathrm{~km}$, taking into consideration that Baba et al. (2014) states that the nearest stations are more likely to have similar behaviors with respect to the treated variables (Table 1 ).

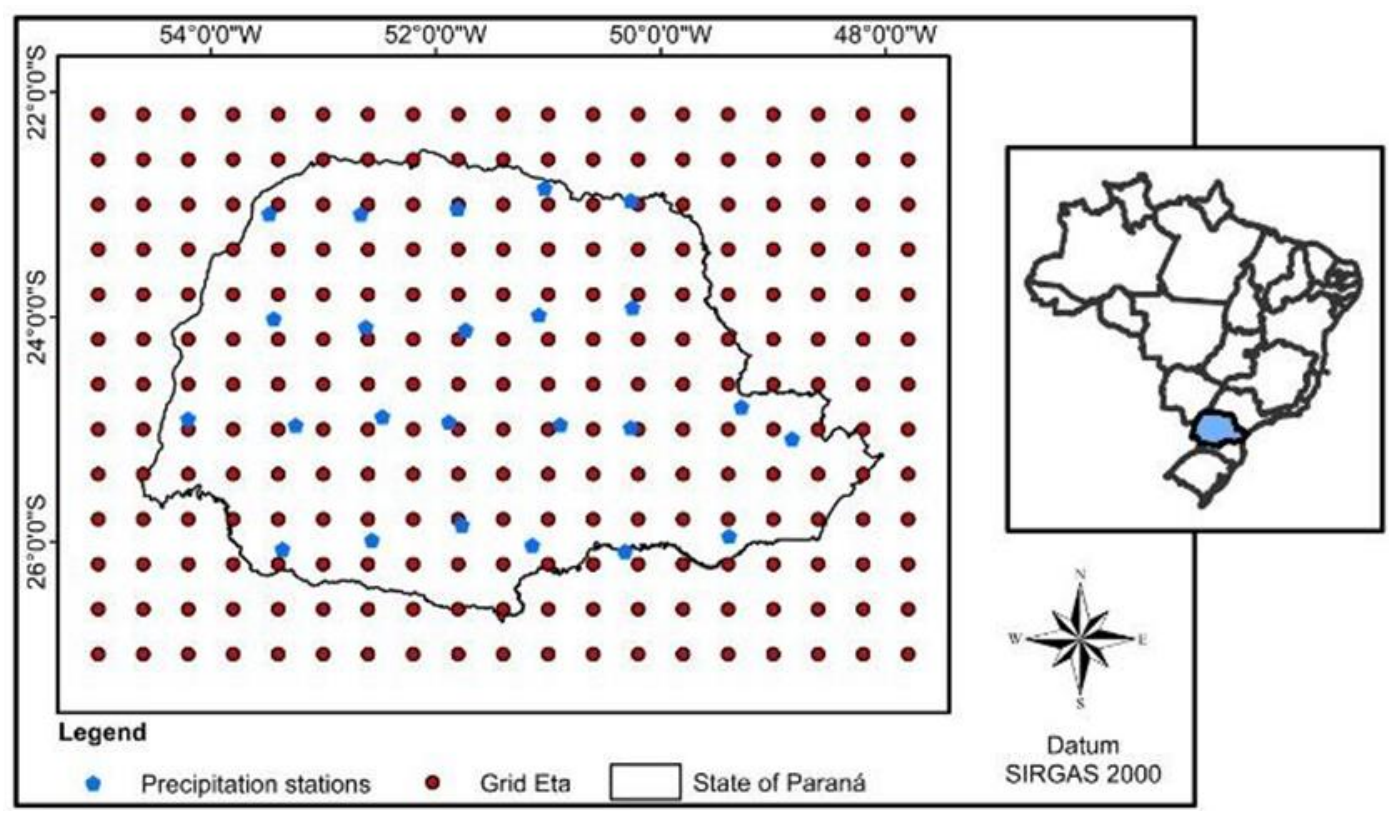

Figure 1. Spatial distribution of the 24 precipitation stations and grid of Eta/MIROC5 model with 824 pixels covering the State of Paraná. 


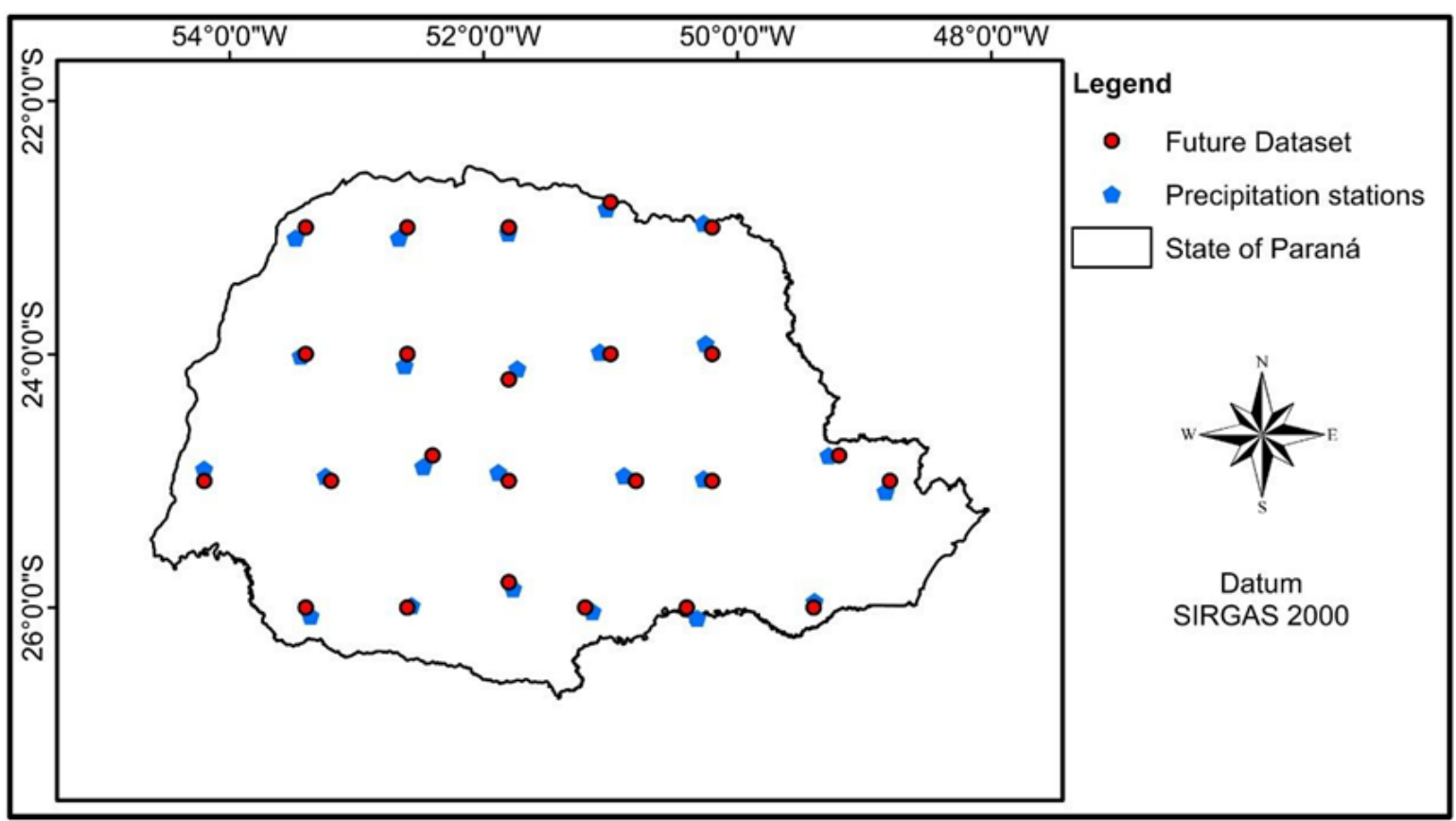

Figure 2. Spatial distribution of the 24 precipitation stations in the State of Paraná and the simulated data set simulated with Eta/MIROC.

In order to detect trends, the Mann-Kendall non-parametric statistical was used in the precipitation series. The series of 1980 to 2010 were put together with the series 2016 to 2050, considering a single series at each point studied. For this, the test statistic $\mathrm{Z}$ was used (Equations $1,2,3$ and 4):

$Z= \begin{cases}\frac{(S-1)}{\sqrt{\operatorname{var}(S)}} & \text { if } S>0 \\ 0 & \text { if } S=0 \\ \frac{(S+1)}{\sqrt{\operatorname{var}(S)}} & \text { if } S<0\end{cases}$

where:

$S=\sum_{i=1}^{n-1} \sum_{j=i+1}^{n} \operatorname{sgn}\left(x_{j}-x_{i}\right)$

$\operatorname{sgn}\left(x_{j}-x_{i}\right)=\left\{\begin{array}{c}+1, \text { if } x_{j}>x_{i} \\ 0, \text { if } x_{j}=x_{i} \\ -1, \text { if } x_{j}<x_{i}\end{array}\right.$

$\operatorname{var}(S)=\frac{n(n-1)(2 n+5)-\sum_{i=1 \ldots m} t_{i}\left(t_{i}-1\right)\left(2 t_{i}+5\right)}{18}$

Where $\operatorname{sgn}\left(x_{j}-x_{i}\right)$ is the sign function, $n$ is the number of data points, $m$ is the number of tied groups and $t_{i}$ denotes the number of observations of the $i$-th tied group. A tied group is a set of sample data having the same value.

Positive values of $\mathrm{Z}$ show increasing trends while negative $\mathrm{Z}$ values indicate decreasing trends. For this study a $5 \%$ significance level was considered. 
Table 1. The information of precipitation stations and simulated data set by RCP scenario 4.5 Miroc5.

\begin{tabular}{|c|c|c|c|c|c|c|c|}
\hline \multirow[b]{2}{*}{ No } & \multicolumn{4}{|c|}{ Historical data } & \multicolumn{2}{|c|}{ Simulated data set } & \multirow{2}{*}{ Distance between them $(\mathrm{km})$} \\
\hline & Stations & Latitude & Longitude & Elevation & Latitude & Longitude & \\
\hline 1 & 2454018 & -24.9061 & -54.2014 & 243 & -25.000 & -54.2 & 10.41 \\
\hline 2 & 2653016 & -26.0644 & -53.3622 & 557 & -26.000 & -53.4 & 8.08 \\
\hline 3 & 2453056 & -24.9628 & -53.2439 & 697 & -25.000 & -53.2 & 6.05 \\
\hline 4 & 2453008 & -24.0147 & -53.4397 & 427 & -23.999 & -53.4 & 4.39 \\
\hline 5 & 2353010 & -23.0817 & -53.4811 & 349 & -22.999 & -53.4 & 12.37 \\
\hline 6 & 2552044 & -25.9833 & -52.5667 & 700 & -26.000 & -52.6 & 3.81 \\
\hline 7 & 2452019 & -24.8858 & -52.4739 & 741 & -24.800 & -52.4 & 12.06 \\
\hline 8 & 2452029 & -24.0906 & -52.6214 & 582 & -23.999 & -52.6 & 10.37 \\
\hline 9 & 2352052 & -23.0831 & -52.6667 & 450 & -22.999 & -52.6 & 11.55 \\
\hline 10 & 2551019 & -25.85 & -51.7667 & 1245 & -25.800 & -51.8 & 6.46 \\
\hline 11 & 2451010 & -24.9333 & -51.8833 & 900 & -25.000 & -51.8 & 11.19 \\
\hline 12 & 2451049 & -24.1144 & -51.7342 & 618 & -24.199 & -51.8 & 11.5 \\
\hline 13 & 2351065 & -23.0403 & -51.8056 & 485 & -22.999 & -51.8 & 4.6 \\
\hline 14 & 2651005 & -26.0306 & -51.1419 & 840 & -26.000 & -51.199 & 6.64 \\
\hline 15 & 2450049 & -24.9575 & -50.8917 & 743 & -25.000 & -50.799 & 10.47 \\
\hline 16 & 2351041 & -23.9831 & -51.0831 & 1011 & -23.999 & -50.999 & 8.73 \\
\hline 17 & 2251039 & -22.8517 & -51.0319 & 370 & -22.799 & -50.999 & 6.47 \\
\hline 18 & 2650005 & -26.0833 & -50.3167 & 770 & -26.000 & -50.399 & 12.36 \\
\hline 19 & 2450021 & -24.9831 & -50.2667 & 950 & -25.000 & -50.199 & 7.08 \\
\hline 20 & 2350041 & -23.9167 & -50.25 & 600 & -23.999 & -50.199 & 10.48 \\
\hline 21 & 2250033 & -22.9653 & -50.2661 & 423 & -22.999 & -50.199 & 7.82 \\
\hline 22 & 2549003 & -25.95 & -49.3931 & 810 & -26.000 & -49.399 & 5.57 \\
\hline 23 & 2449006 & -24.8 & -49.2833 & 270 & -24.800 & -49.199 & 8.52 \\
\hline 24 & 2548040 & -25.0833 & -48.8333 & 670 & -25.000 & -48.799 & 9.86 \\
\hline
\end{tabular}

The Mann-Kendall test allows us to detect statistically significant trends, but does not provide estimates of the steepness of the trend slope. For this reason, the application was complemented by Sen's slope estimator. It is defined as (Equation 5):

$B=M d\left(\frac{x_{i}-x_{j}}{t_{i}-t_{j}}\right)$

Where $\mathrm{Md}$ is the value of median and $x_{i}$ and $x_{j}$ are data values at times $t_{i}$ and $t_{j}(i>j)$, respectively.

The Mann-Kendall statistical test and Sen's slope estimator have often been used to detect trend in hydro-meteorological time series. (Gocic and Trajkovic, 2013; Santos and Fragoso, 2013; Yürekli, 2015).

To determine if there are any statistically significant differences between the medians, the Mann-Whitney test was applied; this the series of 1980 to 2010 was compared with the series 2016 to 2050. The Mann-Whitney test statistics are described as (Equation. 6):

$Z=\frac{w-\frac{n \cdot m}{2}}{\sqrt{\frac{n \cdot m(n+m+1)}{12}}}$

Where $n$ is the historic size series, $m$ is the simulated size series, $w$ is defined as the smaller value of $w_{1}$ and $w_{2}$, where (Equations 7 and 8):

$w_{1}=r_{1}-\frac{n(n+1)}{2}$ 
$w_{2}=r_{2}-\frac{m(m+1)}{2}$

To calculate $r_{1}$ and $r_{2}$, both groups (historic series and simulated series) were put in a single set. Afterwards, numeric ranks were assigned to all the observations. In case of equal numbers, an average of the ranking was made to find out their position. Then, the historical and simulated series were separated again, $r_{1}$ is the sum of the ranks of the historic series and $r_{2}$ is the sum of the ranks of the simulated series.

The null hypothesis is stated as the median of the historic series equals the median of the simulated series. If the p-value were less than or equal to the significance level of 0.05 , the decision will be to reject the null hypothesis. It must be concluded that the difference between the population medians is statistically significant.

The 2-Sample Test $t$ was used to compare the precipitation averages between two independent groups, the historical data and simulated data, and to determine if there is a significant difference between them. The null hypothesis is the difference between the population means $\left(\mu_{1}-\mu_{2}\right)$ equals zero. Rejecting the null hypothesis, it can be concluded that the difference between the population means that it is not equal to, or greater than, or less than the reference value chosen in case zero. The Test $t$ (Equation 9):

$t=\frac{\mu_{A}-\mu_{B}}{\sqrt{S^{2}\left(\frac{1}{n_{A}}+\frac{1}{n_{B}}\right)}}$ where $S^{2}=\frac{\left(n_{A}-1\right) S_{A}^{2}+\left(n_{B}-1\right) S_{B}^{2}}{n_{A}+n_{B}-2}$

In which: $S_{A}^{2}$ and $S_{B}^{2}$ are the variances of precipitation values of historical and simulated data; $\mu_{A}$ and $\mu_{B}$ sample means of precipitation values of historical and simulated data, $n_{A}$ and $n_{B}$ is the length of the series, respectively. If the variances are equal, $S^{2}$ will correspond to the variance of both samples.

\section{RESULTS AND DISCUSSION}

For the period 1980 to 2010 and 2016 to 2050, monthly trends of precipitation were obtained by the Mann-Kendall test, the Sen's slope estimator, the Mann-Whitney Test and the Test $t$ and the results are given in Table 2 .

According the results of the Mann Kendall test, there is a significant trend in monthly precipitation series and this was detected on seventeen points of the twenty-four points at the $5 \%$ significance level, while other points had no significant trends.

The monthly precipitation at fifteen points over the State of Paraná tends to increase until 2050 and two points tend to decrease. The points with increased trend are 6, 7, 9, 10, 12-15, 17 21, 23 and 24. The points with decreased trend are point 2 and point 11 (Table 2).

From 1980 to 2050, the monthly rainfall has been declining at the rate of $0.0605 \mathrm{~mm}$ month $^{-1}$ at point 2 and $0.0369 \mathrm{~mm} \mathrm{month}^{-1}$ at point 11 . The points that have an increasing trend, the rates of raising are $0.0967,0.1307,0.0479,0.1273,0.1642,0.0515,0.1186,0.1641,0.0018$, $0.1612,0.1372,0.0443,0.0319,0.0428,0.0192,0.1896$ and $0.0794 \mathrm{~mm} \mathrm{month}^{-1}$, respectively in points $6,7,9,10,12,13,14,15,17,18,19,20,21,23$ and 24.

Still in Table 2, note the results of the Mann-Whitney test (nonparametric) and t tests (parametric). The test results relate to the use of the statistics at each point comparing the period of 1980 to 2010 and 2016 to 2050. It is observed that, even as with the Mann-Kendall test, seventeen points of the twenty-four points show a trend with a significance level of 5\%, meaning that there is a change in the trend of monthly precipitation in the State of Paraná. Only at point 20 does the Mann-Whitney test differ from the other tests, but at the other points, the Mann-Whitney test and Test $t$ confirm the result of the Mann-Kendall test. 
Table 2. Results of statistical tests trend of rainfall in the State of Paraná.

\begin{tabular}{|c|c|c|c|c|c|c|c|c|c|}
\hline & \multicolumn{2}{|c|}{ Mann-Kendall } & \multirow{2}{*}{$\begin{array}{c}\text { Sen's slope } \\
m m \\
\text { month }^{-1}\end{array}$} & & \multicolumn{2}{|c|}{ Mann-Whitney } & \multicolumn{3}{|c|}{ Test $t$} \\
\hline & $\begin{array}{c}p \text {-value } \\
\text { increasing }\end{array}$ & $\begin{array}{c}p \text {-value } \\
\text { decreasing }\end{array}$ & & & Median & $p$-value & Mean & Increment & $p$-value \\
\hline 1 & 0.501 & 0.498 & 0.0000 & $\begin{array}{l}\text { Hist1 } \\
\text { Fut } 1\end{array}$ & $\begin{array}{l}130.20 \\
121.90\end{array}$ & 0.992 & $\begin{array}{l}142.8 \\
143.4\end{array}$ & $+0.42 \%$ & 0.930 \\
\hline 2 & 0.999 & $0.000 *$ & -0.0605 & $\begin{array}{l}\text { Hist2 } \\
\text { Fut } 2\end{array}$ & $\begin{array}{l}160.80 \\
120.77\end{array}$ & $0.000 *$ & $\begin{array}{c}177 \\
142.2\end{array}$ & $-19.66 \%$ & $0.000^{*}$ \\
\hline 3 & 0.083 & 0.917 & 0.0218 & $\begin{array}{l}\text { Hist3 } \\
\text { Fut } 3\end{array}$ & $\begin{array}{l}153.10 \\
154.92\end{array}$ & 0.204 & $\begin{array}{l}168 \\
178\end{array}$ & $+5.95 \%$ & 0.195 \\
\hline 4 & 0.243 & 0.757 & 0.0089 & $\begin{array}{l}\text { Hist4 } \\
\text { Fut } 4\end{array}$ & $\begin{array}{l}122.65 \\
121.91\end{array}$ & 0.584 & $\begin{array}{l}136.6 \\
140.1\end{array}$ & $+2.56 \%$ & 0.590 \\
\hline 5 & 0.153 & 0.846 & 0.0137 & $\begin{array}{l}\text { Hist5 } \\
\text { Fut } 5\end{array}$ & $\begin{array}{l}115.00 \\
121.00\end{array}$ & 0.256 & $\begin{array}{l}136.8 \\
143.9\end{array}$ & $+5.19 \%$ & 0.295 \\
\hline 6 & $0.000 *$ & 1.000 & 0.0967 & $\begin{array}{l}\text { Hist6 } \\
\text { Fut } 6\end{array}$ & $\begin{array}{l}153.15 \\
207.08\end{array}$ & $0.000 *$ & $\begin{array}{l}169 \\
227\end{array}$ & $+34.32 \%$ & $0.000^{*}$ \\
\hline 7 & $0.000 *$ & 1.000 & 0.1307 & $\begin{array}{l}\text { Hist7 } \\
\text { Fut } 7\end{array}$ & $\begin{array}{l}138.70 \\
204.38\end{array}$ & $0.000 *$ & $\begin{array}{l}157 \\
230\end{array}$ & $+46.49 \%$ & $0.000 *$ \\
\hline 8 & 0.399 & 0.600 & 0.0031 & $\begin{array}{l}\text { Hist8 } \\
\text { Fut } 8\end{array}$ & $\begin{array}{l}122.30 \\
121.37\end{array}$ & 0.963 & $\begin{array}{l}138.9 \\
140.3\end{array}$ & $+1.01 \%$ & 0.821 \\
\hline 9 & $0.000 *$ & 0.999 & 0.0479 & $\begin{array}{l}\text { Hist } 9 \\
\text { Fut } 9\end{array}$ & $\begin{array}{l}100.55 \\
121.77\end{array}$ & $0.000 *$ & $\begin{array}{l}116.1 \\
141.3\end{array}$ & $+21.7 \%$ & $0.000^{*}$ \\
\hline 10 & $0.000 *$ & 1.000 & 0.1273 & $\begin{array}{l}\text { Hist10 } \\
\text { Fut } 10\end{array}$ & $\begin{array}{l}167.35 \\
229.32\end{array}$ & $0.000 *$ & $\begin{array}{l}180 \\
251\end{array}$ & $+39.44 \%$ & $0.000^{*}$ \\
\hline 11 & 0.995 & $0.004 *$ & -0.0369 & $\begin{array}{l}\text { Hist11 } \\
\text { Fut } 11\end{array}$ & $\begin{array}{l}144.70 \\
122.00\end{array}$ & $0.001 *$ & $\begin{array}{l}164.7 \\
144.1\end{array}$ & $-12.51 \%$ & $0.003^{*}$ \\
\hline 12 & $0.000 *$ & 1.000 & 0.1642 & $\begin{array}{l}\text { Hist12 } \\
\text { Fut } 12\end{array}$ & $\begin{array}{l}119.75 \\
197.46\end{array}$ & $0.000 *$ & $\begin{array}{c}131.5 \\
226\end{array}$ & $+71.86 \%$ & $0.000^{*}$ \\
\hline 13 & $0.000 *$ & 0.999 & 0.0515 & $\begin{array}{l}\text { Hist13 } \\
\text { Fut } 13\end{array}$ & $\begin{array}{l}103.10 \\
128.94\end{array}$ & $0.000 *$ & $\begin{array}{l}120.4 \\
148.6\end{array}$ & $+23.42 \%$ & $0.000^{*}$ \\
\hline 14 & $0.000 *$ & 1.000 & 0.1186 & $\begin{array}{l}\text { Hist14 } \\
\text { Fut } 14\end{array}$ & $\begin{array}{l}134.15 \\
201.88\end{array}$ & $0.000 *$ & $\begin{array}{c}148.8 \\
218\end{array}$ & $+46.5 \%$ & $0.000^{*}$ \\
\hline 15 & $0.000 *$ & 1.000 & 0.1641 & $\begin{array}{l}\text { Hist15 } \\
\text { Fut } 15\end{array}$ & $\begin{array}{l}122.10 \\
212.52\end{array}$ & $0.000 *$ & $\begin{array}{c}139.5 \\
235\end{array}$ & $+68.46 \%$ & $0.000^{*}$ \\
\hline 16 & 0.451 & 0.549 & 0.0018 & $\begin{array}{l}\text { Hist16 } \\
\text { Fut } 16\end{array}$ & $\begin{array}{l}133.20 \\
121.85\end{array}$ & 0.508 & $\begin{array}{l}151 \\
147\end{array}$ & $-2.65 \%$ & 0.551 \\
\hline 17 & $0.000 *$ & 1.000 & 0.1612 & $\begin{array}{l}\text { Hist } 17 \\
\text { Fut } 17\end{array}$ & $\begin{array}{c}93.55 \\
183.20\end{array}$ & $0.000 *$ & $\begin{array}{c}114.5 \\
206\end{array}$ & $+79.91 \%$ & $0.000^{*}$ \\
\hline 18 & $0.000 *$ & 1.000 & 0.1372 & $\begin{array}{l}\text { Hist18 } \\
\text { Fut } 18\end{array}$ & $\begin{array}{l}112.65 \\
193.35\end{array}$ & $0.000 *$ & $\begin{array}{c}128.4 \\
202\end{array}$ & $+57.32 \%$ & $0.000^{*}$ \\
\hline 19 & $0.000 *$ & 0.999 & 0.0443 & $\begin{array}{l}\text { Hist19 } \\
\text { Fut } 19\end{array}$ & $\begin{array}{l}110.65 \\
121.61\end{array}$ & $0.011 *$ & $\begin{array}{l}123.5 \\
142.6\end{array}$ & $+15.46 \%$ & $0.003^{*}$ \\
\hline 20 & $0.009 *$ & 0.991 & 0.0319 & $\begin{array}{l}\text { Hist20 } \\
\text { Fut } 20\end{array}$ & $\begin{array}{l}112.70 \\
119.89\end{array}$ & 0.063 & $\begin{array}{l}129.1 \\
142.8\end{array}$ & $+10.61 \%$ & $0.043^{*}$ \\
\hline 21 & $0.000 *$ & 0.999 & 0.0428 & $\begin{array}{l}\text { Hist21 } \\
\text { Fut } 21\end{array}$ & $\begin{array}{l}100.80 \\
121.83\end{array}$ & $0.001 *$ & $\begin{array}{l}116.9 \\
139.3\end{array}$ & $+19.16 \%$ & $0.000^{*}$ \\
\hline 22 & 0.064 & 0.935 & 0.0192 & $\begin{array}{l}\text { Hist22 } \\
\text { Fut } 22\end{array}$ & $\begin{array}{l}120.50 \\
121.38\end{array}$ & 0.514 & $\begin{array}{l}129.4 \\
137.9\end{array}$ & $+6.57 \%$ & 0.164 \\
\hline 23 & $0.000^{*}$ & 1.000 & 0.1896 & $\begin{array}{l}\text { Hist23 } \\
\text { Fut } 23\end{array}$ & $\begin{array}{l}101.15 \\
197.23\end{array}$ & $0.000 *$ & $\begin{array}{c}113.8 \\
216\end{array}$ & $+89.81 \%$ & $0.000^{*}$ \\
\hline 24 & $0.000^{*}$ & 1.000 & 0.0794 & $\begin{array}{l}\text { Hist24 } \\
\text { Fut } 24\end{array}$ & $\begin{array}{l}115.70 \\
152.82\end{array}$ & $0.000 *$ & $\begin{array}{l}129.0 \\
164.3\end{array}$ & $+27.36 \%$ & $0.000^{*}$ \\
\hline
\end{tabular}

* Statistically significant trends at the 5\% significance level. 
A study by Cera and Ferraz (2015) analyzed precipitation trends in Rio Grande do Sul for three sets of data, with a comparison of the observed precipitation data (1982-2006) and simulated data by RegCM3 Regional Model (2070-2086) also showed an increasing trend for that State. They applied the Run test and Pettit test to certify the homogeneity of data for the series 1982 to 2006; but the tests gave different results and the Mann-Kendall test was used and this confirmed the Pettit test, indicating an increased trend of precipitation at a significant level of $99 \%$ in extreme north and central areas of the State of Rio Grande do Sul. The same study also analyzed the trend for future climate and the increase in precipitation trend at a $90 \%$ level of significance in the western, southern and central state was observed.

Other research similar to the study above was that of Doyle et al. (2012) in the La Plata Basin (LPB), where the northern part of this basin includes the State of Paraná. They employed the PRECIS regional climate modeling system for the annual rainfall and used precipitation data in the recent past (1961-1990) and in a future (2071-2100) climate at 5 and 10\% confidence levels and all stations showed positive trends with the values exceeding $8 \mathrm{~mm} \mathrm{yr}^{-1}$ over southern Brazil. For that same location, Marengo et al. (2012) made use of the Eta/HadCM3 Model configured with a 40-km grid size and was run over 1961 to 1990 to represent baseline climate, and 2011 to 2100 to simulate possible future changes. They detected a rainfall increase in the South East of South America (by about 30-50\%).

According to PBMC (2013), in southern Brazil and northern Argentina, trends for increased rainfall and river flows have been observed since the mid-twentieth century, with Paraná and La Plata Rivers showing a downward trend from 1901 to 1970 and a systematic increase in flows from the early 1970s to the present. It is also claimed that Southern region disasters such as landslides, death by drowning and building collapses may be more frequent. Agriculture and livestock in the region are vulnerable to climate change. There are numerous records of the El Niño Southern Oscillation (ENSO) phenomenon, which accentuates the conditioning/adversity features of the climate on agricultural production, determining production records or widespread losses. It should be added to the weather condition already affected by the ENSO, records of air temperature increase in various municipalities of Rio Grande do Sul, Santa Catarina and Paraná, which inevitably influence not only the agriculture and food security, but environmental conditions such as the hydrologic cycle and population health. Increases in rainfall and river flow, despite the uncertainties, are likely to intensify, as projected by the IPCC scenarios (IPCC, 2014). Temperatures will follow the pattern of increase in average values, with reduced episodes of frosts and cold days.

The location of points and the direction of trends for monthly precipitation data series during the period 1980 to 2050 are shown in Figure 3. Significant increasing trends were found in almost all the Mesoregions for the State of Paraná, except in West and West Central, where there wasn't any trend. In the South West and South Central, two points were detected for decreasing trend, but increasing trends also were found. This result is similar to that obtained by Zandonadi and Acquaotta (2016) for Paraná State: both results exhibited an increasing trend in the region of Curitiba (located in Metropolitan Curitiba), Castro (located in East Central), Irati (located in South East), Maringá and Londrina (both located in North Central), but differ in Campo Mourão region (located in West Central), where this study didn't show a trend and the other showed decreased trend. 


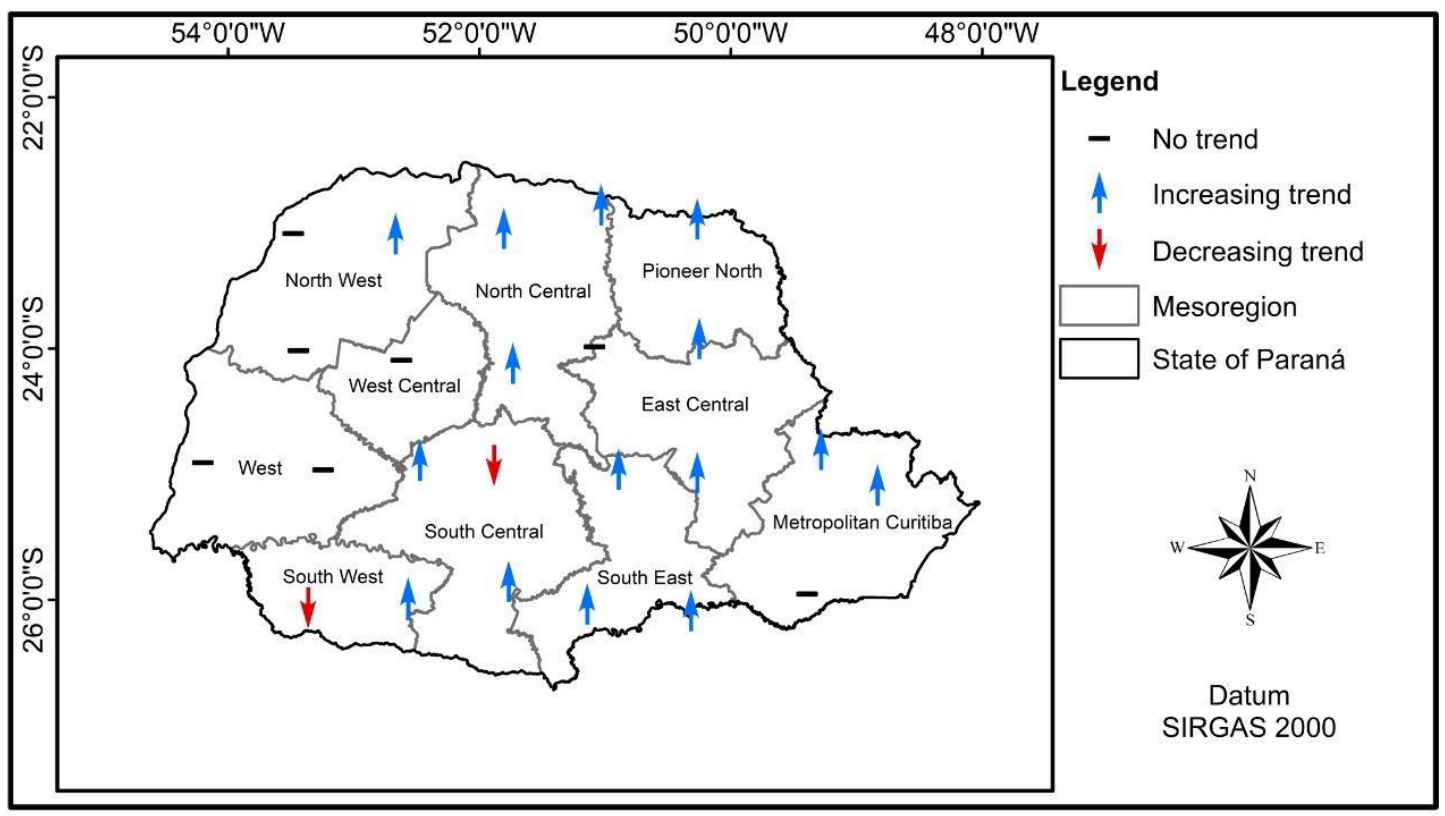

Figure 3. Spatial distribution of precipitation stations with increasing, decreasing and no trends during the period 1980 to 2050 .

The Figure 4 shows the monthly precipitation of seventeen points where there is trend increasing and decreasing the values. A large variability in monthly precipitation accumulation in graphics is observed, for instance, in Figure $4 \mathrm{j}$, where the maximum value of monthly accumulation reaches approximately $1000 \mathrm{~mm}$, whereas the graphic of Figure 4o) reaches 500 $\mathrm{mm} / \mathrm{month}^{-1}$. The red line confirms the trend displayed in Table 2 and adrees with Grimm et al. (2000), that say that in South Brazil there are seasonal characteristics of rainfall that can change when there is the El Niño/La Niña, causing extreme precipitation events as excess or deficit.

Observe the high variability between each month in Figure 4. In Figure 4b), the average of the historical series is $169 \mathrm{~mm} \mathrm{month}^{-1}$ and the mean in the simulated series is $227 \mathrm{~mm} \mathrm{month}{ }^{-1}$. This represents an increase of $34.32 \%$. In the time series of graphic Figure 4k), the means are 114.5 and $206 \mathrm{~mm} \mathrm{month}^{-1}$, an increase of $79.91 \%$. The same happens in the graphic of Figure 41), a rain increase of $57.32 \%$. According to Table 2, the maximum increment $(89.81 \%)$ is in Figure $4 p$ ), and the maximum reduction (19.66\%) in Figure 4a). Thus, if materializing expectations of these increases, there may be positive and negative impacts. An example of a positive impact is the replenishment of groundwater and an example of a negative impact is the increase of floods.

\section{CONCLUSIONS}

Considering the historical series (1980-2010) with the simulated series (2016-2050) that was simulated by the Eta/MIROC5 at twenty-four points, monthly precipitation showed increasing trends at fifteen locations in the State of Paraná and two sites showed a decrease in the monthly rainfall trend.

In some places, there is a big difference between the average monthly precipitation of 1980 to 2010 compared with the average expected precipitation of 2016 to 2050 .

The results also exhibited great variability in monthly rainfall for both the historical series and the simulated series. 
a)

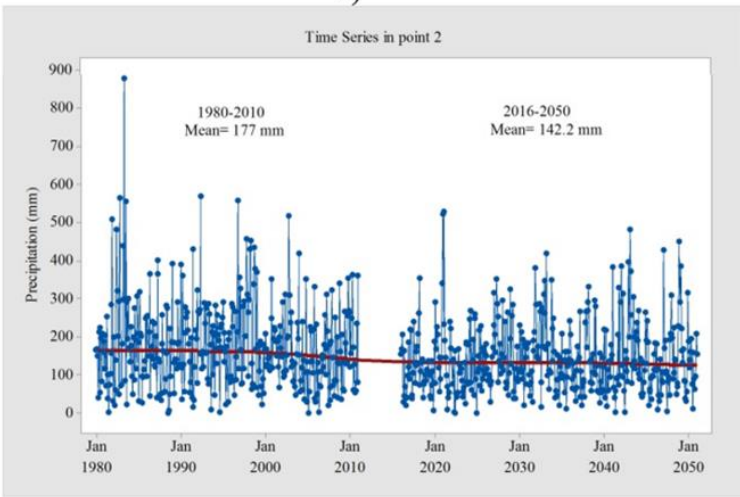

c)

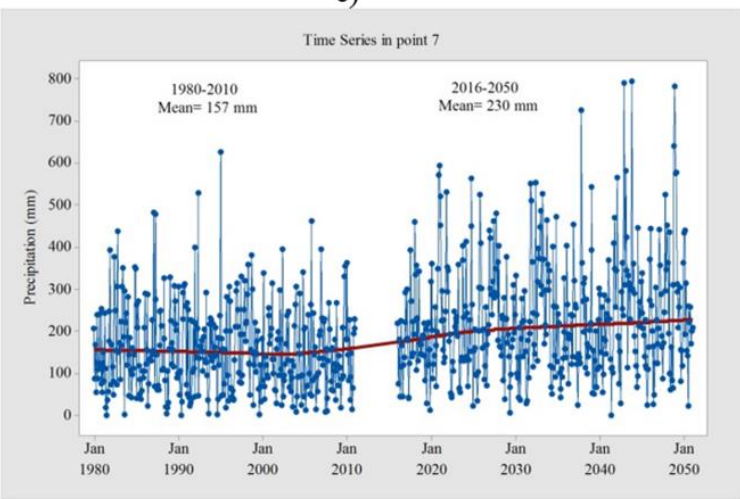

e)

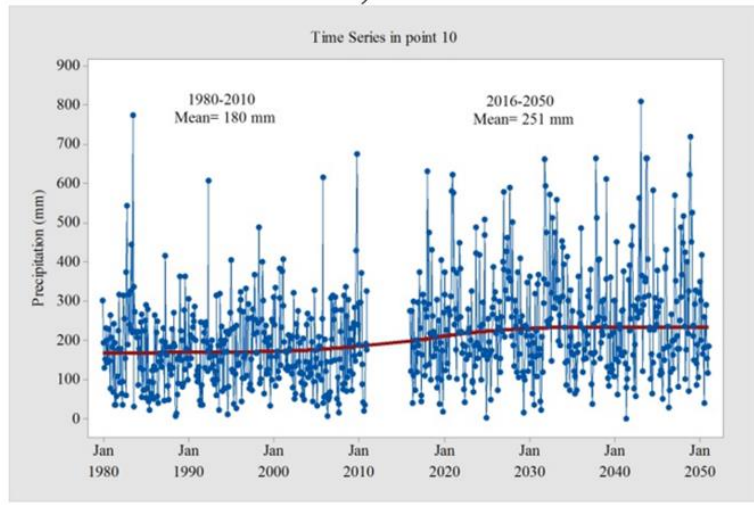

g)

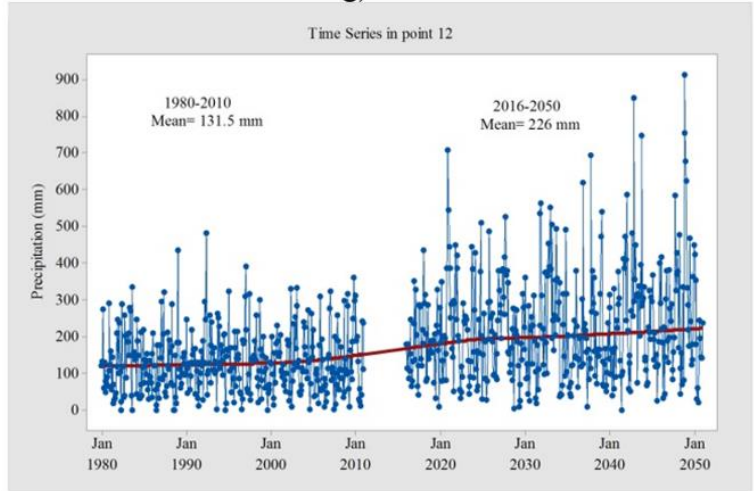

b)

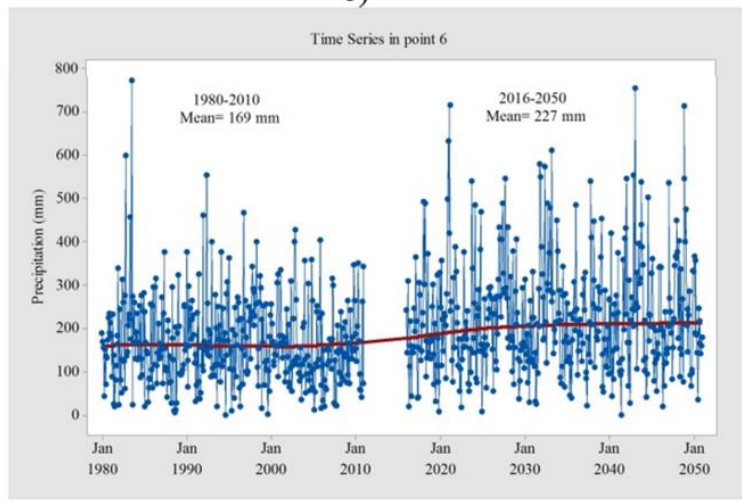

d)

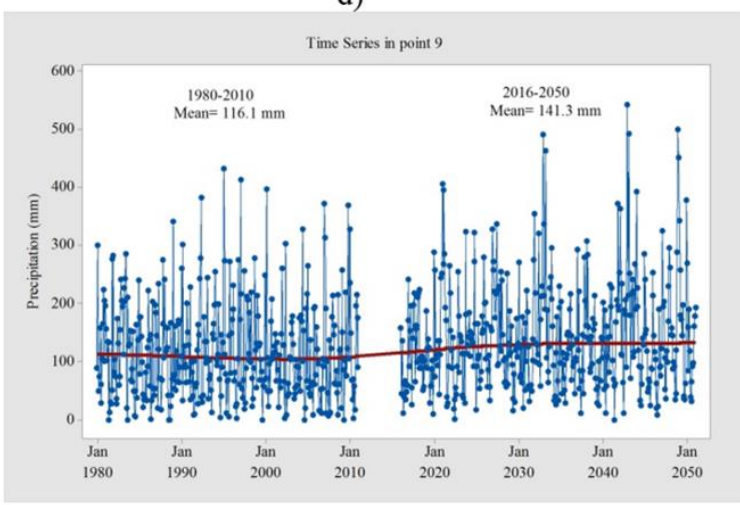

f)

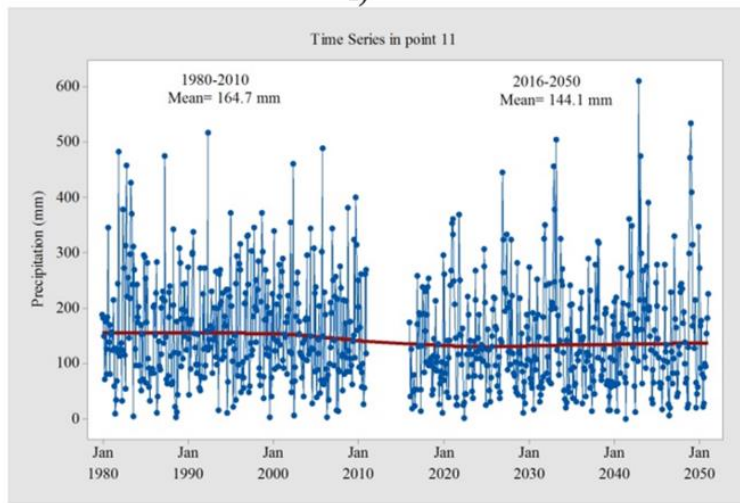

h)

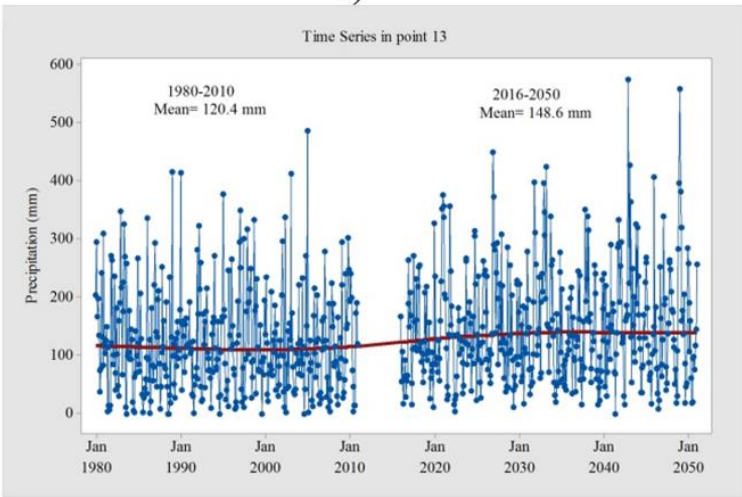

Figure 4. Temporal variation at points where show changes in precipitation trends during the period 1980-2050, along with the mean of historical and simulated precipitation. Continue. 


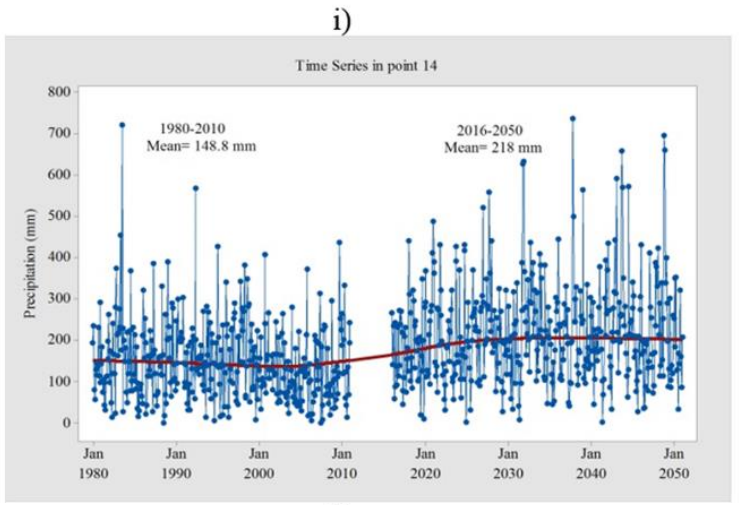

k)

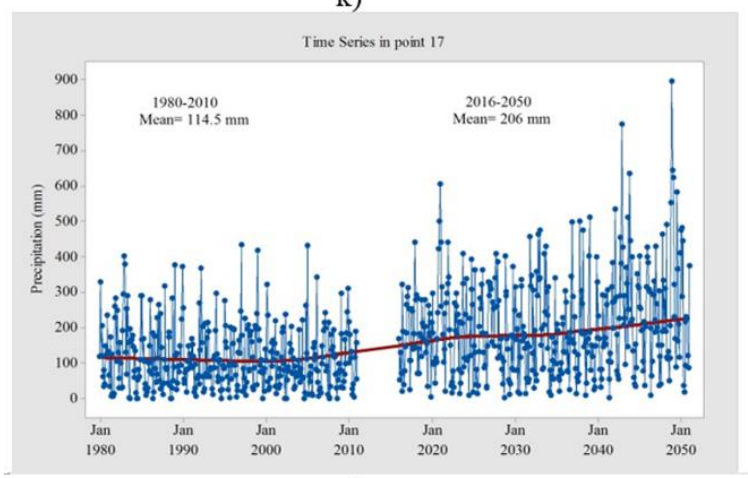

m)

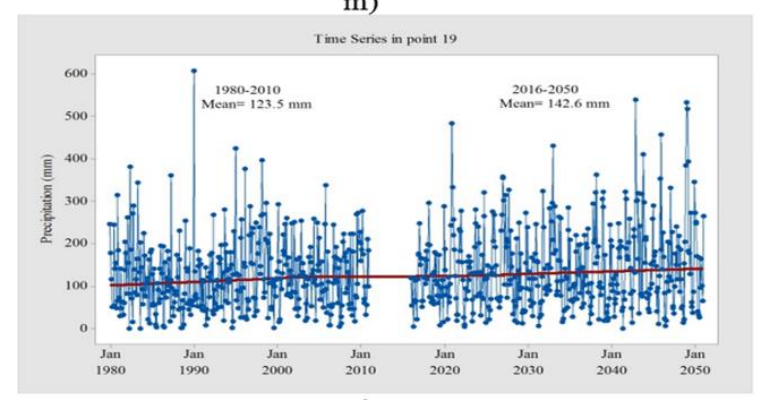

o)

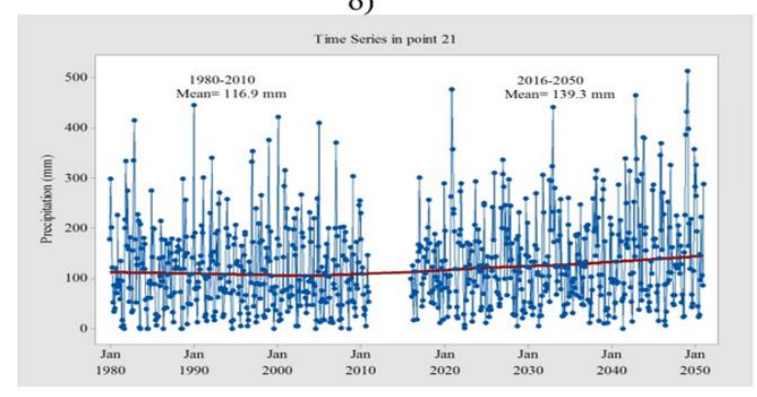

j)
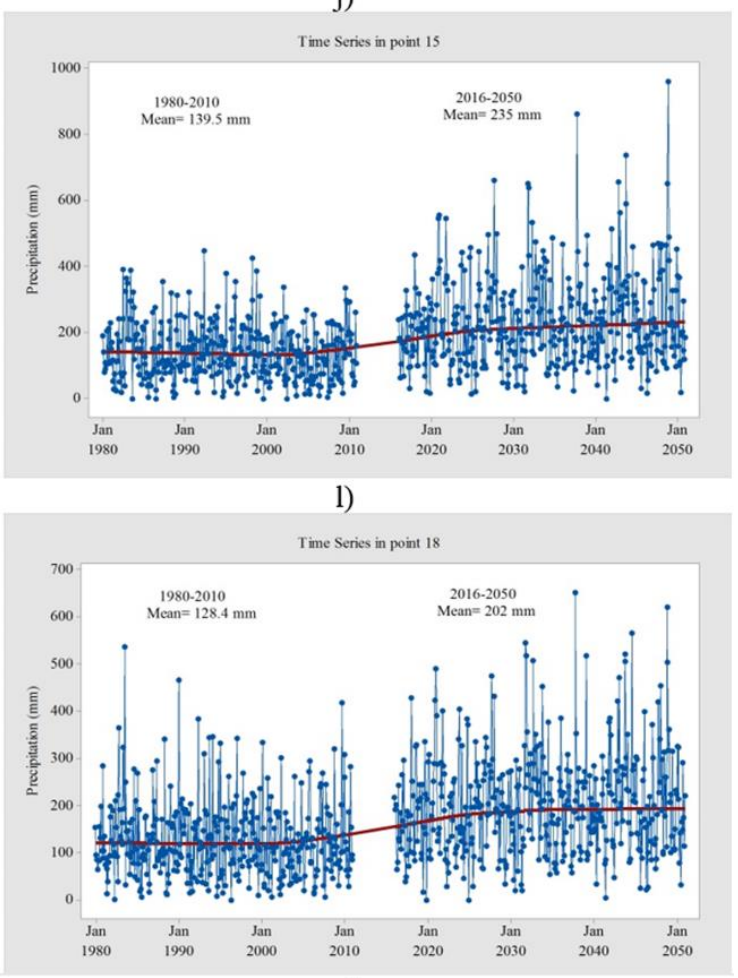

n)

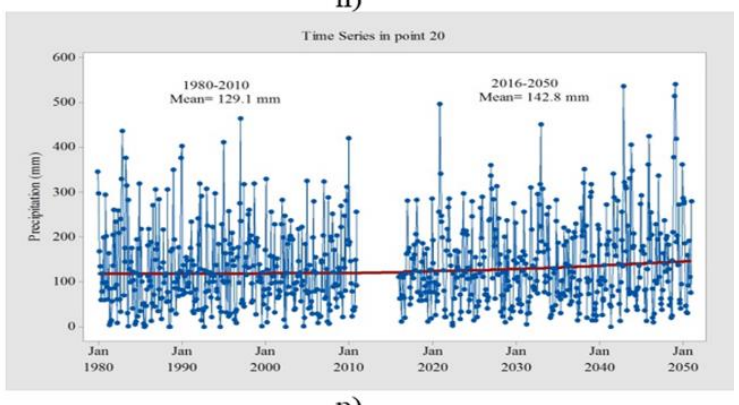

p)

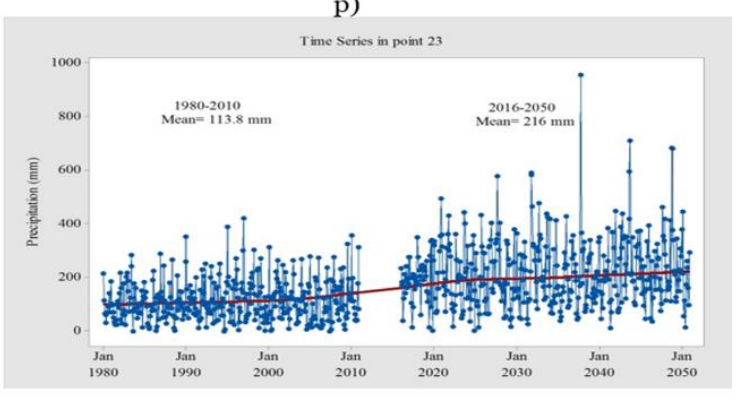

q)

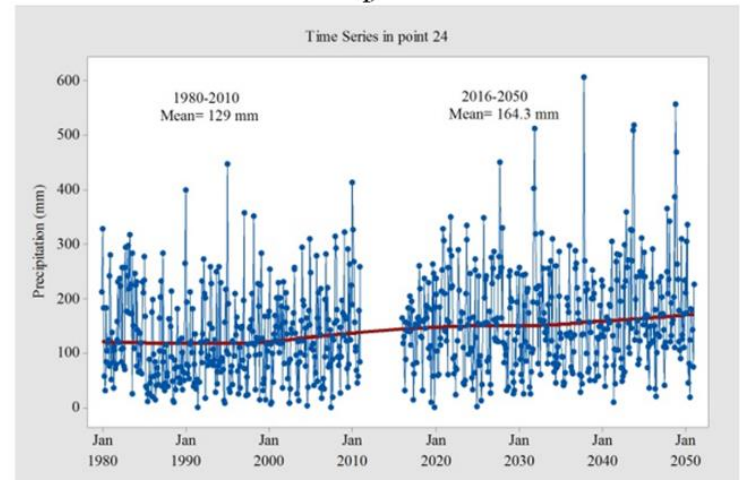

Figure 4. Continued. 


\section{REFERENCES}

ADAM, K. N.; COLliSCHONN, W. Análise dos impactos de mudanças climáticas nos regimes de precipitação e vazão na bacia hidrográfica do rio Ibicuí. Revista Brasileira de Recursos Hídricos, v. 18, n. 3, p. 69-79, 2013. http://dx.doi.org/10.21168/rbrh.v18n3.p69-79

BABA, R. K.; VAZ, M. S. M. G.; COSTA, J. D. Correção de dados agrometeorológicos utilizando métodos estatísticos. Revista Brasileira de Meteorologia, v. 29, n.4, p. 515526, 2014. http://dx.doi.org/10.1590/0102-778620130611

BARBOSA, S. E. S.; BARBOSA JÚNIOR, A. R.; SILVA, G. Q.; CAMPOS, E. N. B.; RODRIGUES, V.C. Geração de modelos de regionalização de vazões máximas, médias de longo período e mínimas de sete dias para a Bacia do Rio do Carmo, Minas Gerais. Revista Engenharia Sanitária e Ambiental, v. 10, n. 1, p. 64-71, 2005. http://dx.doi.org/10.1590/S1413-41522005000100008

CERA, J. C.; FERRAZ, S. E. T. Variações climáticas na precipitação no sul do Brasil no clima presente e futuro. Revista Brasileira de Meteorologia, v. 30, n.1, p. 81-88, 2015. http://dx.doi.org/10.1590/0102-778620130588

CHOU, S. C.; MARENGO, J. A.; LYRA, A. A.; SUEIRO, G.; PESQUERO, J. F.; ALVES, L. M.; KAY, G.; BETTS, R.; CHAGAS, D. J.; GOMES, J. L.; BUSTAMANTE, J. F.; TAVARES, P. Downscaling of South America present climate driven by 4-member HadCM3 runs. Journal Climate Dynamics, v. 38, p. 635-653, 2011. http://dx.doi.org/10.1007/s00382-011-1002-8

DOYLE, M. E.; SAURRAL, R. I.; BARROS, V. R. Trends in the distributions of aggregated monthly precipitation over the La Plata Basin. International Journal of Climatology, $\mathrm{v}$. 32, n. 14, p. 2149-2162, 2012. http://dx.doi.org/10.1002/joc.2429

GIAROLLA, A.; RESENDE, N.; CHOU, S. C.; TAVARES, P. S.; RODRIGUES, D. C. Coffee beverage quality assessment based on Eta/CPTEC-HadCM3 model (A1B-IPCC/SRES scenario), Southeastern Brazil. Geophysical Research Abstracts, v. 14, n. 1, p. 6224, 2012.

GOCIC, M.; TRAJKOVIC, S. Analysis of changes in meteorological variables using MannKendall and Sen's slope estimator statistical tests in Serbia. Global and Planetary Change, v.100, p. 172-182, 2013. http://dx.doi.org/10.1016/j.gloplacha.2012.10.014

GRIMM, A. M.; BARROS, V. R.; DOYLE, M. E. Climate Variability in Southern South America Associated with El Niño and La Niña Events. Journal of Climate, v. 13, p. 3558, 2000. https://doi.org/10.1175/1520-0442(2000)013\%3C0035:CVISSA\%3E2.0.CO;2

IPCC. Climate change 2014: mitigation of climate change. Contribution of working group III. Cambridge: Cambridge University Press, 2014.

KIM, D. W.; DEO, R. C.; CHUNG, J. H.; LEE, J. S. Projection of heat wave mortality related to climate change in Korea. Natural Hazards, v. 80, p. 623-637, 2016. http://dx.doi.org/10.1007/s11069-015-1987-0 
MARENGO, J. A.; HOU, S. C.; KAY, G.; ALVES, L. M.; PESQUERO, J. F.; SOARES, W. R.; SANTOS, D. C.; LYRA, A. A.; SUEIRO, G.; BETTS, R.; CHAGAS, D. J.; GOMES, J. L.; BUSTAMANTE, J.; TAVARES, P. Development of regional future climate change scenarios in South America using the Eta CPTEC/HadCM3 climate change projections: climatology and regional analyses for the Amazon, São Francisco and the Paraná River basins. Climate Dynamics, v. 38, p. 1829-1848, 2012. http://dx.doi.org/10.1007/s00382011-1155-5

MARENGO, J. A.; JONES, R.; ALVES, L. M.; VALVERDE, M. C. Future Change of Temperature and Precipitation Extremes in South America as Derived from the PRECIS Regional Climate Modeling System. International Jounal of Climatology, v. 29, n. 15, p. 2241-2255, 2009. http://dx.doi.org/10.1002/joc.1863

PBMC. Executive Summary: Impacts, vulnerability and adaptation to climate change. Contribution from GT2 to the Primeiro Relatório de Avaliação Nacional sobre de Mudanças Climáticas (RAN1) of the painel brasileiro de mundança climática (PBMC). Rio de Janeiro: UFRJ, 2013. 28p.

PRUSKI, F. F.; PEREIRA, S. B.; NOVAES, L. F.; Silva, D. D.; Ramos, M. M. Precipitação média anual e vazão específica média de longa duração, na Bacia do São Francisco. Revista Brasileira de Engenharia Agrícola e Ambiental, v. 8, n. 2/3, p.2 47-253, 2004. http://dx.doi.org/10.1590/S1415-43662004000200013

SANTOS, M.; FRAGOSO, M. Precipitation variability in Northern Portugal: data homogeneity assessment and trends in extreme precipitation indices. Atmospheric Research, v. 131, p. 34-45, 2013. http://dx.doi.org/10.1016/j.atmosres.2013.04.008

SINGH, V.; GOYAL, M. K. Analysis and trends of precipitation lapse rate and extreme indices over north Sikkim eastern Himalayas under CMIP5ESM-2M RCPs experiments. $\begin{array}{llllll}\text { Atmospheric Research, } & \text { v. } & \text { 167, } & \text { p. }\end{array}$ http://dx.doi.org/10.1016/j.atmosres.2015.07.005

VUUREN, D P. V.; EDMONDS, J.; KAINUMA, M.; RIAHI, K.; THOMSON, A.; HIBBARD, K.; HURTT, G. C.; KRAM, T.; KREY, V.; LAMARQUE, J. F.; MASUI, T.; MEINSHAUSEN, M.; NAKICENOVIC, N.; SMITH, S. J.; ROSE, S. K. The representative concentration pathways: an overview. Climatic Change, v. 109, p. 5-31, 2011. http://dx.doi.org/10.1007/s10584-011-0148-z

YÜREKLI, K. Impact of climate variability on precipitation in the Upper Euphrates - Tigris Rivers Basin of Southeast Turkey. Atmospheric Research, v. 154, p. 25-38, 2015. http://dx.doi.org/10.1016/j.atmosres.2014.11.002

ZANDONADI, L.; ACQUAOTTA, F.; FRATIANNI, S.; ZAVATTINI, J. A. Changes in precipitation extremes in Brazil (Paraná River Basin). Theoretical and Applied Climatology, v. 123, p. 741-756, 2016. http://dx.doi.org/10.1007/s00704-015-1391-4 


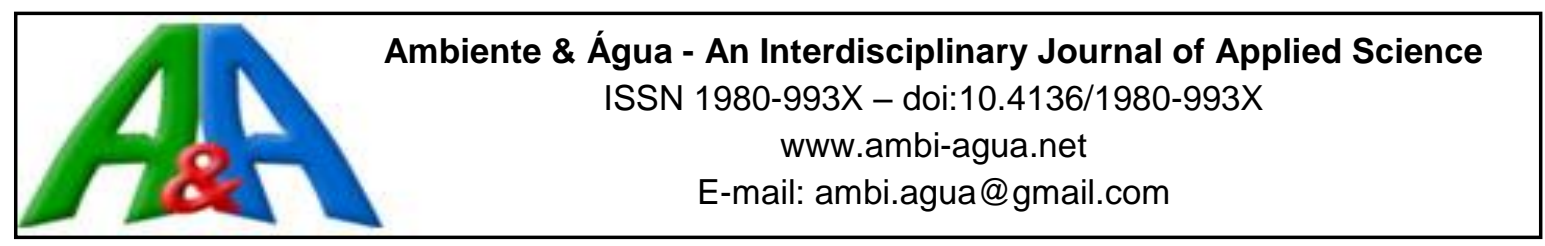

\title{
Relationships between land use and water quality obtained for the evaluation of genotoxic effects in plant bioindicators
}

\author{
ARTICLES doi:10.4136/ambi-agua.2299
}

Received: 16 Jul. 2018; Accepted: 18 Dec. 2018

\begin{abstract}
Jéssica Sieklicki ${ }^{\circledR}$; Nilton Cesar Pires Bione ${ }^{\circledR}$; Paulo Costa de Oliveira-Filho ${ }^{\circledR}$; Viviane Fernandes de Souza ${ }^{10}$; Kelly Geronazzo Martins* ${ }^{*}$

Universidade Estadual do Centro-Oeste (UNICENTRO), Irati, PR, Brasil

Departamento de Engenharia Ambiental (DENAM). E-mail: jessica.sieklicki@gmail.com,

bione@irati.unicentro.br, paulocostafh@gmail.com, vfsouza@irati.unicentro.br, kellygm77@gmail.com

*Corresponding author
\end{abstract}

\begin{abstract}
Anthropic activities as well as land use and occupation are closely linked to water and soil quality. An alternative to assess their influence on water quality in water bodies is through biomonitoring using Allium cepa as a bioindicator organism. This technique allows the detection of cytogenetic abnormalities in Allium cepa root meristematic cells after contact with analyzed water samples. Thus, we evaluated the genotoxic potential of water samples from the Rio das Antas (Antas River) along the urban perimeter of the city of Irati, Paraná, Brazil. With the aid of GeoEye Satellite high-resolution fused orbital images, we searched for possible relationships between the use and occupation of land around this river. Biomonitoring was performed at three different sampling points. Statistical equality between the negative control and Point 1 and between Points 2 and 3 was obtained using Fisher's test and a Principal Coordinate Analysis (PCoA). The former presented a low frequency of abnormalities chromosomes and the latter presented larger averages. In addition, Point 1 had strong influence of tree vegetation. Points 2 and 3, demonstrated a strong influence of urbanized area, with significant degradation of permanent preservation areas (áreas de preservação permanente (APP). The results showed remarkable anthropogenic interference to the ecosystem. Furthermore, this indicates importance of an APP watercourses functioning to preserve the quality of the water resources.
\end{abstract}

Keywords: alternative method of water quality analysis, chromosomal abnormalities, remote sensing.

\section{Relações pontuais entre o uso e ocupação da terra e a qualidade da água obtida pela avaliação dos efeitos genotóxicos em bioindicadores vegetais}

\section{RESUMO}

As atividades antrópicas bem como o uso e ocupação da terra estão intimamente ligadas à qualidade da água e do solo. Uma alternativa para avaliar suas influências na qualidade da água em corpos hídricos é através do biomonitoramento utilizando Allium cepa como organismo bioindicador. Esta técnica permite detectar anormalidades citogenéticas nas células meristemáticas radiculares de Allium cepa após o contato com a amostra de água analisada. 
Assim, realizou-se a avaliação do potencial genotóxico de águas do Rio da Antas no perímetro urbano do município de Irati-PR e com o auxílio de imagens orbitais fusionadas de alta resolução do satélite Geoeye, buscou-se possíveis relações com o uso e ocupação da terra do entorno deste rio. O biomonitoramento foi realizado em três pontos amostrais distintos. Integrando-se os dados, obteve-se, com o teste de Fisher e mediante uma análise de coordenadas principais (PCoA), uma igualdade estatística entre o controle negativo e o ponto 1 e entre o ponto 2 e 3, sendo que os primeiros apresentaram baixa frequência de anormalidades cromossômicas e os últimos, médias maiores. Além disso, o ponto 1 apresentou forte influência de vegetação arbórea e os pontos 2 e 3, forte influência de área urbanizada, com expressiva degradação das áreas de preservação permanente (APPs). Os resultados confirmaram a notável interferência antrópica ao ecossistema, bem como, a importância da APP na preservação e qualidade do recurso hídrico.

Palavras-chave: anormalidades cromossômicas, metodologia alternativa de análise da qualidade da água, sensoriamento remoto.

\section{INTRODUCTION}

The urbanization process of many Brazilian cities occurred along riverbanks and brought detrimental consequences for bodies of water, the quality of the air, soil, fauna and flora of the region (Fendrich and Oliynik, 2002).

Anthropogenic activities such as land use and occupation are factors that interfere with water and soil quality. Another factor of significant relevance is the advancement of technologies and products in the industrial and agricultural sectors, which have helped to bring about the introduction of new chemical agents in the environment, thereby impacting the ecosystem equilibrium (FUNASA, 2002). The destruction of the riparian forests contributes to the silting of water bodies. As a result, this caused increases of turbidity, erosion, disequilibrium of the flood regime and the involvement of wild fauna (Oliveira-Filho et al., 1994).

Environmental quality monitoring can be performed through conventional physicochemical and microbiological assessments combined with specific assessments to investigate changes in the cellular metabolism of bioindicators. Moreover, they can applied to evaluate differences in some genetic structures due to the presence of substances with varying degrees of toxicity. In addition to representing a low costs, according to Grant (1994), plant species such as Allium cepa and Tradescantia ssp. are effective in environmental monitoring to assess the mutagenic potential of air, water and soil pollutants. Because of the similarities in the morphology of the chromosomes of eukaryotic organisms (plants and animals), they may also respond in an action mode of mutagenic agents (Constantin and Owens, 1982).

Experiments using Allium cepa as a test organism reveal and classify parameters such as cytotoxicity with mitotic index, mutagenicity with frequency of micronuclei, and genotoxicity with the frequency of chromosomal abnormalities during meristematic cell division of roots exposed to the analyzed samples (Fiskesjö, 1993). Thus, the genotoxic action of possible pollutants in the samples can be determined (Leme and Morales, 2009). The genotoxicity test using Allium cepa was validated by the United Nations Environment Program and the International Chemical Safety Program (Grover and Satwinderjeet, 1999).

It is a fact that the use and occupation of the land interfere with the quality of a water body, and this interference does not occur only in a localized way, but reaches the whole region that surrounds it (Oliveira et al., 2012; Costa, et al., 2015). Thus, proximity analyses are valuable to detect the use and occupation of the land around the sampling points and to assist in the evaluation of water quality. 
The use of remote sensing as a tool for analysis and control of environmental issues has become essential. The evolution in the technological area increasingly favors the development of numerous terrestrial-environmental monitoring satellites allowing for the collection of qualitative and quantitative data on a global, regional or local scale, as well as determining the degree of environmental degradation among other measurements (Mascarenhas et al., 2009).

The purpose of this study was to evaluate the influence of urban and peri-urban soil use and occupation through the monitoring of the Rio das Antas' (Antas River) water quality and its possible genotoxic effects at predefined points. By means of high-resolution orbital images the classification of land use and cover was carried out by comparing them with the results obtained in the cytogenetic evaluations of the bioindicator vegetation.

\section{MATERIALS AND METHODS}

\subsection{Study area}

The study was carried out in the urban area of the municipality of Irati, Paraná, Brazil. (Figure 1) located $150.34 \mathrm{~km}$ from the state capital, Curitiba (IPARDES, 2017). The municipality was founded in 1907, and since then it has experienced increases in population along with economic and industrial growth. These factors interfere directly and indirectly with the preservation of the water quality of the municipality. It has a $999,517 \mathrm{~km}^{2}$ extension, an estimated population of 60,425 inhabitants with $73.6 \%$ of households having access to adequate sanitary sewage (IBGE, 2017). The rivers that surround the municipality are the Rio dos Patos, Rio Caratuva, Rio das Antas, Rio Preto, Rio Riozinho, Rio Cachoeira, Rio Ponte Alta, Río Quente and Rio Taquari, with their courses being directed to the Tibagi, Iguaçu and Ivaí river basins. These tributaries all belong to the Paraná River Basin (Andrade and Felchak, 2009).

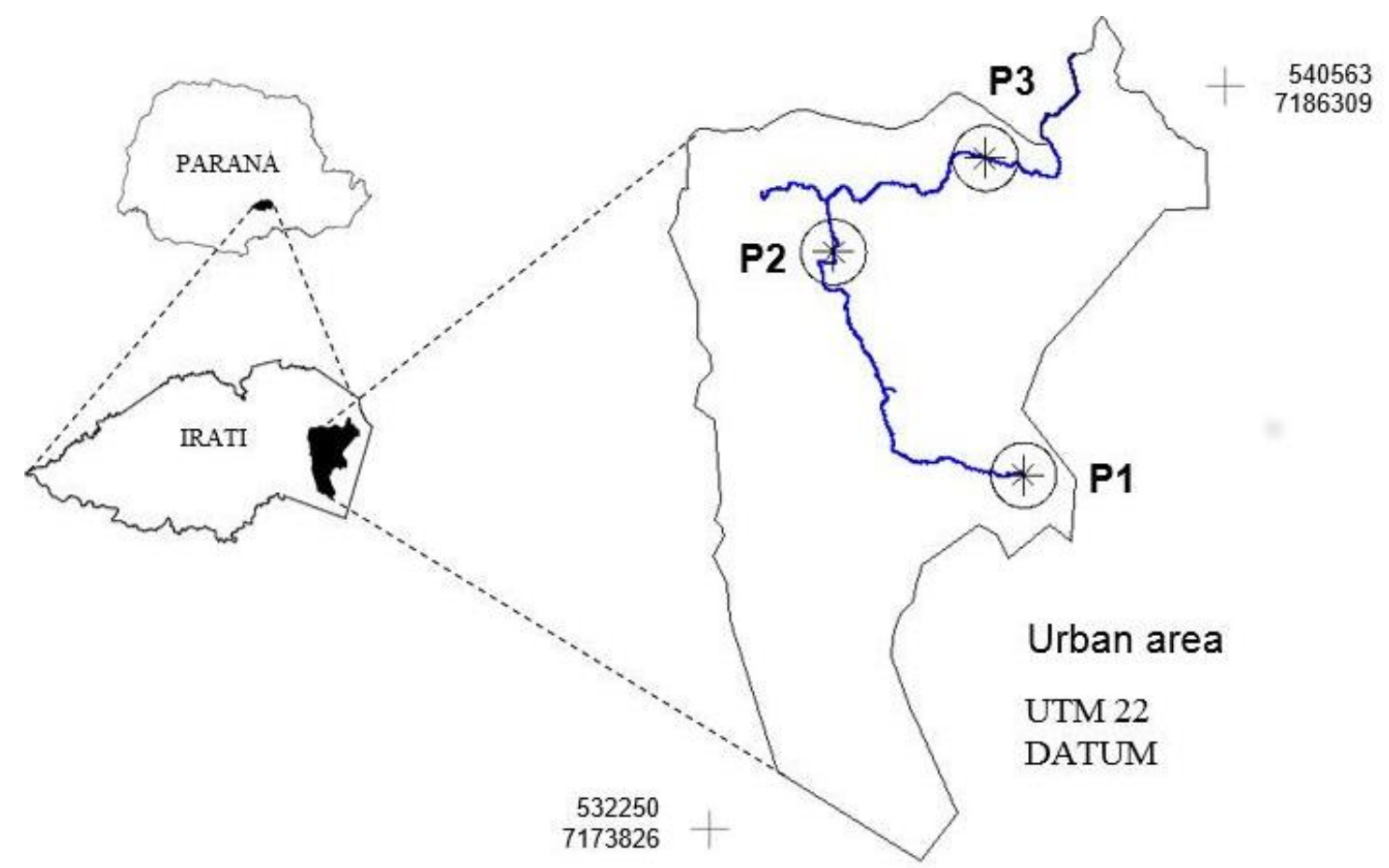

Figure 1. Urban area of the municipality of Irati, Paraná showing the sampling points P1, P2 and P3.

Source: research data.

The Rio das Antas is considered one of the main water bodies of the municipality of Irati. Its origin is in the Serra do Nhapindazal (Nhapindazal mountain range), an area of urban expansion of the municipality. Additionally, its greater extension crosses the urbanized area, 
crosses several neighborhoods, receiving several tributaries before leaving this perimeter when passing under the bridge in BR 277, between the coordinates $25^{\circ} 28^{\prime} 02^{\prime \prime}$ South and $50^{\circ} 39^{\prime} 04^{\prime \prime}$ West. It flows into the river Imbituvão, belonging to the Tibagi River Basin (Andrade and Felchak, 2009) and according to the SUREHMA Ordinance $n^{\circ} 003 / 91$ it is classified as a second order river (SUREHMA, 1991).

Through orbital images, an accurate visual analysis of the surroundings of the Antas River along its urban route was carried out at three different collection points (P1, P2 and P3) in relation to the use and occupation of the land in its surroundings. Since Point 1 is located near the springs; Point 2 and Point 3 are located in areas of urban consolidation.

\subsection{Mapping of study areas}

With the aid of multispectral orthoimagery fused with spatial resolution of $0.50 \mathrm{~m}$, from the GeoEye satellite from 2013, obtained from the Municipality of Irati, the mapping of the study area was carried out, and for each collection point, a buffer zone, that is, a distance band that surrounds each of these points, with a radius of $500 \mathrm{~m}$, covering a total area of 79 ha (encompassing the proximity around each point).

After the buffers were created, they were mapped. Classes were defined for the use and occupation of the land with the greatest influence in the analyzed areas. Then, through cognitive interpretation and utilizing the technique of vectorization on canvas, polygons were created and associated with the defined classes.

\subsection{Assays with Allium cepa}

Three water collections (campaigns) were carried out, in the months of September and December of 2016 and March of 2017, at the Antas River at predefined collection points. Bioassays with Allium cepa (onion) bulbs were placed in separate aquariums. Three assays were performed by collecting, one for each sample and leaving a fourth assay for positive control; following the protocols for plant cell mitosis (Jordão, 1998) along with adaptations of the assay as validated by the United Nations Environment Program (UNEP) as a standard efficient for the monitoring of genotoxicity and mutagenicity (Kumari et al., 2009).

The bioassays were placed randomly by distributing twenty onion bulbs into four aquariums (five bulbs each) containing distilled water (negative control) and left for a period of 96 hours for root growth. Then, five roots of each bulb were randomly collected in each aquarium to perform cytogenetic analyses. The distilled water was replaced by water samples from each collection point of the river. And in the aquarium room, the distilled water was replaced by potassium dichromate solution $1.4 \mathrm{mg} . \mathrm{L}^{-1}$ (positive control).

After 48 hours, the same root harvesting procedure was performed and the roots collected were fixed in ethanol and acetic acid solution $(3: 1 \mathrm{v} / \mathrm{v})$ and stored in $70 \%$ alcohol under refrigerated conditions until they were analyzed by light microscopy. For the cytogenetic analyses, the roots were hydrolyzed in $1 \mathrm{~N} \mathrm{HCl}$ solution at $60^{\circ} \mathrm{C}$ for 10 minutes and the cytological slides were made by a crushing technique and were stained with $1 \%$ carmin propionic.

Three cytological slides were prepared for the mitotic analyses. Each slide containing one root per bulb, being evaluated 500 cells per phase of mitosis totalizing 2000 cells in a total of 15 slides per treatment. Cells with the most representative abnormalities were photographed using the Olympus CX31 Optical Microscope / SC30 camera.

\subsection{Statistical analyses}

In order to determine whether there were statistical differences in the percentage of abnormalities (dependent variable) as a function of the 3 study points and the controls (factor), a one-way ANOVA analysis was performed after checking for gaussianity assumptions 
(Shapiro-Wilk Normality test) and homogeneity of variances (Bartlett). Peer-to-peer comparisons were also performed by using Fisher's test.

The relationships between the percentage of chromosomal abnormalities and the classes of land use and occupation were investigated through a Principal Coordinate Analysis (PCoA), The analyses were carried out with the aid of software R (specifically, the vegan and MASS packages). For all statistical procedures, values of $p<0.05$ were considered significant.

\section{RESULTS AND DISCUSSION}

After completing the mapping of the study areas, eight classes were defined for land use and occupation, which through cognitive interpretation were more evident. They are:

- Urbanized areas: according to Magalhães et al. (2013): "[...]the result of anthropic occupation over the territory; are areas that have continuous occupancy of buildings, or that have suffered anthropic impact for urban occupation in some way ";

- Reforestation: Area used for the cultivation of species of commercial interest;

- Tree vegetation: can be defined as a group of species constituted by large trees, present mainly in forests and woodlands.

- Underground vegetation: mainly grasses;

- Bodies of water: rivers, lakes and lagoons;

- Exposed soil: soil devoid of any vegetation;

- Capoeira: area of secondary vegetation (Linhares et al., 2003);

- Agricultural cultivation: occupied area by any stage of agricultural culture.

The classification of the image allowed the calculation of the areas equivalent to each class previously described. The results of area and respective occupation by class can be verified in Figure 2. Point 1 area near the springs of Rio das Antas showed about $77 \%$ of green areas, tree vegetation $(48.21 \%)$, undergrowth $(9.84 \%)$, reforestation $(10.69 \%)$ and capoeira $(8.07 \%)$. Along the way the population density increases and in Points 2 and 3 the predominant class was the urbanized area with $84.06 \%$ and $56.84 \%$ respectively.

Cytogenetic analyses in meristematic cells of Allium cepa roots showed some type of chromosomal abnormality in all phases of mitosis, which demonstrates the genotoxic potential of water samples at all collection points. Chromosome abnormalities visualized as chromosomal bridges and adhesions, inconclusive chromosomes in the equatorial plate of the cell, chromosomal fragments, early rise of chromosomes or retardant chromosomes culminated in the formation of micronuclei (Figure 3). The micronuclei are formed by cytoplasmic portions of chromatin, have a round or oval shape, are located near the nucleus and are formed by lysis in the DNA molecule during mitotic division, days or weeks after this undergoes mutagenic agent interference (Stich and Rosin, 1983; Stich et al., 1984). The other chromosomal alterations, according to Vidakovié-Cifrek et al. (2002) can be visualized at any stage of cell division as evidence of mutagenic effects arising from agents that cause DNA breaks (clastogenic agents) or that induce abnormal chromosomal segregation or aneuploidy (aneugenic agents), classified by the type of alteration it produces.

Genotoxic effects of different chemical agents have been described in the literature as being responsible for varied chromosomal alterations in different exposed organisms, among them man (Natarajan, 2002). According to Grant (1994), the evaluation of the genotoxicity caused by environmental pollutants in tests using Allium cepa as a bioindicator has been shown to be very efficient, as well as for the quality evaluation of waters affected by anthropic influences (Fiskesjö, 1993; Fatima and Ahmad, 2006). 


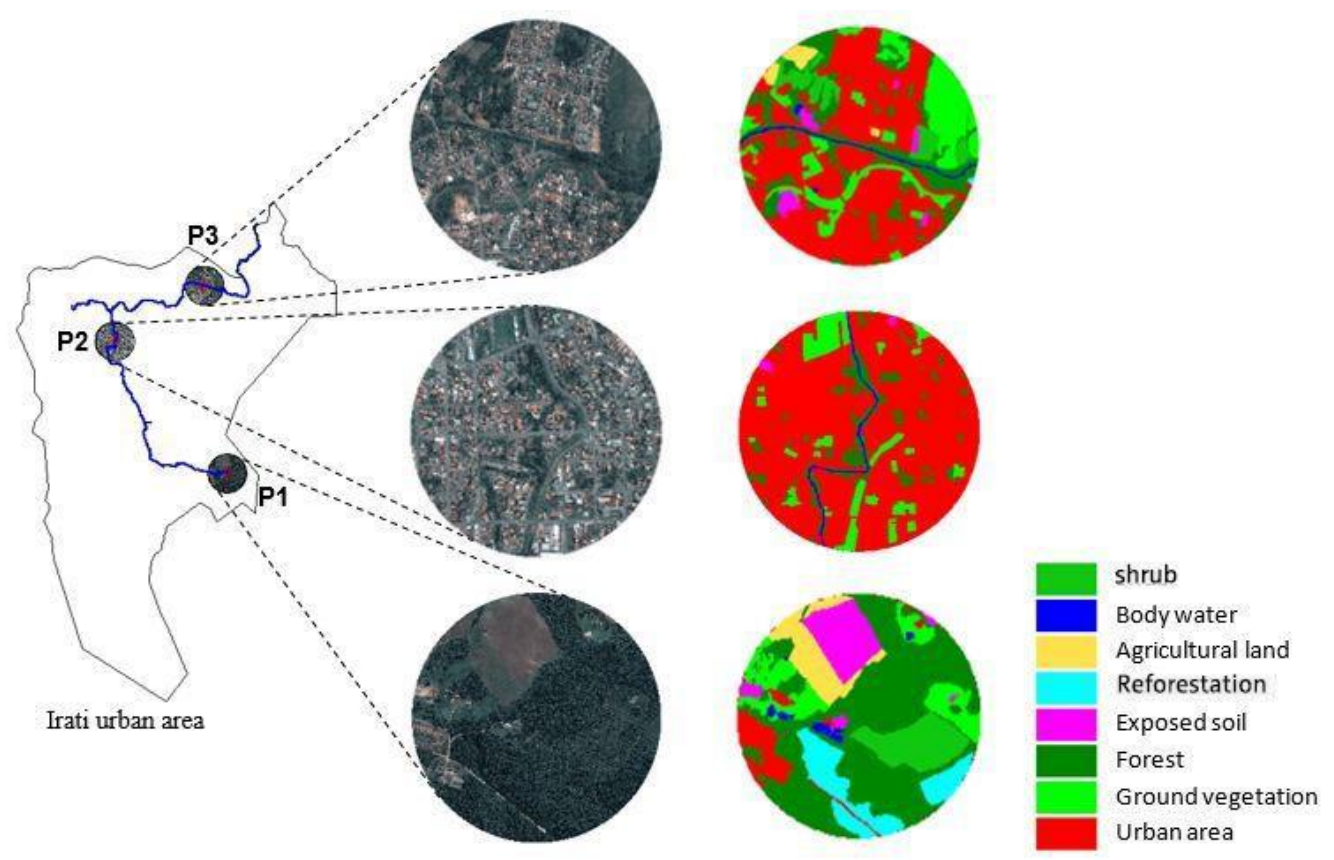

Figure 2. Classification of the use and occupation of the land to the surroundings of the sampling points.

Source: research data.

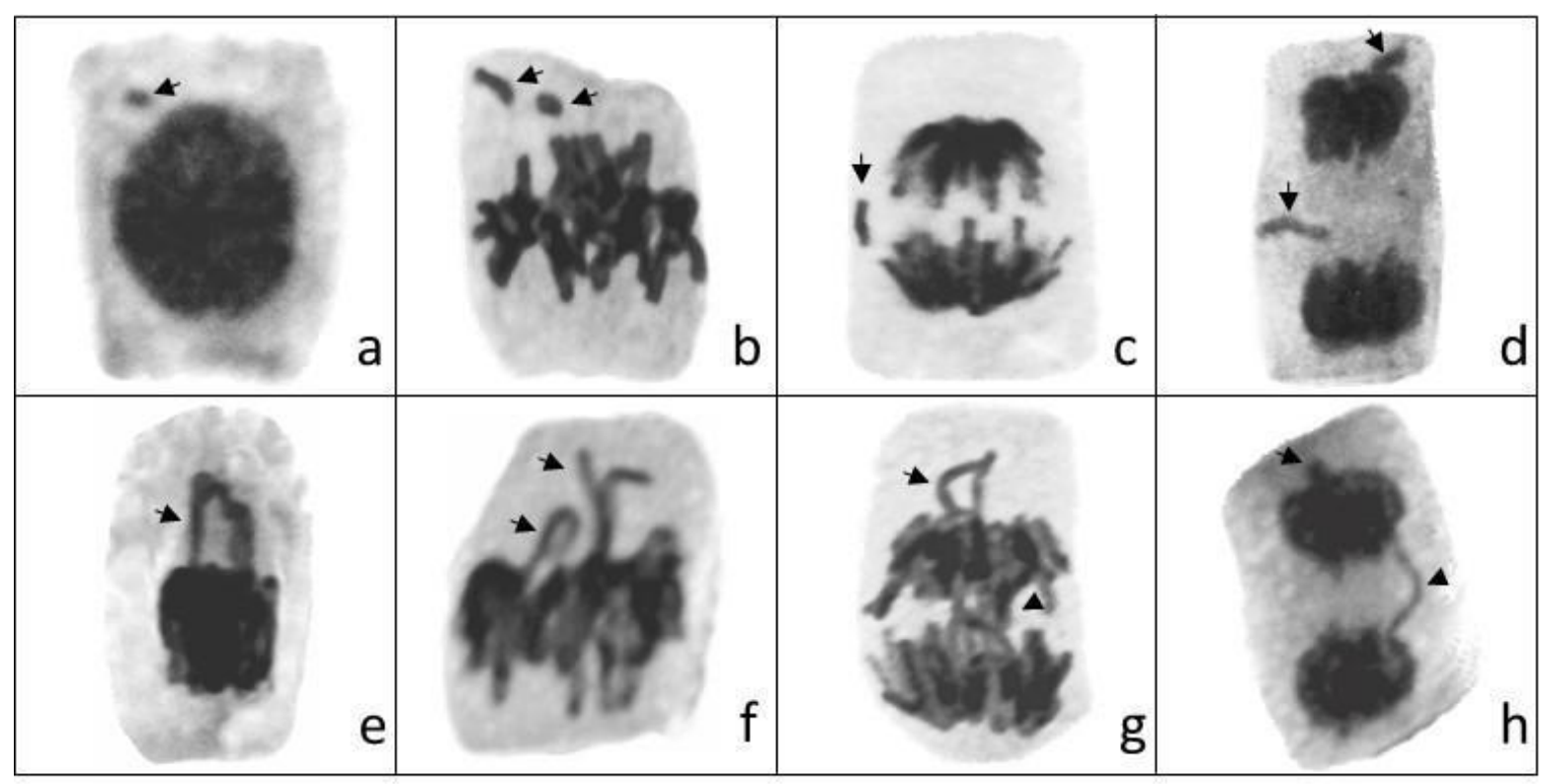

Figure 3. Major chromosomal abnormalities found in Allium cepa cells. a) Prophase with micronucleus (arrow); b) Metaphase with non-conjoined chromosome fragments (arrows); c) Anaphase with chromosome fragment (arrow); d) Telophase with chromosomes not assembled to the nucleus (arrows); e) Prophase with stickiness chromosomes (arrow); f) Metaphase with early ascending chromosomes (arrows); g) Anaphase with early ascending chromosomes (arrow) and stickiness chromosomes (arrowhead); h) Non-conjoined chromosome telophase (arrow) and chromosome bridge (arrowhead).

Source: research data.

In relation to the cytogenetic analyses in the three sample points and controls, three statistically distinct groups $(\mathrm{F}=33,10 ; \mathrm{p}<0,01)$ were identified, the first one referring to Points 2 and 3 (statistically equal averages) by Point 1 and the negative control and finally a third 
group formed by the positive control, (Table 1, Figure 4). These results are consistent with what is expected since Point 1, near the source (origin) of the study river, is characterized as a region with higher vegetation index and less urbanized when compared to Points 2 and 3, which are characterized as regions with less vegetation, more urbanized and consequently, more eutrophic. Moraes and Jordão (2002) report that plants collected in eutrophic rivers present a higher index of chromosomal alterations when compared to plants that develop in uncontaminated waters. Results similar to those found in this work are described by Oliveira $e t$ al. (2011; 2012), and Taniwaki et al. (2013).

Table 1. Number of cells analyzed and percentage of abnormalities in controls and by collection at each sampling point.

\begin{tabular}{|c|c|c|c|c|c|}
\hline & Collection 1 & Collection 2 & Collection 3 & \multirow[t]{2}{*}{ NTCA } & \multirow[t]{2}{*}{ (\%) TCA } \\
\hline & $(\%)$ CAA & $(\%)$ CAA & $(\%) \mathrm{CAA}$ & & \\
\hline $\mathrm{CN}$ & - & - & - & 6000 & $12.90 \mathrm{c}$ \\
\hline $\mathrm{CP}$ & - & - & - & 6000 & $24.80 \mathrm{a}$ \\
\hline Point 1 & $2000-13.25$ & $2000-13.50$ & $2000-12.15$ & 6000 & $12.97 \mathrm{c}$ \\
\hline Point 2 & $2000-22.70$ & $2000-19.45$ & $2000-16.95$ & 6000 & $19.70 \mathrm{~b}$ \\
\hline Point 3 & $2000-18.55$ & $2000-19.35$ & $2000-16.30$ & 6000 & $18.07 \mathrm{~b}$ \\
\hline
\end{tabular}

$\mathrm{CAA}=$ Number of Abnormal Cells Analyzed; NTCA $=$ Total Number of Cells Analyzed; $\mathrm{MCA}=$ Average Cells Assayed; $\mathrm{CN}=$ Negative Control; $\mathrm{CP}=$ Positive Control. Averages followed by the same letter do not differ statistically from each other, by the Fisher test at $5 \%$ significance. Source: research data.

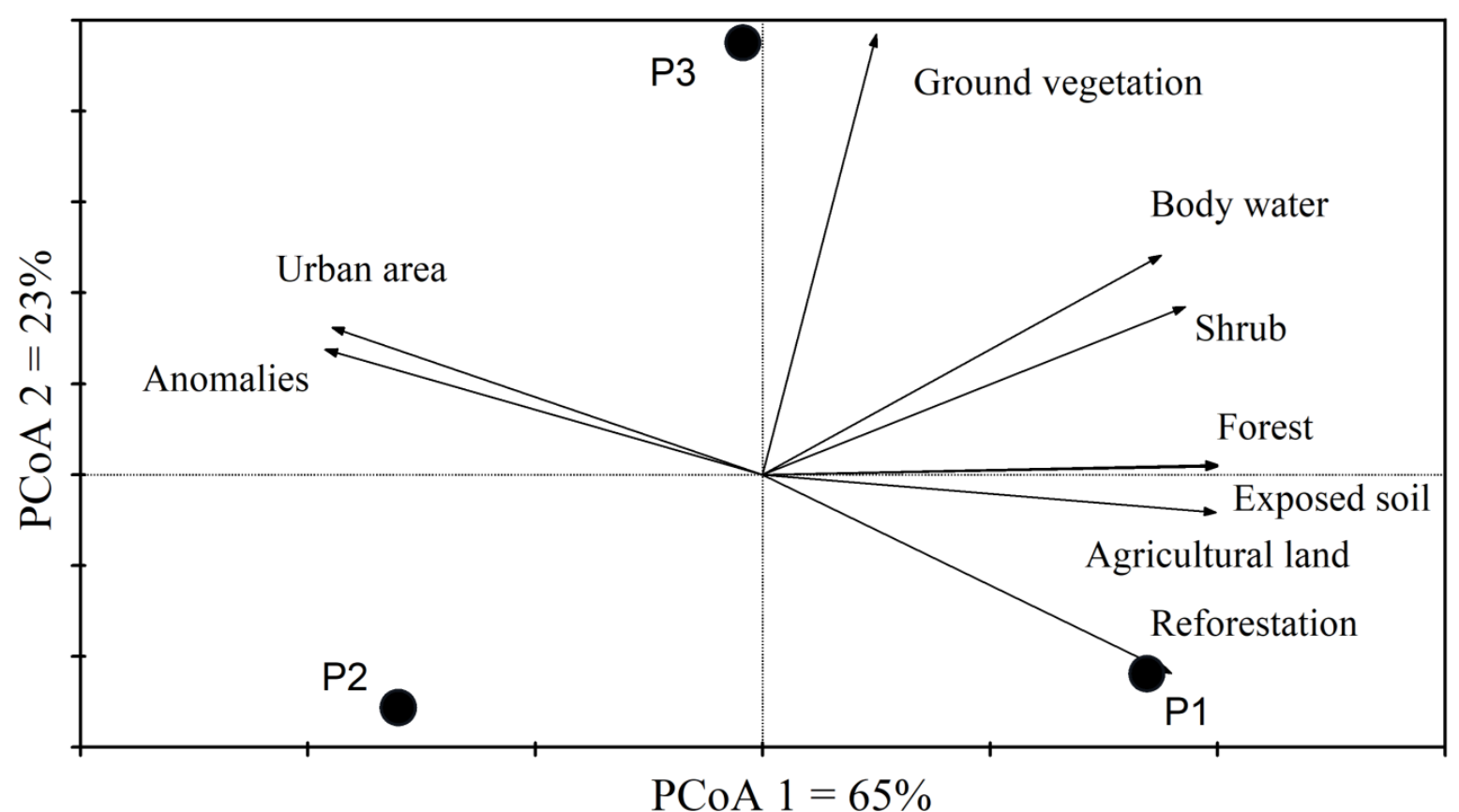

Figure 4. Principal Coordinates Analysis (PCoA).

Source: research data.

In relation to the results already presented, it is possible to discriminate the statistically significant interference of land use and occupation on water quality via genotoxic effect. The Principal Coordinates Analysis (PCoA) (Figure 4), showed that Point 1 is heavily influenced by tree vegetation, especially by areas of natural regeneration. Points 2 and 3, are strongly influenced by the urbanized area in part due to the percentage of chromosomal abnormalities in Allium cepa test. 
The sampling Points 2 and 3 were the ones that presented the worst results referring to the water quality of the Antas River as evidenced by the presence of chromosomal abnormalities in the A. cepa toxicity test. Therefore, it is possible to say that the use and occupation of the land directly influence the quality of these waters, being that the anthropic occupation near the water course negatively impacts its quality.

According to a study by Andrade and Felchak (2009), the Antas River presents several problems resulting from disorderly occupation, such as the absence of riparian forest due to the occupation (accumulation) of the valley bottom, silting due to the creek-free banks and the recti linearization (straightening) process of some stretches of the river, accumulation of organic matter due to lack of sanitation and disposal of industrial chemical wastes not treated correctly. The main problem is the clandestine (possibly illegal) disposal of sewage and the extravasation of it in areas where the sewage network intersects with the rainwater network, and the pluvial network with the sewage network.

The riparian forests are areas around bodies of water, established as APPs. According to Law No. 12,651 / 2012, which established the New Forest Code, APP is: "[...]protected area, covered or not by native vegetation, with the environmental function of preserving water resources, landscape, geological stability and biodiversity, facilitate the genetic flow of fauna and flora, protect the soil and ensure the well-being of human populations." Also, in accordance with this law, it is considered as APP, in rivers with a width of less than $10 \mathrm{~m}$, a marginal range of $30 \mathrm{~m}$, as is the case in Antas River. The law also provides for the urban land regularization of specific interest of areas that are occupying APP and for environmental regularization purposes that a non-buildable strip with a minimum width of $15 \mathrm{~m}$ on each side must be maintained. Nonetheless, it should be pointed out that in most of the areas analyzed in this study, it was not widely observed in Points 2 and 3, located in areas of urban consolidation.

Works such as Marmontel and Rodrigues (2015), Cândido et al. (2015) and Silva et al. (2016), have already verified that anthropic actions, together with the devastation of the ciliary forest, negatively influence the water quality of the water bodies. Furthermore, in places where there is greater preservation of the vegetation the quality water is also better.

\section{CONCLUSIONS}

The results were obtained in the bioassays using Allium cepa as test organisms. Combined with orbital satellite imagery, statistical analyses were effective as alternative validation tools to monitor the toxic effects of possible pollutants present in water bodies with compromised water quality. Accompanied by physical-chemical analyses to prove their results, these can become even more significant.

The Antas River (Rio das Antas) is experiencing significant degradation of PPAs, especially in urban consolidation areas. The results indicated that water quality is intrinsically related to land use and occupation. The sampling area near the sources of the Rio das Antas (P1) has a significant portion of arboreal vegetation, a fact that contributes to a better quality of the water of the locale (region). However, the remaining sample areas (P2 and P3), suggest a greater deterioration in water quality as evidenced by the greater presence of chromosomal abnormalities in the Allium cepa test. These areas suffer from the detrimental impact on the anthropic occupation and a consequent lack of PPAs; a fact that supports the observed results.

One can then verify the remarkable interference that man can bring to the ecosystem. Also, the importance of PPAs for a watercourse, can assist in greater preservation and better quality of the water resources. 


\section{REFERENCES}

ANDRADE, A. R.; FELCHAK, I. M. A poluição urbana e o impacto na qualidade da água do Rio das Antas - Irati/PR. Geoambiente On-line, v. 1, n. 12, p. 108-132, 2009. https://dx.doi.org/10.5216/rev.\%20geoambie.v0i12.25985

CÂNDIDO T. S.; MIRANDA, J. H.; ABREU, M. V. S.; QUARTAROLI, L. Avaliação da qualidade da água por meio de parâmetros físico-químicos e a influência do uso e ocupação do solo. Científica Univiçosa, v. 7, n. 1, p. 329-334, 2015.

CONSTANTIN, M. J.; OWENS, E. T. Introduction and perspective of plant genetic and cytogenetic assays. Mutation Research, v. 99, p. 13-3, 1982. https://doi.org/10.1016/0165-1110(82)90027-6

COSTA, A. C.; DOMINGUES G.; DÜSMAN, E.; ALMEIDA, I. V.; VICENTINI, V. E. P. Citotoxicidade das águas do rio do peixe (São Paulo-Brasil) em células meristemáticas de raiz de Allium cepa L. Bioscience Journal, v. 31, n. 1, p. 248-258, 2015. http://dx.doi.org/10.14393/BJ-v31n1a2015-15069

FATIMA, R. A.; AHMAD, M. Genotoxicity of industrial wastewaters obtained from two different pollution sources in northern India: A comparison of three bioassays. Mutation Research, v. 609, p. 81-91, 2006. https://doi.org/10.1016/j.mrgentox.2006.06.023

FENDRICH, R.; OLIYNIK, R. Manual de Utilização das Águas Pluviais. 1. Ed. Curitiba: Livraria do Chain, 2002. 190p.

FISKESJÖ, G. The Allium cepa test in wastewater monitoring. Environmental Toxicology and Water Quality, v. 8, p. 291-298, 1993. https://dx.doi.org/ 10.1002/tox.2530080306

FUNASA (Brasil). Textos de epidemiologia para vigilância ambiental em saúde. 1. ed. Brasília: Ministério da Saúde, 2002. 132 p.

GRANT, W. F. The present status of higher plant bioassays for the detection of environmental mutagens. Mutation Research, v. 310, p. 175-185, 1994. https://doi.org/10.1016/00275107(94)90112-0

GROVER, I. S.; SATWINDERJEET, K. Genotoxicity of wastewater samples from sewage and industrial effluent detected by the Allium root anaphase aberration and micronucleus assays. Mutation Research, v. 426, p. 183-188, 1999. https://doi.org/10.1016/S00275107(99)00065-2

IBGE. Irati: panorama. In: IBGE. Cidades. Available in: https://cidades.ibge.gov.br/v4/brasil/pr/irati/panorama. Access: 25 Jul. 2017.

IPARDES. Caderno estatístico: Município de Irati. Available in: http://www.ipardes.gov.br/cadernos/MontaCadPdf1.php?Municipio=84500\&btOk=ok. Access: 25 Jul. 2017.

JORDÃO, B. Q. Mitose em células vegetais. In: JORDÃO, B. Q. (Org.) Práticas de Biologia Celular. Londrina: Ed. UEL, 1998.

KUMARI, M.; MUKHERJEE, A.; CHANDRASEKARAN, N. Genotoxicity of silver nanoparticles in Allium cepa. Science of the Total Environment, v. 407, p. 5243-5246, 2009. https://dx.doi.org/10.1016/j.scitotenv.2009.06.024 
LEME, D. M.; MORALES, M. A. M. Allium cepa test in environmental monitoring: A review on its application. Mutation Research, v. 682, p. 71-81, 2009. https://dx.doi.org/10.1016/j.mrrev.2009.06.002

LINHARES, C. A.; ASSIREU, A. T.; ALVES, D. S. Discriminação entre floresta primária, secundária e restinga utilizando o operador de fragmentação assimétrica $\left(\mathrm{F}_{\mathrm{A}}\right)$. In: SIMPÓSIO BRASILEIRO DE SENSORIAMENTO REMOTO, 2003, Belo Horizonte. Anais[...] Belo Horizonte: SBSR, 2003. p. 2787-2789.

MAGAlHÃES, M. A.; TOSCANO, V. N.; BERGAMASCHI, R. B. Área, densidade e população: o caso de áreas urbanas e urbanizadas dos municípios do Espírito Santo. Planejamento e políticas públicas, v. 40, p. 219-256, 2013.

MARMONTEL, C. V. F.; RODRIGUES, V. A. Parâmetros Indicativos para Qualidade da Água em Nascentes com Diferentes Coberturas de Terra e Conservação da Vegetação Ciliar. Floresta e ambiente, v. 22, n. 2, p. 171-181, 2015. http://dx.doi.org/10.1590/21798087.082014

MASCARENHAS, L. M. A.; FERREIRA, M. E.; FERREIRA, L. G. Sensoriamento Remoto como instrumento de controle e proteção ambiental: análise da cobertura vegetal remanescente na bacia do rio Araguaia. Sociedade \& Natureza, v. 21, n. 1, p. 5-18, abr. 2009. http://dx.doi.org/10.1590/S1982-45132009000100001

MORAES D. S. L.; JORDÃO B. Q. Degradação de recursos hídricos e seus efeitos sobre a saúde humana. Revista de Saúde Pública, v. 36, p. 370-374, 2002. https://dx.doi.org/10.5007/1807-1384.2016v13n3p163

NATARAJAN, A. T. Chromosome aberration: past, present and future. Mutation Research, v. 504, p. 3-16, 2002. https://doi.org/10.1016/0165-1218(88)90034-1

OLIVEIRA-FILHO, A. T.; ALMEIDA, R. J.; MELLO, J. M.; GAVILANES, M. L. Estrutura fitossociológica e variáveis ambientais em um trecho de mata ciliar do córrego Vilas Boas, Reserva Biológica do Poço Bonito, Lavras-MG. Revista Brasileira de Botânica, v. 17, n. 1, p. 67-85, 1994. http://dx.doi.org/10.1590/S0102-33062004000400005

OLIVEIRA, L. M.; VOLTOLINI, J. C.; BARBÉRIO, A. Potencial mutagênico dos poluentes na água do rio Paraíba do Sul em Tremembé, SP, Brasil, utilizando o teste Allium cepa. Revista Ambiente \& Água, v. 6, p. 90-103, 2011. https://dx.doi.org/10.4136/ambiagua. 176

OLIVEIRA, J. P. W.; DOS SANTOS, R. N.; PIBERNAT, C. C.; BOEIRA, J. M. Genotoxicidade e Análises Físico-Químicas das águas do Rio dos Sinos (RS) usando Allium cepa e Eichhornia crassipes como bioindicadores. BBR - Biochemistry and Biotechnology Reports, v. 1, p. 15-22, 2012. https://dx.doi.org/10.4136/ambi-agua.1459

SILVA, L. L. F.; MORAES, M. F.; SILVA, R. B. Influência do uso e ocupação do solo na qualidade da água em bacias de captação para o abastecimento público. $2016.59 \mathrm{f}$. Monografia (Graduação em Engenharia Ambiental e Sanitária) - Universidade Federal de Goiás, Goiânia, 2016.

STICH, H. F.; ROSIN, M. Quantitating the synergistic effect of smoking and alcohol consumption with the micronucleus test on human buccal mucosa cells. International Journal of Cancer, v. 31, n. 3, p. 305-308, 1983. https://dx.doi.org/10.1002/ijc.2910310309 
STICH, H. F.; ROSIN, M.; VALLEJERA, M. O. Reduction with vitamin A and beta-carotene administration of proportion of micronucleated buccal mucosa cells in Asian betel nut and tobacco chewers. Lancet, n. 8388, p. 1204-1206, 1984. https://dx.doi.org/10.1016/S0140-6736(84)91692-1

SUREHMA (PR). Bacia do Rio Tibagi - portaria Surehma n003/91 de 21 de março de 1991. Diário Oficial [do] Estado, Curitiba, 21 março 1991. Available in: http://www.recursoshidricos.pr.gov.br/arquivos/File/enquadramento-b-tibagi.pdf. Access: Apr. 2018.

TANIWAKI, R. T.; ROSA, A. H.; MARYUAMA, C. R.; FERRARI, L.; CALIJURI, M. C.; MOSCHINI-CARLOS, V.O. A Influência do uso e ocupação do solo na qualidade e genotoxicidade da água no reservatório de Itupararanga-SP, Brasil. Interciencia, v. 38, p. 164-170, 2013.

VIDAKOVIÉ-CIFREK, M.; PAVLICA, I.; REGULA, D. P. Cytogenetic damage in shallot (Allium cepa) root meristems induced by oil industry "high-density brines". Environmental Contamination and Toxicology, v. 43, n. 3, p. 284-291, 2002. https://doi.org/10.1007/s00244-002-1223-2 


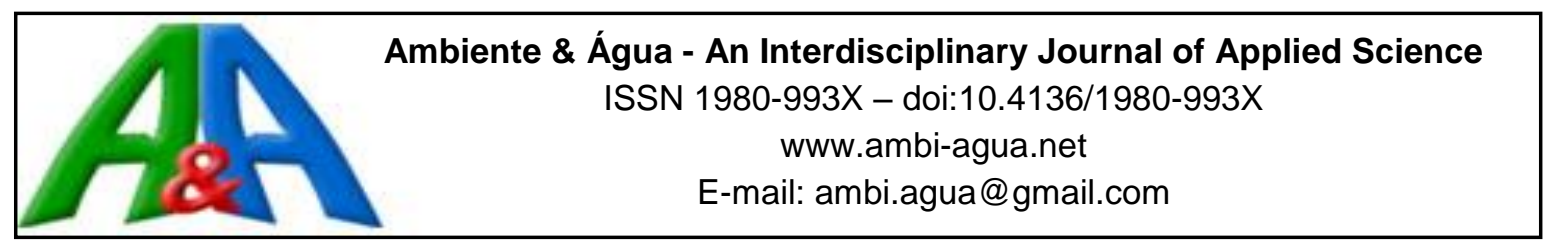

\title{
Impacts of land-use change on southeast Amazonia basin streamflow
}

\author{
ARTICLES doi:10.4136/ambi-agua.2303
}

Received: 22 Jul. 2018; Accepted: 24 Jan. 2019

\author{
Vinicius Marques Louzada*iD; Celso Bandeira de Melo Ribeiro \\ Universidade Federal de Juiz de Fora (UFJF), Juiz de Fora, MG, Brasil \\ Faculdade de Engenharia. Departamento de Engenharia Sanitária e Ambiental (ESA). \\ E-mail: vinicius.marques@engenharia.ufjf.br, celso.bandeira@ufjf.edu.br \\ *Corresponding author
}

\begin{abstract}
The Amazon region is the subject of growing interest in the international scientific community due to the environmental services provided by its dense forests in climate regulation and freshwater. Despite many efforts from environmental management agencies and research centers, this region can still be considered poorly monitored, especially given its large regional and global importance. Rainfall-runoff models are presented as a good alternative to the estimated flow rates in inaccessible or difficult to watch places. This study simulated stream flows for a representative part of the Amazon basin using the Soil and Water Assessment Tool (SWAT) redistributed hydrological model, adopting as reference the streamflow observed in Altamira gauge station. The authors emphasize that a database was specially prepared with physical parameters such as land use, topography and soil types, and weather data encompassing the years from 1985 to 2012, at a daily time step. The chosen approach allowed carrying out hydrologic simulations that were consistent with the flow values observed at the Altamira gauge station, providing better understanding of hydraulic-hydrological processes in the Xingu subbasin and information for planning and decision-making on the management of water resources in this important river basin.
\end{abstract}

Keywords: Amazon basin, hydrologic modeling, land use change.

\section{Impacto na mudança de uso do solo na vazão de uma bacia do sudeste da Amazônia}

\section{RESUMO}

A Região Amazônica vem despertando interesse crescente da comunidade científica internacional devido às amplas possibilidades ambientais que suas densas florestas têm a oferecer no que diz respeito à regulação climática e recursos hídricos. Apesar dos muitos esforços de agências reguladoras de meio ambiente e centros de pesquisa, esta região ainda pode ser considerada pouco monitorada, especialmente dada sua grande importância regional e global. Modelos de vazão são apresentados como uma boa alternativa para taxas de fluxos estimadas em lugares inacessíveis ou de difícil monitoração. O objetivo deste trabalho é simular vazões para uma porção significativa da Bacia Amazônica usando o modelo hidrológico semidistribuído SWAT (Soil and Water Assessment Tool), adotando como referência as vazões 
observadas na estação de monitoramento de Altamira. Ressaltamos que um banco de dados foi especialmente preparado com parâmetros físicos, como uso do solo, topografia e tipos de solo, e informações do clima compreendidas entre os anos de 1985 e 2012, numa escala de tempo diária. A abordagem metodológica permitiu que fossem realizadas simulações hidrológicas muito condizentes com os valores de fluxos observados na estação de monitoramento de Altamira, permitindo um melhor entendimento dos processos hidráulico-hidrológicos na subbacia do Xingu e fornecendo informação para planejamento e tomada de decisões no que concerne ao gerenciamento de recursos hídricos nesta importante bacia.

Palavras-chave: bacia Amazônica, modelagem hidrológica, mudança de uso do solo.

\section{INTRODUCTION}

The Amazon is one of the most complex ecosystems in the world; it is a place where it is possible to find researchers from all over the Earth trying to find new species or new medicine from plants (Gutbelert, 2002). Non-governmental and governmental organizations from all over the world also pursue the preservation of animals, plants and water resources (Goodwin, 2014).

Although it is known that natural resources must be preserved, the Amazon is facing issues with deforestation, especially for wood, commerce and plantations (Ferreira et al., 2005). According to Brazil's Ministry of the Environment, deforestation has decreased since 2004. However, the region still loses about $6000 \mathrm{~km}^{2}$ of natural forest every year. Another significant issue is the construction of the Belo Monte hydroelectric power plant, which is going to generate 11.233 MW of electricity and cause the inundation of $668 \mathrm{~km}^{2}$ (Berman, 2012).

Analyzing all that has been said, it was possible to conclude that studies should be done on that area to guarantee a sustainable exploitation of all natural resources. One type of study that is increasing worldwide is the use of mathematical models.

To plan the use of a basin and predict how this basin will respond to changes in soil use, deforestation and occupation, a mathematical model is used that simulates reality and provides an important tool to make the decisions. With a long data series, it is possible to estimate the impact of an action on a basin (Lenhart et al., 2002). Models are mathematical equations that intend to describe and simulate what will occur in the basin, and there are different models that can be used for a variety of purposes, according to the author's goal (Souza, 2015).

The model being used in this article is the Soil and Water Assessment Tool (SWAT) model. The SWAT model was developed by USDA Agricultural Research Service (USDA-ARS) and Texas A\&M AgriLife Research (Arnold et al., 1998). This model has recently been used in different hydrological studies in Brazil (Bressiani et al., 2015; Pereira et al., 2016). This research simulates different scenarios and how the streamflow responds to changes in land use.

\section{MATERIALS AND METHODS}

\subsection{Study Area}

The hydrological modeling was made in the Xingu River's subbasin (Figure 1), in the Amazon, between the coordinates UTM $8330743.862 \mathrm{~m}$ and $9851708.200 \mathrm{~m} ; 1319966.175 \mathrm{~m}$ and $1915083.081 \mathrm{~m}$. The basin has an approximate area of $509000 \mathrm{~km}^{2}$ that is distributed along the states of Mato Grosso (MT) and Pará (PA).

According to Koppen's classification model, the basin has two climates; the north part is classified as Am - Tropical Monsoon, with most of the rain occurring during the 7 to 9 hottest months. The rest of the basin the classification is Aw - Tropical Wet and Dry, where the precipitation occurs during the summer season and has a dry winter (Sampaio et al., 2011).

Rev. Ambient. Água vol. 14 n. 2, e2303 - Taubaté 2019 


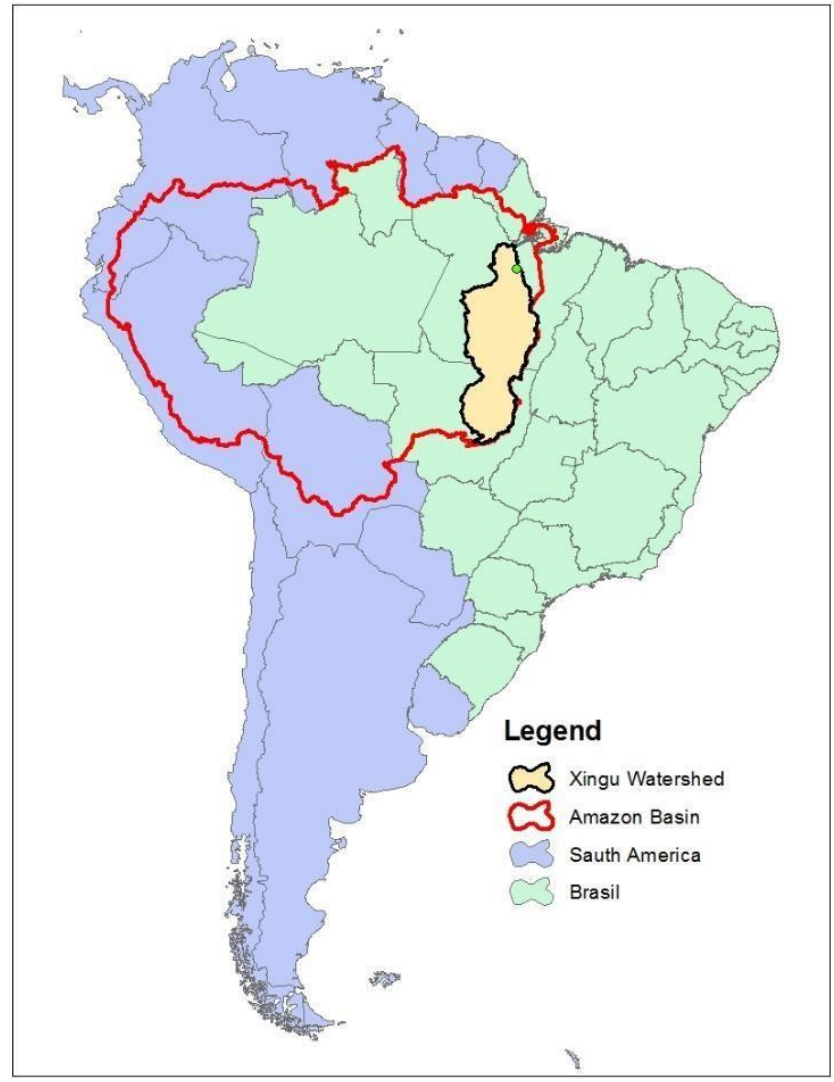

Figure 1. Xingú sub-basin, located in Amazon basin.

\subsection{Meteorological Data}

The meteorological data (relative humidity, solar radiation, wind speed and temperature) were obtained from 40 weather stations from INMET - National Meteorology Institute. Using this data, it was possible to calculate the necessary statistics for the model to run the simulation. It is noteworthy that rainfall data from 204 ANA - National Water Agency rainfall stations were used too.

\subsection{Types of Soil, Land Use Map, and Types of Soil and Land Use Map}

The main types of soils found in the Amazon basin are: Acrisol (38.47\%), Ferrasol (37.64\%) and Leptosol (11.78\%). The soil map (Figure 2a), with $5 \mathrm{~km}$ resolution was obtained in the ISRIC global database. The soil characteristics were obtained from the Pedo-Transfer Function (Saxton and Rawls, 2006). The land-use map (Figure 2b) was obtained from the MODIS sensor with a $1 \mathrm{~km}$ resolution (Friedl et al., 2010). The digital elevation models (Figure $3 a$ ) and slope maps (Figure 3b) were obtained from the TOPODATA global database (Hydrosheds), with a $1 \mathrm{~km}$ resolution.

The model was previously prepared in ArcGis with the following data: soil use, soils type, climatological data and the digital elevation model (DEM). The database comprehends the years between 1985 and 2012 .

The model was used to simulate streamflow in the basin cited above, during a period of 28 years, between 1985 and 2012, of which the first two years were used to warm-up the model.

The simulation results were imported to the Soil \& Water Assessment Tool - Calibration and Uncertainty Procedures (SWAT-CUP), where it is possible to do a static analysis and compare the data simulated by the program with the observed data. It is also possible to verify which parameters are more sensible, which allowed the calibration and validation of the model, making it possible to predict the stream flow in a more accurate way. 
a)

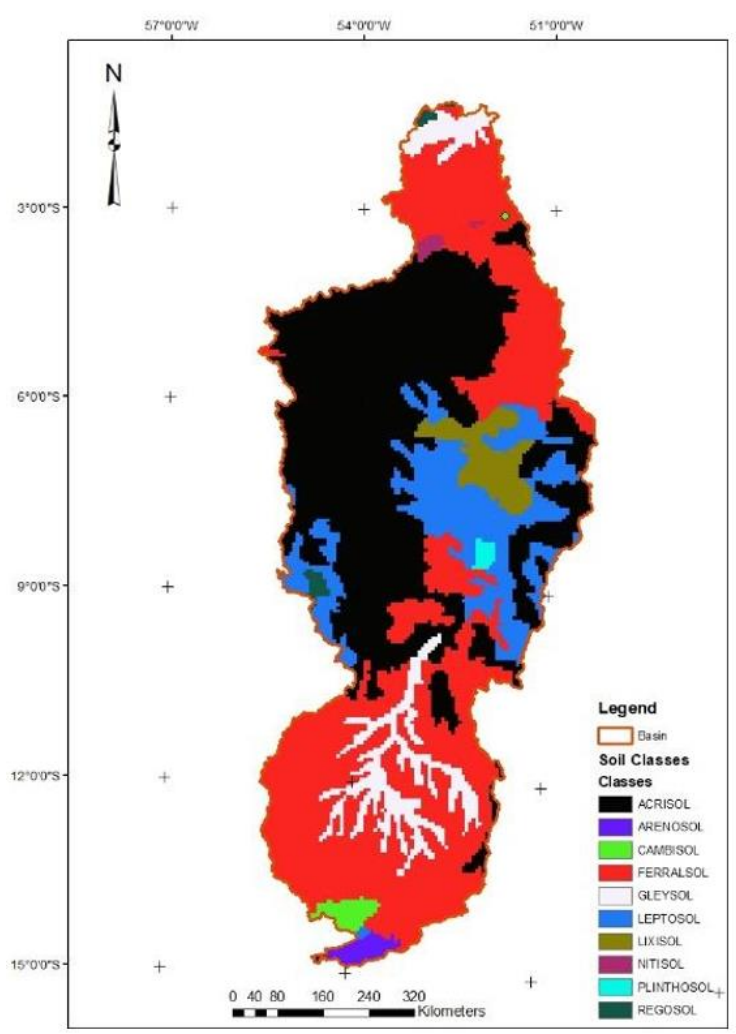

Figure 2. a) Types of soil; b) Land-use map.

a)

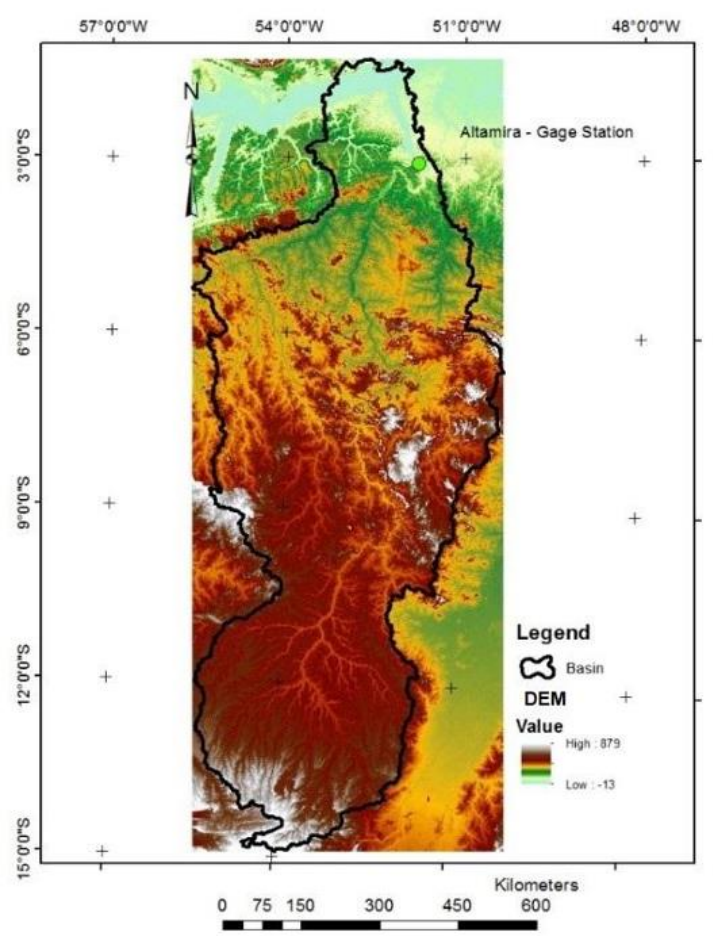

b)

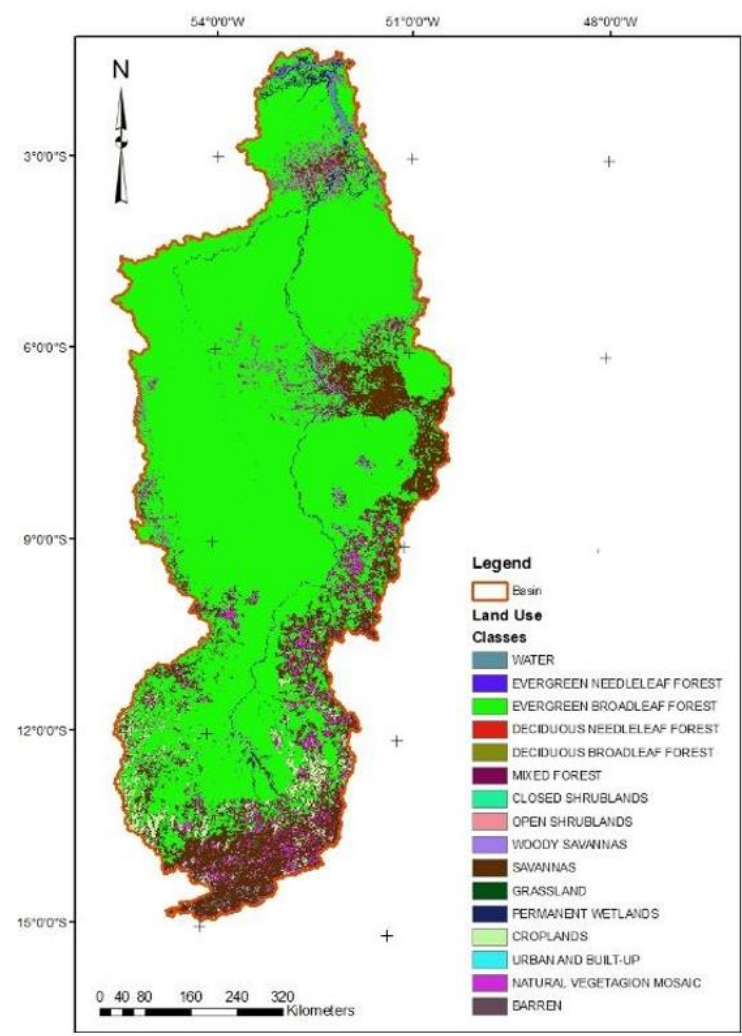

b)

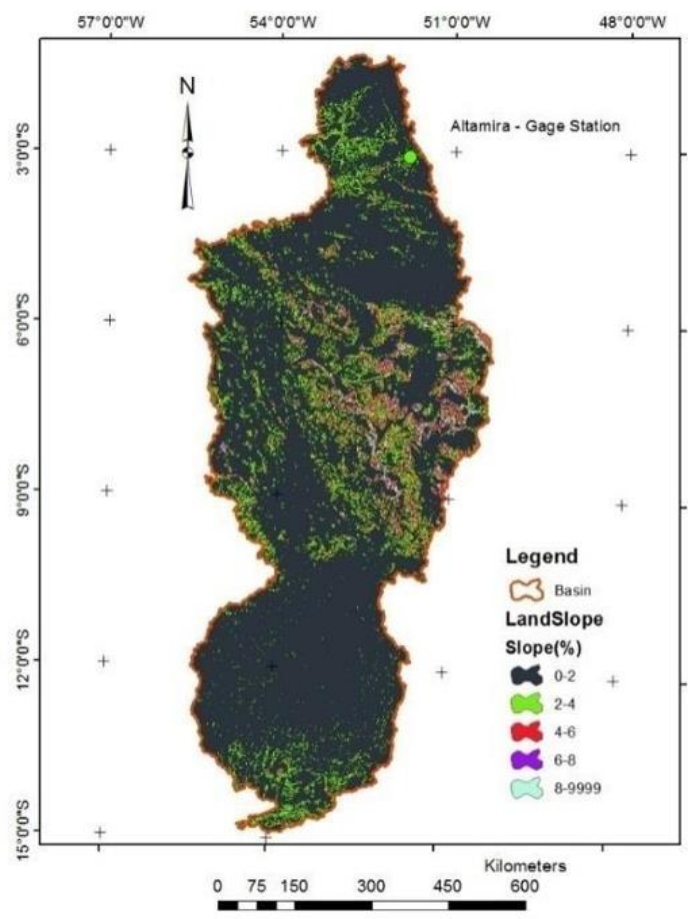

Figure 3. a) Digital Elevation Model; b) Slope map. 
For the calibration process, data from two monitoring points were used, belonging to the ANA - National Agency of Water. The first one at the beginning of the basin and the second at another point located in the course of the same river. The first monitoring point is named Boa Sorte (code 18460000). On this point, there is data available from January 1976 to February 2009. However, the model's database only starts on 1985; therefore, data from before that year was not taken into consideration.

After calibrating and validating the model, the values in all subbasins that contribute to the point where the first monitoring point is located were replaced. After changing the values, the model was run one more time. Next, the calibration and validation process for the second point, called Altamira (code 18850000), was initiated. Once again, the database available was larger than the model, so the authors only considered data from after 1985.

In the calibration and validation process for the second point, the values were only replaced on the subbasins between the first and the second points; the authors did not change any values on the subbasins that contribute for the first calibration point or the subbasins after the second point.

The second point was of interest because it is situated where the government of Brazil is building a hydroelectricity plant. Once the model is calibrated and validated, it will be possible to simulate and verify the impact of land use change in streamflow and power generation.

SWAT-CUP makes some statistical analyses and gives a few parameters to evaluate the model's efficiency. In this paper, the authors are going to use three parameters to check if the model is corresponding in a good way to reality.

\subsection{Statistical Evaluation Criteria}

Streamflow simulations were evaluated using different statistical criteria. According to Moriasi et al. (2007), the parameters that can be used are:

Coefficient of determination $\left(\mathrm{R}^{2}\right)$ : describe the proportion of the variance in measured data. $\mathrm{R}^{2}$ ranges from 0 to 1 and values greater than 0.5 are acceptable.

Nash-Sutcliffe efficiency (NSE): determine the relative magnitude of data variance compared to the measured data variance.

Percent bias (PBIAS): indicates the tendency of the simulated data to be larger or smaller than the observed values (Equations 1 and 2).

$$
\begin{gathered}
\text { NSE }=1-\frac{\sum_{i=1}^{n}(\text { Yobs }- \text { Ysim })^{2}}{\sum_{i=1}^{n}(\text { Yobs }- \text { Ymean })^{2}} \\
\text { PBIAS }=\frac{\sum_{i=1}^{n}(\text { Yobs }- \text { Ysim }) * 100}{\sum_{i=1}^{n}(\text { Yobs })}
\end{gathered}
$$

Model evaluations used in this study were based on performance ratings suggested by Moriasi et al. (2007) for a monthly time step, as shown in Tables 1 and 2.

Table 1. Reported performance ratings for PBIAS.

\begin{tabular}{lcccc}
\hline Model & Value & Performance rating & Modeling Phase & Reference \\
\hline SWAT & $<10 \%$ & Very Good & Calibration and Validation & Van Liew et al. $(2007)$ \\
SWAT & $<10 \%$ to $<15 \%$ & Good & Calibration and Validation & Van Liew et al. $(2007)$ \\
SWAT & $<15 \%$ to $<25 \%$ & Satisfactory & Calibration and Validation & Van Liew et al. (2007) \\
SWAT & $>25 \%$ & Unsatisfactory & Calibration and Validation & Van Liew et al. $(2007)$ \\
\hline
\end{tabular}

Adapted from Moriasi et al. (2007). 
Table 2. Reported performance ratings for NSE.

\begin{tabular}{|c|c|c|c|c|}
\hline Model & Value & Performance rating & Modeling Phase & Reference \\
\hline SWAT & $>0.65$ & Very Good & $\begin{array}{l}\text { Calibration and } \\
\text { Validation }\end{array}$ & Saleh et al. (2000) \\
\hline SWAT & 0.54 to 0.65 & Adequate & $\begin{array}{l}\text { Calibration and } \\
\text { Validation }\end{array}$ & Saleh et al. (2000) \\
\hline SWAT & $>0.50$ & Satisfactory & $\begin{array}{l}\text { Calibration and } \\
\text { Validation }\end{array}$ & $\begin{array}{l}\text { Santhi et al. (2001); adapted by } \\
\text { Bracmort } \text { et al. }(2006)\end{array}$ \\
\hline
\end{tabular}

Adapted from Moriasi et al. (2007).

\subsection{Land Use Change}

Images with the different types of land use were obtained from the MODIS Land Cover Product Type, (MCD12Q1). These products have annual basis and its historical series is available from 2001. These images were produced by supervised classification algorithms, with a spatial resolution of $500 \mathrm{~m}$, covering the soil surface of the planet (Friedl et al., 2010).

\section{RESULTS AND DISCUSSION}

\subsection{Calibration Process}

Lelis et al. (2012), Paim and Menezes (2009) and Andrade et al. (2013) present the most common parameter used to calibrate the SWAT model, especially for hydrology variables. Based on the parameter they presented, a few tests were made to check which one would be more sensitive for the specific model. After the simulations, the best parameters were determined and are shown in Table 3.

Table 3. Most sensitive parameters.

\begin{tabular}{|c|c|c|c|c|}
\hline Parameter & Description & Range of parameter & Best Value & Units \\
\hline CN2 & Surface runoff & 35 to 98 & 75.163 & - \\
\hline ESCO & Compensation of soil evaporation & 0 to 1 & 0.2958 & - \\
\hline ALPHA_BF & Base flow & 0 to 1 & 0.40416 & $1 /$ day \\
\hline RCHRG_DP & Deep aquifer percolation & 0 to 1 & 0.5458 & - \\
\hline SLSUBBSN & Average length of lateral ramp & 10 to 150 & 32.75 & $\mathrm{~m}$ \\
\hline EPCO & Compensation for plant grown & 0 to 1 & 0.85416 & - \\
\hline SURLAG & Surface runoff retardation coefficient & 0.05 to 24 & 20.3078 & - \\
\hline CH_W2 & Average width of main channel at top of bank & 0 to 1000 & 287.5 & $\mathrm{~m}$ \\
\hline CH_L2 & Length of main channel & -0.05 to 500 & 160.383 & $\mathrm{~km}$ \\
\hline CH_N2 & $\begin{array}{l}\text { Manning's roughness coefficient value for the } \\
\text { main channel }\end{array}$ & -0.01 to 0.3 & 0.200 & - \\
\hline
\end{tabular}

After determining which parameters should be changed, a simulation including all ten variables was made as to define the best value for each one. The statistical analysis is shown in Table 4. The data shown in the table is for the second point used.

Table 4. Calibration results.

\begin{tabular}{lcc}
\hline $\mathbf{R}^{\mathbf{2}}$ & NSE & PBIAS \\
\hline $\mathbf{0 . 6 3}$ & 0.59 & 17.3 \\
\hline
\end{tabular}

As stated by Rocha et al. (2012), the SWAT model is highly sensitive to the input data and $\mathrm{R}^{2}$ represents the correlation between observed and simulated data. As cited by the author and by Moriasi et al. (2007), values of $\mathrm{R}^{2}$ greater than 0.5 are usually acceptable. This shows a good correspondence between the values estimated by the model and the ones simulated by the program. 
For the NSE parameter, Moriasi et al. (2007) defines the range between 0.54 and 0.64 as adequate. This corroborates what Rocha et al. (2012) present values higher than 0.5 are not discarded, and other authors have used this efficiency. The value of 0.59 is classified as adequate for the specific model.

The last parameter used to evaluate the model was PBIAS; according to Moriasi et al. (2007), PBIAS can indicate poor model performance. The range of $15 \%$ to $25 \%$ is considered adequate by Van Liew et al. (2007). The value of $17.3 \%$ found after calibration was considered satisfactory.

All three parameters used to evaluate calibration process are sensitive to input data quality and indicate how well the model is representing the observed values in the basin. Analyzing the results shown in Tables 1 and 2, based on the literature, it was found that the model satisfactorily corresponds to the observed data.

\subsection{Land Use Change}

The land-use spatial-temporal analysis for the Xingu watershed was performed using MODIS images with $500 \mathrm{~m}$ spatial resolution along the 2001-2012 period, with sixteen different classes of land cover, as follows: evergreen needleleaf forest, evergreen broadleaf forest, deciduous needleleaf forest, deciduous broadleaf forest, savannas, grasslands, woody savannas, permanent wetlands, cropland/natural vegetation mosaic - CNVM, cropland, mixed forest, closed shrublands, open shrublands, urban and built-up and barren or sparsely vegetated.

The greatest identified coverage loss in Xingu watershed between 2001 and 2012 refers to the evergreen broadleaf forest class (Figure 4a), while the largest expansions occurred in the areas of savannas (Figure $4 \mathrm{~b}$ ) and croplands (Figure 4c), respectively.

a)

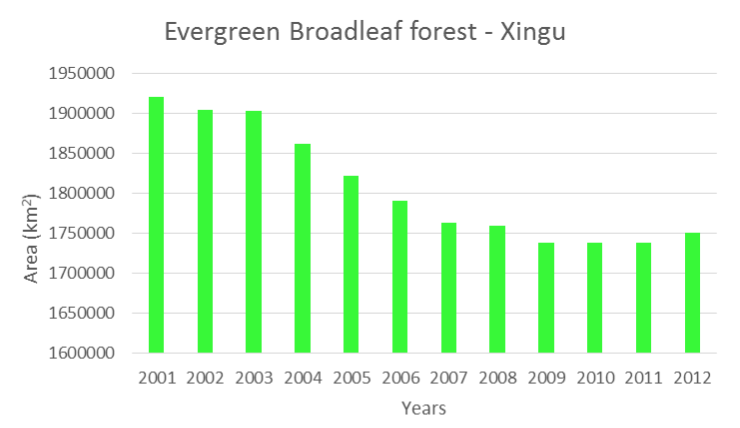

b)

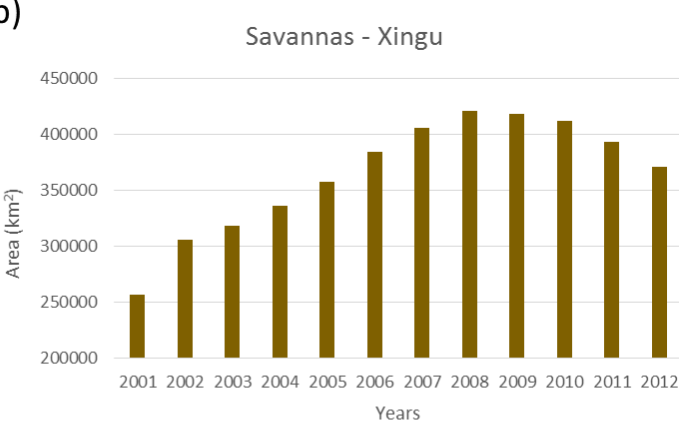

c)

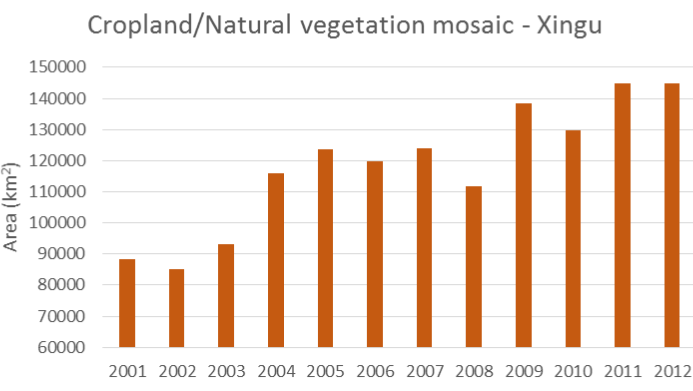

Years

Figure 4. Land use change in Xingu watershed: a) Evergreen Broadleaf Forest; b) Savannas, c) Cropland/Natural Vegetation Mosaic.

\subsection{SWAT Simulation}

After the calibration, two simulations were made using different land use maps: one for 2002, and another to 2012. The simulation dataset project present 307 watersheds with average area of around $1769.84 \mathrm{~km}^{2}$ (Figure 5). 

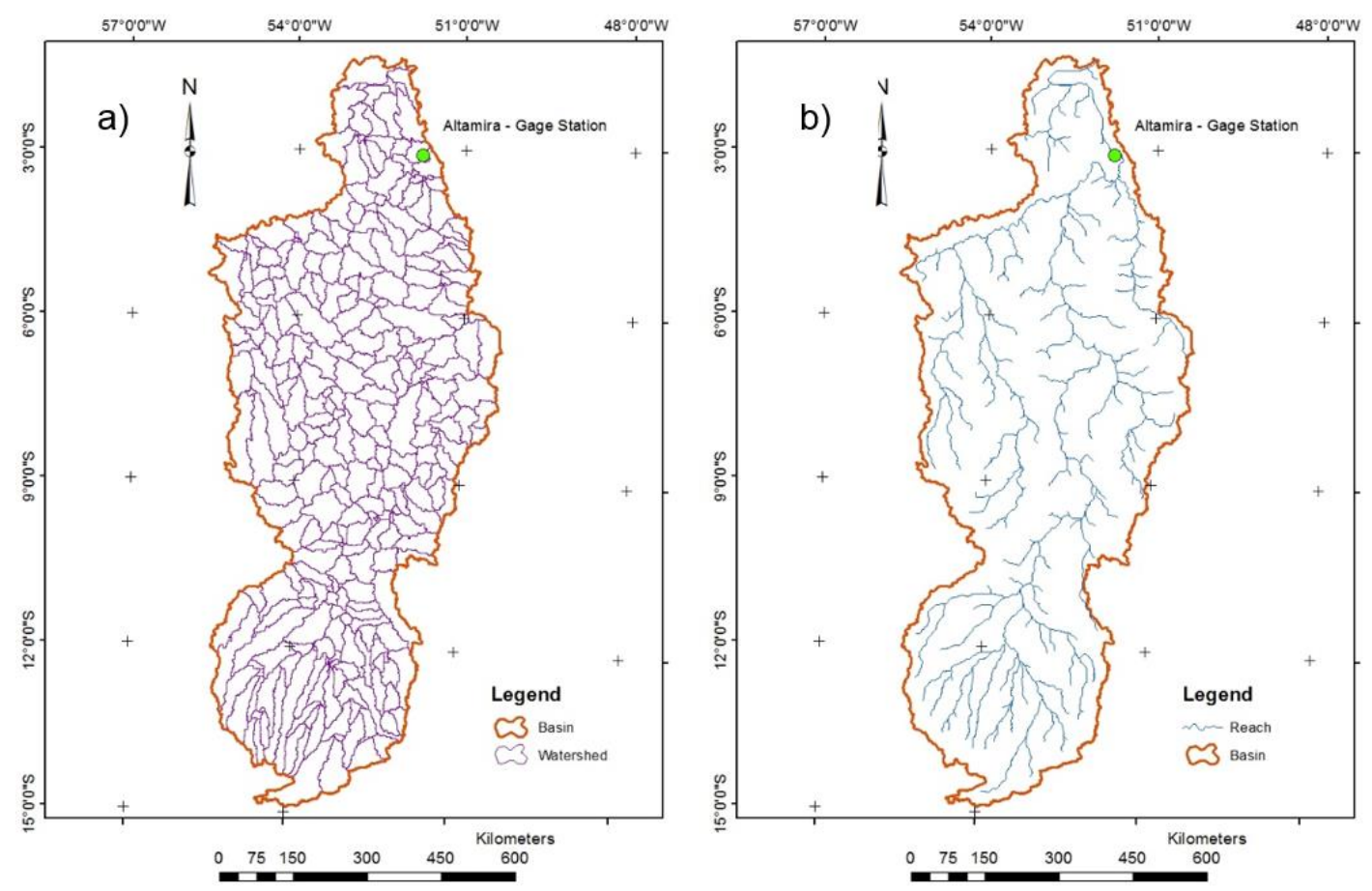

Figure 5. Discretization of representation watershed in SWAT model project for the Xingu: a) Watersheds; b) Stream.

Simulated and observed monthly flows at Altamira gauge station are presented for 01/1985 to 12/2012 in Figure 6, to visually evaluate the performance.

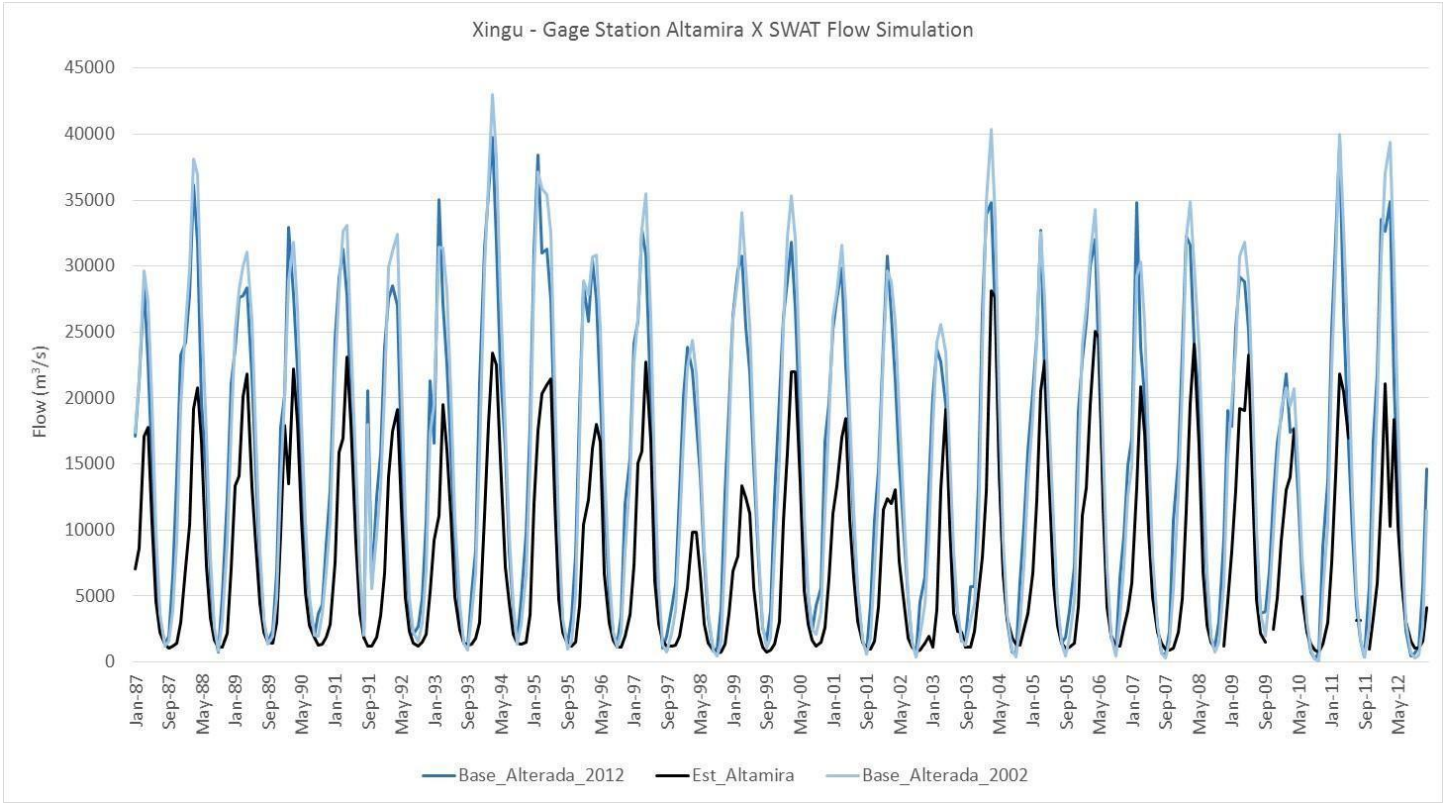

Figure 6. Observed and simulated monthly flows from 01/1985 to 12/2012.

Figure 6 shows that the simulated stream flows for 2002 and 2012 are higher than the observed data from Altamira station. It is also possible to observe on the graphic that simulated flow for 2002 is almost the same as for 2012, with a few higher peaks for the year of 2002. This fact goes against prediction, due to changes in land use, once the Evergreen Broadleaf forest had decreased as the Savanna had increased, less evapotranspiration and rainfall is expected, and an increase of water percolation, resulting in the decrease of streamflow in the Xingu River. 


\section{CONCLUSION}

The model has been calibrated for the subbasin of Xingu River, presenting satisfactory results for the years between 1997 and 1999. However, it is still possible to improve the calibration of the model, achieving a model that represents the reality in a more accurate way.

The streamflow results demonstrate that the land use change from 2002 to 2012 did not cause a significant difference at the Altamira gauge station. There little difference in power plant energy generation in Belo Monte during this period.

When properly calibrated and validated, the SWAT model is a very efficient tool to plan interventions and changes in basins. It saves time and can predict results for any modifications that may occur at the site.

\section{ACKNOWLEDGEMENTS}

We would like to acknowledge the financial support provided by $\mathrm{CNPq}$, Brazilian National Council for Scientific and Technological Development for conducting this research work.

\section{REFERENCES}

ANDRADE, M. A.; MELLO, C. R.; BESKOW, S. Simulação Hidrológica em uma bacia Hidrográfica Representativa de Latossolos na Região Alto Rio Grande, MG. Revista Brasileira de Engenharia Agrícola e Ambiental, v. 17, n. 1, p. 69-76, 2013.

ARNOLD, J. G.; SRINIVASAN, R.; MUTTIAH, R. S.; WILLIAMS, J. R. Large area hydrologic modeling and assessment-Part 1: Model Development. Journal of the American Water Resources Association, v. 34, n. 1, p. 73-89, 1998. https://doi.org/10.1111/j.1752-1688.1998.tb05961.x

BERMANN, C. O projeto da Usina Hidrelétrica Belo Monte: a autocracia energética como

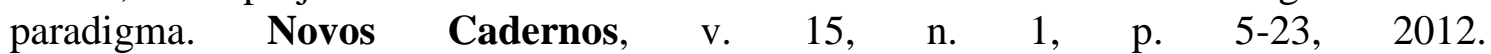
http://dx.doi.org/10.5801/ncn.v15i1.895

BRESSIANI, D. A.; GASSMAN, P. W.; FERNANDES, J. G.; GARBOSSA L. H. P.; SRINIVASAN, R.; BONUMÁ, N. B.; MENDIONDO, E. M. Review of Soil and Water Assessment Tool (SWAT) applications in Brazil: Challenges and prospects. International Journal of Agricultural and Biological Engineering, v. 8, n. 3, p. 9-35, 2015. http://dx.doi.org/10.3965/j.ijabe.20150803.1765

FERREIRA, L. V.; VENTICINQUE, E.; ALMEIDA, S. O desmatamento na Amazônia e a importância das áreas protegidas. Estudos Avançados, v. 19, n. 53, 2005. http://dx.doi.org/10.1590/S0103-40142005000100010

FRIEDL, M. A.; SULLA-MENASHE, D.; TAN, B.; SCHNEIDER, A.; RAMANKUTTY, N.; SIBLEY, A.; HUANG, X. MODIS Collection 5 global land cover: Algorithm refinements and characterization of new datasets. Remote Sensing of Environment, v. 114, n. 1, p. 168-182, 2010. https://doi.org/10.1016/j.rse.2009.08.016

GOODWIN, S. Forest Solutions. Vancouver: Greenpeace, 2014.

GUTBERLET, J. Zoneamento da Amazônia: uma visão crítica. Estudos Avançados, v. 16, n. 46, 2002. http://dx.doi.org/10.1590/S0103-40142002000300013

LELIS, T.A.; CALIJURI, M. L.; SANTIAGO, A. F.; LIMA, D. C.; ROCHA, E. O. Análise de Sensibilidade e Calibração do Modelo SWAT Aplicado em Bacia Hidrográfica da Região Sudeste do Brasil. Revista Brasileira de Ciência do Solo, v. 36, p. 623-634, 2012. 
LENHART, T.; ECKHARDT, K.; FOHRER, N.; FREDE, G. Comparison of two different approaches of sensitivity analysis. Physics and Chemistry of the Earth, v. 27, p. 645654, 2002. https://doi.org/10.1016/S1474-7065(02)00049-9

MORIASI, D. N.; ARNOLD, J. G.; VAN LIEW, M. W.; BINGNER, R. L.; HARMEL, R. D.; VEITH, T. L. Model Evaluation Guidelines for Systematic Quantification of Accuracy in Watershed Simulation. American Society of Agricultural and Biological Engineers, v. 50, n. 3, p. 885-900, 2007. http://dx.doi.org/10.13031/2013.23153

PAIM, J. B.; MENEZES, J. T. Estimate of Sediment Budget of the Tijucas River Basin Applying SWAT Hydrologic Model. Revista Geográfica Acadêmica, v. 3, n. 2, 2009.

PEREIRA, D. R.; MARTINEZ, M. A.; PRUSKI, F. F.; SILVA, D. D. Hydrological simulation in a basin of typical tropical climate and soil using the SWAT model part I: Calibration and validation tests. Journal of Hydrology: Regional Studies, v. 7, p. 14-37, 2016. https://doi.org/10.1016/j.ejrh.2016.05.002

ROCHA, E. O.; CALIJURI, M. L.; SANTIAGO, A. F.; ASSIS, L. C.; ALVES, L. G. S. The Contribution of Conservation Practices in Reducing Runoff, Soil Loss, and Transport of Nutrients at the Watershed Level. Water Resourses Management, v. 26, n. 13, 2012. https://doi.org/10.1007/s11269-012-0106-1

SAMPAIO, M. S.; ALVES, M. C.; SANCHES, L. Uso de Sistema de Informação Geográfica para comparar a classificação climática de Koppen-Geiger e de Thornthwaite. In: SIMPÓSIO BRASILEIRO DE SENSORIAMENTO REMOTO, 15., 2011, Curitiba. Anais[...] São José dos Campos: INPE, 2011.

SAXTON K. E.; RAWLS, W. J. Soil Water Characteristic Estimates by Texture and Organic Matter for Hydrologic Solutions. Soil Science Society of Agronomy Journal, v. 70, n. 5, p. 1569-1578, 2006. http://dx.doi.org/10.2136/sssaj2005.0117

SOUZA, V. A. S. Monitoramento Hidrossedimentológico com Suporte do Modelo SWAT na Amazônia Ocidental - Bacia do Rio Machadinho/RO. 2015. Dissertaão (Mestrado em Engenharia Civil) - COPPE, UFRJ, 2015.

VAN LIEW, M. W.; VEITH, T. L.; BOSCH, D. D.; ARNOLD, J. G. Suitability of SWAT for the conservation effects assessment project: A comparison on USDA-ARS experimental watersheds. Journal of Hydrologic Engineering, v. 12, n. 2, p. 173-189, 2007. https://doi.org/10.1061/(ASCE)1084-0699(2007)12:2(173) 


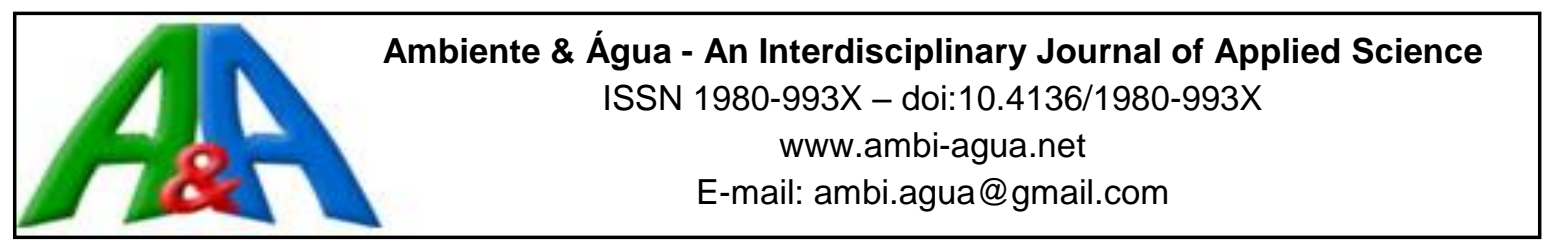

\title{
Biomonitors to evaluate the toxic potential of urban solid waste landfill leachate
}

ARTICLES doi:10.4136/ambi-agua.2326

Received: 06 Sep. 2018; Accepted: 18 Dec. 2018

\author{
Catiele Vieira1 $^{1 D}$; Annette Droste ${ }^{2 *(D)}$ \\ ${ }^{1}$ Universidade FEEVALE (FEEVALE), Novo Hamburgo, RS, Brasil \\ Instituto de Ciências da Saúde (ICS). E-mail: catyele_2003@hotmail.com \\ ${ }^{2}$ Universidade FEEVALE (FEEVALE), Novo Hamburgo, RS, Brasil \\ Programa de Pós-graduação em Qualidade Ambiental. E-mail: annette@ feevale.br \\ *Corresponding author
}

\begin{abstract}
The accentuated increase in the production of solid urban waste (SUW) and the consequent accumulation of leachate in landfills increase the risk of environmental contamination. Biomonitors are used to assess the toxicity of pollutants on living organisms. In this study, the pollutant potential of leachate from SUW from a deactivated landfill was evaluated by bioassays with Lactuca sativa L. and Lycopersicon esculentum Mill., and the relationship between chemical characteristics of the effluent and biological parameters was analyzed. The effluent was tested in its raw form and diluted in distilled water at concentrations of 75 and $50 \%$. The percentage of germination, root growth (RG), mitotic index (MI), chromosomal abnormalities index (CAI), and micronuclei frequency (MCN) were analyzed. In the presence of effluent, germination and MI decreased, while RG, CAI and MCN frequencies increased in relation to the negative control (distilled water) for both species. Lead, iron and zinc presented negative relation with seed germination for both species, with RG of $L$. sativa and MI of $L$. esculentum, as well as a positive relation with MCN frequency in the studied species. Because of its larger chromosomes, L. sativa is a more suitable biomonitor of SUW leachate toxicity than L. esculentum. Even though the landfill is deactivated, it is necessary to treat this effluent, in order to minimize environmental impacts.
\end{abstract}

Keywords: bioassay, effluent, toxicity.

\section{Biomonitores para avaliação do potencial tóxico do lixiviado de aterro de resíduos sólidos urbanos}

\section{RESUMO}

O aumento acentuado da produção de resíduos sólidos urbanos (RSU) e o consequente acúmulo de lixiviado em aterros potencializam o risco de contaminação do meio ambiente. Biomonitores são utilizados para avaliação da toxicidade dos poluentes sobre os organismos vivos. Neste estudo, foram avaliados o potencial poluidor do lixiviado de RSU de um aterro desativado por bioensaios com Lactuca sativa L. e Lycopersicon esculentum Mill. e a relação entre características químicas do efluente e os parâmetros biológicos analisados. O efluente foi testado na sua forma bruta e diluído em água destilada, nas concentrações de 75 e $50 \%$. Foram 
analisados o percentual de germinação, o crescimento radicular (CR), os índices mitótico (IM) e de anomalias cromossômicas (IAC), e a frequência de micronúcleos (MCN). Na presença do efluente, a germinação e o IM diminuíram, enquanto que o CR, IAC e a frequência de MCN aumentaram em relação ao controle negativo (água destilada) para ambas as espécies. Chumbo, ferro e zinco apresentaram relação negativa com a germinação das sementes de ambas as espécies, com o CR de L. sativa e com o IM de L. esculentum, além de uma relação positiva com a frequência de MCN nas espécies estudadas. L. sativa, por apresentar cromossomos maiores, é uma biomonitora de toxicidade de lixiviado de RSU mais adequada do que $L$. esculentum. Mesmo que o aterro esteja desativado, é necessário o tratamento deste efluente, com vistas a minimizar os impactos ambientais.

Palavras-chave: bioensaio, efluente, toxicidade.

\section{INTRODUCTION}

Population growth, together with technological development and increased consumption, lead to a rise in solid urban waste (SUW). In Brazil, the generation of SUW in 2016 totaled approximately 78.3 million tons (ABRELPE, 2016). The need for large expanses of land for final waste disposal and the possibility of environmental contamination make SUW management a major challenge for city administration (Rosa et al., 2017).

Landfills remain the most common SUW disposal practices, due to simple execution and relatively low cost (Yang et al., 2014). Landfills can be classified as sanitary, controlled and dumps. Sanitary landfills employ technology to minimize the environmental impact and possible human health risks, using things like composite liners that act as a low-permeable barrier, preventing liquid from leaching. At controlled landfills, the waste is simply covered with earth, with no leachate or biogas collection or processing. At dumps, the waste is left exposed on the ground (IBAM, 2001).

According to the most recent outlook on solid waste in Brazil, from 2016, conducted by the Brazilian Association of Public Cleaning and Special Waste Companies (ABRELPE), of all the waste collected in Brazilian municipalities, $58.4 \%$ is sent to sanitary landfills and $41.6 \%$ to controlled landfills and dumps (ABRELPE, 2016). This is despite Law 12,305/2010, which instituted the National Policy on Solid Waste, determining an end to controlled landfill and dump activities, as these means of disposal are considered incompatible with environmental protection. A maximum period of four years from the date of sanctioning was established for replacement with sanitary landfills.

Leachate, the byproduct resulting from the breakdown of solid waste, calls for closer attention due to its variability and the complexity in treating it, not to mention the myriad environmental impacts it can cause. Leachate can contain high levels of metals, suspended particles and organic matter. Leaching occurs in operating landfills, but also once they have been deactivated, as the organic matter continues to degrade and breakdown (Rosa et al., 2017).

Characterizing the leachate is an important factor in establishing a strategy to effectively manage it (El-Fadel et al., 2002), as the chemical composition tends to vary greatly (Budi et $a l ., 2016)$. The characteristics depend on the type of deposited waste, the means of disposal, management and length of time the landfill has existed. They are also greatly influenced by meteorological factors, among which rainfall volumes and air temperature are important (ElFadel et al., 2002). Due to the highly soluble substances and toxic composites, beside soil contamination, leaching may lead to the contamination of groundwater and aquifers in areas surrounding landfills, negatively impacting the environment and public health (Rosa et al., 2017). CONAMA Resolution 397/2008 of Brazil's National Council on the Environment (CONAMA, 2008) establishes the conditions and standards for disposing of this class of effluents.

Rev. Ambient. Água vol. 14 n. 2, e2326 - Taubaté 2019 
Leachate toxicity tests can be conducted by means of bioassays using plant species sensitive to toxicity of complex composites, although studies are scarce (Silva et al., 2015; Budi et al., 2016). Among the leading species for conducting toxicity bioassays evaluating seed germination, root growth, cell division and chromosome behavior and structure organization are Lactuca sativa L. (lettuce) and Lycopersicon esculentum Mill. (tomato), as they constitute species sensitive to toxic agents and germinate rapidly, while are also easily found in stores throughout the year at a low cost (Silva et al., 2015).

Within this context, the study proposed the following objectives: (a) to assess the toxic potential of SUW leachate in a deactivated controlled landfill by means of bioassays using $L$. sativa and L. esculentum; (b) to identify the biomonitoring organism and biological parameter most suited to detecting effluent toxicity; (c) to verify the relation between the physical and chemical properties of the leachate and the data obtained for biological parameters.

\section{MATERIALS AND METHODS}

\subsection{Deactivated controlled landfill}

The SUW landfill, occupying an area of $4,750 \mathrm{~m}^{2}$, is located in a municipality with a population of 22,514 inhabitants (IBGE, 2017), located in the Metropolitan Region of Porto Alegre, the capital of Rio Grande do Sul state, in the south of Brazil. The landfill remained activated for 13 years until 2005.

\subsection{Collection and analysis of leachate physical and chemical parameters}

A 5-liter sample of leachate was collected at the landfill in January 2017. Collection, storage, preservation and transport of the leachate sample were in full accord with criteria established by the Standard Methods for the Examination of Water and Wastewater (APHA et al., 2012). The following parameters were noted: $\mathrm{pH}$, temperature, electric conductivity (EC) and dissolved oxygen (DO) with the aid of the AK88-ASKO ${ }^{\circledR}$ multi-parameter meter; biochemical oxygen demand $\left(\mathrm{BOD}_{5}\right)$, by manometry (SM 5210); chemical oxygen demand (COD), by titration ( $\mathrm{SM} 5220)$; ammoniacal nitrogen $\left(\mathrm{NH}_{3}-\mathrm{N}\right)$, by titration $\left(4500 \mathrm{NH}_{3}\right)$; nitrite $\left(\mathrm{NO}_{2}\right)$, through ultraviolet-visible spectroscopy ( $\left.\mathrm{SM} 4500 \mathrm{NO}_{2-}\right)$; nitrate $\left(\mathrm{NO}_{3}\right)$, through ultraviolet-visible spectroscopy ( $\mathrm{SM} 4500 \mathrm{NO}_{3}$ ) and concentrations of iron $(\mathrm{Fe})$, zinc $(\mathrm{Zn})$, lead $(\mathrm{Pb})$, cadmium $(\mathrm{Cd})$, nickel $(\mathrm{Ni})$ and copper $(\mathrm{Cu})$, by flame atomic absorption spectroscopy (SM 3111).

\subsection{Bioassays}

Bioassays were prepared in a laminar flow chamber in the laboratory. Leachate was used in its raw form ( $100 \%$ original concentration) and diluted in distilled water, at concentrations of $75 \%$ and $50 \%$. Distilled water was used as the negative control, and for positive control, the minimum inhibitory concentration of copper $\left(3 \mathrm{mg} \mathrm{L}^{-1}\right.$ of $\left.\mathrm{CuSO}_{4}\right)$ was used, equal to the lowest concentration of the metal able to inhibit root growth (Di Salvatore et al., 2008). Lactuca sativa and L. esculentum seeds were germinated in Petri dishes with a diameter of $9 \mathrm{~cm}$, containing a sheet of quantitative filter paper (GE Healthcare ${ }^{\mathrm{TM}}$ ) sterilized and moistened with $5 \mathrm{~mL}$ solution of the specified solutions (leachate concentrations and controls). Three dishes were prepared for each treatment and biomonitor, each containing fifteen seeds and sealed with plastic film. The dishes were kept at a temperature of $25 \pm 1^{\circ} \mathrm{C}$, for a 16 -hour photoperiod.

\subsection{Germination}

Germinated seeds in each dish were counted after two days of exposure to the treatments, according to Aguiar et al. (2016). Seeds showing evidence of root protrusion, visible without the aid of instruments, were considered germinated. The data were used to calculate the average of germinated seeds for each biomonitor in each treatment. 


\subsection{Root growth}

Root growth was assessed after seven days of exposure to the treatments (Carvalho et al., 2014) with the aid of a millimeter rule. Root lengths of five random seedlings per dish were measured, totaling 15 seedlings per treatment and biomonitor. Root length was measured from the hypocotyl of the seedling to the apical meristem of the root system, according to Gatti et al. (2004).

\subsection{Mitotic index, chromosomal abnormality index and micronuclei frequency}

Root tips were randomly removed from five seedlings from each Petri dish after two days of exposure, totaling 15 roots per treatment and organism. The tips were fixed in an ethanol: acetic acid $(3: 1 \mathrm{v} / \mathrm{v})$ solution for 24 hours at room temperature and then transferred to $70 \%$ ethanol at $4{ }^{\circ} \mathrm{C}$. Of the 15 roots removed per treatment, the meristem region of only 10 random roots were used. The remaining material was kept in reserve. To prepare the microscopic slides, the root tips were sequentially treated for 2 minutes in distilled water, then hydrolyzed for 6 minutes in $\mathrm{HC} 11 \mathrm{~N}$ and washed again for 2 minutes in distilled water. Microscopic slides were prepared according to Cuchiara et al. (2012). The hydrolyzed root tips were squashed on microscopic slides and stained with $2 \%$ aceto-orcein. The number of cells in mitosis and cells with chromosomal abnormalities, and the number of micronuclei (MCN) were counted at 500 cells per root through the scanning technique, using an optic microscope (Nikon Eclipse E200) at 400x magnification. The mitotic index (MI) was calculated using the formula $\mathrm{MI}=[$ (number of mitotic cells/total cells)100]. The chromosomal abnormalities index (CAI) was calculated by $\mathrm{CAI}=[($ number of cells with abnormality/total cells in division)100]. Micronuclei frequency was expressed as MCN/100 cells.

\subsection{Statistical analysis}

Data were subjected to the Shapiro-Wilk normality test and as they complied with assumption of normality, differences between the averages were analyzed by ANOVA, followed by the Duncan test. The relation between biological parameters and the metals $\mathrm{Pb}, \mathrm{Fe}$ and $\mathrm{Zn}$ was verified using the Pearson correlation coefficient. All statistical analysis was conducted using the SPSS program, version 20.0, at $5 \%$ probability.

\section{RESULTS AND DISCUSSION}

The COD value was three times greater than the $\mathrm{BOD}_{5}$ in the raw leachate sample (Table 1). $\mathrm{BOD}_{5}$ refers to the biodegradable organic mass, while COD refers to all the oxidizable matter in the effluent (CETESB, 2016). The $\mathrm{BOD}_{5} / \mathrm{COD}$ calculated for the raw leachate was 0.29 . Due to the $\mathrm{BOD}_{5} / \mathrm{COD}$ ratio, the landfill in the present study would be classified as moderately stable, according to the Solid Waste Association of North America (SWANA, 1997) classification. This ratio could be considered an indicator of the level of organic matter biodegradability, which diminishes over time (El-Fadel et al., 2002).

The leachate presented $\mathrm{pH}$ levels higher than 7 (Table 1). The $\mathrm{pH}$ variation over the years is linked to the $\mathrm{COD}$ and $\mathrm{BOD}_{5}$ values, with the $\mathrm{pH}$ starting at around 5.5 and increasing to around 8 within two years of the landfill initiating operations. An alkaline $\mathrm{pH}$ is usually found in landfills after depositing waste for 10 years (Farquhar, 1989), which would corroborate the findings of this study.

The electric conductivity (EC) value of the raw leachate sample was $1,562 \mu \mathrm{S} \mathrm{cm}^{-1}$ (Table 1), double the average found by Riguetti et al. (2015), which, when analyzing the toxicity of leachate from a sanitary landfill located in the state of Minas Gerais, Brazil, recorded an EC average of approximately $630 \mu \mathrm{S} \mathrm{cm}^{-1}$ in a period of one year. High EC indicates a large volume of ions present in the effluent. In general, levels above $100 \mu \mathrm{S} \mathrm{cm}^{-1}$ indicate environmental impacts (CETESB, 2016). 
Table 1. Physical and chemical characteristics of different leachate concentrations, with their respective detection limit.

\begin{tabular}{|c|c|c|c|c|c|}
\hline \multirow{2}{*}{ Parameters } & \multicolumn{3}{|c|}{ Leachate } & \multirow[t]{2}{*}{ Detection limit } & \multirow[t]{2}{*}{ CONAMA 397/2008 } \\
\hline & $100 \%$ & $75 \%$ & $50 \%$ & & \\
\hline $\mathrm{pH}$ & 7.22 & 7.26 & 7.35 & 2.00 & n.i. \\
\hline Temperature $\left({ }^{\circ} \mathrm{C}\right)$ & 17.8 & 16.8 & 16.5 & 0.0 & n.i. \\
\hline $\mathrm{BOD}_{5}\left(\mathrm{mg} \mathrm{O}_{2} \mathrm{~L}^{-1}\right)$ & 39 & 40 & 44 & 5.0 & n.i. \\
\hline $\mathrm{COD}\left(\mathrm{mg} \mathrm{O}_{2} \mathrm{~L}^{-1}\right)$ & 131 & 92 & 62 & 3.10 & n.i. \\
\hline $\mathrm{EC}\left(\mu \mathrm{S} \mathrm{cm}^{-1}\right)$ & 1,562 & 1,200 & 852 & 200 & n.i. \\
\hline $\mathrm{DO}\left(\mathrm{mg} \mathrm{L}^{-1}\right)$ & 3.2 & 5.9 & 7.4 & 0.0 & n.i. \\
\hline Ammoniacal nitrogen $\left(\mathrm{mg} \mathrm{L}^{-1}\right)$ & 36.3 & 28.2 & 18.1 & 5.0 & 20.0 \\
\hline Nitrite $\left(\mathrm{mg} \mathrm{L}^{-1} \mathrm{~N}\right.$ in $\left.\mathrm{NO}_{2}\right)$ & 0.289 & 0.206 & 0.225 & 0.002 & n.i. \\
\hline Nitrate $\left(\mathrm{mg} \mathrm{L}^{-1} \mathrm{~N}\right.$ in $\left.\mathrm{NO}_{3}\right)$ & 0.2516 & 0.2418 & 3.1063 & 0.0785 & n.i. \\
\hline $\mathrm{Fe}\left(\mathrm{mg} \mathrm{L}^{-1}\right)$ & 1.181 & 0.541 & 0.277 & 0.1414 & 15.0 \\
\hline $\mathrm{Zn}\left(\mathrm{mg} \mathrm{L}^{-1}\right)$ & 0.017 & 0.020 & 0.018 & 0.0095 & 5.0 \\
\hline $\mathrm{Pb}\left(\mathrm{mg} \mathrm{L}^{-1}\right)$ & 0.056 & 0.041 & 0.037 & 0.0112 & 0.5 \\
\hline $\mathrm{Cd}\left(\mathrm{mg} \mathrm{L}^{-1}\right)$ & n.d. & n.d. & n.d. & 0.0075 & 0.2 \\
\hline $\mathrm{Ni}\left(\mathrm{mg} \mathrm{L}^{-1}\right)$ & n.d. & n.d. & n.d. & 0.0643 & 2.0 \\
\hline $\mathrm{Cu}\left(\mathrm{mg} \mathrm{L}^{-1}\right)$ & n.d. & n.d. & n.d. & 0.0316 & 1.0 \\
\hline
\end{tabular}

n.i. $=$ not informed by CONAMA Resolution 397/2008.

The concentration of ammoniacal nitrogen was $36.3 \mathrm{mg} \mathrm{L}^{-1}$, considered high, according to CONAMA Resolution 397/2008 (20.0 $\left.\mathrm{mg} \mathrm{L}^{-1}\right)$, with this constituting the only parameter found over the limit permitted in legislation (CONAMA, 2008). To the contrary, the concentrations of DO and metals detected were low (Table 1). In the early years, young landfills produce a leachate with greater pollutant potential, due to the presence of metals in higher concentrations. The older the landfill, the higher the index of ammoniacal nitrogen due to hydrolysis and fermentation, and the lower the concentrations of organic matter and metal ions (Renou et al., 2008). In the raw leachate, these ions are associated with organic and inorganic colloidal particles and in the form of complexes. The reductive conditions of the effluent and the alkaline $\mathrm{pH}$ lead to metal ions being complexed in the form of sulfides, sulfates, carbonates and oxyhydroxides and also precipitated in insoluble composites considerably reducing bioavailability of the metals (Riguetti et al., 2015).

At its maximum concentration, leachate reduced the germination capacity of $L$. sativa, with $86.6 \%$ of the seeds germinating. Comparably, the raw leachate from a deactivated sanitary landfill located in the region of Vale dos Sinos, in the state of Rio Grande do Sul, Brazil, also presented toxicity for this species, with $90 \%$ of the seeds germinating (Klauck et al., 2015). Lycopersicon esculentum seeds appeared to be more sensitive than the L. sativa seeds, with the leachate reducing the number of germinated seeds with an increase in concentration and completely inhibited germination at a $100 \%$ concentration (Table 2 ).

This study recorded a significant increase in root length in the presence of leachate when compared to the controls in both plant species (Table 2). The lower concentration of leachate $(50 \%)$ led to a higher average in root growth in L. sativa $(5.70 \mathrm{~cm})$ and $L$. esculentum $(8.28$ $\mathrm{cm})$. Rodrigues et al. (2013) also noted root growth stimulation for L. sativa when analyzing the water from an urban stream located in the municipality of Alfenas, in the state of Minas Gerais, Brazil, and attributed this result to a greater offer of nutrients provided by the organic load in water. 
Table 2. Values (average \pm standard deviation) of germination percentage (GM), root growth (RG in $\mathrm{cm})$, mitotic index (MI), chromosomal abnormality index (CAI) and micronuclei frequency (MCN) in Lactuca sativa and Lycopersicon esculentum exposed to leachate and control treatments.

\begin{tabular}{|c|c|c|c|c|c|c|}
\hline \multirow{3}{*}{\multicolumn{2}{|c|}{ Parameters }} & \multicolumn{5}{|c|}{ Treatments } \\
\hline & & \multicolumn{3}{|c|}{ Leachate } & \multicolumn{2}{|c|}{ Controls } \\
\hline & & $100 \%$ & $75 \%$ & $50 \%$ & $\mathrm{H}_{2} \mathrm{O}$ & $\mathrm{CuSO}_{4}$ \\
\hline \multirow{5}{*}{$\begin{array}{l}L . \\
\text { sativa }\end{array}$} & GM & $86.66 \pm 6.66 \mathrm{c}$ & $93.33 \pm 0.00 \mathrm{abc}$ & $95.55 \pm 3.84 \mathrm{ab}$ & $100.00 \pm 0.00 \mathrm{a}$ & $88.88 \pm 3.84 b c$ \\
\hline & RG & $4.24 \pm 0.68 \mathrm{c}$ & $4.99 \pm 0.85 \mathrm{~b}$ & $5.70 \pm 0.92 \mathrm{a}$ & $4.11 \pm 1.08 c$ & $2.00 \pm 0.98 \mathrm{~d}$ \\
\hline & MI & $4.98 \pm 1.13 \mathrm{~b}$ & $5.36 \pm 1.41 \mathrm{~b}$ & $5.14 \pm 1.29 b$ & $9.58 \pm 1.79 \mathrm{a}$ & $4.58 \pm 0.52 b$ \\
\hline & CAI & $28.04 \pm 11.48 b$ & $25.68 \pm 7.69 b$ & $13.94 \pm 5.72 b$ & $13.94 \pm 5.72 \mathrm{a}$ & $30.93 \pm 8.05 b$ \\
\hline & $\mathrm{MCN}$ & $4.64 \pm 1.23 \mathrm{c}$ & $3.56 \pm 1.35 \mathrm{~b}$ & $3.06 \pm 0.83 \mathrm{ab}$ & $2.38 \pm 0.51 \mathrm{a}$ & $4.70 \pm 1.40 \mathrm{c}$ \\
\hline \multirow{5}{*}{$\begin{array}{l}\text { L. } \\
\text { esculentum }\end{array}$} & GM & 0 & $24.44 \pm 16.77 \mathrm{c}$ & $51.11 \pm 13.87 \mathrm{~b}$ & $88.88 \pm 10.18 \mathrm{a}$ & $66.66 \pm 6.66 \mathrm{ab}$ \\
\hline & RG & n.a. & $7.94 \pm 1.44 a b$ & $8.28 \pm 1.15 \mathrm{a}$ & $6.83 \pm 1.41 \mathrm{~b}$ & $5.67 \pm 1.95 \mathrm{c}$ \\
\hline & MI & n.a. & $2.74 \pm 0.66 \mathrm{c}$ & $4.24 \pm 0.54 b$ & $4.82 \pm 0.45 \mathrm{a}$ & $2.10 \pm 0.31 \mathrm{~d}$ \\
\hline & CAI & n.a. & $12.96 \pm 5.95 \mathrm{a}$ & $7.29 \pm 5.16 \mathrm{a}$ & $7.04 \pm 2.82 \mathrm{a}$ & $21.63 \pm 13.77 b$ \\
\hline & $\mathrm{MCN}$ & n.a. & $0.14 \pm 0.16 b$ & $0.04 \pm 0.08 \mathrm{a}$ & $0.00 \pm 0.00$ & $0.06 \pm 0.09 \mathrm{ab}$ \\
\hline
\end{tabular}

Averages followed by the same letter on the line do not differ significantly in accord with the Duncan test at $5 \%$ probability / n.a. $=$ not analyzed.

For both species studied, the MI was significantly lower in the different leachate concentrations and in the positive control than in the negative control (Table 2). In Allium cepa, besides recording negative effects from the leachate on the MI in five of the six municipal solid waste landfill sites analyzed in Southern Poland, a negative relation was noted between the physical and chemical quality of each leachate and their genotoxicity (Kwasniewska et al., 2012), which corroborates with the results obtained in this study with L. sativa and $L$. esculentum. Alterations of the mitotic index are considered good indicators of environmental pollution, especially in the assessment of substances with cytotoxic potential (Leme and MarinMorales, 2009).

In L. esculentum, CAI values in the leachate concentrations and in the negative control did not differ and were lower than those of the positive control. Lycopersicon esculentum chromosomes are smaller, as such, this characteristic complicated the analysis of chromosomal abnormalities for this plant species. Further, in the raw leachate treatment (100\%), the $L$. esculentum seeds did not germinate, as such, the comparison with other plant species is jeopardized. Lactuca sativa, on the other hand, showed significantly higher CAI values in leachate concentrations and in the positive control, when compared to the negative control (Table 2). Chromosomal abnormalities (CA) are changes that occur in the chromosome structure through the action of chemical and physical agents or can even occur spontaneously (Leme and Marin-Morales, 2009).

The quantified CA were constituted by $\mathrm{C}$-metaphase, isolated chromosome, or anaphase and telophase with bridges (Figure 1). A break down in the spindle apparatus is responsible for aneugenic alterations resulting from disturbances in spindle activity. The chromosomes are not correctly linked to the spindle and do not take on the correct position in the cell and, thus, they are spread throughout it internally instead. The chromosomal bridges are clastogenic alterations observed in anaphase and telophase and occur due to a loss of telomeres, the region responsible for guaranteeing chromosome protection and stability, preventing erroneous fusions and pairings (Leme and Marin-Morales, 2009).

The occurrence of MCN in L. esculentum was low, with the negative control not presenting them. In L. sativa, greater MCN frequency was noted, even registering $\mathrm{MCN}$ in the negative control $(2.38 \mathrm{MCN})$. The highest frequencies were found when plants were exposed to raw leachate (4.64 MCN) and the positive control (4.70 MCN). We may infer that the MCNs found 
in the negative control form spontaneously. For other treatments, the higher MCN frequency in relation to the control shows the toxic effect of leachate and $\mathrm{CuSO}_{4}$. The MCNs are tiny cell structures formed through chromosomal loss or chromosomal fragmentation caused by CA and also due to the structural alteration in the spindle apparatus fibers, which can be induced by genotoxic agents or even may be a result of spontaneous mutation (Kieling-Rubio et al., 2015).

The $\mathrm{CuSO}_{4}$ was shown to be a good positive control, as it was able to damage both plant species, observed by means of reduced germination and root growth, by the reduced number of cells in mitosis and also by the stimulation and increase of CA and MCN frequency (Table 2). Despite copper figuring as an essential micronutrient in plant development, in elevated concentrations it becomes toxic, inhibiting several plant metabolism processes (KabataPendias, 2011).

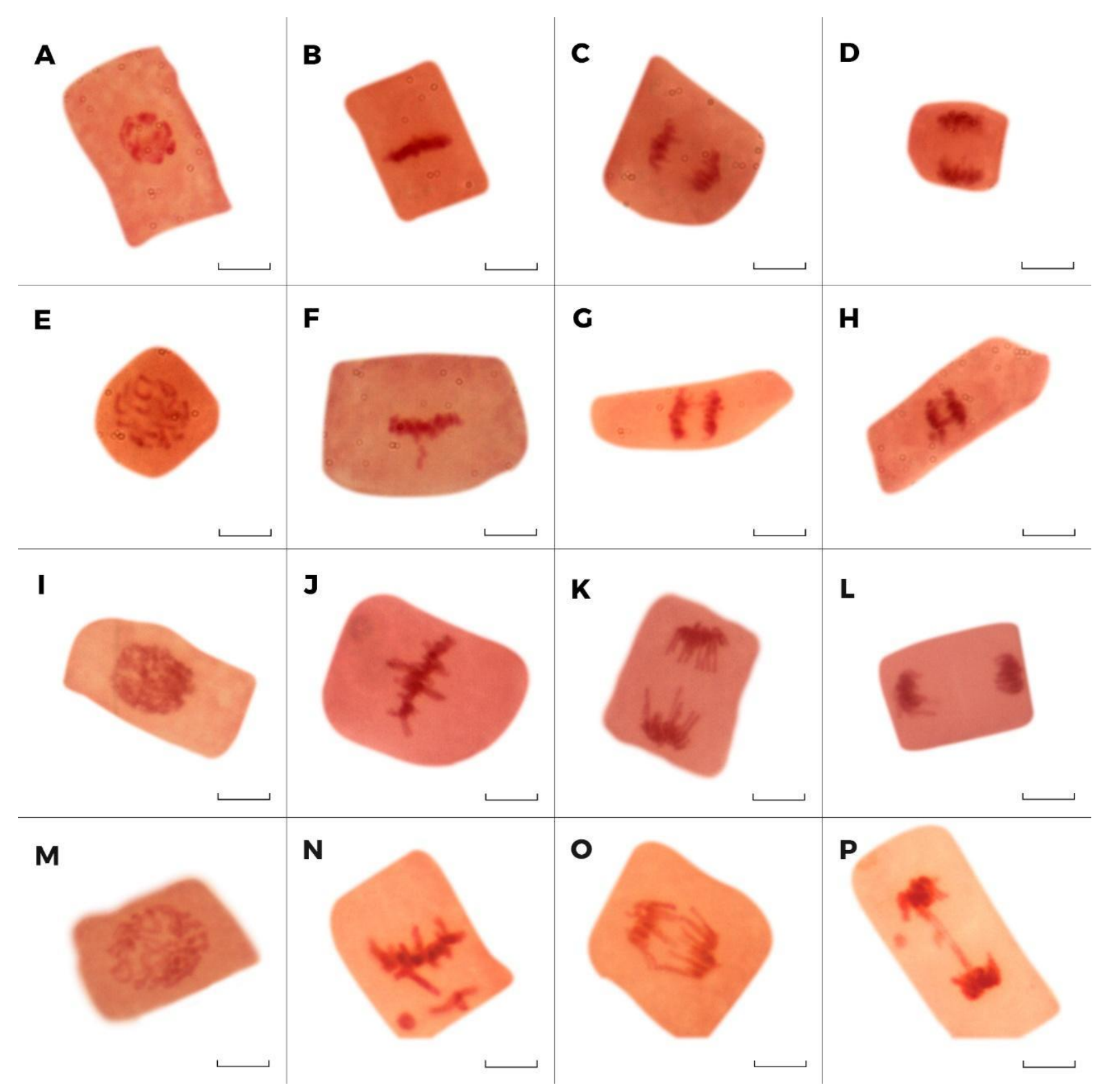

Figure 1. Chromosomes with and without abnormalities observed in Lycopersicon esculentum (A - H) and Lactuca sativa (I - P) root meristematic cells exposed to different leachate concentrations. (A and I) prophase; (B and J) metaphase; (C and $\mathrm{K}$ ) anaphase; (D and $\mathrm{L}$ ) telophase; (E and $\mathrm{M}) \mathrm{C}$-metaphase; $(\mathrm{F}$ and $\mathrm{N}$ ) metaphase with isolated chromosome; ( $\mathrm{G}$ and $\mathrm{O}$ ) anaphase with bridge; ( $\mathrm{H}$ and $\mathrm{P}$ ) telophase with bridge and MCN. Bar: $10 \mu \mathrm{m}$ 
L. esculentum germination and $\mathrm{MI}$ related negatively with $\mathrm{Pb}, \mathrm{Fe}$ and $\mathrm{Zn}(\mathrm{r}=-0.728$; $\mathrm{p}<0.001),(\mathrm{r}=-0,757 ; \mathrm{p}<0.001)$, respectively, while the frequency of MCN was positively related to the same metals $(\mathrm{r}=0.449 ; \mathrm{p}=0.013)$. In $L$. sativa, germination was also negatively related to $\mathrm{Pb}$ and $\mathrm{Fe}(\mathrm{r}=-0.720 ; \mathrm{p}<0.001)$. Root growth showed a negative relation with $\mathrm{Pb}(\mathrm{r}=-$ $0.571 ; \mathrm{p}<0.001)$ and $\mathrm{Fe}(\mathrm{r}=-0.585 ; \mathrm{p}<0.001)$, while the frequency of $\mathrm{MCN}$ related positively to $\mathrm{Pb}(\mathrm{r}=0.570 ; \mathrm{p}<0.001)$ and $\mathrm{Fe}(\mathrm{r}=0.582 ; \mathrm{p}<0.001)$. Despite being considered essential micronutrients in plant metabolism (Kabata-Pendias, 2011), when Fe and Zn are present in elevated concentration in the environment, they may induce the formation of micronuclei (Kieling-Rubio et al., 2015) and reduce germination and root growth (Wang et al., 2011). Lead does not play an essential role in plant metabolism and it is also considered one of the most toxic metals to them. Its toxic effects are chiefly related to fundamental biological process damage, such as photosynthesis, growth and mitosis (Kabata-Pendias, 2011). This metal may delay or inhibit plant germination, as described for wheat (Lamhamdi et al., 2011), while also interfering in root growth (Moraes et al., 2014). The relation found between the formation of $\mathrm{MCN}$ and $\mathrm{Pb}$ was also observed in Vicia faba root cells, with MCN frequency used as one of the parameters to determine the toxic potential of $\mathrm{Pb}$ (Pourrut et al., 2011). The reduction in cell division induced by $\mathrm{Pb}$ may be associated to this metal's link to the cell wall and membranes, increasing rigidity and defects in microtubule organization. As a result, malformation of the microtubules can lead to an increase in the number of chromosomal abnormalities (Jiang et al., 2014).

\section{CONCLUSIONS}

The physical and chemical results indicate that the controlled landfill is at the methanogenic stage. Based on the analysis of biological parameters in different leachate concentrations, one may conclude that the effluent presents potential toxicity for L. sativa and L. esculentum, as it reduced the germination percentage and the number of mitotic divisions in both plant species, while also promoting the formation of chromosomal abnormalities and micronuclei, especially in L. sativa. The rise in root growth may be associated with the volume of organic matter present in the effluent. Biological parameters that best responded to the effluent toxicity were seed germination and the number of mitotic divisions, along with MCN frequency for L. sativa. The reduced index of CA and MCN in L. esculentum may be associated with the small size of chromosomes in comparison with L. sativa, thus jeopardizing visibility. It is also possible to infer that both plant species demonstrated being efficient biomonitors of environmental quality by showing evidence of sensitivity to the analyzed variables. However, L. sativa showed a more significant treatment $\mathrm{x}$ response relation in all analyzed biological parameters, which allowed for a unique interpretation of the results from specific leachate treatments. The relation noted between germination, root growth, MI and MCN frequency indicated a negative influence on the species studied from $\mathrm{Pb}, \mathrm{Fe}$ and $\mathrm{Zn}$ present in the effluent. This relation reiterates the importance of associating physical and chemical analysis with an assessment of biological parameters, by means of assays using environmental quality biomonitors. Based on these findings, one may suggest that, even with a controlled SUW landfill deactivated for over a decade, there is a need to treat this effluent, with the goal of minimizing possible impacts on the environment.

\section{ACKNOWLEDGEMENTS}

The authors thank Universidade Feevale for the infrastructure and the Scientific Initiation Grant awarded to the first author. 


\section{REFERENCES}

ABRELPE. Panorama dos Resíduos Sólidos no Brasil 2016. São Paulo, 2016. Available in: http://www.abrelpe.org.br/Panorama/panorama2016.pdf. Access: 21 Mar. 2018.

AGUIAR, L. L.; VIEIRA, L. F. A.; DAVID, J. A. O. Evaluation of the toxic potential of coffee wastewater on seeds, roots and meristematic cells of Lactuca sativa L. Ecotoxicology and Environmental Safety, v. 133, p. 366-372, 2016. https://dx.doi.org/10.1016/j.ecoenv.2016.07.019

APHA; AWWA; WPCF. Standard methods for the examination of water and wastewater. Washington, 2012. $1360 \mathrm{p}$.

BUDI, S.; SULIASIH, A.; OTHMAN, M. S.; HENG, L. Y.; SURIF, S. Toxicity identification evaluation of landfill leachate using fish, prawn and seed plant. Waste Management, Viena, v. 55, p. 231-237, 2016. https://doi.org/10.1016/j.wasman.2015.09.022

CARVAlHO, W. P.; CARVAlHO, G. J.; ABBADE-NETO, D. O.; TEIXEIRA, L. G. V. Alelopatia de extratos de adubos verdes sobre a germinação e crescimento inicial de alface. Bioscience Journal, v. 30, n. 1, p. 11-11, 2014.

CETESB. Relatório de qualidade das águas superficiais. Apêndice D. Significado ambiental e sanitário das variáveis de qualidade das águas e dos sedimentos e metodologias analíticas e de amostragem. São Paulo, 2016. 46 p.

CONAMA. Resolução $n^{\circ}$ 397, de 03 de abril de 2008. Altera o inciso II do $\S 4^{\circ}$ e a Tabela X do $\S 5^{\circ}$, ambos do art. 34 da Resolução do Conselho Nacional do Meio AmbienteCONAMA no 357 , de 2005, que dispõe sobre a classificação dos corpos de água e diretrizes ambientais para o seu enquadramento, bem como estabelece as condições e padrões de lançamento de efluentes. Diário Oficial da União, Brasília, DF, 07 abril de 2008. Available in: http://www.mma.gov.br/port/conama/legiabre.cfm?codlegi $=459$ Access: 08 July 2018.

CUCHIARA, C. C.; BORGES, C. S.; BOBROWSKI, V. L. C. Sensibilidade de sementes de hortaliças na avaliação da qualidade da água em bioensaios. Revista Biotemas, v. 25, n. 3, p. 19-27, 2012. https://dx.doi.org/10.5007/2175-7925.2012v25n3p19

EL-FADEL, M.; BOU-ZEID, R.; CHAHINE, W.; ALAYLI, B. Temporal variation of leachate quality from pre-sorted and baled municipal solid waste with high organic and moisture content. Waste Management, v. 22, p. 269-282, 2002. https://dx.doi.org/10.1016/S0956053X(01)00040-X

FARQUHAR G. J. Leachate: production and characterization. Canadian Journal of Civil Engineering, v. 16, p. 317-325, 1989. https://dx.doi.org/10.1139/189-057

GATTI, A. B.; PEREZ, S. C. J. G. A.; LIMA, M. I. S. Atividade alelopática de extratos aquosos de Aristolochia esperanzae O. Kuntze na germinação e no crescimento de Lactuca sativa L. e Raphanus sativus L. Acta Botanica Brasilica, v. 18, n. 3, p. 459-472, 2004. https://dx.doi.org/10.1590/S0102-33062004000300006

INSTITUTO BRASILEIRO DE ADMINISTRAÇÃO MUNICIPAL - IBAM. Manual de gerenciamento integrado de resíduos sólidos. Rio de Janeiro, 2001. Available in: http://www.resol.com.br/cartilha4/manual.pdf. Access: 21 Mar. 2018. 
IBGE. Diretoria de Pesquisas. Coordenação de População e Indicadores Sociais. Estimativas da população residente: Ivoti. 2017. Available in: https://cidades.ibge.gov.br/brasil/rs/ivoti/panorama Access: 20 Apr. 2018.

JIANG, Z.; QIN, R.; ZHANG, H. H.; ZOU, J. H.; SHI, Q. Y.; WANG, J. R.; JIANG, W. S.; LIU, D. H. Determination of Pb genotoxic effects in Allium cepa root cells by fluorescent probe, microtubular immunofluorescence and comet assay. Plant Soil, v. 383, n. 1-2, p. 357-372, 2014. https://doi.org/10.1007/s11104-014-2183-9

KABATA-PENDIAS, A. Trace elements in soil and plants. 4. ed. New York: Taylor and Francis Group, 2011. 505 p.

KIELING-RUBIO, M. A.; BENVENUTI, T.; COSTA, G. M.; PETRY, C. T.; RODRIGUES, M. A. S.; SCHMITT, J. L.; DROSTE, A. Integrated environmental assessment of streams in the Sinos River basin in the state of Rio Grande do Sul, Brazil. Brazilian Journal of Biology, v. 75, n. 2, suppl., p. 105-113, 2015. http://dx.doi.org/10.1590/1519-6984.1013

KLAUCK, C. R.; RODRIGUES, M. A. S.; SILVA, L. B. Evaluation of phytotoxicity of municipal landfill leachate before and after biological treatment. Brazilian Journal of Biology, São Carlos, v. 75, n. 2, p. 57-62, 2015. https://dx.doi.org/10.1590/15196984.1813

KWASNIEWSKA, J.; NALECZ-JAWESKI, G.; SKRZYPCZAK, A.; PLAZA, G. A.; MATEJCZYK, M. An assessment of the genotoxic effects of landfill leachates using bacterial and plant tests. Ecotoxicology and Environmental Safety, v. 75, p. 55-62, 2012. https://doi.org/10.1016/j.ecoenv.2011.08.020

LAMHAMDI, M.; BAKRIM, A.; AARAB, A.; LAFONT, R.; SAYAH, F. Lead phytotoxicity on wheat (Triticum aestivum L.) seed germination and seedlings growth. Comptes $\begin{array}{lllllll}\text { Rendus Biologies, } & \text { v. } 334, \quad \text { n. } 2, \quad \text { p. 118-126, }\end{array}$ https://doi.org/10.1016/j.crvi.2010.12.006

LEME, D. M.; MARIN-MORALES, M. A. Allium cepa test in environmental monitoring: A review on its application. Mutation Research, v. 682, p. 71-81, 2009. https://doi.org/10.1016/j.mrrev.2009.06.002

MORAES, C. L.; MARINI, P.; FERNANDO, J. A.; MORAES, D. M.; CASTRO, L. A. S.; LOPES, F. N. Alterações fisiológicas e ultraestruturais de plântulas de tomate induzidas por chumbo. Revista Iheringia, v. 69, n. 2, p. 313-322, 2014.

POURRUT, B.; JEAN, S.; SILVESTRE, J.; PINELLI, E. Lead-induced DNA damage in Vicia faba root cells: potential involvement of oxidative stress. Mutation Research, v. 726, n. 2, p. 123-128, 2011. https://dx.doi.org/10.1016/j.mrgentox.2011.09.001

RENOU S.; GIVAUDAN, J. G.; DIRASSOUYAN, F.; MOULIN, P. Landfill leachate treatment: review and opportunity. Journal of Hazardous Materials, v. 150, p. 468-493, 2008. https://doi.org/10.1016/j.jhazmat.2007.09.077

RIGUETTI, F. P.; CARDOSO, C. A. L.; CAVAlHEIRO, A. A.; LENZI, E.; FIORUCCI, A. R.; SILVA, M. S. Manganês, zinco, cádmio, chumbo, mercúrio e crômio no chorume de aterro sanitário em Dourados, MS, Brasil. Revista Ambiente \& Água, v. 10, n. 1, p. 153 163, 2015. http://dx.doi.org/10.4136/ambi-agua.1538 
RODRIGUES, L. C. A.; BARBOSA, S.; PAZIN, M.; MASELlI, B. S.; BEIJO, L. A.; KUMMROW, F. Fitotoxicidade e citogenotoxicidade da água e sedimento de córrego urbano em bioensaio com Lactuca sativa. Revista Brasileira de Engenharia Agrícola e Ambiental, v. 1 17, n. 10, p. 1099-1108, 2013.

ROSA, B. P.; PAULA, B. C. L.; COLEONE, E. S. A.; CAMPOS, F. Impactos causados em cursos d'água por aterros controlados desativados no Município de São Paulo, Sudeste do Brasil. Revista Brasileira de Gestão e Sustentabilidade, v. 4, n. 7, p. 63-76, 2017. https://dx.doi.org/10.21438/rbgas.040707

SILVA, A. S.; RIBEIRO, L. S.; PAIVA, W.; MELO, M. C.; MONTEIRO, V. E. D. Avaliação do potencial tóxico dos resíduos sólidos urbanos da cidade de Campina Grande - PB. Revista Matéria, v. 20, n. 4, p. 840-851, 2015.

SOLID WASTE ASSOCIATION OF NORTH AMERICA - SWANA. Leachate generation, collection and treatment at municipal solid waste disposal facilities. Silver Spring, 1997.

WANG, H.; GUANGRONG, Z.; GUOQING, S.; FANGTING, P. Toxicity of $\mathrm{Cu}, \mathrm{Pb}$ and $\mathrm{Zn}$ on seed germination and young seedlings of wheat (Triticum aestivum L.). In: COMPUTER AND COMPUTING TECHNOLOGIES IN AGRICULTURE, 5., 2011, Beijing, China. Proceedings[...] Berlin: Springer, 2011. p. 231-240.

YANG, N.; DAMGAARD, A.; LÜ, F.; SHAO, L. M.; BROGAARD, L. K. S.; HE, P. J. Environmental impact assessment on the construction and operation of municipal solid waste sanitary landfills in developing countries: China case study. Waste Management, v. 34, p. 929-937, 2014. https://doi.org/10.1016/j.wasman.2014.02.017 


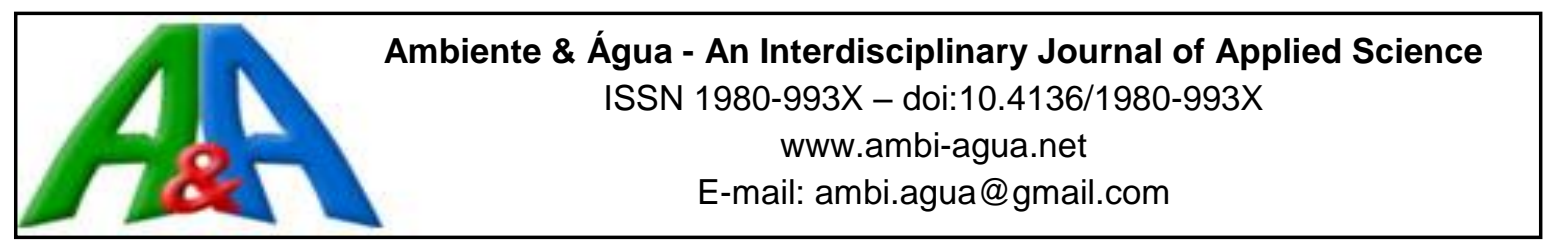

\title{
Ozonation improves physical attributes in domestic sewage effluent
}

\author{
ARTICLES doi:10.4136/ambi-agua.2328
}

Received: 13 Sep. 2018; Accepted: 24 Jan. 2019

\author{
Osli Barreto Camilo Júnior ${ }^{*}$; ; Delvio Sandri ${ }^{\circledR}$; \\ Ernandes Rodrigues de Alencar $^{2}$; ; Lucas Ferraz Hebling ${ }^{2}(D$ \\ ${ }^{1}$ Universidade de Brasília (UnB), Brasília, DF, Brasil \\ Faculdade de Agronomia e Medicina Veterinária (FAV/UnB). \\ Programa de Pós-Graduação em Agronomia. E-mail: oslijr@gmail.com \\ ${ }^{2}$ Universidade de Brasília (UnB), Brasília, DF, Brasil \\ Faculdade de Agronomia e Medicina Veterinária (FAV/UnB). E-mail: sandri@unb.br, \\ ernandesalencar@unb.br, hebling123@gmail.com \\ *Corresponding author
}

\begin{abstract}
Root Zone Wastewater Treatment (RZWT) is an option of natural wastewater treatment widely studied throughout the world, being a technology based on physical, chemical and biological processes. However, there are some attributes in effluent that occasionally are not eliminated by RZWT. In this context, the use of ozone may contribute to mineralization, disinfection, detoxification, and, especially, color and turbidity removal. Ozone is an excellent oxidant, with great potential to reduce color, turbidity and other attributes in liquids, such as in wastewater treatment. This paper evaluated the effect of different ozone exposure times $(0,30$, 60, 90, 120 and 150 minutes) and the application of different dosages of ozone $(0,4,10,17,25$ and $35 \mathrm{mg} \mathrm{L}^{-1}$ of $\mathrm{O}_{3}$ ) on Hydrogeonic Potential (pH), Electrical Conductivity (EC), Dissolved Oxygen (OD), Total Alkalinity (Alk.), Sodium (Na) and Potassium (K) in domestic sewage effluent treated by the RZWT. Different exposure times and ozone dosages did not influence the attributes Potassium, Sodium, Ammonia and Total Solids. Color and turbidity decreased, while $\mathrm{pH}$, Alkalinity and Dissolved Oxygen increased at all exposure times and $\mathrm{O}_{3}$ dosages in relation to the non-ozonized effluent.
\end{abstract}

Keywords: color, ozone, root zone wastewater treatment, turbidity.

\section{Ozonização promove a melhoria de atributos físicos em efluente de esgoto doméstico}

\section{RESUMO}

O Sistema de Zona de Raízes (SRZ) é uma opção natural de tratamento de efluentes amplamente estudado em todo o mundo, sendo uma tecnologia baseada em processos físicos, químicos e biológicos. No entanto, existem alguns atributos no efluente que ocasionalmente não são eliminados pelo SZR. Nesse contexto, o uso do ozônio pode contribuir para a mineralização, desinfecção, desintoxicação e, principalmente, remoção de cor e turbidez. $\mathrm{O}$ ozônio é um excelente oxidante, com grande potencial para reduzir a cor, a turbidez e outros atributos em líquidos, assim como no tratamento de efluentes. O objetivo deste trabalho foi avaliar o efeito de diferentes tempos de exposição ao ozônio (0, 30, 60, 90, 120 e 150 minutos) e a aplicação de diferentes dosagens de ozônio $\left(0,4,10,17,25\right.$ e $35 \mathrm{mg} \mathrm{L}^{-1}$ de $\left.\mathrm{O}_{3}\right)$ sobre 
Potencial Hidrogeônico (pH), Condutividade Elétrica (CE), Oxigênio Dissolvido (OD), Alcalinidade Total (Alk.), Sódio (Na) e Potássio (K) no efluente doméstico tratado pelo SZR. Diferentes tempos de exposição e dosagens de ozônio não influenciaram os atributos Potássio, Sódio, Amônia e Sólidos Totais. A cor e a turbidez diminuíram, enquanto o pH, a alcalinidade e o oxigênio dissolvido aumentaram em todos os momentos de exposição e as dosagens de $\mathrm{O}_{3}$ em relação ao efluente não-ozonizado.

Palavras-chave: cor, ozônio, sistema de zona de raízes, turbidez.

\section{INTRODUCTION}

The use of septic tanks, followed by Root Zone Wastewater Treatment (RZWT), is an option of natural wastewater treatment system widely studied throughout the world, being a technology based on physical, chemical and biological processes which normally occur naturally in ecosystems, such as in natural floodplains (Kadlec and Wallace, 2009).

The main function of a wastewater treatment system is to remove the pollutant load, whether colloidal or soluble compounds. However, some attributes in the effluent occasionally are not eliminated. In this context, the use of ozone may contribute to mineralization, disinfection, detoxification, and, especially, color and turbidity removal (Bhatta et al., 2015).

Today, ozone is still used for disinfection, but due to its superior oxidizing ability it is also used for a several other purposes including taste-and-odor control, color removal, iron and manganese oxidation, turbidity removal, algal removal, increasing the biodegradability of natural organic matter (NOM), and oxidation of specific micropollutants (Araújo et al., 2016; Bhatta et al., 2015; Bukhari et al., 2019; Freitas-Silva et al., 2013; Lage Filho, 2010).

Once dissolved in water, the ozone reacts with a large number of organic compounds in two different possible ways: direct oxidation, such as molecular ozone, or indirect reaction through the formation of secondary oxidants, such as free radicals, particularly the hydroxyl radical (Subha and Muthukumar, 2012; Wajahat et al., 2019).

Despite the importance of ozone, it is noteworthy that the use of innovative technologies such as biogenic nanoparticles (BNPs), magnetotactic bacteria (MTB), and Phytogenic Magnetic Nanoparticles (PMNPs) is increasing in wastewater treatment, especially in the removal of heavy metals and specific compounds. In this way, studies related to ozonation should take into account all drawbacks including high cost, complex operation, and toxic and chemical reducing agents required to synthesize and control system operation (Ali et al., 2017; 2018).

Considering the importance of ozonation in wastewater treatment, whether domestic or industrial, the objective of this paper was to evaluate the application of different dosages and exposure times to ozone on physical and chemical attributes in domestic sewage effluent, obtained after Root Zone Wastewater Treatment (RZWT).

\section{MATERIAL AND METHODS}

The Root Zone Wastewater Treatment (RZWT) is located at the Água Limpa Farm (ALF) of the University of Brasília (UnB) (15 57'16" S, 47 55'89' W and altitude of $1.103 \mathrm{~m}$ ). The Laboratory of Water Analysis and the Laboratory of Storage and Preprocessing of Agricultural Products of the Faculty of Agronomy and Veterinary Medicine (UnB) performed the analyses of the effluent before and after applying ozonation.

The effluent generated at the Água Limpa Farm is mostly from sanitary discharges and a refectory, which, for its composition, is characterized as domestic effluent. The daily volume 
generated is quite variable due to its frequency of use and oscillation of amount of people who attend the ALF, and it is not equal among the days of the week.

The RZWT consists of a set of four equal units built in rectangular fiberglass structures, with dimensions of $2.5 \mathrm{~m}$ (width), 6.5 (length) and $0.5 \mathrm{~m}$ (height). The first unit was cultivated with taboa (Typha spp); the second with Brazilian Papyrus (Cyperus Giganteus); the third with umbrella papyrus (Cyperus alternifolius), and a fourth system without a plant (witness).

An ozone generator O\&LM, Ozone \& Life ${ }^{\circledR}$ brand generated the ozone gas. In the process of gas generation, oxygen $90 \%$ pure and humidity free was used as input, obtained from the Mark Plus Oxygen Concentrator.

In order to produce the ozone gas $\left(\mathrm{O}_{3}\right)$, the oxygen went through a refrigerated reactor, in which the Dielectric Barrier Discharge (DBD) occurs. This type of discharge consists in applying a high voltage between two parallel electrodes, having between them a dielectric (glass) and a free space. In this free space, a discharge is produced in the form of filaments, where electrons are generated with sufficient energy to produce the breakdown of the oxygen molecules, forming the ozone $\left(\mathrm{O}_{3}\right)$ (Lage Filho et al., 2008).

To evaluate the effect of exposure times of ozonation (0, 30, 60, 90, 120 and 150 minutes) and to optimize the analyses, two glass containers were used in each stage, where $\mathrm{O}_{3}$ was equally divided. The containers were hermetically sealed and had $10 \mathrm{~cm}$ of internal diameter and $20 \mathrm{~cm}$ of useful height, having in its plastic cover, a porous diffuser through which the gas was introduced in a flow of $1.0 \mathrm{~L} \mathrm{~min}^{-1}$.

The first two treatments were the exposure times of 30 and 90 min (one in each container). As soon as the time of $30 \mathrm{~min}$ finished, it was replaced by the $60 \mathrm{~min}$ treatment, thus, at the end of the $90 \mathrm{~min}$, four treatments had already been completed ( 0 - witness, 30, 60 and $90 \mathrm{~min}$ ). The last two treatments $(120$ and $150 \mathrm{~min})$ followed the same sequence. At the end of the 120 min treatment, this container was replaced with distilled water until the completion of the experiment, i.e., for another $30 \mathrm{~min}$ until the treatment of $150 \mathrm{~min}$ was completed.

For the treatment with different dosages of ozone $\left(0,4,10,17,25\right.$ and $3 \mathrm{mg} \mathrm{L}^{-1}$ of $\left.\mathrm{O}_{3}\right)$, only one container was used. The treatments performed consecutively from the lowest to the highest dosage. The first effluent sample was exposed to a dosage of $4 \mathrm{mg} \mathrm{L}^{-1}$ of $\mathrm{O}_{3}$ for $30 \mathrm{~min}$, the second sample was added and the dosage was increased from 4 to $10 \mathrm{mg} \mathrm{L}^{-1}$ which remained for more $30 \mathrm{~min}$. The dosages of 17, 25 and $35 \mathrm{mg} \mathrm{L}^{-1}$ of $\mathrm{O}_{3}$ followed the same sequence.

In order to carry out the laboratory analyses, the methodologies of analysis of the Standard Methods for the Examination of Water and Wastewater (APHA et al., 2005) were used or adapted. APHA Method no. 4500-0 (for Dissolved Oxygen); no. 2320 (for Total Alkalinity); no. 2130 (for Turbidity); no. 2120 (for Color); no. 2540 (for Solids); no. $4500-\mathrm{NO}_{3}$ (for Ammonia); no. 3500 - Na (for Sodium); and no. 3500 - K (for Potassium). To apply different exposure times to $\mathrm{O}_{3}$, four collection campaigns were carried out in November 2017, and to evaluate the different dosages of $\mathrm{O}_{3}$, three collection campaigns were carried out in December 2017. In each campaign, $6 \mathrm{~L}$ of effluent in sterilized containers were collected, always at 1 p.m. due to higher volume of sewage at this time. The containers were packed in ice packs, which were transported to the laboratory and refrigerated at $4^{\circ} \mathrm{C}$ (APHA et al., 2005).

The results of the experiments were analyzed using the Software Assistant (Silva and Azevedo, 2016), applying the Duncan test at 1 and 5\% of probability, considering the collection dates as the replicates.

\section{RESULTS AND DISCUSSION}

\subsection{Potential Hydrogen (pH)}

There was an increase in $\mathrm{pH}$ values in the effluent samples, either as a function of exposure times due to the variation of the ozone dosages (Figure 1). 
The $\mathrm{pH}$ values of the effluent exposed to the times of ozonation were higher than the effluent without ozonation, being the largest of 8.38 and the lowest of 7.46 (without ozonation). The time of $30 \mathrm{~min}$ differed from the times of 90, 120 and $150 \mathrm{~min}$. A variation of $8.7 \%$ might be observed for the time of $30 \mathrm{~min}$, up to $12.3 \%$ for the times of 120 and $150 \mathrm{~min}$, demonstrating that the greatest variation occurred up to $30 \mathrm{~min}$, after the beginning of $\mathrm{O}_{3}$ application (Figure $1)$.
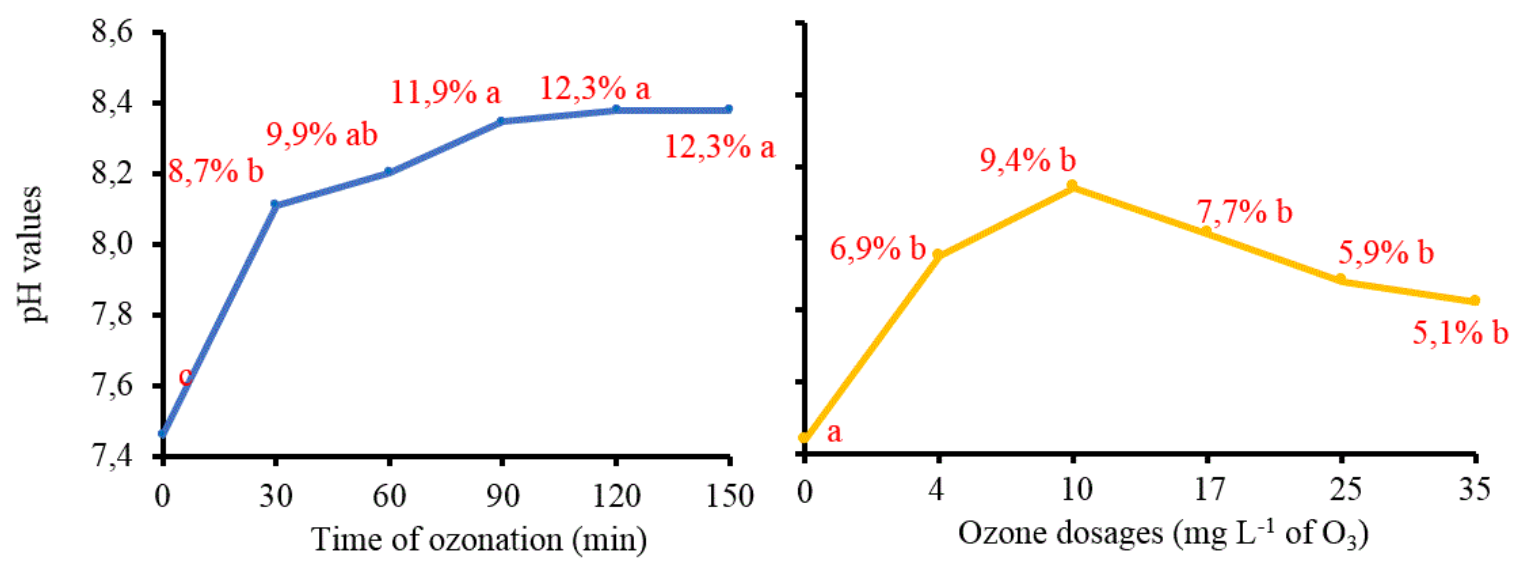

Figure 1. $\mathrm{pH}$ values of the domestic sewage effluent as a function of the exposure times 0, 30, 60, 90,120 and $150 \mathrm{~min}$ at the dosage of $12 \mathrm{mg} \mathrm{L}^{-1}$ of $\mathrm{O}_{3}$ and to the dosages of $0,4,10,17,25$ and $35 \mathrm{mg} \mathrm{L}^{-1}$ of $\mathrm{O}_{3}$ for $30 \mathrm{~min}$ and variation, in $\%$, in relation to the effluent without ozonation. Different letters between the times of ozonation or $\mathrm{O}_{3}$ dosages differ from each other by the Duncan test at $1 \%$ probability.

As the $\mathrm{O}_{3}$ dosages varied, the $\mathrm{pH}$ values increased, reaching $8.14\left(10 \mathrm{mg} \mathrm{L}^{-1}\right.$ of $\left.\mathrm{O}_{3}\right)$, differing from the effluent without ozonation, but equal to the other dosages. After the dosage of $10 \mathrm{mg} \mathrm{L}^{-1}$ of $\mathrm{O}_{3}$, a reduction in the $\mathrm{pH}$ values was observed until the highest dosage evaluated (35 $\mathrm{mg} \mathrm{L}^{-1}$ of $\mathrm{O}_{3}$ ), but not significantly (Figure 1). The $\mathrm{pH}$ drop from the $25 \mathrm{mg} \mathrm{L}^{-1} \mathrm{O}_{3}$ dosage can be attributed to the formation of short chain acid compounds (acetic and oxalic acid, for example), resulting from the partial oxidation of more complex substances promoted by ozone as observed by Aquino and Pires (2016).

As ozone acts on the effluent, there is the release of hydroxide ions $\left(\mathrm{OH}^{-}\right)$making these predominant over hydrogen $\mathrm{H}^{+}$ions. When the $\mathrm{pH}$ reaches 8.0, practically half of the $\mathrm{O}_{3}$ introduced is decomposed into several intermediate forms of oxygen, over a period of $10 \mathrm{~min}$ (Lage Filho et al., 2008; Coelho et al., 2015).

This fact may explain the increase in $\mathrm{pH}$ values in the effluent samples with variation of the exposure time. When the $\mathrm{pH}$ value of the effluent is above 8.0, most of the ozone is decomposed into $\mathrm{OH}^{-}$, which induces an increasingly alkaline condition, interfering with the attributes of the effluent sample.

Bhatta et al. (2015) observed a slight increase in $\mathrm{pH}$ values in their study on the treatment of wastewater by ozone produced in dielectric barrier discharge, in agreement with the results found here. Likewise, Silva and Daniel (2015) observed an increase in $\mathrm{pH}$ values $(\mathrm{p}=0.05)$ for the ozonized effluents compared to the UASB reactor effluent.

\subsection{Electrical Conductivity (EC) and Total Alkalinity}

Ozonation promoted a significant reduction in EC values as a function of time of ozonation and a reduction of Alkalinity as a function of $\mathrm{O}_{3}$ dosages (Figure 2).

As the time of exposure of the effluent to the $\mathrm{O}_{3}$ increased, there was a reduction of $7.5 \%$ in the EC values at 120 min compared to the effluent without exposure to $\mathrm{O}_{3}$. The grand mean 
of the treatment for different ozone dosages was $1281 \mu \mathrm{S} \mathrm{cm}^{-1}$, with values ranging from 1295 ( $0 \mathrm{mg} \mathrm{L}^{-1}$ of $\left.\mathrm{O}_{3}\right)$ to $1272\left(17 \mathrm{mg} \mathrm{L}^{-1}\right.$ of $\left.\mathrm{O}_{3}\right)$, but not differing between dosages.

Regarding total alkalinity, the grand mean obtained by the different exposure times was $56 \mathrm{mg} \mathrm{L}^{-1}$ of $\mathrm{CaCO}_{3}$, with values ranging from 53 to $59 \mathrm{mg} \mathrm{L}^{-1}$ of $\mathrm{CaCO}_{3}$, showing no significant difference by the $1 \%$ Duncan test.
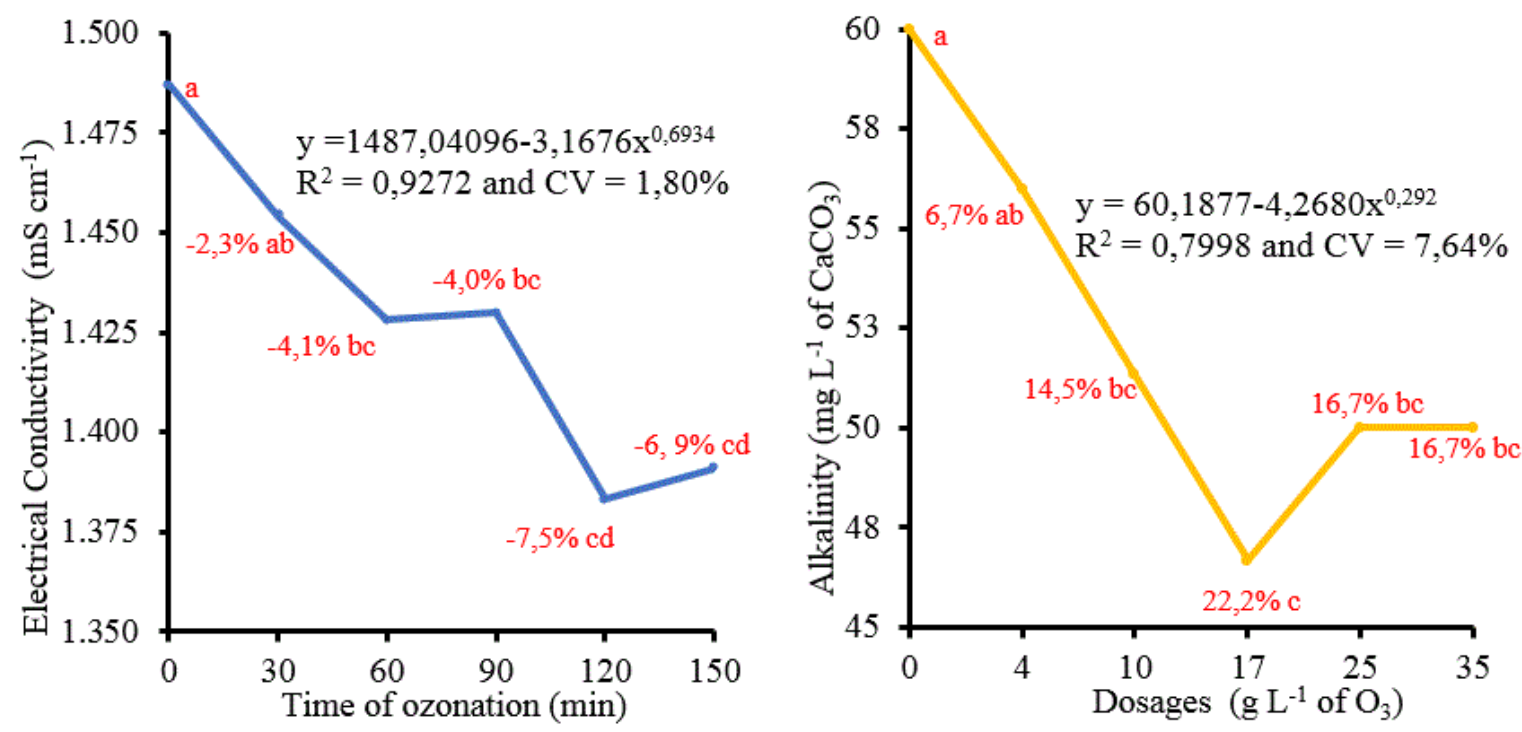

Figure 2. Electrical Conductivity of the domestic sewage effluent as a function of the exposure times of $0,30,60,90,120$ and $150 \mathrm{~min}$ at the dosage of $12 \mathrm{mg} \mathrm{L}^{-1}$ of $\mathrm{O}_{3}$, and total alkalinity as a function of the time of exposure of the effluent at the dosages of $0,4,10,17,25$ and $35 \mathrm{mg} \mathrm{L}^{-1}$ of $\mathrm{O}_{3}$ for $\quad 30 \mathrm{~min}$ and variation, in $\%$, in relation to the effluent without ozonation. Different letters between times of ozonation or $\mathrm{O}_{3}$ dosages differ from each other by the Duncan test at $1 \%$ probability.

In the treatment as a function of the $\mathrm{O}_{3}$ dosages, there was a reduction in the alkalinity values with the increase in the ozone dosages up to $17 \mathrm{mg} \mathrm{L}^{-1}$, tending to stabilize from this dosage. The grand mean in the treatment was $52.33 \mathrm{mg} \mathrm{L}^{-1}$ of $\mathrm{CaCO}_{3}$, with values ranging from $46.67 \mathrm{mg} \mathrm{L}^{-1}$ (17 $\mathrm{mg} \mathrm{L}^{-1}$ of $\mathrm{O}_{3}$ dosage) to $60 \mathrm{mg} \mathrm{L}^{-1}$ (without ozonation), an average reduction of $22.2 \%$ (Figure 2).

Considering the basic $\mathrm{pH}$ values in both treatments, the buffering power (alkalinity) of the effluent treated with $\mathrm{O}_{3}$ is adequate. It is worth highlighting that alkalinity is not the standard classification for natural waters or emission of sewage, showing the importance of this parameter in the control of certain unit processes used in water treatment plants (Von Sperling, 2014).

\subsection{Dissolved Oxygen (DO)}

The Dissolved Oxygen (DO) values were higher at all times of ozonation and at all $\mathrm{O}_{3}$ dosages compared with the effluent without ozonation (Figure 3).

The grand mean in the treatment as a function of time of exposure to $\mathrm{O}_{3}$ was $15.16 \mathrm{mg} \mathrm{O}_{2} \mathrm{~L}^{-1}$, with values ranging from 5.5 to $19.3 \mathrm{mg} \mathrm{O}_{3} \mathrm{~L}^{-1}$ for 0 and $90 \mathrm{~min}$, respectively, representing elevation of $351 \%$. While at the exposure times of 30,60, 120 and $150 \mathrm{~min}$ the increases were 253, 282, 349 and $318 \%$, respectively (Figure 3).

The grand mean when varying the $\mathrm{O}_{3}$ dosages was $21.28 \mathrm{mg} \mathrm{O}_{3} \mathrm{~L}^{-1}$, with values ranging from 6.2 to $26.2 \mathrm{mg} \mathrm{O}_{3} \mathrm{~L}^{-1}$. There was an increase in DO values of $424 \%\left(17 \mathrm{mg} \mathrm{L}^{-1} \mathrm{O}_{3}\right)$ and $413 \%\left(25 \mathrm{mg} \mathrm{L}^{-1} \mathrm{O}_{3}\right)$ in relation to the effluent without ozonation. 

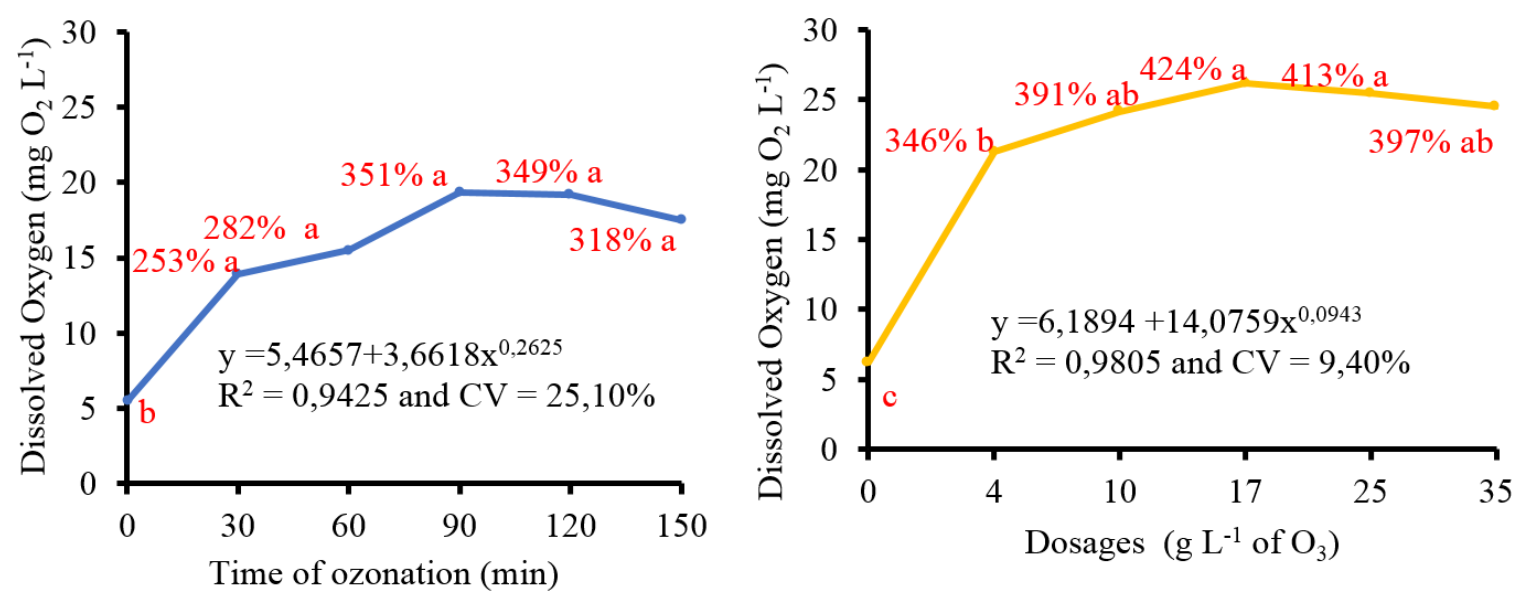

Figure 3. Dissolved Oxygen $\left(\mathrm{mg} \mathrm{O}_{2} \mathrm{~L}^{-1}\right)$ of the domestic sewage effluent as a function of times of the exposure of $0,30,60,90,120$ and $150 \mathrm{~min}$ at the dosage of $12 \mathrm{mg} \mathrm{L}^{-1}$ of $\mathrm{O}_{3}$ and as a function of the dosages of $0,4,10,17,25$ and $35 \mathrm{mg} \mathrm{L}^{-1}$ of $\mathrm{O}_{3}$ for $30 \mathrm{~min}$ and variation, in $\%$, in relation to the effluent without ozonation. Different letters between times of ozonation and $\mathrm{O}_{3}$ dosage differ from each other by the Duncan test at $1 \%$ probability.

The significant increase in DO as a function of the time of exposure and to the $\mathrm{O}_{3}$ dosages is explained by the fact that the $\mathrm{O}_{3}$ applied to the effluent is rapidly converted into $\mathrm{O}_{2}$, raising its concentration in the environment. This phenomenon was also observed by Bhatta et al. (2015) where the DO values of the effluent, after the treatment with ozone, increased significantly, reaching the value of $9.55 \mathrm{mg} \mathrm{O}_{2} \mathrm{~L}^{-1}$ in that study.

\subsection{Turbidity}

There was a decrease in the turbidity values in the effluent samples both in relation to the exposure times and in relation to $\mathrm{O}_{3}$ dosages (Figure 4).
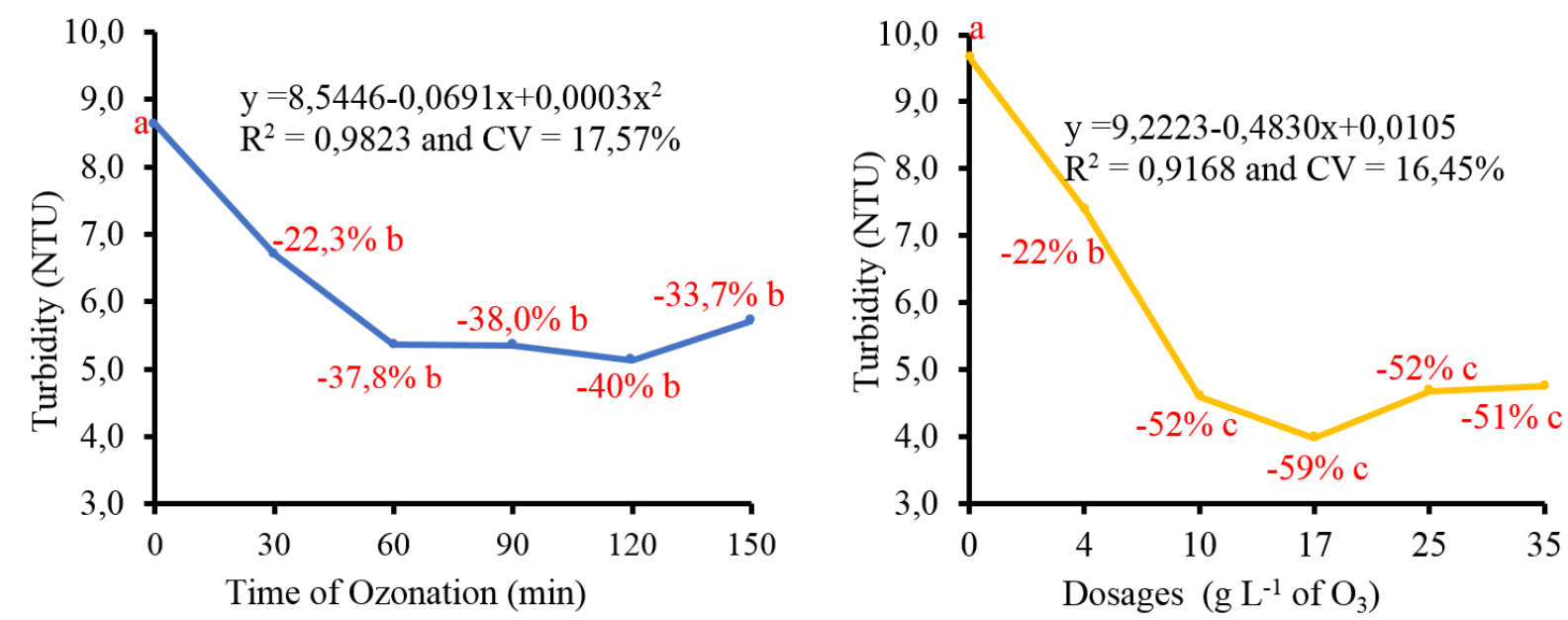

Figure 4. Turbidity in NTU of domestic sewage effluent treated as a function of the exposure times of $0,30,60,90,120$ and $150 \mathrm{~min}$ at the dosage of $12 \mathrm{mg} \mathrm{L}-1$ of $\mathrm{O}_{3}$ and as a function of the dosages of 0 , $4,10,17,25$ and $35 \mathrm{mg} \mathrm{L}^{-1}$ of $\mathrm{O}_{3}$ for $30 \mathrm{~min}$ and variation, in \%, in relation to the effluent without ozonation. Different letters between times of ozonation and $\mathrm{O}_{3}$ dosages differ from each other by the Duncan test at $1 \%$ probability.

The grand mean in treatment as a function of time of exposure was $6.2 \mathrm{NTU}$, being the highest value 8.63 and the lowest $5.1 \mathrm{NTU}$ (0 and $120 \mathrm{~min}$ of exposure), representing a reduction of $40.0 \%$. 
As a function of the $\mathrm{O}_{3}$ dosages, the grand mean of turbidity was $5.8 \mathrm{NTU}$, representing a reduction of $23.42 \%$ in the dosage of $\mathrm{mg} \mathrm{L}^{-1}$ of $\mathrm{O}_{3}$, and of $52.43 \%$ and $58.86 \%$ in the dosages 25 and $35 \mathrm{mg} \mathrm{L}^{-1}$ of $\mathrm{O}_{3}$, respectively (Figure 4).

In this study, the greatest reductions in turbidity values were $40.0 \%$ and $58.9 \%$ at $120 \mathrm{~min}$ of exposure and $17 \mathrm{mg} \mathrm{L}^{-1}$ of $\mathrm{O}_{3}$, respectively. Cabrera-Díaz et al. (2016) observed higher turbidity removal values, reaching $99.2 \%$ in combined treatment of vinasse (anaerobic filterreactor and ozonation process); however, using a concentration of $100 \mathrm{mg} \mathrm{L}^{-1}$ of $\mathrm{O}_{3}$ and a contact period of 3 hours.

The reason for the decreasing values of turbidity while increasing ozone dosages and exposures times are that some particles and high weight organic compounds would be destroyed by ozone and converted into dissolved compounds like observed by Xu et al. (2002).

The reduction in turbidity values were positive, considering there was a reduction close to $60.0 \%$ in the dosage of $17 \mathrm{mg} \mathrm{L}^{-1}$ of $\mathrm{O}_{3}$ for $30 \mathrm{~min}$. On the other hand, Li et al. (2015), in a study on biofiltration and ozonation for effluent treatment, observed a turbidity reduction of $90.0 \%$ using a dosage of $5 \mathrm{mg} \mathrm{L}^{-1}$ of $\mathrm{O}_{3}$ and a flow of $1.5 \mathrm{~m}^{3} \mathrm{~h}^{-1}$, respecting local limits for the discharge of urban effluents into water bodies.

\subsection{Color}

There was a reduction in color values at all exposure times and at all ozone dosages (Figure $5)$.

The grand mean of the color as a function of exposure times to $\mathrm{O}_{3}$ was 96.0 of standard APHA color with progressive reduction, reaching 49.7 at $120 \mathrm{~min}$ of exposure. In percentage, the reduction was $47.0 \%$ at $30 \mathrm{~min}$ and $76.2 \%$ at $120 \mathrm{~min}$

Regarding the treatment with different dosages of ozone, there was a reduction of $67.7 \%$ at the dosage of $4 \mathrm{mg} \mathrm{L}^{-1}$ of $\mathrm{O}_{3}$ and of $81.5 \%$ at the dosage of $17 \mathrm{mg} \mathrm{L}^{-1}$ of $\mathrm{O}_{3}$ (Figure 5).
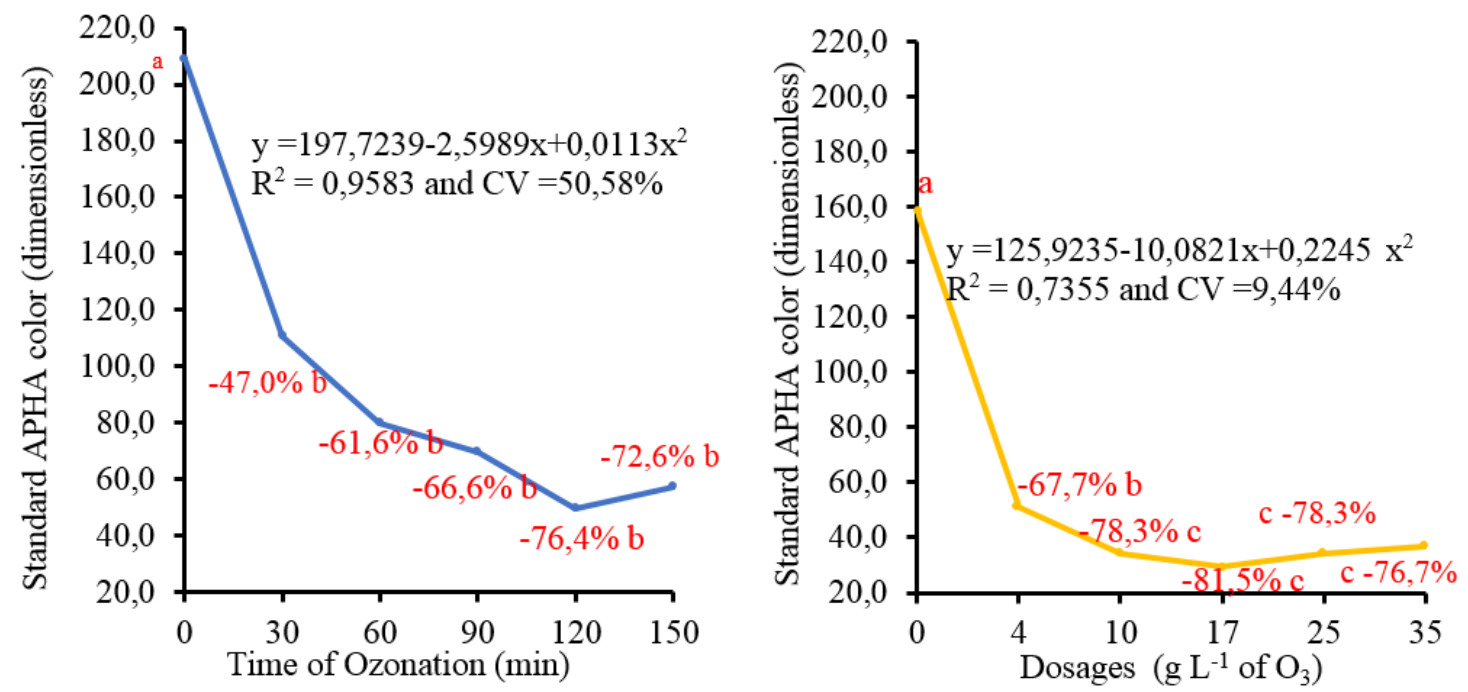

Figure 5. Standard APHA color (dimensionless) values of treated domestic sewage effluent as a function of the exposure times of $0,30,60,90,120$ and $150 \mathrm{~min}$ at the dosage of $12 \mathrm{mg} \mathrm{L}^{-1}$ of $\mathrm{O}_{3}$ and as a function of the dosages of $0,4,10,17,25$ and $35 \mathrm{mg} \mathrm{L}^{-1}$ of $\mathrm{O}_{3}$ for 30 min and variation, in \%, in relation to the effluent without ozonation. Different letters between times of ozonation and dosages of $\mathrm{O}_{3}$ differ from each other by the Duncan test at $1 \%$ probability.

The greatest color reductions (76.2\% and $81.5 \%)$, are corroborated by Cabrera-Díaz et al. (2016) and Li et al. (2015), in which Cabrera-Díaz et al. (2016) observed color removals of 93.7\% (UPt-Co) in a combined treatment of vinasse (anaerobic filter-reactor and ozonation process) emphasizing the effectiveness of the ozonation process in the color and turbidity 
removal of this residue. Li et al. (2015), on the other hand, using biofiltration and ozonation for effluent treatment, observed a general efficiency for color removal of $70.0 \%$, similar to the one obtained in the present study. Bhatta et al. (2015) observed visually, in their study on the treatment of wastewater by ozone, that the ozonized samples went from a dark gray color to a light color, close to the standard color of the water.

\subsection{Ammonia, Sodium, Potassium and Total Solids}

The average values of ammonia, sodium, potassium and total solids were not influenced as a function of exposure times and $\mathrm{O}_{3}$ dosages.

Considering the average values, there was a tendency of ammonia elevation in absolute values, and there was no statistical difference, attributed, in part, to the great variability of the results, i.e, there was no consistent evidence that the time of ozonation and the $\mathrm{O}_{3}$ dosages have influence on the ammonia contents.

Regarding sodium and potassium, there was great homogeneity of the values, both as a function of time and of $\mathrm{O}_{3}$ dosages, i.e., parameters that were not influenced by ozonation.

The total solids, although showing some variations between the exposure times and $\mathrm{O}_{3}$ dosages, did not present significant differences, leading to the conclusion, as well as in the parameters ammonia, sodium and potassium, that ozonation does not influence their values.

\section{CONCLUSIONS}

Ozonation reduced color and turbidity values both as a function of exposure times and as a function of $\mathrm{O}_{3}$ dosages. There was a maximum reduction of $76.2 \%$ in color at $120 \mathrm{~min}$ of exposure and of $81.5 \%$ in turbidity at the concentration of $17 \mathrm{mg} \mathrm{L}^{-1}$ of $\mathrm{O}_{3}$.

There was an increase in $\mathrm{pH}$, Total Alkalinity and Dissolved Oxygen (OD) values. At 120 min of exposure, there was a $12.30 \%$ increase in $\mathrm{pH}$ and at the dose of $4 \mathrm{mg} \mathrm{L}^{-1}$ of $\mathrm{O}_{3}$ the increase was $9.4 \%$. Alkalinity increased $22.2 \%$ at the dose of $17 \mathrm{mg} \mathrm{L}^{-1}$ of $\mathrm{O}_{3}$, whereas OD values increased $351 \%$ at 90 min of exposure and $424 \%$ at the dose of $17 \mathrm{mg} \mathrm{L}^{-1}$ of $\mathrm{O}_{3}$.

Potassium, sodium, ammonia and total solids were not influenced by exposure time and ozone dosages.

\section{ACKNOWLEDGMENTS}

To CNPq for the financial assistance. Universal Call - MCTI / CNPq No 14/2013. Process: 480332 / 2013-4.

\section{REFERENCES}

ALI, I.; PENG, C.; KHAN, Z. M.; NAZ, I.; SULTAN, M. An overview of heavy metal removal from wastewater using magnetotactic bacteria. Journal of Chemical Technology \& Biotechnology, v. 93, n. 10, p. 2817-2832, 2018.

ALI, I.; PENG, C.; NAZ, I.; KHAN, Z. M.; SULTAN, M.; ISLAM, T.; ABBASI, I. A. Phytogenic magnetic nanoparticles for wastewater treatment: a review. RSC Advances, v. 7, n. 64, p. 40158-40178, 2017.

AQUINO, S.; PIRES, E. C. Assessment of ozone as a pretreatment to improve anaerobic digestion of vinasse. Brazilian Journal of Chemical Engineering, v. 33, n. 2, p. 279$285,2016$.

APHA; AWWA; WPCF. Standard methods for the examination of water and wastewater. 21. ed. Washington D.C., 2005.

Rev. Ambient. Água vol. 14 n. 2, e2328 - Taubaté 2019 
ARAÚJO, K. S. D.; ANTONELLI, R.; GAYDECZKA, B., GRANATO, A. C.; MALPASS, G. R. P. Advanced oxidation processes: a review of fundamentals and applications in the treatment of urban and industrial wastewaters. Revista Ambiente \& Água, v. 11, n. 2, p. 387-401, 2016.

BHATTA, R.; KAYASTHA, R.; SUBEDI, D. P.; JOSHI, R. Journal of Chemistry, v. 2015, 6 p., 2015. https://doi.org/10.1155/2015/648162

BUKHARI, K.; AHMAD, N.; SHEIKH, I. A.; AKRAM, T. M. Effects of Different Parameters on Photocatalytic Oxidation of Slaughterhouse Wastewater Using TiO. Polish Journal $\begin{array}{llllllll}\text { of Environmental Studies, } & \text { v. 28, } & \text { n. } 3, & \text { p. } & 1-10,\end{array}$ http://dx.doi.org/10.15244/pjoes/90635

CABRERA-DÍAZ, A.; PEREDA-REYES, I.; DUEÑAS-MORENO, J.; VÉLIZ-LORENZO, E.; DÍAZ-MARRERO, M. A.; MENÉNDEZ-GUTIÉRREZ, C. L.; ZAIAT, M. Combined treatment of vinasse by an upflow anaerobic filter-reactor and ozonation process. Brazilian Journal of Chemical Engineering, v. 33, n. 4, p. 753-762, 2016.

COELHO, C. C. de S.; FREITAS-SILVA, O.; CAMPOS, R. D. S.; BEZERRA, V. S.; CABRAL, L. M. Ozonização como tecnologia pós-colheita na conservação de frutas e hortaliças: Uma revisão. Revista Brasileira de Engenharia Agrícola e Ambiental, v. 19, n. 4, p. 369-375, 2015.

FREITAS-SILVA, O.; MORALES-VALLE, H.; VENÂNCIO, A. Potential of Aqueous Ozone to Control Aflatoxigenic Fungi in Brazil Nuts. ISRN biotechnology, v. 2013, 6 p., 2013. https://dx.doi.org/10.5402/2013/859830

KADLEC, R. H.; WALLACE, S. Treatment wetlands. $2^{\text {nd }}$ ed. Boca Raton: CRC press, 2009. p. 03-05.

LAGE FILHO, F. A. Avaliação da filtração e ozonização de efluente sanitário primário: aspectos de inativação microbiana e variáveis de ozonização. Química Nova, v. 31, n. 2, p. 312-316, 2008.

LAGE FILHO, F. A. Ozone application in water sources: effects of operational parameters and water quality variables on ozone residual profiles and decay rates. Brazilian Journal of Chemical Engineering, v. 27, n. 4, p. 545-554, 2010.

LI, X.; SHI, H.; LI, K.; ZHANG, L. Combined process of biofiltration and ozone oxidation as an advanced treatment process for wastewater reuse. Frontiers of Environmental Science \& Engineering, v. 9, n. 6, p. 1076-1083, 2015.

SILVA F. A. S.; AZEVEDO C. A. V. The Assistat Software Version 7.7 and its use in the analysis of experimental data. African Journal Agricultural Research, v. 11, n. 39, p. 3733-3740, 2016. http://dx.doi.org/10.5897/AJAR2016.11522

SILVA, G. H. R.; DANIEL, L A. Desinfecção de efluente anaeróbio com o uso de ozônio/cloro. Engenharia Sanitária e Ambiental. v. 20, n. 2, p. 279-288. 2015. http://dx.doi.org/10.1590/S1413-41522015020000083662

SUBHA, B.; MUTHUKUMAR, M. Optimization of ozonation process for the reduction of excess sludge production from activated sludge process of sago industry wastewater using central composite design. The Scientific World Journal, v. 2012, 8 p., 2012. http://dx.doi.org/10.1100/2012/239271 
VON SPERLING, M. Características das águas residuárias. In: VON SPERLING, M. Introdução à qualidade das águas e ao tratamento de esgotos. Belo Horizonte: DESA; UFMG, 2014. p. 24-42, 82-126.

XU, P.; JANEX, M. L.; SAVOYE, P.; COCKX, A.; LAZAROVA, V. Wastewater disinfection by ozone: main parameters for process design. Water Research, v. 36, n. 4, p. 10431055, 2002.

WAJAHAT, R.; YASAR, A.; KHAN, A. M.; TABINDA, A. B.; BHATTI, S. G. Ozonation and Photo-Driven Oxidation of Ciprofloxacin in Pharmaceutical Wastewater: Degradation Kinetics and Energy Requirements. Polish Journal of Environmental Studies, v. 28, n. 3 p. 1-6, 2019. http://dx.doi.org/10.15244/pjoes/90597 


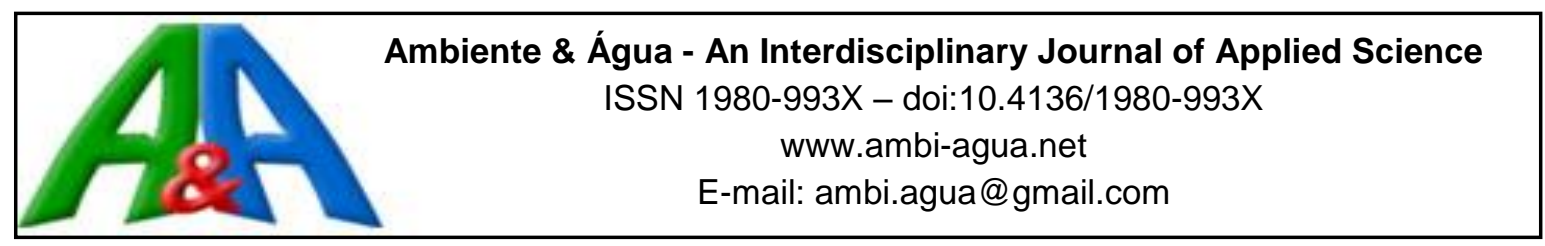

\title{
Frequency of mentum deformity in Chironomus sancticaroli (Diptera: Chironomidae) in a laboratory culture
}

\author{
ARTICLES doi:10.4136/ambi-agua.2337
}

Received: 01 Oct. 2018; Accepted: 01 Feb. 2019

\begin{abstract}
Mariana Silveira Guerra Moura e Silva ${ }^{1 *}$; Ana Lúcia Silva MarigoĐ; William Viveiros ${ }^{3}$ id ; Mônica Luisa Kuhlmann ${ }^{3}$

${ }^{1}$ Embrapa Meio Ambiente (EMBRAPA), Jaguariúna, SP, Brasil

Laboratório de Ecossistemas Aquáticos. E-mail: mariana.silveira@embrapa.br

${ }^{2}$ Universidade Estadual de Campinas (UNICAMP), Campinas, SP, Brasil

Instituto de Geociências (IGE). E-mail: analuciamarigo@yahoo.com.br

${ }^{3}$ Companhia Ambiental do Estado de São Paulo (CETESB), São Paulo, SP, Brasil

Divisão de Análises Hidrobiológicas. E-mail: wviveiros@sp.gov.br, mkuhlmann@sp.gov.br

*Corresponding author
\end{abstract}

\begin{abstract}
The midge Chironomus sancticaroli (Diptera: Chironomidae) has been used in ecotoxicological tests because it is sensitive to a variety of inorganic pollutants. Among the parameters used to evaluate the toxicity of a substance is the frequency of mentum deformity, which is part of the oral system of this organism. However, there is still no consensus on the baseline level (percentage) of acceptable deformities in laboratory cultures not exposed to pollutants. The determination of this variable is important to ensure the validity of bioassays and to compare cultures from different research and teaching institutions. Once this value is established, it will also be used to monitor the quality of organisms cultured, since factors such as inbreeding could increase the frequency of mentum deformity. Thus, the objective of this study was to quantify the percentage of mentum deformity in the fourth instar of $C$. sancticaroli larvae from the culture of the Laboratory of Aquatic Ecosystems, at Embrapa Meio Ambiente. The average frequency of mentum deformity obtained was $6,63 \%$. It is believed that factors such as the renewal of the culture with the inclusion of spawns from the laboratories of other institutions, as well as the control of the quality of the dilution water and the sediment of the breeding may have contributed to a low frequency of mentum deformity of the culture observed in this study.
\end{abstract}

Keywords: bioindicator, ecotoxicology, inbreeding.

\section{Estudo para determinação da frequência de deformidade do mento em Chironomus sancticaroli (Diptera: Chironomidae) em cultura de laboratório}

\section{RESUMO}

A espécie Chironomus sancticaroli (Diptera: Chironomidae) tem sido utilizada em testes ecotoxicológicos por ser sensível a uma variedade de poluentes inorgânicos. Um dos parâmetros utilizados para avaliar a toxicidade de uma substância é a frequência de deformidade 
do mento, que faz parte do sistema oral deste organismo. Entretanto, ainda não há consenso a respeito do nível basal (porcentagem) de deformidade aceitável em culturas de laboratório não expostas a poluentes. A determinação desta variável é importante para assegurar a validade de bioensaios e comparar culturas de diferentes instituições de pesquisa e ensino. Uma vez estabelecido, este número também será usado para o controle da qualidade dos organismos criados, já que fatores como o endocruzamento poderiam aumentar a frequência de deformidade do mento. Assim, o objetivo deste estudo foi quantificar a porcentagem de deformidade do mento em larvas de quarto instar de $C$. sancticaroli de cultura do Laboratório de Ecossistemas Aquáticos da Embrapa Meio Ambiente. A média de frequência de deformidade obtida para a cultura foi de $6,63 \%$. Acredita-se que fatores como a renovação da cultura com a inclusão de desovas de laboratórios de outras instituições, assim como o controle da qualidade da água de diluição e do sedimento da criação, podem ter contribuído para uma baixa frequência de deformidade do mento da cultura.

Palavras-chave: bioindicadores, ecotoxicologia, endocruzamento.

\section{INTRODUCTION}

Aquatic insects of the family Chironomidae (Diptera) are widely used as bioindicators of environmental impacts, because their entire larval cycle occurs in sediment, where they interact with contaminants that tend to accumulate in this compartment of the aquatic ecosystem. Furthermore, they are ubiquitous in distribution, sensitive to various pollutants and present a relatively short life cycle, being ideal candidates for ecotoxicological studies (Park and Choi, 2009). They are also indicated for ecotoxicological studies because they present rapid responses and easy manipulation of the cultures (USEPA, 2000; OECD, 2007). They present varieties of feeding habits, from the filtration of particles in the water column to the predation of small organisms.

The genus Chironomus (Diptera, Chironomidae) is an organism of great importance in the group of benthic bioindicators. It plays a relevant role in the food chain and in sediment nutrient cycling. Further, it is easily cultured in the laboratory. Its larval cycle is aquatic, in direct contact with the sediment, where it remains buried. The life cycle of the individuals of the genus Chironomus comprises four phases: egg, larval period (4 stages), pupa, and adult. Soon after the egg hatches, in the first stage, the larva remains between the sediment particles and feeds on detritus (Chironomus is classified as a gathering collector), but can also be planktonic. From the second stage, the larvae construct cocoons that shelter them and increase in size, until reaching the stage of pupa and soon after, adult, which is terrestrial (Bonani, 2010). They are found in most aquatic environments and can be very tolerant to extreme environmental conditions such as variations in $\mathrm{pH}$, temperature, dissolved oxygen, salinity, depth, and speed of currents. In order to survive in habitats with low concentrations of dissolved oxygen, the larvae present hemoglobin, which gives it a reddish coloration, long abdominal gills and undulating movement (Viveiros, 2012).

Sanseverino and Nessimian (2008) describe that several genera of the family Chironomidae are reported in studies of deformities, and the genus Chironomus (Meigen 1803) is the most-cited. Comparing the incidence of deformities in many genera of Chironomidae in Canadian lakes, Hudson and Ciborowski (1996b) suggested Chironomus, Phaenopsectra and Procladius because of their wide distribution and sensitivity to the formation of deformities. In the cephalic capsules of the larvae of Chironomus several sensorial structures and mouthparts are inserted; one of them is the mentum. They are composed of chitin which is a biological component of high strength.

Chironomus may present deformities in mentum when exposed to radiation-contaminated

Rev. Ambient. Água vol. 14 n. 2, e2337 - Taubaté 2019 
sediments (Williams et al., 2001), heavy metals (Callisto et al., 2000; Deliberalli et al., 2018), pesticides (Hamilton and Saether, 1971), among others. These same authors report high frequencies of deformity in the chironomids in their different larval instars, evidencing such structure as one of the most sensitive and important for use in biomonitoring. Such deformities can be of different types and intensities, including lack or excess of teeth, gap, bifurcation of the central tooth, asymmetry, wear and break. To apply the metric as a quality criterion, CETESB (2017) standardized the data acquisition in order to minimize subjectivity considering as deformities missing and excessive teeth, Kohn gap and bifurcation of the central tooth. In these field studies, deformity is observed as an effect of toxic substances, however, there is no national or international standard protocol for its use as an endpoint in ecotoxicological bioassay (Viveiros, 2012).

At the individual level, deformities do not impair emergency, but they decrease body size and retard development. Further bioaccumulation may occur in deformed individuals. Individual differences reflect microhabitat conditions and genetic differences linked to resistance mechanisms (Janssens de Bisthoven et al., 1998). Studies suggest that some types of deformity are related to the inbreeding and age of laboratory-maintained creations (Vogt et al., 2013). Besides that, there are few published studies with $C$. sancticaroli for deformity in culture. However, there is no consensus on the rate of acceptable baseline deformity in laboratory for Chironomus cultures. These data are important for the assessment of test organism fitness before their use in ecotoxicological tests in order to determine the level of deformity.

This study evaluated the incidence of mentum deformities in individuals of Chironomus sancticaroli in cultures maintained in the Laboratory of Aquatic Ecosystems at Embrapa Meio Ambiente.

\section{MATERIAL AND METHODS}

\subsection{Culture conditions:}

C. sancticaroli egg masses from Laboratory of Aquatic Ecosystems (LEA) - Embrapa Meio Ambiente were placed into plastic trays of approximately 30 x 37 x $8 \mathrm{~cm}$ containing $\sim 1$ $\mathrm{cm}$ of sand washed and calcinated in muffle for total elimination of organic matter (Dornfeld, 2006). The water used was sterilized and reconstituted in the laboratory (Jonsson and Maia, 1999), with controlled aeration and temperature $\left(25^{\circ} \mathrm{C} \pm 1{ }^{\circ} \mathrm{C}\right)$ and photoperiod $12 \mathrm{~h}$ light $/ 8 \mathrm{~h}$ dark. The water column was aerated through porous stone and air mini compressor. The newly hatched larvae were fed once daily with Tetramin ${ }^{\circledR}$, according to the concentration indicated in Fonseca and Rocha (2004) until reaching the last larval stage ( $4^{\text {th }}$ instar).

\subsection{Bioassay procedures:}

After reaching the 4th instar, 454 larvae were randomly separated, on different dates, from the same culture to prepare microscope slides with the cephalic capsules, with an average size of $0.32 \pm 0.02 \mathrm{~mm}$, corresponding to this larval stage, according to Strixino and Strixino (1982). The cephalic capsule was separated from the larvae body using a fine-pointed forceps and mounted in slides with ventral part upward in the Hoyer medium. That medium is composed of gum arabic, chloral hydrate, glycerol and water and is used to make semi-permanent slide mounts for examination of the cephalic capsule under microscope. For the calculation of deformity frequencies, mentum was considered deformed when presenting: exceeding or missing teeth, central teeth bifurcation or Kohn gap. The last one is a type of deformity where a cavity is formed in the tooth. It differs from a break by having smooth edges. The frequency of deformities was expressed as a percentage of the total of analyzed larvae. Four batches of larvae were analyzed under the same laboratory conditions at different dates: 10/04/17; $11 / 06 / 17$ e $12 / 07 / 17$ and 12/12/18.

Rev. Ambient. Água vol. 14 n. 2, e2337 - Taubaté 2019 


\section{RESULTS AND DISCUSSION}

A total of 454 fourth instar larvae of Chironomus sancticaroli from the Laboratory of Aquatic Ecosystems of Embrapa Meio Ambiente were analyzed, and an average frequency of $6.63 \%$ of mentum deformity was found (Figure 1). The types of deformity found were: "missing teeth", "excess teeth", "gap" and "central tooth bifurcation" (Figure 1).

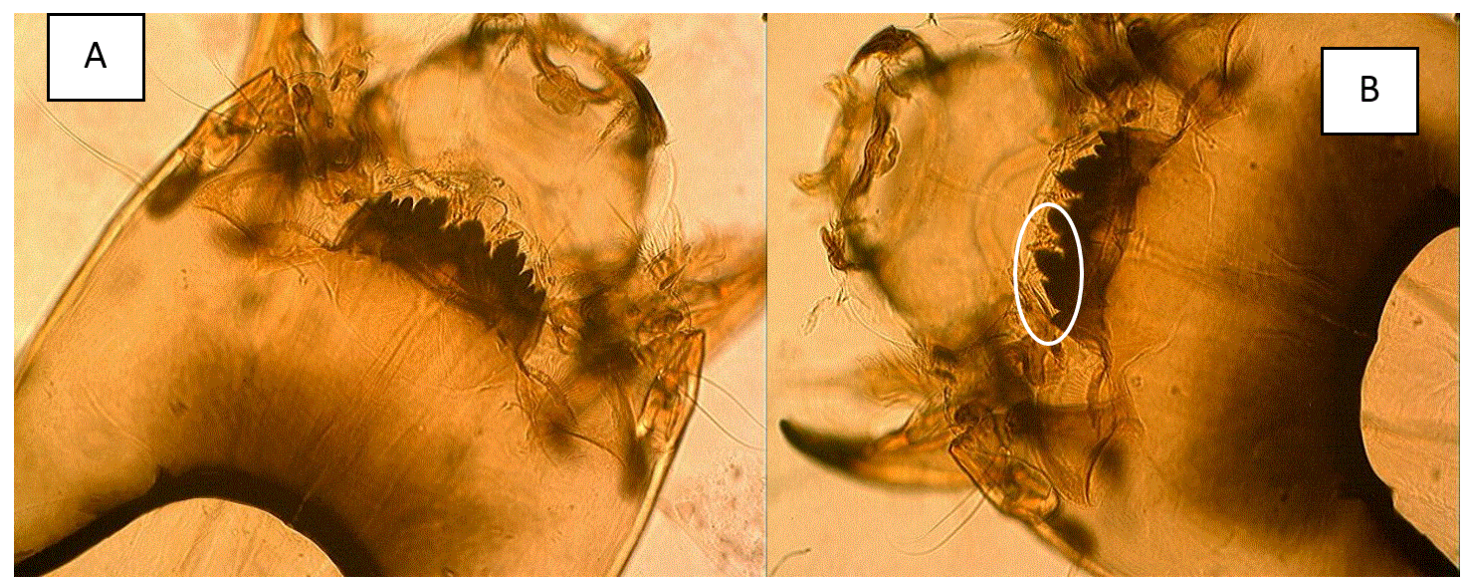

Figure 1. Example of mentum deformity found at Chironomus sancticaroli culture from Laboratory of Aquatic Ecosystems, at Embrapa Meio Ambiente. Normal tooth (A) and mentum with absence of lateral teeth deformity type (B). Microscope amplification of 100x.

For field data (larvae in the natural environment), Burt et al. (2003) defined the frequency of deformities on Chironomus population collected in reference sites of the Great Lakes as $2.1 \pm 0.2 \%$, but the authors considered that for rivers, streams and bogs the basal value could be less than $1 \%$. Hudson and Ciborowski (1996b) also observed smaller percentages of mentum deformity at sites considered as "reference" ones (not impacted). Considering the quality criteria stated by CETESB (CETESB, 2017), frequencies above $6 \%$ mean that the site has bad quality and probably receives chemical contaminants. In laboratory assays, larger percentages than the present study have been observed in control condition. In test control, Hudson and Ciborowski (1996a) observed until 7.4\% of deformity for $C$. salinarius; a very similar result (until 7.3\%) was obtained by Arambourou and coworkers (2015) for C. riparius; Kwak and Lee (2005) found $18.2 \%$ for C. plumosus, Bonani (2010), when exposing organisms of $C$. sancticaroli to the test control sediment obtained a mean deformity of $20.2 \%$ and $13 \%$ at Viveiros (2012). On the other hand, Dornfeld (2006); evaluating the toxicity of cadmium and copper in $C$. xanthus assays, observed only $2.0 \%$ deformity in control larvae. In laboratory culturing, Rebechi and Silva (2012) observed 9\% of mentum deformity in C. sancticaroli (instar II) reared in standard conditions and $48 \%$ in III instar, while Viveiros (2012) observed an average of $13 \%$ for the same specie (IV instar). Despite these data, the criteria used for field studies should not be applied directly to laboratories tests, because the environmental conditions are different.

Long time chironomid cultures generally exhibit high levels of inbreeding, and this could impact the reliability of ecotoxicological tests using this strains. The introduction of new cultures from other laboratories, and also the use of field-collected strains are alternatives to reduce inbreeding (Nowak et al., 2007).

Vogt et al. (2013) and Bird et al. (1995) have highlighted the importance of inbreeding in the level of mouthpart deformities in C. riparius larvae. According to them, unpredictable environmental variables may have a greater influence on the approach to field studies, whereas population effects (e.g. inbreeding) may be more pronounced in laboratory studies. These same authors observed a direct relation between the increase of deformities of the mentum in $C$. 
riparius with the increase of inbreeding. Sanseverino and Nessimian (2008) mentioned increased central tooth deformities in the 4th and 6th generations of their cultures, associating the fact with inbreeding. Thus, field populations of $C$. riparius have greater genetic diversity than the laboratory populations, being less subject to the deformity of the mentum induced by the stressors. Vermeulen et al. (2000) also found a high incidence of deformities in their cultures and in the controls of their tests (from 34 to 56\%) and concluded that the crossing between relatives in the cultures is the main thing responsible for the high indexes found. The same condition was observed by Bird (1997) and Janssens de Bisthoven (2001) including the organisms age and no renovation of the cultures. Culture condition can also promote deformities, as observed by Madden et al. (1992). These researchers obtained high deformity frequencies $(20-46 \%)$ in larvae maintained in artificial substrate (Martin's solution) but diminished frequency (19\%) when natural water was used in the culture. On the other hand, Dickman et al. (1992) observed a reduction of mentum deformity in organisms maintained in a clean sediment after collecting them in contaminated sites with HPA's. According to Jeyasingham and Ling (1997), the origin of the organisms and the substrate that is used in the cultures can influence the frequencies of mentum deformity, but it is possible to reduce them until F2 generation.

Further study still has to be performed in order to define if the level of deformity found is in this experiment can be considered low, and if it may be related to the fact that the culture of Embrapa Meio Ambiente received spawnings from other institutions, reducing inbreeding within the population. A further aspect in this context concerns inheritance. The insertion of new spawns, preferably from other laboratories, also brings the advantage of renewing culture from the point of view of its age. Sanseverino and Nessimian (2008) observed that the presence of some mentum deformities (split of median tooth, multiple teeth) was related to the age of the culture for Chironomus tentans, because of inbreeding.

In addition, the control of water and sediment quality variables (using reconstituted water and calcinated sand) may contribute to the low percentage of deformity found. Nevertheless, it is important to evaluate and monitor the fluctuation of the deformity in this culture in order to be able to use this parameter (frequency of mentum deformity) in assessment of the health of organisms and for detecting the need for culture renewal.

\section{CONCLUSIONS}

The cultures of Chironomus sancticaroli of Embrapa Meio Ambiente showed low frequency of deformities when compared to other studies, suggesting that the procedures developed have been effective in prevent inbreeding effects.

Evaluating and monitoring the fluctuation of mentum deformity in laboratory culture is important in order to be able to use this parameter in the evaluation of the health of the organisms and to detect the need for culture renewal.

Further studies are required in order to define the acceptable level of deformity in Chironomus sancticaroli raised in laboratory which can ensure the reliability of the culture.

It is interesting to perform genetic tests to quantify inbreeding among insect populations cultured in laboratory.

\section{REFERENCES}

ARAMBOUROU, H.; BRANCHU, P.; BEISEL, J-N. Increase in Developmental Instability in a Field-Collected Chironomus Population Maintained Under Laboratory Conditions. Bulletin of Environmental Contamination Toxicology, v. 94, p. 681-687, 2015. https://doi.org/10.1007/s00128-015-1497-5 
BIRD, G. A.; SCHWARTZ, W. J.; JOSEPH, D. L. The effect of $210 \mathrm{~Pb}$ and lead on the induction of mental deformities in Chironomus tentans larvae and on their growth and survival. Environmental Toxicology and Chemistry, v. 14, n. 12, p. 2125-2130, 1995. https://doi.org/10.1002/etc.5620141216

BIRD, G. A. Deformities in cultured Chironomus tentans larvae and the influence of substrate on growth, survival and mentum wear. Environmental Monitoring and Assessment, v. 45, p. 273-283, 1997. https://doi.org/10.1023/A:1005782803930

BONANI, F. Avaliação de deformidades morfológicas em larvas de Chironomus (Diptera, Chironomidae) na bacia do rio Piracicaba e sua aplicação no biomonitoramento. 2010. 80f. Dissertação (Mestrado em Ecologia e Recursos Naturais) - Centro de Ciências Biológicas e da Saúde, Universidade Federal de São Carlos, São Carlos, 2010.

BURT, J.; CIBOROWSKI, J. J. H.; REYNOLDSON, T. B. Baseline incidence of Mouthpart Deformities in Chironomidae (Diptera) From The Laurentian Great Lakes, Canadá. Journal of Great Lakes Research, v. 29, n. 1, p. 172-180, 2003. https://doi.org/10.1016/S0380-1330(03)70425-0

CALliSTO, M.; MARQUES, M. M.; BARBOSA, F. A. Deformities in larval Chironomus (Diptera, Chironomidae) from the Piracicaba river, southeast Brazil. SIL Proceedings, 1922-2010, v. $27, \quad$ n. $5, \quad$ p. $2699-2702, \quad$ https://doi.org/10.1080/03680770.1998.11898157

COMPANHIA AMBIENTAL DO ESTADO DE SÃO PAULO. Qualidade das Águas Superficiais no Estado de São Paulo 2016. São Paulo: CETESB, 2017.

DELIBERALLI, W.; CANSIAN, R. L.; PEREIRA, A. A. M.; LOUREIRO, R. F.; HEPP, L. U.; RESTELLO, R. M. The effects of heavy metals on the incidence of morphological deformities in Chironomidae (Diptera). Zoologia, v. 35, p. 1-7, 2018. http://dx.doi.org/10.3897/zoologia.35.e12947

DICKMAN, M.; BRINDLE, I.; BENSON, M. Evidence of teratogens in sediments of the Niagara river watershed as reflected by chironomid (Diptera: Chironomidae) deformities. Journal of Great Lakes Research, v. 18, n. 3, p. 467-480, 1992. https://doi.org/10.1016/S0380-1330(92)71312-4

DORNFELD. C. B. Utilização de Chironomus sp (Diptera: Chironomidae) para avaliação da qualidade de sedimentos e contaminação por metais. 2006. Tese (Doutorado) Escola de Engenharia de São Carlos, Universidade de São Paulo, São Carlos, 2006.

FONSECA, A. L.; ROCHA, O. Laboratory cultures of the native species Chironomus xanthus Rempel, 1939 (Diptera: Chironomidae). Acta Limnologica Brasiliensia, v. 16, n. 2, p. 153-161, 2004.

HAMILTON, A. L.; SAETHER, O. A. The occurrence of characteristic deformities in the chironomid larvae of several Canadian lakes. Canadian Entomologist, v. 103, p. 363368, 1971. https://doi.org/10.4039/Ent103363-3

HUDSON, L. A.; CIBOROWSKI, J. H. Teratogenic and genotoxic responses of larval Chironomus salinarius group (Diptera: Chironomidae) to contaminated sediment. Environmental Toxicology and Chemistry, v. 15, n. 8, p. 1375-1381, 1996a. https://doi.org/10.1002/etc.5620150817 
HUDSON, L. A.; CIBOROWSKI, J. H. Spatial and taxonomic variation in incidence of mouthpart deformities in midge larvae (Diptera: Chironomidae: Chironomini). Canadian Journal of Fisheries and Aquatic Sciences, v. 53, p. 297-304, 1996 b. https://doi.org/10.1139/f95-199

JANSSENS DE BISTHOVEN, L.; NUYTS, P.; GODDERIS, B.; OLLEVIER, F. Sublethal parameters in deformed Chironomus larvae: clues to understanding their biomarker value. Freshwater Biology, v. 39, n. 1, p. 179-191, 1998. https://doi.org/10.1046/j.13652427.1998.00265.x

JANSSENS DE BISTHOVEN, L.; POSTMA, J.; VERMEULEN, A.; GOEMANS, G.; OLLEVIER, F. Morphological deformities in Chironomus riparius Meigen larvae after exposure to cadmium over several generations. Water, Air and Soil Pollution, v. 129, p. 167-179, 2001. https://doi.org/10.1023/A:1010367524314

JEYASINGHAM, K.; LING, N. Head capsule deformities in Chironomus zealandicus (Diptera: Chironomidae): influence of site and substrate. New Zealand Journal of Marine and $\begin{array}{llllll}\text { Freshwater } & \text { Research, } & \text { v. } & 31, & \text { p. }\end{array}$ https://doi.org/10.1080/00288330.1997.9516756

JONSSON, C. M.; MAIA, A. H. N. Protocolo de avaliação de agentes microbianos de controle de pragas para registro como biopesticidas. Testes tóxico patológicos em organismos não alvo do ambiente aquático: organismos zooplanctônicos, fitoplanctônicos e vertebrados. Jaguariúna: Embrapa Meio Ambiente, 1999. (Documentos, v. 11).

KWAK, I. S.; LEE, W. Mouthpart Deformity and Developmental Retardation Exposure of Chironomus plumosus (Diptera: Chironomidae) to Tebufenozide. Bulletin of Environmental Contamination and Toxicology, v. 75, n. 5, p. 859-865, 2005. https://doi.org/10.1007/s00128-005-0829-2

MADDEN, C. P.; SUTER, P. J.; NICHOLSON, B. C.; AUSTIN, A. D. Deformities in Chironomid larvae as indicators of pollution (pesticide) stress. Netherlands Journal of Aquatic Ecology, v. 26, n. 2-4, p. 551-557, 1992. https://doi.org/10.1007/BF02255289

NOWAK C, VOGT C, DIOGO B, SCHWENK K. Genetic impoverishment in laboratory cultures of the test organism Chironomus riparius. Environmental Toxicology and Chemistry, v. 26, p. 1018-1022, 2007. https://doi.org/10.1897/06-349R.1

OECD. Test No. 225: Sediment-water Lumbriculus toxicity test using spiked sediment. OECD Guideline for the Testing of Chemicals. Paris, 2007.

PARK, S.Y.; CHOI, J. Genotoxic effects of nonylphenol and bisphenol exposure in aquatic biomonitoring species: Freshwater crustacean, Daphnia magna, and aquatic midge, Chironomus riparius. Bulletin of Environmental Toxicology and Chemistry, v. 83, p. 463-468, 2009. https://doi.org/10.1007/s00128-009-9745-1

REBECHI, D.; SILVA, M. N. Setting the reference for the use of Chironomus sancticaroli (Diptera: Chironomidae) as bioindicator: Ontogenetic pattern of larval headstructures. Zoologia, v. 29, n. 2, p. 167-171, 2012.

SANSEVERINO, A. M.; NESSIMIAN, J. L. Assimetria Flutuante em Organismos Aquáticos e sua Aplicação para Avaliação de Impactos Ambientais. Oecologia Brasiliensis, v. 12, n. 3, p. 382-405, 2008.

STRIXINO, S. T.; STRIXINO, G. Ciclo de Vida de Chironomus sancticaroli (Diptera, Chironomidae). Revista Brasileira de Entomologia, v. 26, n. 2, p. 183-189, 1982. 
USEPA. Methods for measuring the toxicity and bioaccumulation of sediment-associated contaminants with freshwater invertebrates. EPA 600/R-99-064. Duluth, 2000.

VERMEULEN, A. C.; LIBERLOO, G.; DUMONT, P.; OLLEVIER, F.; GODDEERIS, B. Exposure of Chironomus riparius larvae (Diptera) to lead, mercury and $\beta$-stosterol: effects on mouthpart deformation and moulting. Chemosphere, v. 41, p. 1581-1591, 2000. https://doi.org/10.1016/S0045-6535(00)00033-3

VIVEIROS, W. Chironomus sancticaroli: do cultivo em laboratório ao ensaio ecotoxicológico com amostras ambientais de sedimento. 2012. 91 f. Dissertação (Mestrado em Ciências na Área de Tecnologia Nuclear - Materiais) - Instituto de Pesquisas Energéticas e Nucleares, Universidade de São Paulo, São Paulo, 2012.

VOGT, C.; LANGER-JAERICH, M.; ELASSER, O.; SCHMIDT, C.; VAN DONGEN, S.; KOHLER, H.; OEHLMANN, J.; NOWAK, C. Effects of inbreeding on mouthpart deformities of Chironomus riparius under sublethal pesticide exposure. Environmental

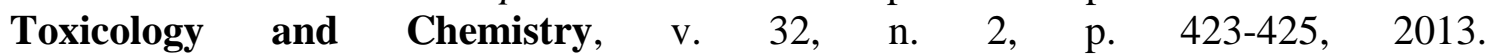
https://doi.org/10.1002/etc.2071

WILliams, D. D.; NESTEROVITCH, A. I.; TAVARES, A. F.; MUZZATTI, E. G. Morphological deformities occurring in Belarusian chironomids (Diptera: Chironomidae) subsequent to the Chernobyl nuclear disaster. Freshwater Biology, v. 46, p. 503-512, 2001. https://doi.org/10.1046/j.1365-2427.2001.00699.x 